\title{
ZUSAS
}

science for a changing world

Long Valley Coring Project, Inyo County, California, 1998Preliminary Stratigraphy and Images of Recovered Core

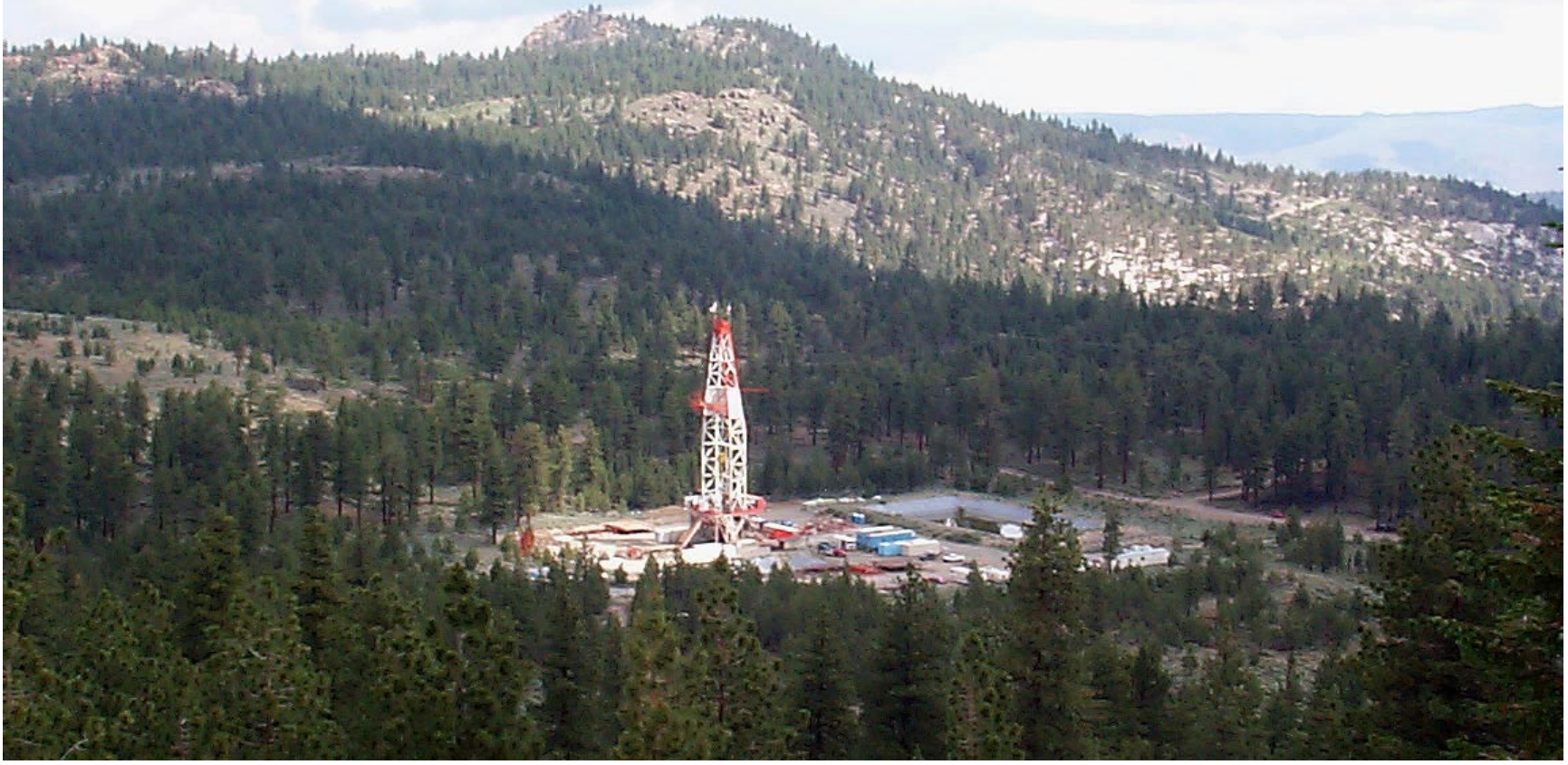




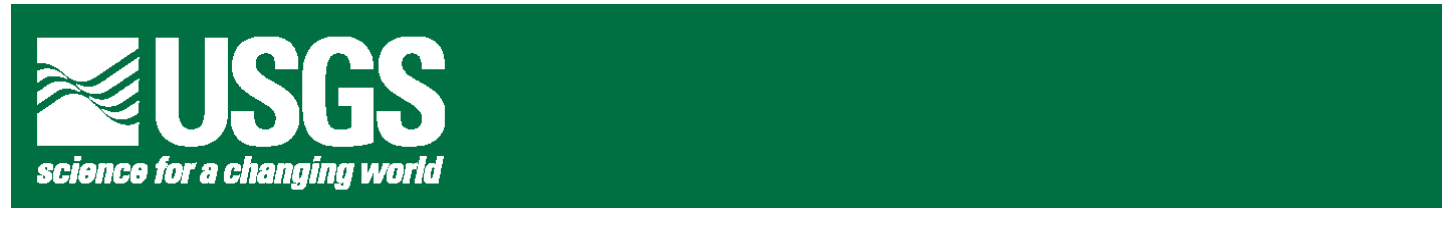

\section{Long Valley Coring Project, 1998- Preliminary Stratigraphy and Images of Recovered Core}

By Penelope C. Sackett1, Vicki S. McConnell2, Angela L. Roach ${ }^{3}$, Susan S. Priest ${ }^{1}$ and John H. Sass 1

Open-File Report 99-158

1999

This report is preliminary and has not been reviewed for conformity with U.S. Geological Survey (USGS) editorial standards or with the North American Stratigraphic Code. Any use of trade, firm, or product names is for descriptive purposes only and does not imply endorsement by the U.S. Government.

\section{U.S. DEPARTMENT OF THE INTERIOR}

\section{U.S. GEOLOGICAL SURVEY}

${ }^{1}$ U.S. Geological Survey, 2255 North Gemini Drive, Flagstaff, AZ 86001-1698

${ }^{2}$ Oregon Department of Geology and Mineral Industries, 1831 First Street, Baker City, OR $97184-3442$

${ }^{3}$ Hawaii Institute of Geophysics and Planetology, 2525 Correa Road Honolulu, HI 96822-2219 
Sackett and others, 1999, USGS OFR 99-158

\section{DISCLAIMERS}

This Compact Disc Read-Only-Memory (CD-ROM) publication was prepared by an agency of the United States Government. Neither the United States Government nor any agency thereof, nor any of their employees, makes any warranty, expressed or implied, or assumes any legal liability or responsibility for the accuracy, completeness or usefulness of any information, apparatus, product, or process disclosed in this report, or represents that its use would not infringe on privately owned rights. Reference therein to any specific commercial product, process, or service, by trade name, trademark, manufacturer, or otherwise does not necessarily constitute or imply its endorsement, recommendation, or favoring by the United States Government or any agency thereof.

Although all data and software published on this CD-ROM have been used by the USGS, no warranty, expressed or implied, is made by the USGS as to the accuracy of the data and related materials and (or) the functioning of the software. The act of distribution shall not constitute any such warranty, and no responsibility is assumed by the USGS in the use of this data, software, or related materials.

\section{ABSTRACT}

Phase III of the Long Valley Exploratory Well, the Long Valley Coring Project, obtained continuous core between the depths of 7180 and $9831 \mathrm{ft}$ (2188 to 2996 meters) during the summer of 1998. This CD-ROM contains a compendium of information designed to facilitate post-drilling research focussed on the study of the core. Included are a preliminary stratigraphic column compiled primarily from field observations and a general description of well lithology for the Phase III drilling interval. Also included are highresolution digital photographs of every core box ( 10 feet per box) as well as scanned images of pieces of recovered core. The user can easily move from the stratigraphic column to corresponding core box photographs for any depth. From there, compressed, "unrolled" images of the individual core pieces (core scans) can be accessed. Those interested in higher resolution core scans can go to archive CDs stored at a number of locations specified herein. All core is stored at the USGS Core Research Center in Denver, Colorado where it is available to researchers following the protocol described in this report. Preliminary examination of core images provided by this and the archive CDs should assist researchers in narrowing their choices when requesting core splits.

\section{THE LONG VALLEY EXPLORATORY WELL}

Long Valley Exploratory Well (LVEW) is situated on the resurgent dome of Long Valley Caldera, at the boundary of the Sierra Nevada and the Basin and Range Province in eastern California Figure 1. Long Valley Caldera was created by a catastrophic, voluminous eruption of high-silica rhyolite, approximately 760,000 years ago. Since that time, minor volcanic activity in the area has recurred every few hundred years and major volcanic episodes associated with the caldera magma system occur at a frequency of about every 200,000 years (Bailey, 1989). LVEW was drilled to assess the potential of a deep geothermal resource beneath the resurgent dome, help improve assessments of volcanic risk from major or minor volcanic eruptions emanating from the central caldera, and provide a "hole of opportunity" for testing drilling instruments and technology (Figure 2),

LVEW began in 1989 as an engineering and scientific research well for the U.S. Department of Energy's Magma Energy Program. Original plans called for drilling to a total depth of 18,000 feet to be accomplished in four phases. Phase I was completed in 1989 to a depth of 2650 feet. In 1991, Phase II deepened the hole to 7200 feet, with emphasis on exploring the geothermal energy potential of a deep magmatic source. Data from Phase II suggested that downhole temperatures, which reached $100{ }^{\circ} \mathrm{C}$ at the bottom of the well, were too cool for geothermal development (Sass and others, 1991), although, 
mineralogical evidence suggested that, in the past, the temperatures had been as high as $350{ }^{\circ} \mathrm{C}$ for the same depth (McConnell and others, 1997).

The Long Valley Coring Project (LVCP), operated during July through September 1998, was the third phase of drilling at LVEW. This phase deepened the existing hole from 7200 feet to a final depth of 9831 feet. Unlike the previous two phases of drilling in which core was recovered only at specific intervals, LVCP recovered continuous core throughout the entire section. LVCP was initiated to obtain additional information on magmatic processes both past and present in the caldera. It was envisioned that by deepening the pre-existing borehole it would be possible to gain information about the presence of small magmatic intrusions, the brittle-ductile transition above the inferred magma body, the nature of the temperature gradient, and perhaps the presence of a magma chamber or neogranite. In addition, drilling was expected to provide more details about geothermal energy potential, volcanic hazards and the stratigraphy of Long Valley Caldera, as well as to field-test a newly developed hybrid drilling unit (Sass and others, 1998).

To achieve these goals, LVCP was slated to deepen the existing hole to a depth between 11,500 and 13,000 feet. However, unexpected delays and short bit runs, attributed to thick layers of metaquartzite and minor engineering problems with the hybrid drilling unit, decreased daily recovered footage and cost precious drilling time and money. The final depth achieved was 9831 feet. Nevertheless, the retrieval of over 2500 feet of continuous core provided geologists with a wealth of new data and material for further research efforts.

\section{LVEW STRATIGRAPHY}

During Phases I and II, LVEW passed through the volcanic caldera fill and into the metamorphosed intrusions and metasedimentary basement rock. LVCP continued to drill through a thick sequence of metasedimentary rocks (Figure 3). The metamorphic material is correlative with the Mt Morrison roof pendant which is intruded by Sierra Nevada granites to the west and south of the drillsite. Specifically, graphitic, banded metapelites, metaquartzites, calcareous sandstones, and calc-silicate rocks most resembles the sequence of metamorphic rocks that make up the nearby Ordovician Mt. Aggie Formation (McConnell and others, 1998). Metamorphic patterns in the recovered core are indicative of several episodes of deformation suggesting that multiple processes of metamorphism were active, either simultaneously or sequentially, in the area. Indeed, an increase in contact metamorphic grade in the deepest portion of the core suggests that drilling approached the contact aureole of an intrusive body. Possible sources include Cretaceous age Sierra Nevada granite or neogranite representing the chilled margin from the Long Valley Caldera magma chamber.

LVCP drilling intersected several igneous intrusions in the metamorphic rocks. Their chemistry and alteration vary greatly, suggesting intrusion at different times or multiple episodes of emplacement and magmatic activity in the caldera. Several intrusions are petrographically similar to hypabyssal sills in the overlying volcanic fill found during the earlier phases of drilling. Their cumulative thickness and presence is suggested to account for much of the elevation of the resurgent dome (McConnell and others, 1995). These intrusions may ultimately provide information about the underlying magma chamber.

The presence or absence of geothermal potential should be reflected in changes of temperature with depth. Temperature's in LVEW are unexpectedly low (Figure 4). The last kilometer in the well is isothermal and the bottomhole temperature remains just above $100{ }^{\circ} \mathrm{C}$. Despite these anomalously low temperatures, the core provides abundant evidence of deep hot water circulation. Thick zones of hydrothermal alteration and open veins of pristine crystals of hydrothermal minerals, such as quartz, epidote, chlorite, sulfide minerals, and blade calcite at depths of 8500-8550 and 9100 feet, suggest that vigorous hot water circulation was present in the recent past. 
Sackett and others, 1999, USGS OFR 99-158

In addition to locally stretched and ductilely deformed metasedimentary rocks, the core contains lithologic and structural evidence of recent faulting. Faulting is indicated by fresh fault gouge, open vein brecciation, and open fractures. Two sections show the most significant evidence for recent faulting. Thick fault gauges occur between 8630 and 8910, presumable indicating the largest and most active faults. A deeper sequence stretches from approximately 9420 to 9800 feet, repeating the package of faulted rocks many times; suggesting an active extensional fault zone. This depth coincides with the calculated hypocenters of the Long Valley Caldera seismic swarm from September 1997 to January 1998 (oral communication, Steve Hickman). This intriguing evidence for young and contemporaneous faulting may allow for interpretations of the state of stress in the area of the resurgent dome.

Future plans for the wellsite include continued temperature logging and the emplacement of a package of instruments including seismometers and flow meters to increase the monitoring capabilities of the Long Valley Observatory. A series of add-on science research projects are also underway including detailing geochemistry of fluid inclusions within the hydrothermal minerals, Alpha recoil track age determinations of volcanic rocks, and geophysical modeling of the thermal regime of the caldera.

All of these findings and their implications will be reported at length in future papers. The purpose of this CD-ROM is to introduce the stratigraphy of LVEW from 7178 to 9831 feet and to present images of all recovered core.

\section{SYSTEM REQUIREMENTS}

\section{Minimum system requirements:}

This CD-ROM (OF99_158) was produced in accordance with the ISO 9660 Level 2 standard and Apple Computer's ${ }^{1}$ hierarchical file system (HFS) standard.

The data and text on this CD-ROM require either a Macintosh ${ }^{1}$ or compatible computer, an $\mathrm{IBM}^{2}$ or compatible personal computer, or a UNIX workstation, all equipped with a CDROM drive. The Macintosh should have a 68030 or higher processor (PowerPC recommended), 8 megabytes RAM (64 MB recommended), Apple System Software version 7.1.2 or later (8.1 or later recommended), and a 13 -inch color monitor that can display 256 colors (16.7 million colors recommended). The PC should have an 80386 or higher processor $\left(\right.$ Pentium ${ }^{3}$ recommended), Microsoft Windows ${ }^{4} 3.1$ or higher (Windows 95, 98, or NT recommended), 8 megabytes RAM (64 MB recommended), and a VGA color monitor that can display 256 colors (16.7 million colors recommended). Macintosh, PCs, and UNIX computers should have Adobe Acrobat ${ }^{5}$ Reader 3.0 or higher (3.01 and 4.0 included on this disc for Macintosh and PC) or other software that can translate PDF files and an application that will view JPG files. For more information about viewing JPG files, see the section below on opening JPG files.

\section{To get started:}

On a Macintosh, double-click on the CD-ROM icon and double-click on the file 1_README.TXT. On a PC system with Windows, open Notepad or a word-processing application, change to the CD-ROM device, and open the file 1_README.TXT. On a UNIX work station, mount the CD. If you are unsure about the process of mounting CDs on the work station, see your system administrator for instructions. Once the CD is mounted, use your preferred ASCII text editor or web browser to open the file 1_README.TXT.

Registered trademarks: ${ }^{1}$ Apple Computer and Macintosh, Apple Computer; ${ }^{2}$ IBM, International Business Machines, Corp. ${ }^{3}$ Intel, Corp. ${ }^{4}$ Microsoft, Corp., ${ }^{5}$ Adobe Systems. 
Sackett and others, 1999, USGS OFR 99-158

\section{STRUCTURE}

This CD contains core box photographs, core scans, and a preliminary stratigraphic column of LVEW Phase III. The core box photographs were taken with a Kodak digital still camera and downloaded onto the Long Valley Coring Project computer system. The core scans were produced using a DMT CoreScan ${ }^{\circledR}$. This apparatus rolls a piece of core along its long axis while collecting a continuous digital image, thus producing a planar image of the outer surface of the core.

The optimal way to view the images on this CD is through the PDF file using Adobe Acrobat Reader, supplied on the CD. Navigation through the PDF file should begin with the stratigraphic column. The column is shown on 6 pages with 440 feet on each page. On the left side of the column are the depth intervals and on the right are a series of box numbers and brackets which designate the section of core contained in each box. To zoom in on the stratigraphic column, choose the magnifying glass tool and click over the desired section. To zoom out, choose "zoom out" under the tool section of the menu bar. To view a box photo, use the hand tool and click on the desired box number which is highlighted blue, the document will automatically go to the corresponding box photo page. To view a core scan, use the hand tool to choose from the series of core scans listed underneath the box photo which are also highlighted blue. Clicking on a core scan number will launch a viewer application that will allow you to view the JPG image.

An alternative method of viewing the images is to open the image files directly from the directory structure on the CD. The first level of the directory structure is based on depth. Each directory spans 50-foot intervals. Inside each depth directory are two sub-directories: "BOX_PHOT" for the box photos and "CORE_SCA" for the core scans. Within the box photo subdirectory are JPG images of each core box. Within the core scan subdirectory are subdirectories for each core run (increasing numerical sequence of recovered core) and within these are the JPG images of the core scans. The condition of some of the core runs was such that they were unscannable. The subdirectories representing these runs therefore contain only an explanatory file called "NO_DATA.TXT". Because the core scans and box photos do not always coincide with the exact 50-foot interval assigned to the directories, these core scans and box photos are included in adjacent directories. Please note that depths were measured from the floor of the drill rig Kelly bushing, which was 30 feet above the actual surface of the ground.

\section{OPENING JPG FILES}

Most computer systems can open JPG files using existing software (e.g. drawing programs or a web browser). Following are instructions for configuring Window, Macintosh, or UNIX systems to open JPG files.

\section{Windows users:}

Double-click the JPG file and select the application from the choices displayed. If a viewing application does not automatically launch, use the process outlined below.

Open Windows Explorer, select "View", select "Folder Options", select the "File Types" tab, and scroll down and see if "JPEG Image" is present. If so, select "Edit..." from Edit File Type, select "Edit" again, select "Application used to perform action", select "Browse", and navigate to the application of your choice. Web browsers such as Netscape Navigator/Communicator or Microsoft Internet Explorer will work or you can use drawing or image processing applications such as Adobe Photoshop, or Photoworks Darkroom.

If "JPEG Image" is not present in the "File Types tab", select "New Type..." and fill in the dialog box. "Description of type" is "JPEG Image", "Associated extension" is ".jpg", "Content Type" is "image/jpg", "Default Extension for Content Type" is ".jpg". For the 
"Actions" window, select the "New..." button. Under "Action" enter "open", under "Application used to perform action" select "Browse", and navigate to the application of your choice.

\section{Macintosh users:}

Double-click the JPG file and select the application from the choices displayed. Alternatively, you can simply "drop launch" the file. JPG files can also be opened from within applications that can view JPEG's such as Netscape Navigator, Microsoft Internet Explorer, Adobe Photoshop, Aaron Giles' JPEGView, Kevin Mitchell's GIFConverter, Storm Software's EasyPhoto. In these, as in other Macintosh applications, files are opened by selecting File, Open, navigating to the file to be opened, and clicking Open.

\section{UNIX users:}

Double-click the JPG file. This will automatically open the preferred JPG viewer on your UNIX work station.

\section{READING INSTRUCTIONS -}

\section{Understanding Core Box and Core Scan Nomenclature}

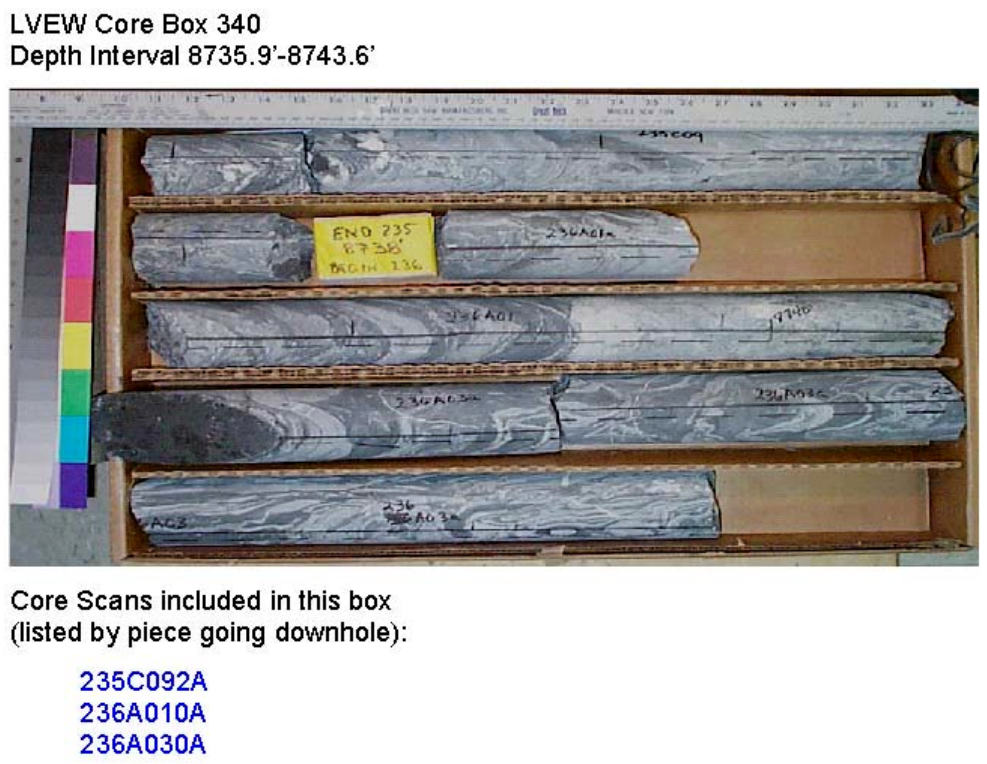

See the "reading instructions" section of the introduction for help interpreting core box photos and core piece nomenclature

Above is a sample box photo page from the PDF file. Above the box photo is the core box number and corresponding depth interval. Depth increases to the right and down through the rows. The core pieces for which there are core scans are linked and highlighted in blue below the core box.

Core scans have 8-character names. The first three characters indicate the core run number. The fourth character indicates a set of pieces that naturally fit together, starting with A. The fifth and sixth characters are subpiece numbers within the set. The eighth character describes the condition of the core piece as follows: 
- A-Artificial. Pieces longer than two feet were artificially cut in order to fit into a core box. These pieces were later fit back together to be scanned, and a " 0 " was placed as the seventh character. Some pieces were longer than the core box and longer than the three foot bed of the core scanner. These pieces needed to be scanned separately because they did not fit in the core scanner. In this case, the separate scans had seventh character designators beginning with 1 and increasing as needed.

- E-extra. This usually reflects core picked up from a previous run.

- R-rolled. This designates pieces of core recovered during a run that have been damaged by the drilling and thus the exact depth cannot be determined.

\section{CORE REQUEST PROTOCOL}

All of the core from LVEW is stored at the USGS Core Research Center (CRC) at the Federal Center in Denver, Colorado. The CRC staff is severely limited, so we strongly urge that researchers begin core selection with examination of the core box photographs and core scan images contained herein, and then proceed (if necessary) to study of the high-resolution images on the Archive CDs. Archive CDs are located at the CRC (Denver, CO), Sandia National Laboratories (Albuquerque, NM), DOSECC Inc. (Salt Lake City, UT), USGS Library (Menlo Park, CA), and the Data Clearing House, International Continental Scientific Drilling Program (Potsdam, Germany). For full addresses see list below.

After a researcher has narrowed down his/her choices through examination of core images, a request to examine specific core should be sent to: Thomas C. Michalski, Director, USGS Core Research Center (see address list below).

A mutually acceptable schedule will then be agreed upon for a visit to the CRC. At the same time, a proposal detailing the approximate number and lengths of core, the research plan for the core, and a schedule for return of the pieces not destroyed should be forwarded to:

LVEW Core Allocation Panel, c/o Vicki S. McConnell, Oregon Department of Geology and Mineral Industries (see address list below).

CRC Staff will, as time and other commitments permit, assist with sampling of cores. However, it may be necessary, when large numbers of splits are required and/or deadlines are tight, for PIs to pay for additional help.

Financial arrangements for slabbing, plugging, or specialized machining of large batches of core will need to be made with CRC approved contractors.

\section{Archive CD locations and core repository}

Thomas C. Michalski, Director, USGS Core Research Center

PO Box 25046, Denver Federal Center, MS 975

Denver, CO, 80225-0046

email: tmichalski@usgs.gov

phone: 303-202-4852

fax: 303-202-4856. 
LVEW Core Allocation Panel, c/o Vicki S. McConnell Oregon Department of Geology and Mineral Industries 1831 First Street Baker City, OR 97184-3442

email: Vicki.McConnell@ state.or.us phone: 541-523-3133

fax: 541-523-5992.

Sandia National Laboratories c/o John T. Finger Albuquerque, NM 87185-1033

OR c/o Ronald D. Jacobson email: jtfinge@sandia.gov Albuquerque, NM 87185-1033 phone: 505-844-8089

fax: 505-844-3952 email: rdjacob@sandia.gov phone: $505-844-0938$ fax: 505-844-3952

International Continental Scientific Drilling Program c/o Ronald Conze, Information Manager of Operational Support Group ICDP Telegraphenberg, D-14473 Potsdam email: conze@gfz-potsdam.de phone: +49 (0) 3312881513

fax +49 (0) 331288 1502/1512

DOSECC INC c/o Dennis Nielson, Energy and Geoscience Institute University of Utah, 423 Wakara Way

Salt Lake City, UT 84108

email: dnielson@egi.utah.edu

phone: 801-585-6855

fax: 801-585-3540

USGS - Library

c/o Nancy Blair

345 Middlefield Road, MS 955

Menlo Park, CA 94025

email: nblair@igsmglib01.wr.usgs.gov

phone: 650-329-5029

reference desk: 650-329-5027

\section{ACKNOWLEDGEMENTS}

The authors wish to express their sincere appreciation to all that helped with the Long Valley Coring Project. In particular, we would like to thank Alex Acosta, Kevin Adams, Roy Bailey, Glenn Bennett, Larry Beyer, Nancy Blair, AJ Blanton, Chuck Bowers, Ronald Conze, Mike Diggles, Wendell Duffield, Chris Farrar, Judy Fierstein, John Finger, Fredd Grubb, Christopher Isbell, Ron Jacobson, Shannon Krasel, Frank Krysiak, Jake Lowenstern, Tom Michalski, Dennis Nielson, Steve Quane, Nodi Rafat, Peter Stauffer, Bob Tilling, and Roy Wilkens. 


\section{REFERENCES CITED}

Bailey, R.A., 1998, oral communication.

Bailey, R.A., 1989, Geologic map of Long Valley Caldera, Mono-Inyo volcanic chain, and vicinity, Eastern California, USGS Miscellaneous Investigations Series Map I1933.

Hickman, S.H., 1998, oral communication.

McConnell, V.S., Shearer, C.K., Eichelberger, J.C., Keskinen, M.J., Layer, P.W., and Papike, J.J., 1995, Rhyolite intrusions in the intracaldera Bishop Tuff, Long Valley Caldera, California, Journal of Volcanology and Geothermal Research, v. 67, p. 42-60.

McConnell, V.S., Valley, J.V., and Eichelberger, J.C., 1997, Oxygen isotope compositions of intracaldera rocks: hydrothermal history of the Long Valley Caldera, California, Journal Volcanology and Geothermal Resources, v. 76, p. 83109.

McConnell, V.S., Roach, A.L., Sackett, P.C., and Sass, J.H., 1989, Long Valley Caldera revealed: A glimpse beneath a Quaternary caldera, EOS, Transactions, American Geophysical Union, v. 79, no. 36, p. 429-432.

Sass, J.H., Jacobson, R., and Sorey, M.L., 1991, Implications of thermal observations in the Long Valley Exploratory Well, EOS, Transactions, American Geophysical Union, v. 72, p. 505.

Sass, J.H., Finger, J.T., and McConnell, V.S., 1998, The Long Valley Coring Project, Geothermal Resources Council Bulletin, v. 27, p. 43-50. 


\section{FIGURES}

\section{Long Valley Caldera}

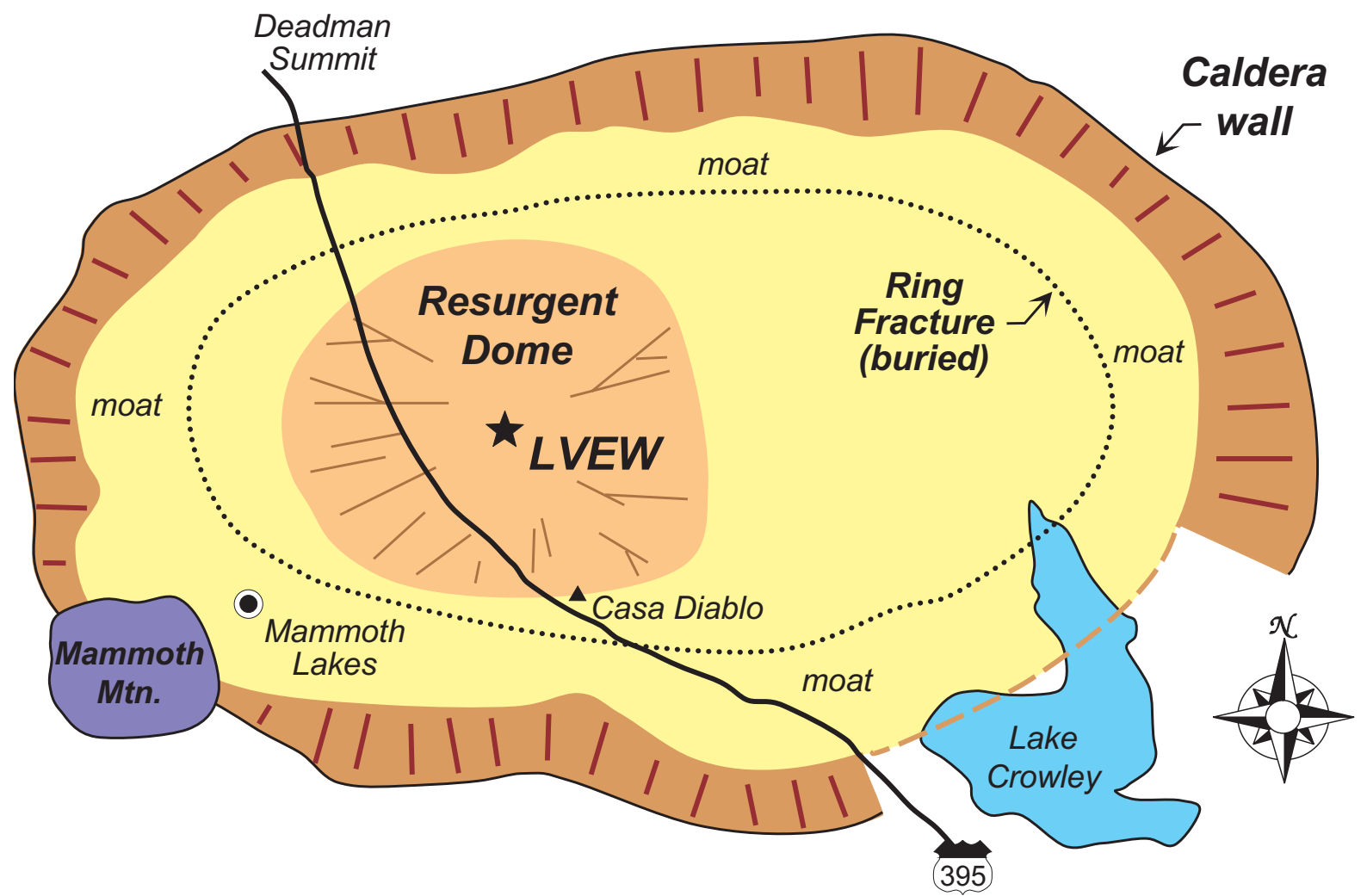

Figure 1. Generalized map of the Long Valley Caldera, California, showing the resurgent dome, Long Valley Exploratory Well, and significant post-caldera-collapse volcanic areas. 


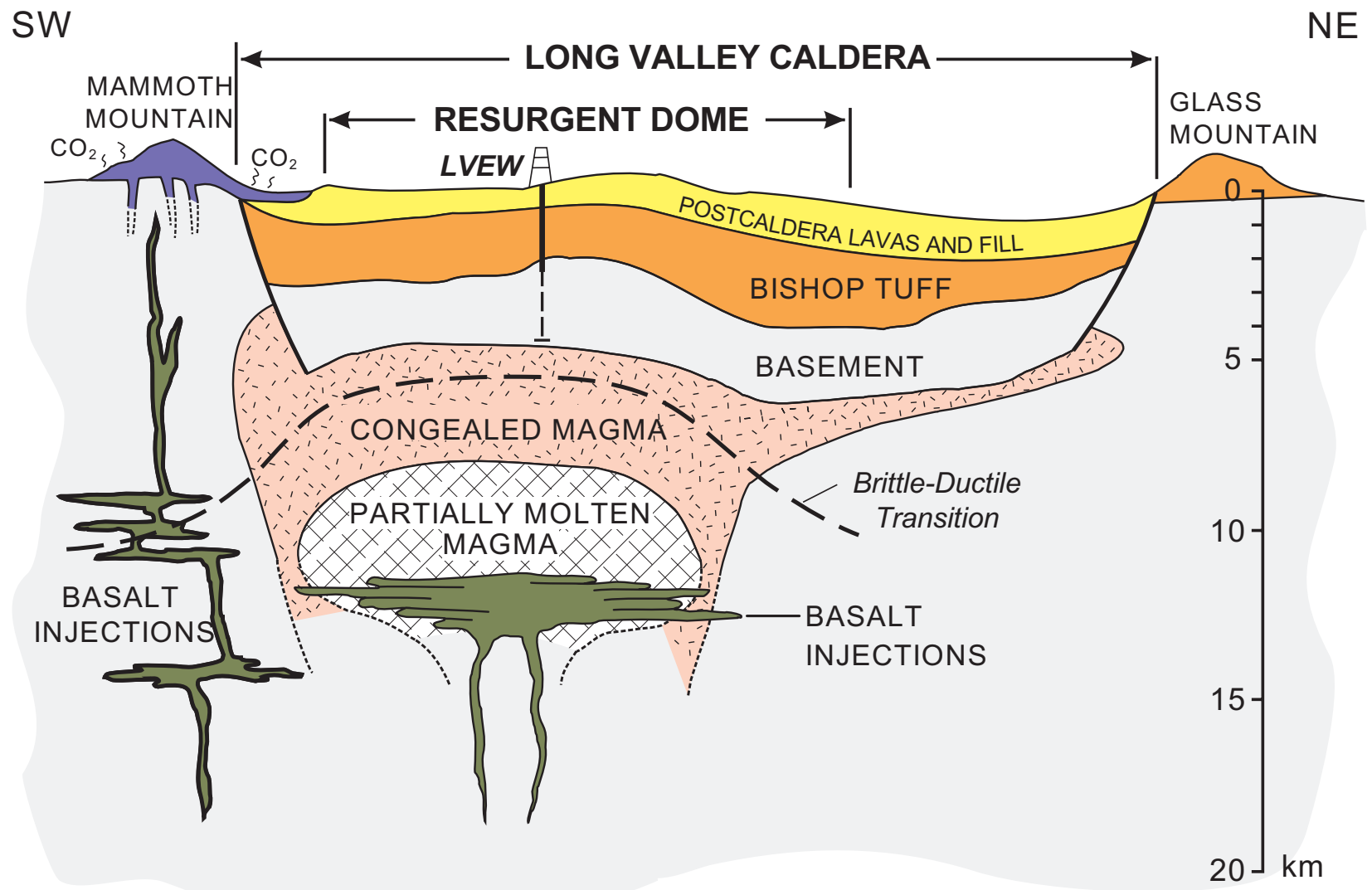

Figure 2. Cross-section from southwest-to-northeast across the caldera complex (R.A. Bailey, oral communication, 1998). The working hypothesis for the presence of recurring volcanic activity associated with the caldera is that mafic injections occur periodically resulting in convective overturn of the rhyolitic magma chamber causing near surface intrusions and volcanic activity. The intrusions then drive periodic hydrothermal fluxes possibly originating in the basement rocks and then traveling laterally through the caldera volcanic fill. 


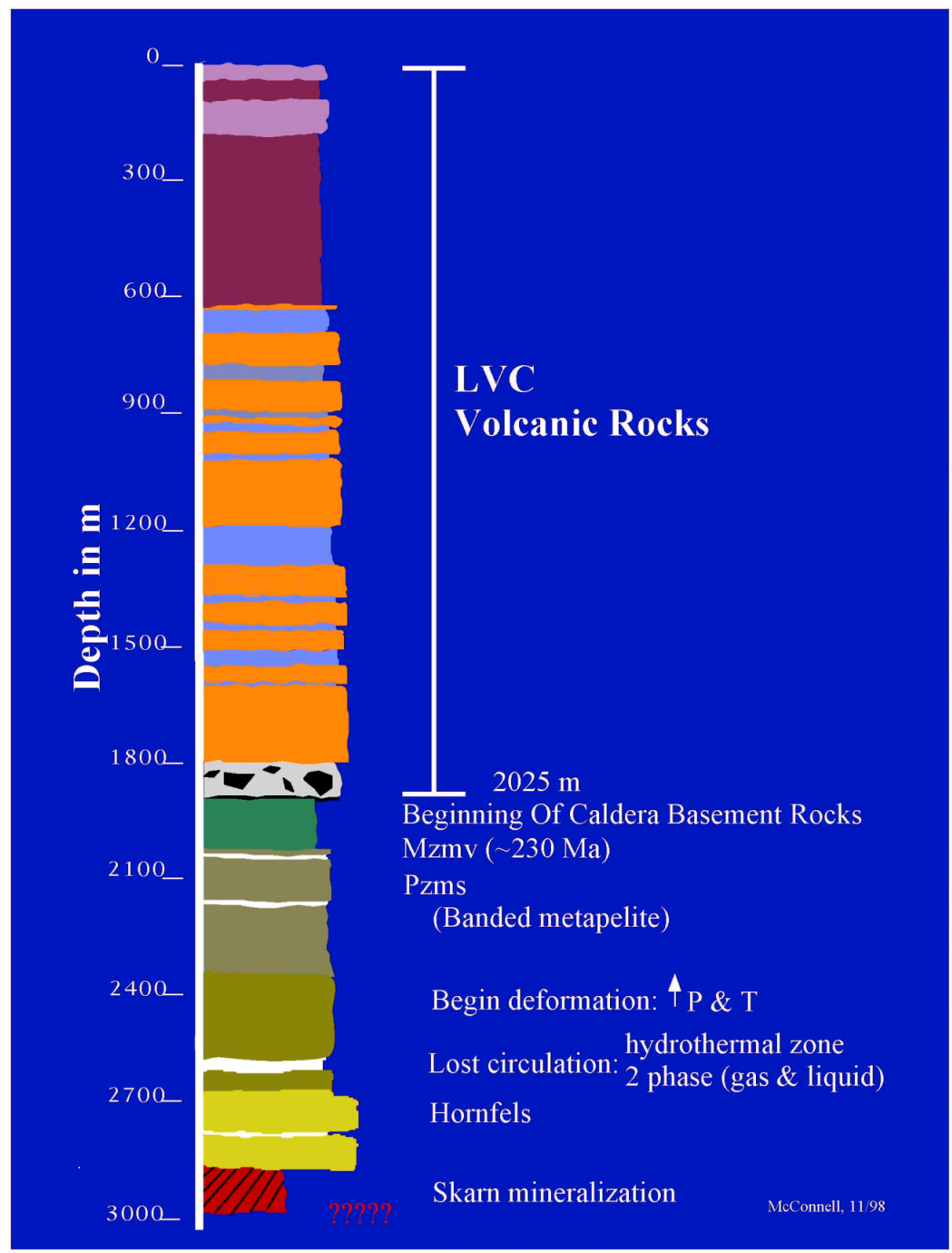

Figure 3. Generalized stratigraphy of the entire Long Valley Exploratory Well. Phases I and II passed through the post-caldera rhyolite flows and domes of the Early Rhyolite unit (purple) and the intra-caldera ashflow fill of the Bishop Tuff (orange). Intruded into the intra-caldera Bishop Tuff are numerous hypabyssal Early Rhyolite granophyric rocks (blue). The basement to the caldera consists of metavolcanic (Mzmv) and metasedimentary rocks (Pzms). The banded metapelites, hornfels, and metaquartzites (white), and calcsilicate rocks are correlated to the Mt. Morrison roof pendant in the nearby Sierra Nevada. Phase III (Long Valley Coring Project) reaches from 7200 to 9831 feet. 


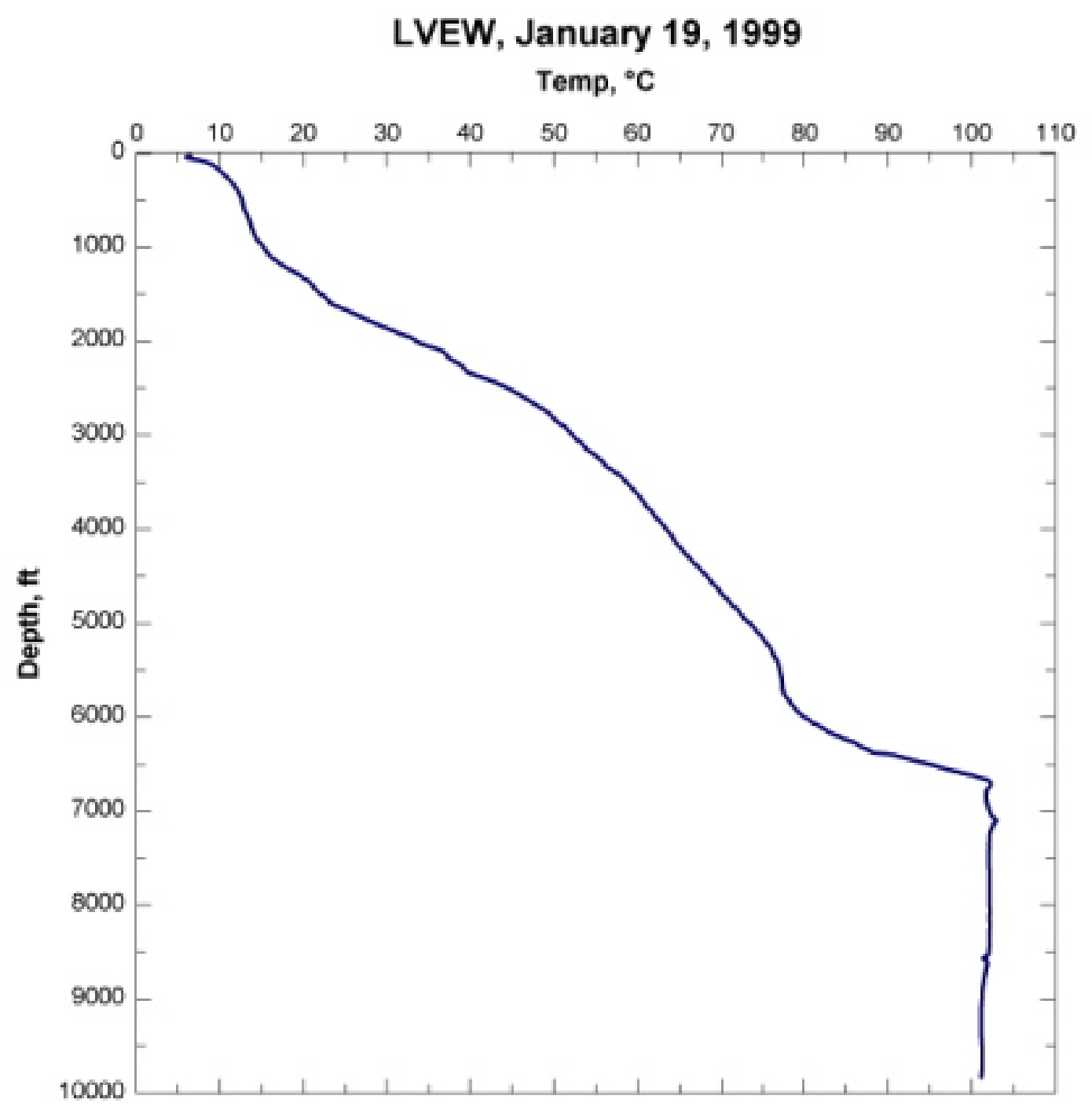

Figure 4. Temperature profile for LVEW from data collected by Ron Jacobson, Sandia National Laboratories. Note the relatively normal geothermal gradient to approximately 6500 feet. Temperatures then become essentially isothermal to the bottom of the well. 


\section{Stratigraphic Column for LVEW Phase III, page 1}
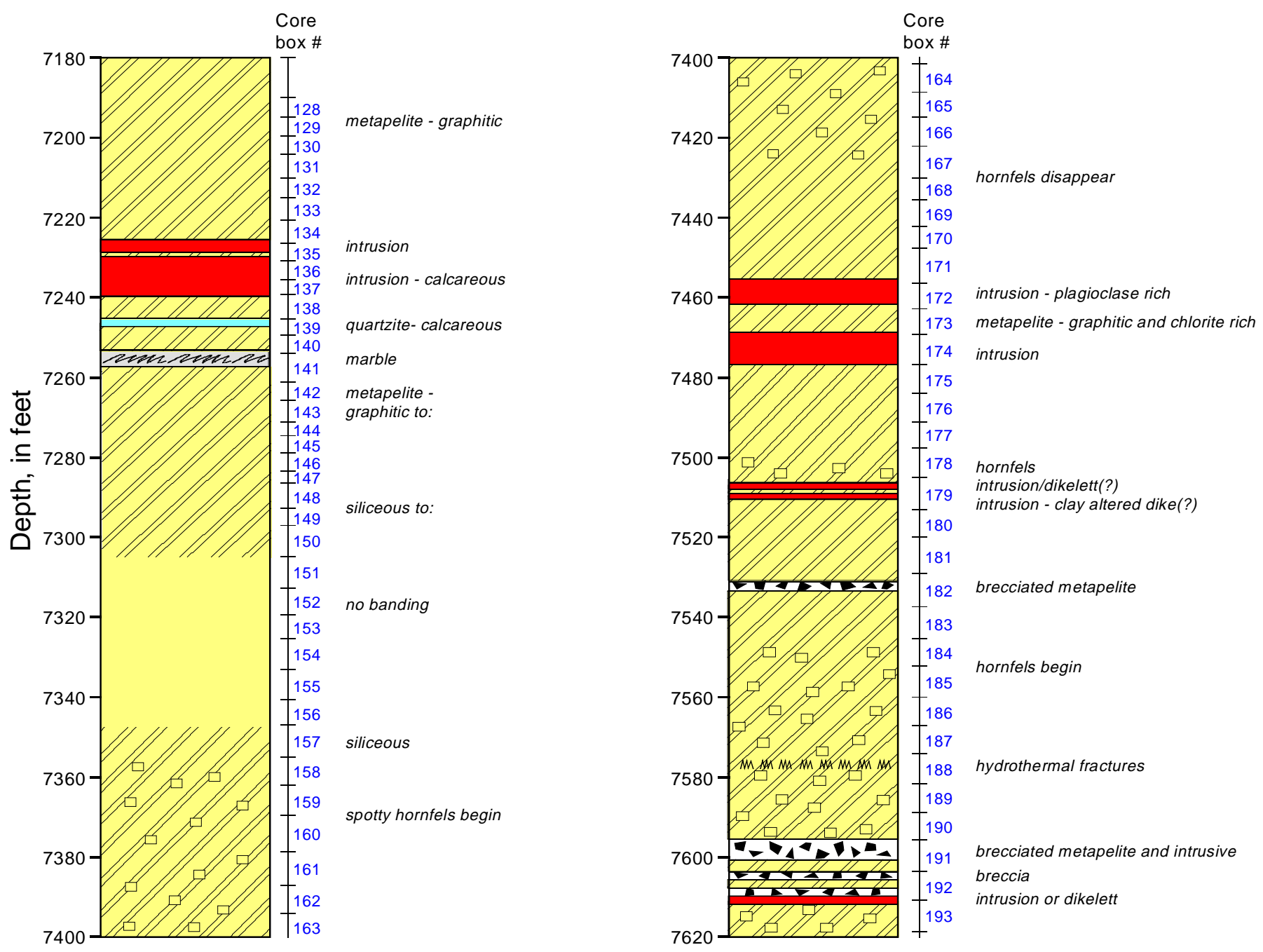

\section{Explanation}

Metapelite with banding

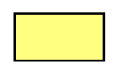

Metapelite no banding

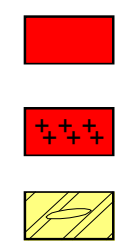

Intrusion

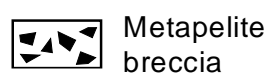

$M M M$

Hydrothermal

Quartzite

Intrusion-

Hornfels

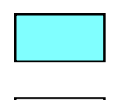

Metapelite with ductile deformation

Calc-silicate

Sandstone

Boudinage deformation veins/fractures

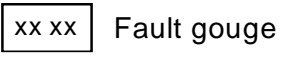

$\square \square$ 2nd generation garnets 


\section{LVEW Core Box 128}

Depth Interval 7190.0'-7194.8'

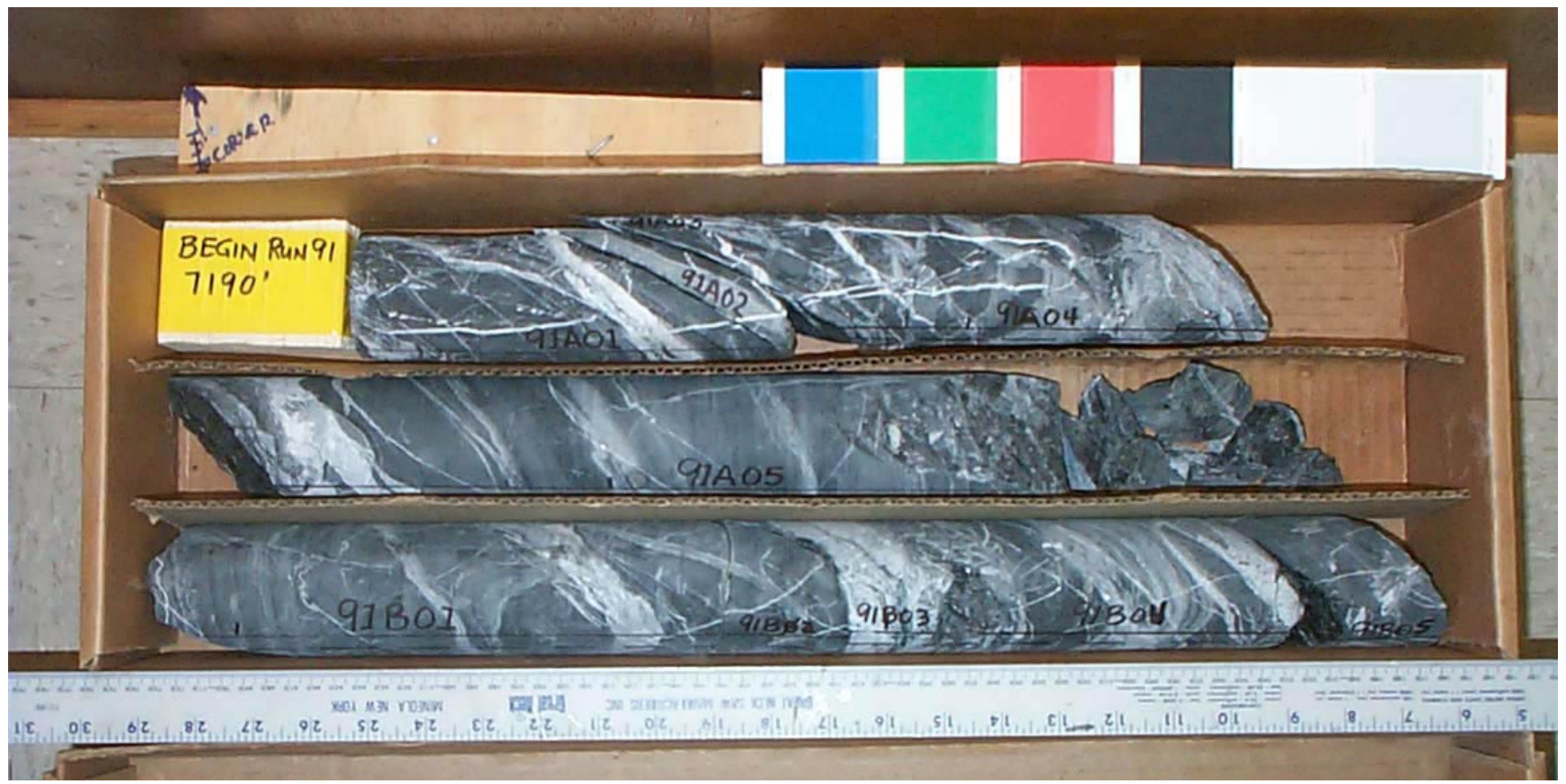

Core Scans included in this box (listed by piece going downhole):
$091 \mathrm{~A} 0100$
$091 \mathrm{~A} 0400$
$091 \mathrm{~A} 0500$
$091 \mathrm{~B} 0100$
$091 \mathrm{~B} 0400$
091B0500

See the "reading instructions" section of the introduction for help interpreting core box photos and core piece nomenclature 
LVEW Core Box 129

Depth Interval 7194.8'-7199.7'

\section{Box Photo Missing}

Core Scans included in this box

(listed by piece going downhole):

091B0600

091B0900

091B1100

091B1200

091B1300

091B1400

091B1500

091B1600

See the "reading instructions" section of the introduction for help interpreting core box photos and core piece nomenclature 


\section{LVEW Core Box 130}

\section{Depth Interval 7199.7'-7204.0'}

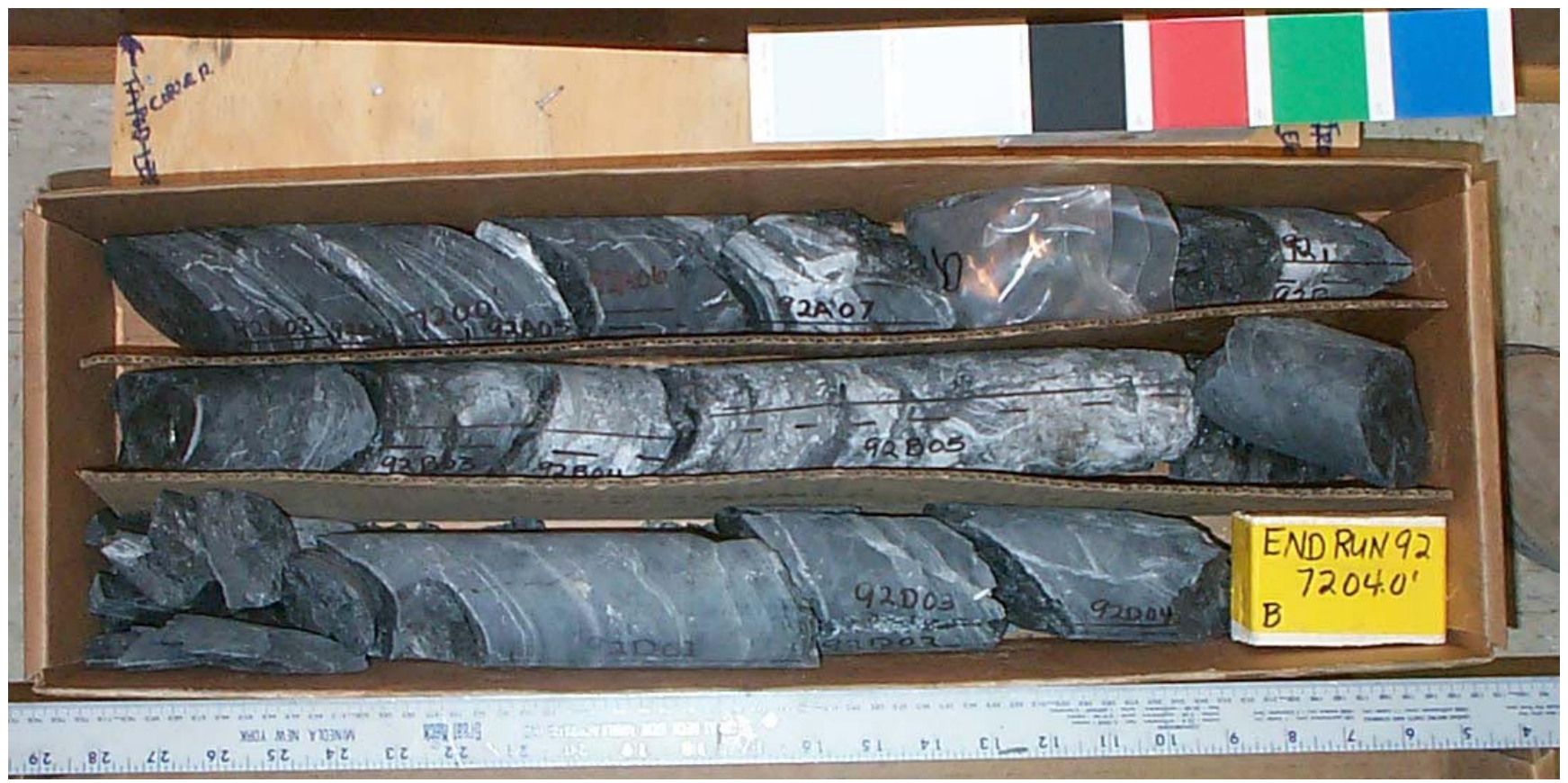

Core Scans included in this box (listed by piece going downhole):
$092 \mathrm{~A} 0100$
092B0500
$092 \mathrm{D} 0100$
092D0400

See the "reading instructions" section of the introduction for help interpreting core box photos and core piece nomenclature 


\section{LVEW Core Box 131}

Depth Interval 7204.0'-7210.0

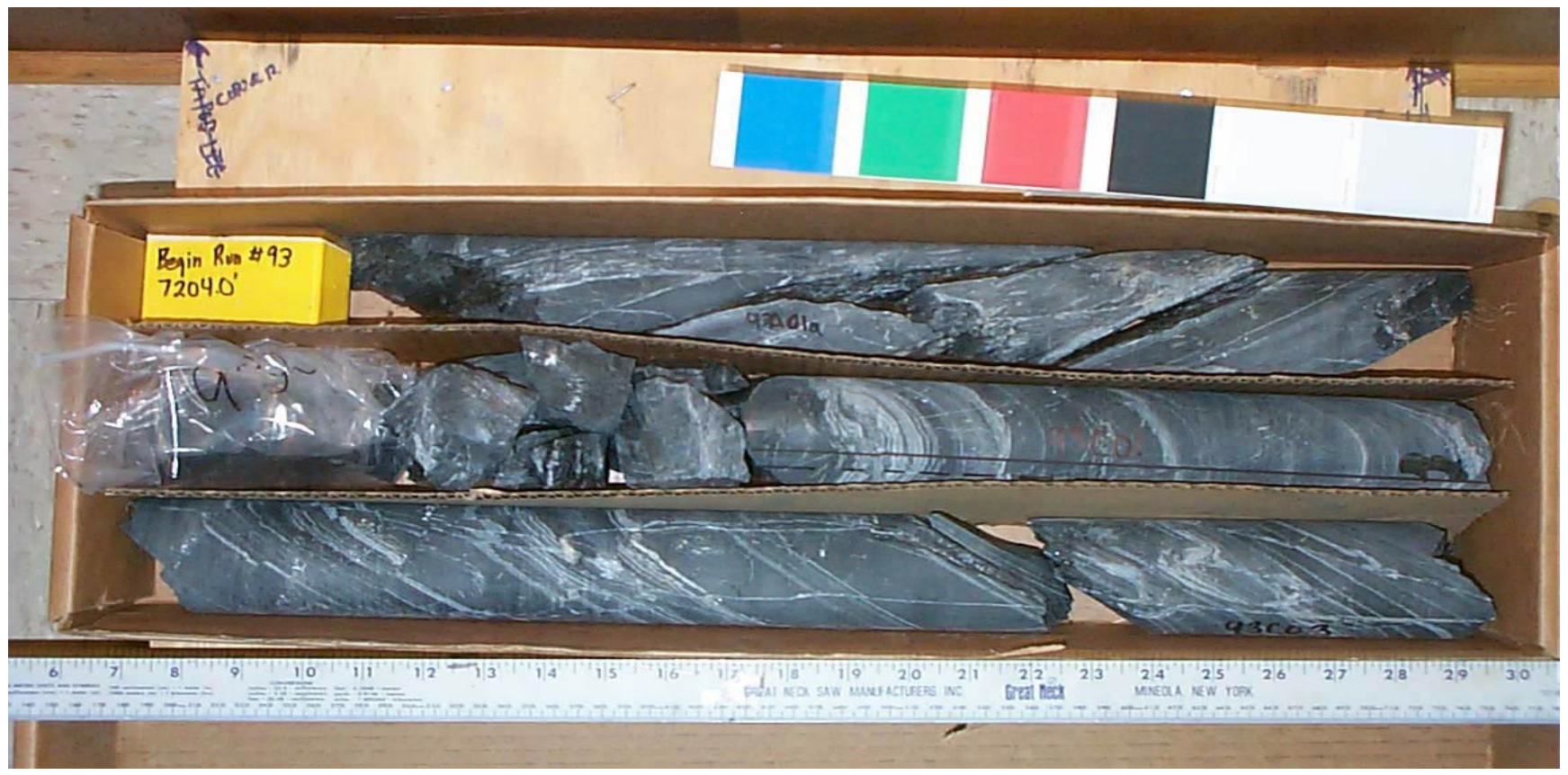

Core Scans included in this box (listed by piece going downhole):
093A0300
$093 \mathrm{C} 0100$
$093 \mathrm{C} 0200$
$093 \mathrm{C} 0300$

See the "reading instructions" section of the introduction for help interpreting core box photos and core piece nomenclature 


\section{LVEW Core Box 132}

\section{Depth Interval 7210.0'-7215.0'}

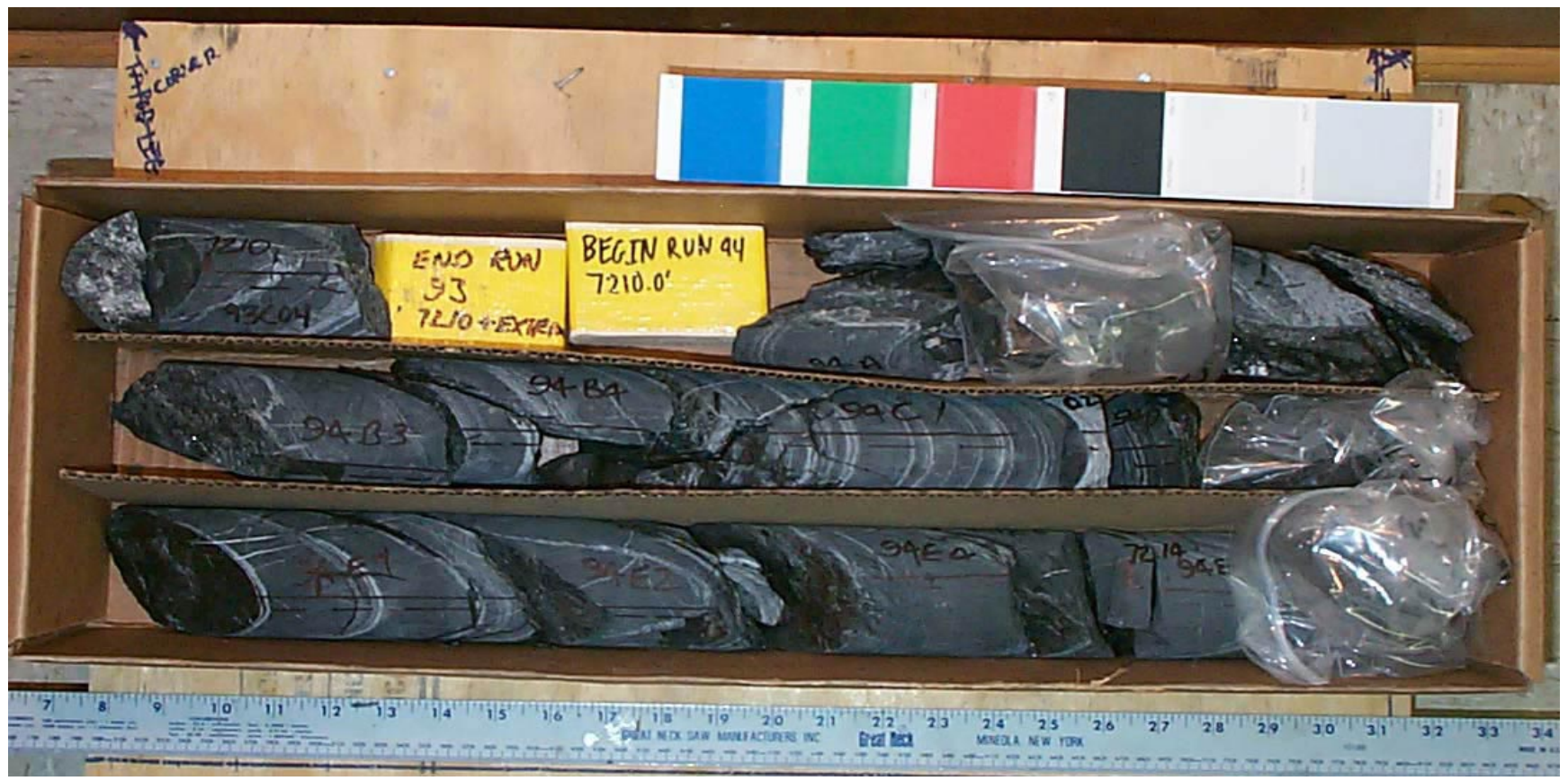

Core Scans included in this box (listed by piece going downhole):
$093 \mathrm{C} 0400$
094B0300
094C0100
094E0100

See the "reading instructions" section of the introduction for help interpreting core box photos and core piece nomenclature 


\section{LVEW Core Box 133}

Depth Interval 7215.0'-7220.5'

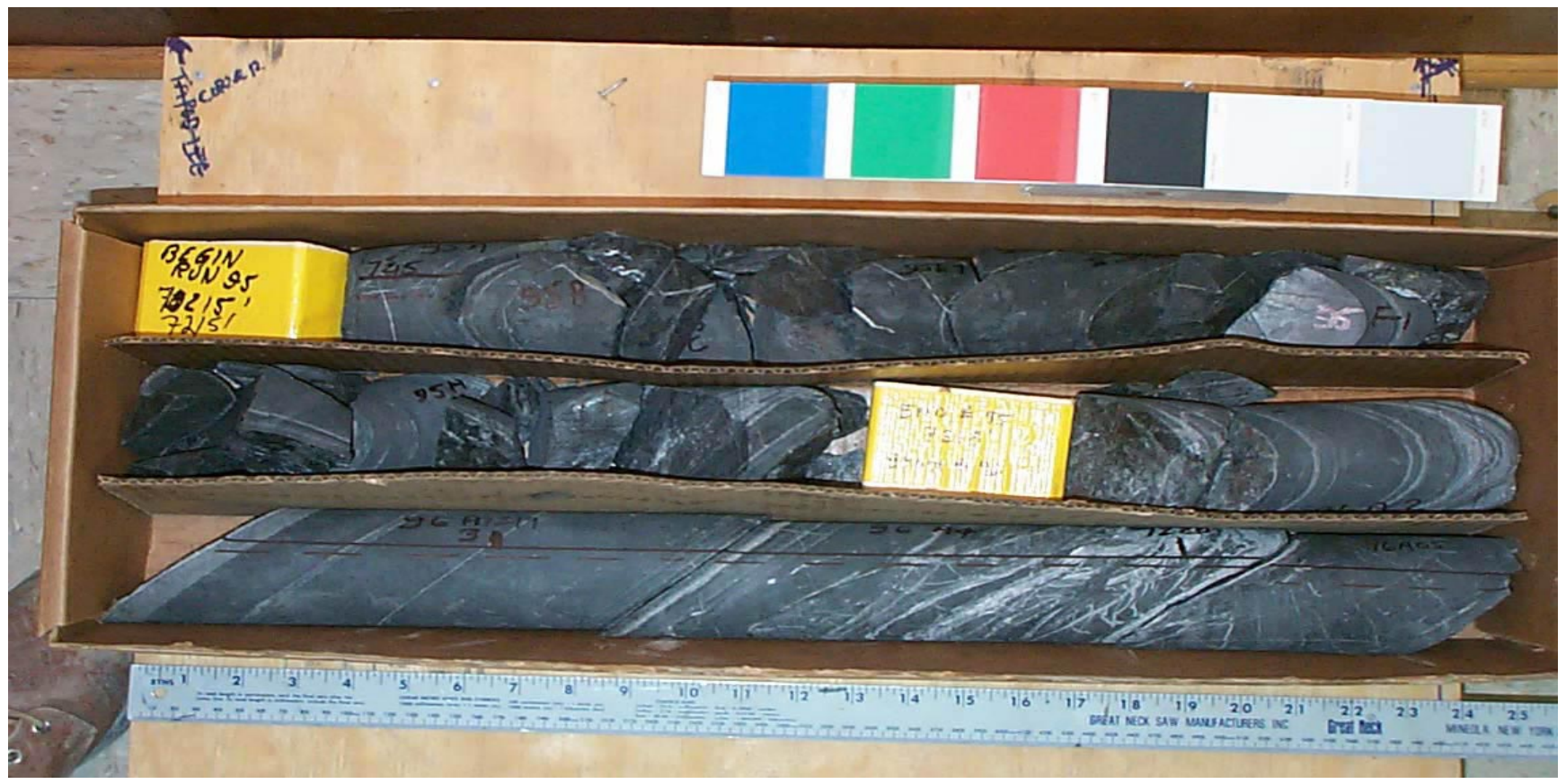

Core Scans included in this box (listed by piece going downhole):
096A0200
096A0300
096A0400
096A0500

See the "reading instructions" section of the introduction for help interpreting core box photos and core piece nomenclature 


\section{LVEW Core Box 134}

Depth Interval 7220.5'-7226.3'

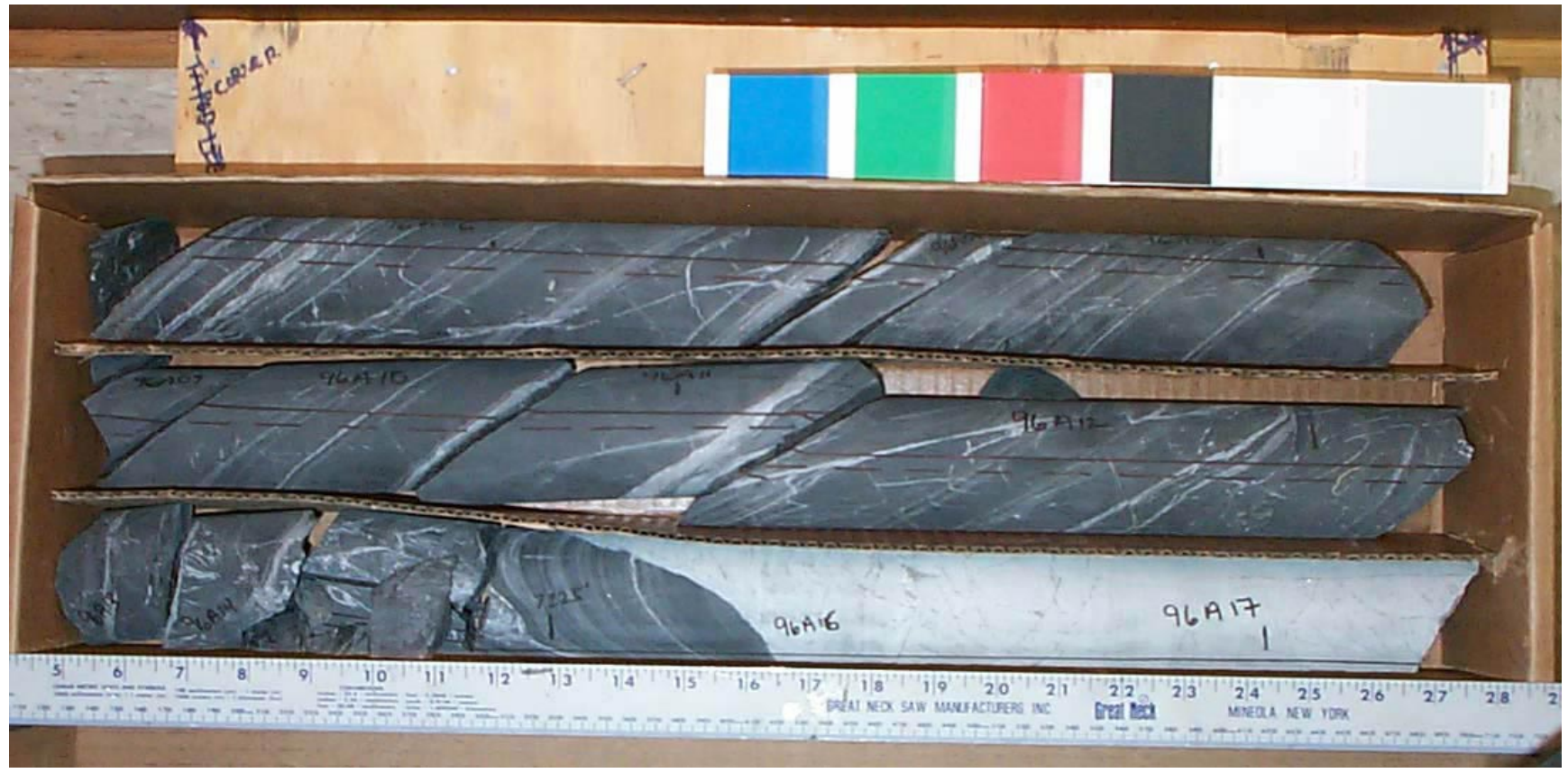

Core Scans included in this box (listed by piece going downhole):
096A0600
096A0800
096A1000
096A1100
096A1200
096A1600

See the "reading instructions" section of the introduction for help interpreting core box photos and core piece nomenclature 


\section{LVEW Core Box 135}

Depth Interval 7226.3'-7230.7'

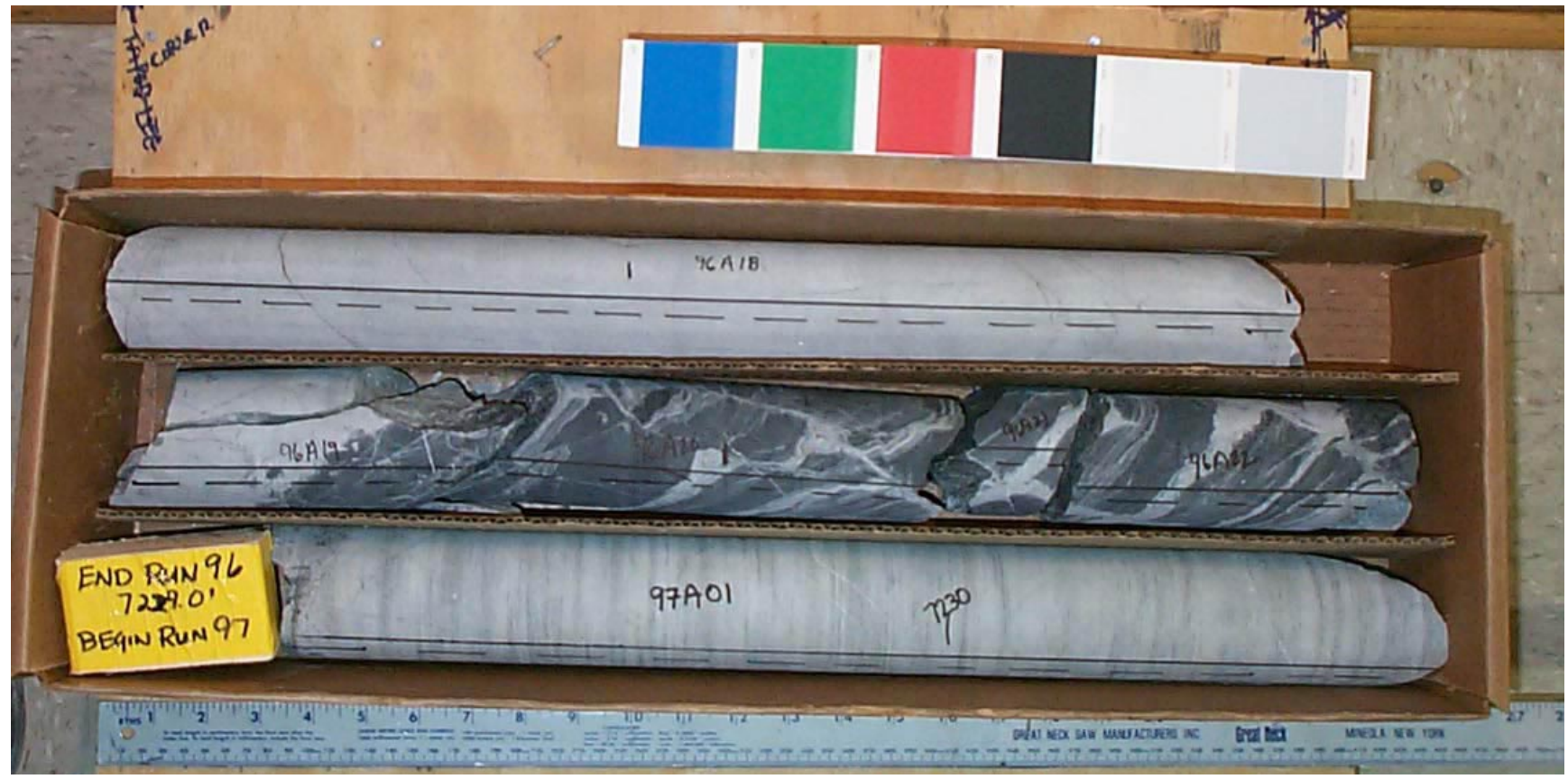

Core Scans included in this box (listed by piece going downhole):
096A1800
096A2000
096A2100
096A2200
097A0100

See the "reading instructions" section of the introduction for help interpreting core box photos and core piece nomenclature 


\section{LVEW Core Box 136}

Depth Interval 7230.7'-7235.6'

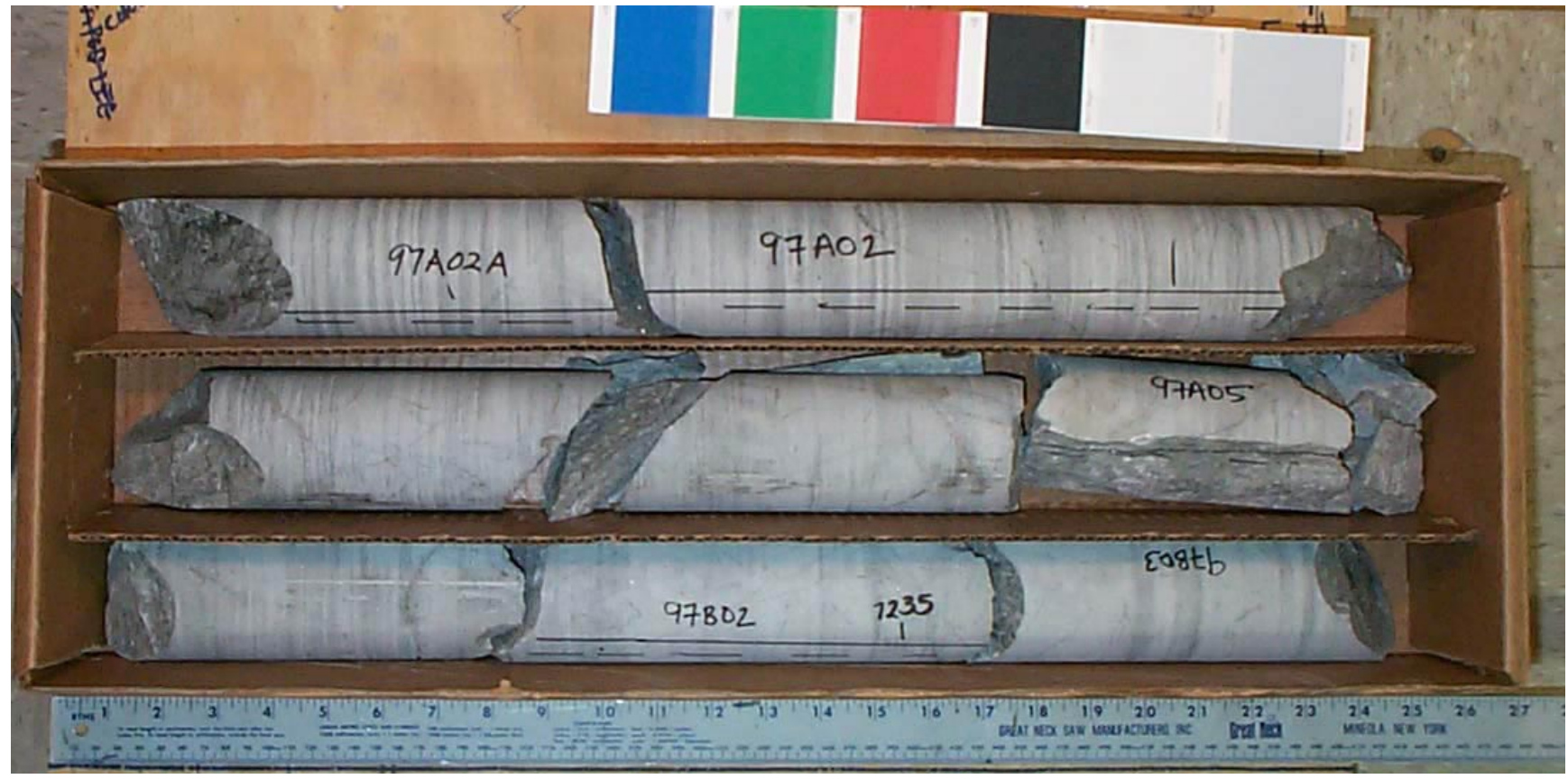

Core Scans included in this box (listed by piece going downhole):
097A020A
$097 \mathrm{~B} 0100$
097B0200
097B0300

See the "reading instructions" section of the introduction for help interpreting core box photos and core piece nomenclature 


\section{LVEW Core Box 137}

Depth Interval 7235.6'-7239.5'

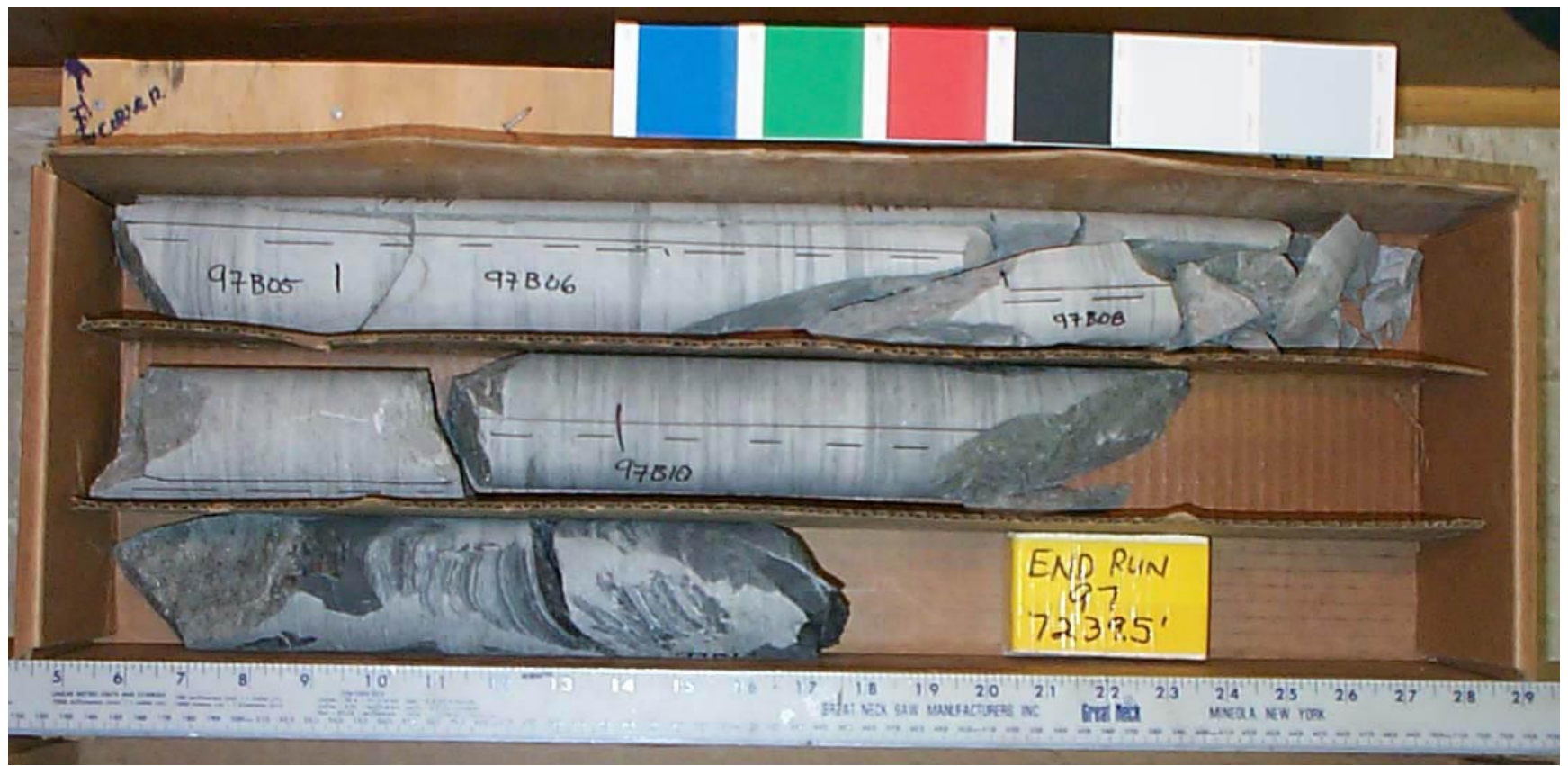

Core Scans included in this box (listed by piece going downhole):
097B1000
097B1200
097B1300

See the "reading instructions" section of the introduction for help interpreting core box photos and core piece nomenclature 


\section{LVEW Core Box 138}

Depth Interval 7239.5'-7245.7'

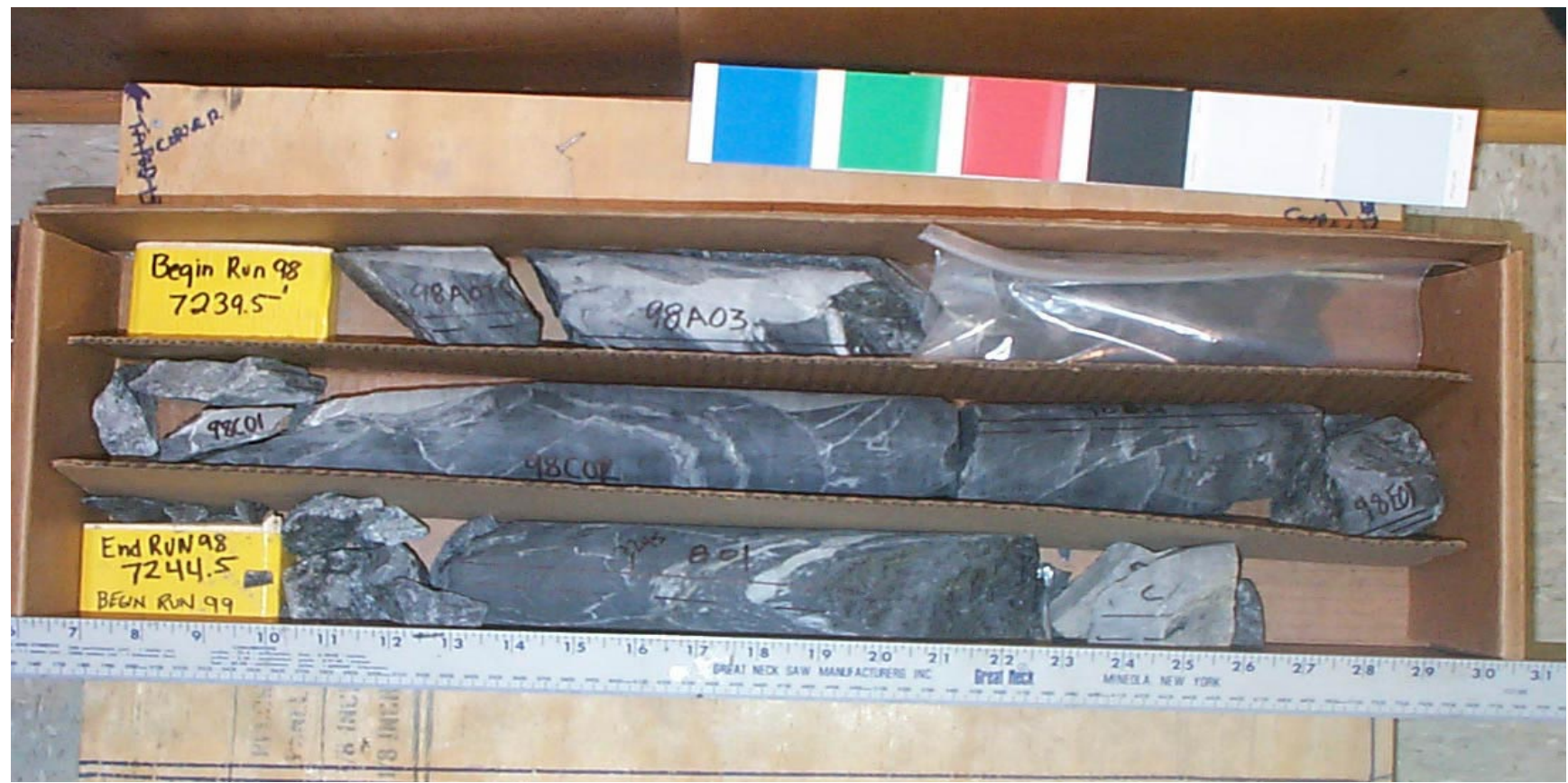

Core Scans included in this box (listed by piece going downhole):
$098 \mathrm{C} 0200$
098D0100
099B0100

See the "reading instructions" section of the introduction for help interpreting core box photos and core piece nomenclature 


\section{LVEW Core Box 139}

\section{Depth Interval 7245.7'-7249.5'}

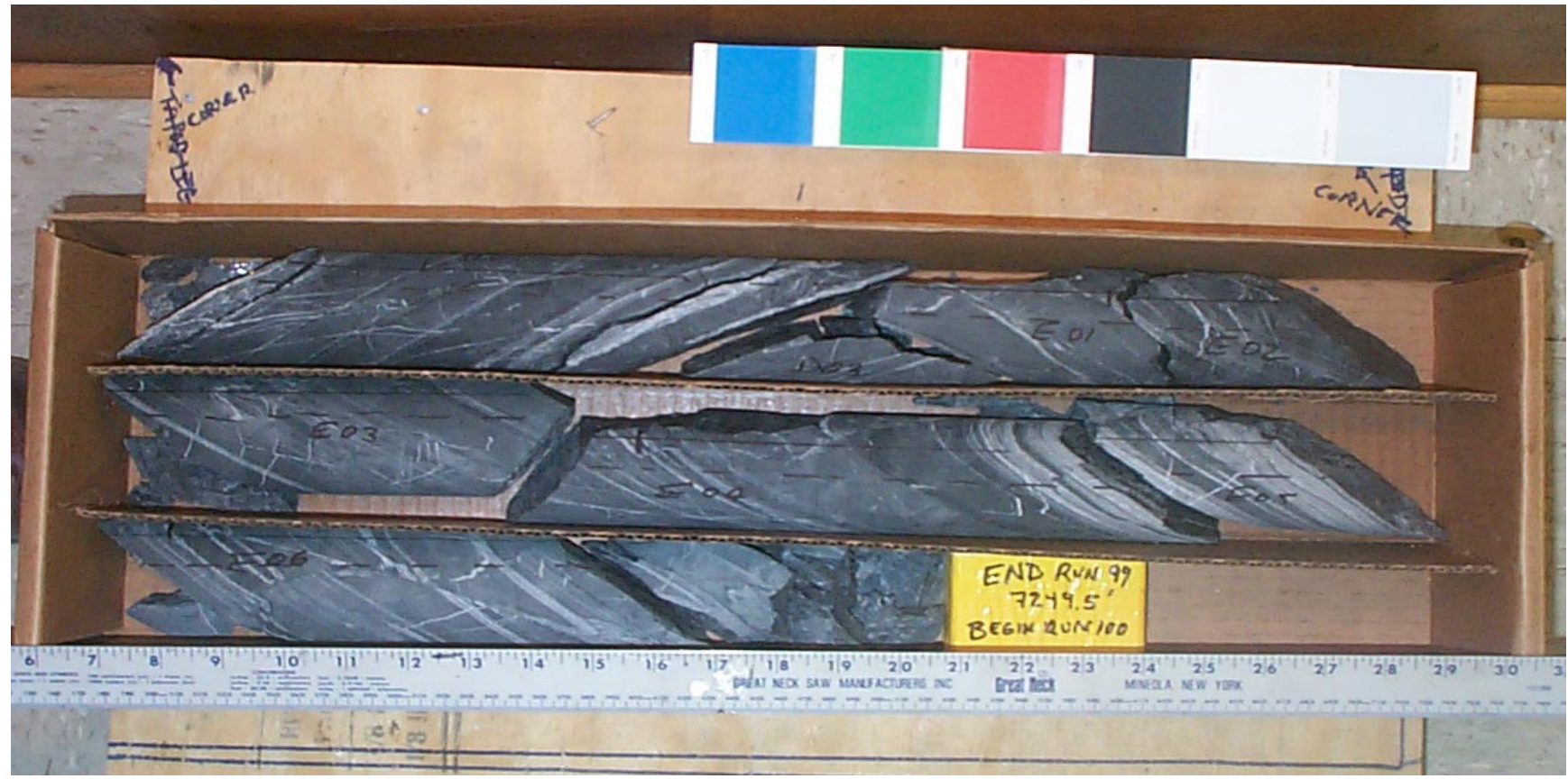

Core Scans included in this box (listed by piece going downhole):
099D0100
099E0300
099E0400
099E0600

See the "reading instructions" section of the introduction for help interpreting core box photos and core piece nomenclature 


\section{LVEW Core Box 140}

Depth Interval 7249.5'-7254.0'

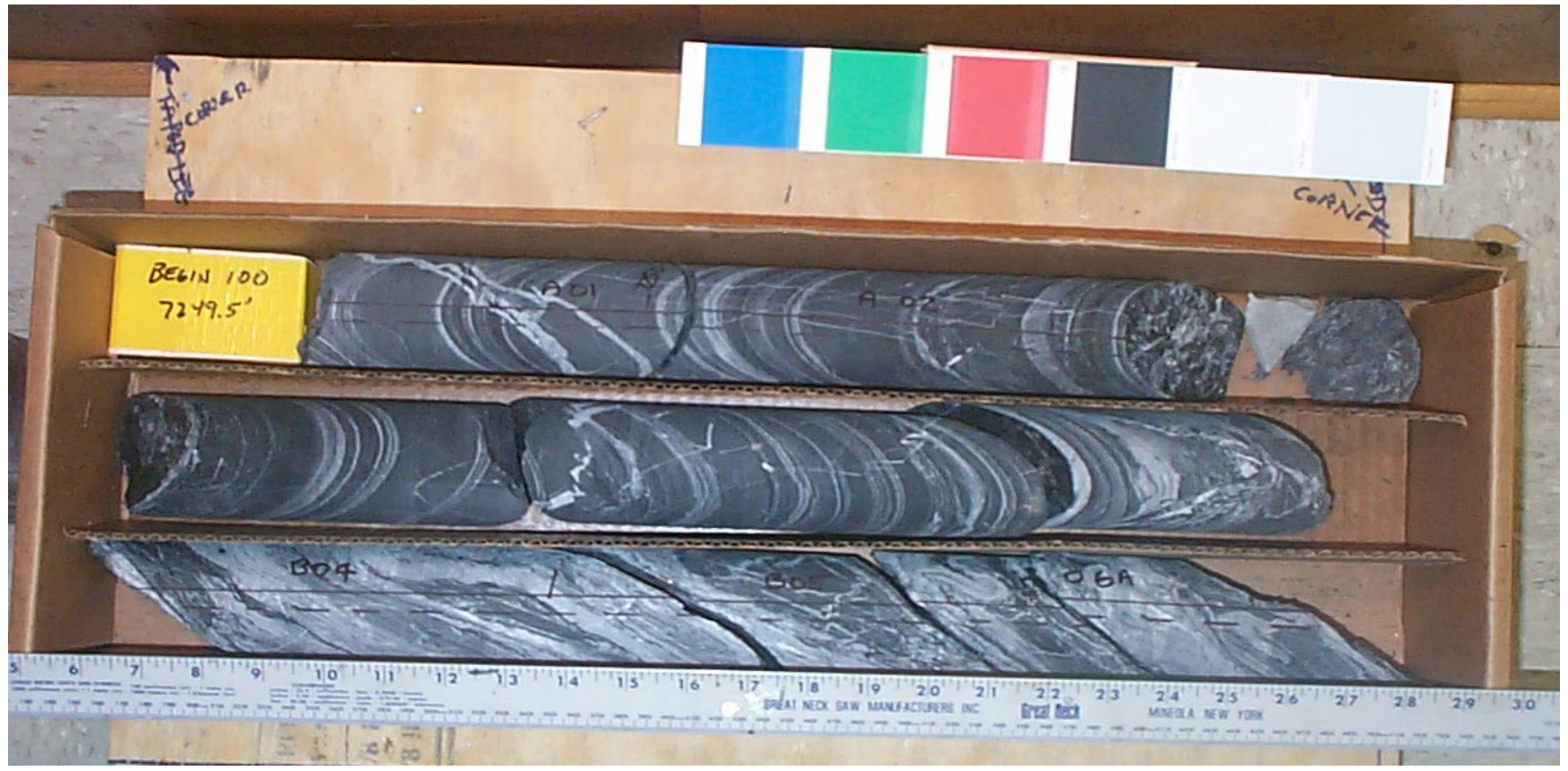

Core Scans included in this box

(listed by piece going downhole):
$100 \mathrm{~A} 0100$
$100 \mathrm{~A} 0200$
100B0100
100B0200
100B0300
100B0400
100B0500
100B060A

See the "reading instructions" section of the introduction for help interpreting core box photos and core piece nomenclature 


\section{LVEW Core Box 141}

\section{Depth Interval 7254.0'-7261.0'}

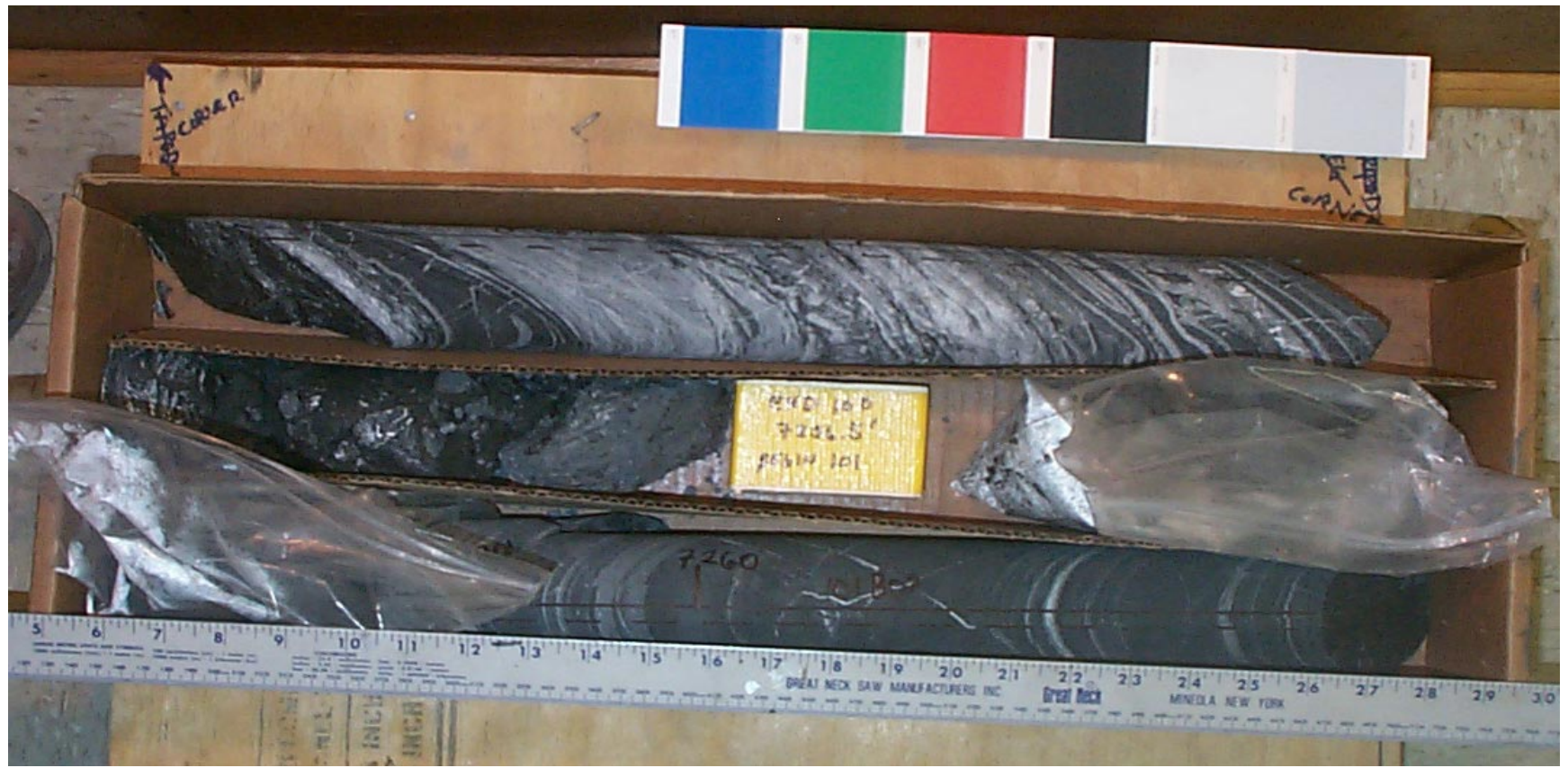

Core Scans included in this box (listed by piece going downhole):

\section{B0700}

$101 \mathrm{~B} 0200$

See the "reading instructions" section of the introduction for help interpreting core box photos and core piece nomenclature 


\section{LVEW Core Box 142}

Depth Interval 7261.0'-7265.9'

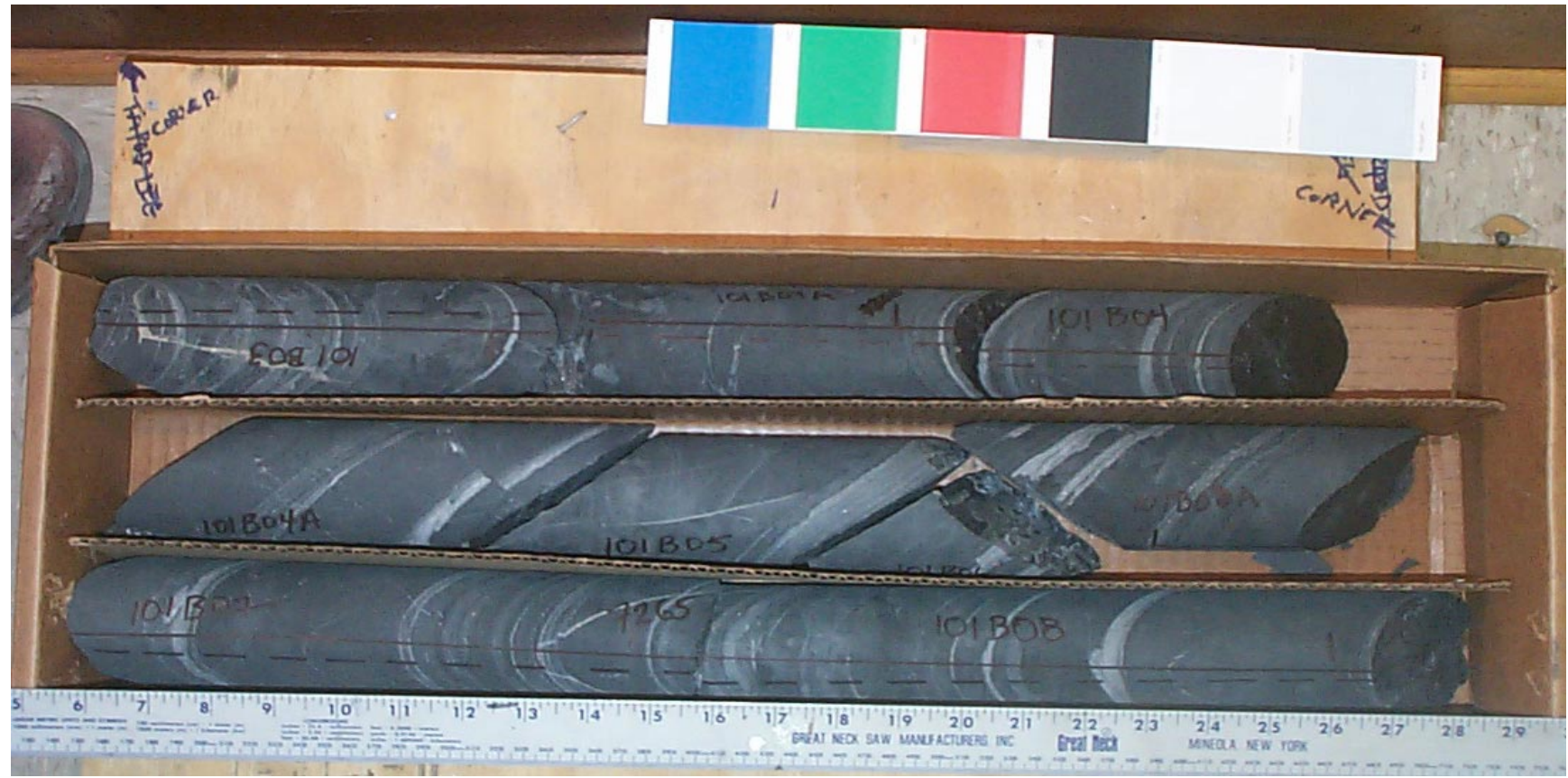

Core Scans included in this box (listed by piece going downhole):
101B0300
101B040A
$101 \mathrm{~B} 0500$
101B070A
$101 \mathrm{~B} 0800$

See the "reading instructions" section of the introduction for help interpreting core box photos and core piece nomenclature 


\section{LVEW Core Box 143}

Depth Interval 7265.9'-7271.1'

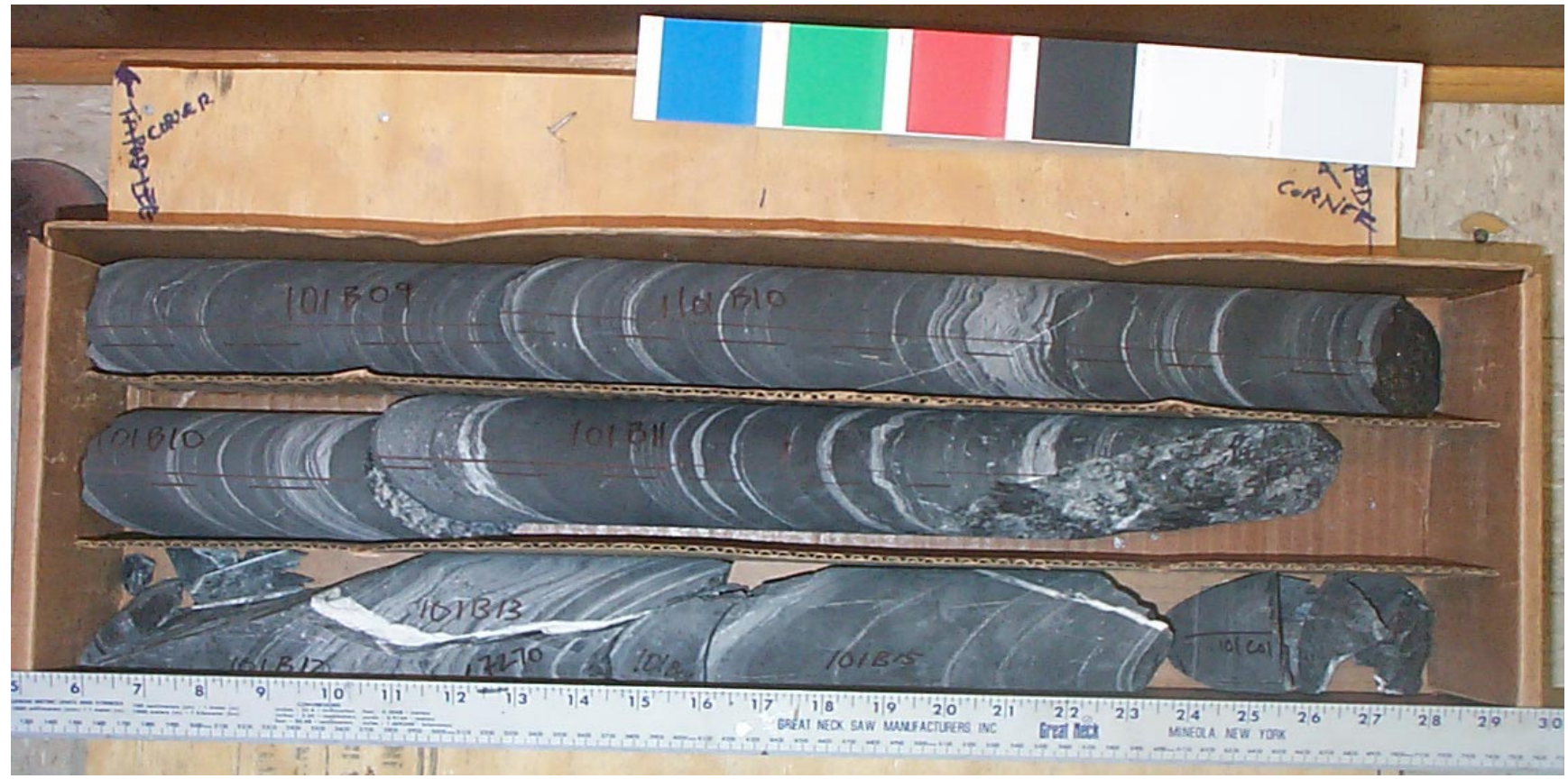

Core Scans included in this box (listed by piece going downhole):
$101 \mathrm{~B} 0900$
101B100A
101B1100
101B1500

See the "reading instructions" section of the introduction for help interpreting core box photos and core piece nomenclature 


\section{LVEW Core Box 144}

\section{Depth Interval 7271.1'-7274.5}

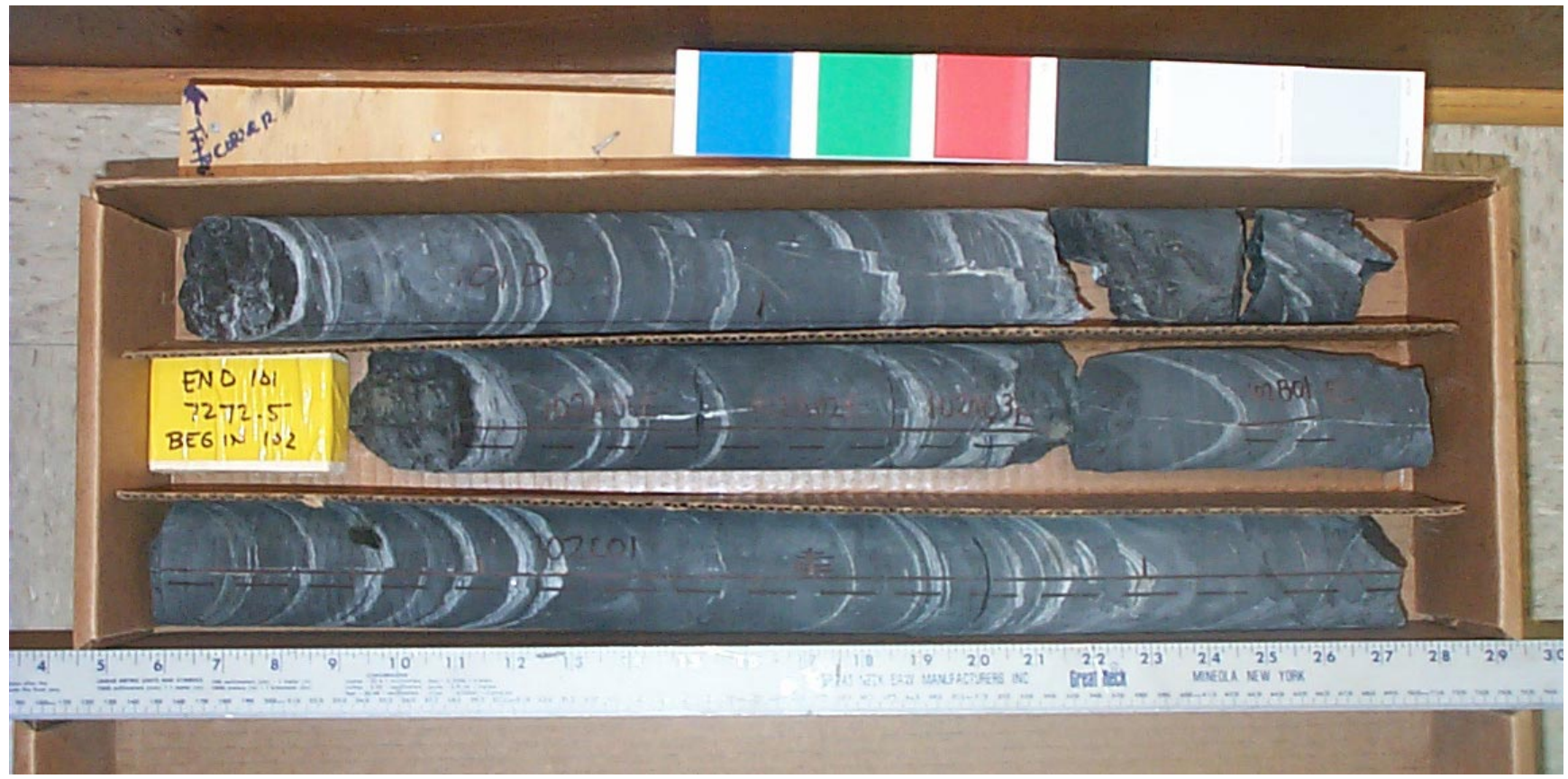

Core Scans included in this box

(listed by piece going downhole):

102A010E
102A020E
102A030E
102C0100

See the "reading instructions" section of the introduction for help interpreting core box photos and core piece nomenclature 


\section{LVEW Core Box 145}

Depth Interval 7274.5'-7278.8'

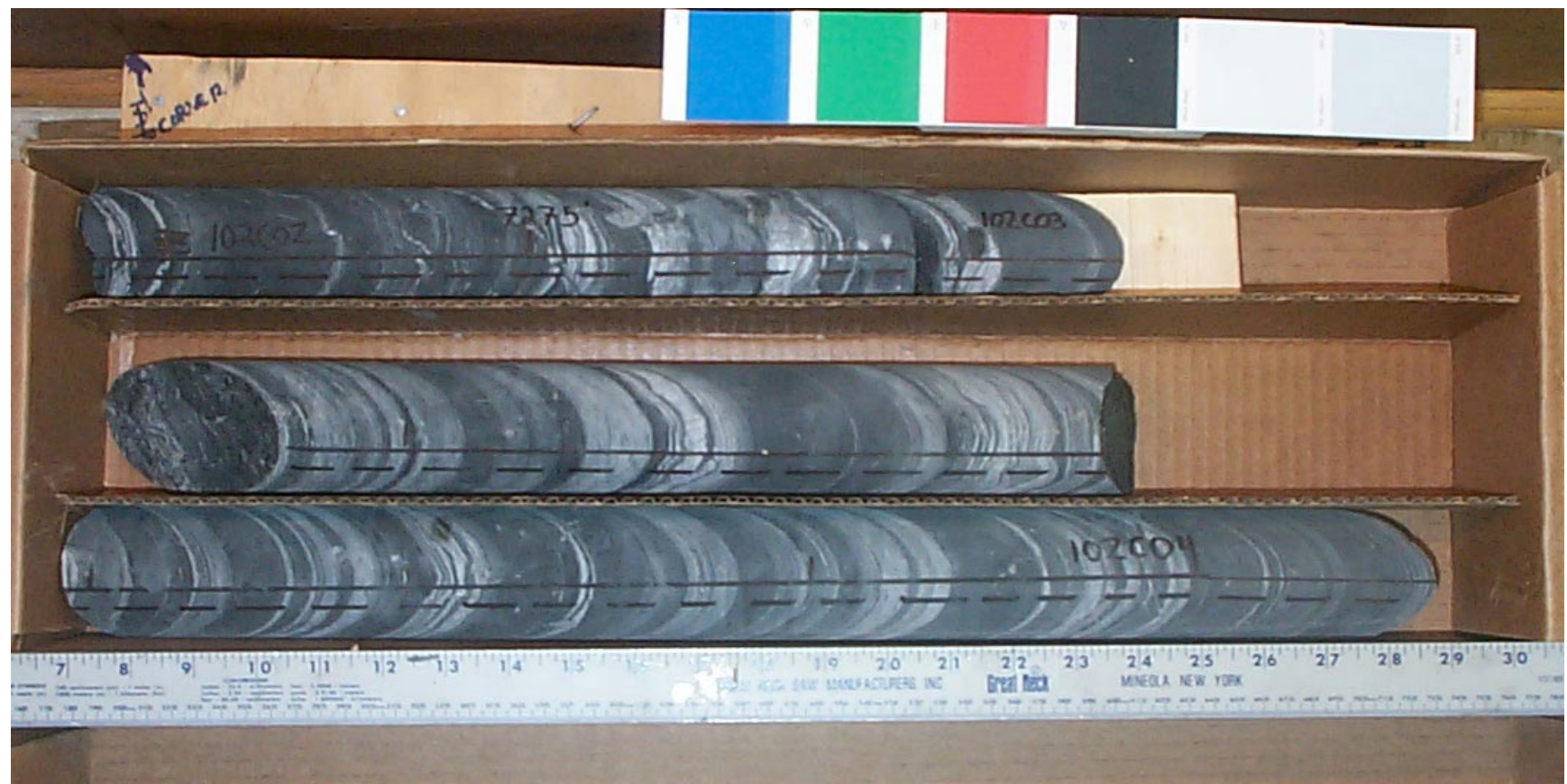

Core Scans included in this box (listed by piece going downhole):

$102 \mathrm{C} 0200$

$102 \mathrm{C} 0400$

See the "reading instructions" section of the introduction for help interpreting core box photos and core piece nomenclature 


\section{LVEW Core Box 146}

Depth Interval 7278.8'-7283.5'

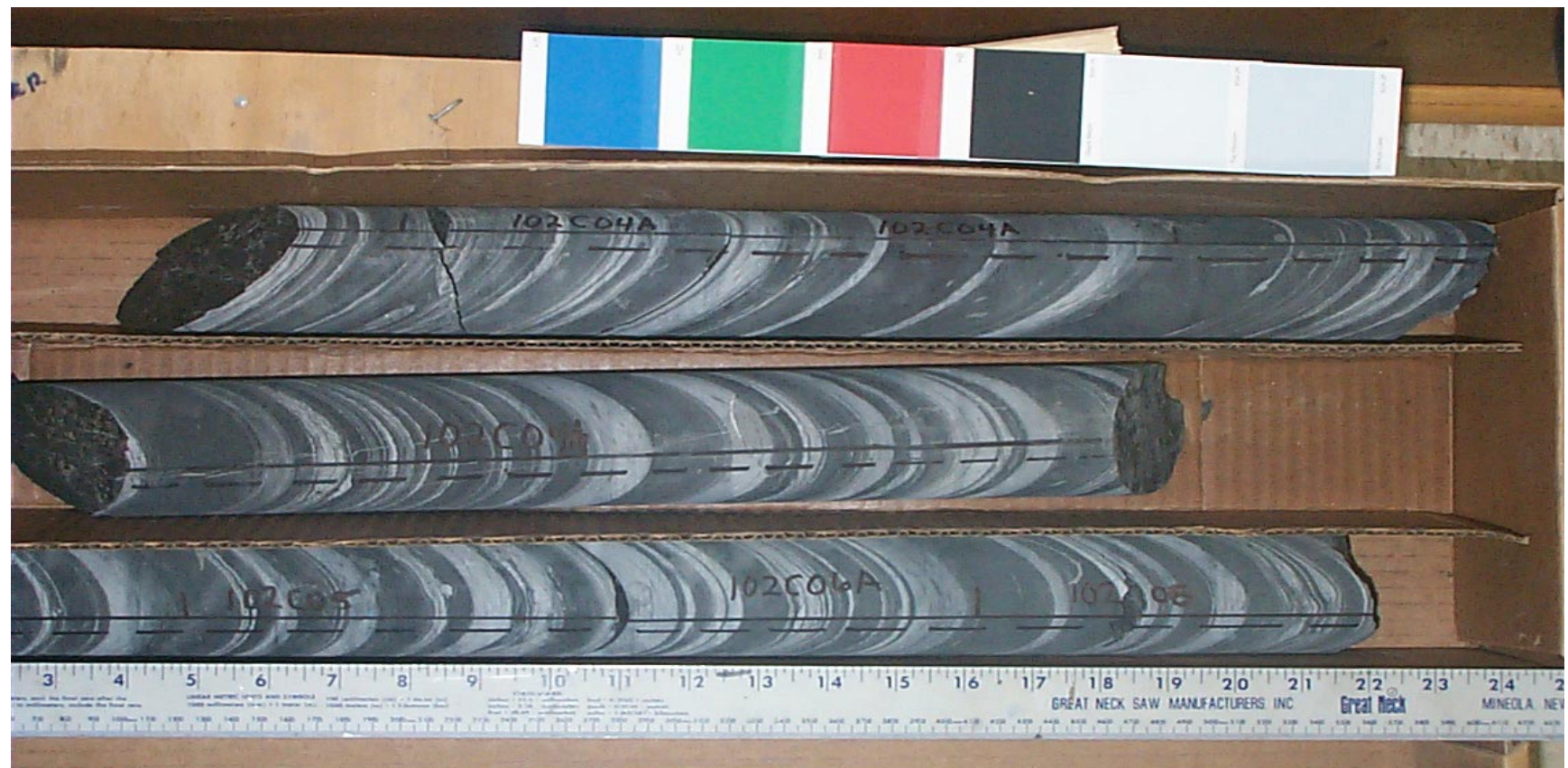

Core Scans included in this box (listed by piece going downhole):
$102 \mathrm{C} 0400$
$102 \mathrm{C} 050 \mathrm{~A}$ $102 \mathrm{C060A}$

See the "reading instructions" section of the introduction for help interpreting core box photos and core piece nomenclature 


\section{LVEW Core Box 147}

Depth Interval 7283.5'-7286.2'

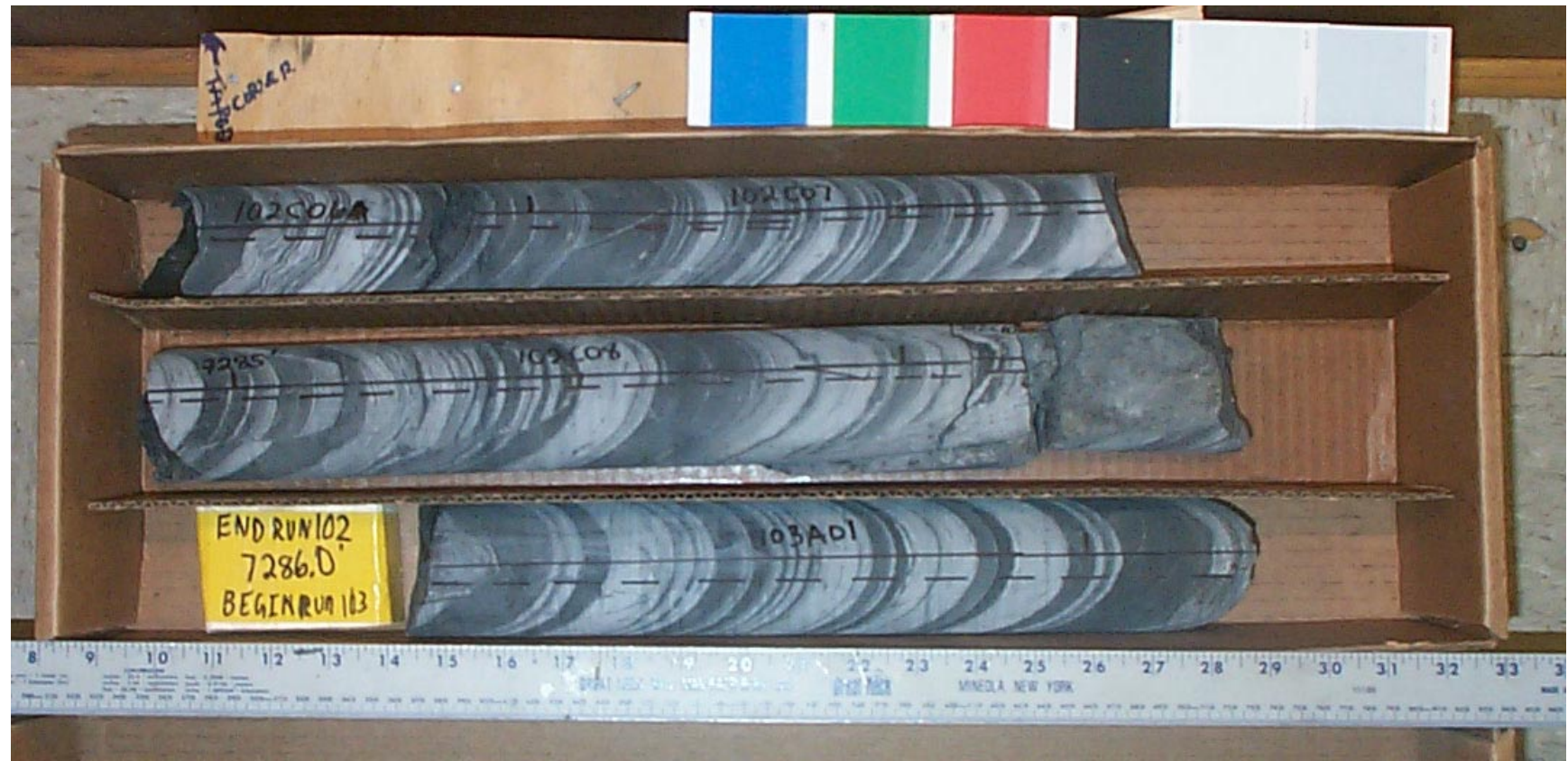

Core Scans included in this box (listed by piece going downhole):
$102 \mathrm{C} 060 \mathrm{~A}$
$102 \mathrm{C} 0700$
$102 \mathrm{C} 0800$
$103 \mathrm{~A} 0100$

See the "reading instructions" section of the introduction for help interpreting core box photos and core piece nomenclature 


\section{LVEW Core Box 148}

Depth Interval 7286.2'-7292.7'

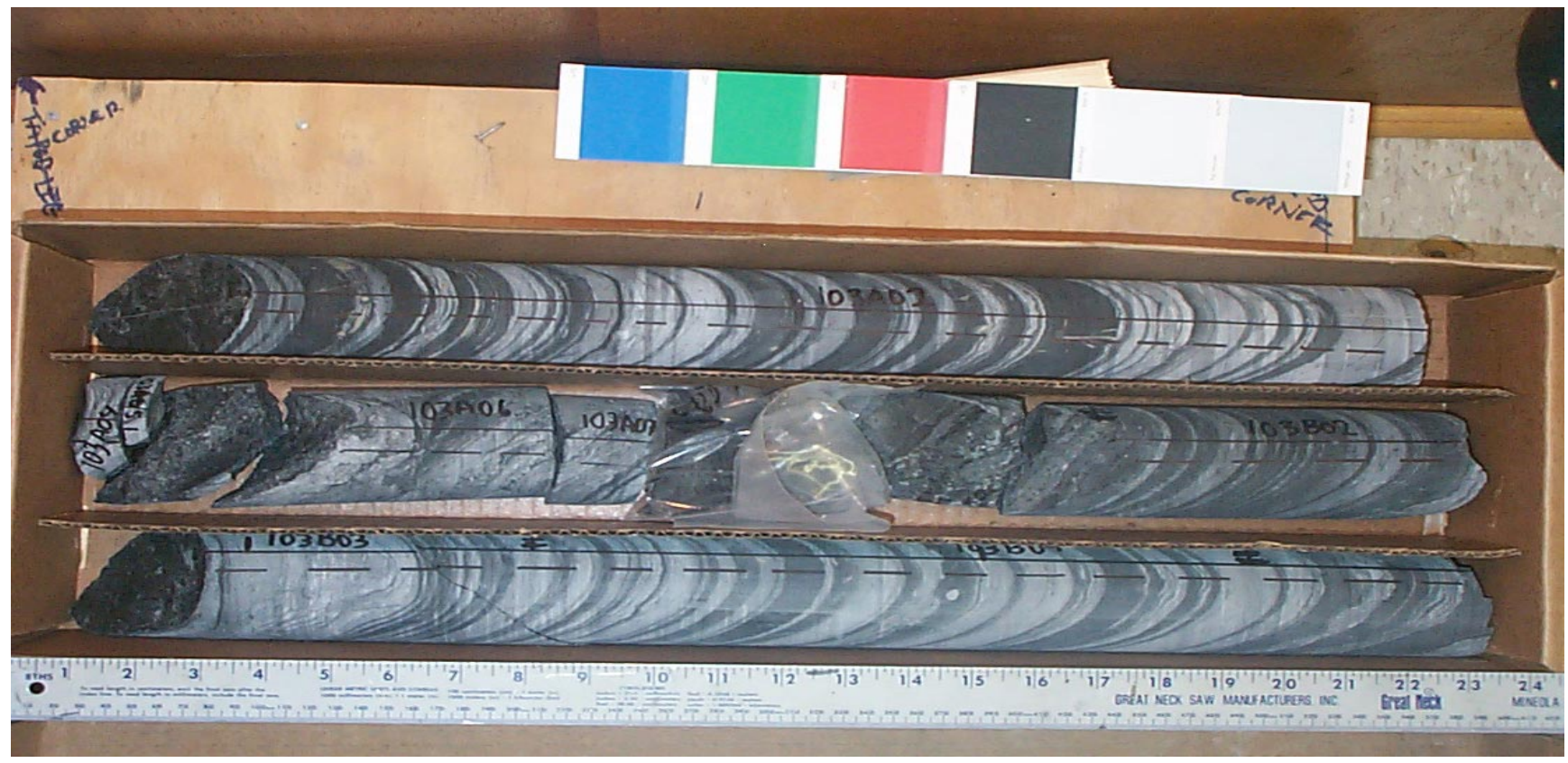

Core Scans included in this box (listed by piece going downhole):
$103 \mathrm{~A} 0200$
103B0200
$103 \mathrm{~B} 0300$
103B0400

See the "reading instructions" section of the introduction for help interpreting core box photos and core piece nomenclature 


\section{LVEW Core Box 149}

Depth Interval 7292.7'-7297.8'

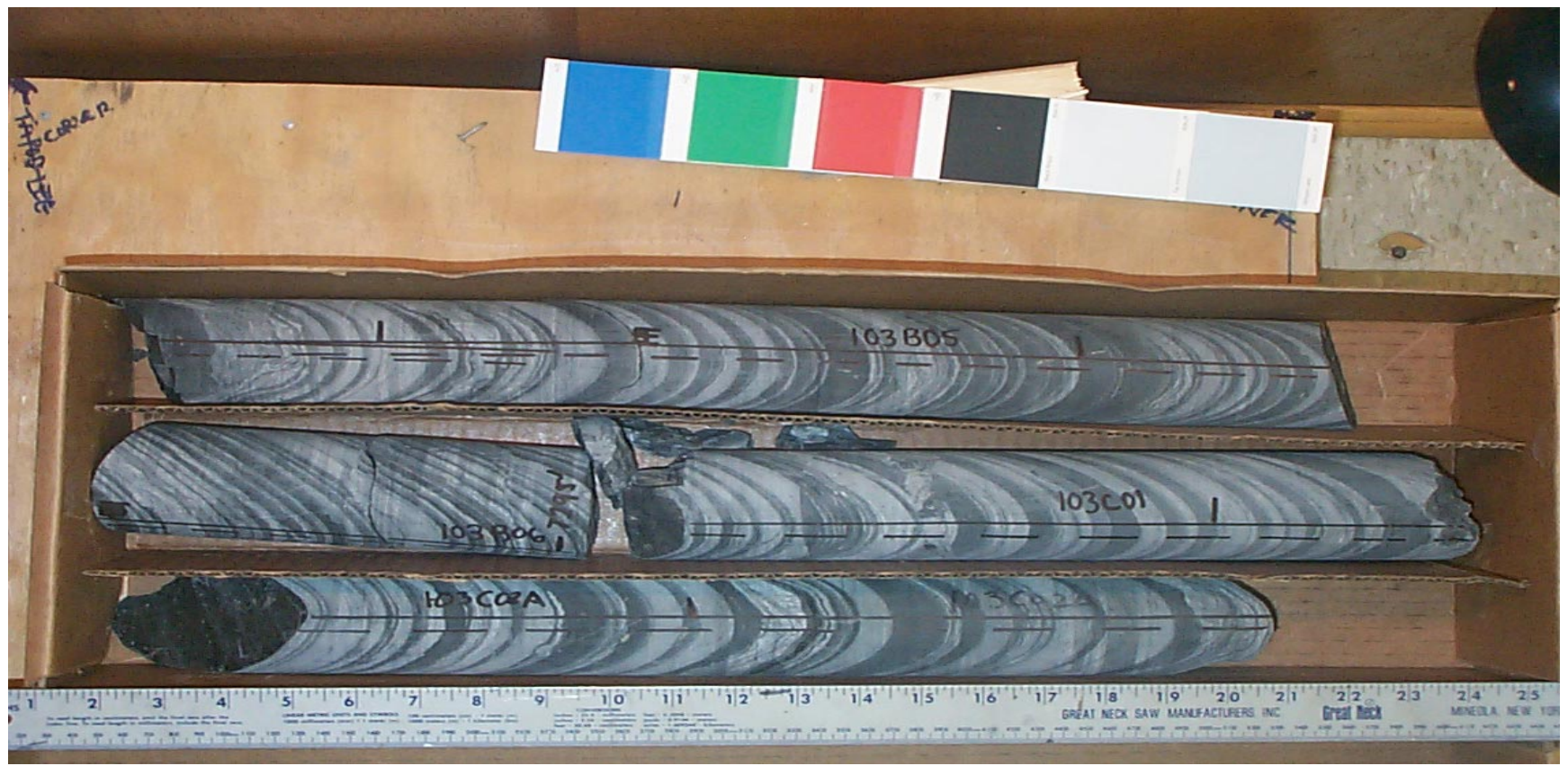

Core Scans included in this box (listed by piece going downhole):

$103 B 0500$
$103 B 0600$
$103 C 0100$
$103 C 020 A$

See the "reading instructions" section of the introduction for help interpreting core box photos and core piece nomenclature 


\section{LVEW Core Box 150}

Depth Interval 7297.8'-7304.7'

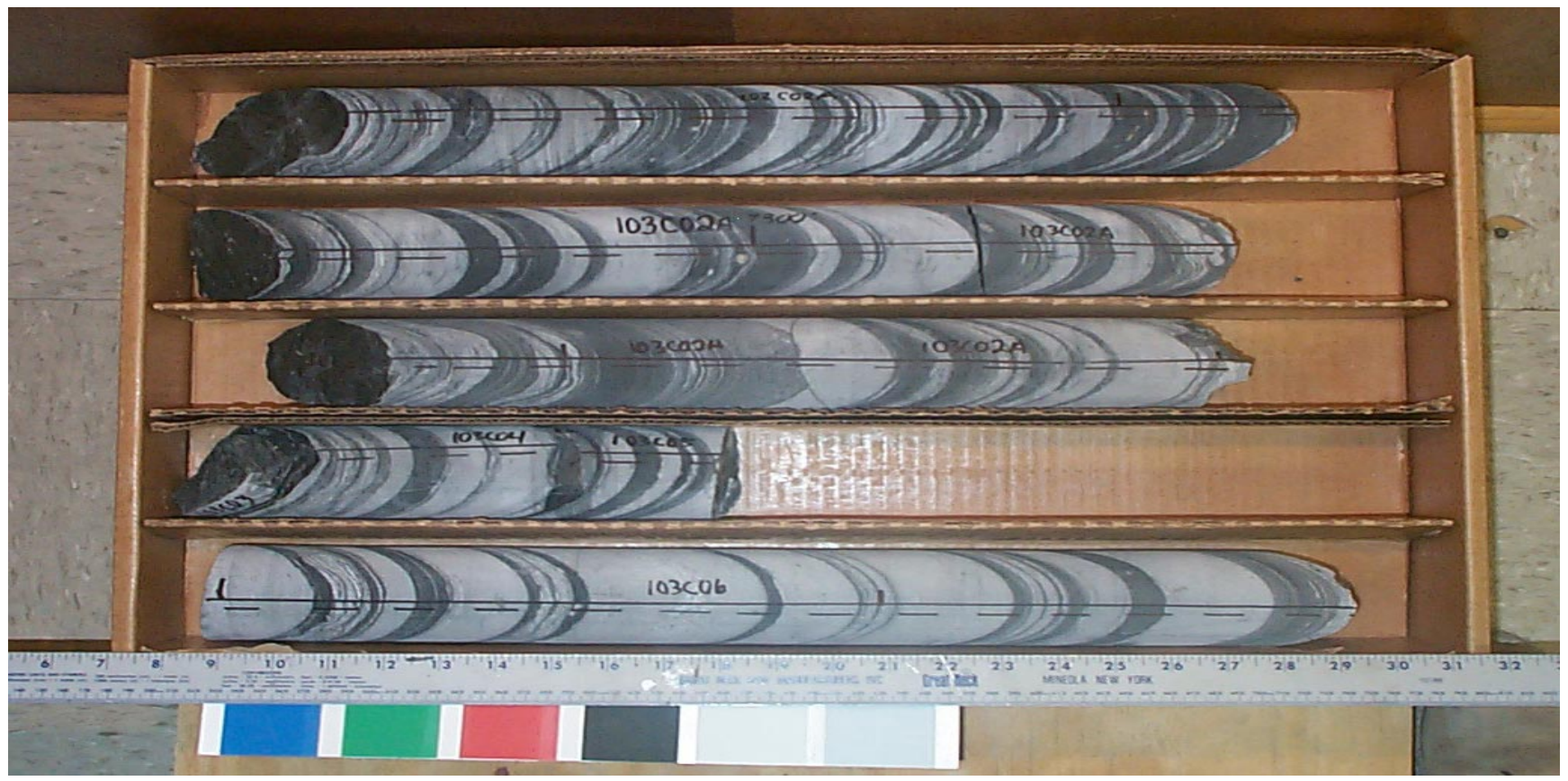

Core Scans included in this box (listed by piece going downhole):

\section{$103 \mathrm{C} 020 \mathrm{~A}$ $103 \mathrm{C} 0400$ $103 \mathrm{C} 0500$ $103 \mathrm{C} 0600$}

See the "reading instructions" section of the introduction for help interpreting core box photos and core piece nomenclature 


\section{LVEW Core Box 151}

\section{Depth Interval 7304.7'-7312.6'}

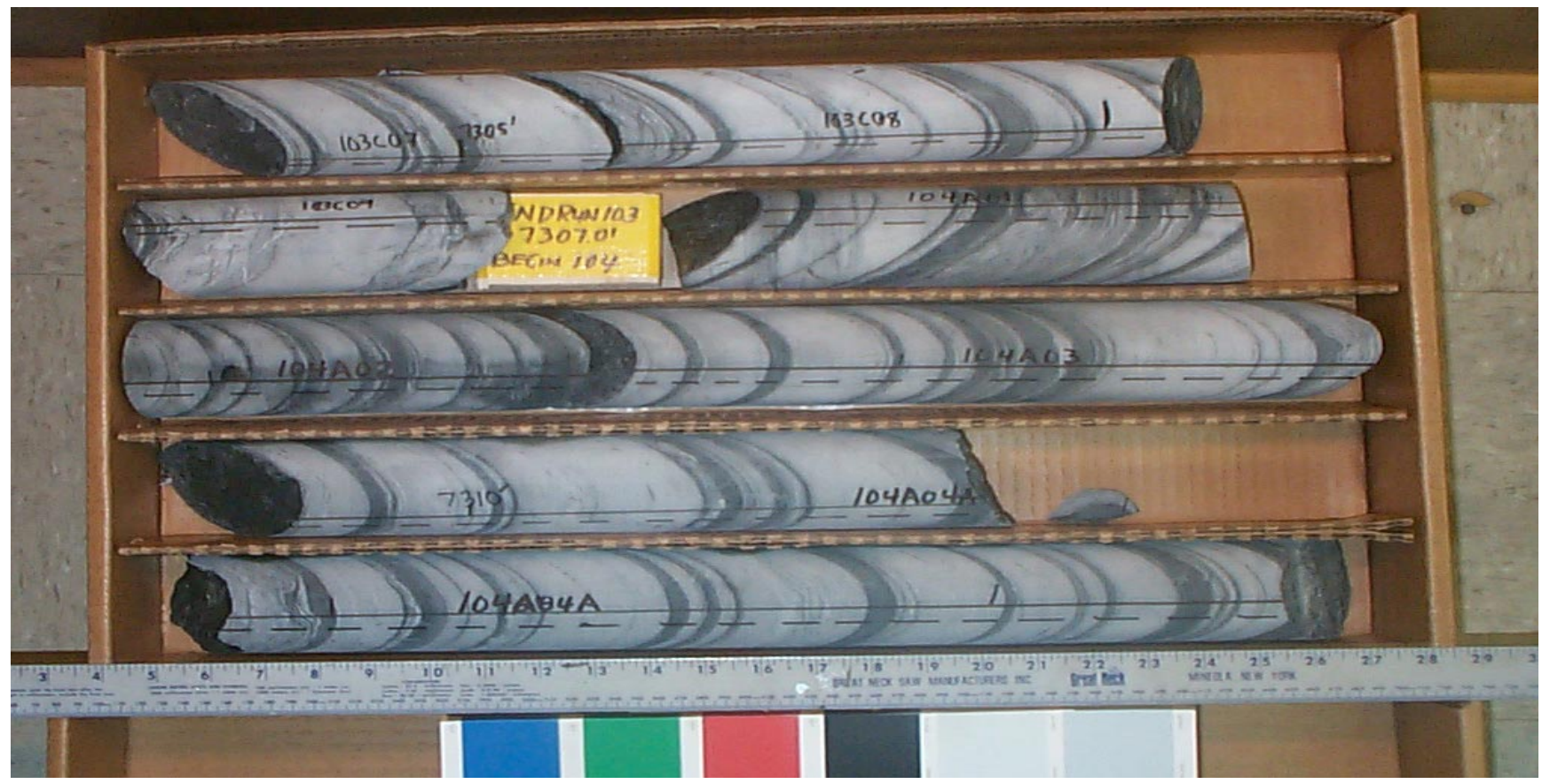

Core Scans included in this box (listed by piece going downhole):

104A0100
$104 A 0200$
$104 A 0300$
104A040A

See the "reading instructions" section of the introduction for help interpreting core box photos and core piece nomenclature 


\section{LVEW Core Box 152}

\section{Depth Interval 7312.6'-7319.6'}

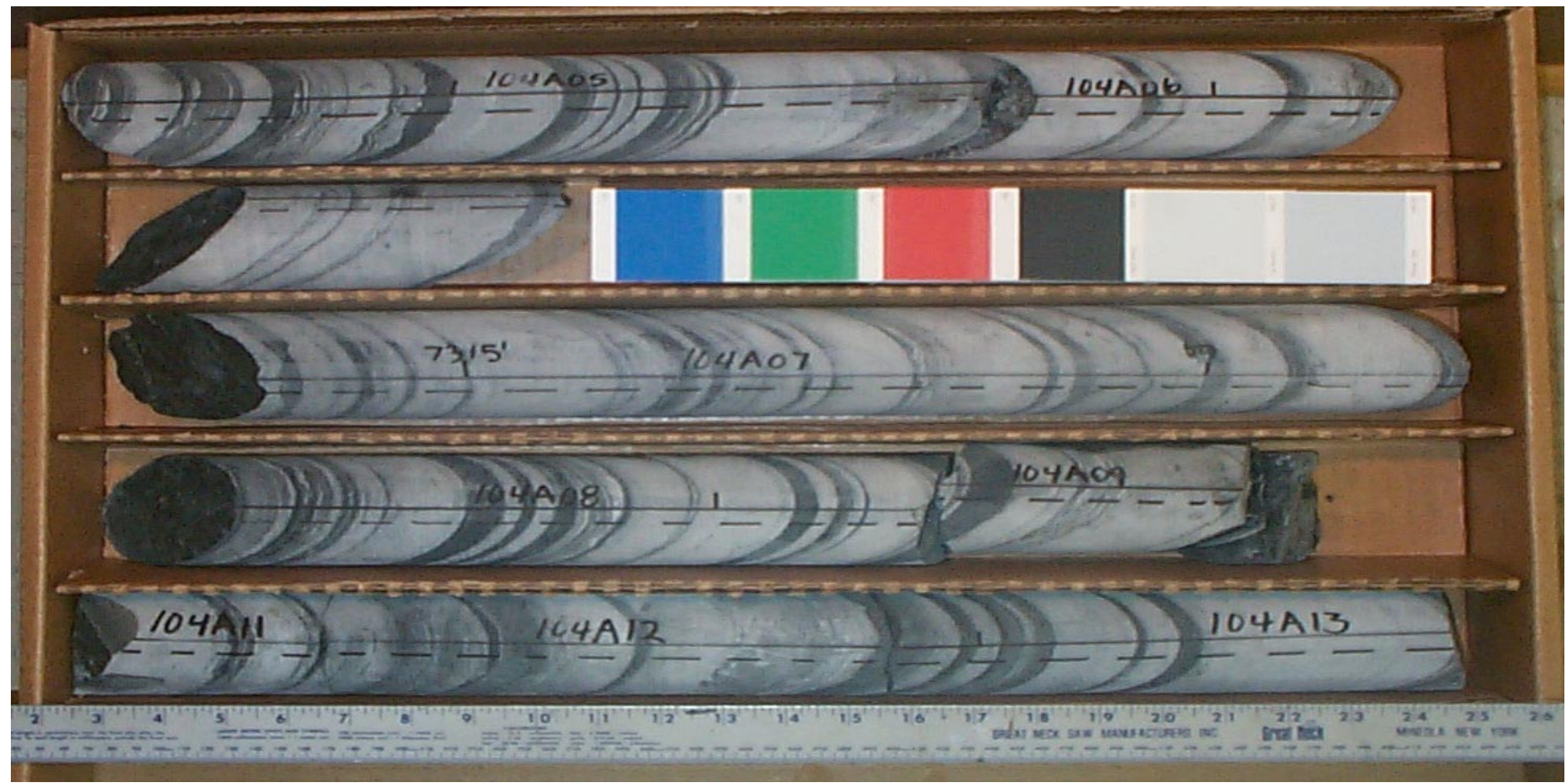

Core Scans included in this box (listed by piece going downhole):

104A0500
104A0600
104A070A
104A0800
104A0900
104A1100
104A1200
104A1300

See the "reading instructions" section of the introduction for help interpreting core box photos and core piece nomenclature 


\section{LVEW Core Box 153}

Depth Interval 7319.6'-7325.3'

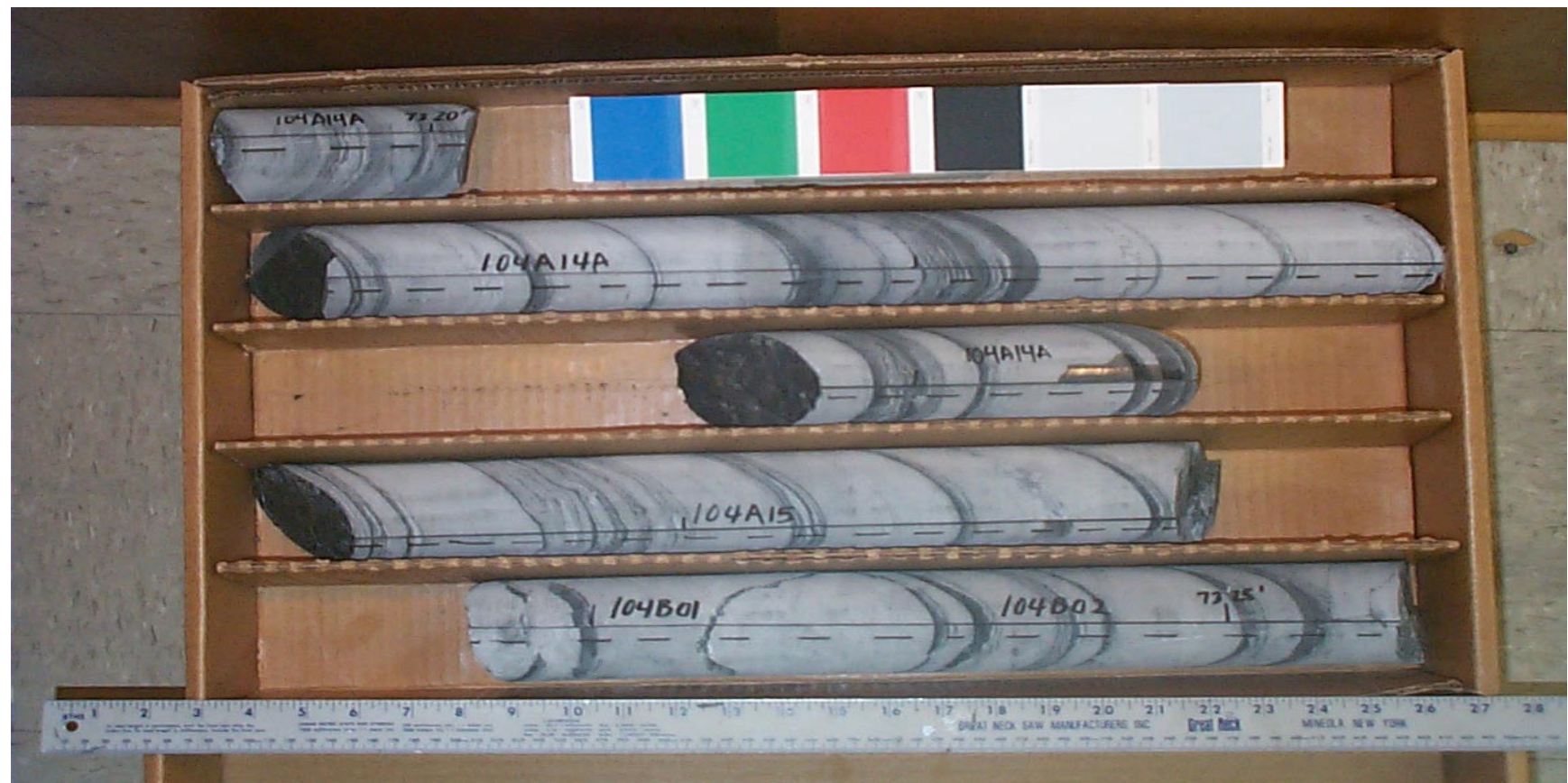

Core Scans included in this box (listed by piece going downhole):

104A140A
104A1500
104B0100
104B0200

See the "reading instructions" section of the introduction for help interpreting core box photos and core piece nomenclature 


\section{LVEW Core Box 154}

\section{Depth Interval 7325.3'-7333.0'}

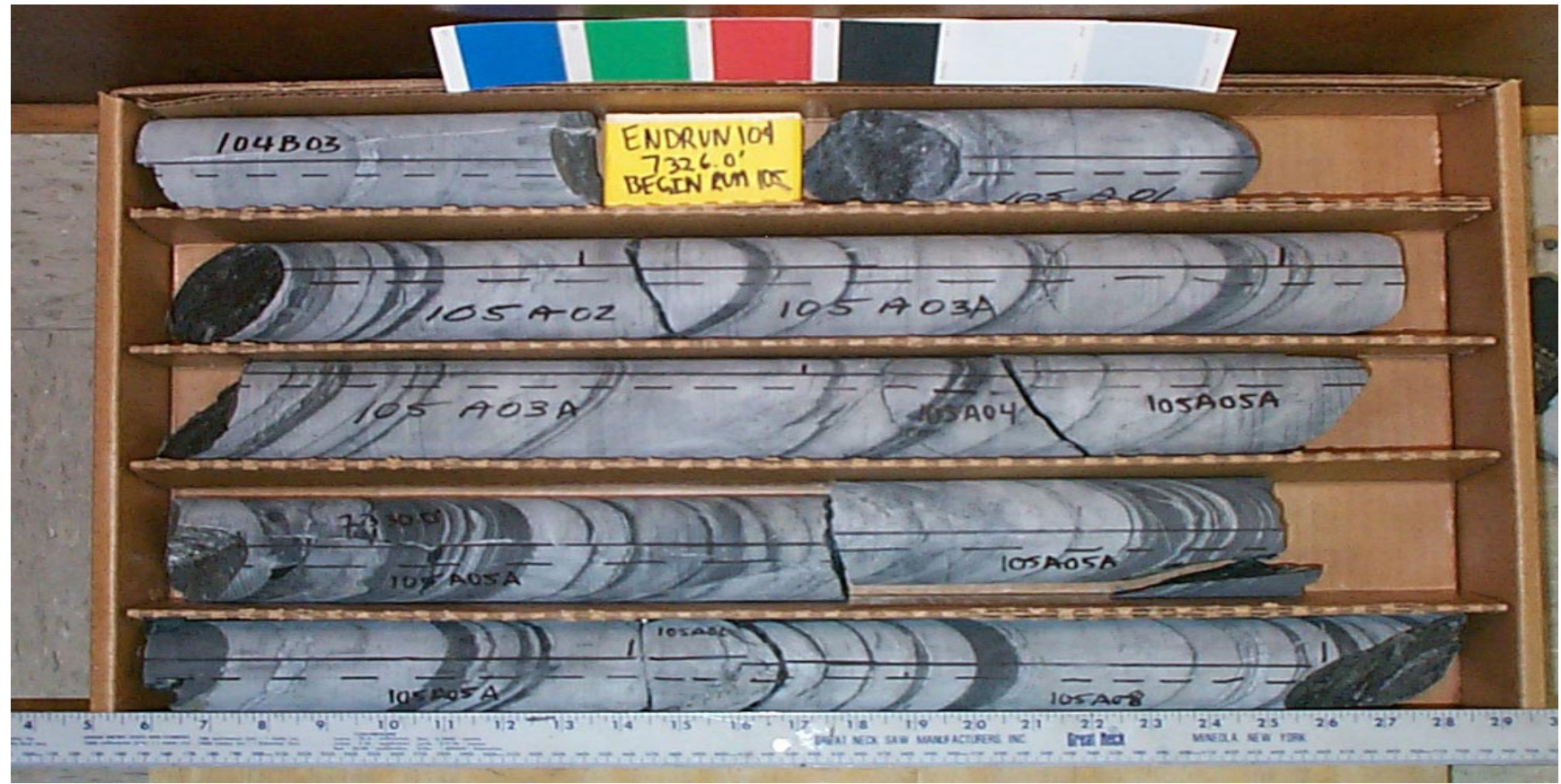

Core Scans included in this box (listed by piece going downhole):

\section{B0300 \\ $105 \mathrm{~A} 0100$ \\ 105A020A}

See the "reading instructions" section of the introduction for help interpreting core box photos and core piece nomenclature 


\section{LVEW Core Box 155}

Depth Interval 7333.0'-7340.5'

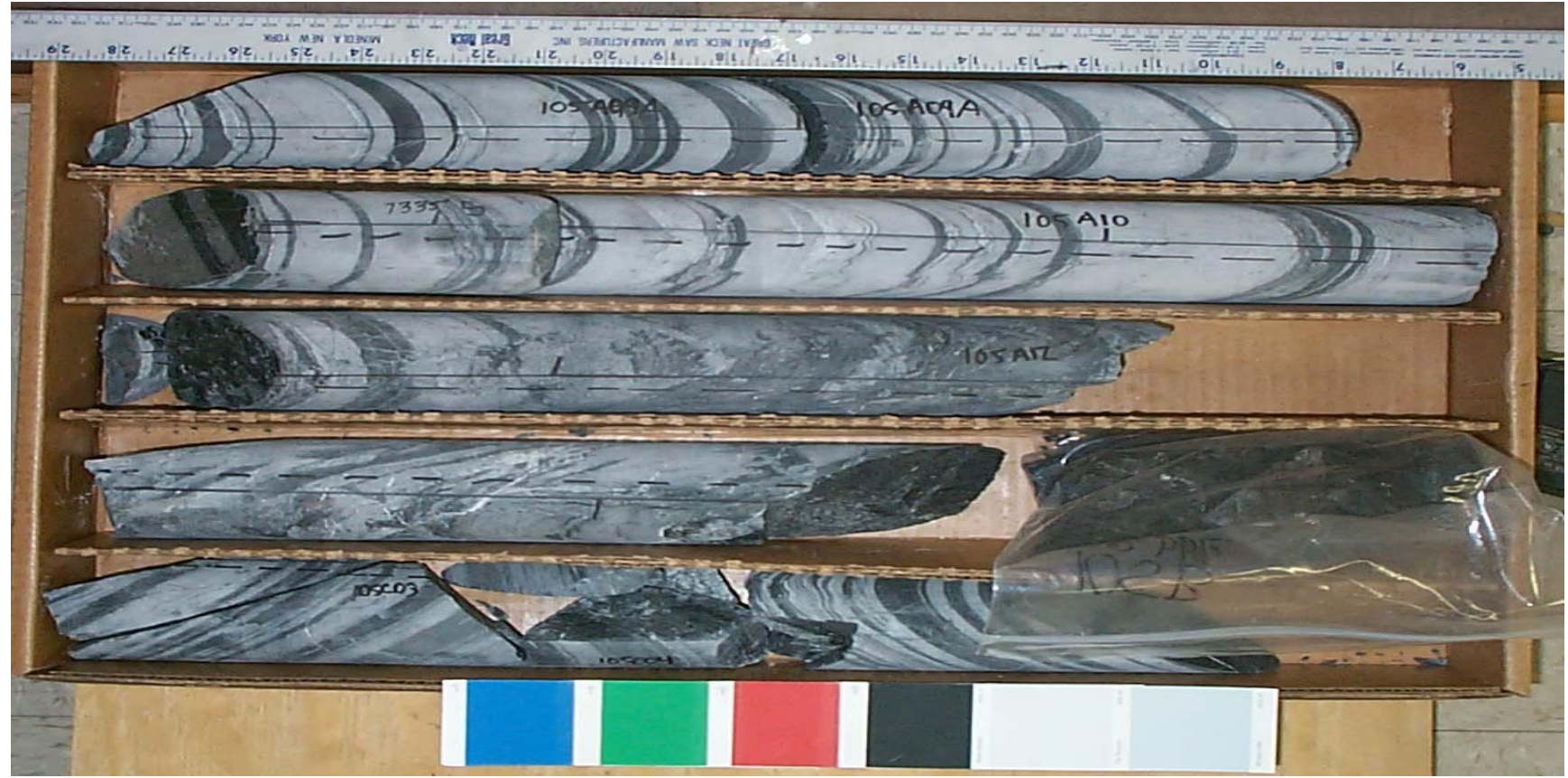

Core Scans included in this box (listed by piece going downhole):

105A090A
105A1000
105A120A

See the "reading instructions" section of the introduction for help interpreting core box photos and core piece nomenclature 


\section{LVEW Core Box 156}

Depth Interval 7340.5'-7346.9'

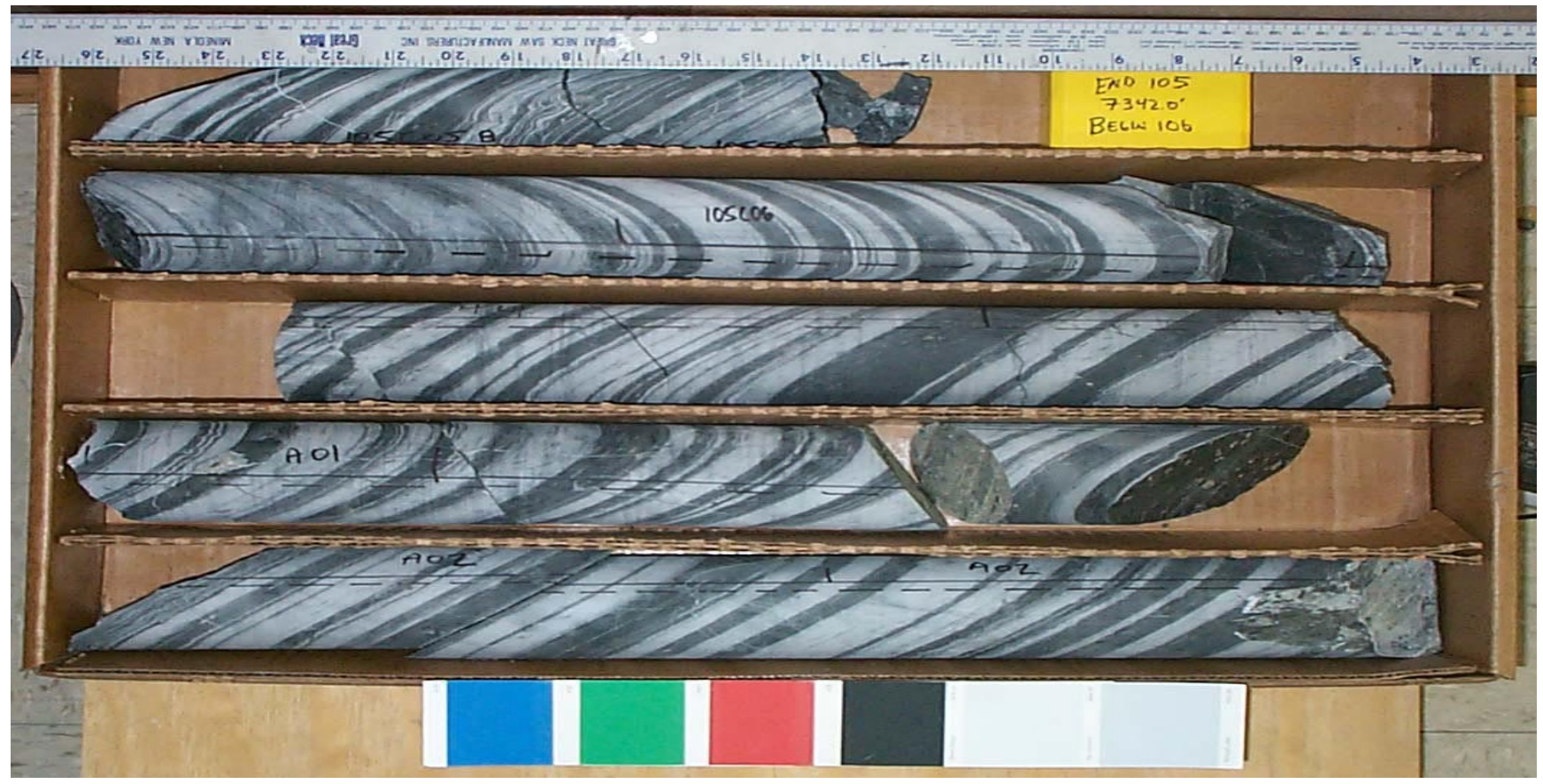

Core Scans included in this box

(listed by piece going downhole):

105C050A
106A010A
106A020A

See the "reading instructions" section of the introduction for help interpreting core box photos and core piece nomenclature 


\section{LVEW Core Box 157}

Depth Interval 7346.9'-7354.7'

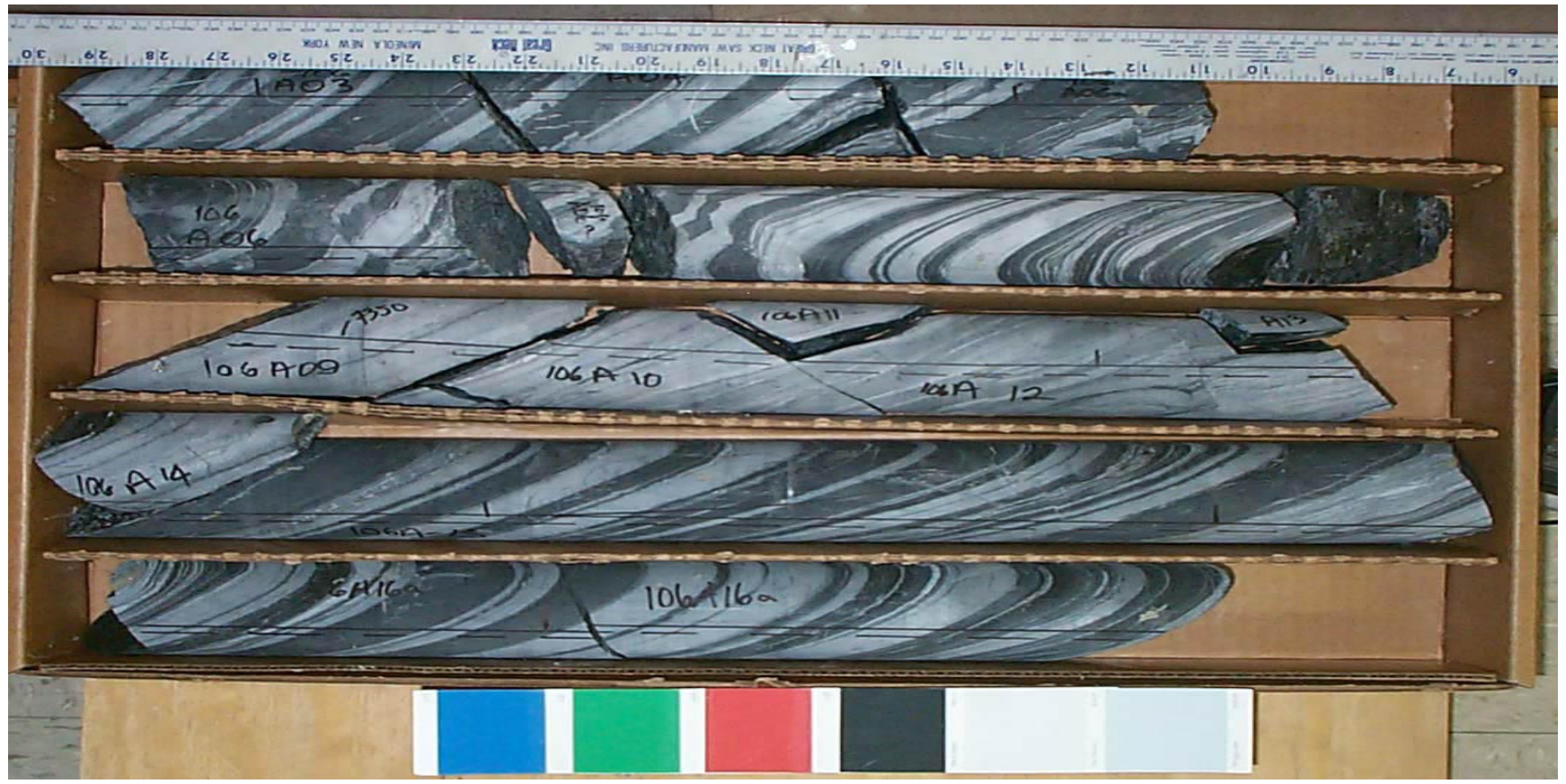

Core Scans included in this box (listed by piece going downhole):

106A0300
106A0400
106A060A
106A0700
106A0900
106A1000
106A1200
106A1500
106A160A

See the "reading instructions" section of the introduction for help interpreting core box photos and core piece nomenclature 


\section{LVEW Core Box 158}

Depth Interval 7354.7'-7361.9'

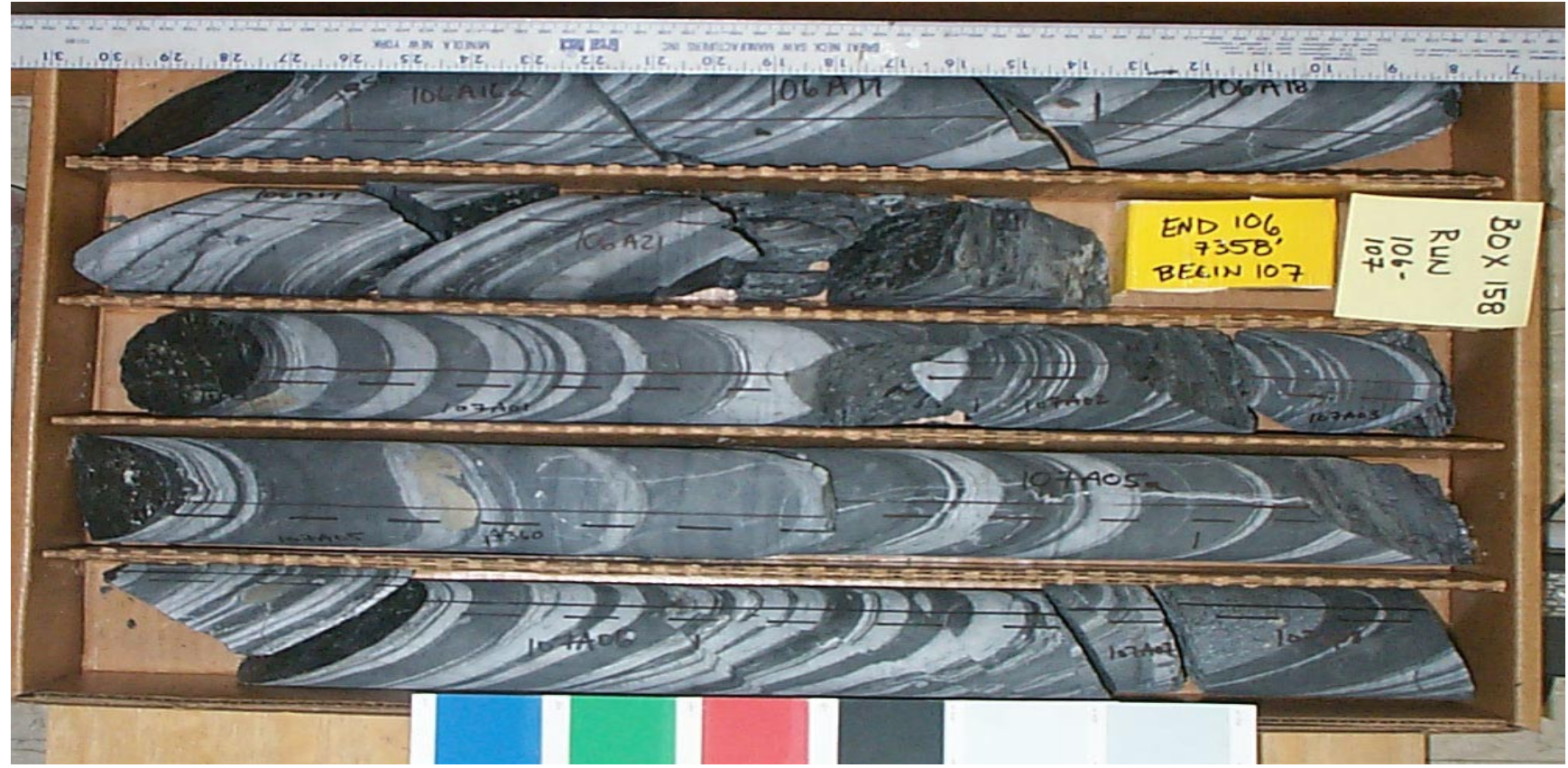

Core Scans included in this box (listed by piece going downhole):

106A160A
106A1700
106A1800
106A1900
107A0100
107A050A
107A0600
107A0800

See the "reading instructions" section of the introduction for help interpreting core box photos and core piece nomenclature 


\section{LVEW Core Box 159}

Depth Interval 7361.9'-7369.8'

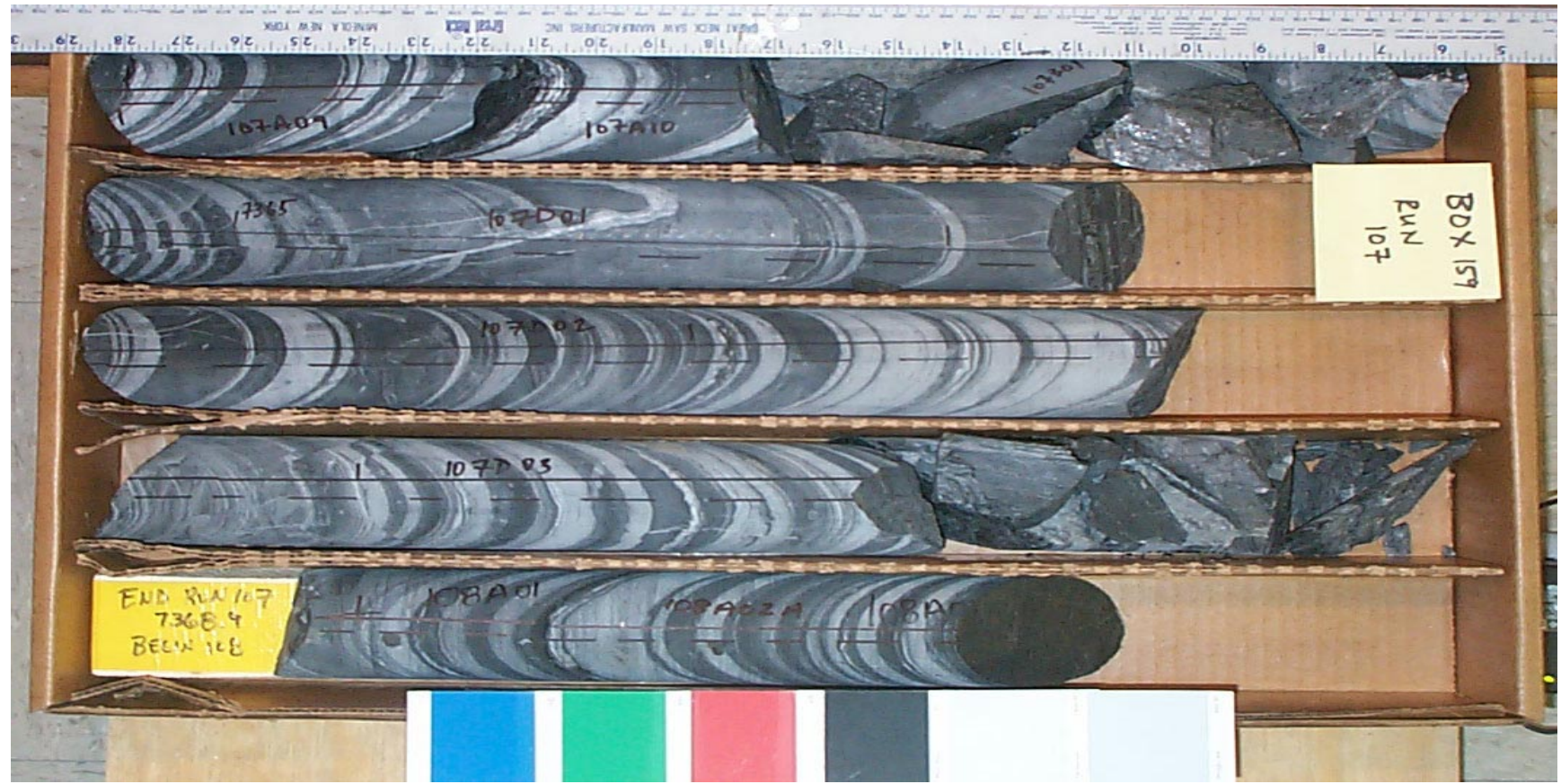

Core Scans included in this box (listed by piece going downhole):
$107 \mathrm{~A} 0900$
$107 \mathrm{~A} 1000$
107D0100
107D0200
107D0300
$108 \mathrm{~A} 0100$
108A0200

See the "reading instructions" section of the introduction for help interpreting core box photos and core piece nomenclature 


\section{LVEW Core Box 160}

Depth Interval 7369.8'-7378.6'

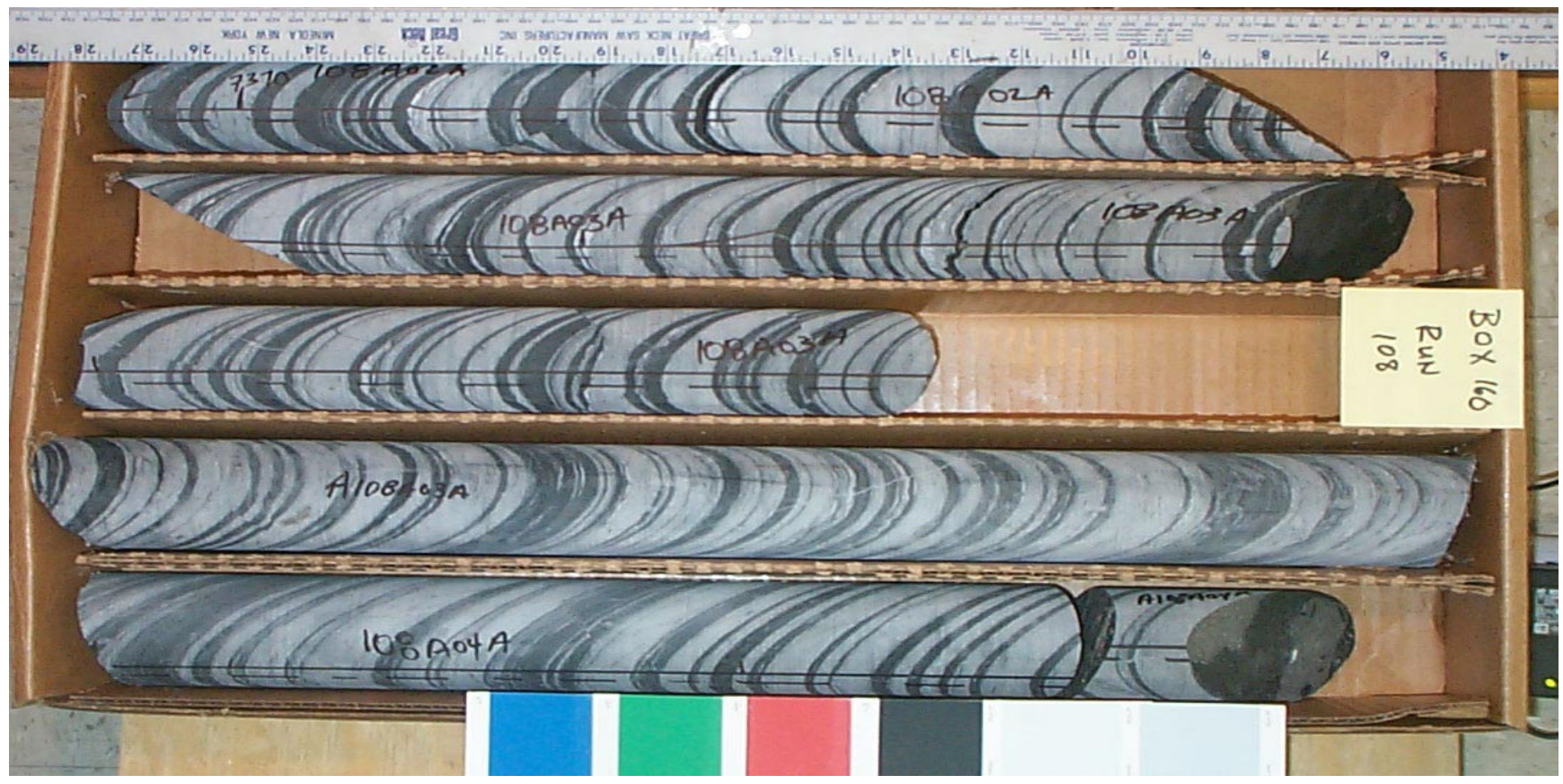

Core Scans included in this box (listed by piece going downhole):
108A0200
108A031A
108A032A
108A040A

See the "reading instructions" section of the introduction for help interpreting ore box photos and core piece nomenclature 
LVEW Core Box 161

Depth Interval 7378.6'-7387.0'

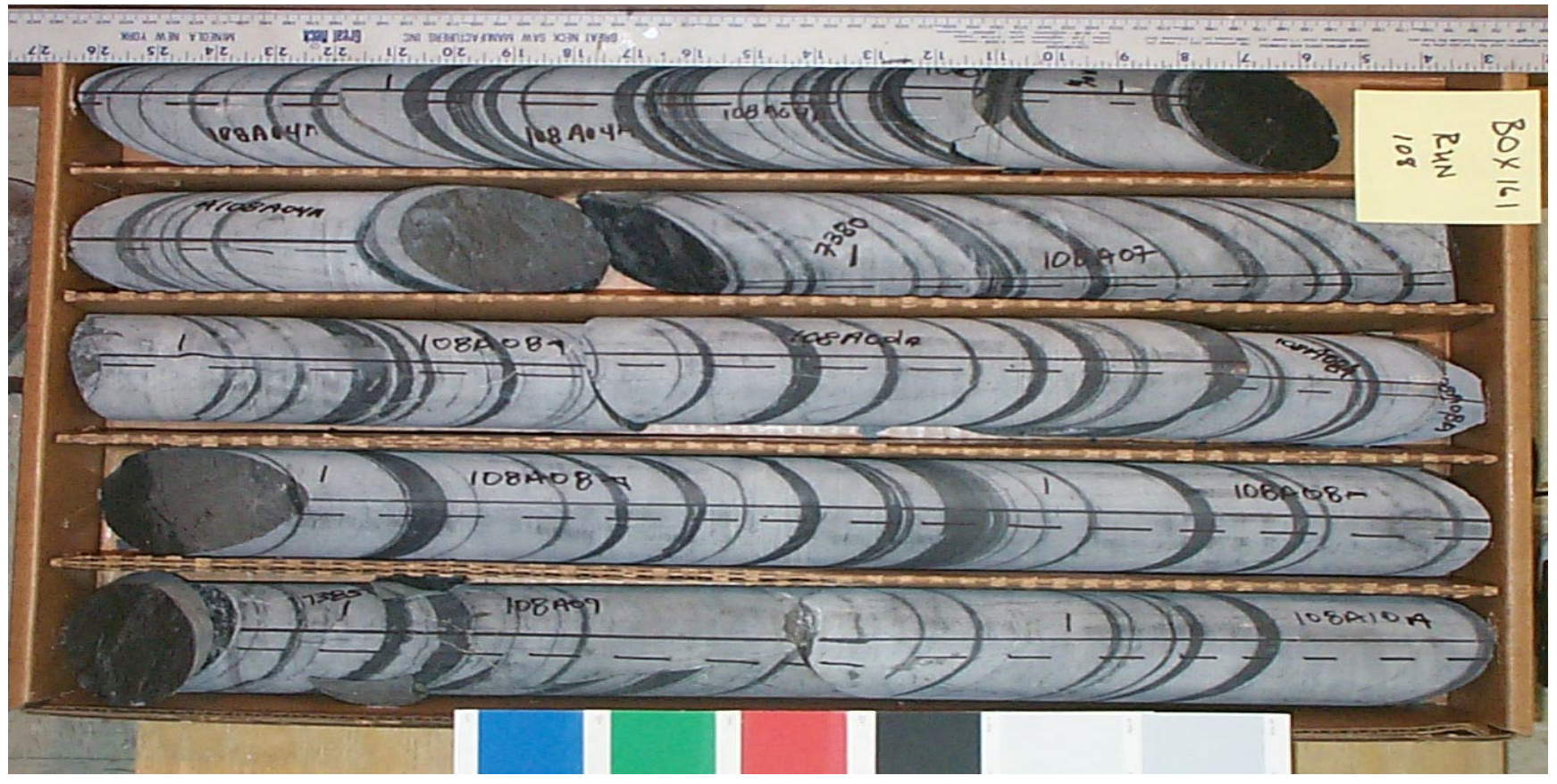

Core Scans included in this box (listed by piece going downhole):

108A040A
108A0700
108A080A
108A090A
108A1000

See the "reading instructions" section of the introduction for help interpreting core box photos and core piece nomenclature 


\section{LVEW Core Box 162}

Depth Interval 7387.0'-7394.0'

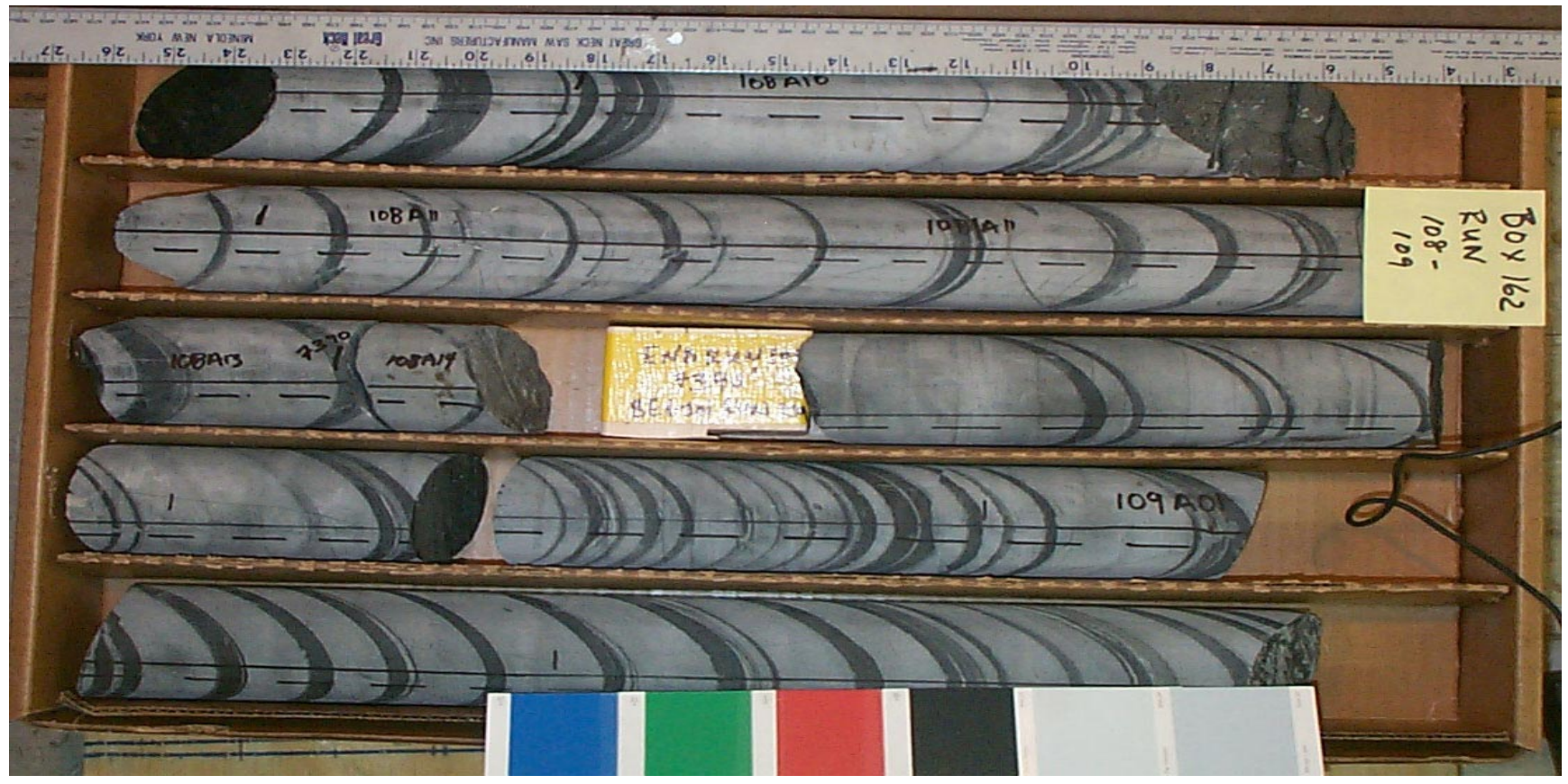

Core Scans included in this box (listed by piece going downhole):
108A1000
108A1100
108A1300
108A1400
109A011A

See the "reading instructions" section of the introduction for help interpreting core box photos and core piece nomenclature 


\section{LVEW Core Box 163}

Depth Interval 7394.0'-7401.6'

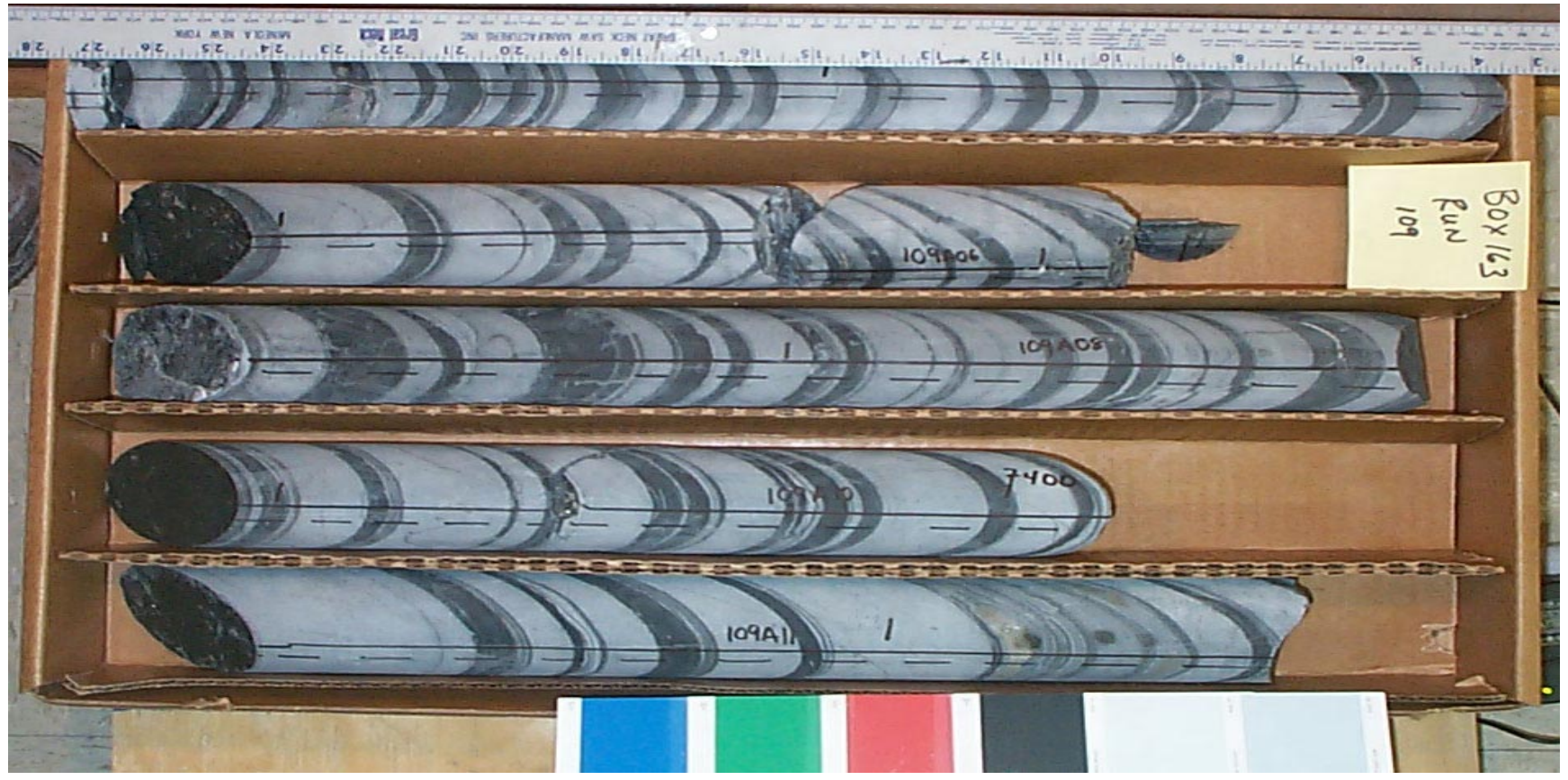

Core Scans included in this box (listed by piece going downhole):
109A012A
109A0300
109A040A
109A0600
109A081A
109A082A
109A1000
109A1100

See the "reading instructions" section of the introduction for help interpreting core box photos and core piece nomenclature 


\section{LVEW Core Box 164}

Depth Interval 7401.6'-7408.4'

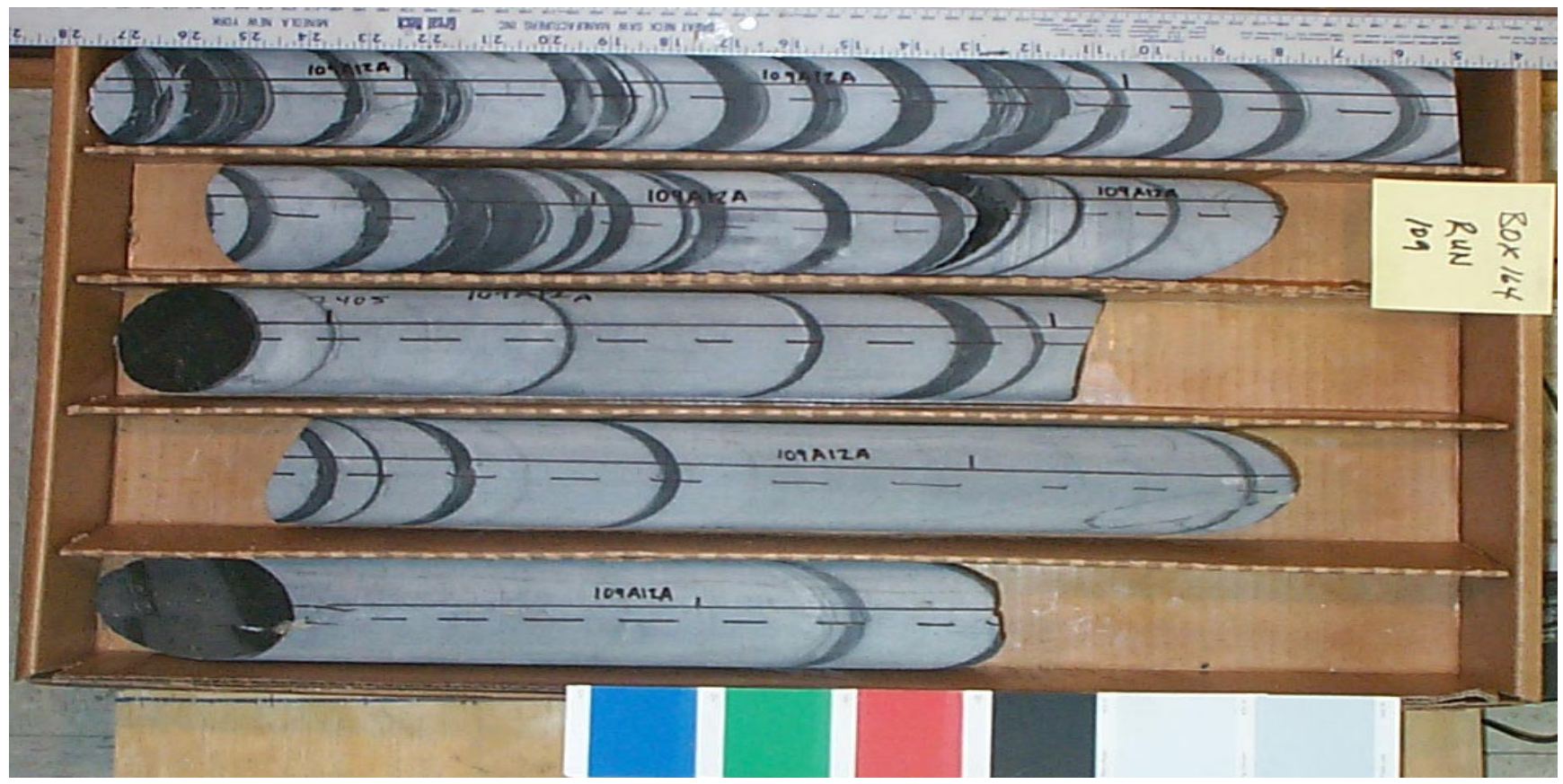

Core Scans included in this box (listed by piece going downhole):

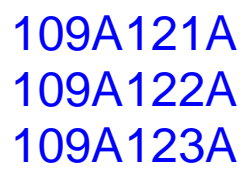

See the "reading instructions" section of the introduction for help interpreting core box photos and core piece nomenclature 


\section{LVEW Core Box 165}

Depth Interval 7408.4'-7414.7'

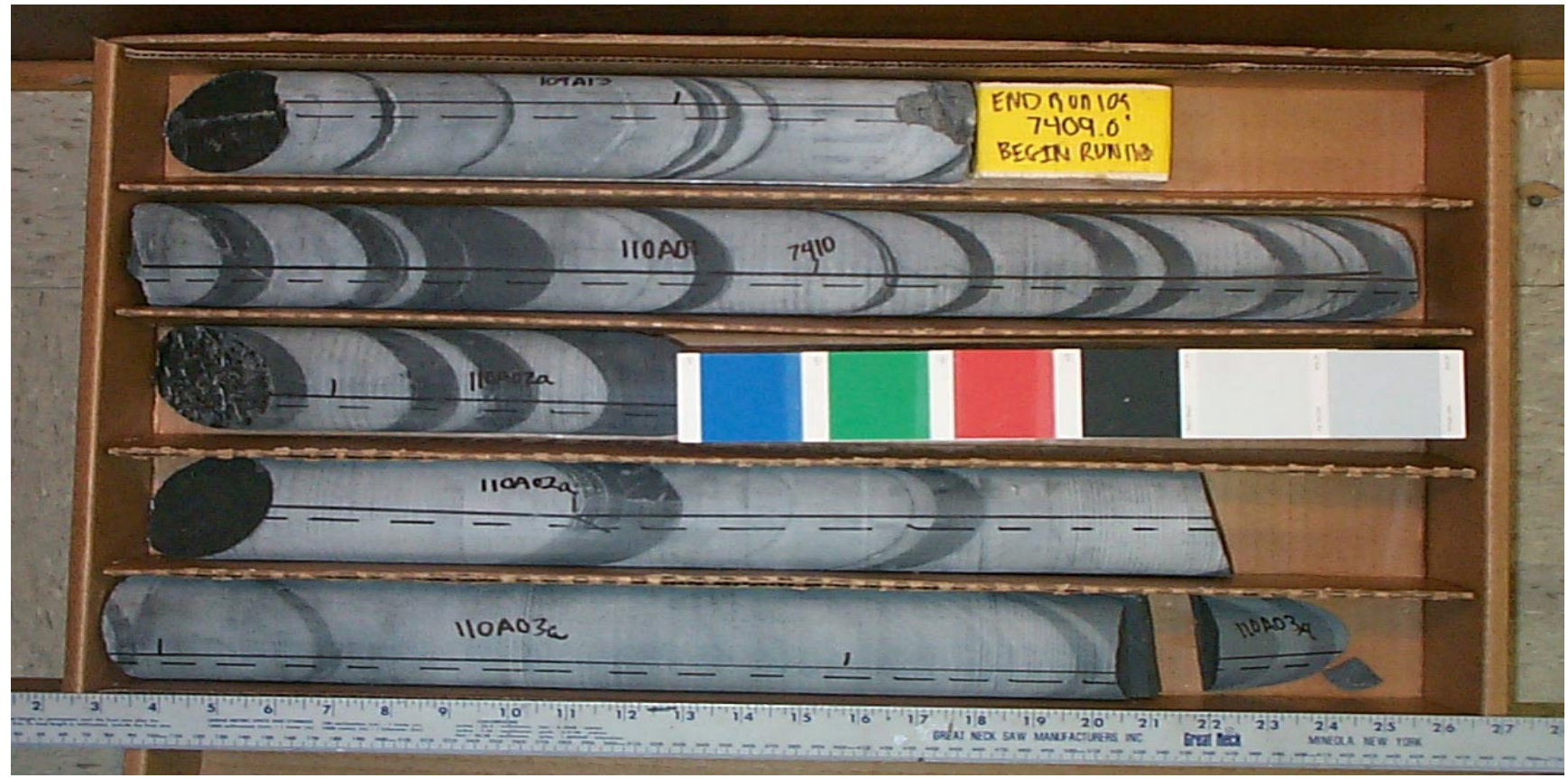

Core Scans included in this box (listed by piece going downhole):

109A123A
109A1300
110A0100
110A020A
110A031A

See the "reading instructions" section of the introduction for help interpreting core box photos and core piece nomenclature 


\section{LVEW Core Box 166}

Depth Interval 7414.7'-7422.1'

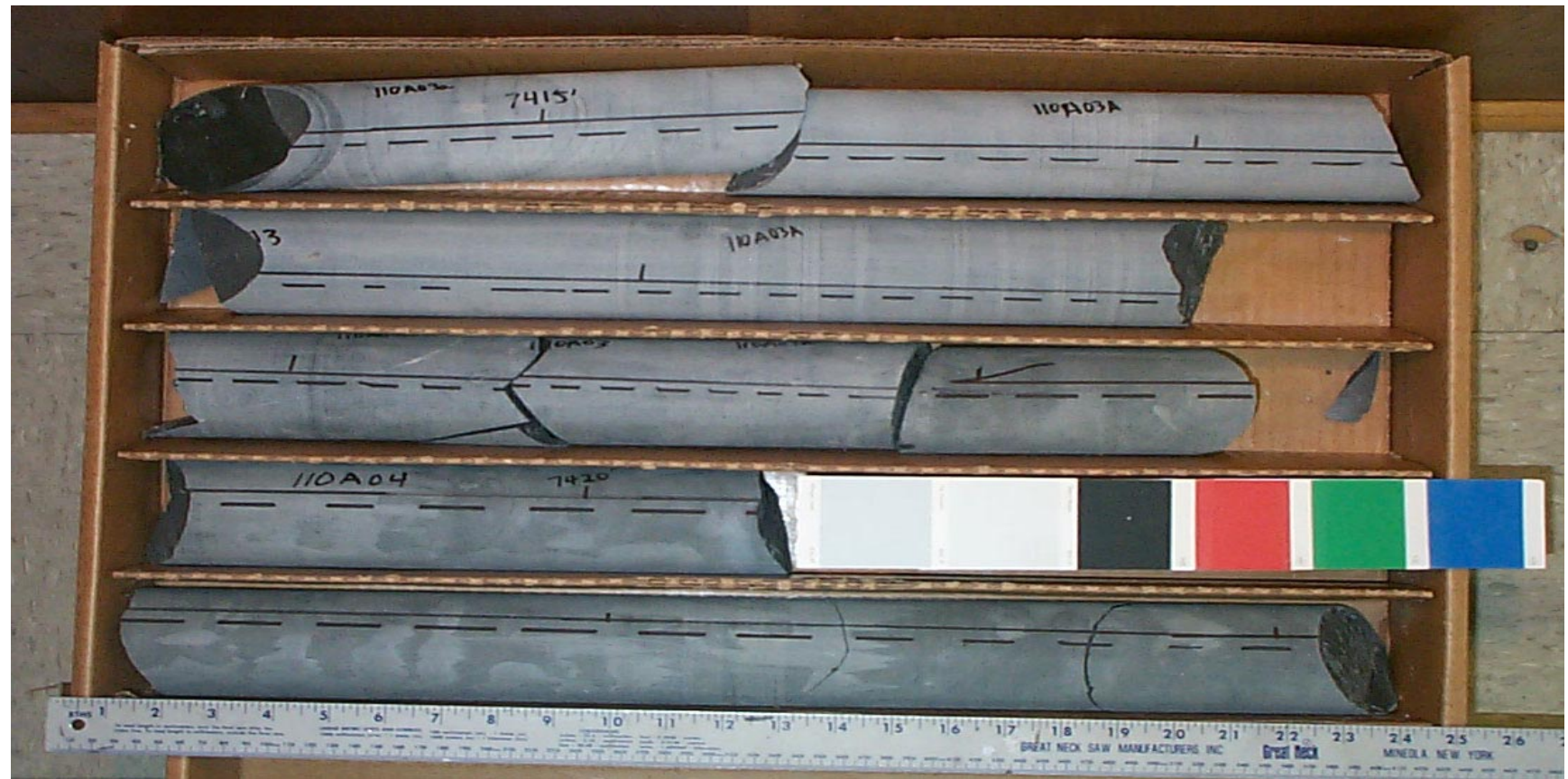

Core Scans included in this box (listed by piece going downhole):

110A031A
110A032A
110A040A

See the "reading instructions" section of the introduction for help interpreting core box photos and core piece nomenclature 


\section{LVEW Core Box 167}

Depth Interval 7422.1'-7430.0'

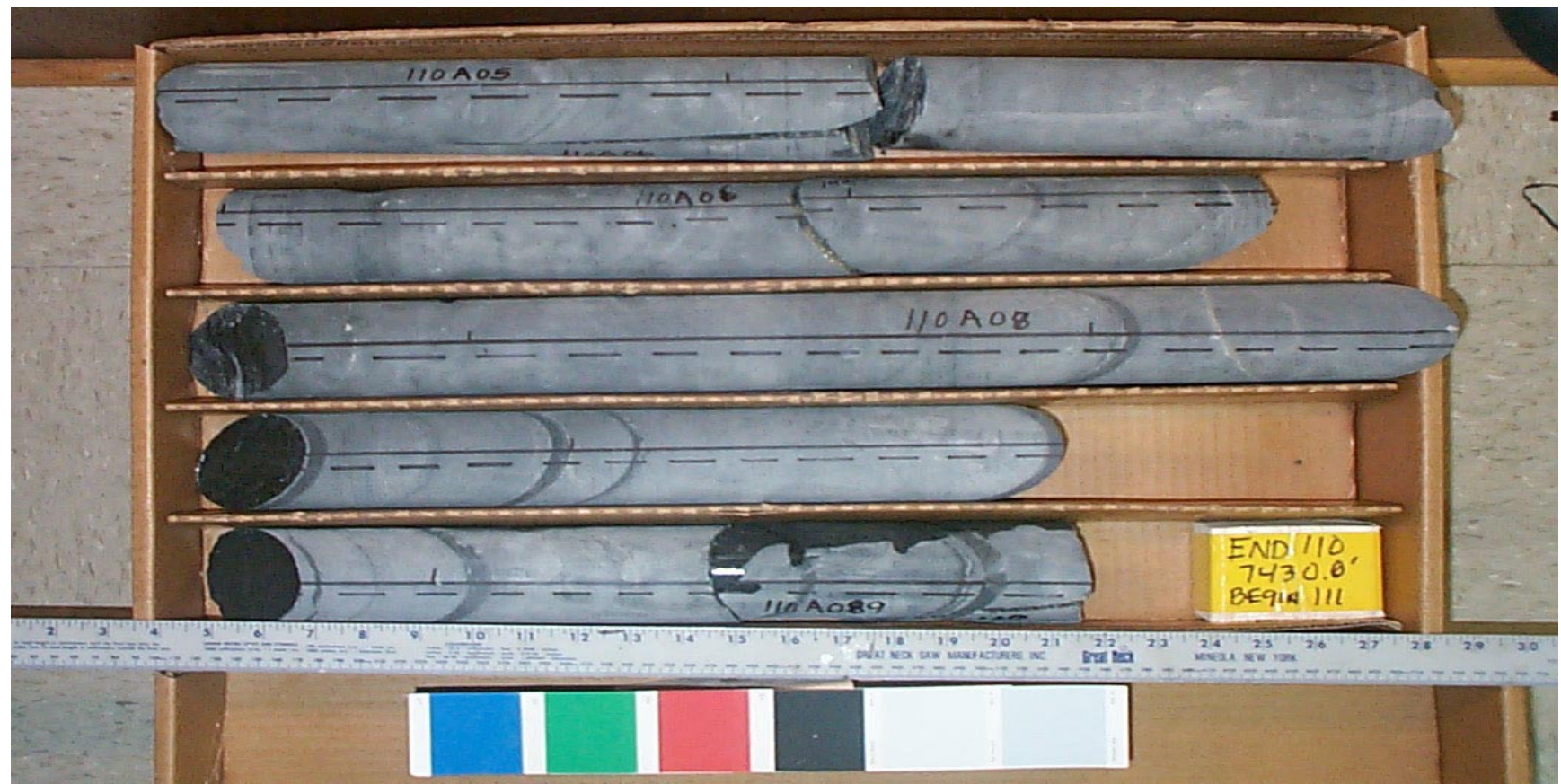

Core Scans included in this box (listed by piece going downhole):

\section{$110 \mathrm{~A} 070 \mathrm{~A}$} $110 \mathrm{~A} 080 \mathrm{~A}$

See the "reading instructions" section of the introduction for help interpreting core box photos and core piece nomenclature 


\section{LVEW Core Box 168}

Depth Interval 7430.0'-7435.6'

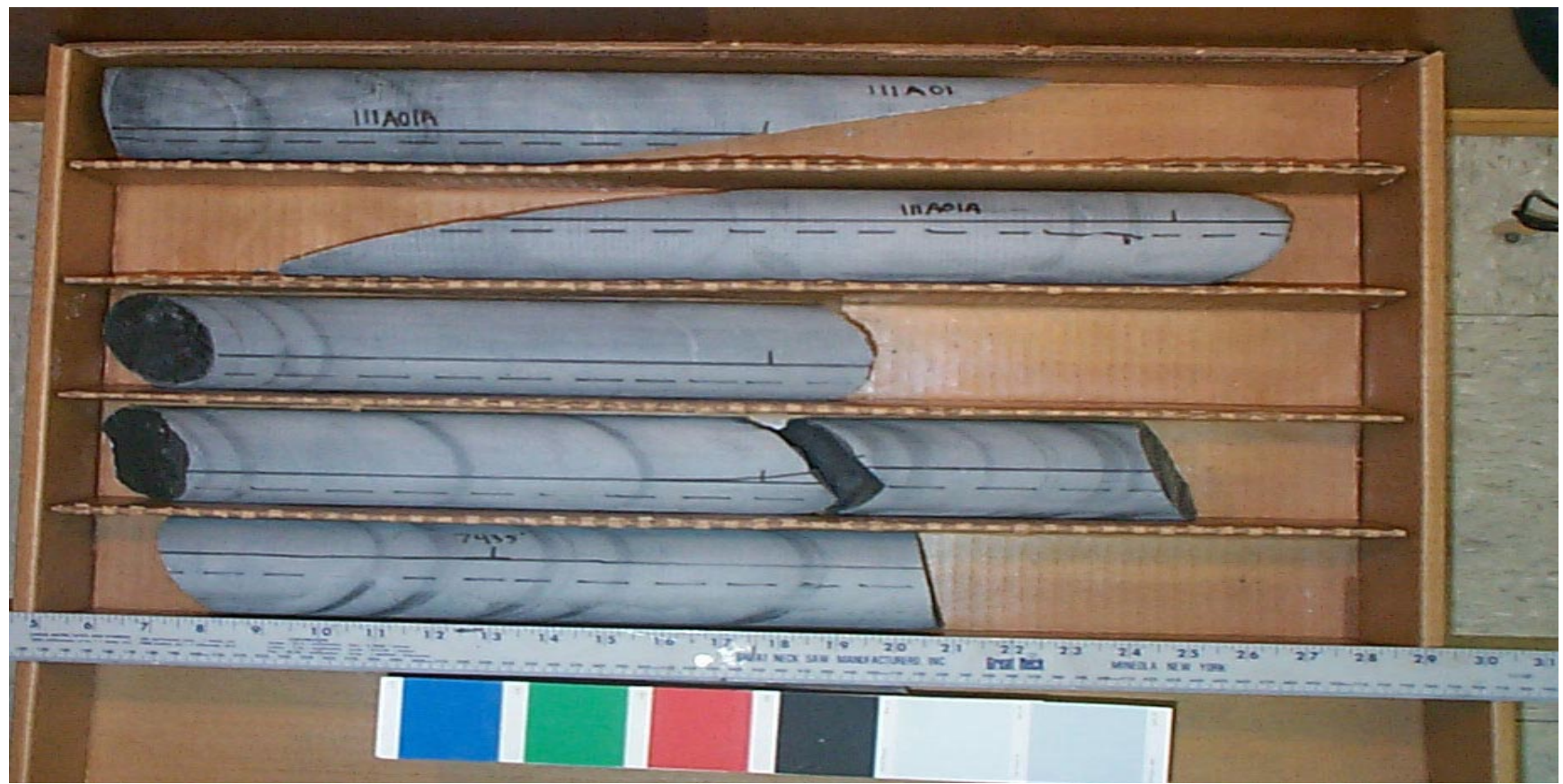

Core Scans included in this box (listed by piece going downhole):

111A010A
111A021A
111A022A
111A023A

See the "reading instructions" section of the introduction for help interpreting core box photos and core piece nomenclature 


\section{LVEW Core Box 169}

Depth Interval 7435.6'-7442.1'

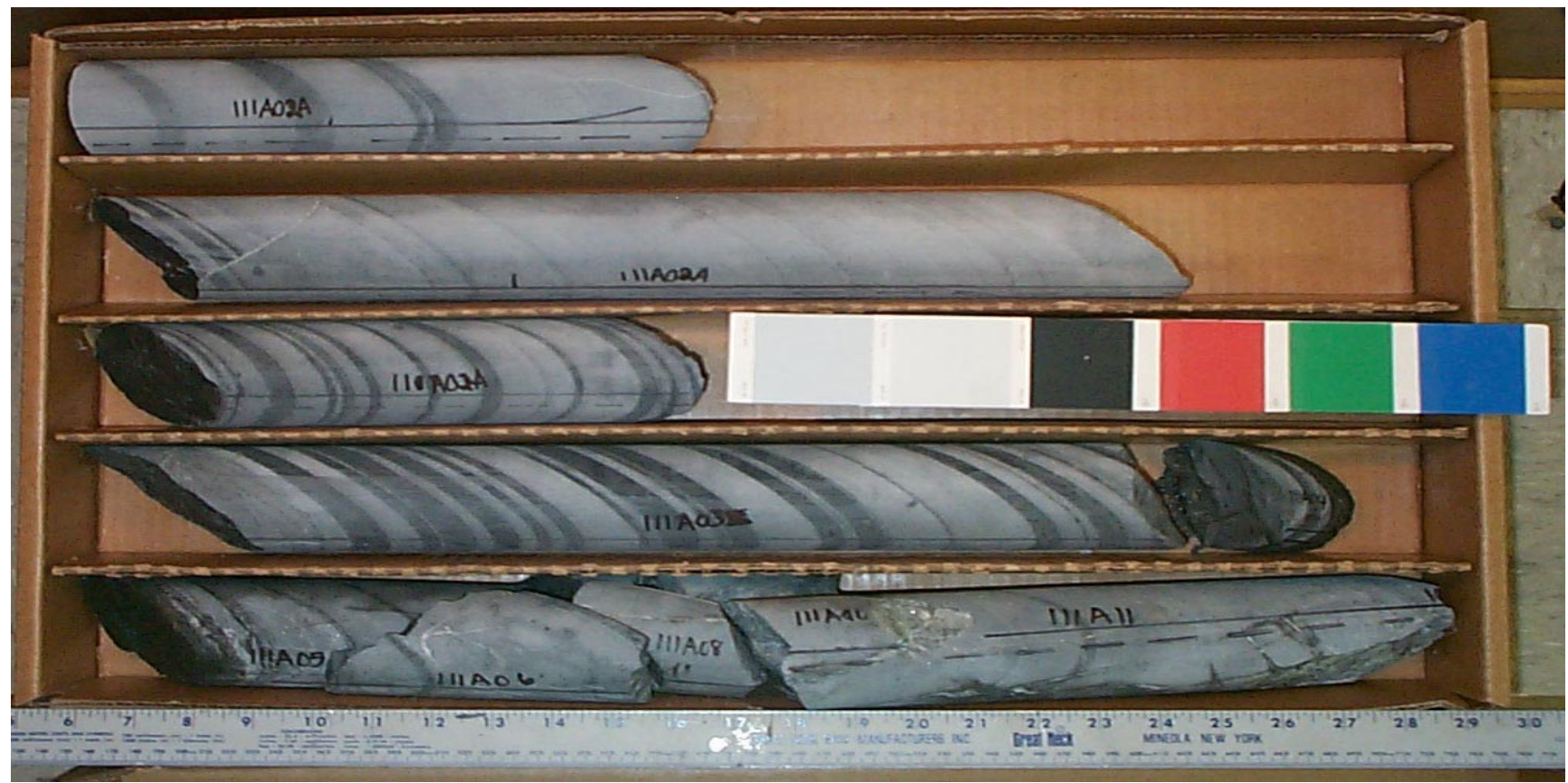

Core Scans included in this box (listed by piece going downhole):
$111 \mathrm{~A} 022 \mathrm{~A}$
$111 \mathrm{~A} 023 \mathrm{~A}$
$111 \mathrm{~A} 031 \mathrm{~A}$
$111 \mathrm{~A} 032 \mathrm{~A}$
$111 \mathrm{~A} 040 \mathrm{~A}$
$111 \mathrm{~A} 0500$
$111 \mathrm{~A} 1100$

See the "reading instructions" section of the introduction for help interpreting core box photos and core piece nomenclature 


\section{LVEW Core Box 170}

\section{Depth Interval 7442.1'-7447.5'}

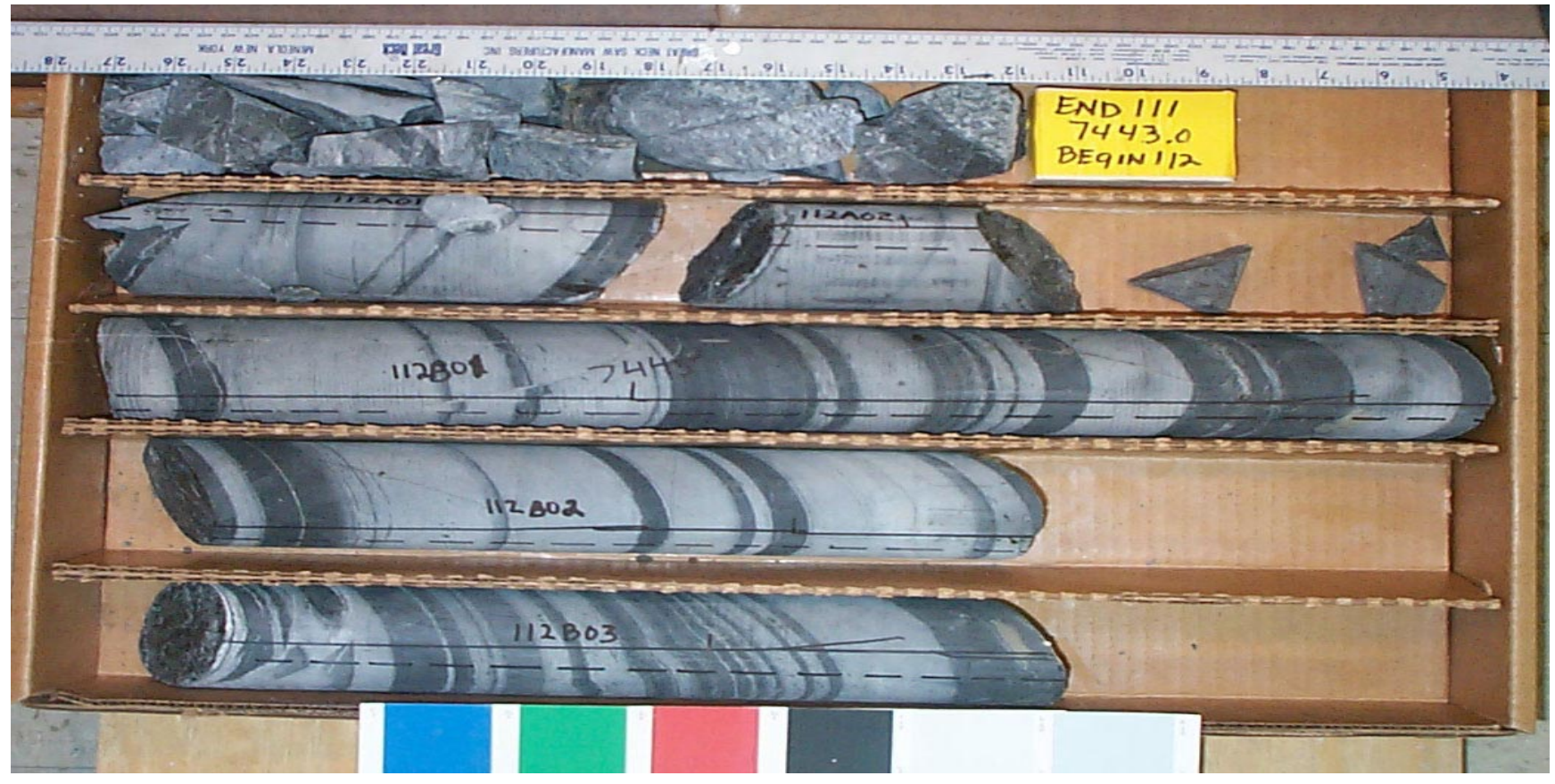

Core Scans included in this box (listed by piece going downhole):

$112 \mathrm{~A} 0100$

$112 \mathrm{~A} 0200$

$112 \mathrm{~B} 0100$

$112 \mathrm{~B} 0200$

$112 \mathrm{~B} 0300$

See the "reading instructions" section of the introduction for help interpreting core box photos and core piece nomenclature 


\section{LVEW Core Box 171}

Depth Interval 7447.5'-7456.3'

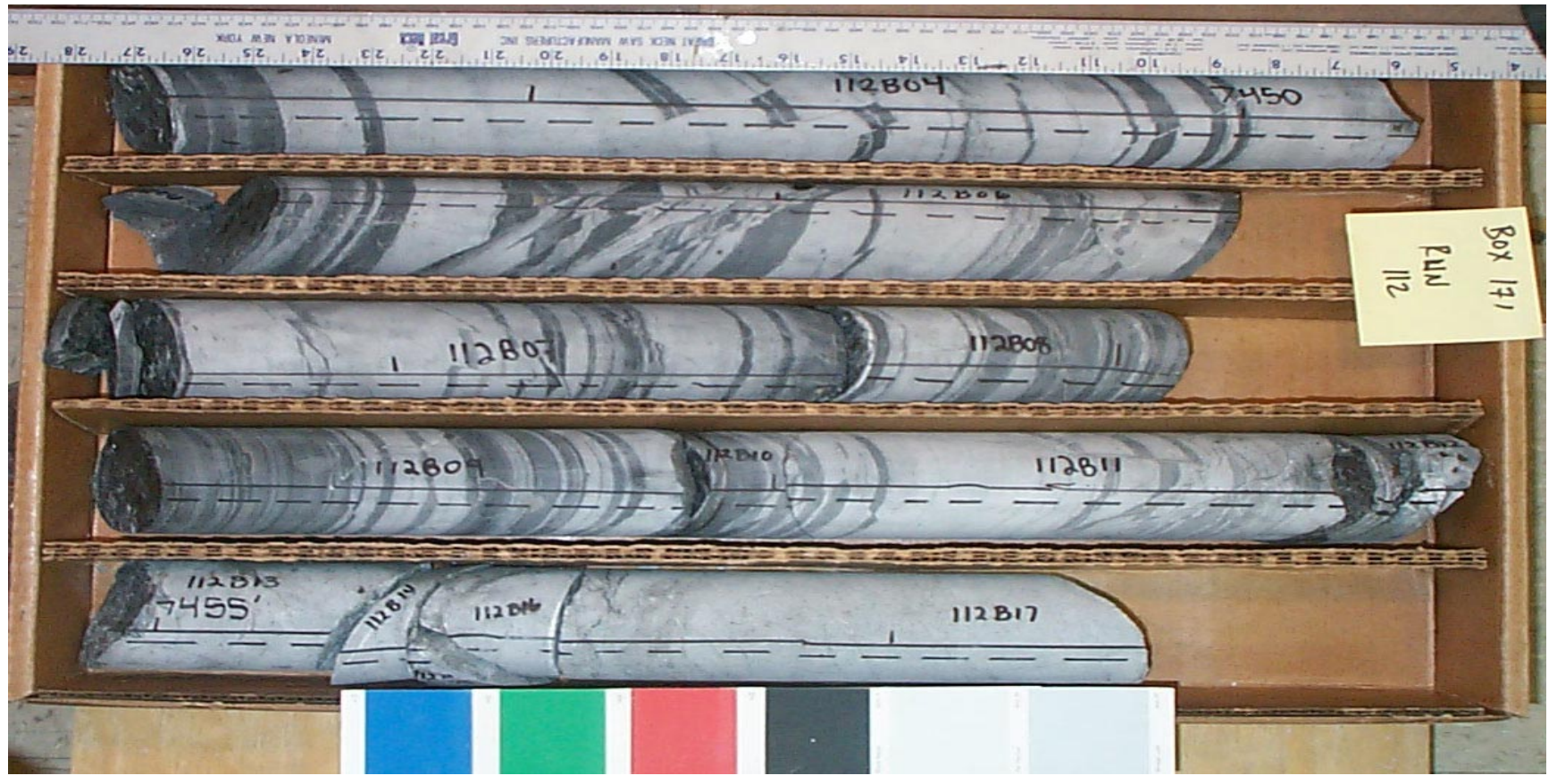

Core Scans included in this box (listed by piece going downhole):

$112 \mathrm{~B} 0400$

$112 \mathrm{~B} 0600$

$112 \mathrm{~B} 0700$

$112 \mathrm{~B} 0800$

$112 \mathrm{~B} 0900$

$112 \mathrm{~B} 1000$

$112 \mathrm{~B} 1100$

$112 \mathrm{~B} 1300$

$112 \mathrm{~B} 1700$

See the "reading instructions" section of the introduction for help interpreting core box photos and core piece nomenclature 


\section{LVEW Core Box 172}

Depth Interval 7456.3'-7463.1'

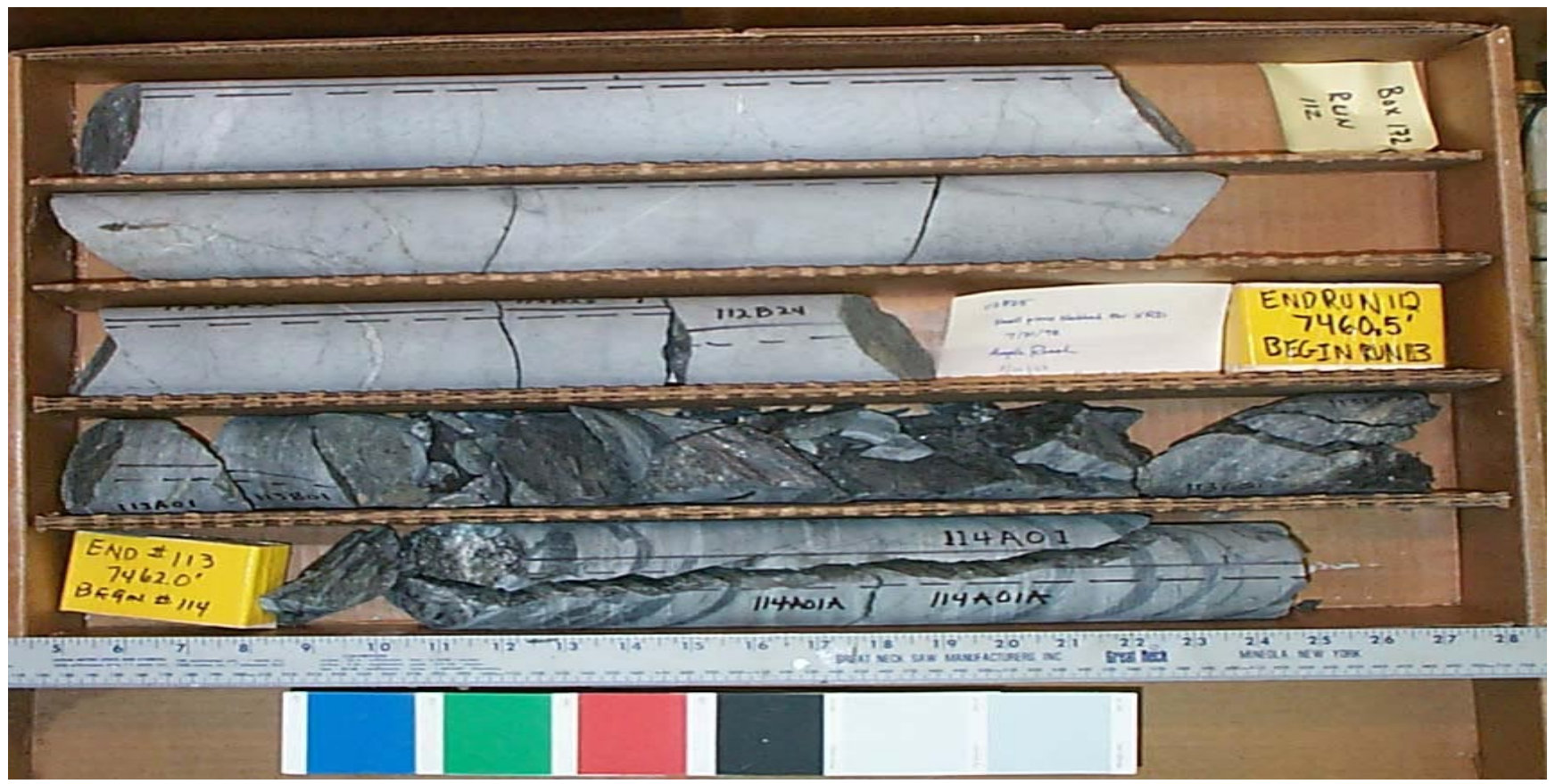

Core Scans included in this box (listed by piece going downhole):

$112 \mathrm{~B} 1800$

$112 \mathrm{~B} 1900$

$112 \mathrm{~B} 2000$

$112 \mathrm{~B} 2100$

$112 \mathrm{~B} 2200$

$112 \mathrm{~B} 2300$

$112 \mathrm{~B} 2400$

$114 \mathrm{~A} 010 \mathrm{~A}$

See the "reading instructions" section of the introduction for help interpreting core box photos and core piece nomenclature 


\section{LVEW Core Box 173}

Depth Interval 7463.1'-7469.3'

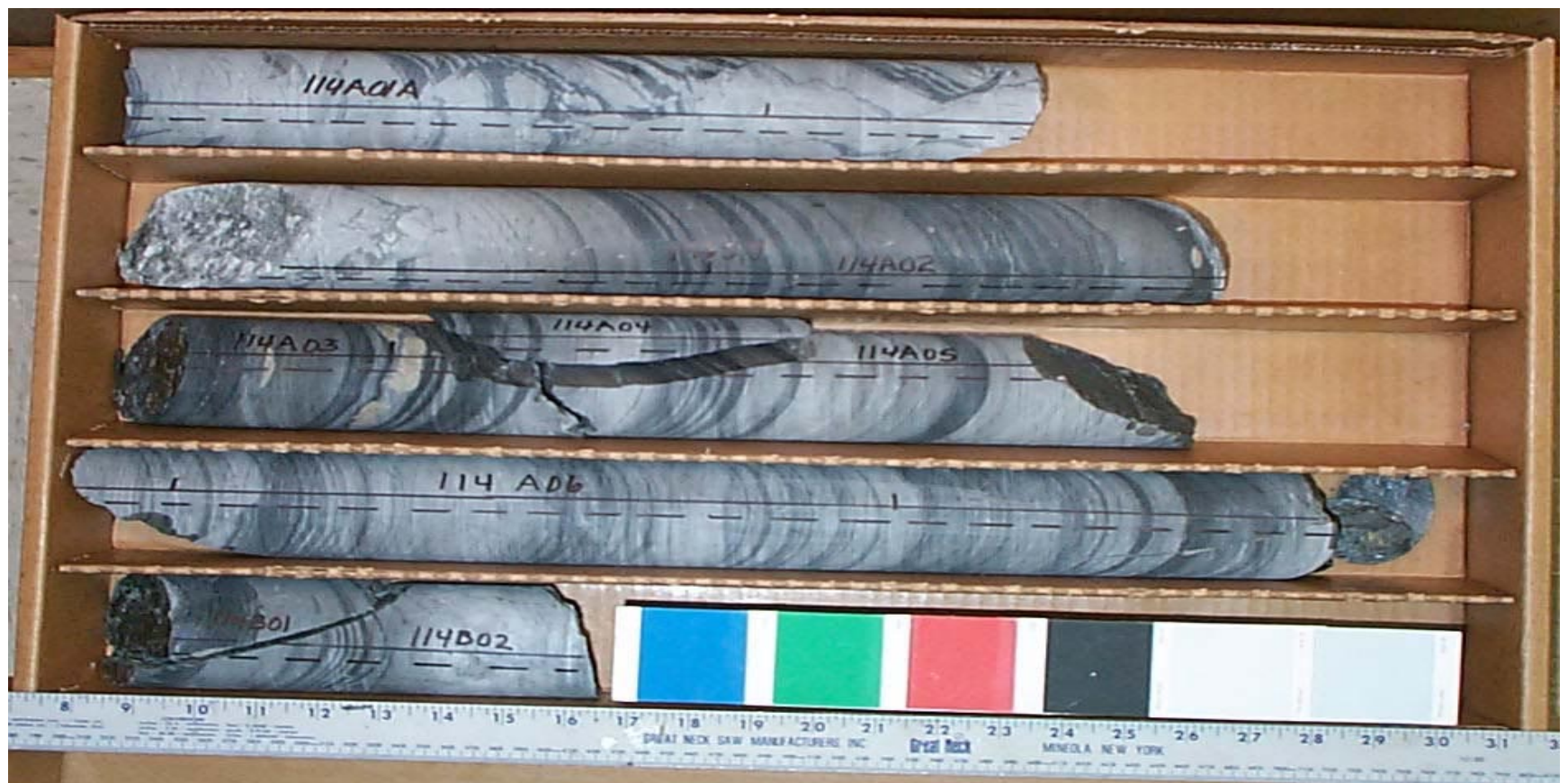

Core Scans included in this box (listed by piece going downhole):

$114 \mathrm{~A} 010 \mathrm{~A}$

$114 \mathrm{~A} 0200$

$114 \mathrm{~A} 0300$

$114 \mathrm{~A} 0500$

$114 \mathrm{~A} 0600$

See the "reading instructions" section of the introduction for help interpreting core box photos and core piece nomenclature 


\section{LVEW Core Box 174}

\section{Depth Interval 7469.3'-7476.8'}

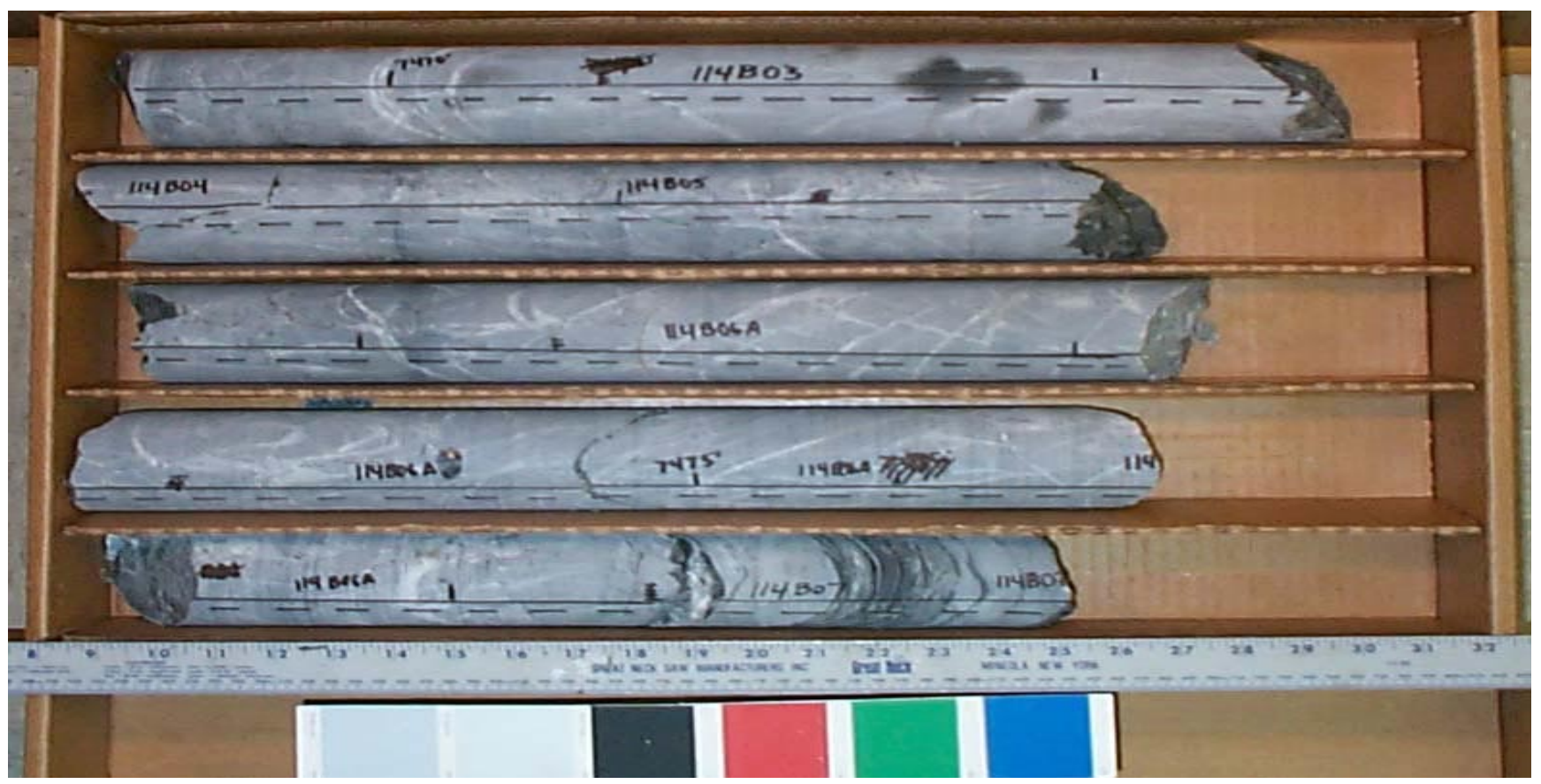

Core Scans included in this box (listed by piece going downhole):

\section{B0300 \\ 114B0500 \\ $114 \mathrm{~B} 061 \mathrm{~A}$ \\ 114B062A \\ 114B071A}

See the "reading instructions" section of the introduction for help interpreting core box photos and core piece nomenclature 


\section{LVEW Core Box 175}

Depth Interval 7476.8'-7484.1'

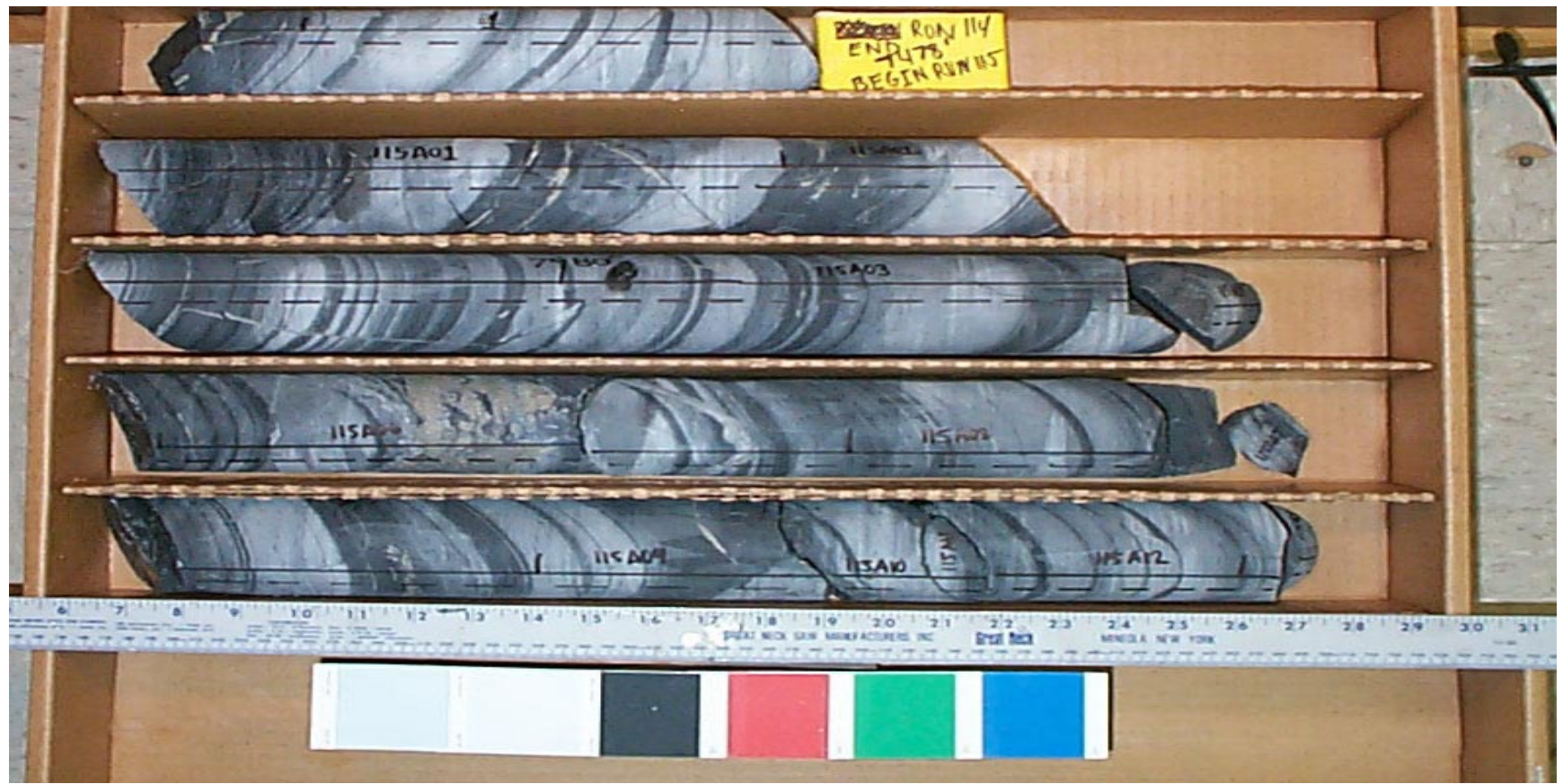

Core Scans included in this box (listed by piece going downhole):

114B072A

$115 \mathrm{~A} 0100$

$115 \mathrm{~A} 0200$

$115 \mathrm{~A} 0300$

$115 \mathrm{~A} 0600$

$115 \mathrm{~A} 0800$

$115 \mathrm{~A} 0900$

$115 \mathrm{~A} 1000$

$115 \mathrm{~A} 1200$

See the "reading instructions" section of the introduction for help interpreting core box photos and core piece nomenclature 


\section{LVEW Core Box 176}

Depth Interval 7484.1'-7490.9'

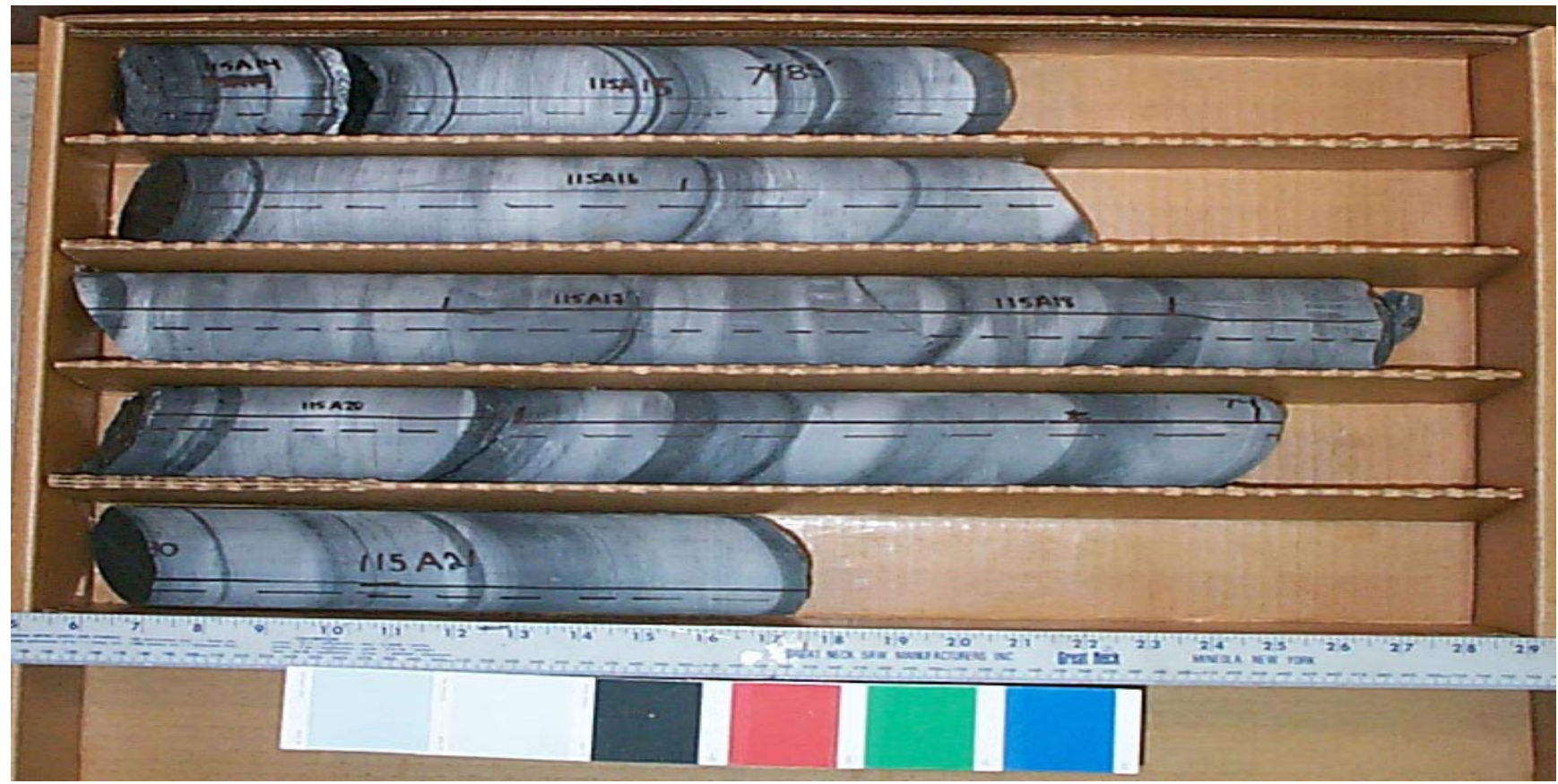

Core Scans included in this box (listed by piece going downhole):
$115 \mathrm{~A} 1400$
$115 \mathrm{~A} 1500$
$115 \mathrm{~A} 1600$
$115 \mathrm{~A} 1700$
$115 \mathrm{~A} 1800$
$115 \mathrm{~A} 200 \mathrm{~A}$
$115 \mathrm{~A} 2100$

See the "reading instructions" section of the introduction for help interpreting core box photos and core piece nomenclature 


\section{LVEW Core Box 177}

Depth Interval 7490.9'-7497.7'

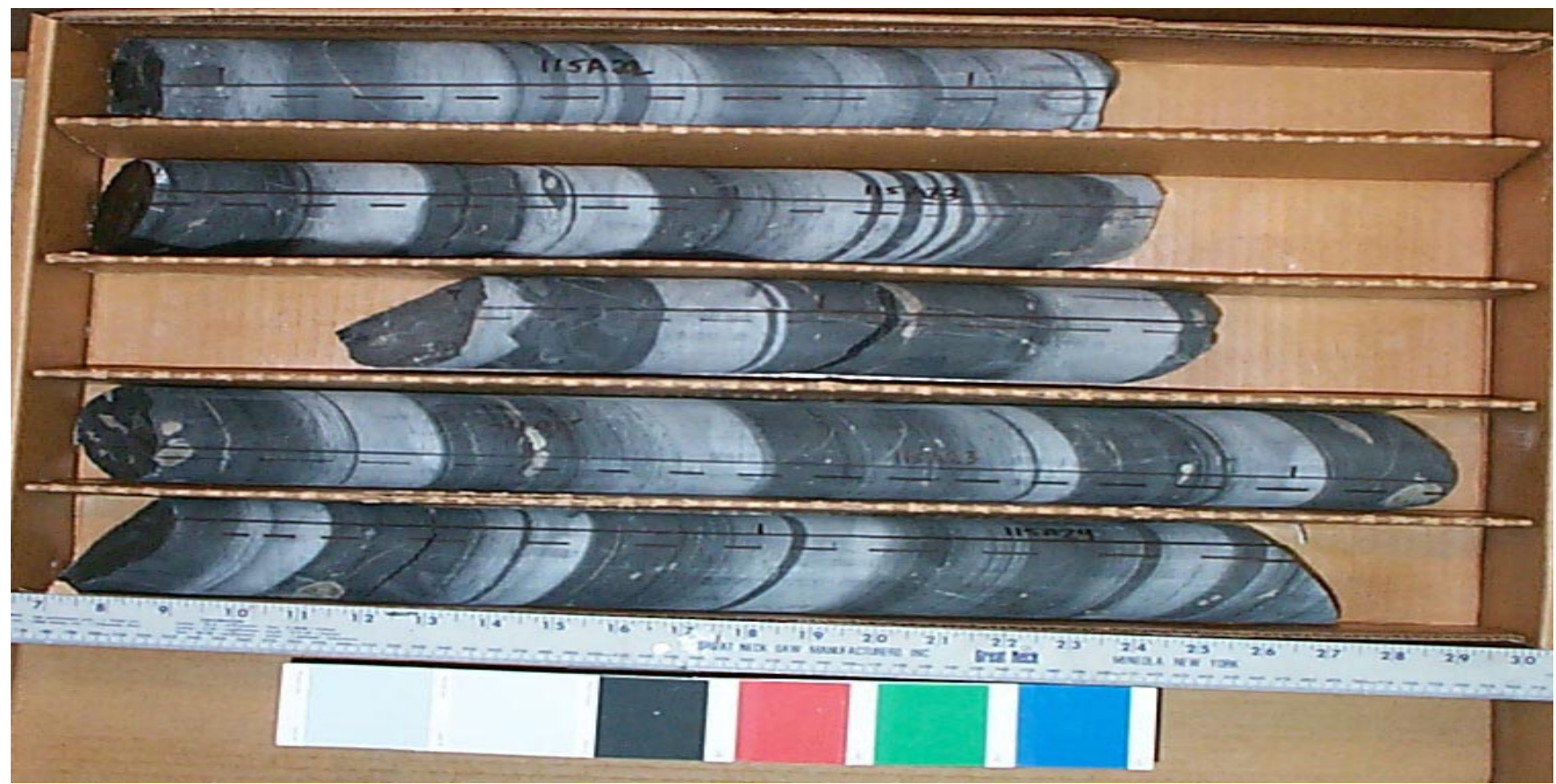

Core Scans included in this box (listed by piece going downhole):

115A2200
115A231A
115A232A
115A241A
$115 A 242 A$

See the "reading instructions" section of the introduction for help interpreting core box photos and core piece nomenclature 


\section{LVEW Core Box 178}

Depth Interval 7497.7'-7505.0'

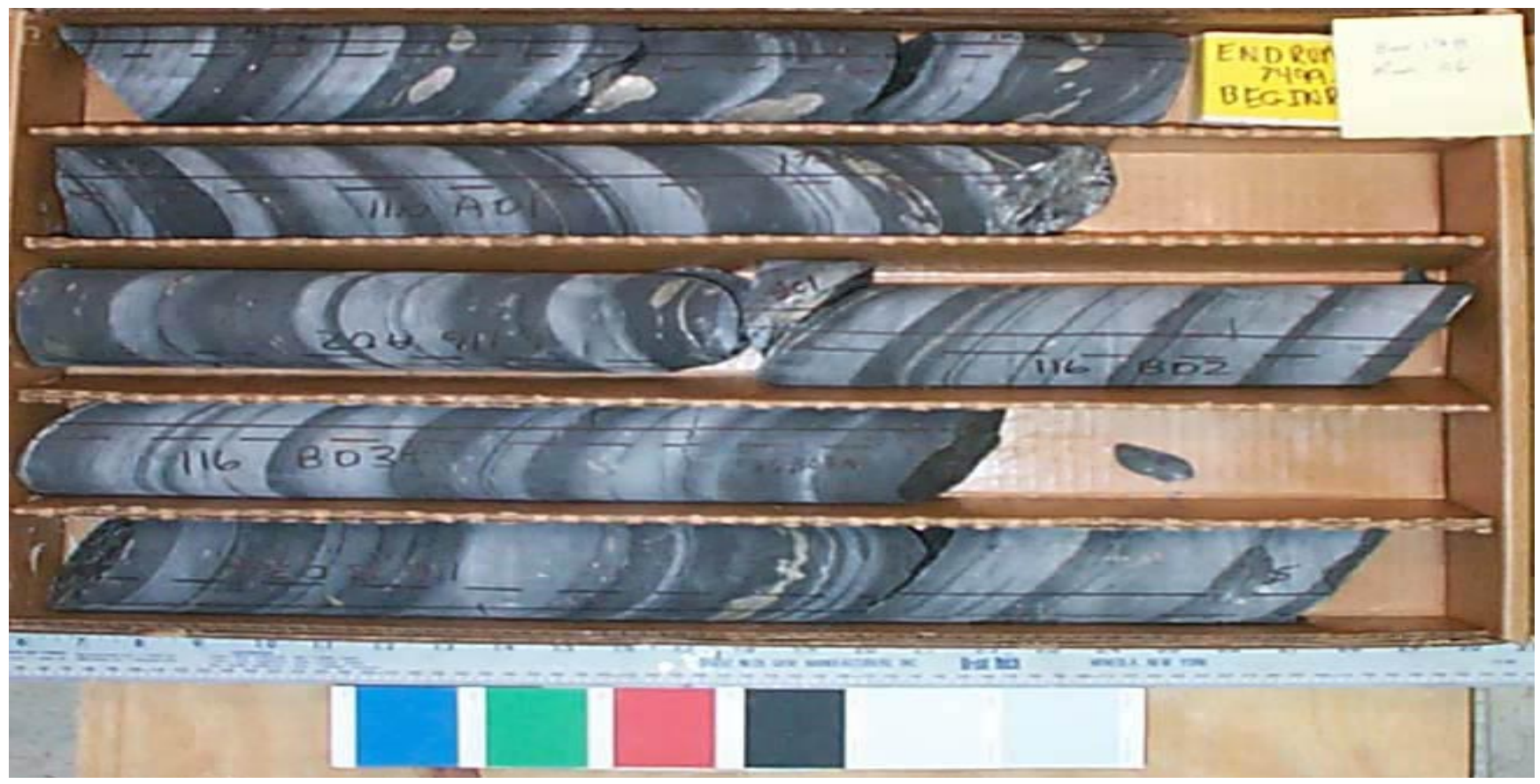

Core Scans included in this box (listed by piece going downhole):
$115 \mathrm{~A} 241 \mathrm{~A}$
$115 \mathrm{~A} 242 \mathrm{~A}$
$115 \mathrm{~A} 2500$
$116 \mathrm{~A} 0100$
$116 \mathrm{~A} 0200$
$116 \mathrm{~B} 0200$
$116 \mathrm{~B} 031 \mathrm{~A}$
116B032A

See the "reading instructions" section of the introduction for help interpreting core box photos and core piece nomenclature 


\section{LVEW Core Box 179}

Depth Interval 7505.0'-7513.0'

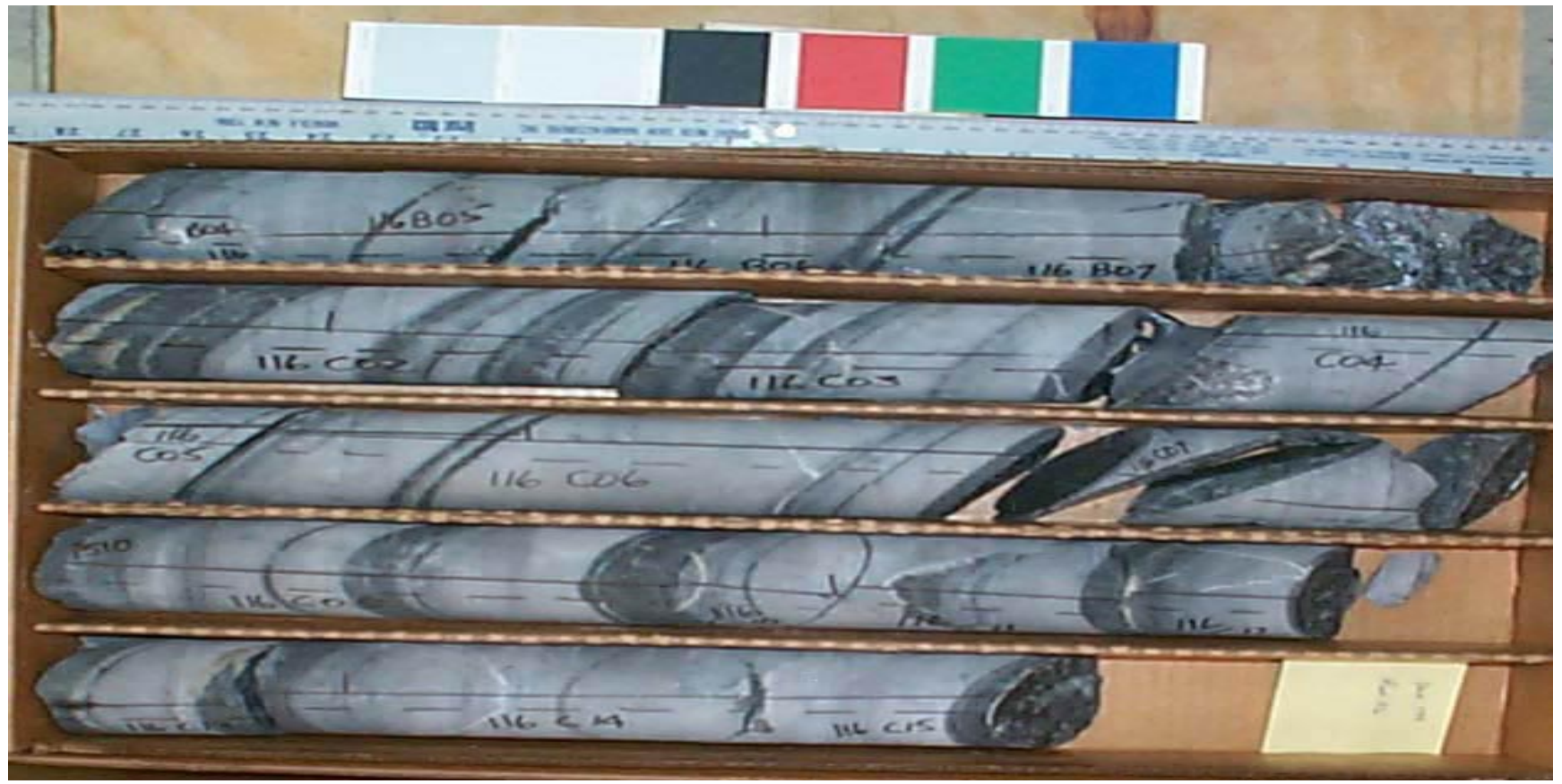

Core Scans included in this box (listed by piece going downhole):
116B0600
$116 \mathrm{C} 0200$
$116 \mathrm{C} 0300$
$116 \mathrm{C} 0400$
$116 \mathrm{C} 0600$
$116 \mathrm{C} 0900$
$116 \mathrm{C} 1100$
$116 \mathrm{C} 1200$
$116 \mathrm{C} 1300$
$116 \mathrm{C} 1400$
$116 \mathrm{C} 1500$

See the "reading instructions" section of the introduction for help interpreting core box photos and core piece nomenclature 


\section{LVEW Core Box 180}

\section{Depth Interval 7513.0'-7520.0'}

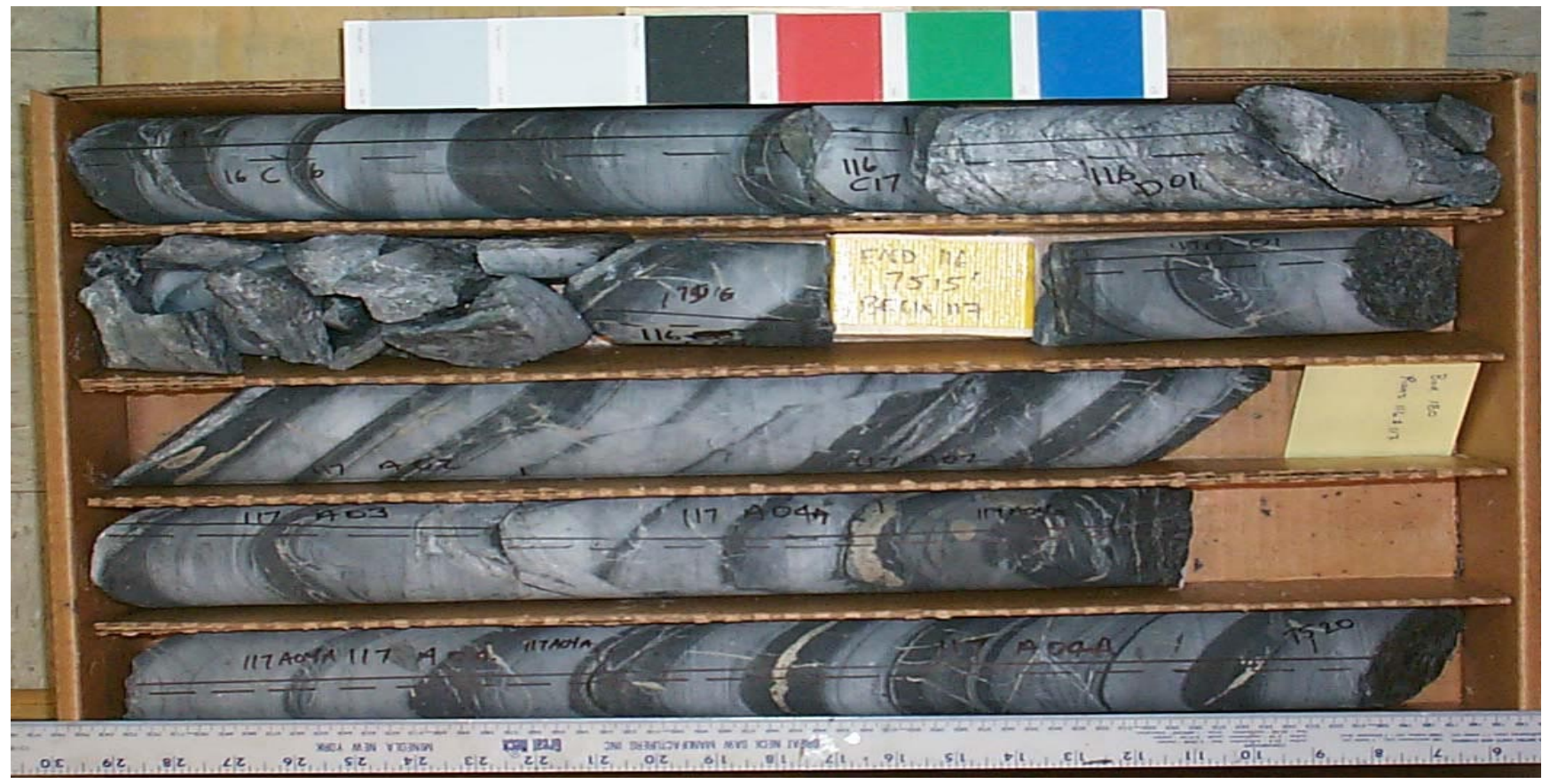

Core Scans included in this box (listed by piece going downhole):
$116 \mathrm{C} 1600$
$116 \mathrm{D} 0100$
$116 \mathrm{~F} 0100$
$117 \mathrm{~A} 0100$
$117 \mathrm{~A} 0200$
$117 \mathrm{~A} 0300$
$117 \mathrm{~A} 0400$

See the "reading instructions" section of the introduction for help interpreting core box photos and core piece nomenclature 


\section{LVEW Core Box 181}

Depth Interval 7520.0'-7529.0'

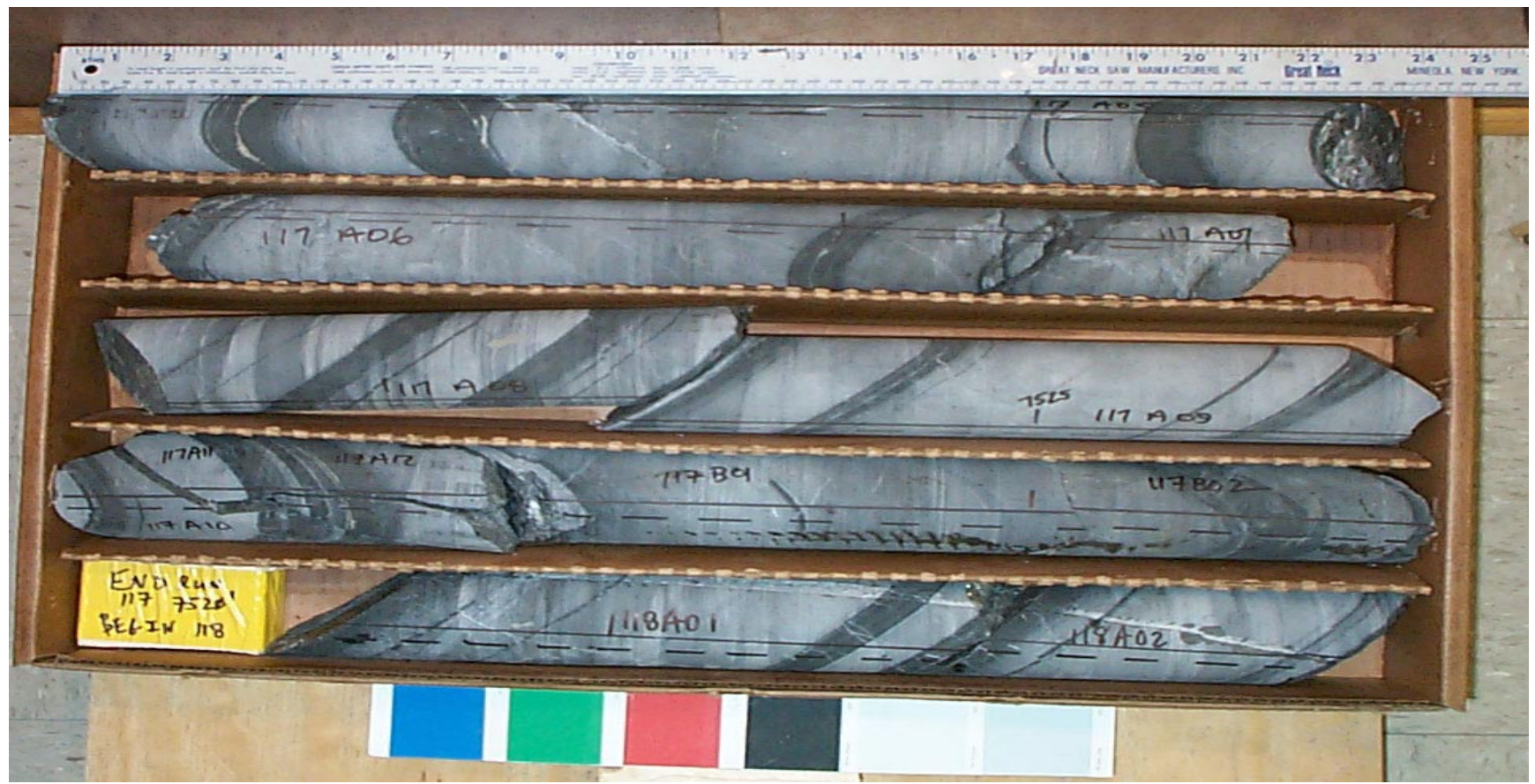

Core Scans included in this box (listed by piece going downhole):
$117 \mathrm{~A} 0500$
$117 \mathrm{~A} 0600$
$117 \mathrm{~A} 0700$
$117 \mathrm{~A} 0800$
$117 \mathrm{~A} 0900$
$117 \mathrm{~B} 0100$
117B0200
$118 \mathrm{~A} 0100$
$118 \mathrm{~A} 0200$

See the "reading instructions" section of the introduction for help interpreting core box photos and core piece nomenclature 


\section{LVEW Core Box 182}

Depth Interval 7529.0'-7537.5'

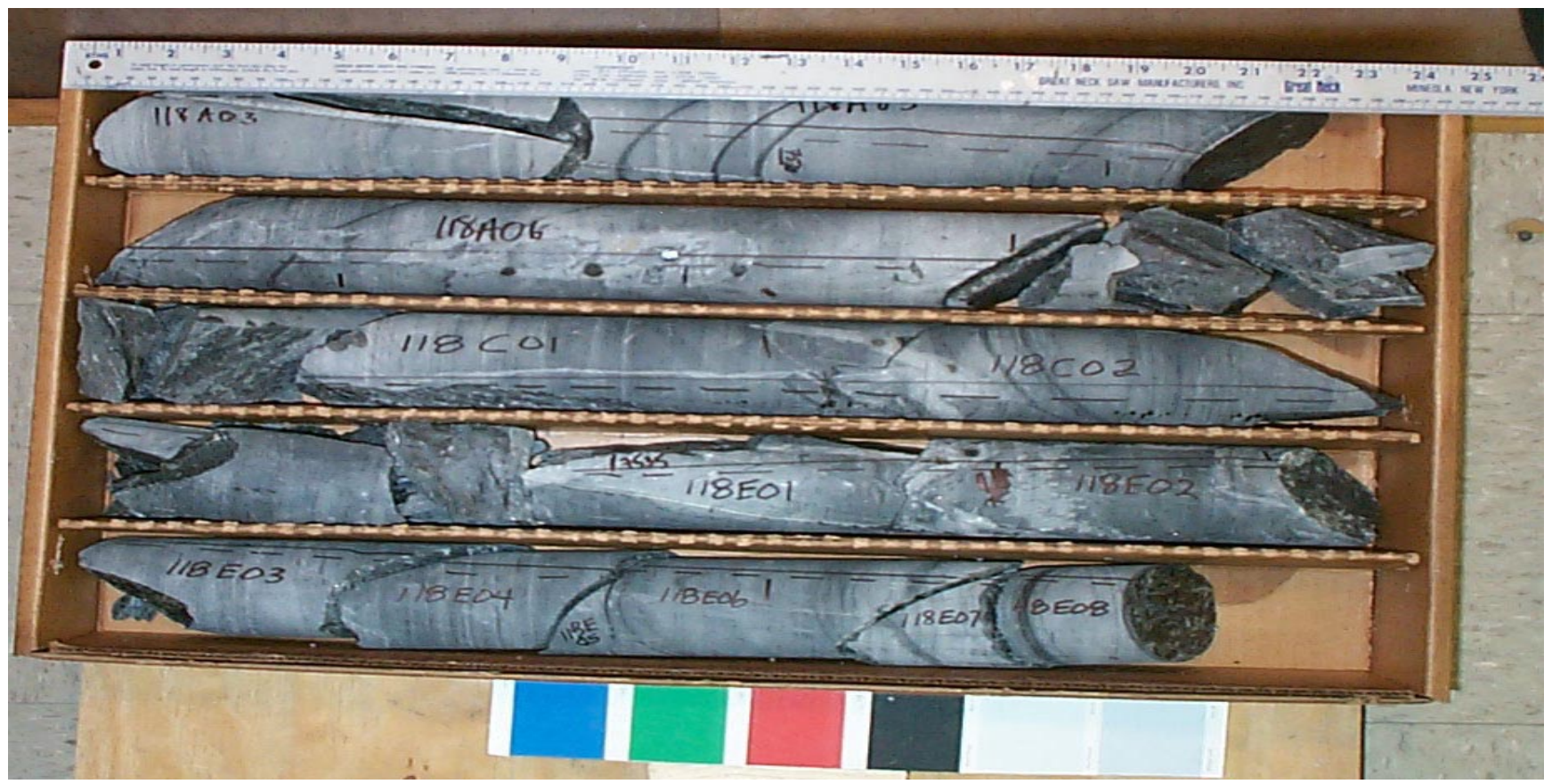

Core Scans included in this box (listed by piece going downhole):
$118 \mathrm{~A} 0500$
$118 \mathrm{~A} 0600$
$118 \mathrm{C} 0200$
$118 \mathrm{E} 0200$
$118 \mathrm{E} 0300$
$118 \mathrm{E} 0600$

See the "reading instructions" section of the introduction for help interpreting core box photos and core piece nomenclature 


\section{LVEW Core Box 183}

Depth Interval 7537.5'-7545.7'

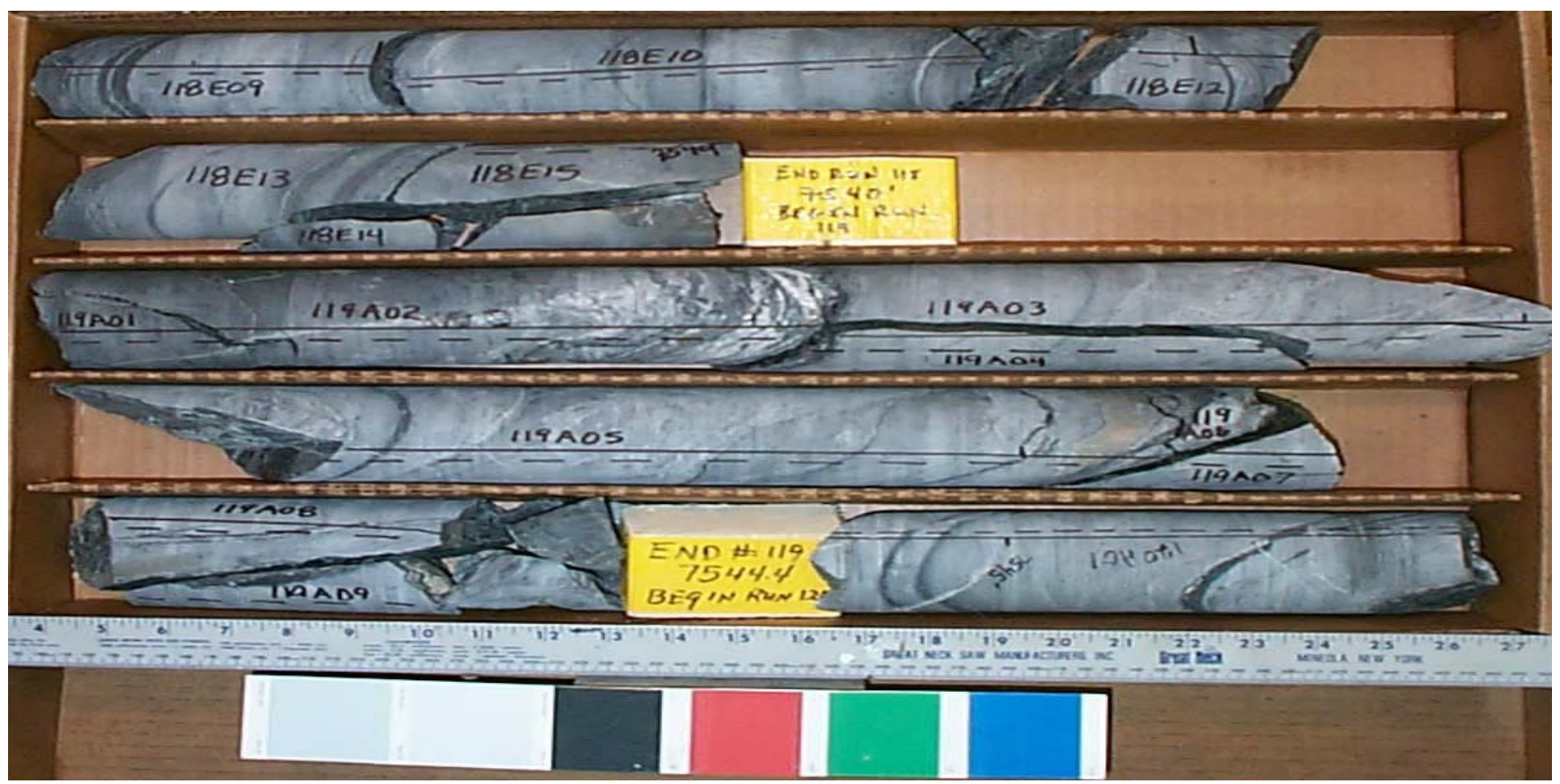

Core Scans included in this box (listed by piece going downhole):

118E0900

$118 \mathrm{E} 1000$

$118 \mathrm{E} 1200$

$118 \mathrm{E} 1300$

$119 \mathrm{~A} 0200$

$119 \mathrm{~A} 0500$

$120 \mathrm{~A} 0100$

See the "reading instructions" section of the introduction for help interpreting core box photos and core piece nomenclature 


\section{LVEW Core Box 184}

Depth Interval 7545.7'-7552.2'

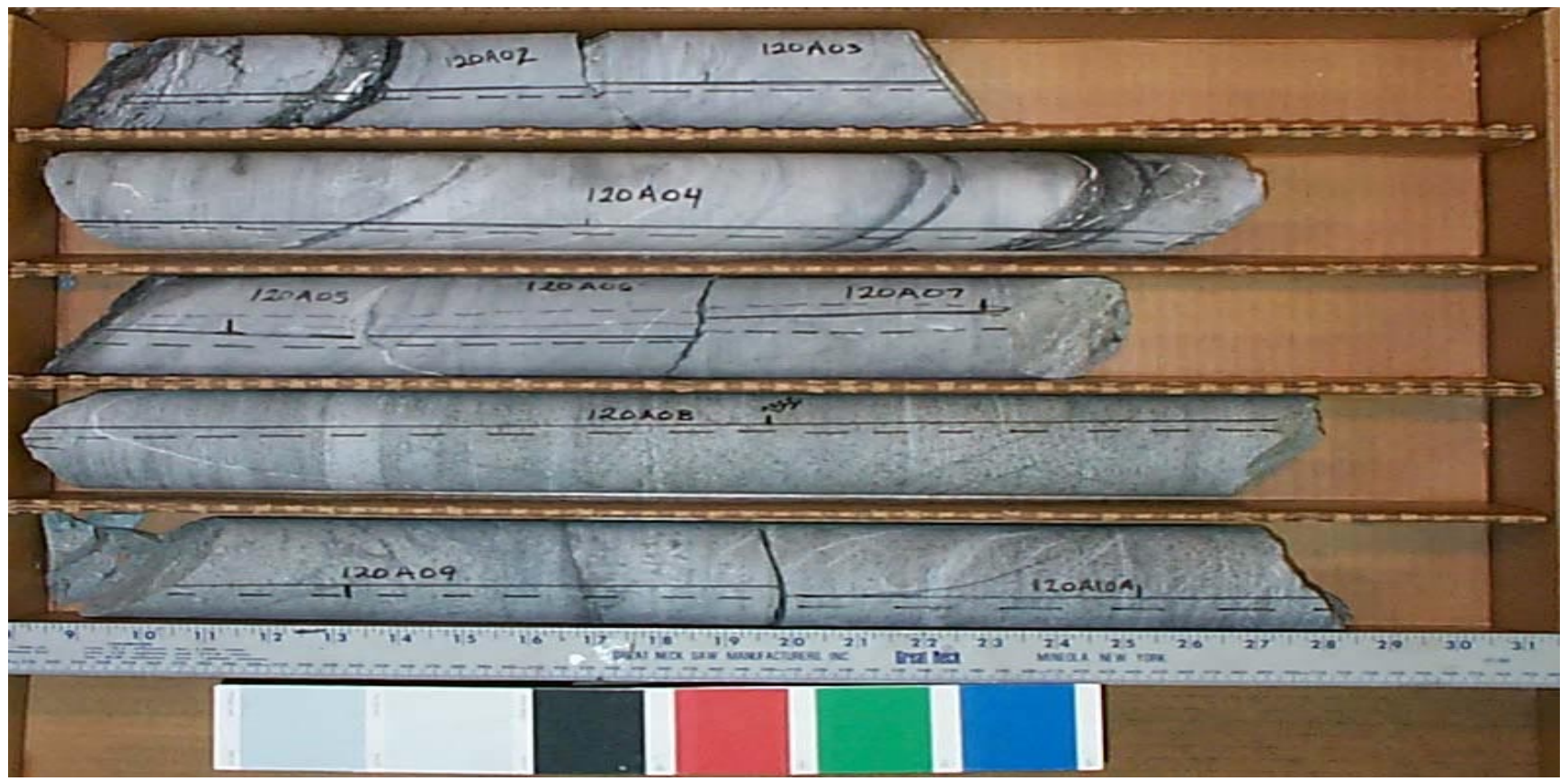

Core Scans included in this box (listed by piece going downhole):
$120 \mathrm{~A} 0200$
$120 \mathrm{~A} 0400$
$120 \mathrm{~A} 0500$
$120 \mathrm{~A} 0600$
$120 \mathrm{~A} 0700$
$120 \mathrm{~A} 0800$
$120 A 0900$
$120 \mathrm{~A} 101 \mathrm{~A}$

See the "reading instructions" section of the introduction for help interpreting core box photos and core piece nomenclature 


\section{LVEW Core Box 185}

Depth Interval 7552.2'-7560.0'

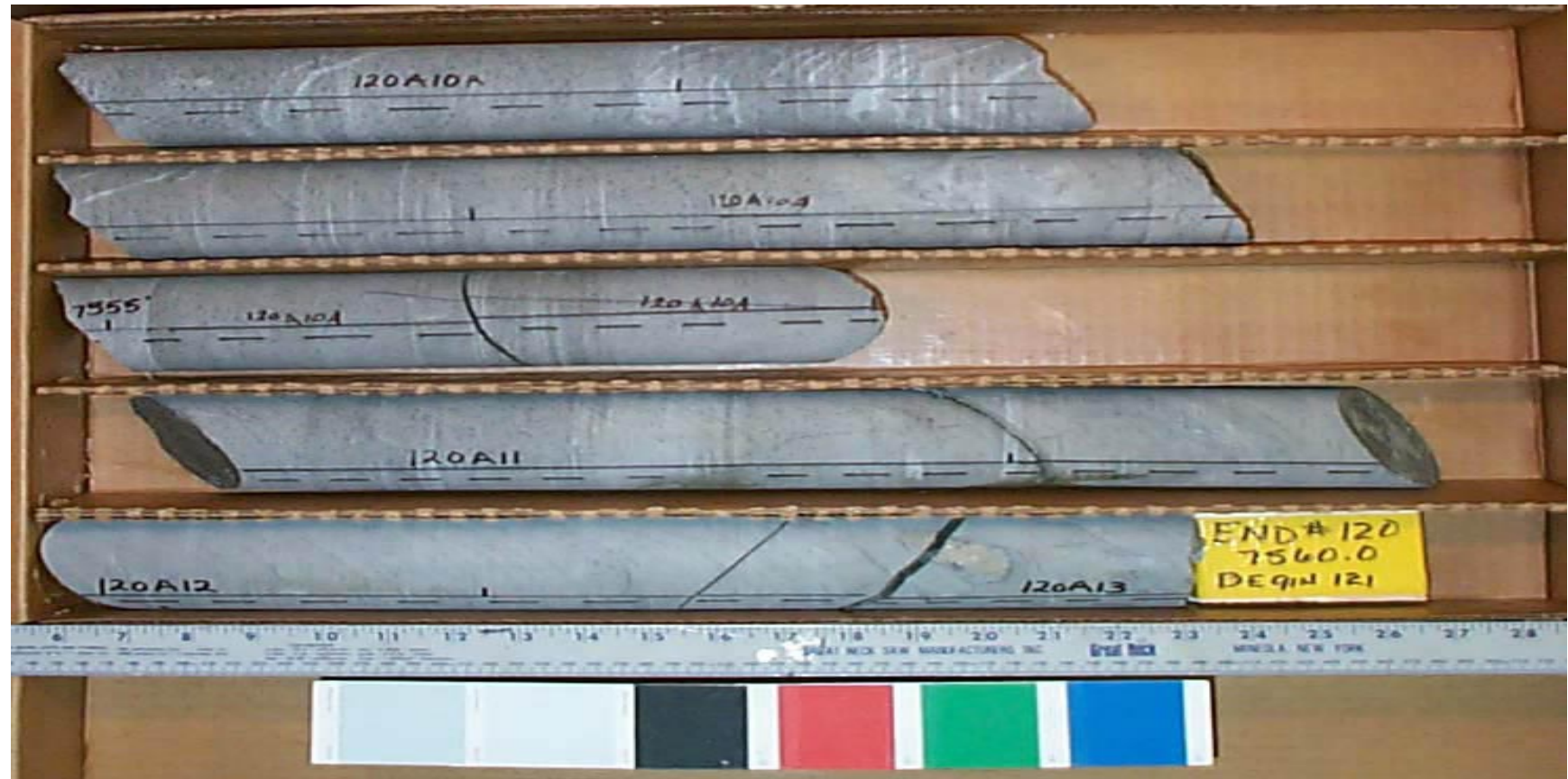

Core Scans included in this box (listed by piece going downhole):

120A101A
120A102A
120A1100
120A120A
120A1300

See the "reading instructions" section of the introduction for help interpreting core box photos and core piece nomenclature 


\section{LVEW Core Box 186}

Depth Interval 7560.0'-7567.0'

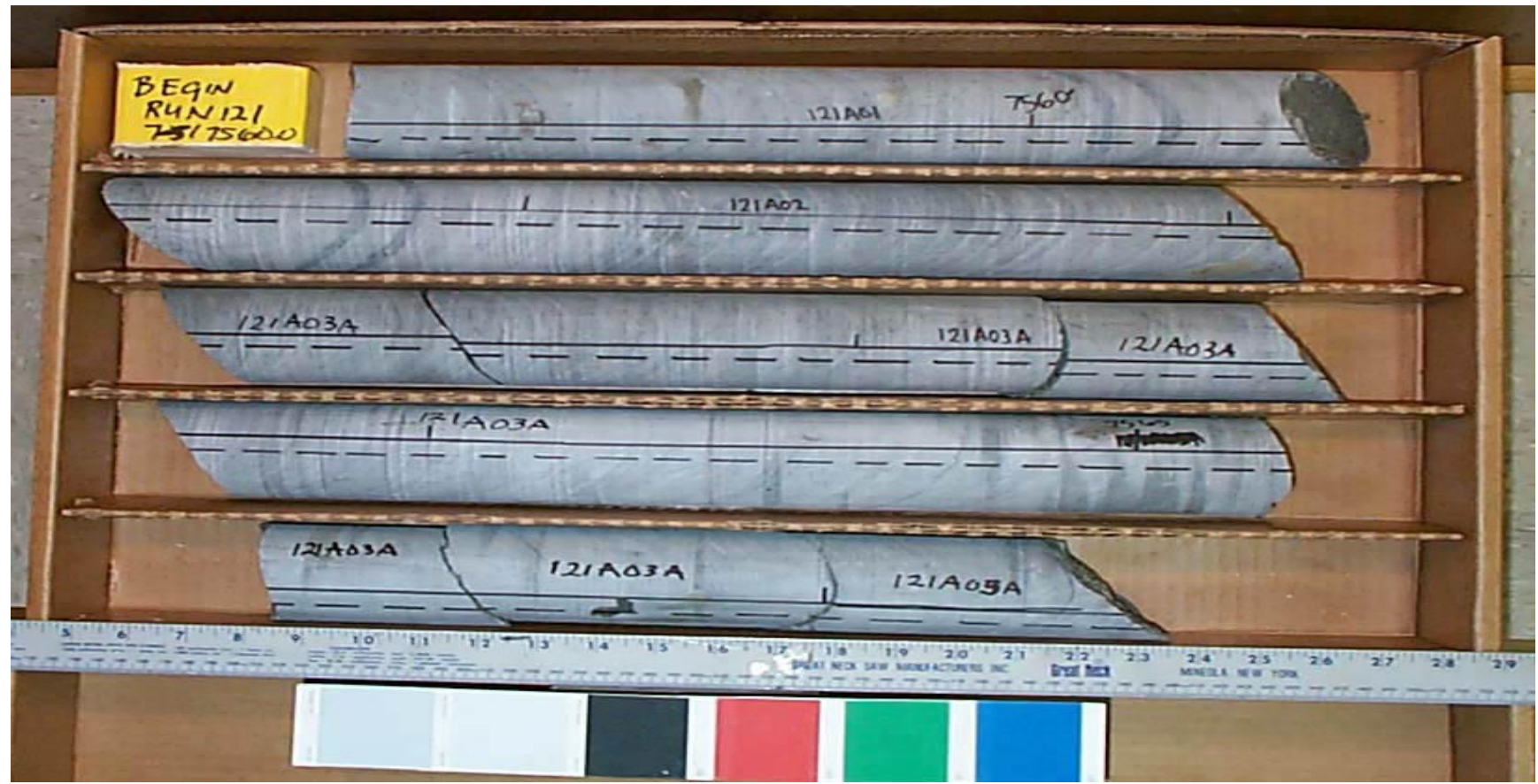

Core Scans included in this box (listed by piece going downhole):

$121 A 0100$
$121 A 0200$
$121 A 031 A$
$121 A 032 A$

See the "reading instructions" section of the introduction for help interpreting core box photos and core piece nomenclature 


\section{LVEW Core Box 187}

Depth Interval 7567.0'-7574.1'

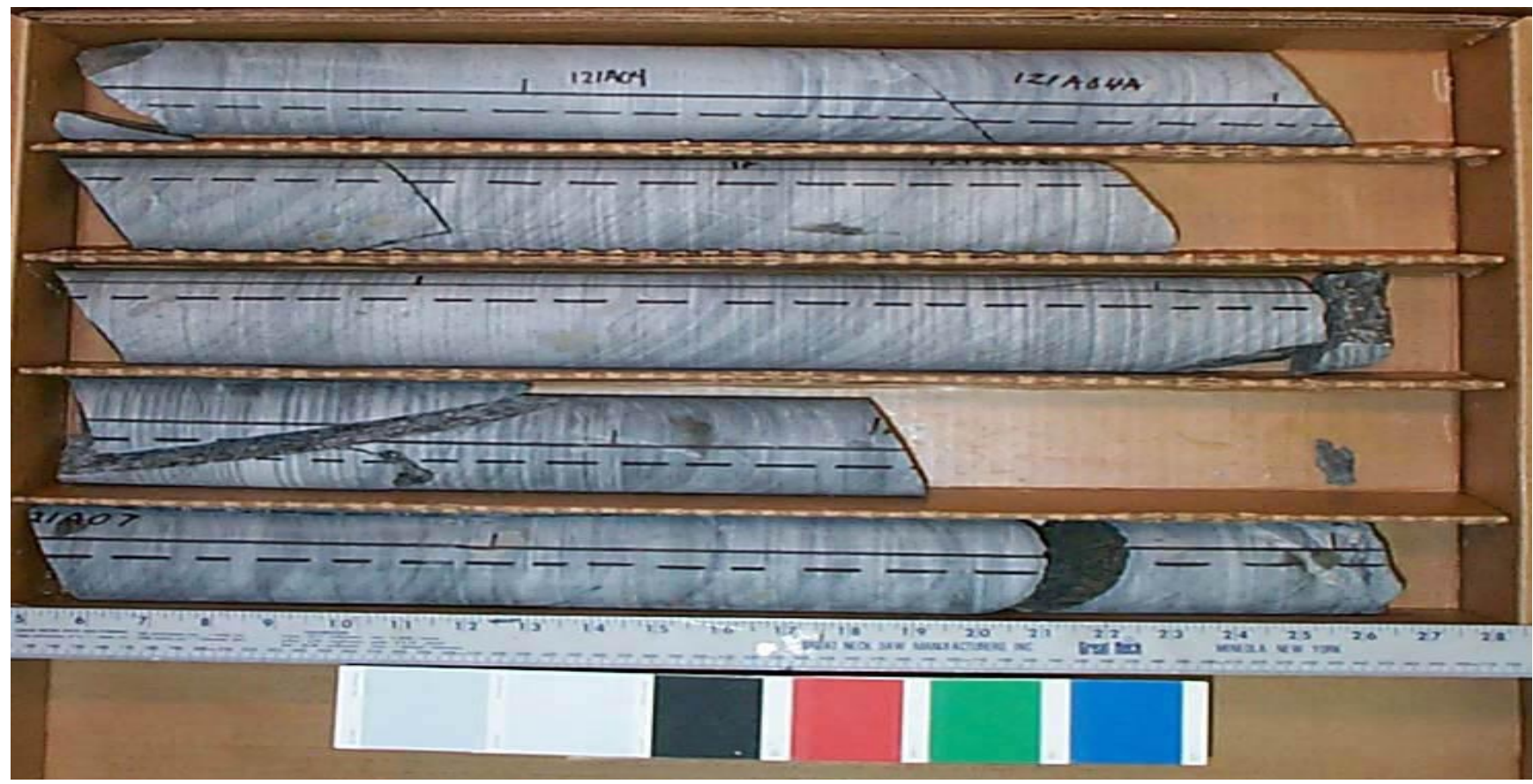

Core Scans included in this box (listed by piece going downhole):
$121 \mathrm{~A} 040 \mathrm{~A}$
$121 \mathrm{~A} 0500$
$121 \mathrm{~A} 060 \mathrm{~A}$
$121 \mathrm{~A} 071 \mathrm{~A}$
$121 \mathrm{~A} 072 \mathrm{~A}$

See the "reading instructions" section of the introduction for help interpreting core box photos and core piece nomenclature 


\section{LVEW Core Box 188}

Depth Interval 7574.1'-7581.7'

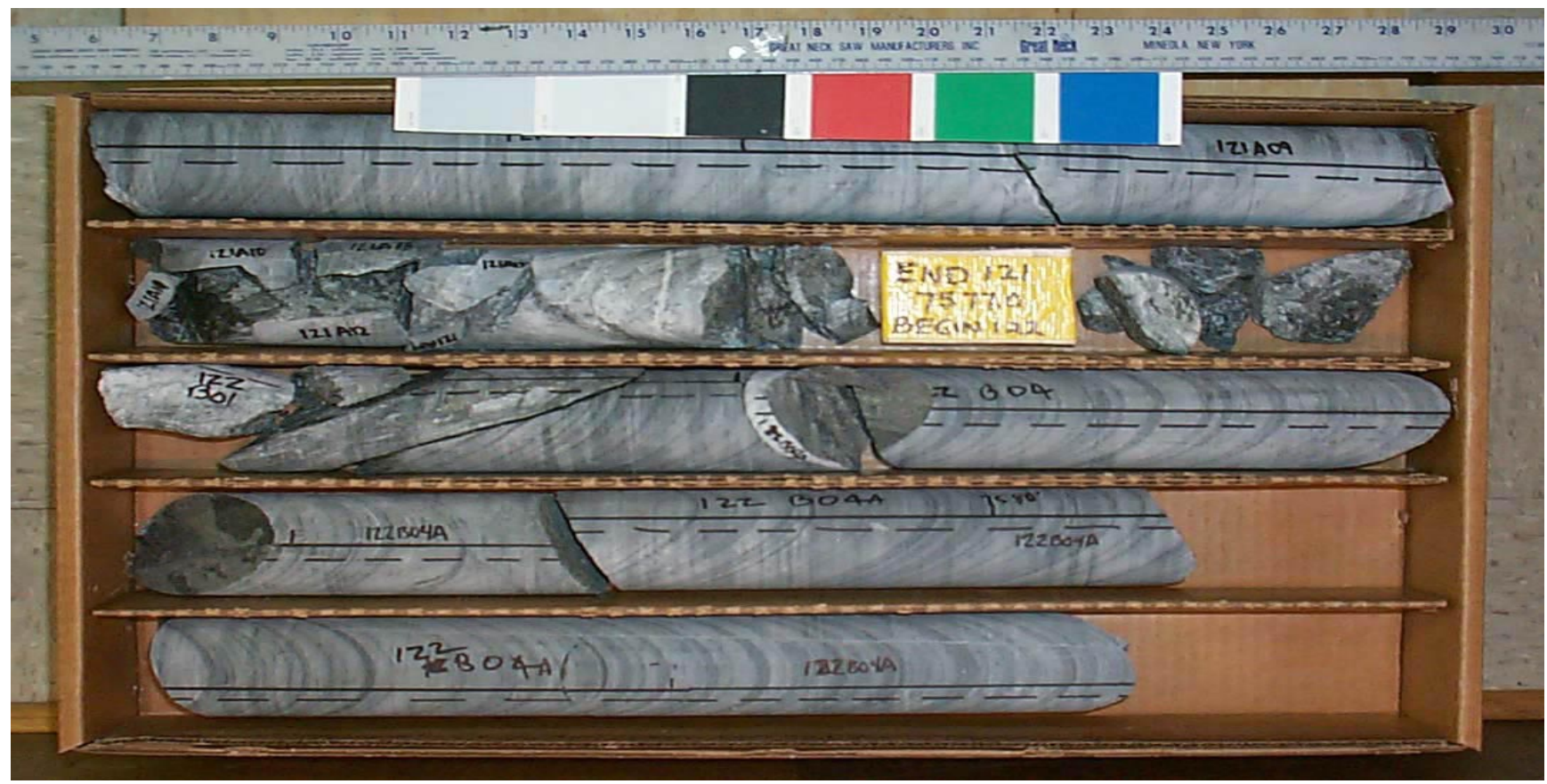

Core Scans included in this box (listed by piece going downhole):
$121 \mathrm{~A} 0800$
$121 \mathrm{~A} 0900$
$122 \mathrm{~B} 041 \mathrm{~A}$
122B042A

See the "reading instructions" section of the introduction for help interpreting core box photos and core piece nomenclature 


\section{LVEW Core Box 189}

Depth Interval 7581.7'-7588.7'

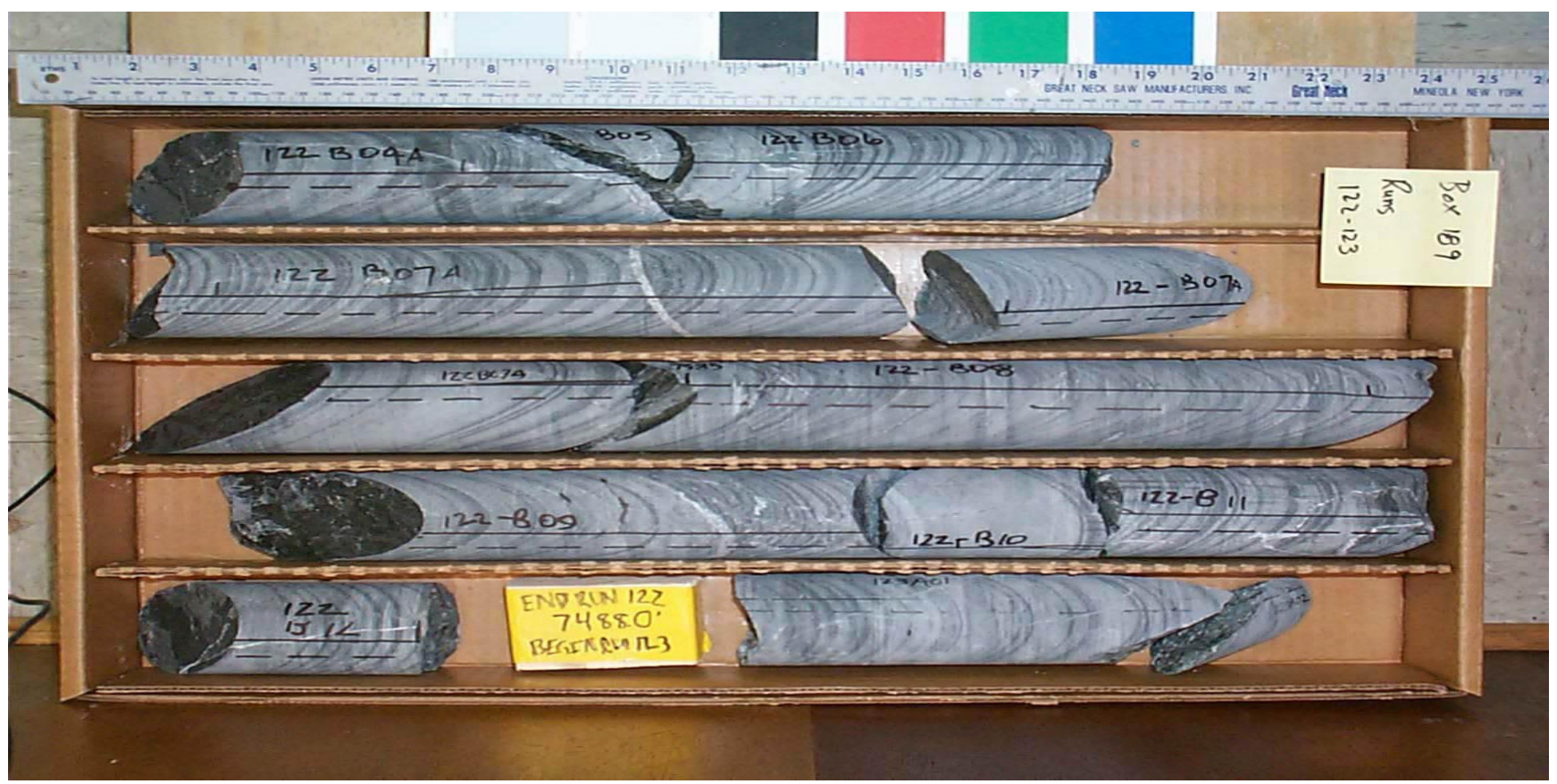

Core Scans included in this box (listed by piece going downhole):
$122 \mathrm{~B} 042 \mathrm{~A}$
$122 \mathrm{~B} 0600$
$122 \mathrm{~B} 070 \mathrm{~A}$
$122 \mathrm{~B} 0800$
$122 \mathrm{~B} 0900$
$122 \mathrm{~B} 1000$
122B 1100
$123 \mathrm{~A} 0100$

See the "reading instructions" section of the introduction for help interpreting core box photos and core piece nomenclature 


\section{LVEW Core Box 190}

Depth Interval 7588.7'-7595.7'

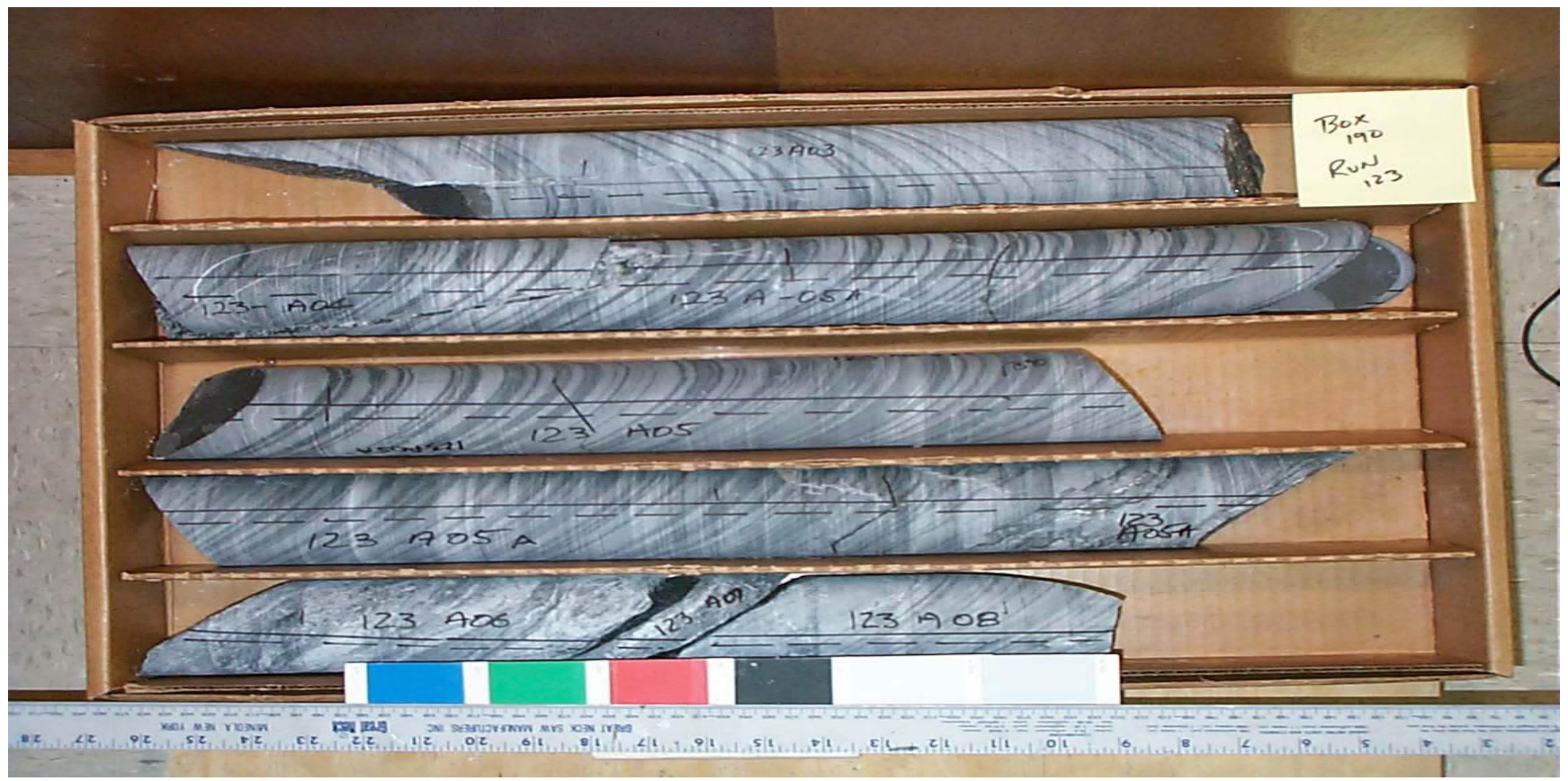

Core Scans included in this box (listed by piece going downhole):
$123 \mathrm{~A} 0300$
$123 \mathrm{~A} 051 \mathrm{~A}$
$123 \mathrm{~A} 052 \mathrm{~A}$
$123 \mathrm{~A} 053 \mathrm{~A}$
$123 \mathrm{~A} 0600$
$123 \mathrm{~A} 0800$

See the "reading instructions" section of the introduction for help interpreting core box photos and core piece nomenclature 


\section{LVEW Core Box 191}

Depth Interval 7595.7'-7603.8'

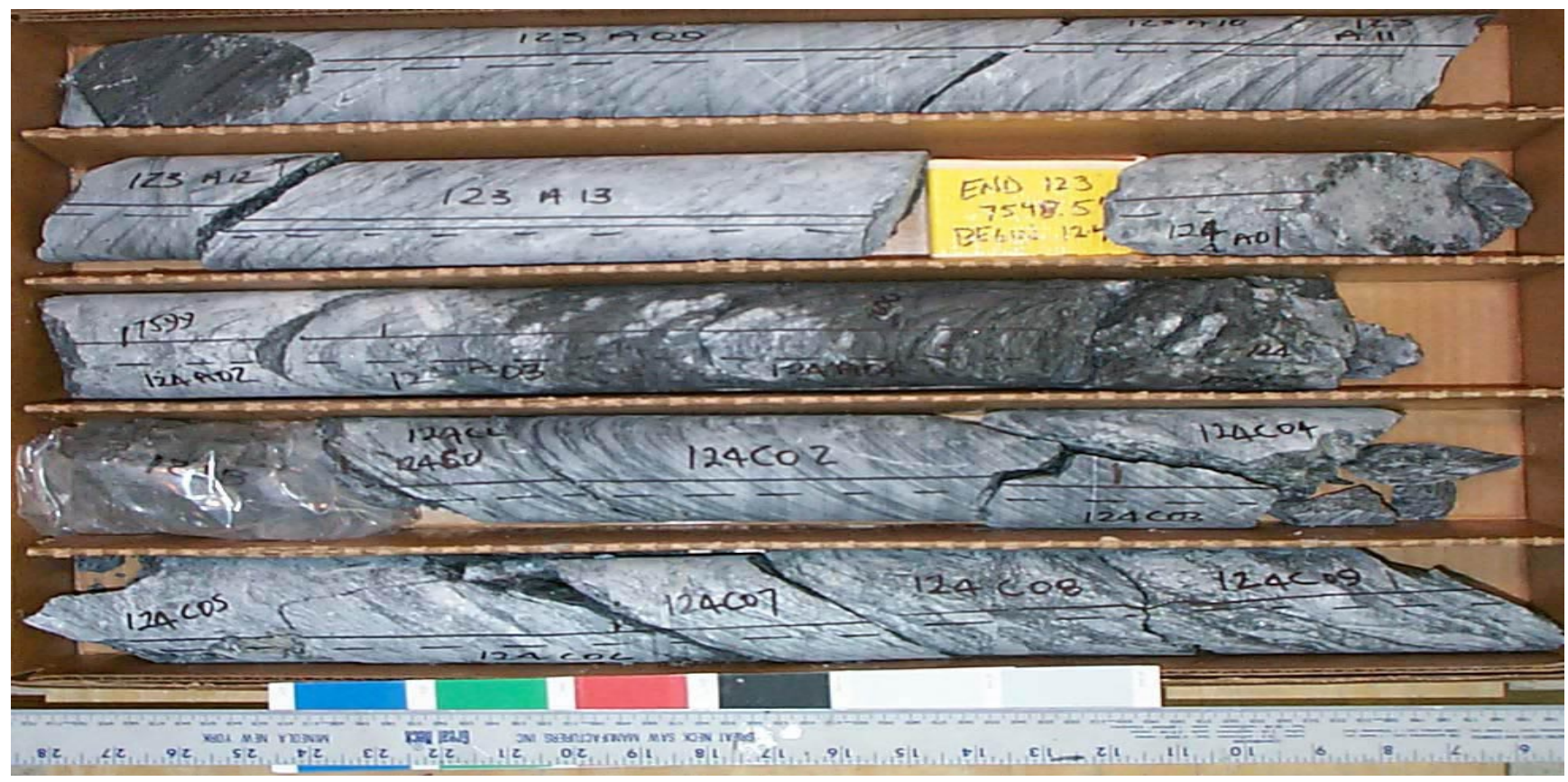

Core Scans included in this box (listed by piece going downhole):
$123 \mathrm{~A} 0900$
$123 \mathrm{~A} 1000$
$123 \mathrm{~A} 1200$
$123 \mathrm{~A} 1300$
$124 \mathrm{~A} 0100$
$124 \mathrm{~A} 0200$
$124 \mathrm{C} 0100$
$124 \mathrm{C} 0200$
$124 \mathrm{C} 0800$
$124 \mathrm{C} 0900$

See the "reading instructions" section of the introduction for help interpreting core box photos and core piece nomenclature 


\section{LVEW Core Box 192}

\section{Depth Interval 7603.8'-7610.6'}

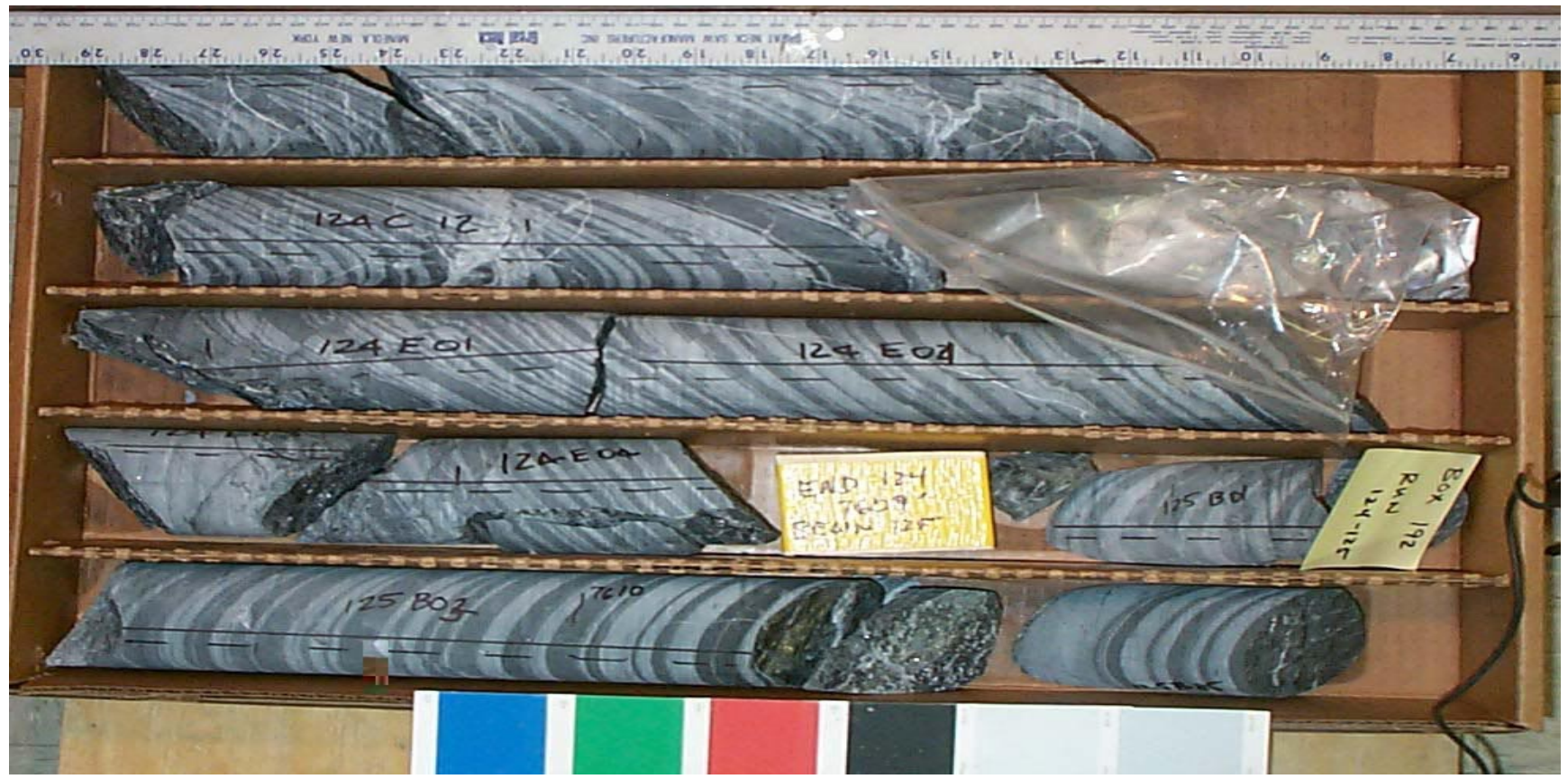

Core Scans included in this box (listed by piece going downhole):
124C1000
$124 \mathrm{C} 1100$
$124 \mathrm{C} 1200$
124E0100
124E0300
124E0400
125B0300

See the "reading instructions" section of the introduction for help interpreting core box photos and core piece nomenclature 


\section{LVEW Core Box 193}

Depth Interval 7610.6'-7618.4'

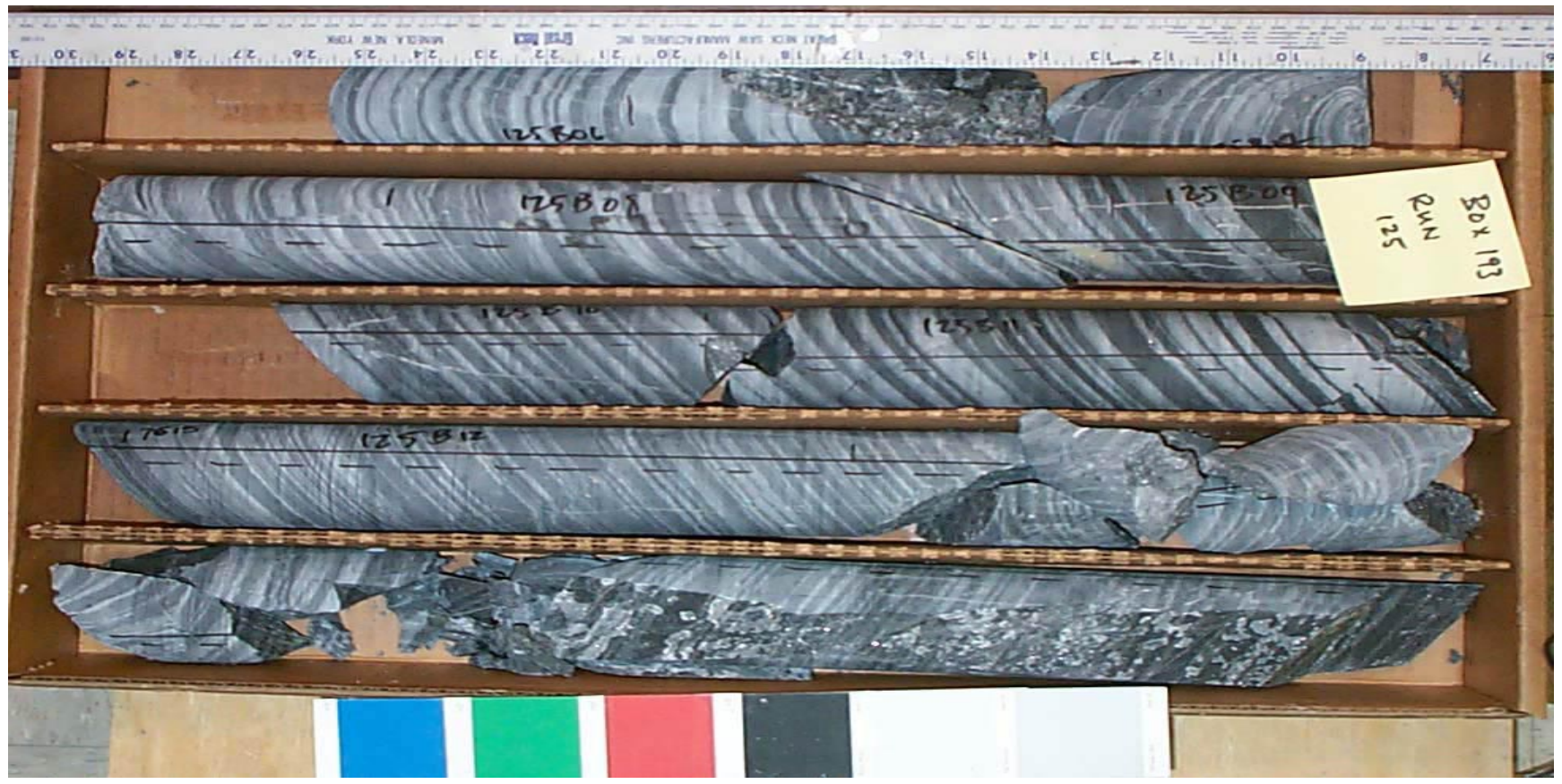

Core Scans included in this box (listed by piece going downhole):
$125 \mathrm{~B} 0600$
$125 \mathrm{~B} 0800$
125B0900
125B1000
$125 \mathrm{~B} 1100$
125B1200

See the "reading instructions" section of the introduction for help interpreting core box photos and core piece nomenclature 


\section{Stratigraphic Column for LVEW Phase III, page 2}

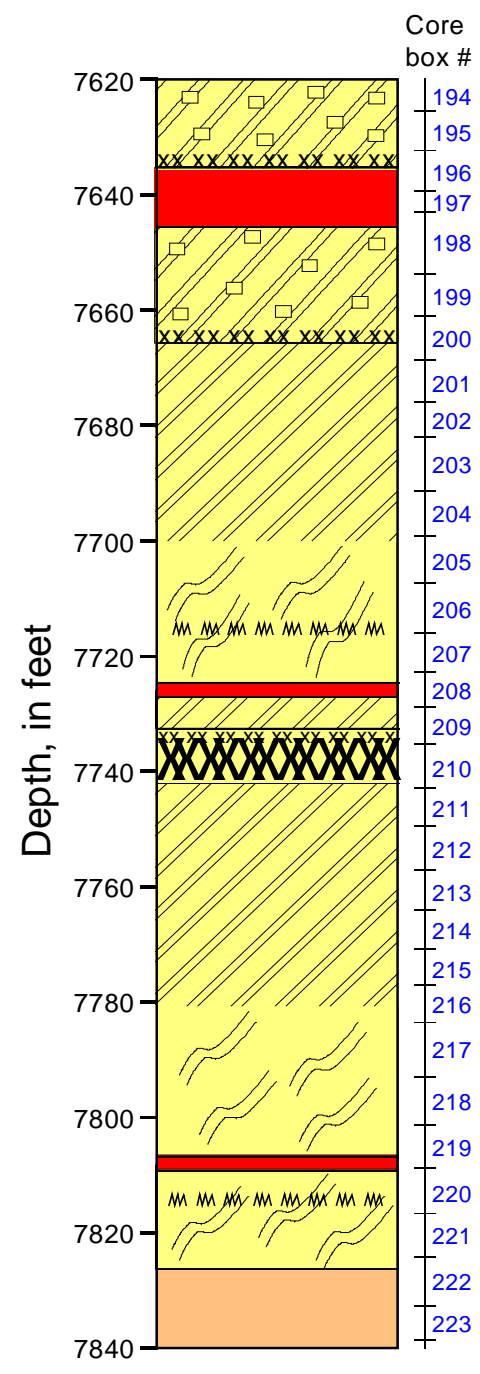

hornfels - graphitic

fault gouge

intrusion - silicified

hornfels - siliceous

fault gouge

ductile folding begins - possible indication of increase in

metamorphic grade

hydrothermal veining

intrusion(?) or ductile contact

fault gouge

ductile folding begins -

calcareous

intrusion(?) - calcareous and altered hydrothermal veining

ductile deformation

calcareous sandstone - prograde metamorphism to garnet/cordierite isograds

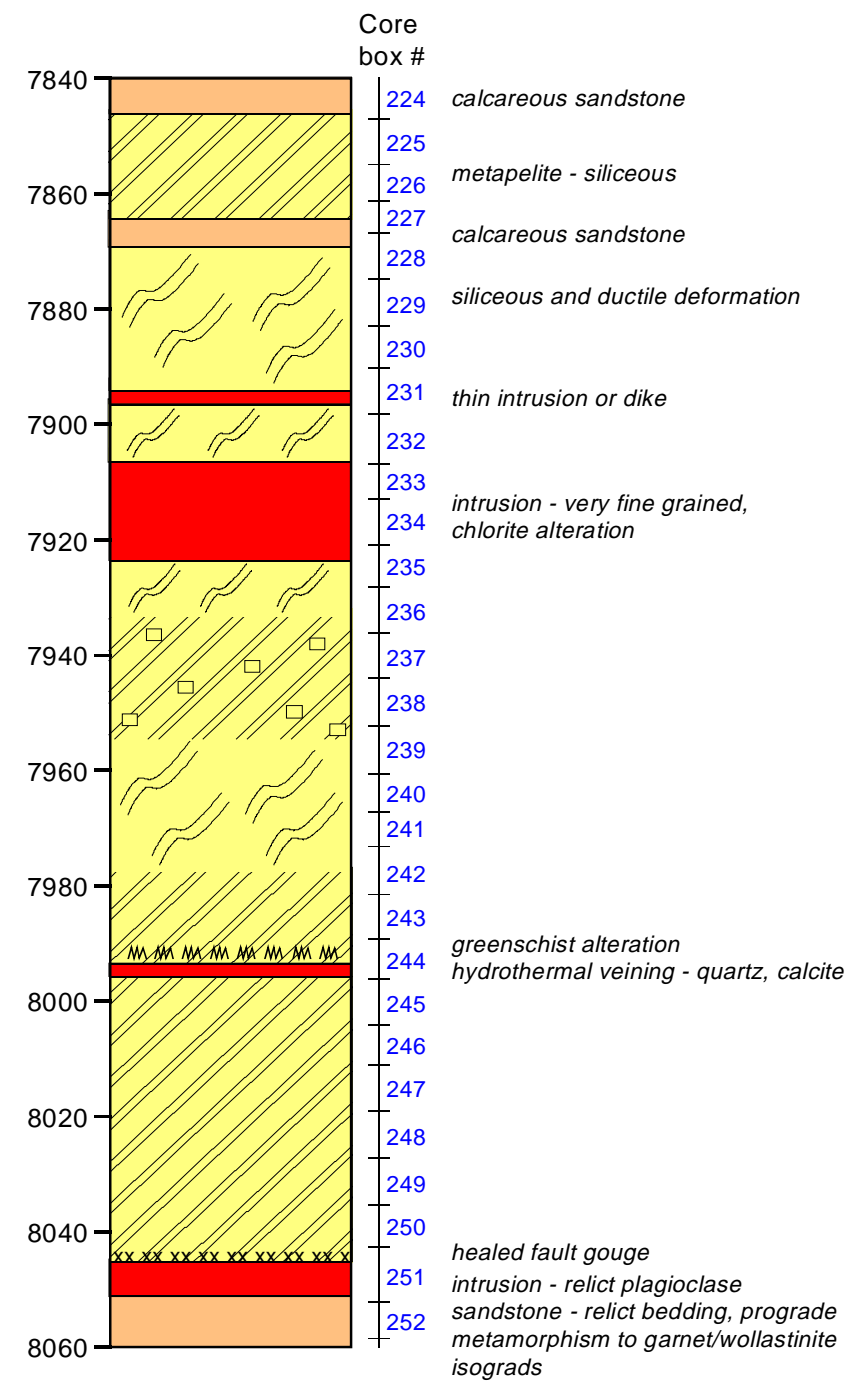

\section{Explanation}

Metapelite with banding

Hornfels

Metapelite with ductile deformation

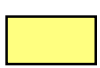

Metapelite no banding

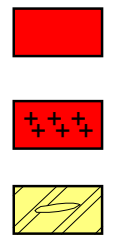

Intrusion

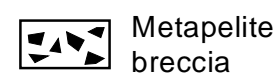

Intrusionmetamorphosed

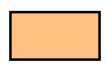

Sandstone

Boudinage deformation
M M M Hydrothermal veins/fractures

$x x x x$ Fault gouge

- 2nd generation garnets 


\section{LVEW Core Box 194}

Depth Interval 7618.4'-7625.4'

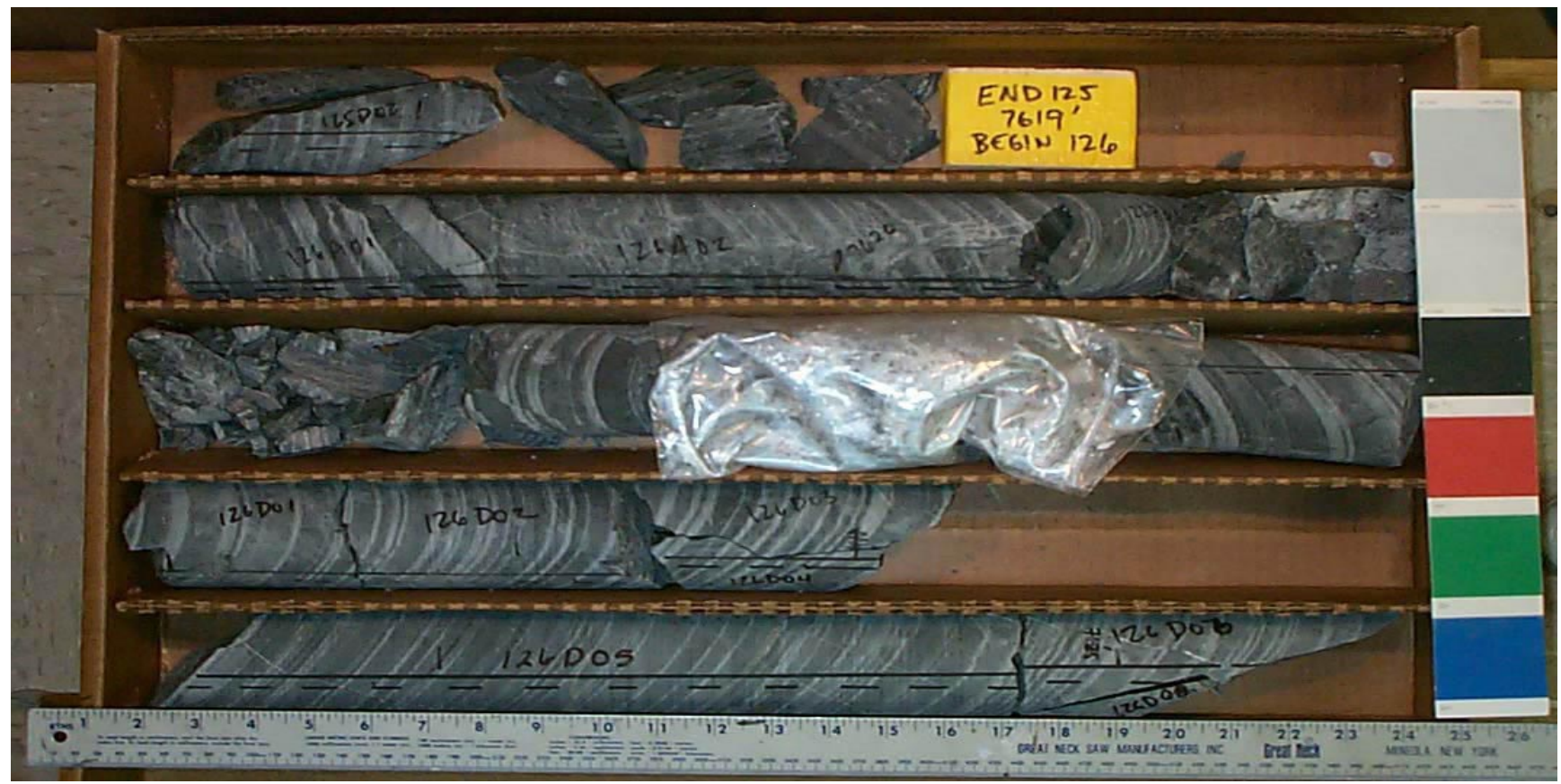

Core Scans included in this box (listed by piece going downhole):
$126 \mathrm{~A} 0100$
$126 \mathrm{~A} 0200$
$126 \mathrm{D} 0100$
$126 \mathrm{D} 0200$
$126 \mathrm{D} 0500$

See the "reading instructions" section of the introduction for help interpreting core box photos and core piece nomenclature 


\section{LVEW Core Box 195}

Depth Interval 7625.4'-7632.2'

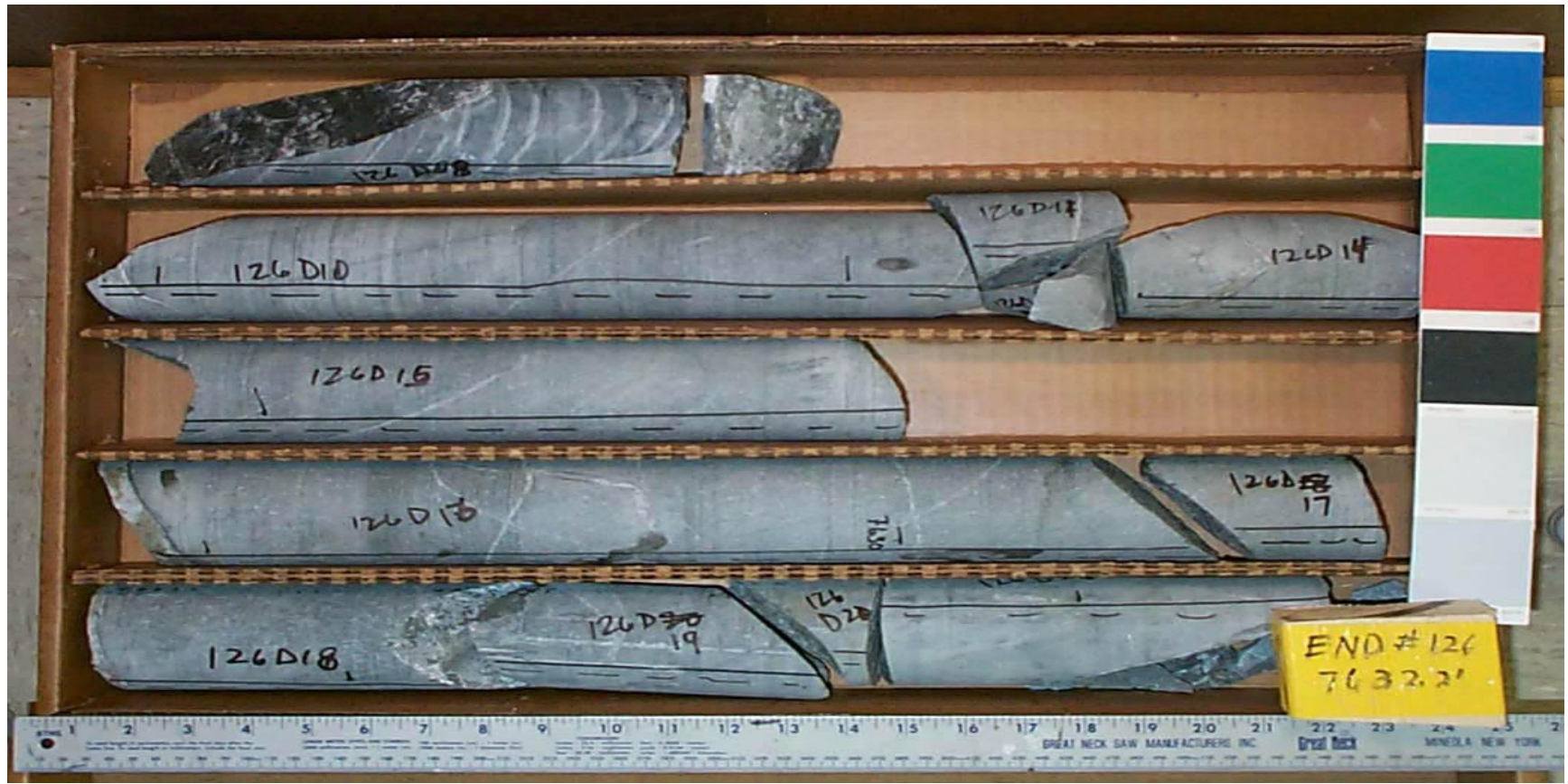

Core Scans included in this box (listed by piece going downhole):
126D1000
$126 \mathrm{D} 1400$
126D1500
$126 \mathrm{D} 1600$
$126 \mathrm{D} 1700$
$126 \mathrm{D} 1800$

See the "reading instructions" section of the introduction for help interpreting core box photos and core piece nomenclature 


\section{LVEW Core Box 196}

Depth Interval 7632.2'-7639.4'

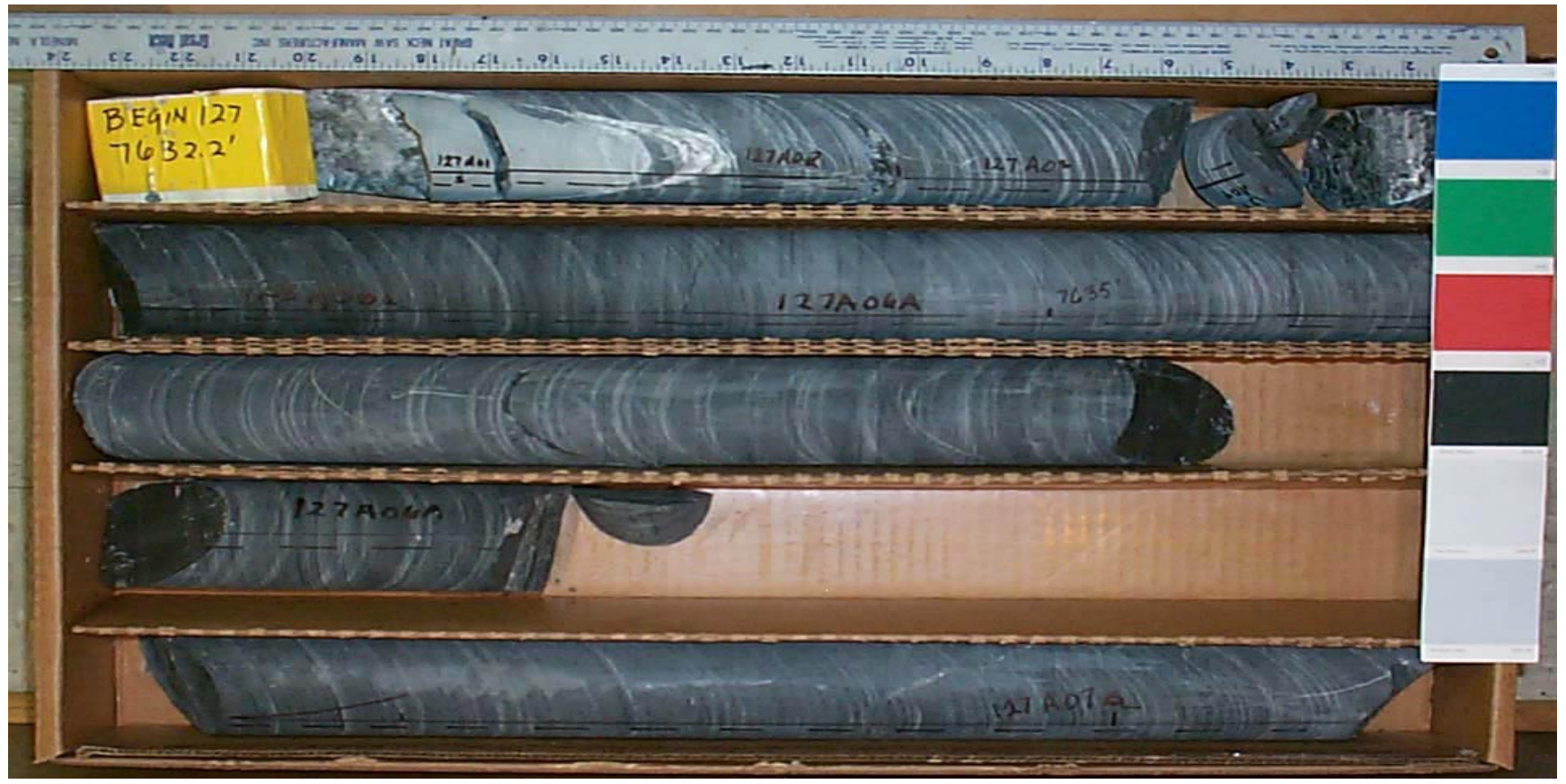

Core Scans included in this box (listed by piece going downhole):
$127 \mathrm{~A} 0200$
$127 \mathrm{~A} 0300$
$127 \mathrm{~A} 0600$
$127 \mathrm{~A} 070 \mathrm{~A}$

See the "reading instructions" section of the introduction for help interpreting core box photos and core piece nomenclature 


\section{LVEW Core Box 197}

Depth Interval 7639.4'-7642.7'

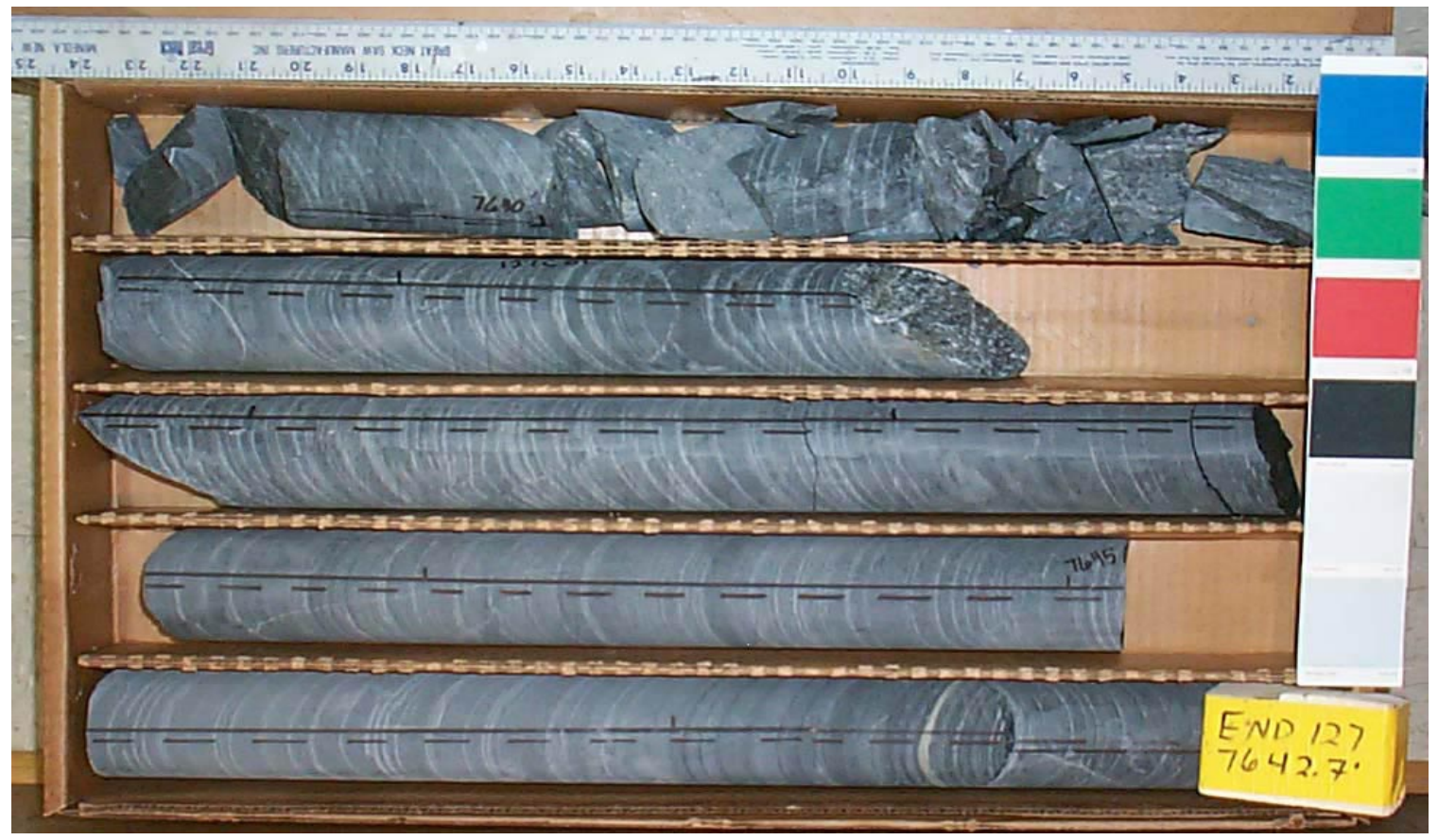

Core Scans included in this box (listed by piece going downhole):

$127 C 0100$
$127 C 021 A$
$127 C 022 A$

See the "reading instructions" section of the introduction for help interpreting core box photos and core piece nomenclature 


\section{LVEW Core Box 198}

Depth Interval 7642.7'-7653.8'

\section{Box Photo Missing}

Core Scans included in this box (listed by piece going downhole):

\section{$128 \mathrm{~A} 011 \mathrm{~A}$ \\ $128 \mathrm{~A} 012 \mathrm{~A}$ \\ $128 \mathrm{~A} 020 \mathrm{~A}$}

See the "reading instructions" section of the introduction for help interpreting core box photos and core piece nomenclature 


\section{LVEW Core Box 199}

Depth Interval 7653.8'-7660.8'

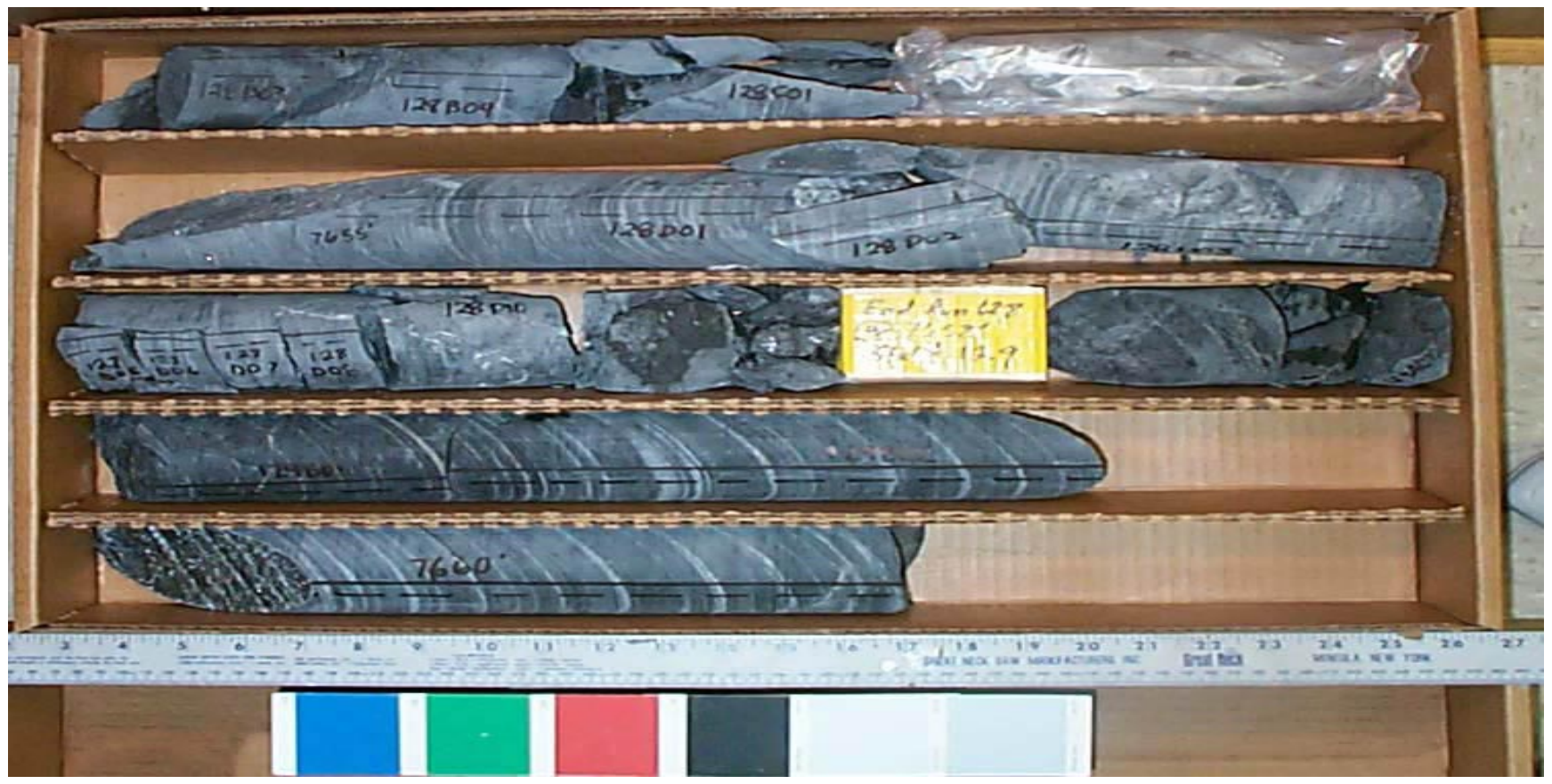

Core Scans included in this box (listed by piece going downhole):

128D0100
128D0300
129B0100
129B0200
129B030A

See the "reading instructions" section of the introduction for help interpreting core box photos and core piece nomenclature 


\section{LVEW Core Box 200}

Depth Interval 7660.8'-7668.4'

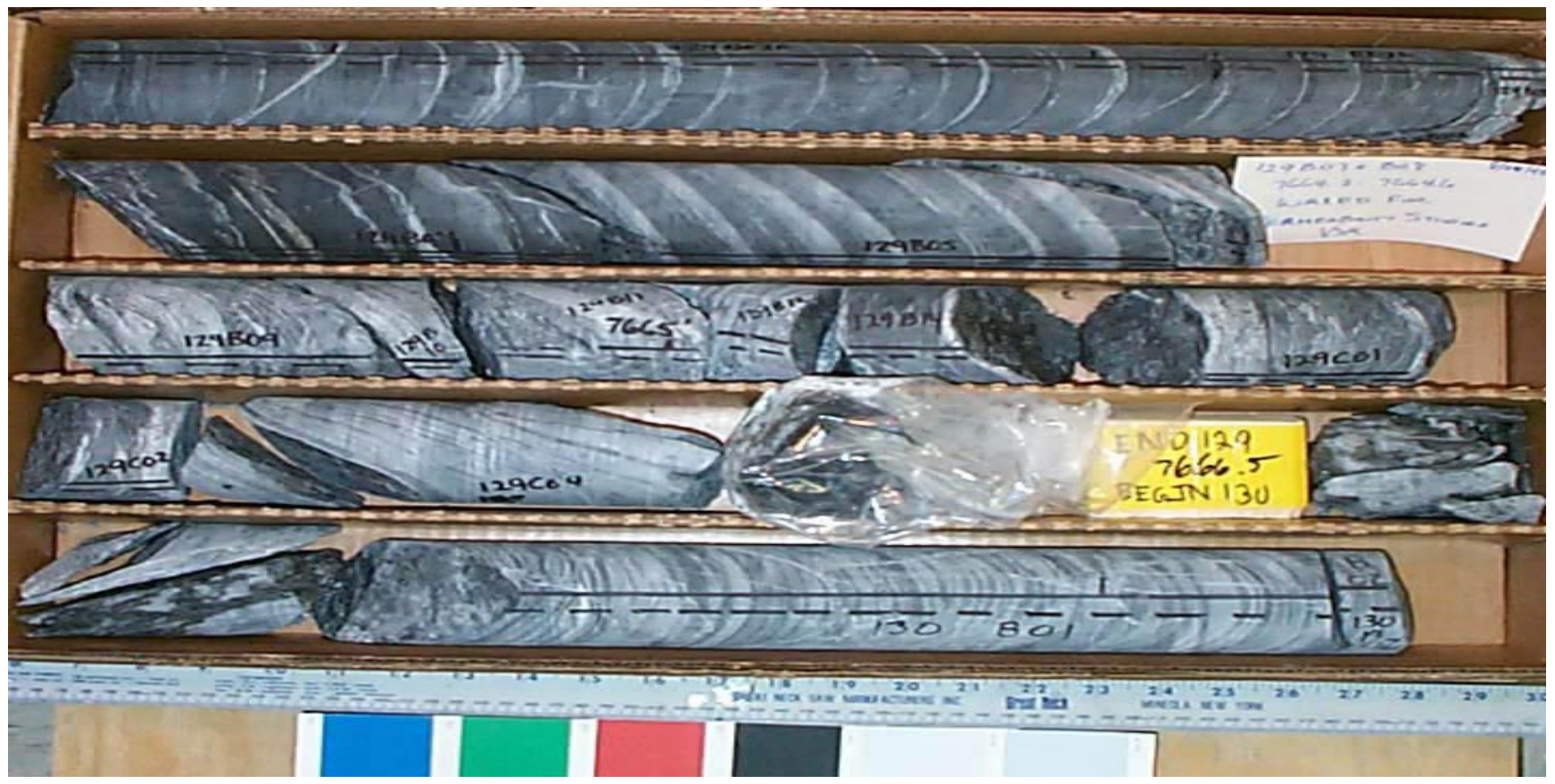

Core Scans included in this box (listed by piece going downhole):

129B030A

129B0400

129B0500

129B0900

$129 \mathrm{C} 0400$

130B0100

130B0200

See the "reading instructions" section of the introduction for help interpreting core box photos and core piece nomenclature 
LVEW Core Box 201

Depth Interval 7668.4'-7676.0'

\section{Box Photo Missing}

Core Scans included in this box (listed by piece going downhole):

130B0300

130B040A

$130 \mathrm{~B} 0500$

$130 \mathrm{~B} 0700$

130B0800

130B0900

See the "reading instructions" section of the introduction for help interpreting core box photos and core piece nomenclature 


\section{LVEW Core Box 202}

Depth Interval 7676.0'-7682.0'

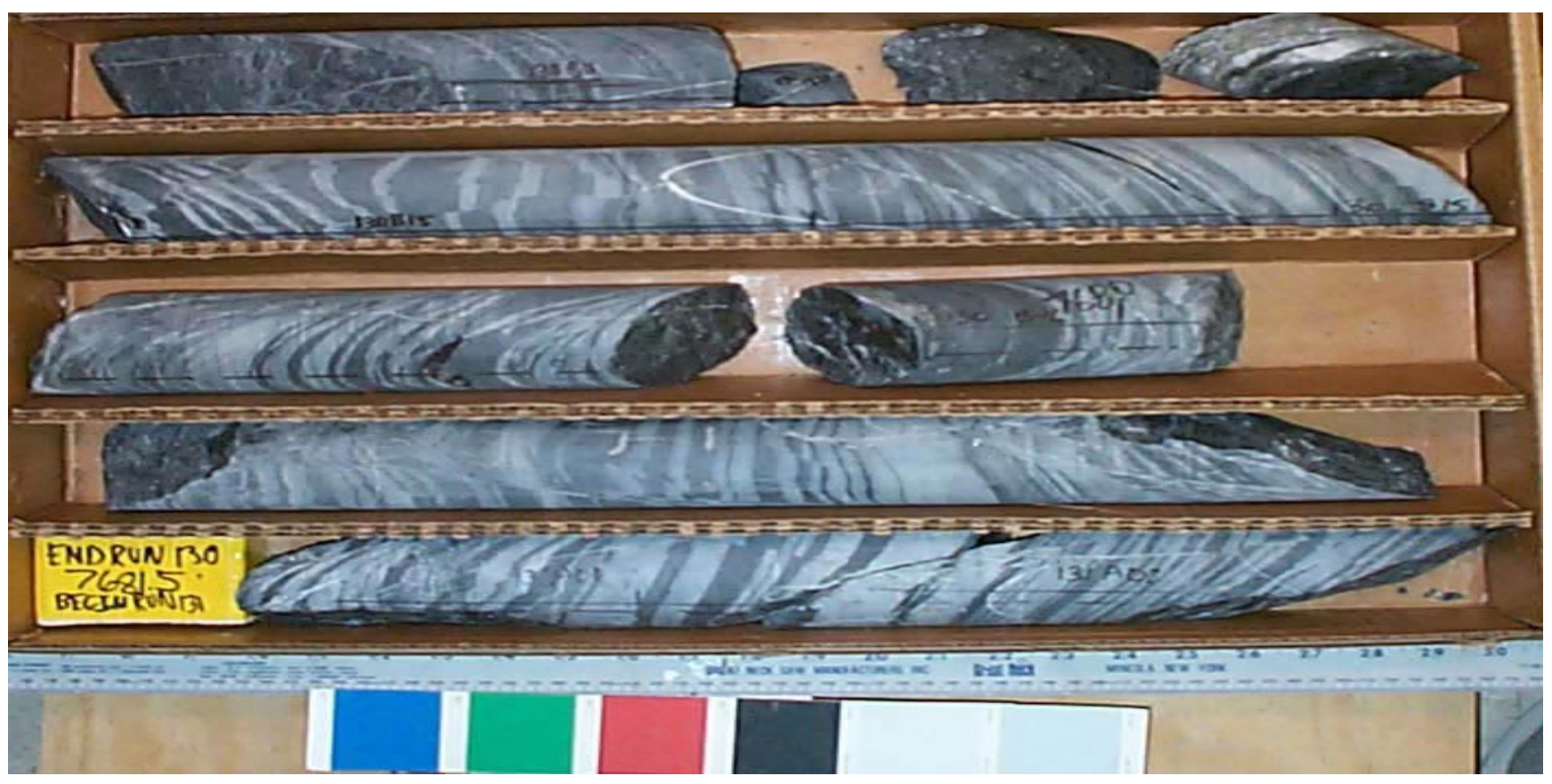

Core Scans included in this box (listed by piece going downhole):
130B1100
130B151A
130B152A
130B1600
130B1700
$131 \mathrm{~A} 0100$

See the "reading instructions" section of the introduction for help interpreting core box photos and core piece nomenclature 


\section{LVEW Core Box 203}

Depth Interval 7682.0'-7691.5'

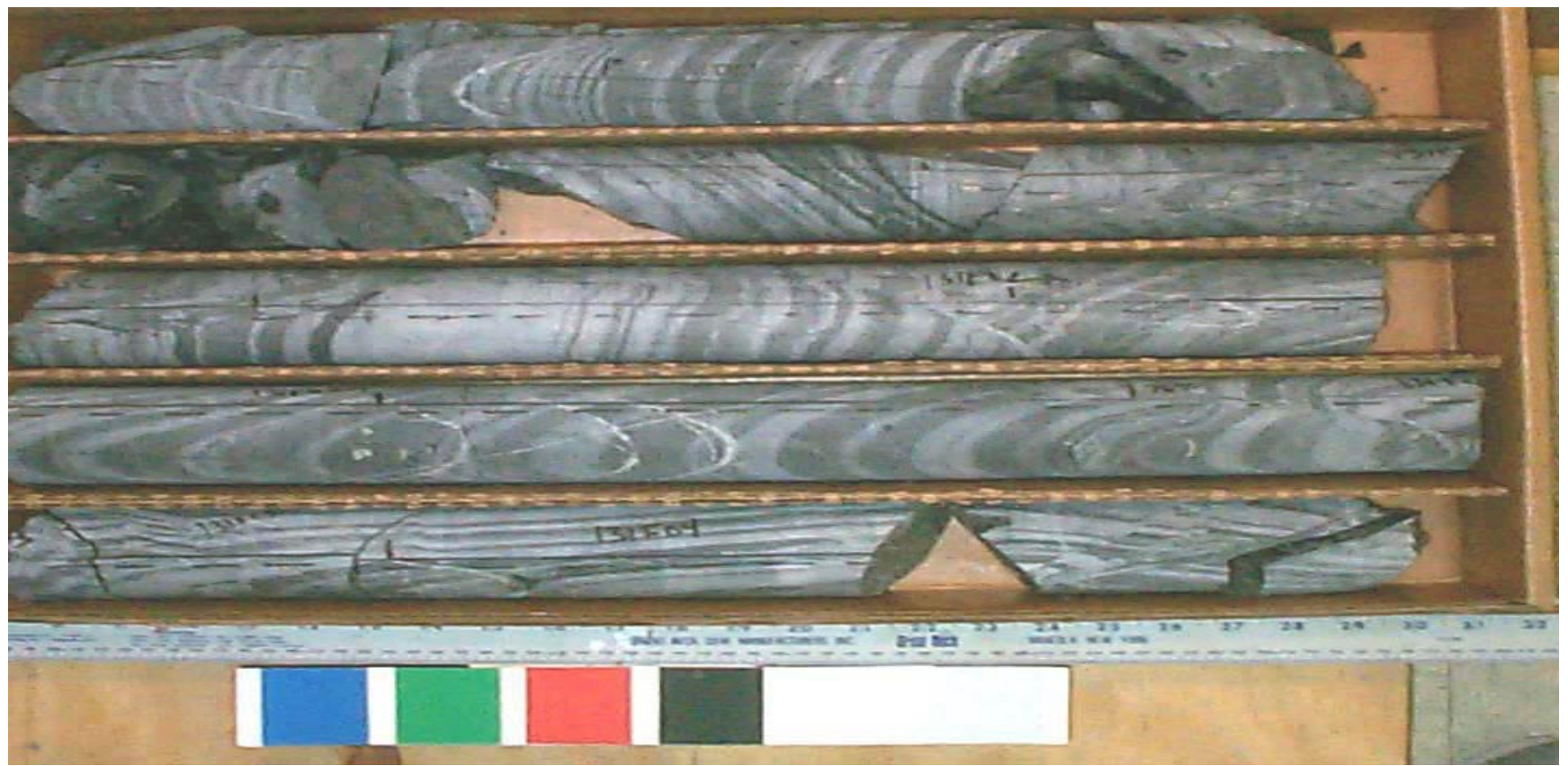

Core Scans included in this box (listed by piece going downhole):

131F0100
131F020A
131F030A
131F0400
131F051A
131F052A

See the "reading instructions" section of the introduction for help interpreting core box photos and core piece nomenclature 


\section{LVEW Core Box 204}

Depth Interval 7691.5'-7699.5'

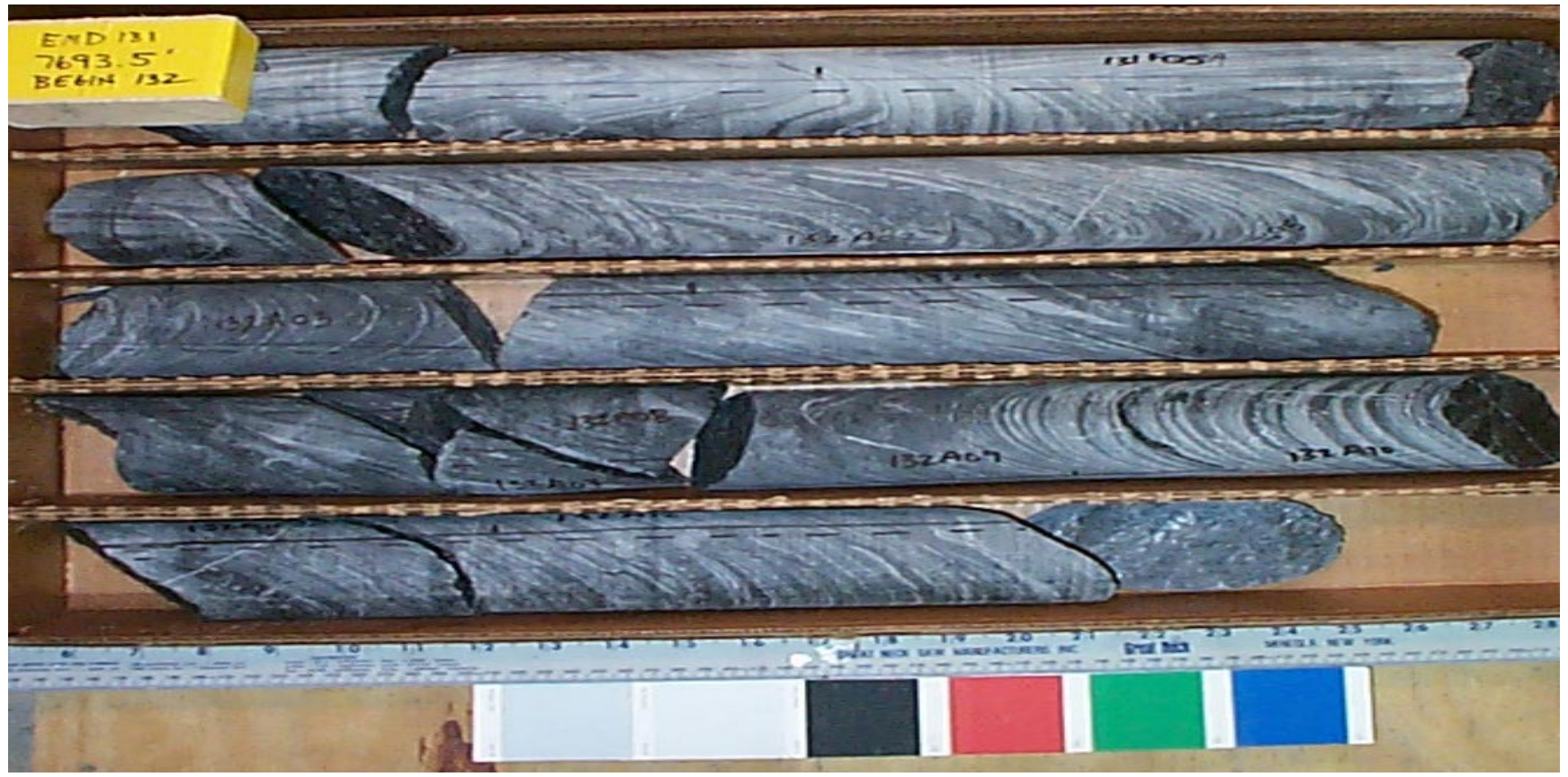

Core Scans included in this box (listed by piece going downhole):
$131 \mathrm{~F} 051 \mathrm{~A}$
$131 \mathrm{~F} 052 \mathrm{~A}$
$132 \mathrm{~A} 0200$
$132 \mathrm{~A} 0300$
$132 \mathrm{~A} 0400$
$132 \mathrm{~A} 0500$
$132 \mathrm{~A} 0900$
$132 \mathrm{~A} 1100$
$132 \mathrm{~A} 1200$

See the "reading instructions" section of the introduction for help interpreting core box photos and core piece nomenclature 


\section{LVEW Core Box 205}

Depth Interval 7699.5'-7707.3'

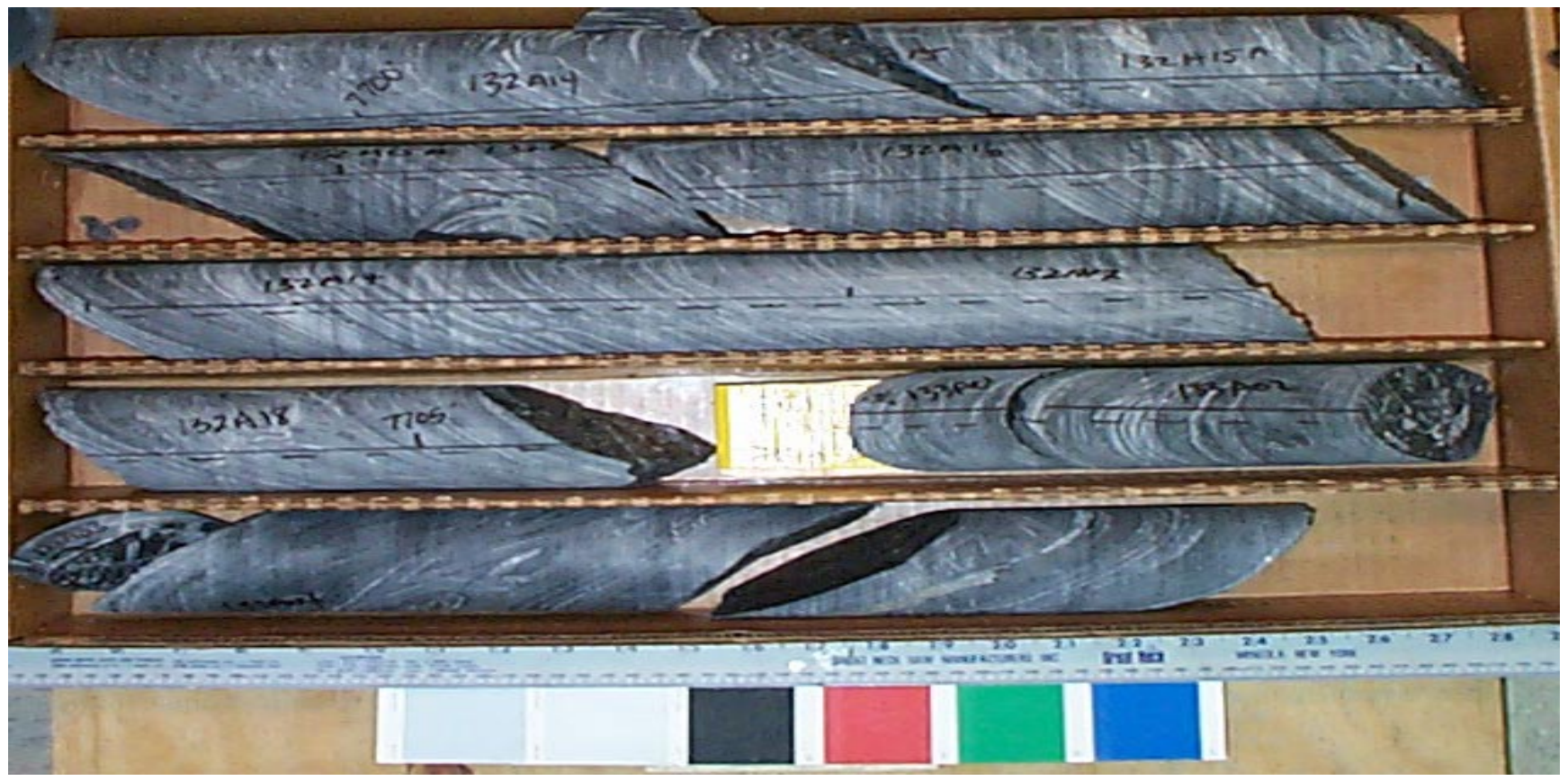

Core Scans included in this box (listed by piece going downhole):
$132 \mathrm{~A} 1400$
132A150A
$132 \mathrm{~A} 1600$
$132 \mathrm{~A} 1700$
$132 \mathrm{~A} 1800$
$133 \mathrm{~A} 0200$
$133 \mathrm{~A} 0400$
$133 \mathrm{~A} 0500$

See the "reading instructions" section of the introduction for help interpreting core box photos and core piece nomenclature 


\section{LVEW Core Box 206}

Depth Interval 7707.3'-7716.0'

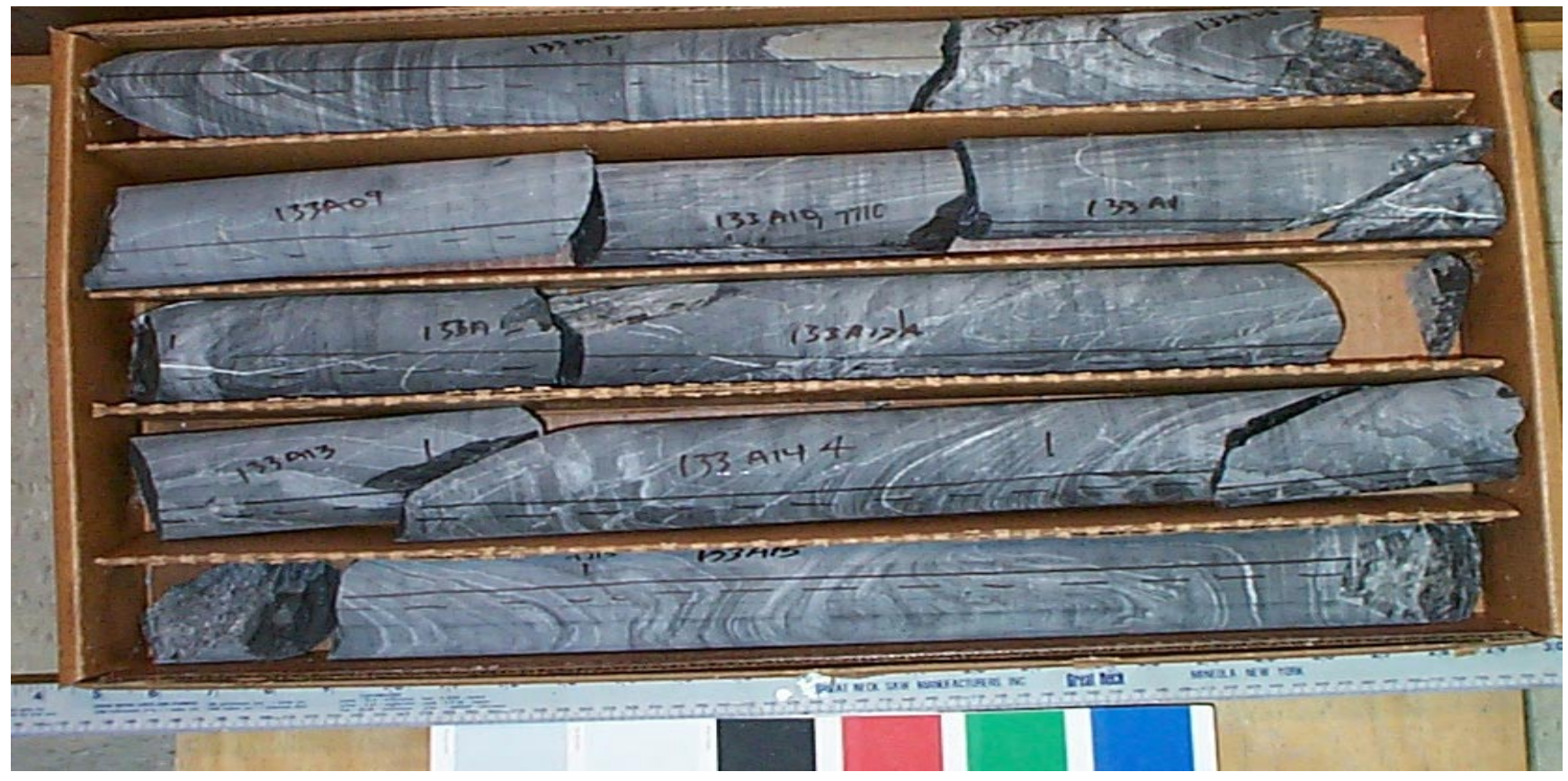

Core Scans included in this box (listed by piece going downhole):
$133 \mathrm{~A} 0600$
$133 \mathrm{~A} 0700$
133А0900
133A 1000
133A1100
133A130A
$133 \mathrm{~A} 1400$
133A1500

See the "reading instructions" section of the introduction for help interpreting core box photos and core piece nomenclature 


\section{LVEW Core Box 207}

Depth Interval 7716.0'-7722.6'

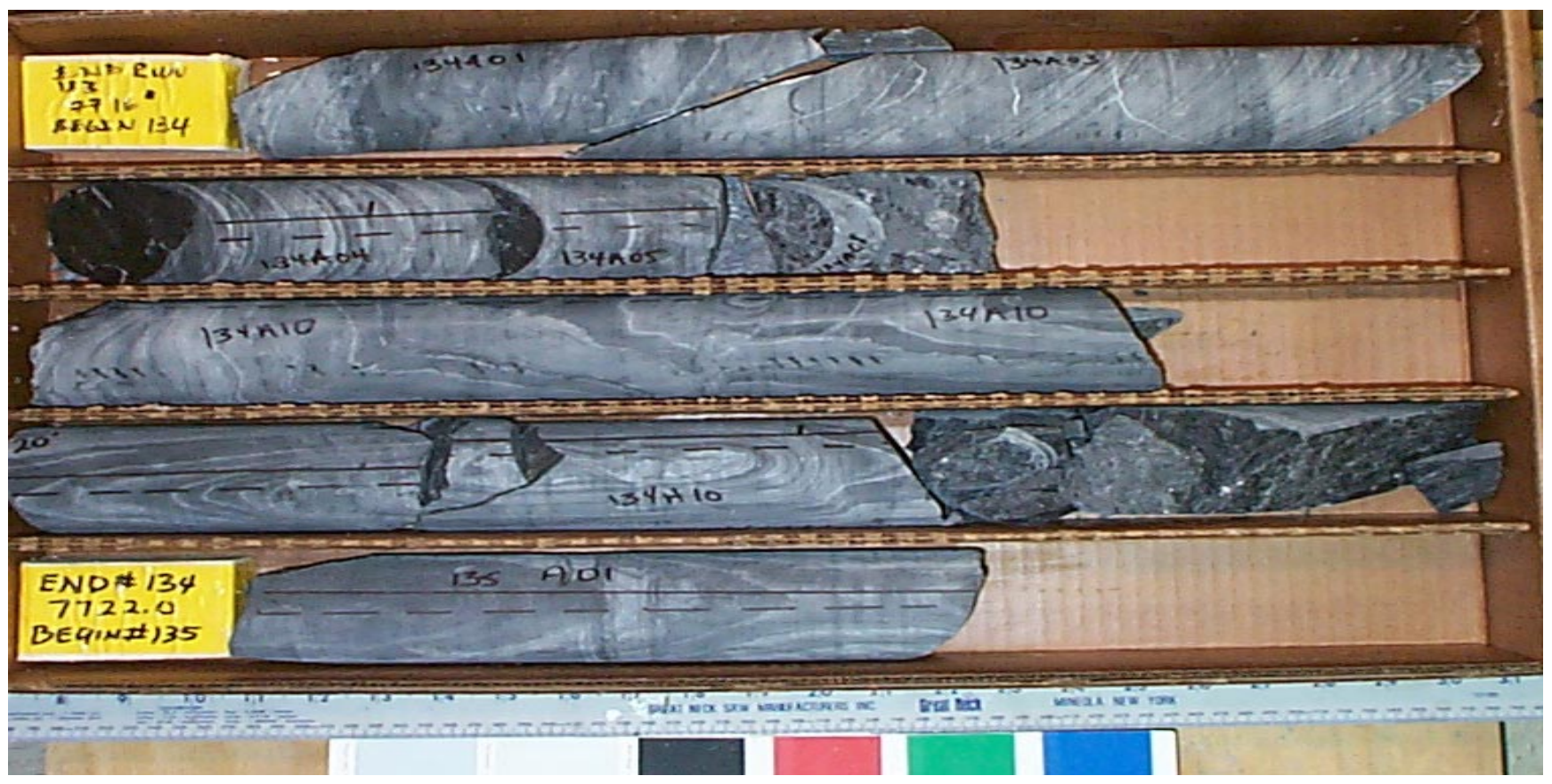

Core Scans included in this box (listed by piece going downhole):

134A0100
$134 A 0300$
$134 A 0400$
$134 A 0500$
$134 A 101 A$
$134 A 102 A$
$135 A 0100$

See the "reading instructions" section of the introduction for help interpreting core box photos and core piece nomenclature 


\section{LVEW Core Box 208}

Depth Interval 7722.6'-7729.0'

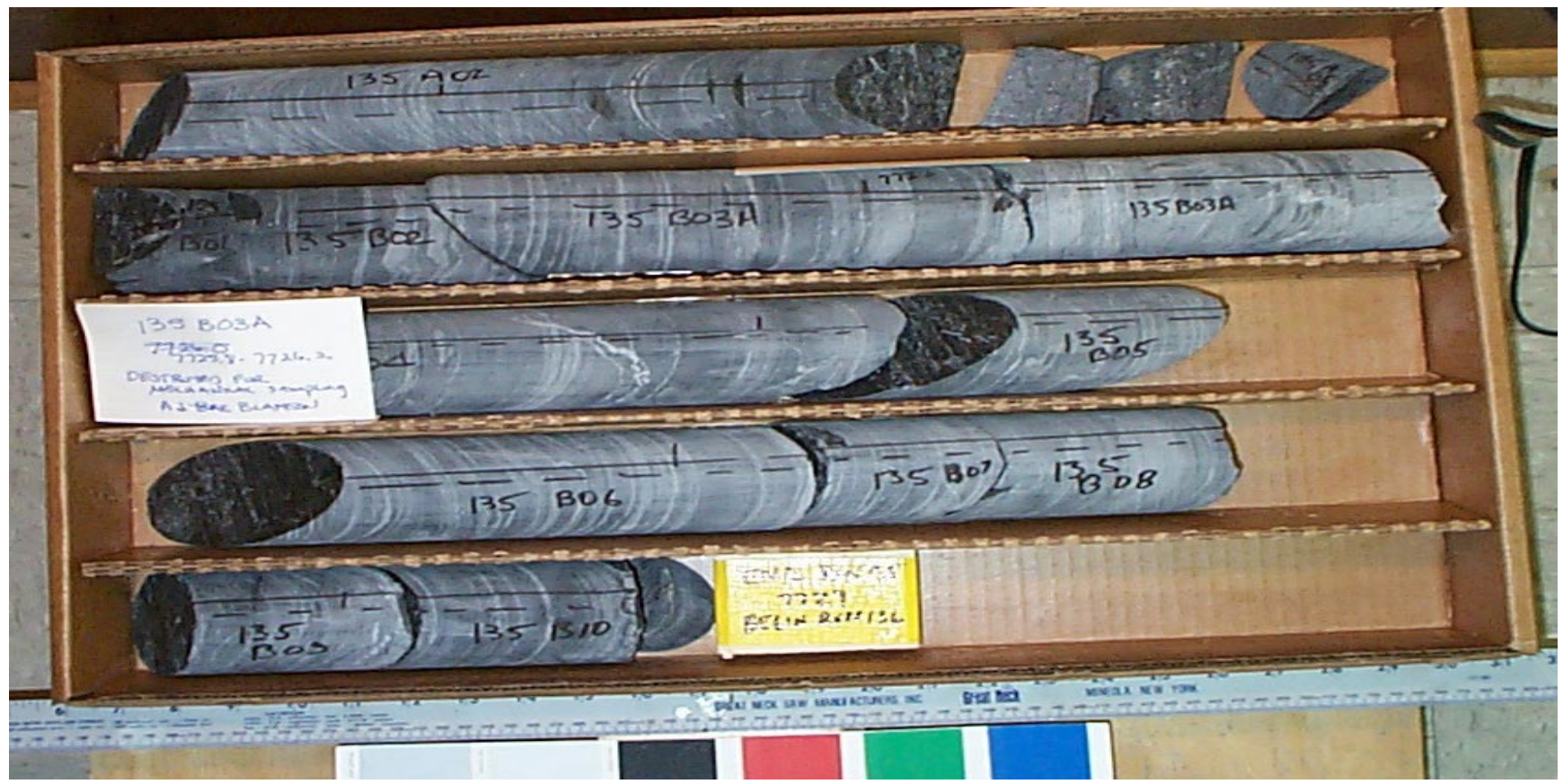

Core Scans included in this box (listed by piece going downhole):
$135 \mathrm{~A} 0200$
$135 \mathrm{~B} 0200$
$135 \mathrm{~B} 030 \mathrm{~A}$
$135 \mathrm{~B} 0400$
135B0600
$135 \mathrm{~B} 0700$
135B0800
135B0900
135B1000

See the "reading instructions" section of the introduction for help interpreting core box photos and core piece nomenclature 


\section{LVEW Core Box 209}

Depth Interval 7729.0'-7735.3'

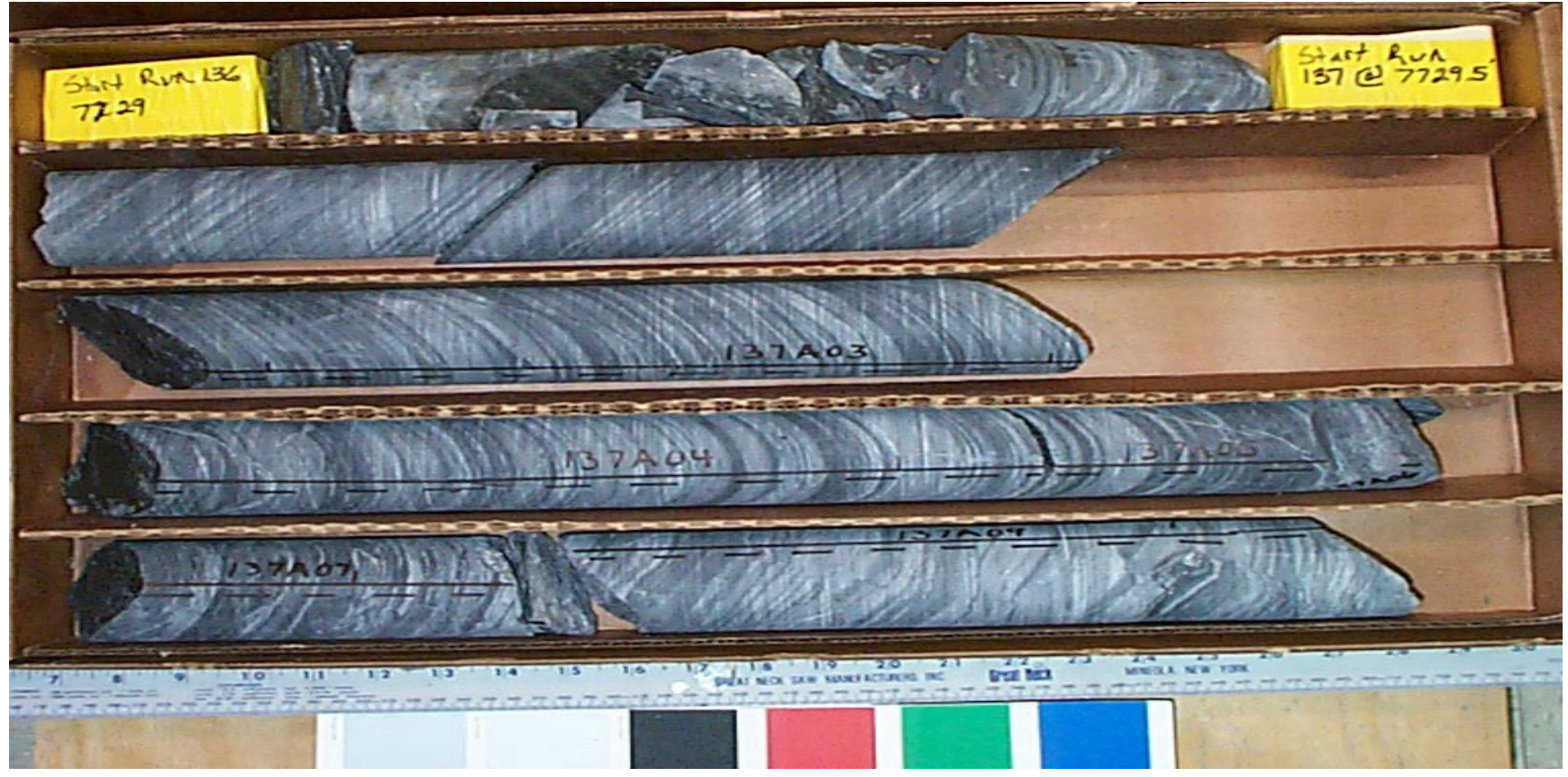

Core Scans included in this box (listed by piece going downhole):
$137 \mathrm{~A} 0100$
$137 \mathrm{~A} 0200$
$137 \mathrm{~A} 0300$
$137 \mathrm{~A} 0400$
$137 \mathrm{~A} 0500$
$137 \mathrm{~A} 0700$
$137 \mathrm{~A} 0900$

See the "reading instructions" section of the introduction for help interpreting core box photos and core piece nomenclature 


\section{LVEW Core Box 210}

Depth Interval 7735.3'-7743.0'

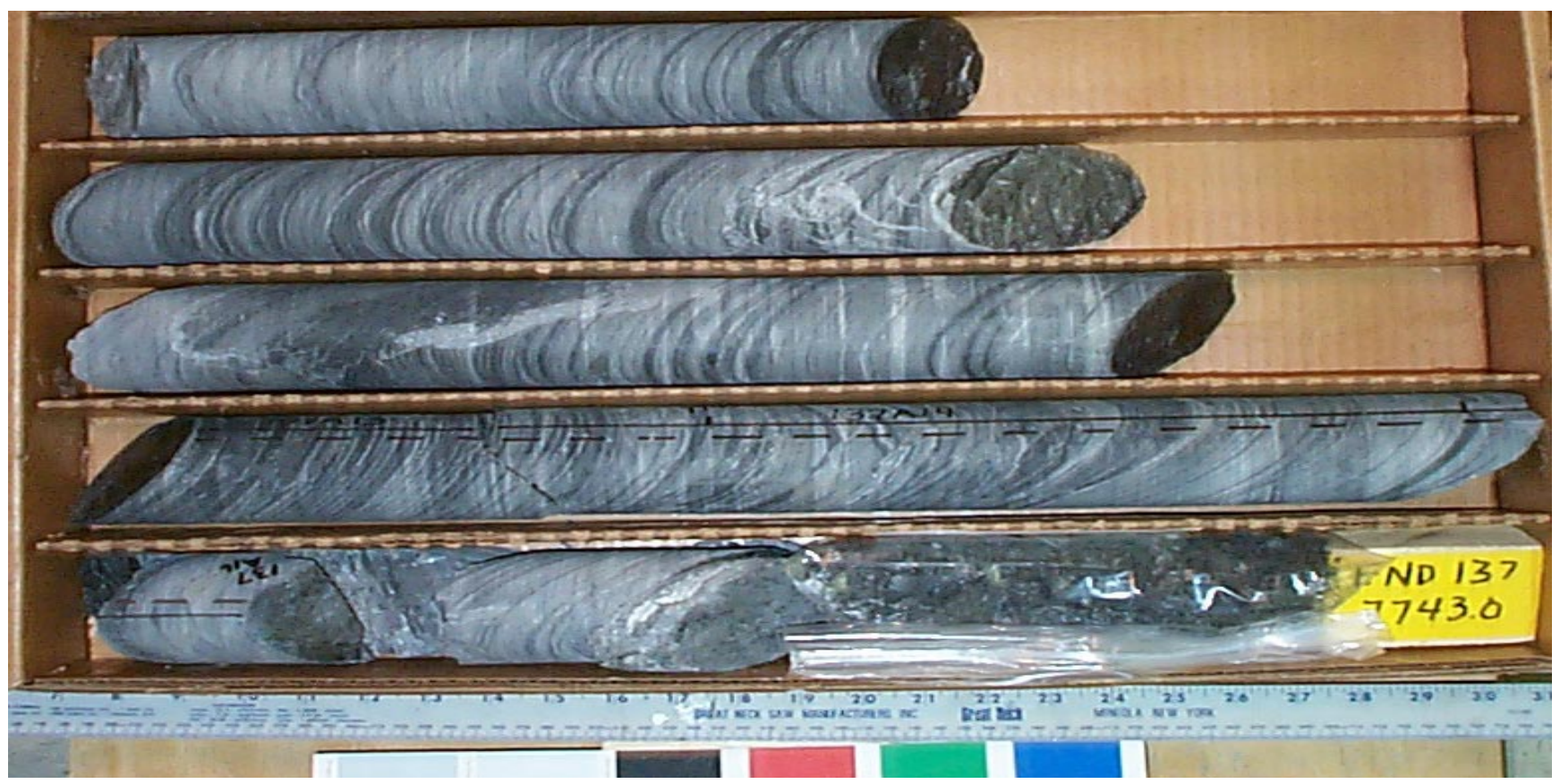

Core Scans included in this box (listed by piece going downhole):
137A 1000
$137 \mathrm{~A} 1100$
$137 \mathrm{~A} 1200$
$137 \mathrm{~A} 1300$
$137 \mathrm{~A} 1400$
137A 1900

See the "reading instructions" section of the introduction for help interpreting core box photos and core piece nomenclature 


\section{LVEW Core Box 211}

Depth Interval 7743.0'-7749.8'

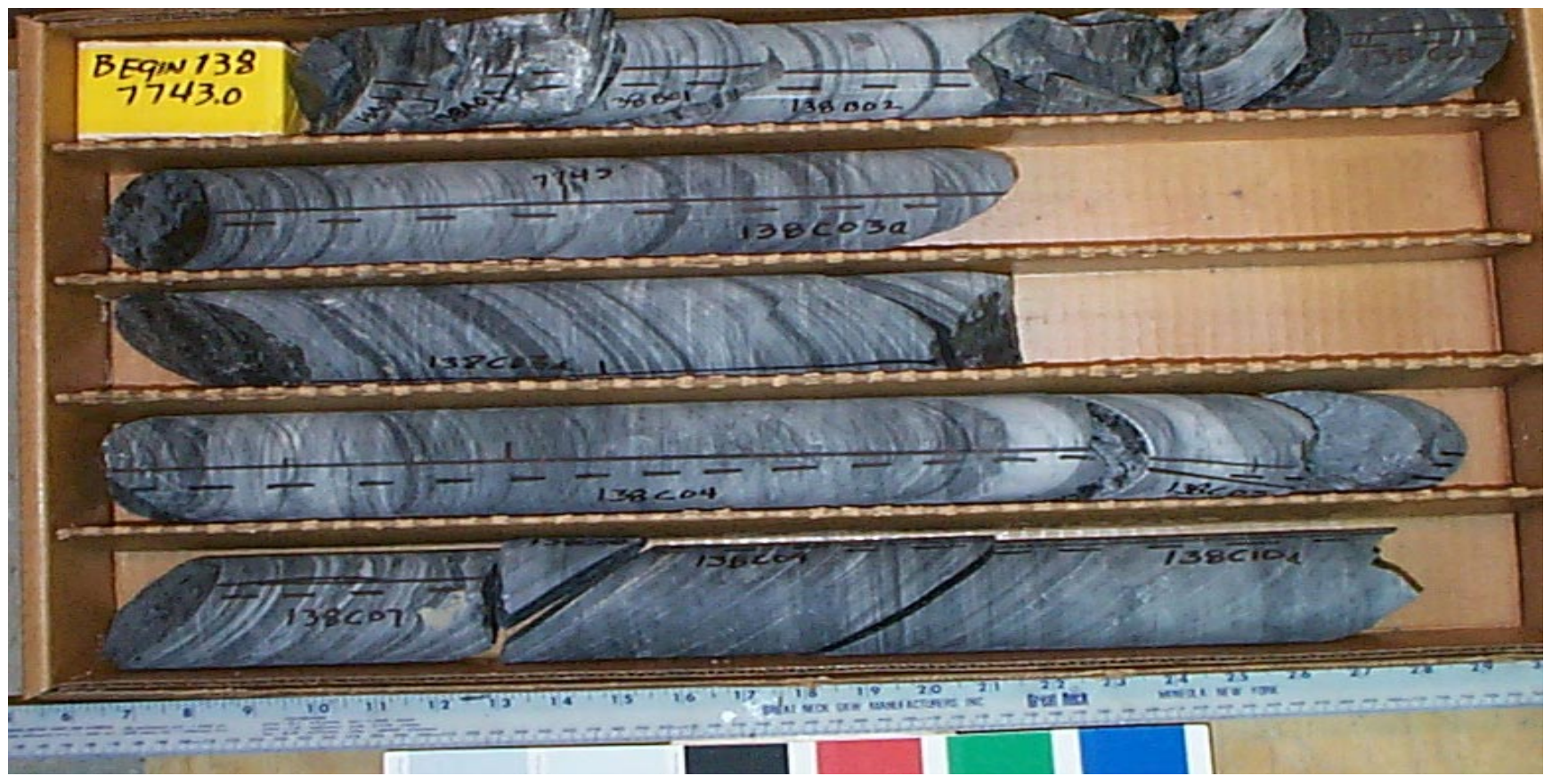

Core Scans included in this box (listed by piece going downhole):

138B0200

$138 \mathrm{C} 0200$

$138 \mathrm{C} 030 \mathrm{~A}$

$138 \mathrm{C} 0400$

$138 \mathrm{C} 0700$

$138 \mathrm{C} 090 \mathrm{~A}$

$138 \mathrm{C} 100 \mathrm{~A}$

See the "reading instructions" section of the introduction for help interpreting core box photos and core piece nomenclature 


\section{LVEW Core Box 212}

Depth Interval 7749.8'-7757.2'

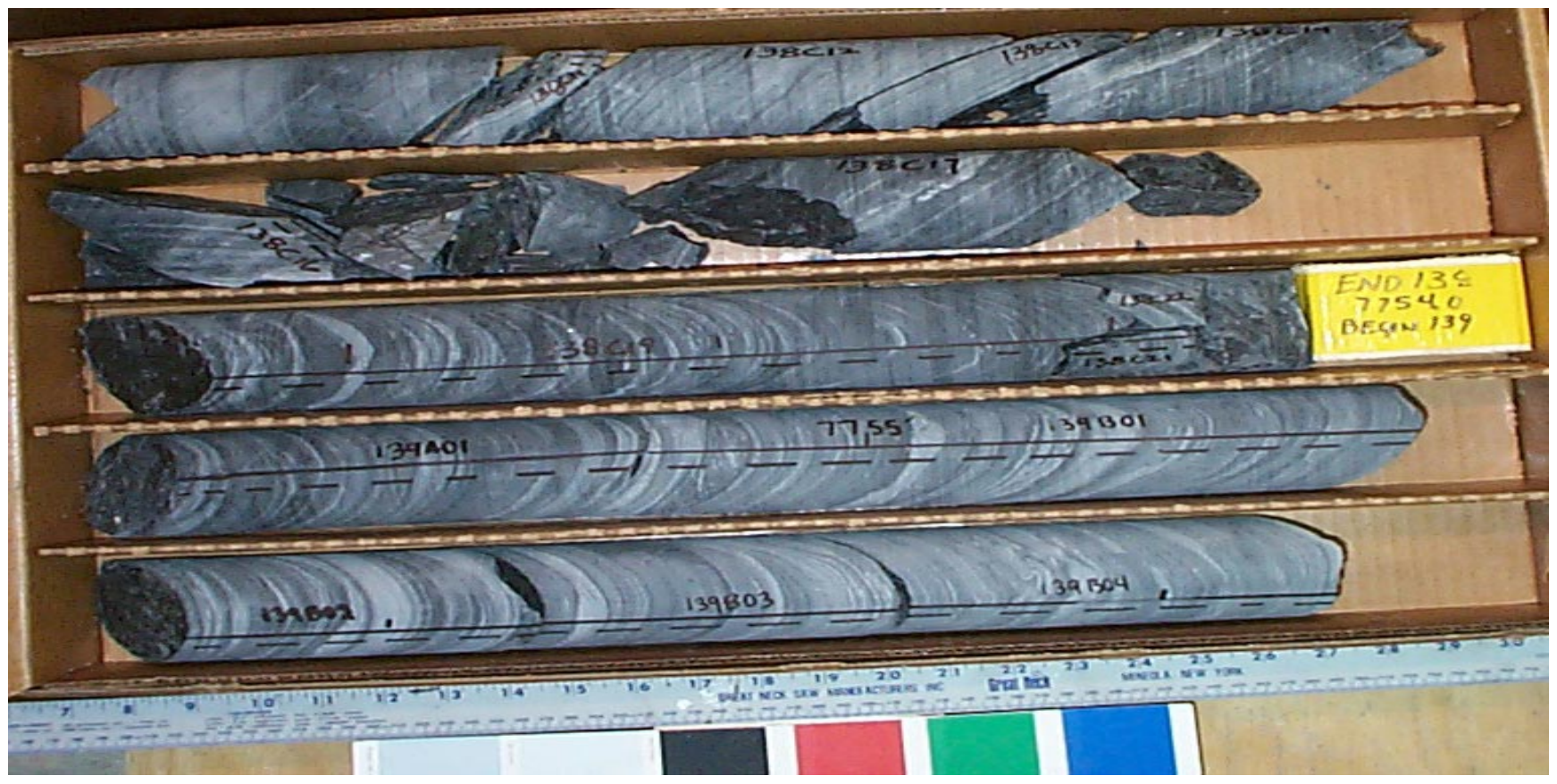

Core Scans included in this box (listed by piece going downhole):
$138 \mathrm{C} 100 \mathrm{~A}$
$138 \mathrm{C} 1200$
$138 \mathrm{C} 1400$
$138 \mathrm{C} 1700$
$138 \mathrm{C} 1900$
139A0100
$139 \mathrm{~B} 0100$
139B0200
139B0300
139B0400

See the "reading instructions" section of the introduction for help interpreting core box photos and core piece nomenclature 


\section{LVEW Core Box 213}

Depth Interval 7757.2'-7764.1'

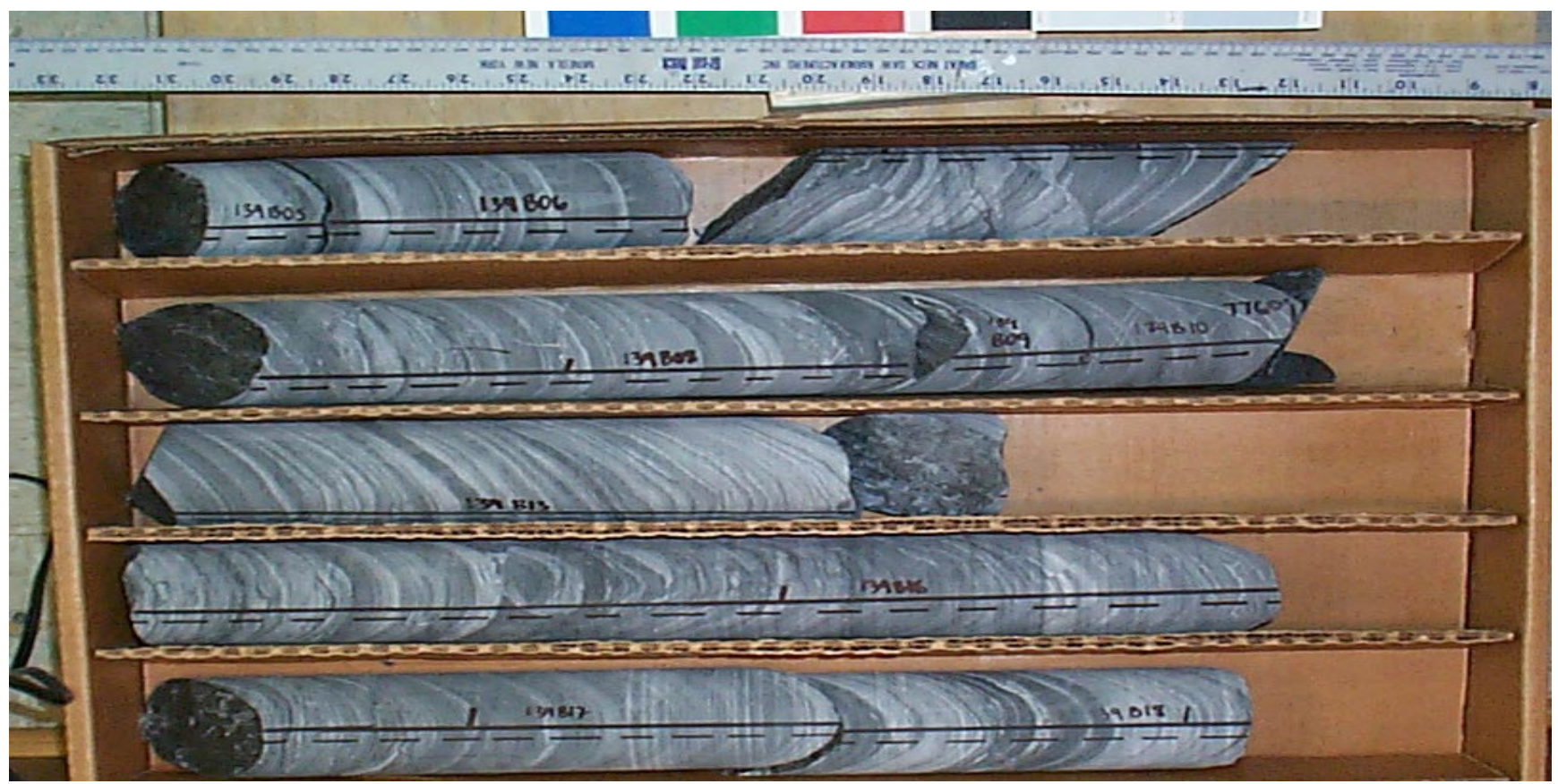

Core Scans included in this box (listed by piece going downhole):

139B0600

139B0700

139B0800

139B 1000

139B1300

139B1600

139B1700

139B1800

See the "reading instructions" section of the introduction for help interpreting core box photos and core piece nomenclature 


\section{LVEW Core Box 214}

Depth Interval 7764.1'-7770.8'

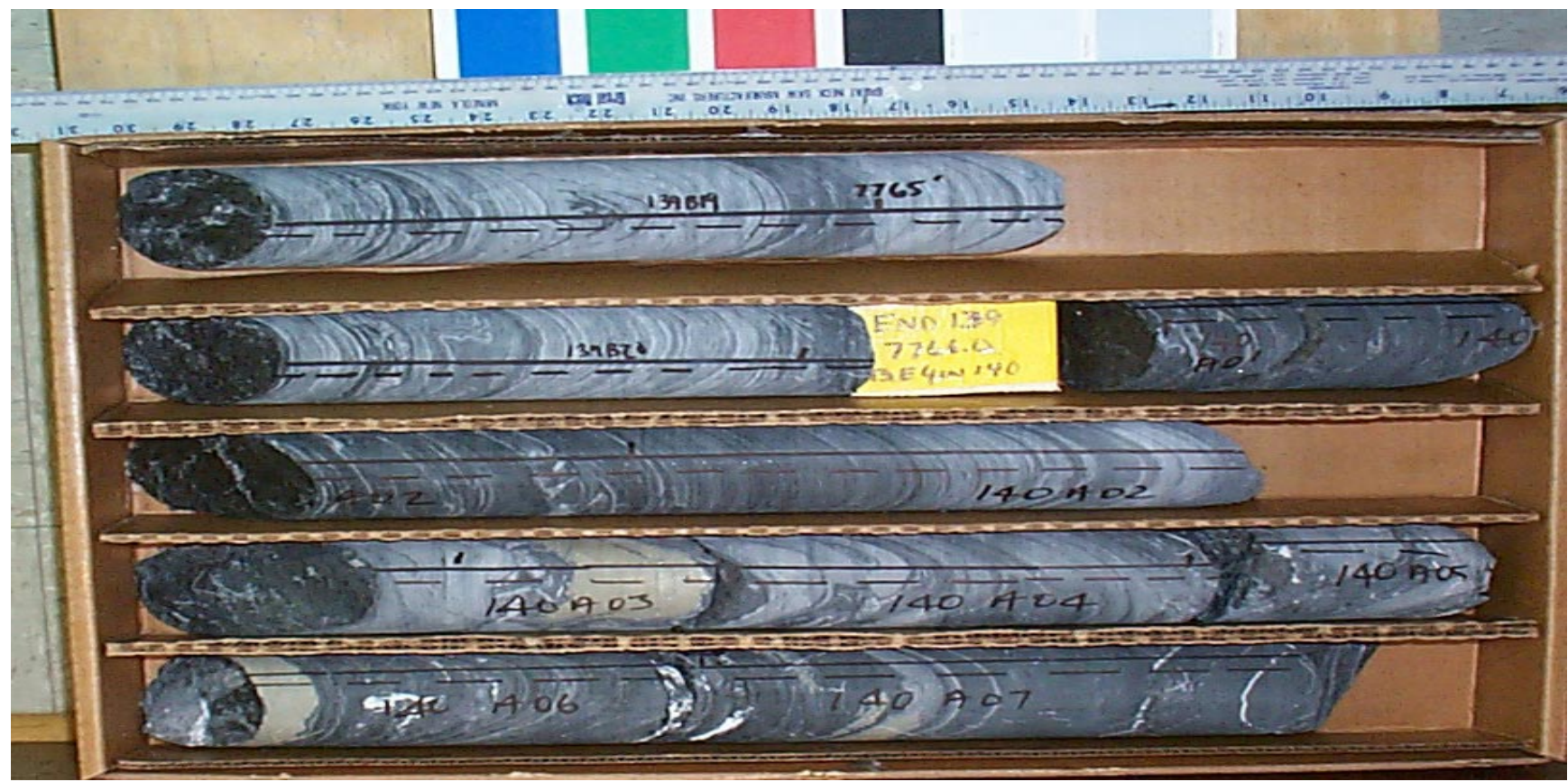

Core Scans included in this box (listed by piece going downhole):
139B1900
139B2000
$140 \mathrm{~A} 020 \mathrm{~A}$
$140 \mathrm{~A} 0300$
$140 \mathrm{~A} 0400$
$140 \mathrm{~A} 0500$
$140 \mathrm{~A} 0600$
$140 \mathrm{~A} 0700$

See the "reading instructions" section of the introduction for help interpreting core box photos and core piece nomenclature 
LVEW Core Box 215

Depth Interval 7770.8'-7777.2'

\section{Missing Core Box}

Core Scans included in this box

(listed by piece going downhole):

$$
\begin{aligned}
& \text { 140A0800 } \\
& \text { 141A0800 } \\
& \text { 141A0900 } \\
& \text { 141A1500 } \\
& \text { 141A1600 }
\end{aligned}
$$

See the "reading instructions" section of the introduction for help interpreting core box photos and core piece nomenclature 


\section{LVEW Core Box 216}

Depth Interval 7777.2'-7783.8'

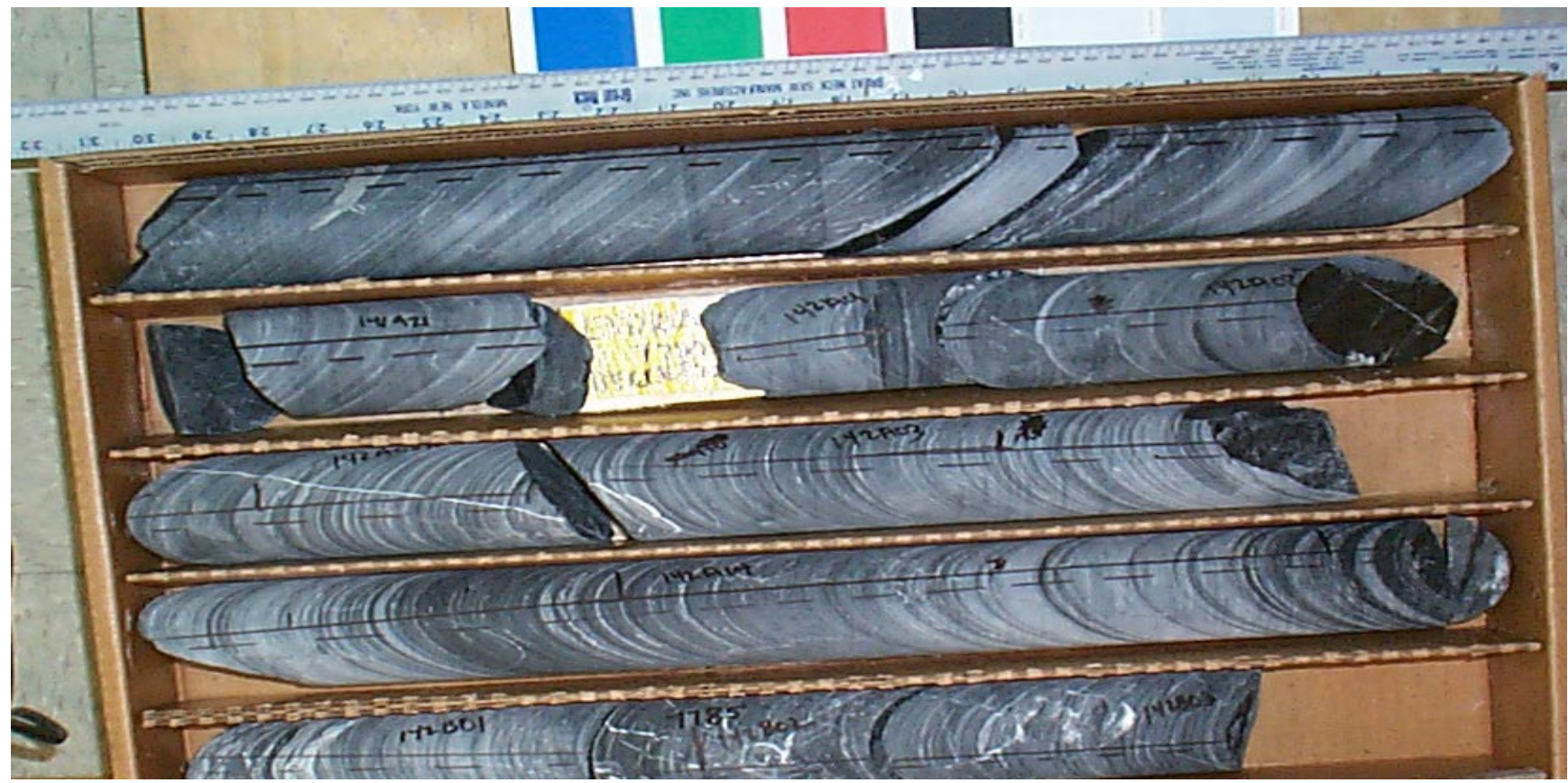

Core Scans included in this box (listed by piece going downhole):
$141 \mathrm{~A} 1700$
$141 \mathrm{~A} 1900$
$141 \mathrm{~A} 2100$
$142 \mathrm{~A} 0100$
$142 \mathrm{~A} 020 \mathrm{~A}$
$142 \mathrm{~A} 0300$
$142 \mathrm{~A} 0400$
$142 \mathrm{~B} 0100$
142B0200
$142 \mathrm{~B} 0300$

See the "reading instructions" section of the introduction for help interpreting core box photos and core piece nomenclature 


\section{LVEW Core Box 217}

Depth Interval 7783.8'-7793.1'

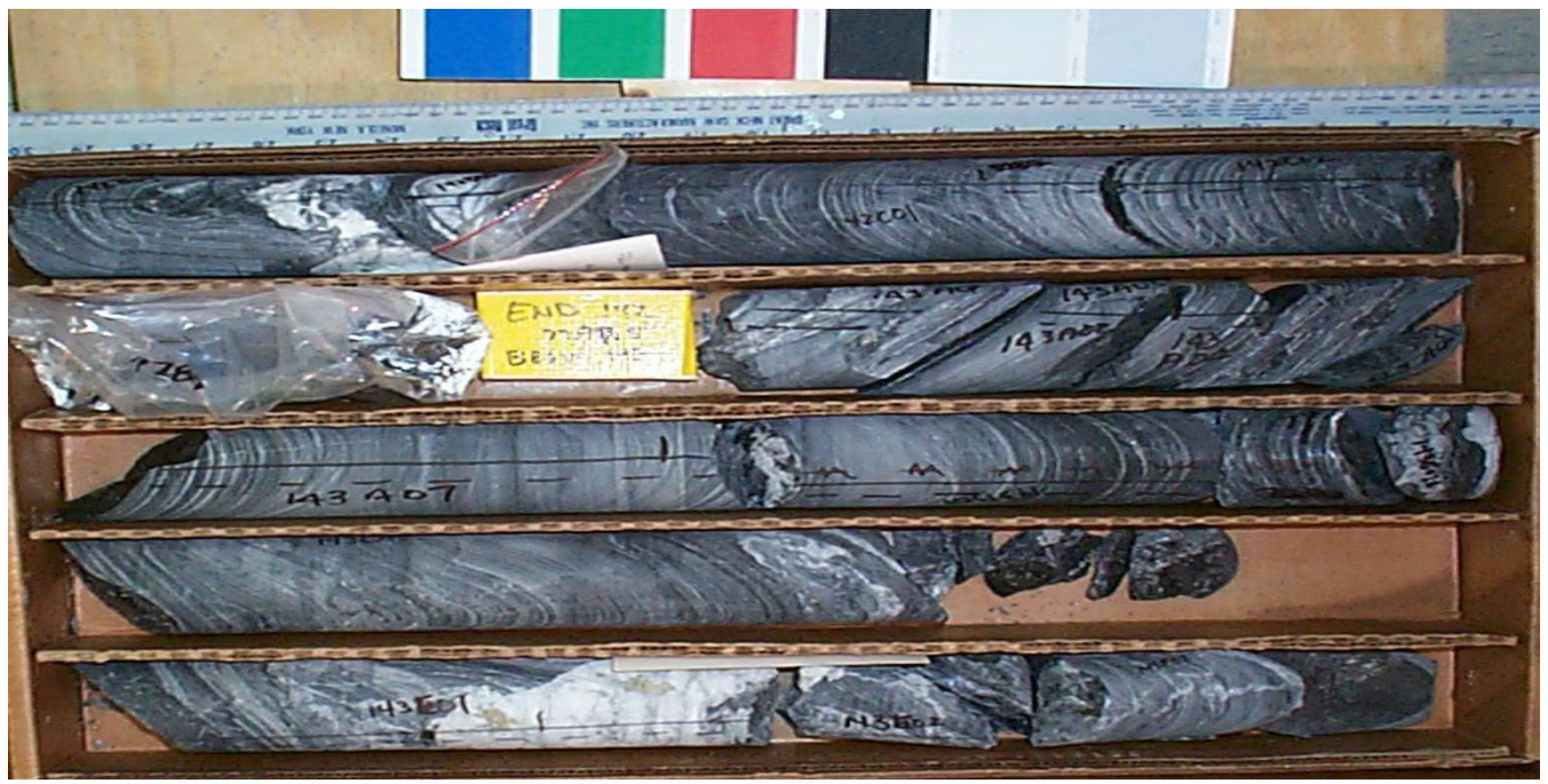

Core Scans included in this box (listed by piece going downhole):
142B0400
$142 \mathrm{C} 0100$
$143 \mathrm{~A} 070 \mathrm{~A}$
143B0100
$143 \mathrm{C} 0100$
$143 \mathrm{C} 0200$
143E0100
143E0200

See the "reading instructions" section of the introduction for help interpreting core box photos and core piece nomenclature 


\section{LVEW Core Box 218}

\section{Depth Interval 7793.1'-7801.4'}

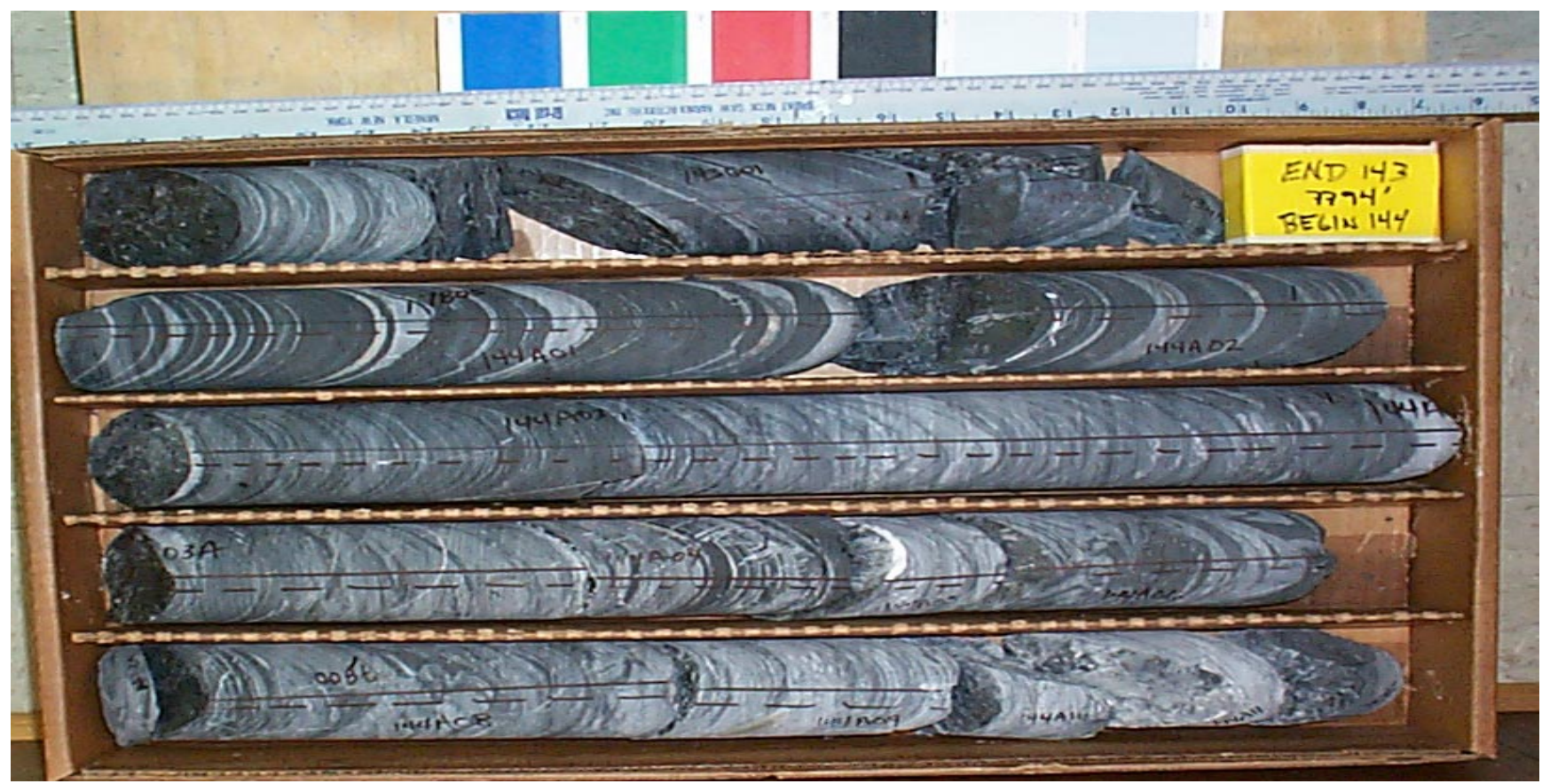

Core Scans included in this box (listed by piece going downhole):
143F0500
$143 \mathrm{G} 0100$
$144 \mathrm{~A} 0100$
$144 \mathrm{~A} 031 \mathrm{~A}$
144A032A
144A033A
$144 \mathrm{~A} 0400$
$144 \mathrm{~A} 0600$
$144 \mathrm{~A} 0800$
$144 \mathrm{~A} 0900$

See the "reading instructions" section of the introduction for help interpreting core box photos and core piece nomenclature 


\section{LVEW Core Box 219}

Depth Interval 7801.4'-7808.8'

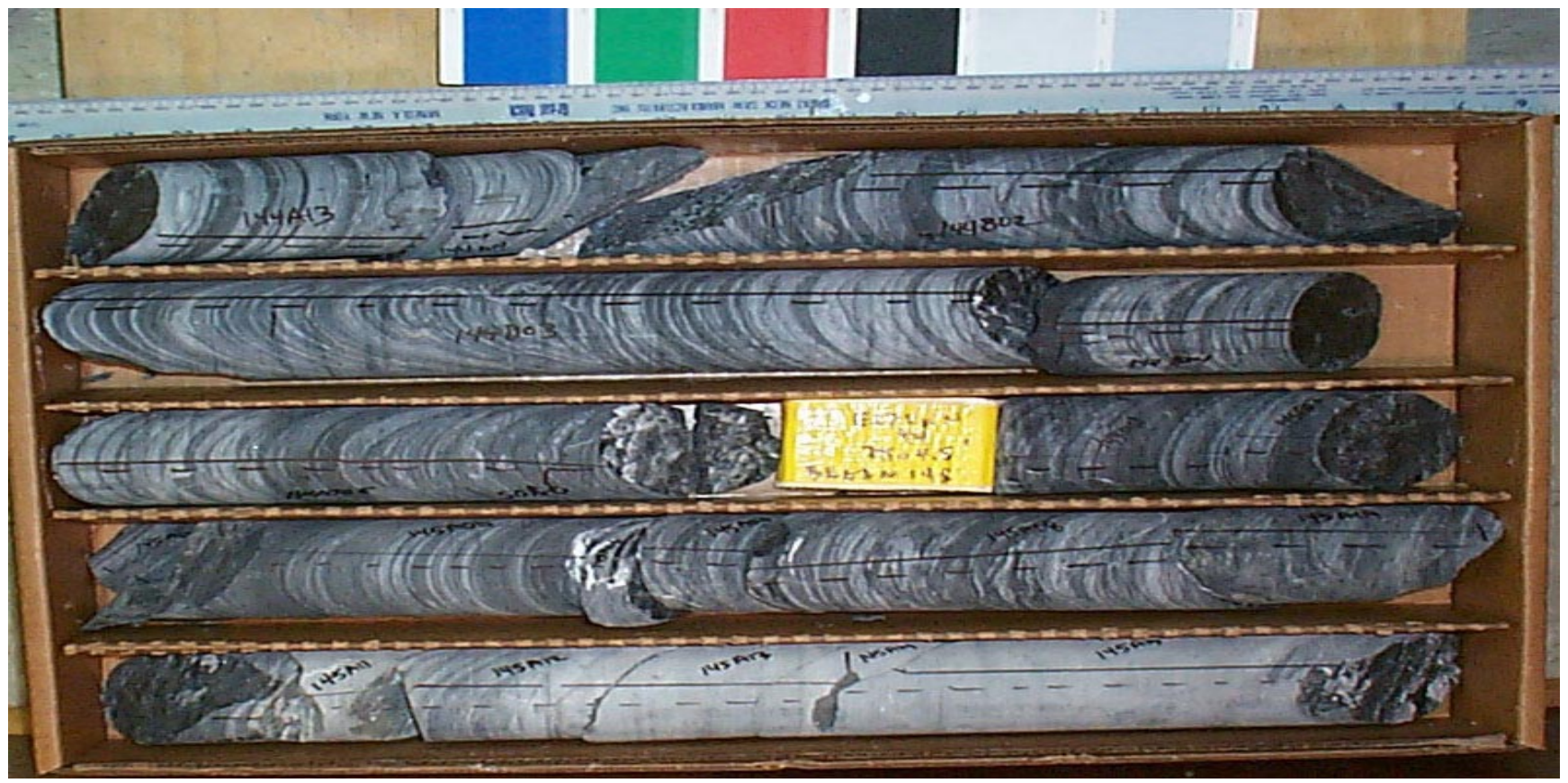

Core Scans included in this box (listed by piece going downhole):
$144 \mathrm{~A} 1300$
144B0200
144B0300
144B0400
144B0500
$145 \mathrm{~A} 0100$
$145 \mathrm{~A} 0500$
$145 \mathrm{~A} 0800$
$145 \mathrm{~A} 1100$
$145 \mathrm{~A} 1200$
$145 \mathrm{~A} 1300$
$145 \mathrm{~A} 1500$

See the "reading instructions" section of the introduction for help interpreting core box photos and core piece nomenclature 


\section{LVEW Core Box 220}

Depth Interval 7808.8'-7816.5'

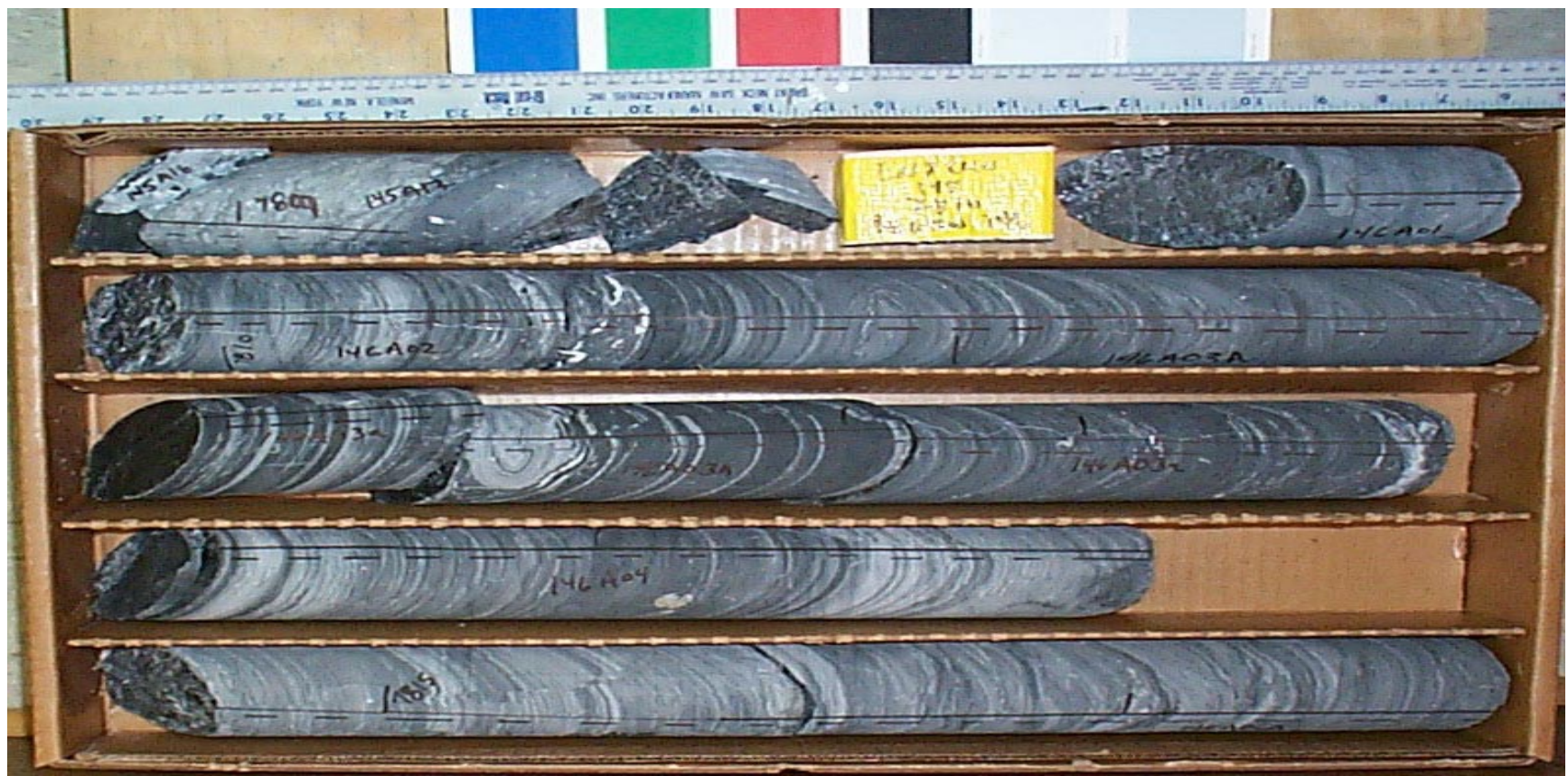

Core Scans included in this box (listed by piece going downhole):
$145 \mathrm{~A} 1700$
$146 \mathrm{~A} 0100$
$146 \mathrm{~A} 0200$
$146 \mathrm{~A} 031 \mathrm{~A}$
146A032A
146A033A
$146 \mathrm{~A} 0400$

See the "reading instructions" section of the introduction for help interpreting core box photos and core piece nomenclature 


\section{LVEW Core Box 221}

\section{Depth Interval 7816.5'-7824.1'}

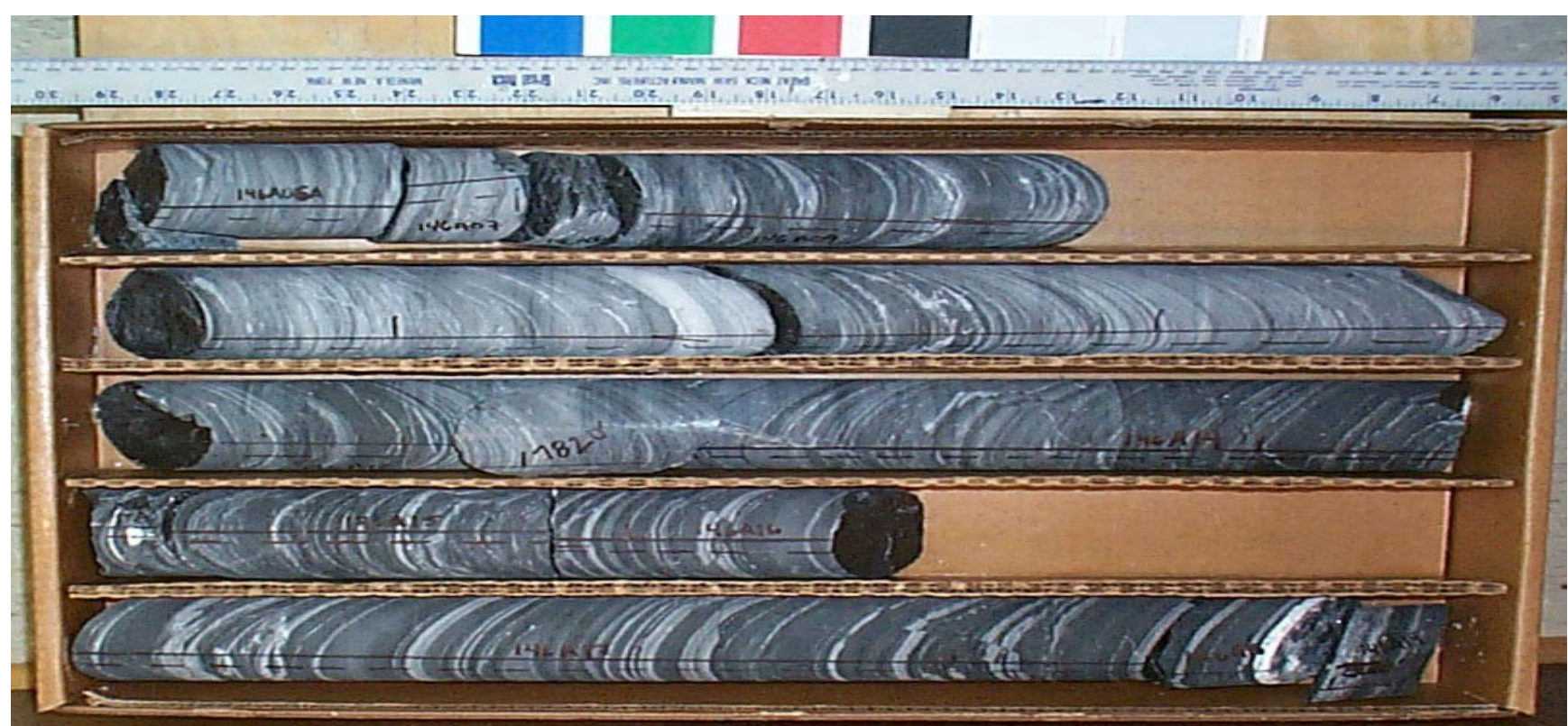

Core Scans included in this box (listed by piece going downhole):

$$
\begin{aligned}
& \text { 146A0500 } \\
& \text { 146A060A } \\
& \text { 146A0700 } \\
& \text { 146A0900 } \\
& \text { 146A1000 } \\
& \text { 146A1100 } \\
& \text { 146A1200 } \\
& \text { 146A1400 } \\
& \text { 146A150A } \\
& \text { 146A1600 } \\
& \text { 146A1700 } \\
& \text { 146A1800 } \\
& \text { 146A1900 }
\end{aligned}
$$

See the "reading instructions" section of the introduction for help interpreting core box photos and core piece nomenclature 


\section{LVEW Core Box 222}

Depth Interval 7824.1'-7832.3'

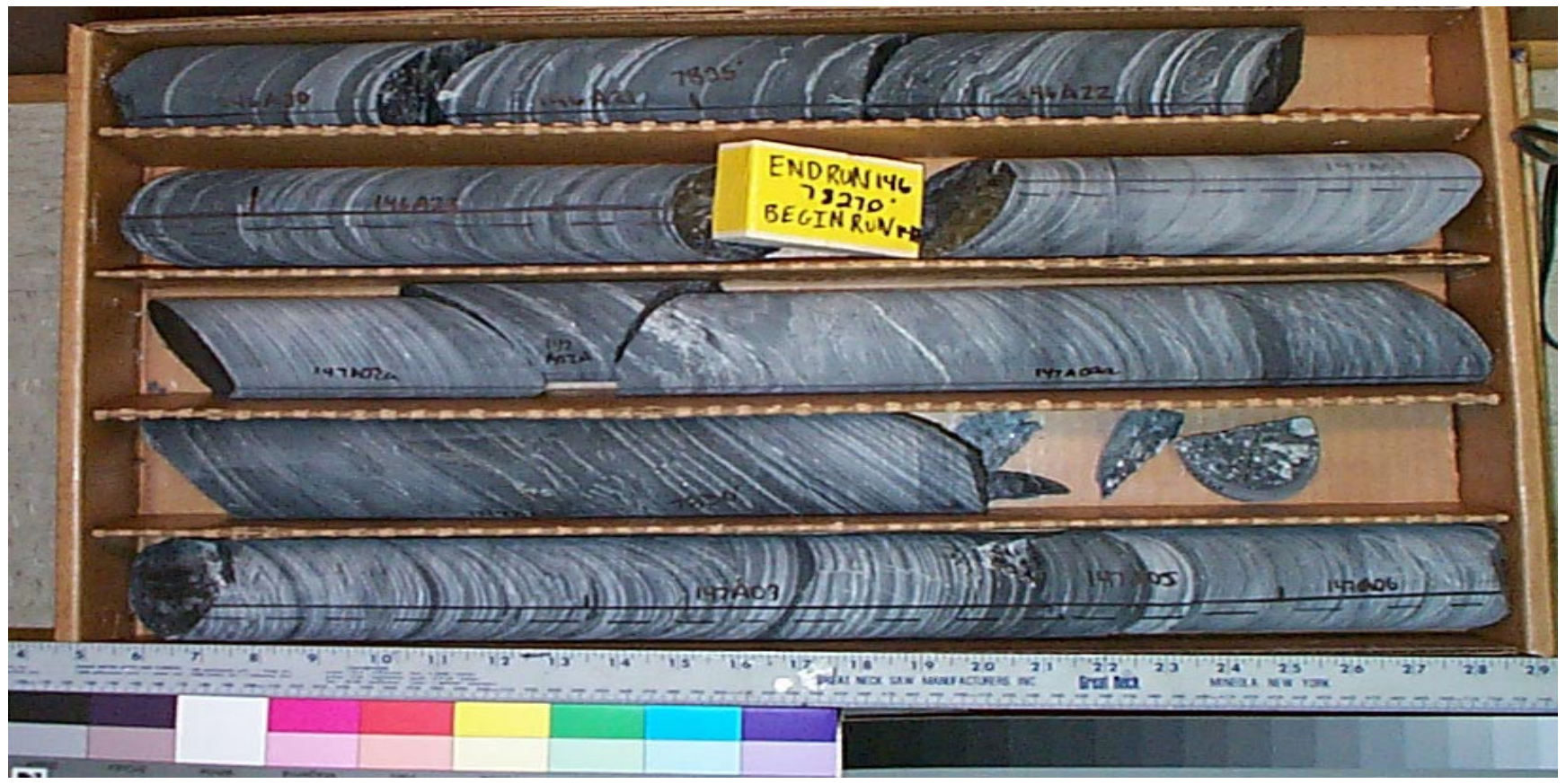

Core Scans included in this box (listed by piece going downhole):

146A2000
146A2100
146A2200
146A2300
147A0100
147A021A
147A022A
147A0300
147A0600

See the "reading instructions" section of the introduction for help interpreting core box photos and core piece nomenclature 


\section{LVEW Core Box 223}

Depth Interval 7832.3'-7838.8'

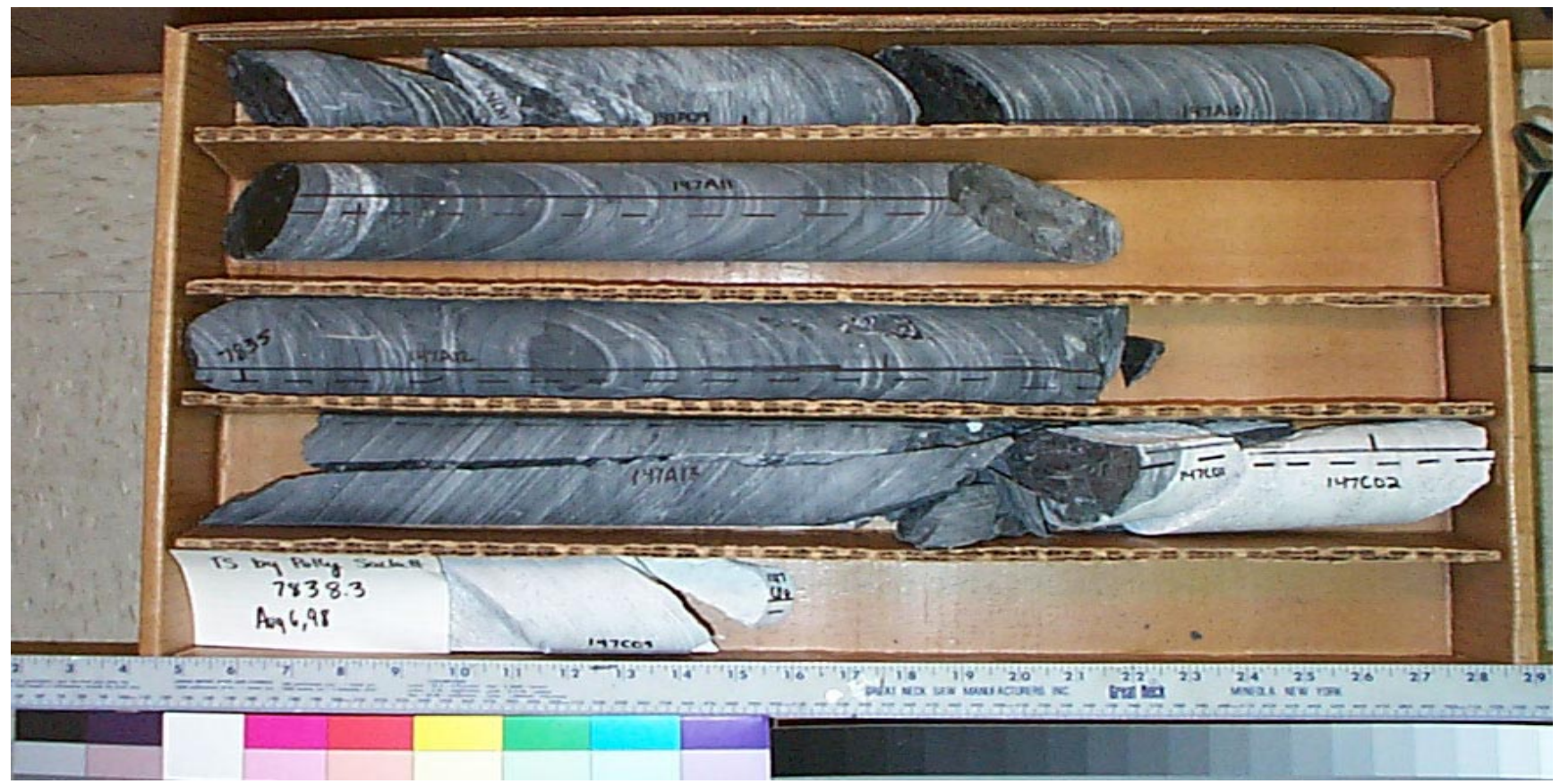

Core Scans included in this box (listed by piece going downhole):

147A0700
147A0900
147A1000
147A1100
147A1200

See the "reading instructions" section of the introduction for help interpreting core box photos and core piece nomenclature 


\section{LVEW Core Box 224}

Depth Interval 7838.8'-7847.2'

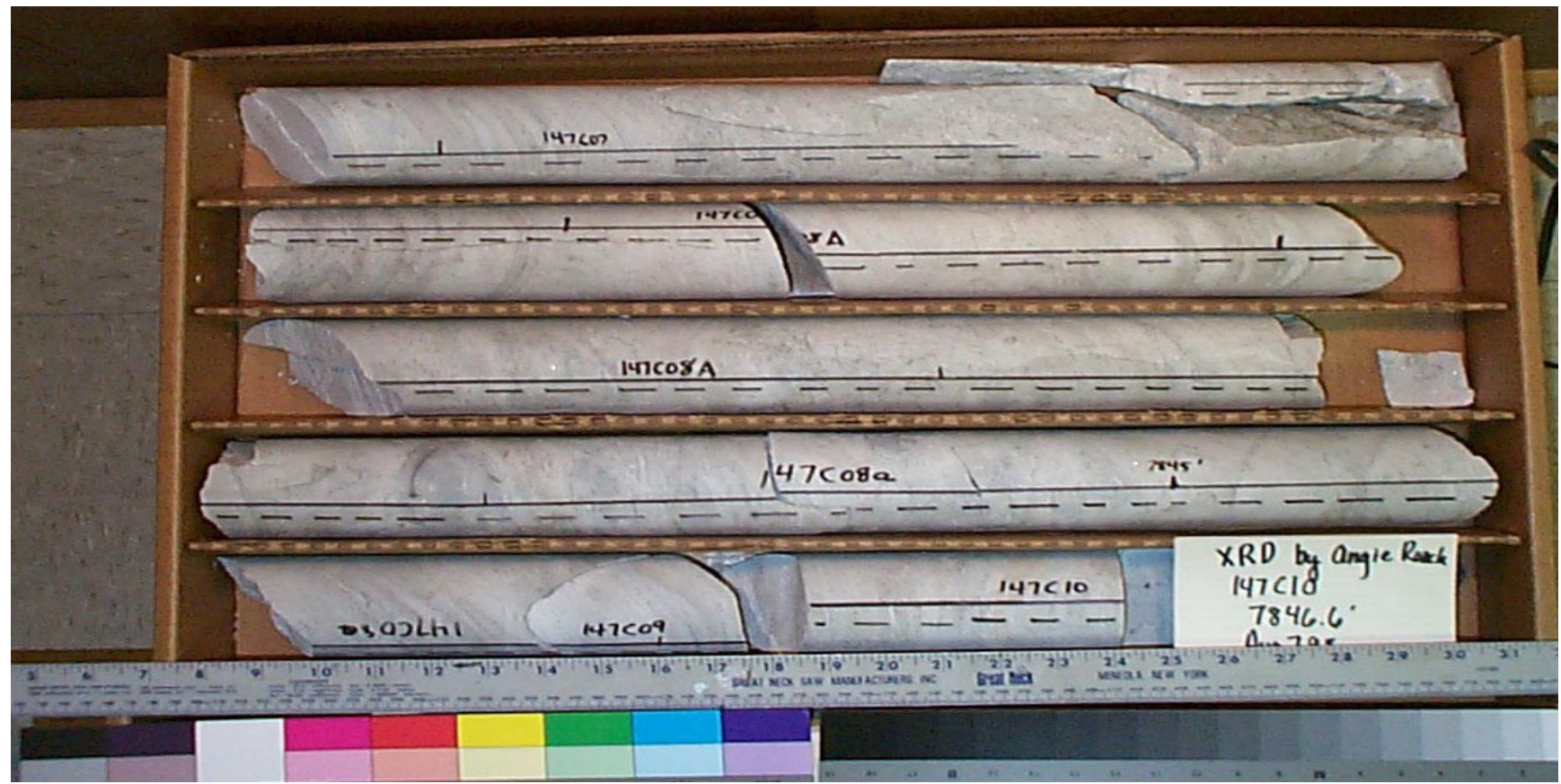

Core Scans included in this box (listed by piece going downhole):

147C0700
147C081A
147C082A
147C083A
147C1000

See the "reading instructions" section of the introduction for help interpreting core box photos and core piece nomenclature 


\section{LVEW Core Box 225}

Depth Interval 7847.2'-7854.8'

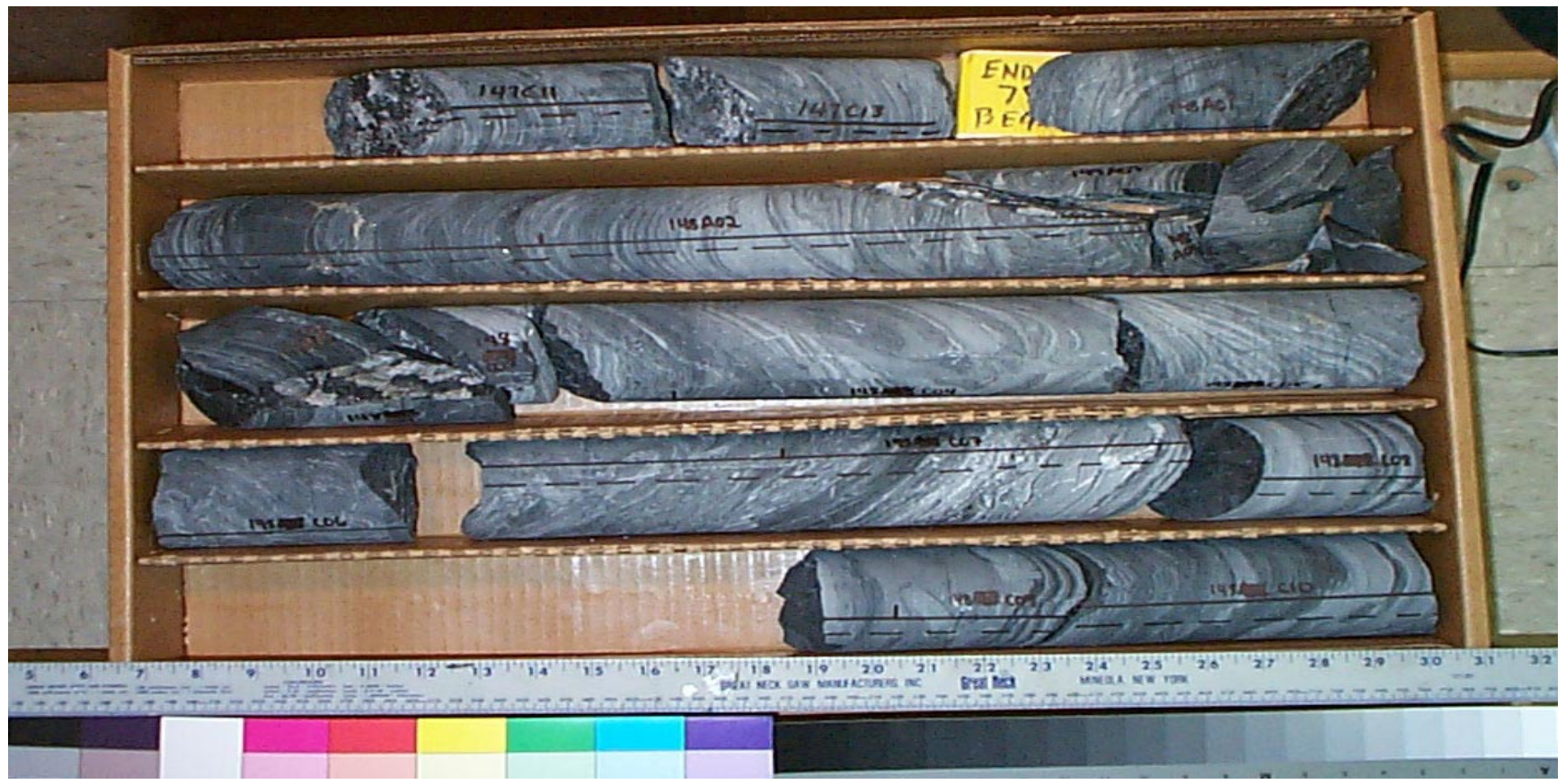

Core Scans included in this box (listed by piece going downhole):
$148 \mathrm{~A} 0100$
$148 \mathrm{~A} 0200$
$148 \mathrm{C} 0400$
$148 \mathrm{C} 0500$
$148 \mathrm{C} 0600$
$148 \mathrm{C} 0700$
$148 \mathrm{C} 0800$
$148 \mathrm{C} 0900$
$148 \mathrm{C} 1000$

See the "reading instructions" section of the introduction for help interpreting core box photos and core piece nomenclature 


\section{LVEW Core Box 226}

Depth Interval 7854.8'-7861.4'

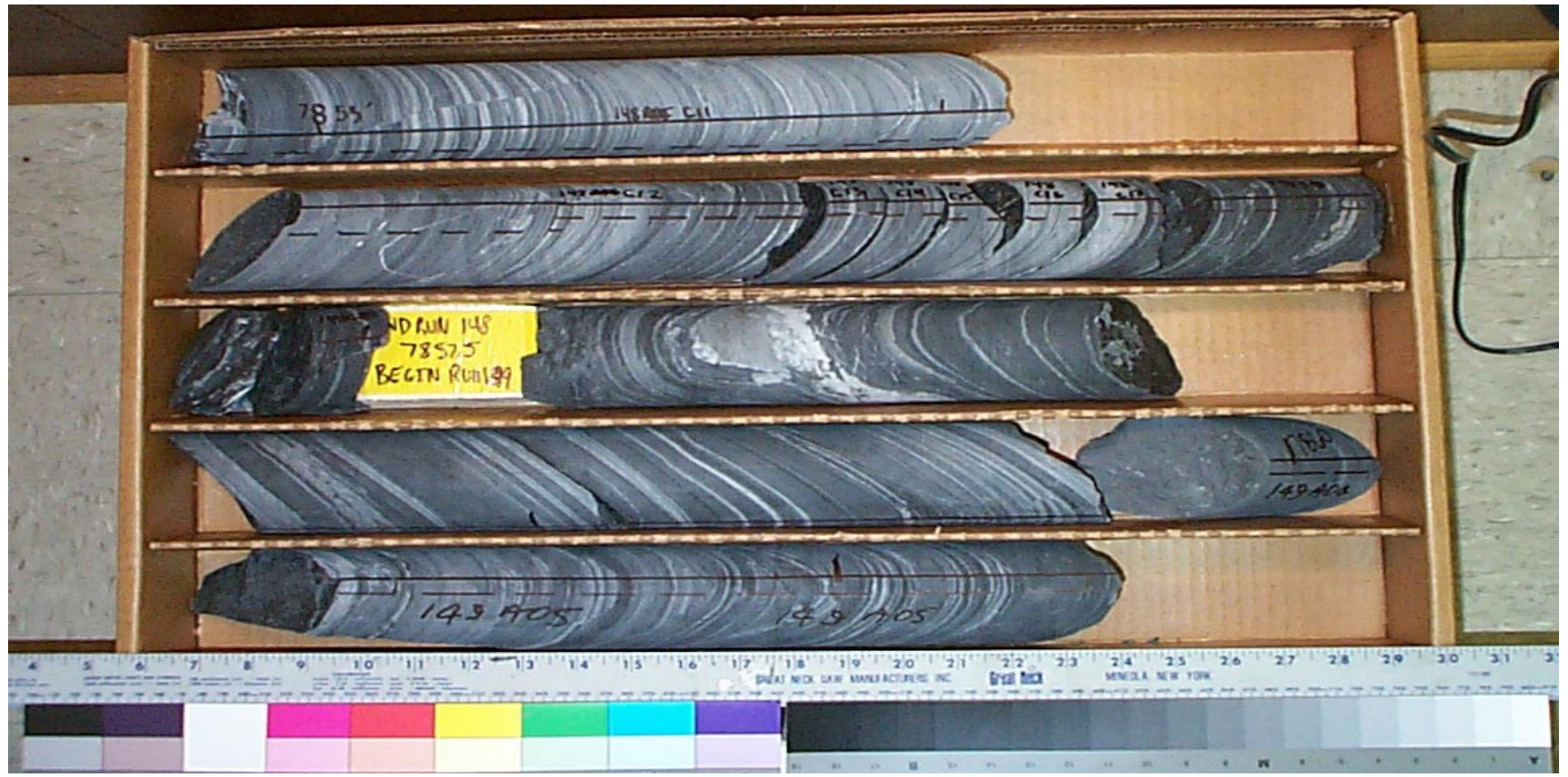

Core Scans included in this box (listed by piece going downhole):
148C1100
$148 \mathrm{C} 1200$
$148 \mathrm{C} 1800$
$149 \mathrm{~A} 0100$
149A0200
149A0300
149A0500

See the "reading instructions" section of the introduction for help interpreting core box photos and core piece nomenclature 


\section{LVEW Core Box 227}

Depth Interval 7861.4'-7866.8'

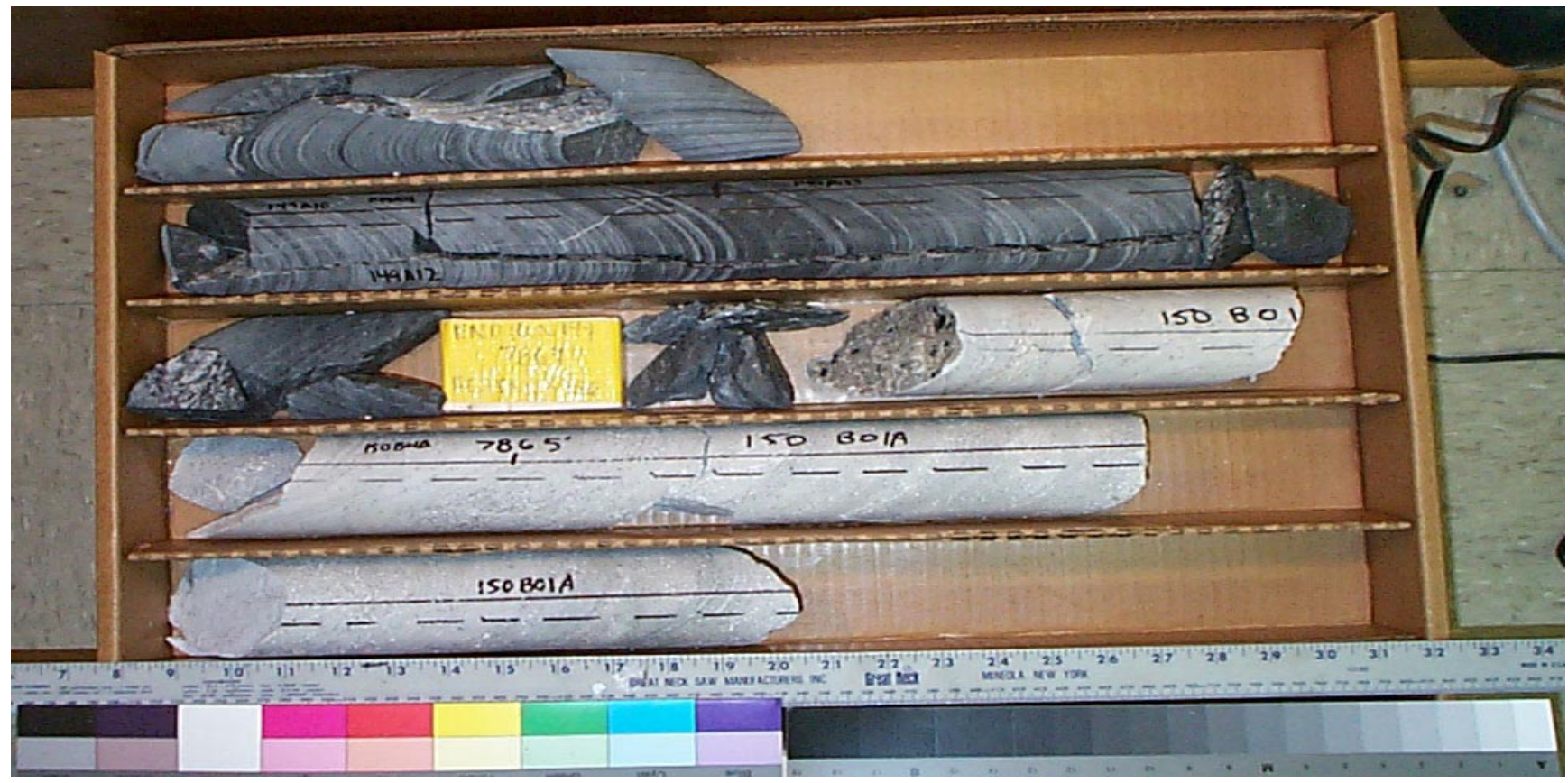

Core Scans included in this box (listed by piece going downhole):

\section{B011A} 150B012A

See the "reading instructions" section of the introduction for help interpreting core box photos and core piece nomenclature 


\section{LVEW Core Box 228}

Depth Interval 7866.8'-7874.7'

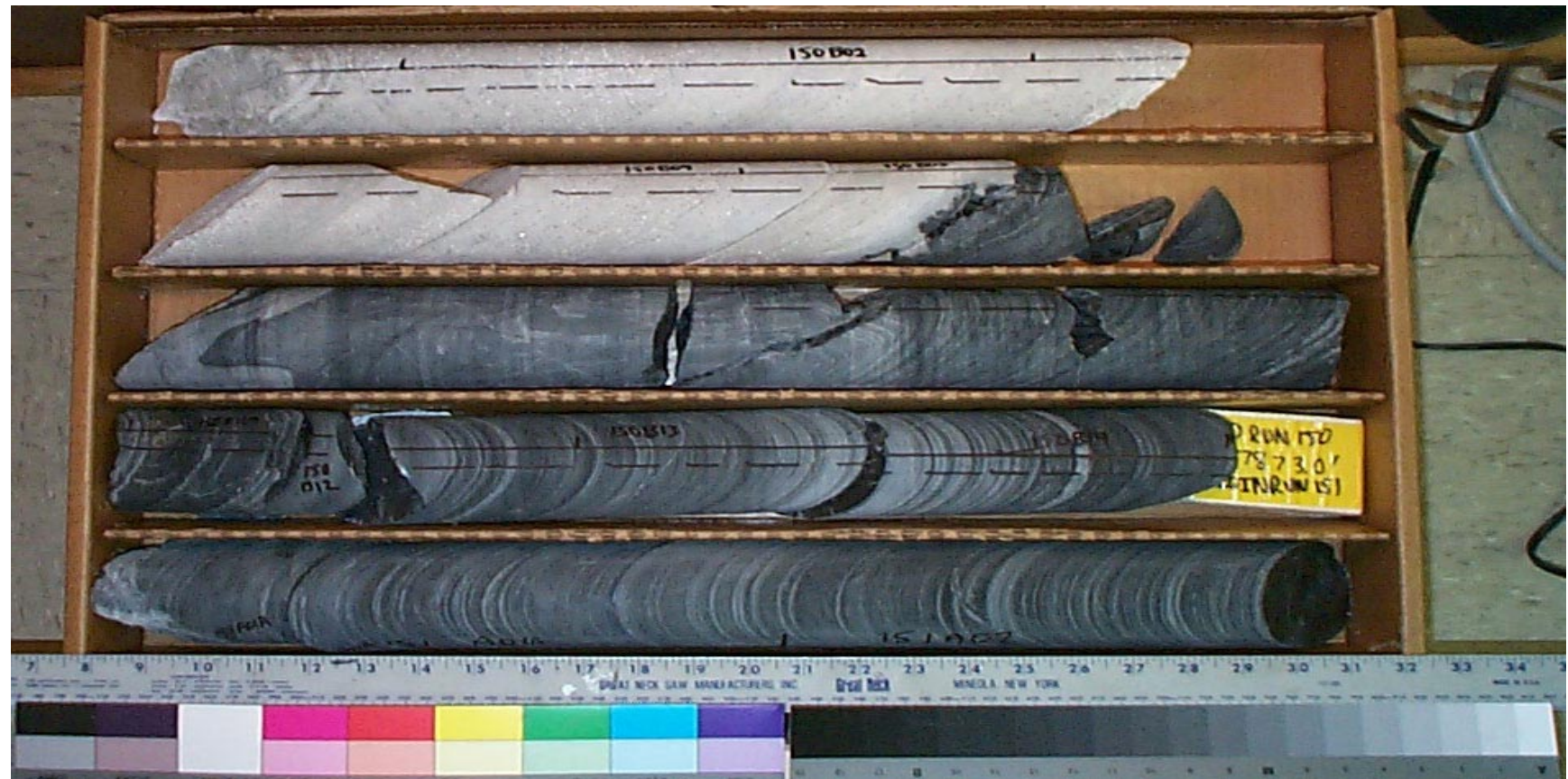

Core Scans included in this box (listed by piece going downhole):

150B0200
$150 B 0300$
$150 B 0400$
$150 B 0500$
$150 B 0800$
$150 B 110 A$
$150 B 1300$
$150 B 1400$
$151 A 010 A$
$151 A 0200$

See the "reading instructions" section of the introduction for help interpreting core box photos and core piece nomenclature 


\section{LVEW Core Box 229}

Depth Interval 7874.7'-7883.0'

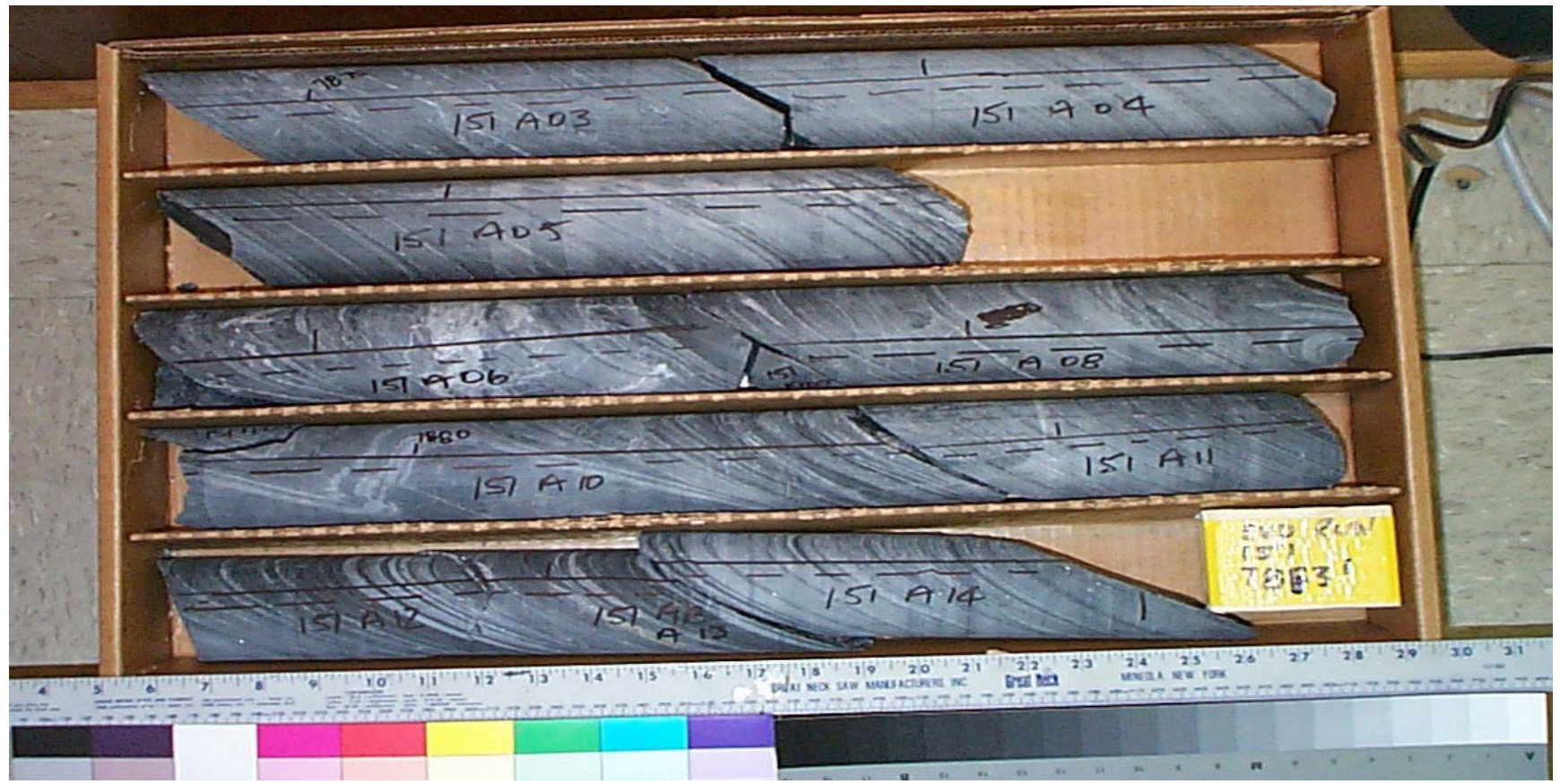

Core Scans included in this box (listed by piece going downhole):
$151 \mathrm{~A} 0300$
$151 \mathrm{~A} 0400$
$151 \mathrm{~A} 0500$
$151 \mathrm{~A} 0600$
$151 \mathrm{~A} 0800$
$151 \mathrm{~A} 1000$
$151 \mathrm{~A} 1100$
$151 \mathrm{~A} 1200$
$151 \mathrm{~A} 1300$
$151 \mathrm{~A} 1400$

See the "reading instructions" section of the introduction for help interpreting core box photos and core piece nomenclature 


\section{LVEW Core Box 230}

Depth Interval 7883.0'-7890.2'

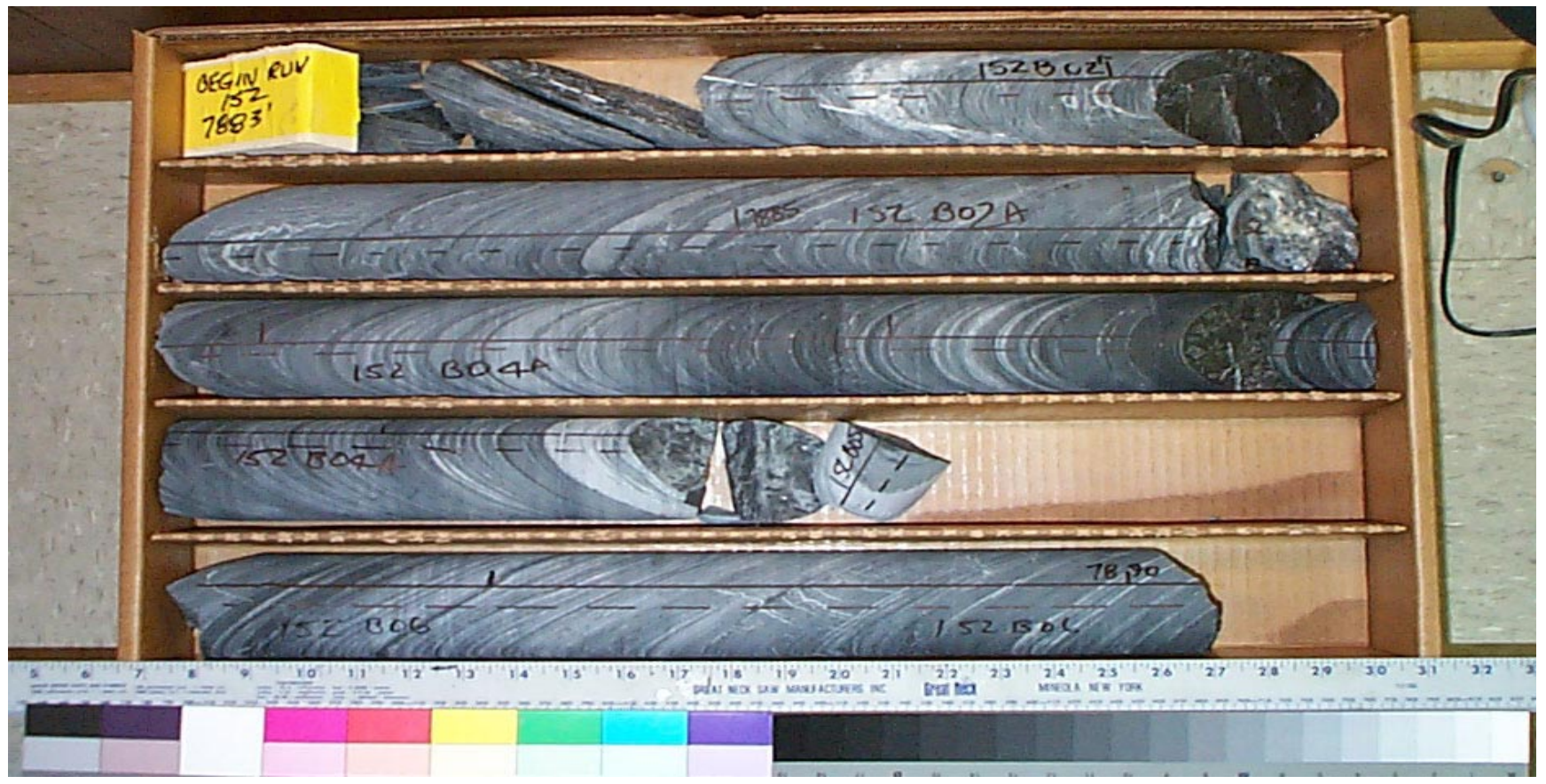

Core Scans included in this box (listed by piece going downhole):

152B020A

$152 \mathrm{~B} 040 \mathrm{~A}$

152B0600

See the "reading instructions" section of the introduction for help interpreting core box photos and core piece nomenclature 


\section{LVEW Core Box 231}

Depth Interval 7890.2'-7898.2'

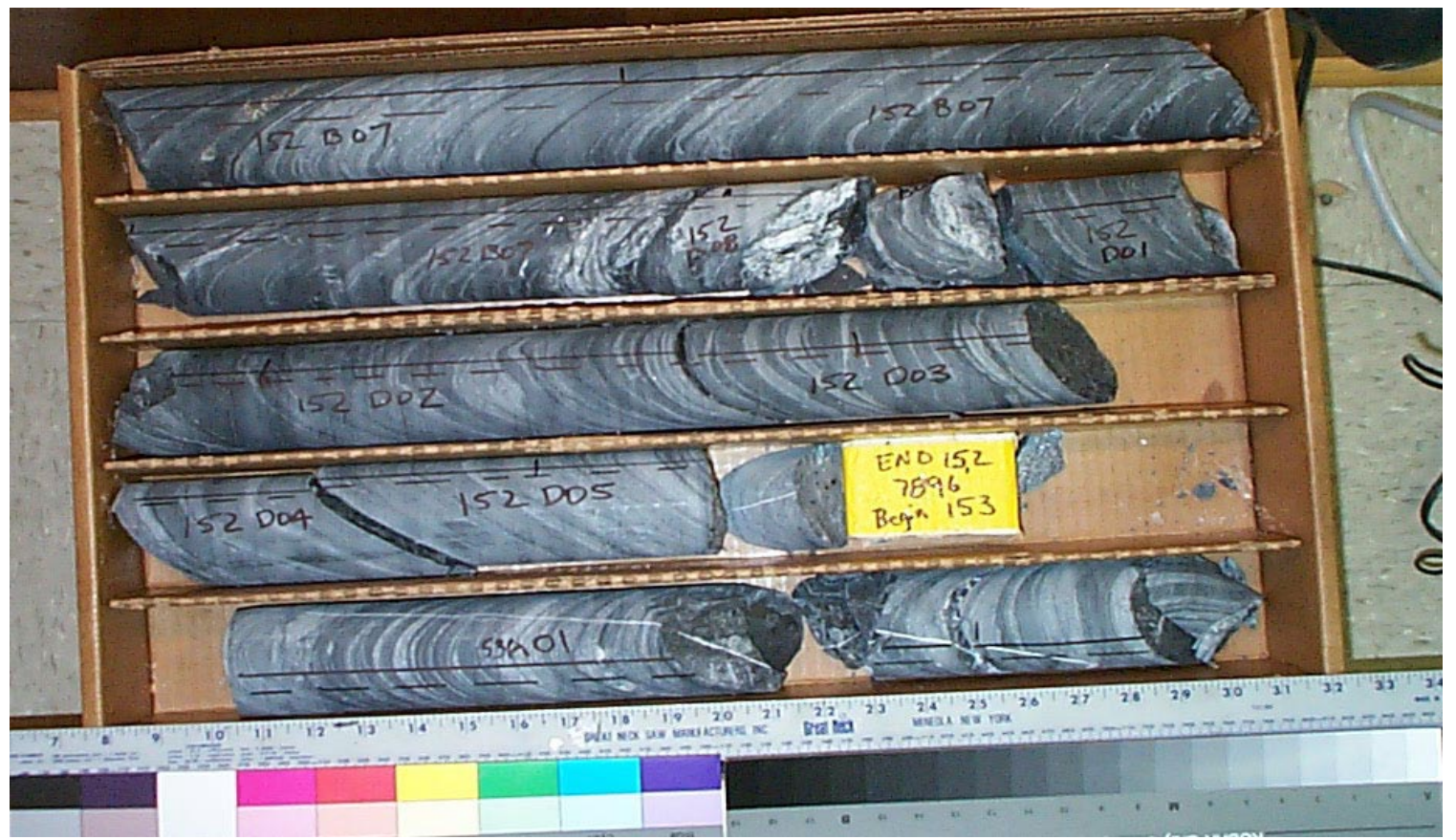

Core Scans included in this box (listed by piece going downhole):
$152 \mathrm{~B} 0700$
$152 \mathrm{~B} 0800$
$152 \mathrm{D} 0100$
$152 \mathrm{D} 0200$
$152 \mathrm{D} 0300$
$152 \mathrm{D} 0400$
$152 \mathrm{D} 0500$
$153 \mathrm{~A} 0100$
153A020A

See the "reading instructions" section of the introduction for help interpreting core box photos and core piece nomenclature 


\section{LVEW Core Box 232}

Depth Interval 7898.2'-7907.0'

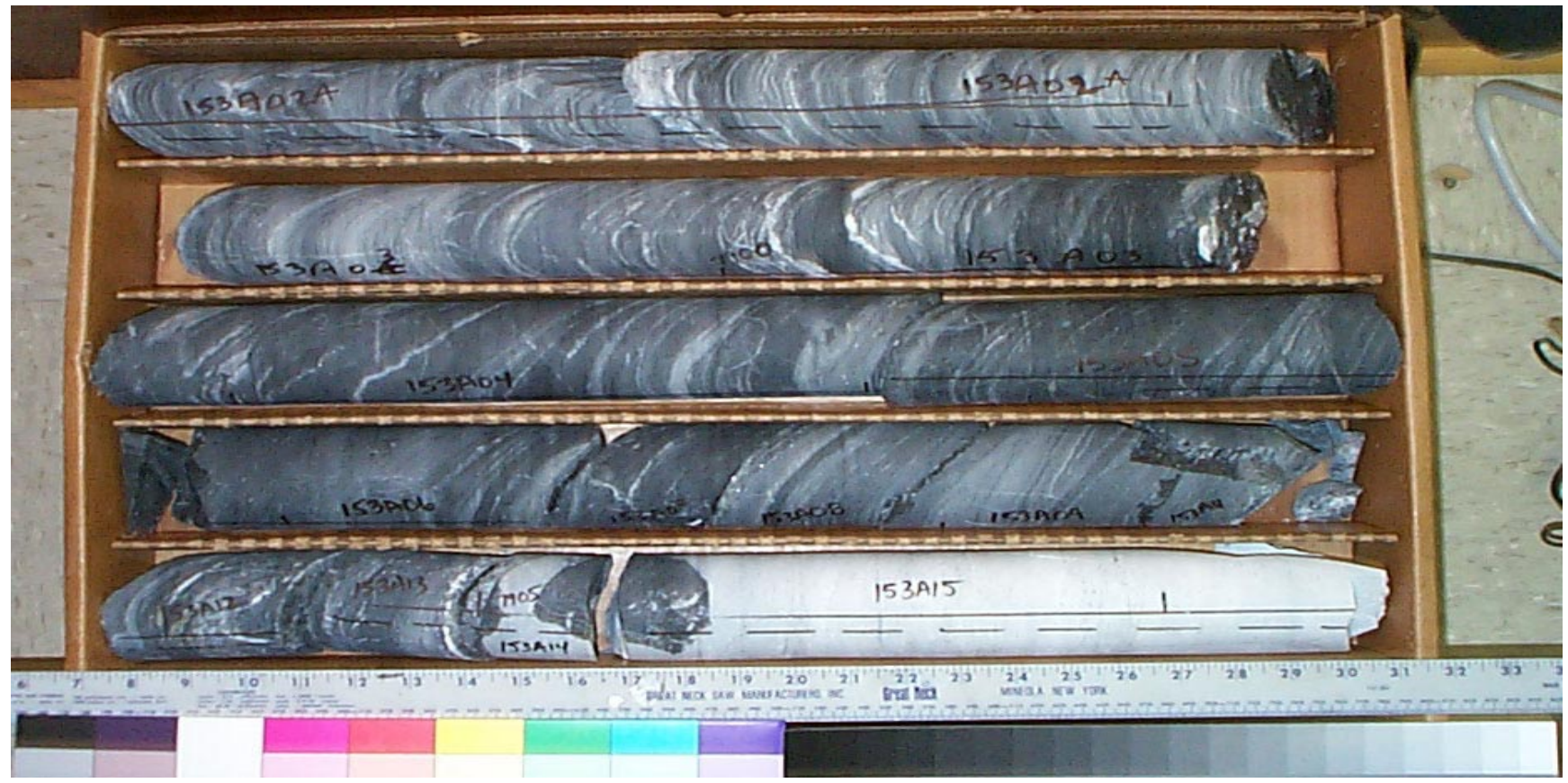

Core Scans included in this box (listed by piece going downhole):
153A020A
$153 \mathrm{~A} 0300$
$153 \mathrm{~A} 0400$
$153 \mathrm{~A} 0500$
153A0600
$153 \mathrm{~A} 0700$
153A0800
$153 \mathrm{~A} 0900$
153A1200
153A1300
153A1500

See the "reading instructions" section of the introduction for help interpreting core box photos and core piece nomenclature 


\section{LVEW Core Box 233}

Depth Interval 7907.0'-7912.9'

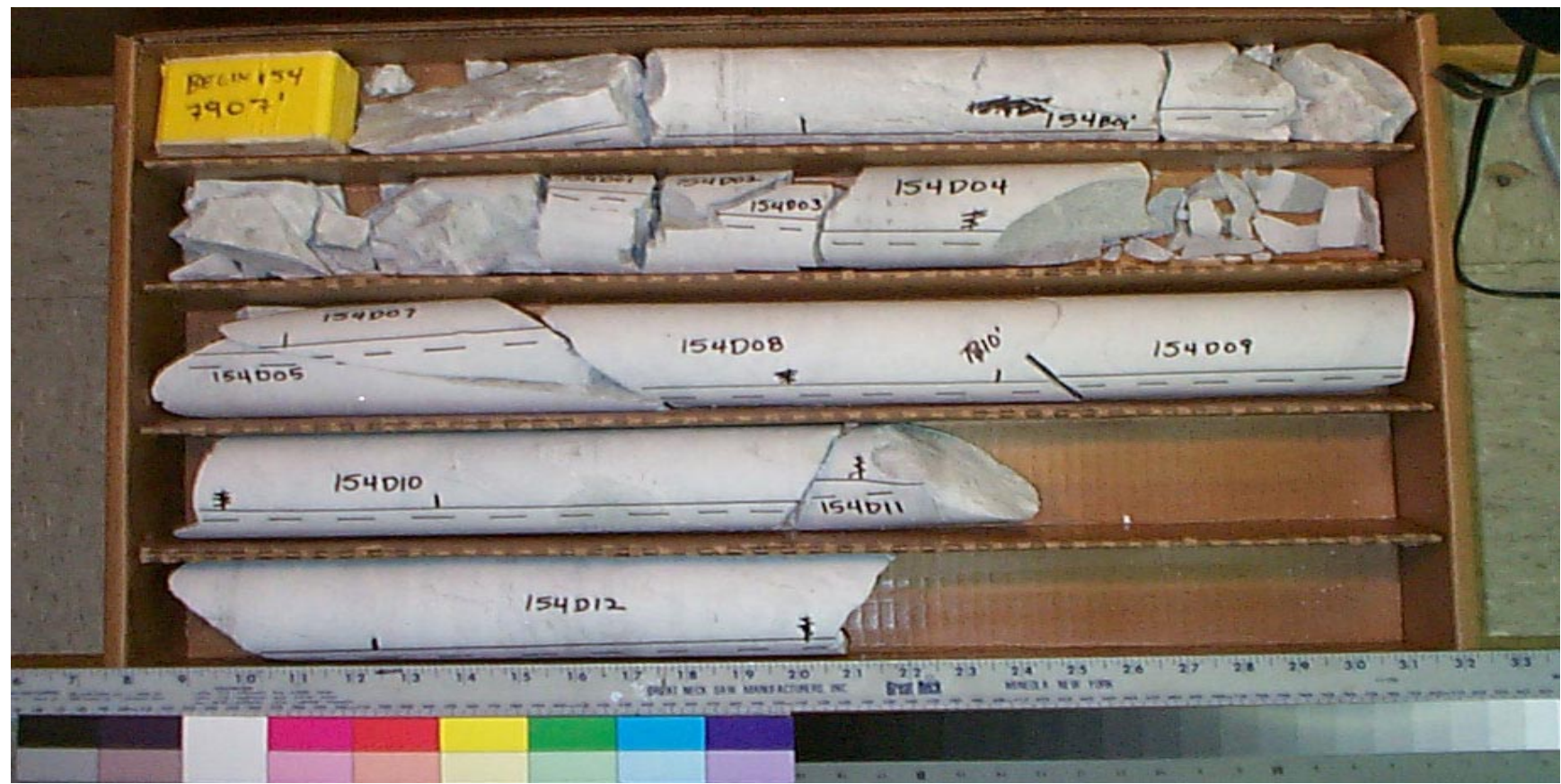

Core Scans included in this box (listed by piece going downhole):
154B0100
154D0400
154D0800
154D0900
154D1000
154D1200

See the "reading instructions" section of the introduction for help interpreting core box photos and core piece nomenclature 
LVEW Core Box 234

Depth Interval 7912.9'-7920.7'

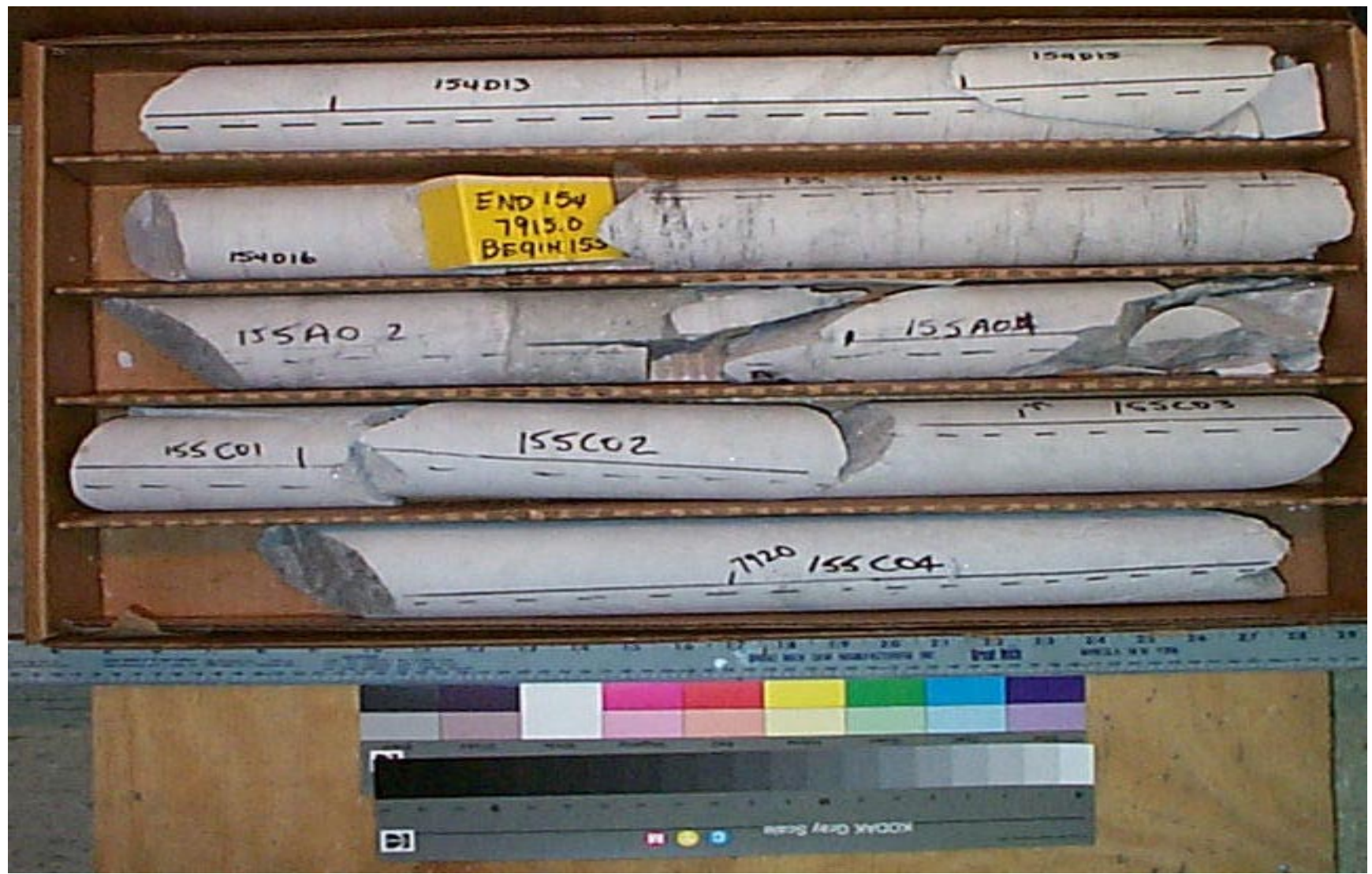

Core Scans included in this box (listed by piece going downhole):

154D1300
154D1600
155A0100
155A0200
155A0400
155C0200
155C0300
$155 C 0400$

See the "reading instructions" section of the introduction for help interpreting core box photos and core piece nomenclature 
LVEW Core Box 235

Depth Interval 7920.7'-7928.2'

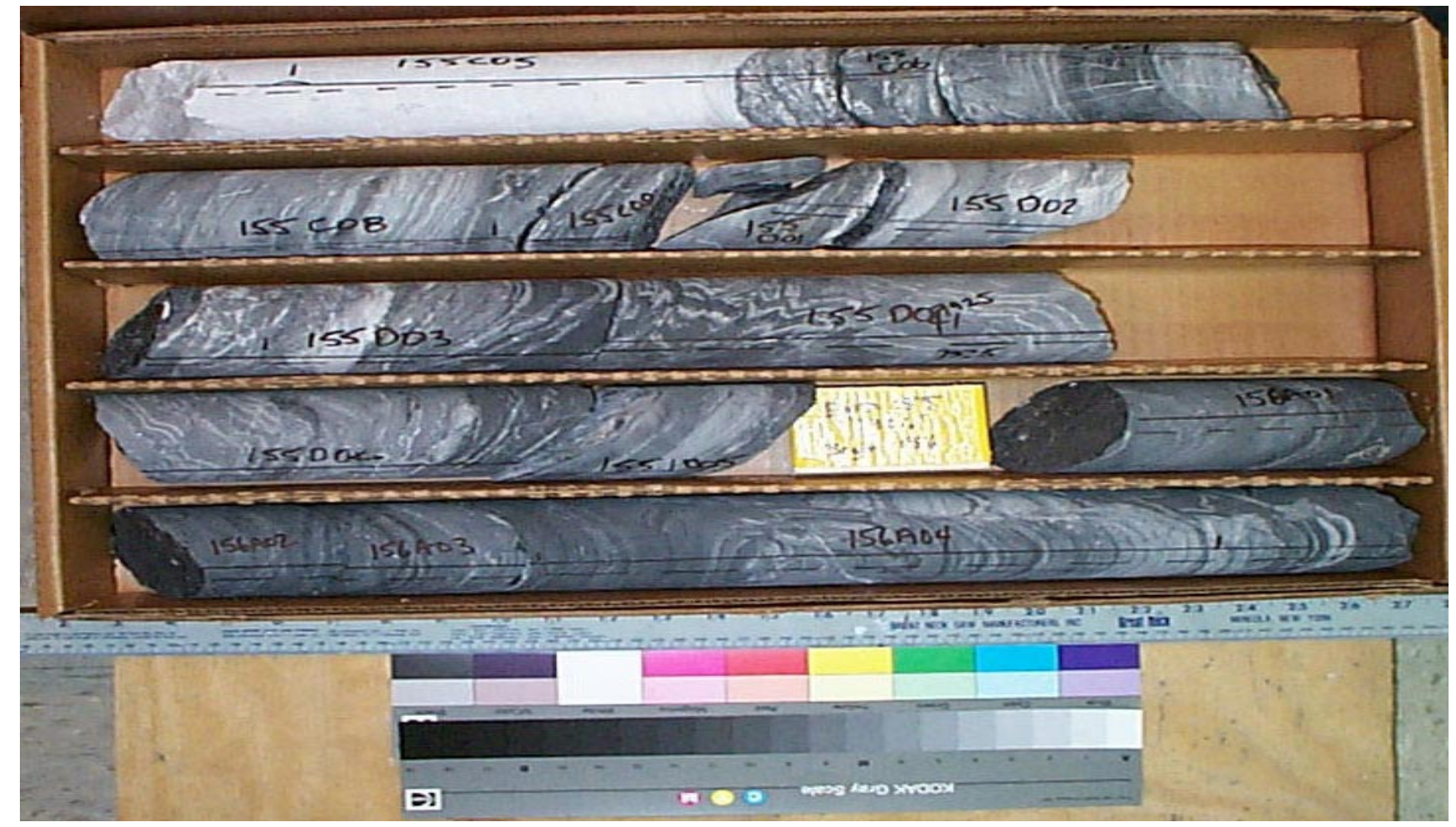

Core Scans included in this box (listed by piece going downhole):
$155 \mathrm{C} 0500$
$155 \mathrm{C} 0600$
$155 \mathrm{C} 0700$
$155 \mathrm{C} 0800$
$155 \mathrm{C} 0900$
155D0200
$155 D 0300$

155D0400 $155 \mathrm{D} 0500$ $156 \mathrm{~A} 0100$ $156 \mathrm{~A} 0200$ $156 \mathrm{~A} 0300$ $156 \mathrm{~A} 0400$

See the "reading instructions" section of the introduction for help interpreting core box photos and core piece nomenclature 


\section{LVEW Core Box 236}

Depth Interval 7928.2'-7936.2'

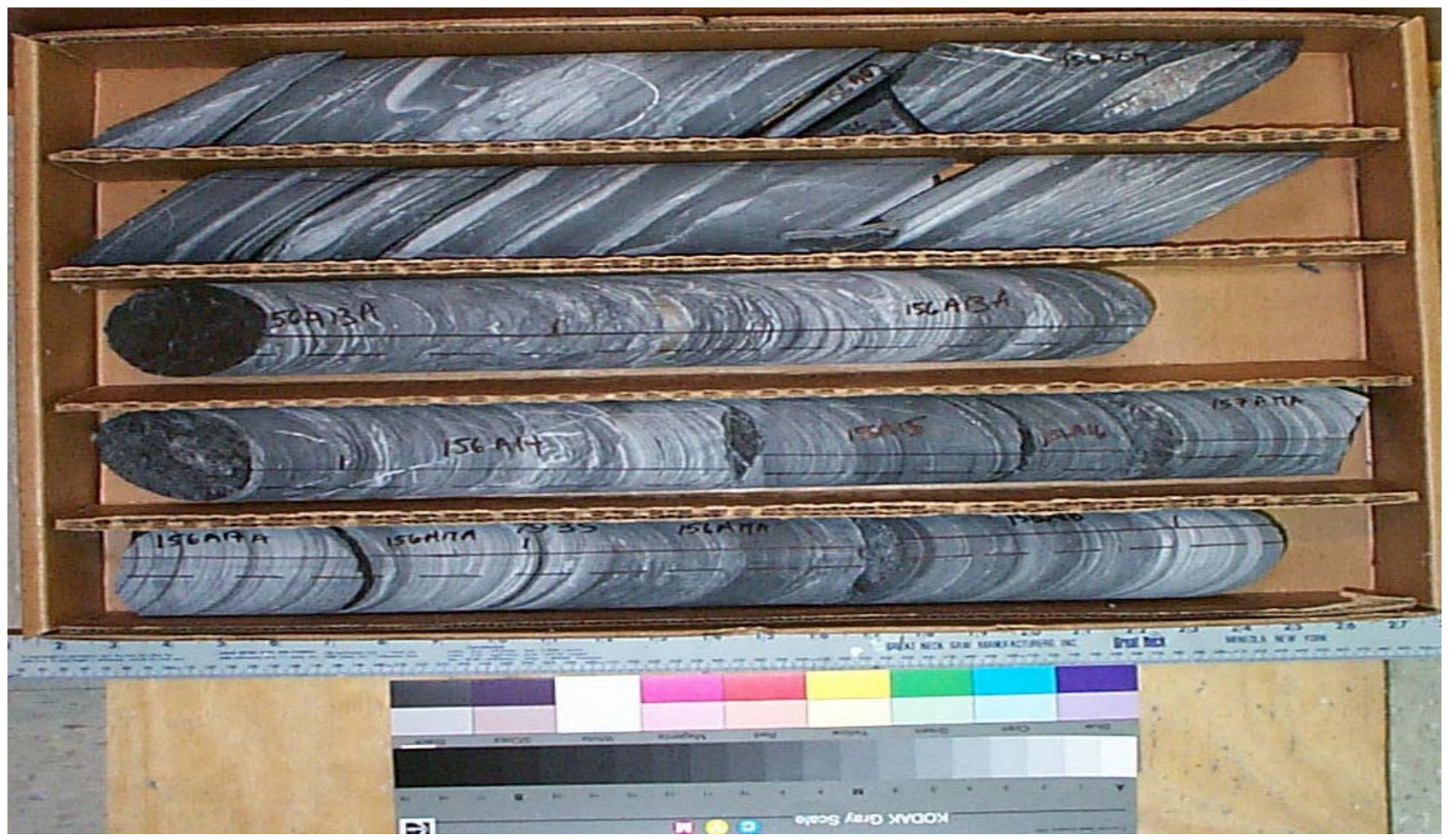

Core Scans included in this box (listed by piece going downhole):

156A0600
156A0900
156A1000
156A1200
156A130A
156A1400
156A1500
156A1800

See the "reading instructions" section of the introduction for help interpreting core box photos and core piece nomenclature 


\section{LVEW Core Box 237}

\section{Depth Interval 7936.2'-7944.0'}

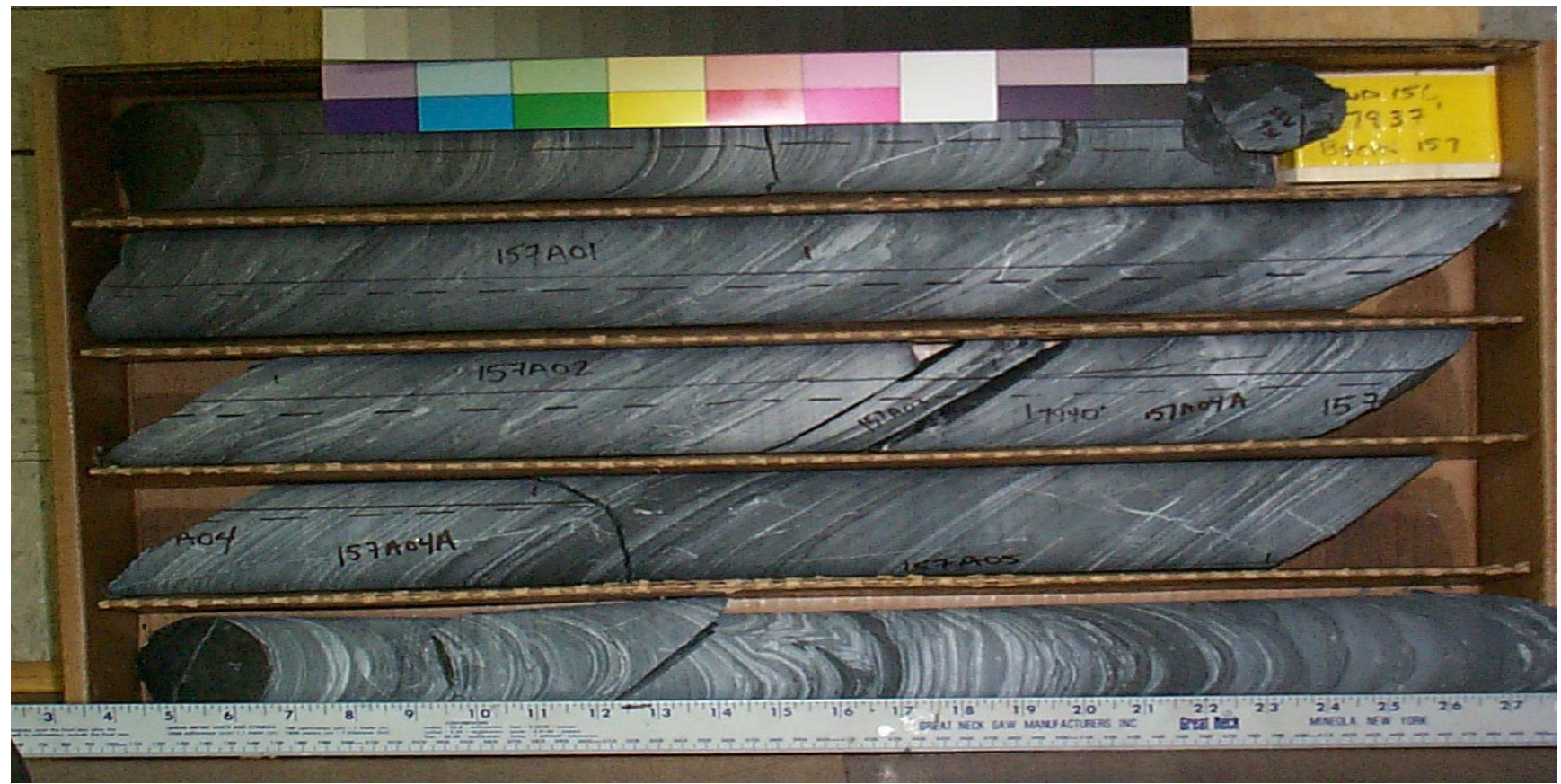

Core Scans included in this box (listed by piece going downhole):
156A1900
156A2000
$156 \mathrm{~A} 2100$
$157 \mathrm{~A} 0100$
$157 \mathrm{~A} 0200$
$157 \mathrm{~A} 0400$
$157 \mathrm{~A} 0500$
$157 \mathrm{~A} 0600$

See the "reading instructions" section of the introduction for help interpreting core box photos and core piece nomenclature 


\section{LVEW Core Box 238}

Depth Interval 7944.0'-7952.2'

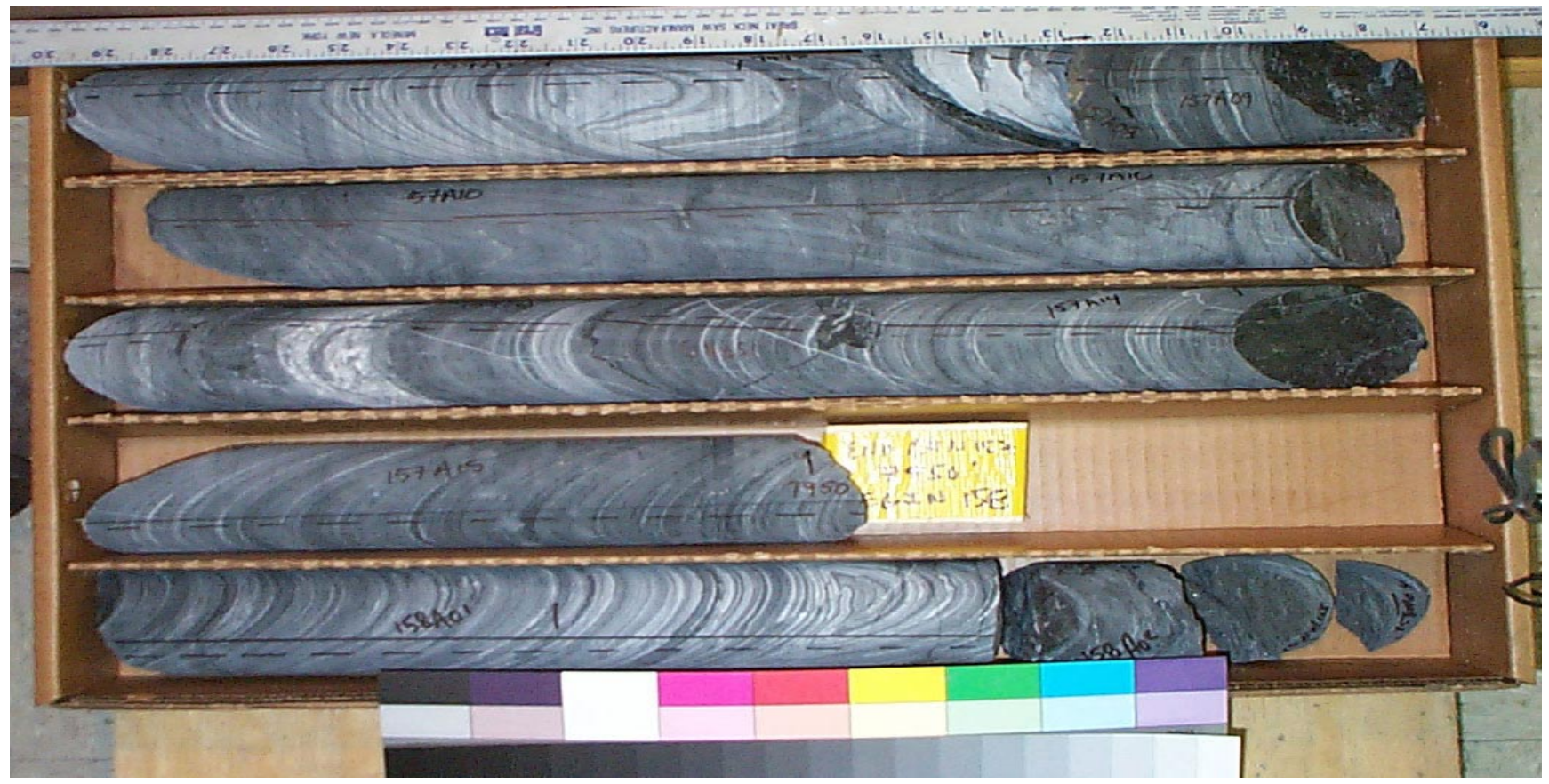

Core Scans included in this box (listed by piece going downhole):
$157 \mathrm{~A} 0700$
$157 \mathrm{~A} 1000$
$157 \mathrm{~A} 1200$
$157 \mathrm{~A} 1400$
157A1500
157A170A
$158 \mathrm{~A} 0100$
$158 \mathrm{~A} 0200$

See the "reading instructions" section of the introduction for help interpreting core box photos and core piece nomenclature 


\section{LVEW Core Box 239}

Depth Interval 7952.2'-7960.3'

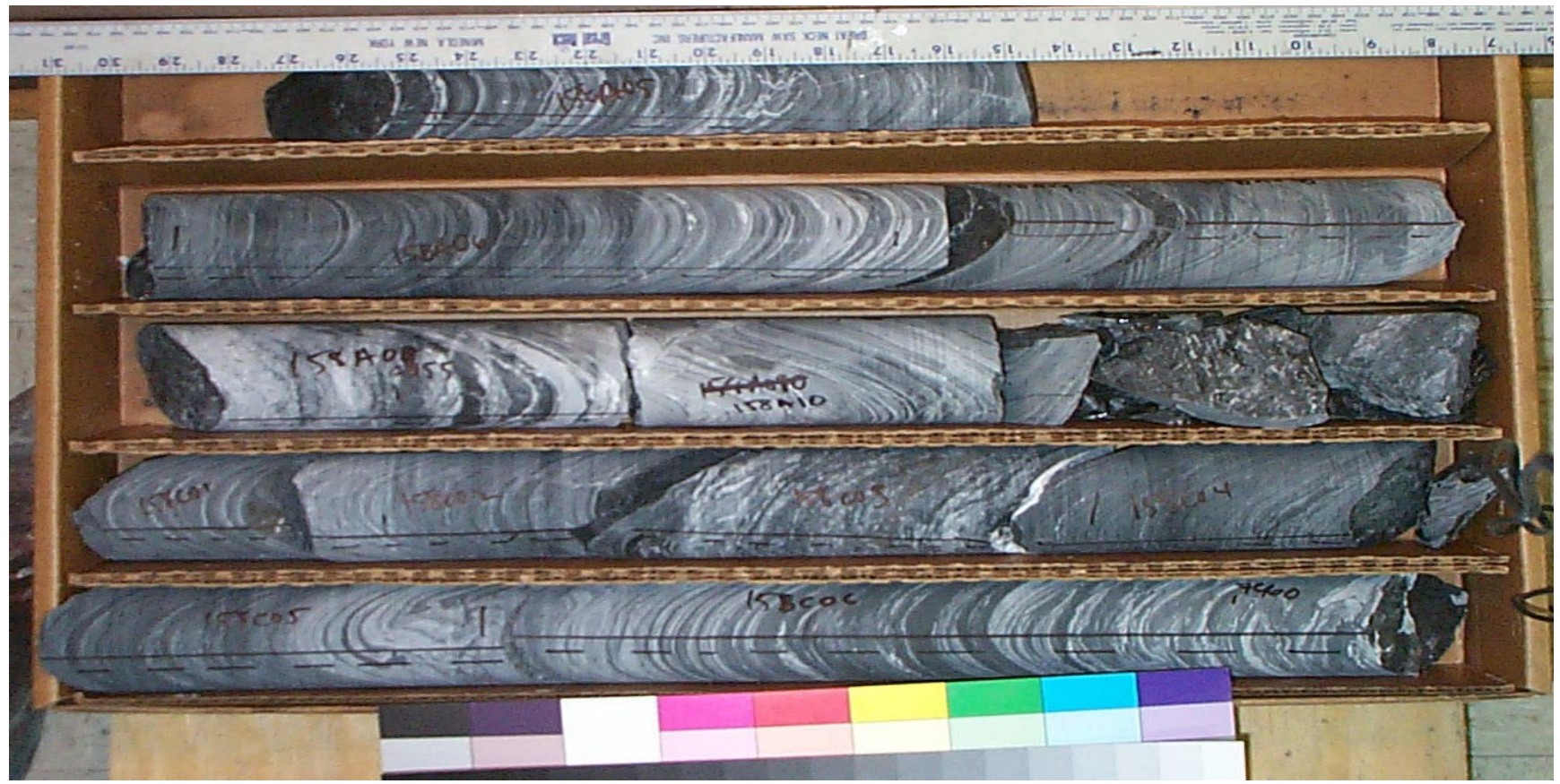

Core Scans included in this box (listed by piece going downhole):

158A0500
$158 A 0600$
$158 A 0800$
$158 A 0900$
$158 A 1000$
$158 C 0100$
$158 C 0200$
$158 C 0300$
$158 C 0400$
$158 C 0500$
$158 C 061 A$

See the "reading instructions" section of the introduction for help interpreting core box photos and core piece nomenclature 


\section{LVEW Core Box 240}

Depth Interval 7960.3'-7967.3'

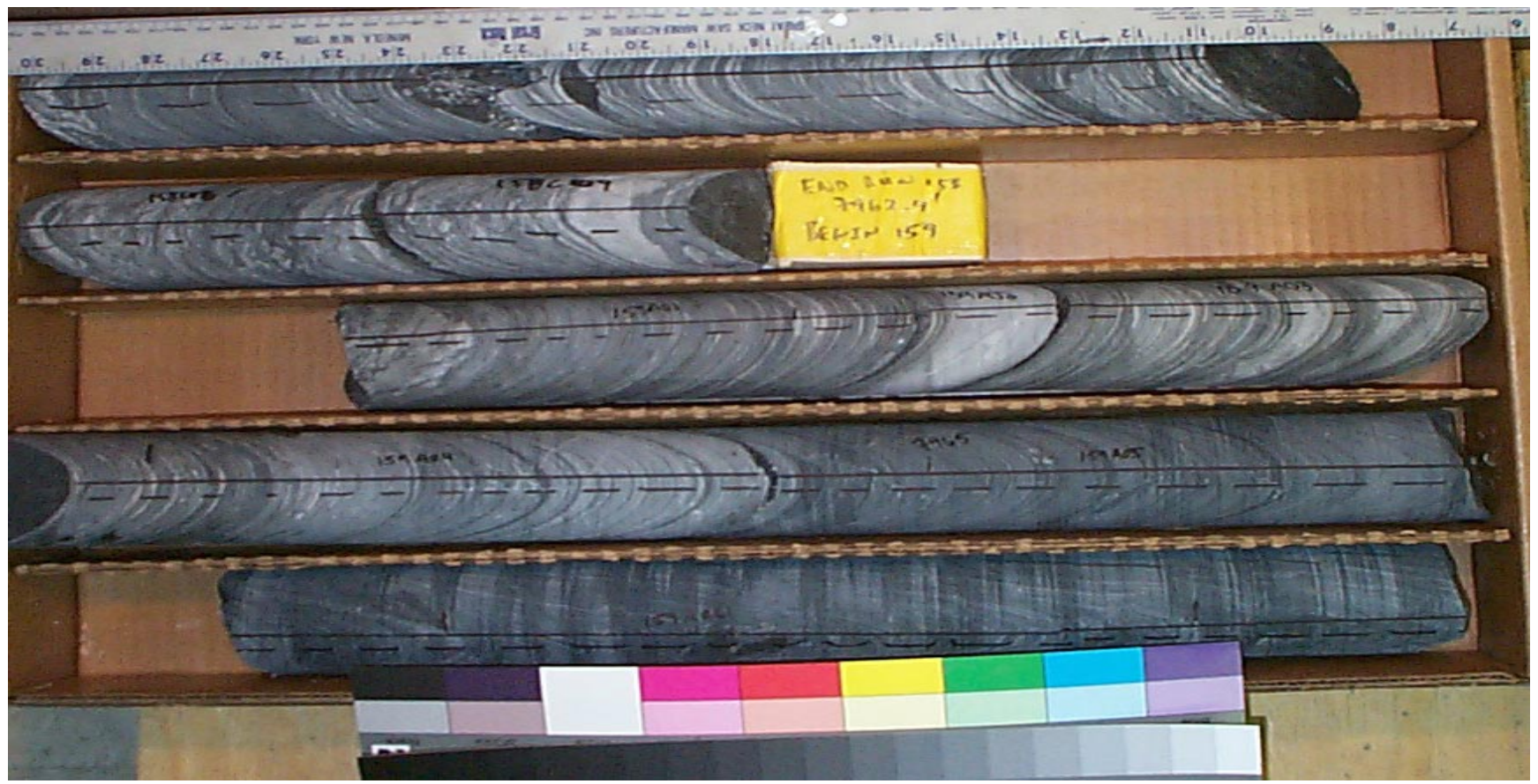

Core Scans included in this box (listed by piece going downhole):
$158 \mathrm{C} 062 \mathrm{~A}$
$158 \mathrm{C} 0700$
$158 \mathrm{C} 0800$
$159 \mathrm{~A} 0100$
$159 \mathrm{~A} 0300$
159A0400
159A0500
159A0600

See the "reading instructions" section of the introduction for help interpreting core box photos and core piece nomenclature 


\section{LVEW Core Box 241}

\section{Depth Interval 7967.3'-7973.4'}

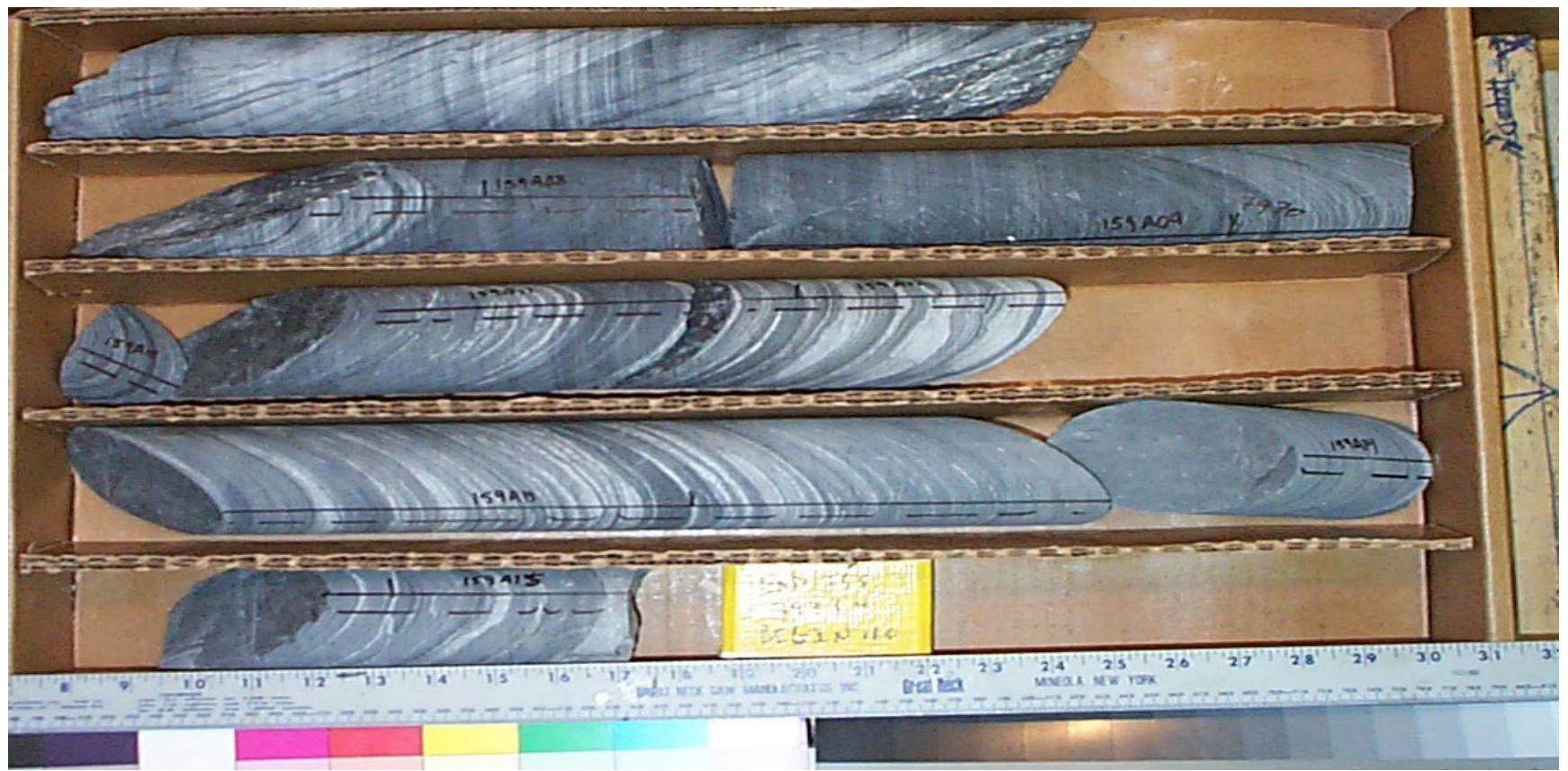

Core Scans included in this box (listed by piece going downhole):
159A0700
159A0800
159A0900
159A1100
159A1200
159A1300
159A 1400
159A 1500

See the "reading instructions" section of the introduction for help interpreting core box photos and core piece nomenclature 


\section{LVEW Core Box 242}

Depth Interval 7973.4'-7981.9'

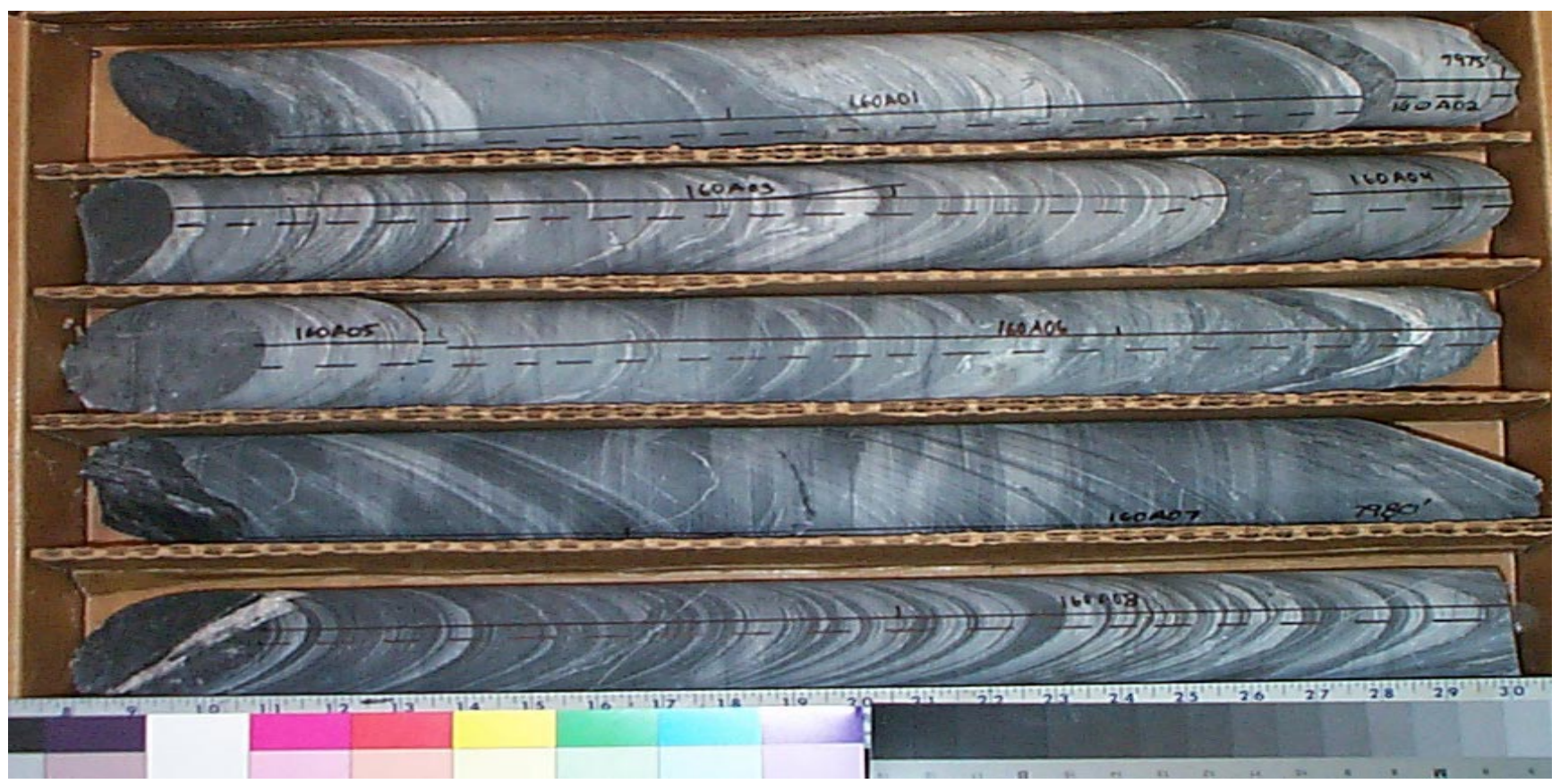

Core Scans included in this box (listed by piece going downhole):

160A0100
160A0300
160A0400
160A061A
160A062A
160A0700
160A0800

See the "reading instructions" section of the introduction for help interpreting core box photos and core piece nomenclature 


\section{LVEW Core Box 243}

Depth Interval 7981.9'-7989.5'

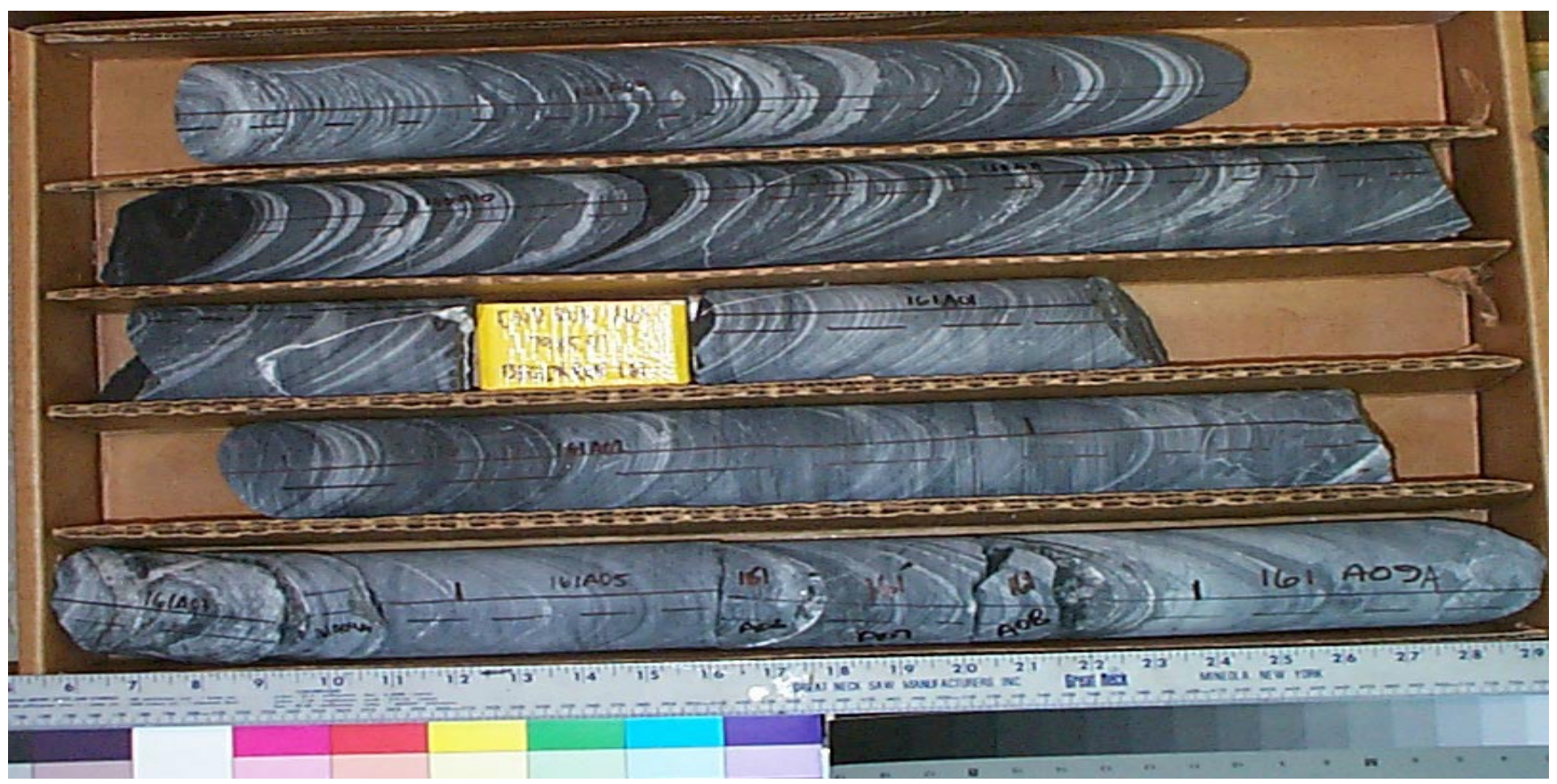

Core Scans included in this box (listed by piece going downhole):

160A0900
160A1000
160A1100
160A1200
161A0100
161A0200
161A0500
161A0700
161A091A

See the "reading instructions" section of the introduction for help interpreting core box photos and core piece nomenclature 


\section{LVEW Core Box 244}

Depth Interval 7989.5'-7996.2'

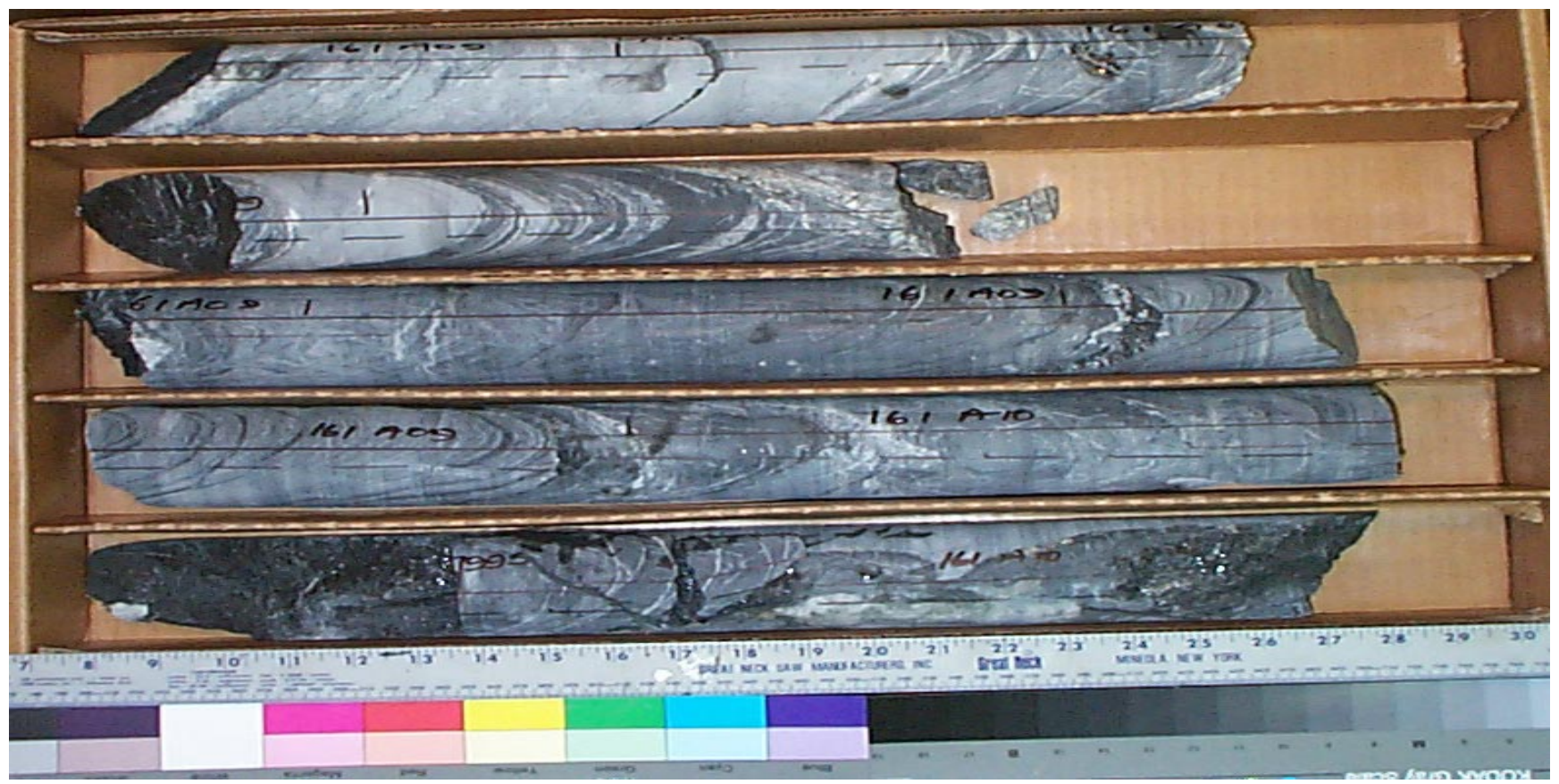

Core Scans included in this box (listed by piece going downhole):

161A091A
161A092A
161A1000

See the "reading instructions" section of the introduction for help interpreting core box photos and core piece nomenclature 


\section{LVEW Core Box 245}

Depth Interval 7996.2'-8004.1'

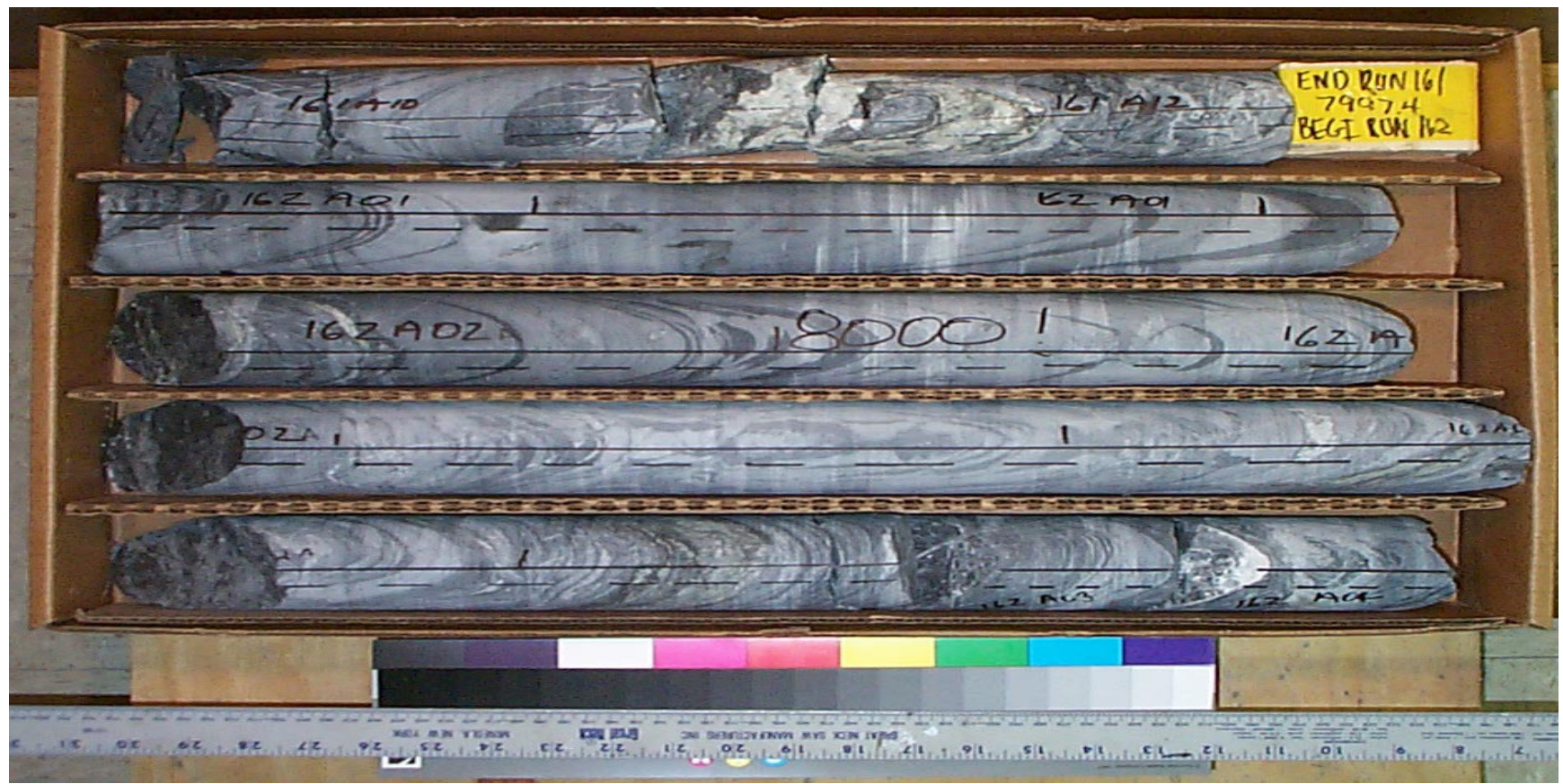

Core Scans included in this box (listed by piece going downhole):
$161 \mathrm{~A} 1200$
$162 \mathrm{~A} 011 \mathrm{~A}$
$162 \mathrm{~A} 012 \mathrm{~A}$
$162 \mathrm{~A} 020 \mathrm{~A}$
$162 \mathrm{~A} 0300$
$162 \mathrm{~A} 0400$

See the "reading instructions" section of the introduction for help interpreting core box photos and core piece nomenclature 


\section{LVEW Core Box 246}

Depth Interval 8004.1'-8011.0'

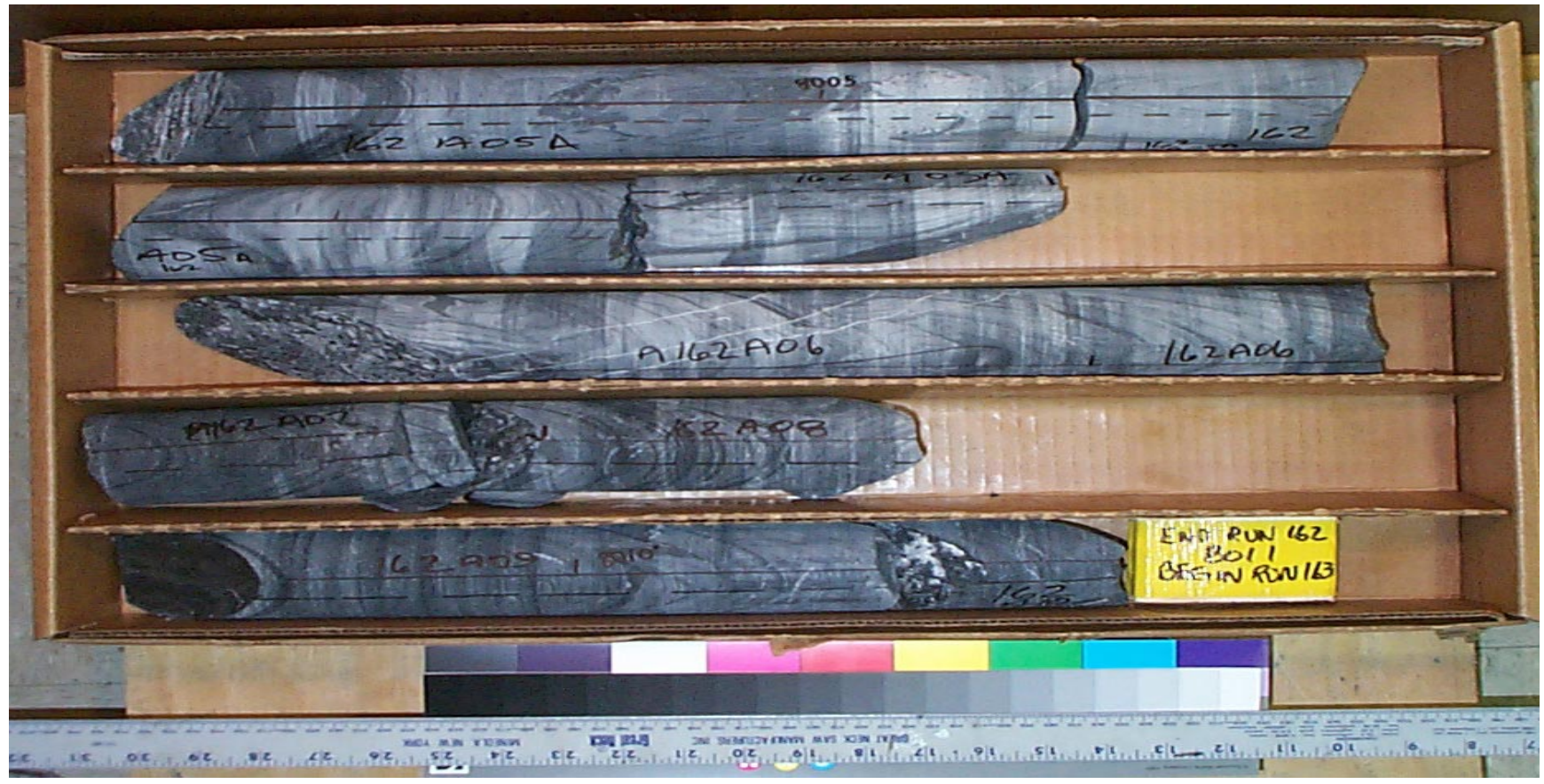

Core Scans included in this box (listed by piece going downhole):
$162 \mathrm{~A} 050 \mathrm{~A}$
$162 \mathrm{~A} 0600$
$162 \mathrm{~A} 0700$
$162 \mathrm{~A} 0800$
$162 \mathrm{~A} 0900$

See the "reading instructions" section of the introduction for help interpreting core box photos and core piece nomenclature 


\section{LVEW Core Box 247}

Depth Interval 8011.0'-8019.2'

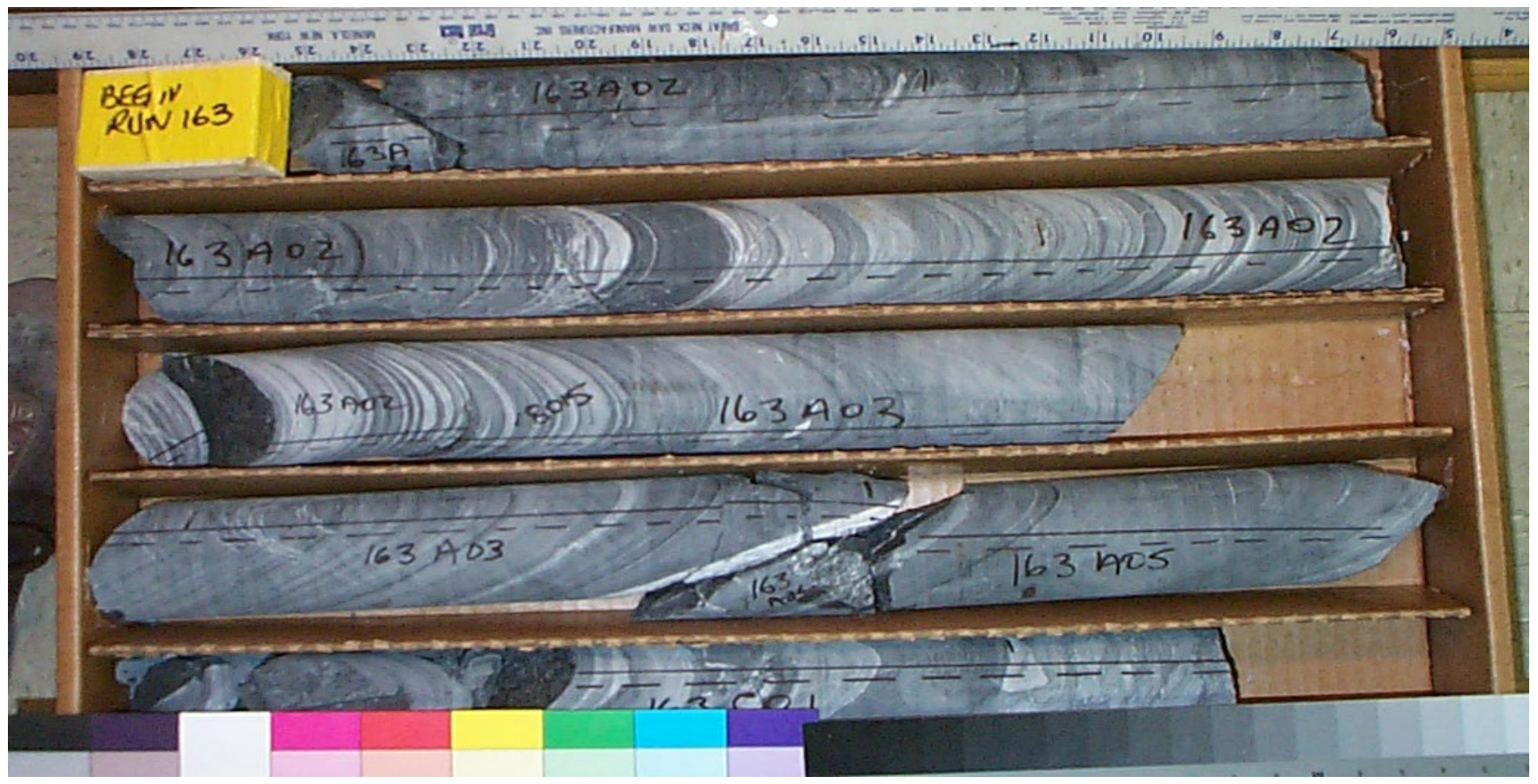

Core Scans included in this box

(listed by piece going downhole):

163A021A
163A022A
163A0500
$163 C 0100$

See the "reading instructions" section of the introduction for help interpreting core box photos and core piece nomenclature 


\section{LVEW Core Box 248}

Depth Interval 8019.2'-8027.5'

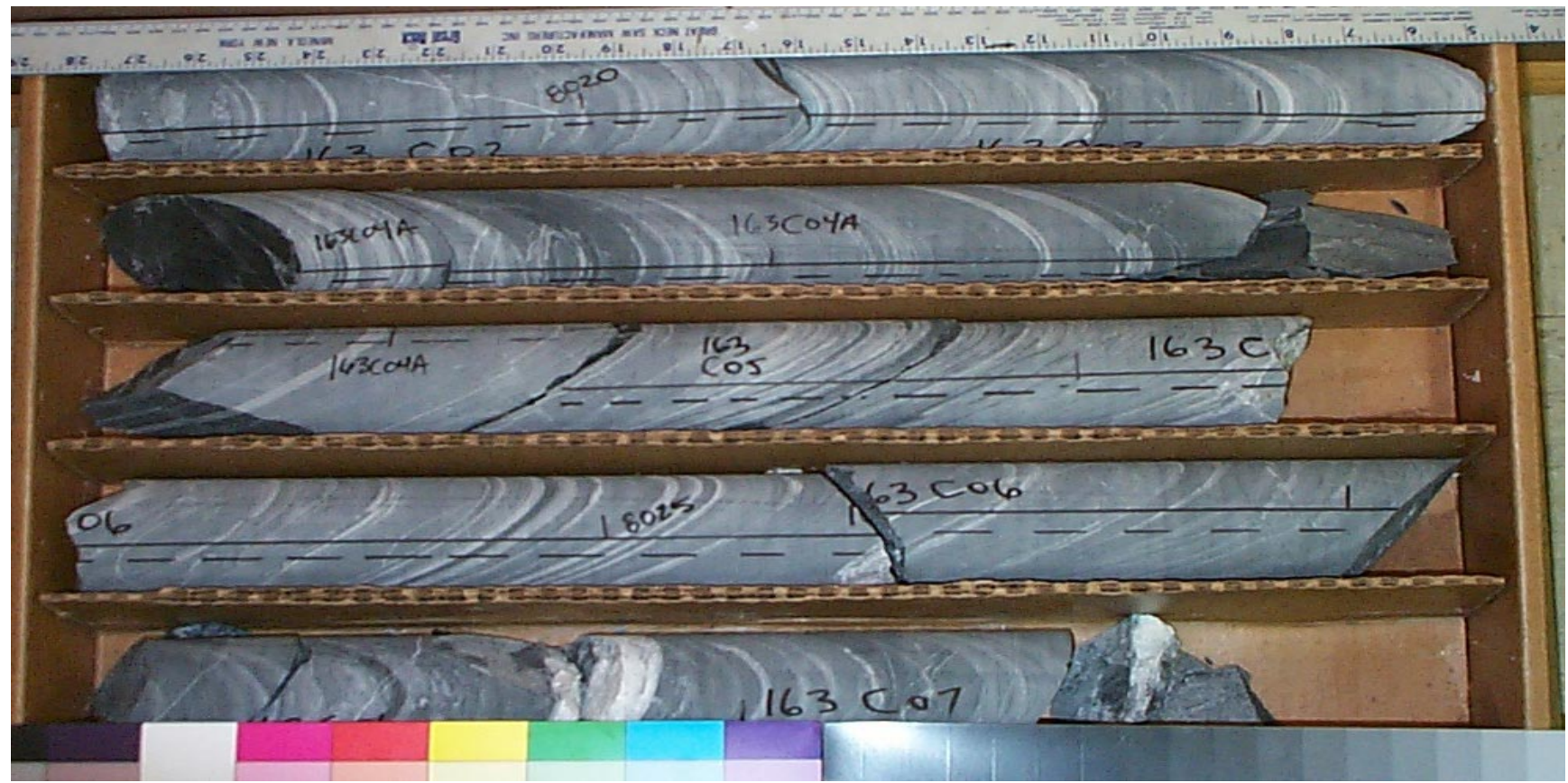

Core Scans included in this box (listed by piece going downhole):

$163 C 0200$
$163 C 0300$
$163 C 041 A$
$163 C 042 A$
$163 C 0500$
$163 C 061 A$
$163 C 062 A$
$163 C 0700$

See the "reading instructions" section of the introduction for help interpreting core box photos and core piece nomenclature 


\section{LVEW Core Box 249}

Depth Interval 8027.5'-8035.5'

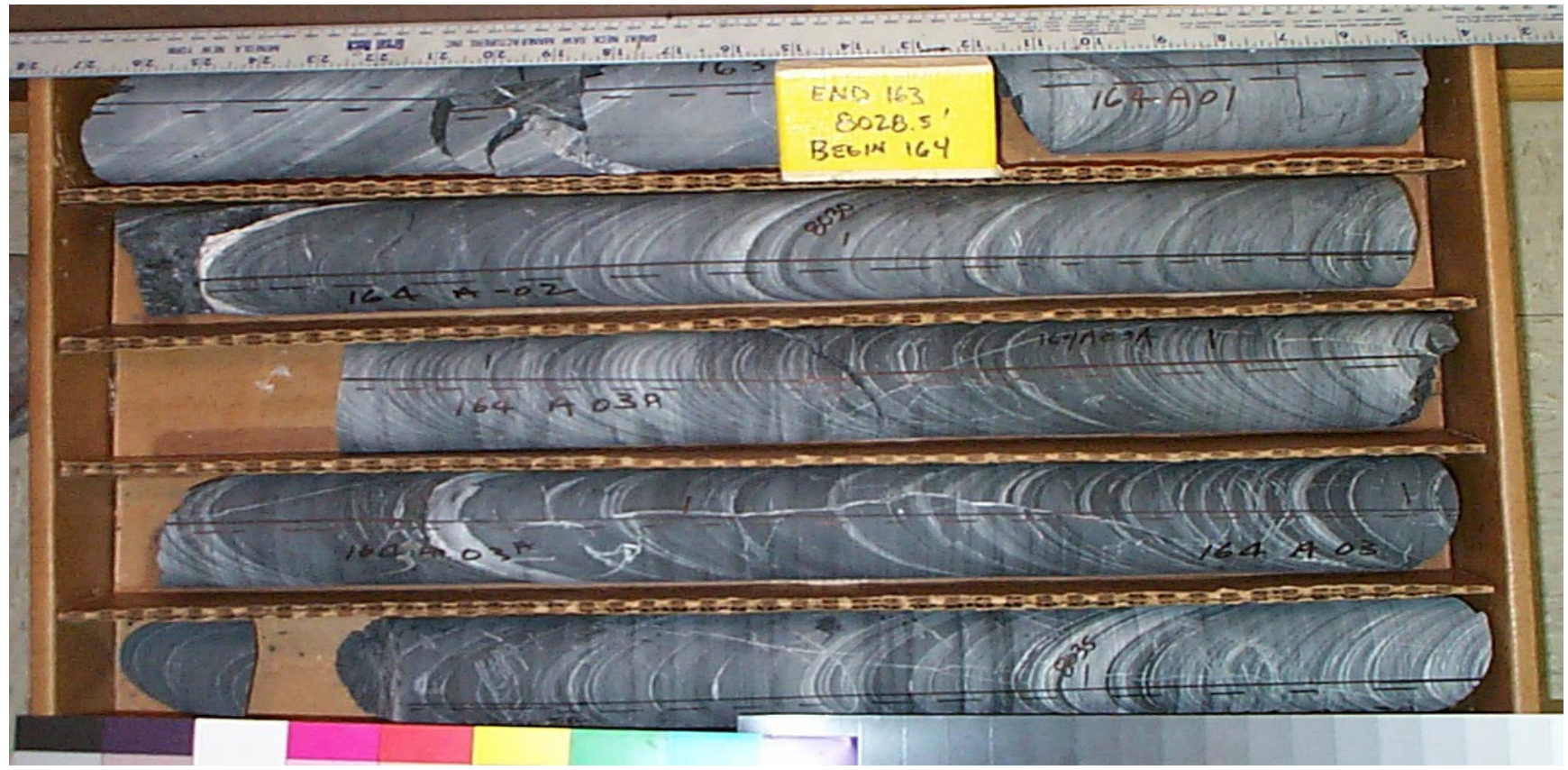

Core Scans included in this box (listed by piece going downhole):

$163 \mathrm{C} 0800$

$164 \mathrm{~A} 0100$

$164 \mathrm{~A} 0200$

$164 \mathrm{~A} 031 \mathrm{~A}$

$164 \mathrm{~A} 032 \mathrm{~A}$

See the "reading instructions" section of the introduction for help interpreting core box photos and core piece nomenclature 


\section{LVEW Core Box 250}

Depth Interval 8035.5'-8042.5'

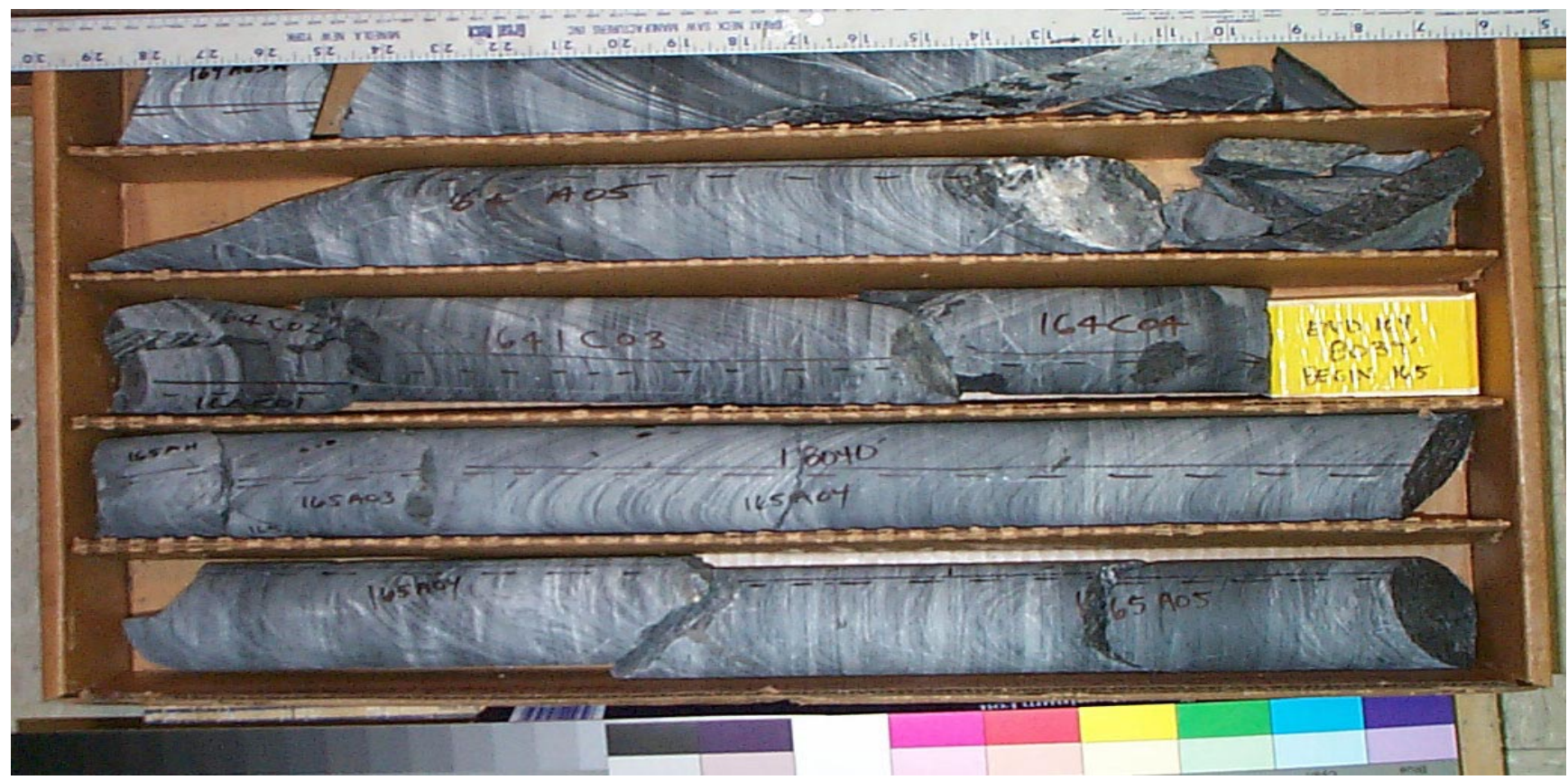

Core Scans included in this box (listed by piece going downhole):
$164 \mathrm{~A} 032 \mathrm{~A}$
$164 \mathrm{~A} 0400$
$164 \mathrm{~A} 0500$
$164 \mathrm{C} 0300$
$164 \mathrm{C} 0400$
$165 \mathrm{~A} 0100$
$165 \mathrm{~A} 041 \mathrm{~A}$
$165 \mathrm{~A} 042 \mathrm{~A}$
$165 \mathrm{~A} 0500$

See the "reading instructions" section of the introduction for help interpreting core box photos and core piece nomenclature 


\section{LVEW Core Box 251}

Depth Interval 8042.5'-8052.1'

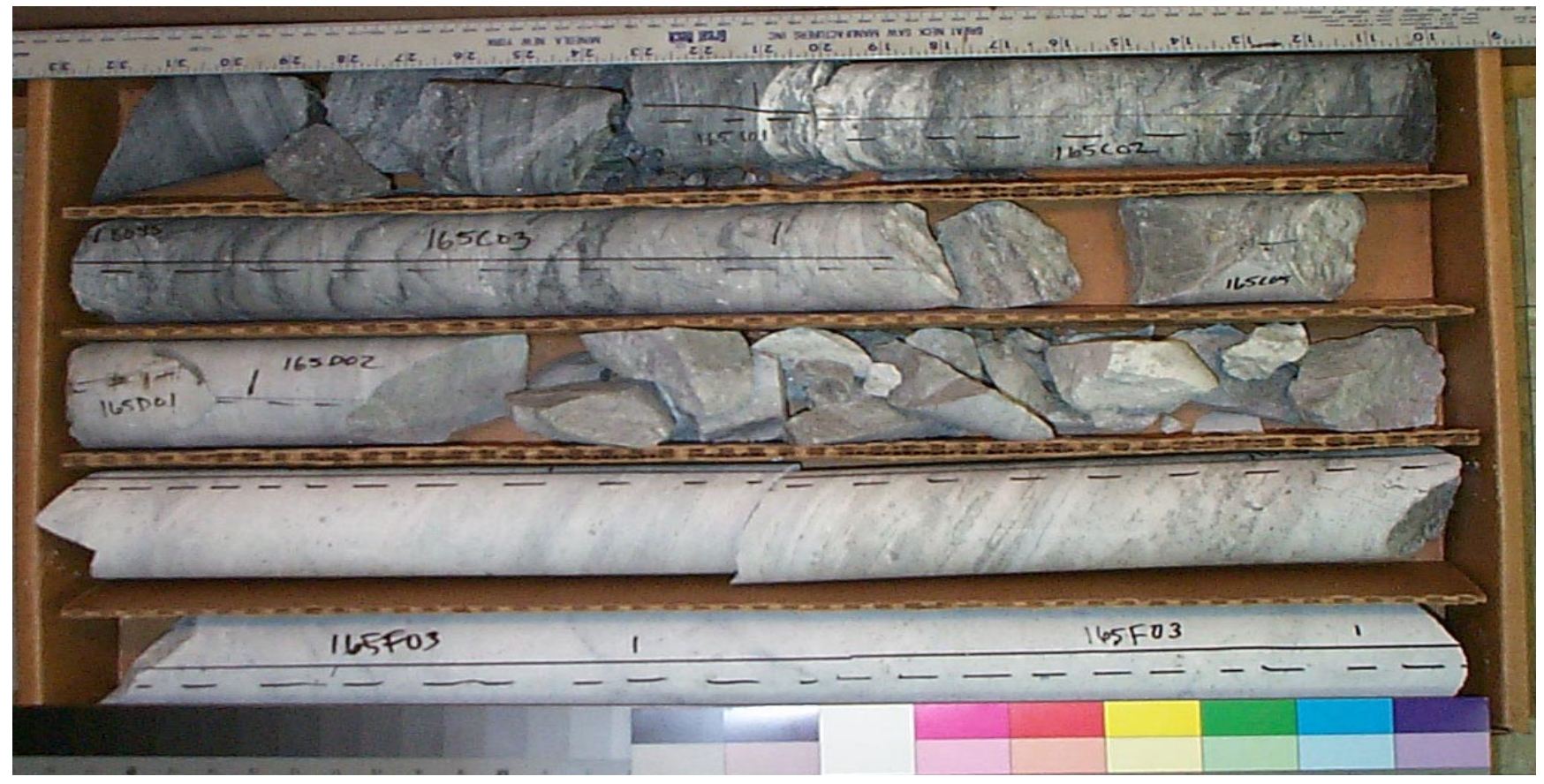

Core Scans included in this box (listed by piece going downhole):
$165 \mathrm{C} 0100$
$165 \mathrm{C} 0200$
$165 \mathrm{C} 0300$
165D0200
$165 \mathrm{~F} 0100$
$165 \mathrm{~F} 0200$
165F0300

See the "reading instructions" section of the introduction for help interpreting core box photos and core piece nomenclature 


\section{LVEW Core Box 252}

\section{Depth Interval 8052.1'-8058.5'}

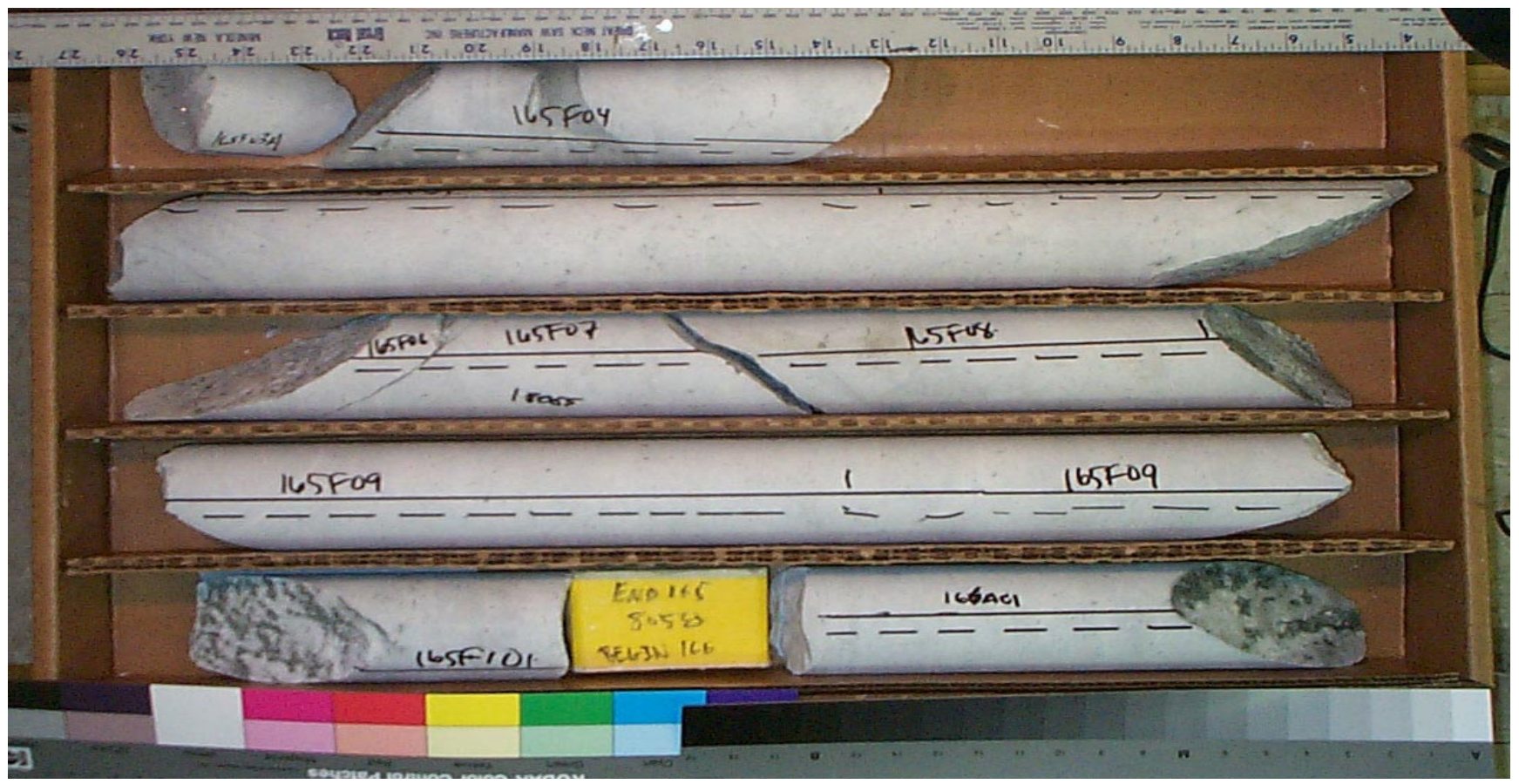

Core Scans included in this box (listed by piece going downhole):
$165 \mathrm{~F} 0400$
$165 \mathrm{~F} 0500$
$165 \mathrm{~F} 0700$
$165 \mathrm{~F} 0800$
$165 \mathrm{~F} 0900$
$165 \mathrm{~F} 1000$
$166 \mathrm{~A} 0100$

See the "reading instructions" section of the introduction for help interpreting core box photos and core piece nomenclature 


\section{Stratigraphic Column for LVEW Phase III, page 3}
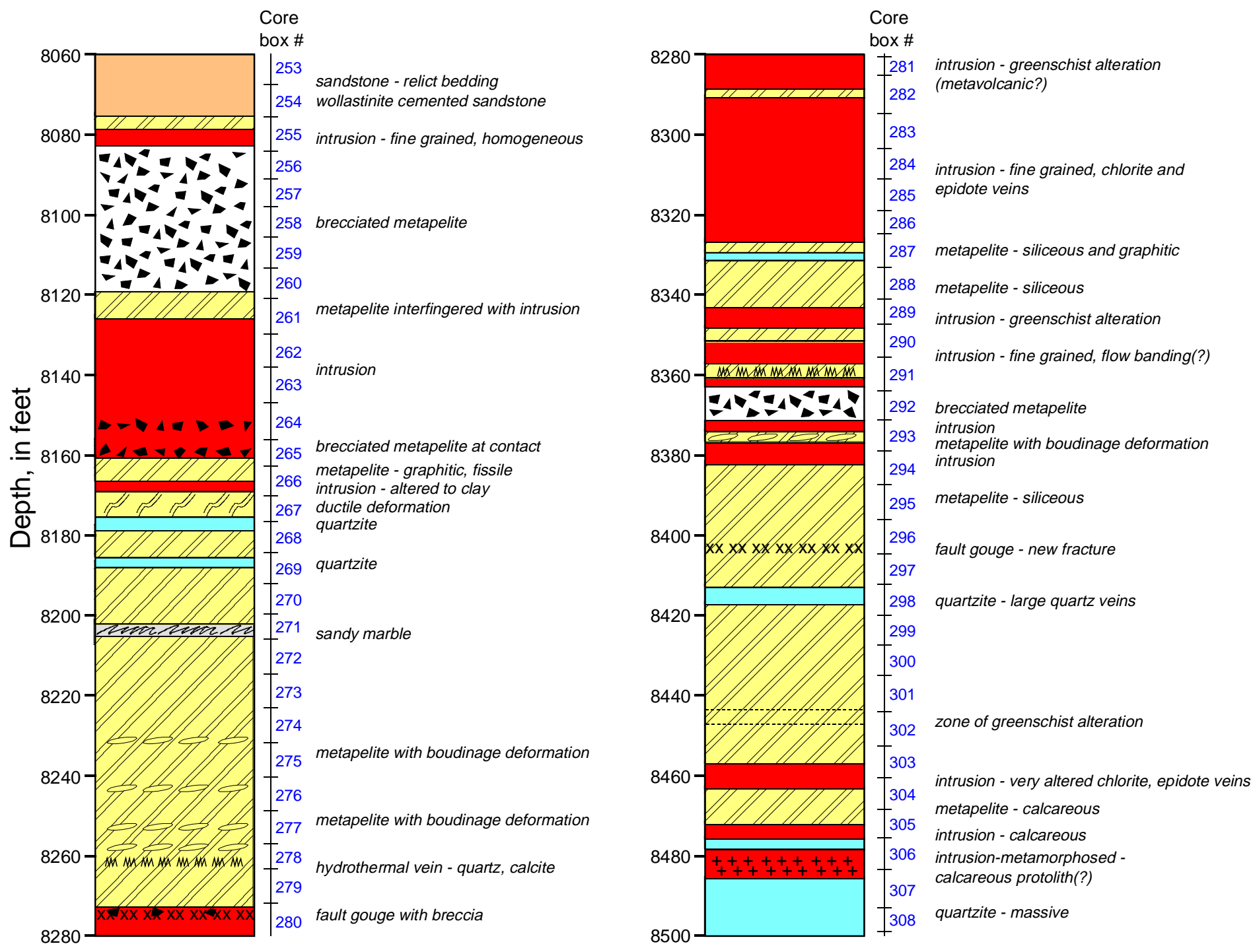

\section{Explanation}

Metapelite with banding

Hornfels

Metapelite with ductile deformation

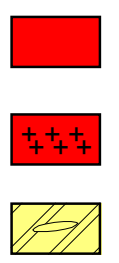

Intrusion

14. Metapelite no banding

Quartzite

Calc-silicate
Intrusionmetamorphosed

Sandstone deformation
M M M Hydrothermal veins/fractures

$x x x x$ Fault gouge

口 2nd generation garnets 


\section{LVEW Core Box 253}

Depth Interval 8058.5'-8067.4'

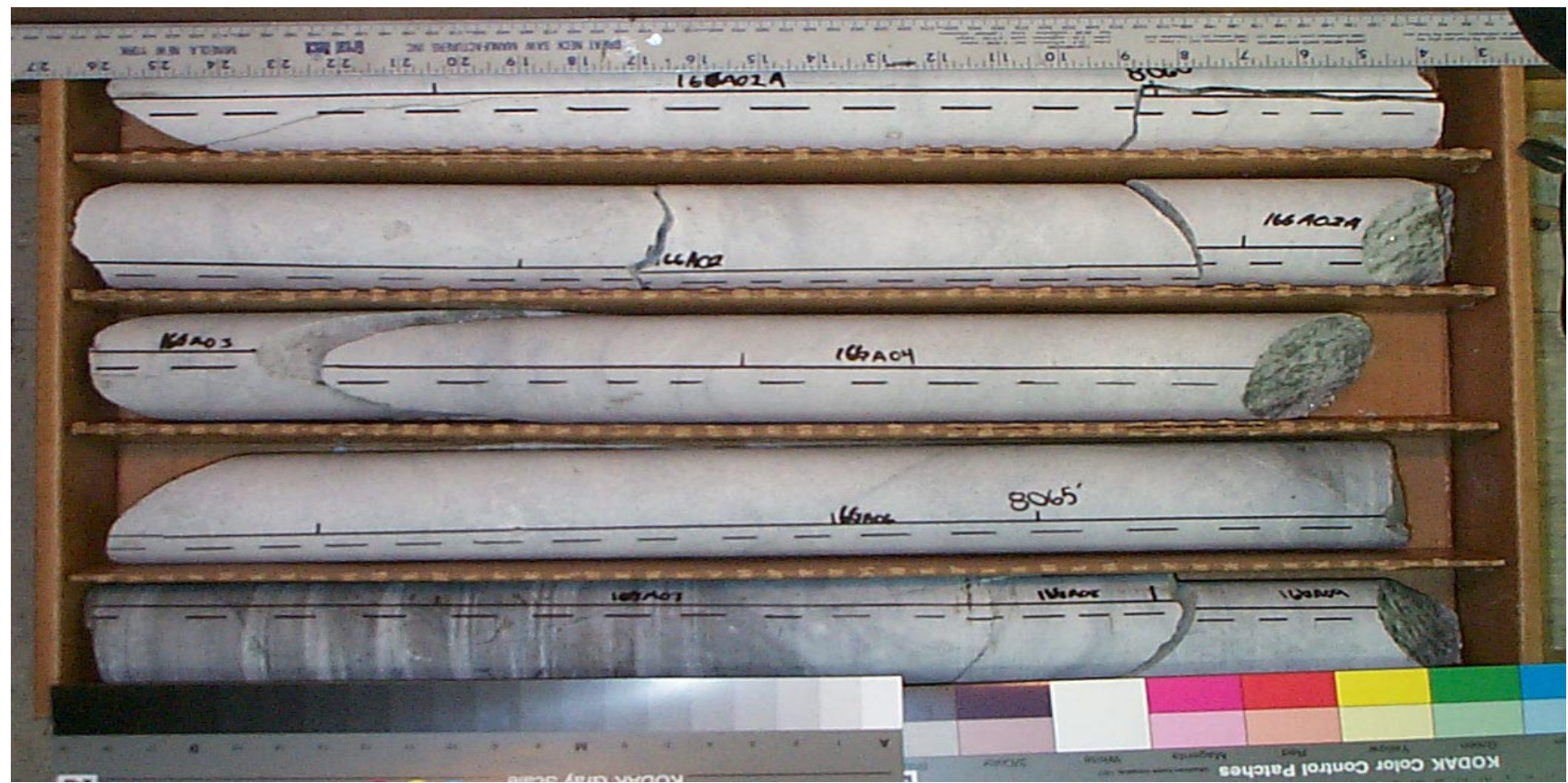

Core Scans included in this box (listed by piece going downhole):

166A021A
166A022A
166A0600
166A0700
166A0900

See the "reading instructions" section of the introduction for help interpreting core box photos and core piece nomenclature 


\section{LVEW Core Box 254}

Depth Interval 8067.4'-8075.6'

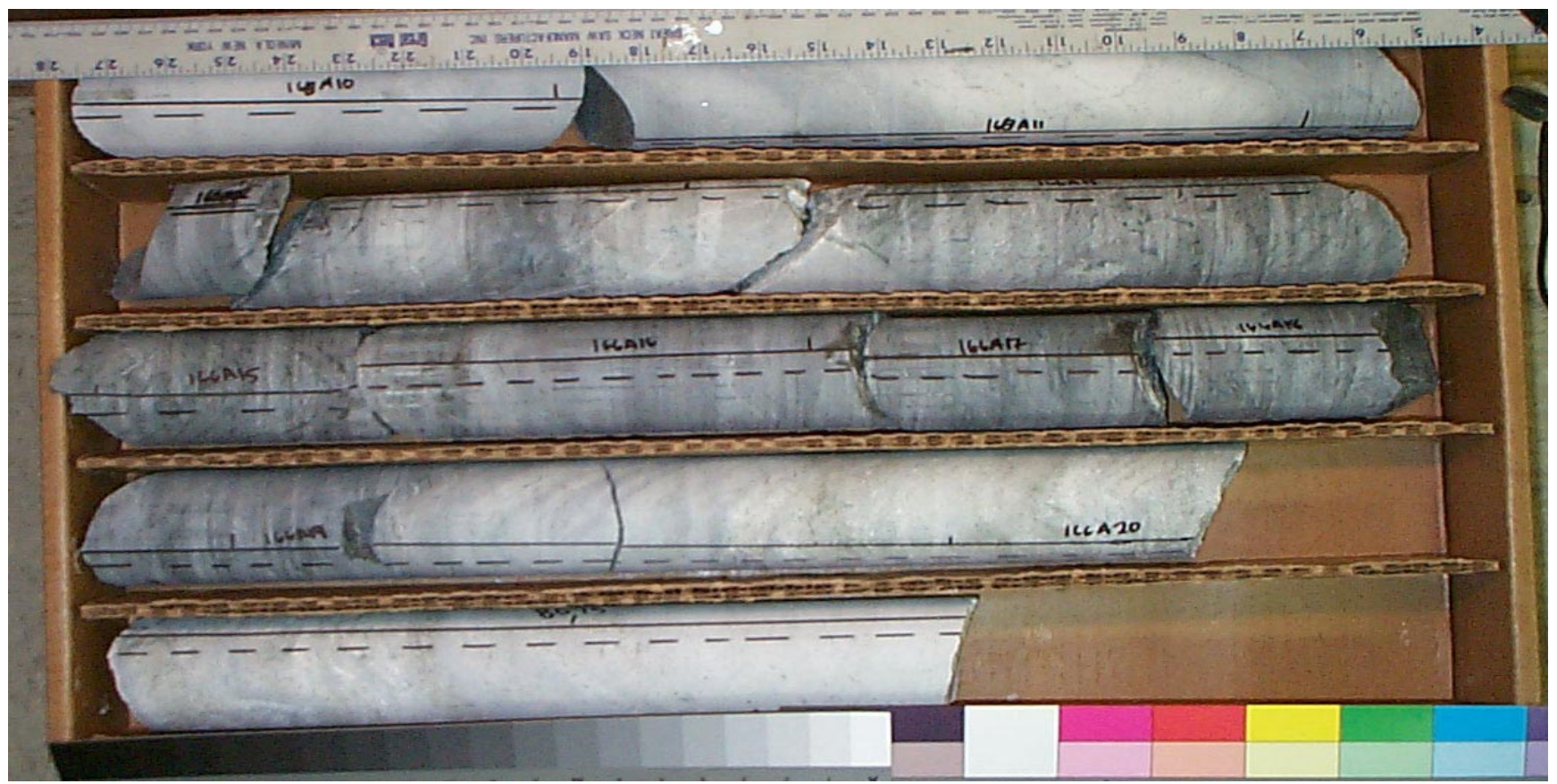

Core Scans included in this box (listed by piece going downhole):

$$
\begin{aligned}
& \text { 166A1000 } \\
& \text { 166A1100 } \\
& \text { 166A1300 } \\
& \text { 166A1400 } \\
& \text { 166A1500 } \\
& \text { 166A1600 } \\
& \text { 166A1700 } \\
& \text { 166A1800 } \\
& \text { 166A1900 } \\
& \text { 166A200A }
\end{aligned}
$$

See the "reading instructions" section of the introduction for help interpreting core box photos and core piece nomenclature 


\section{LVEW Core Box 255}

Depth Interval 8075.6'-8084.0'

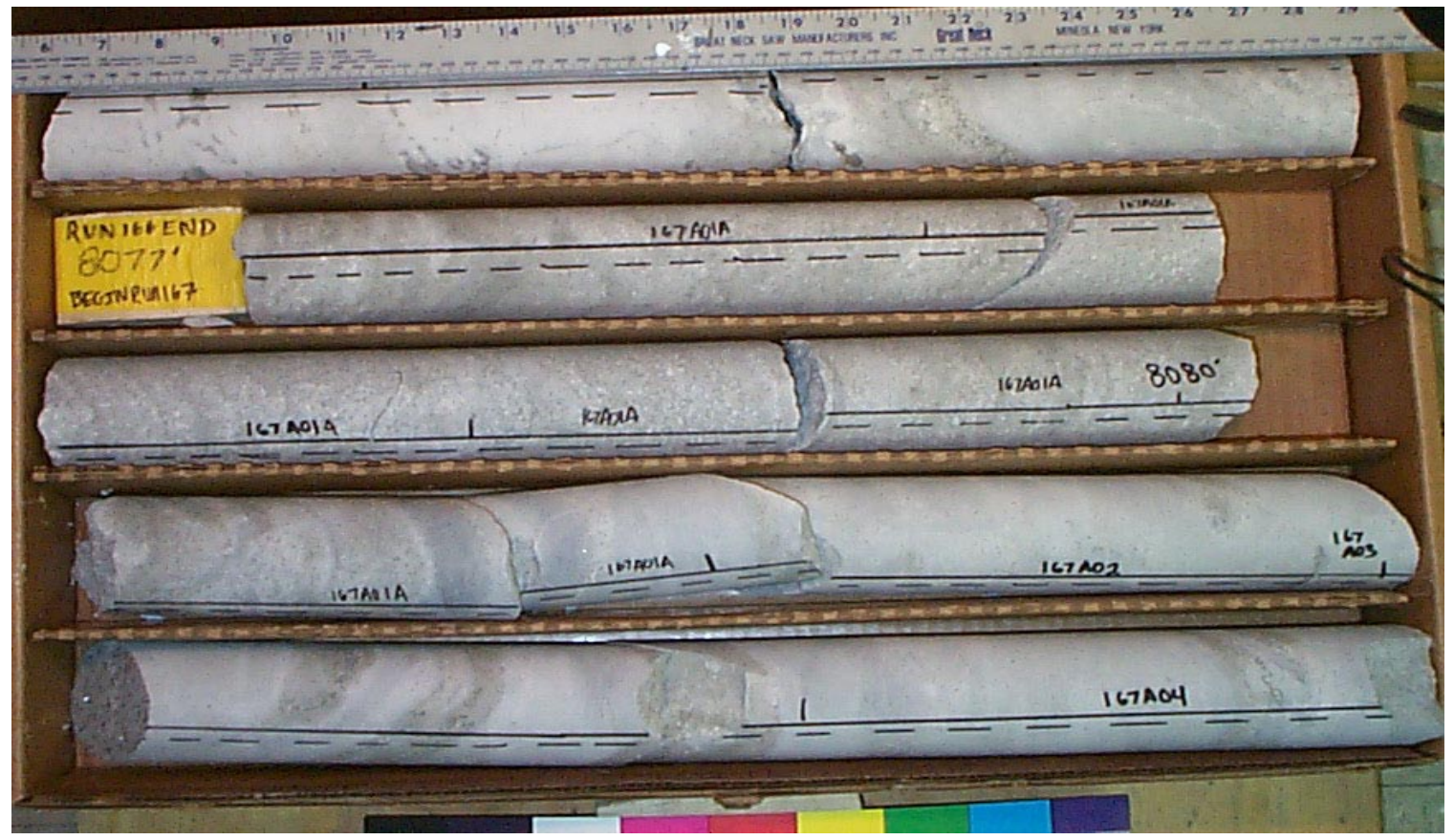

Core Scans included in this box (listed by piece going downhole):

166A200A
166A2100
167A011A
167A012A
167A0200
167A0300
167A041A

See the "reading instructions" section of the introduction for help interpreting core box photos and core piece nomenclature 


\section{LVEW Core Box 256}

Depth Interval 8084.0'-8091.0'

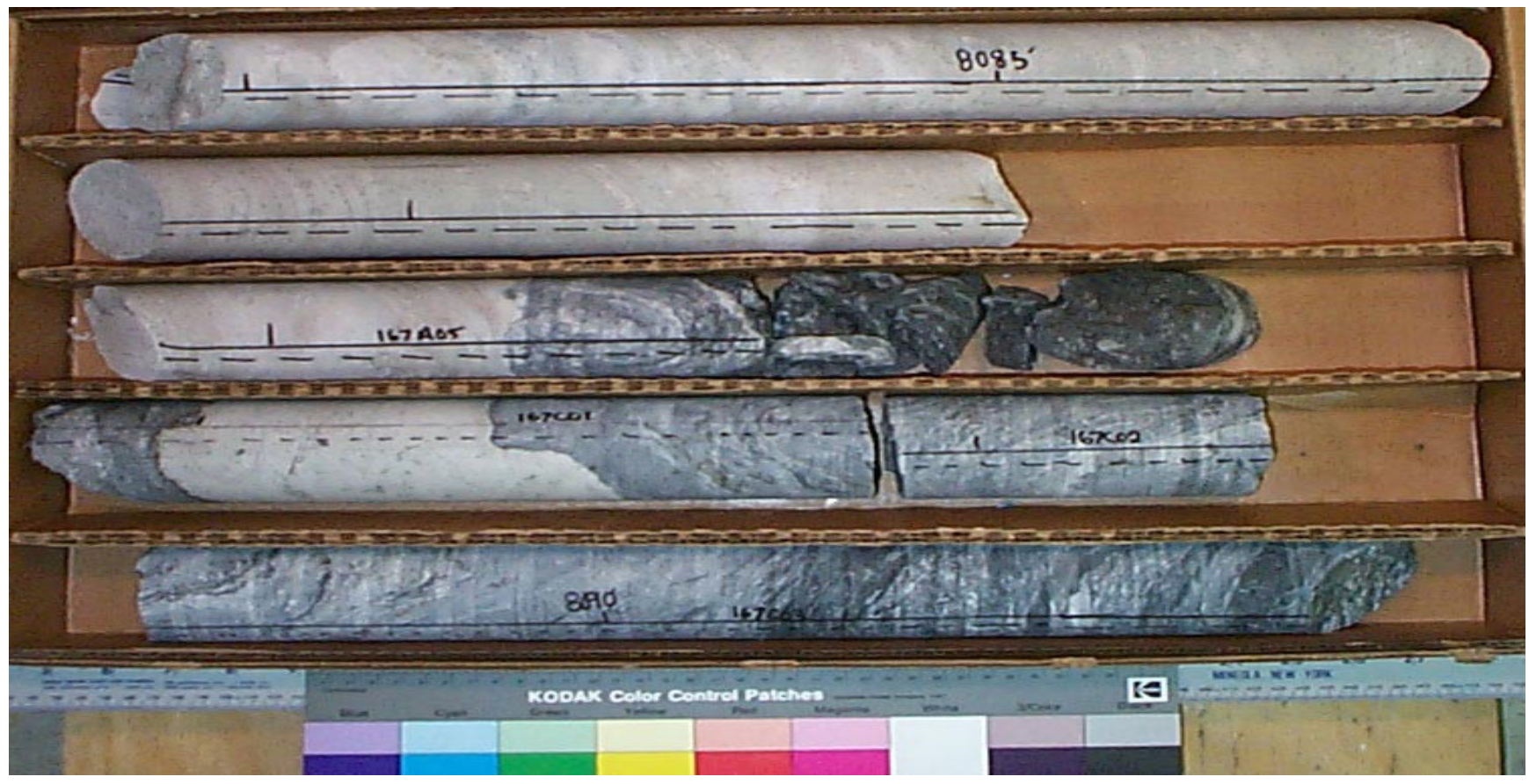

Core Scans included in this box

(listed by piece going downhole):
$167 \mathrm{~A} 042 \mathrm{~A}$
$167 \mathrm{~A} 0500$
$167 \mathrm{C} 0100$
$167 \mathrm{C} 0200$
$167 \mathrm{C} 0300$

See the "reading instructions" section of the introduction for help interpreting core box photos and core piece nomenclature 


\section{LVEW Core Box 257}

Depth Interval 8091.0'-8098.0'

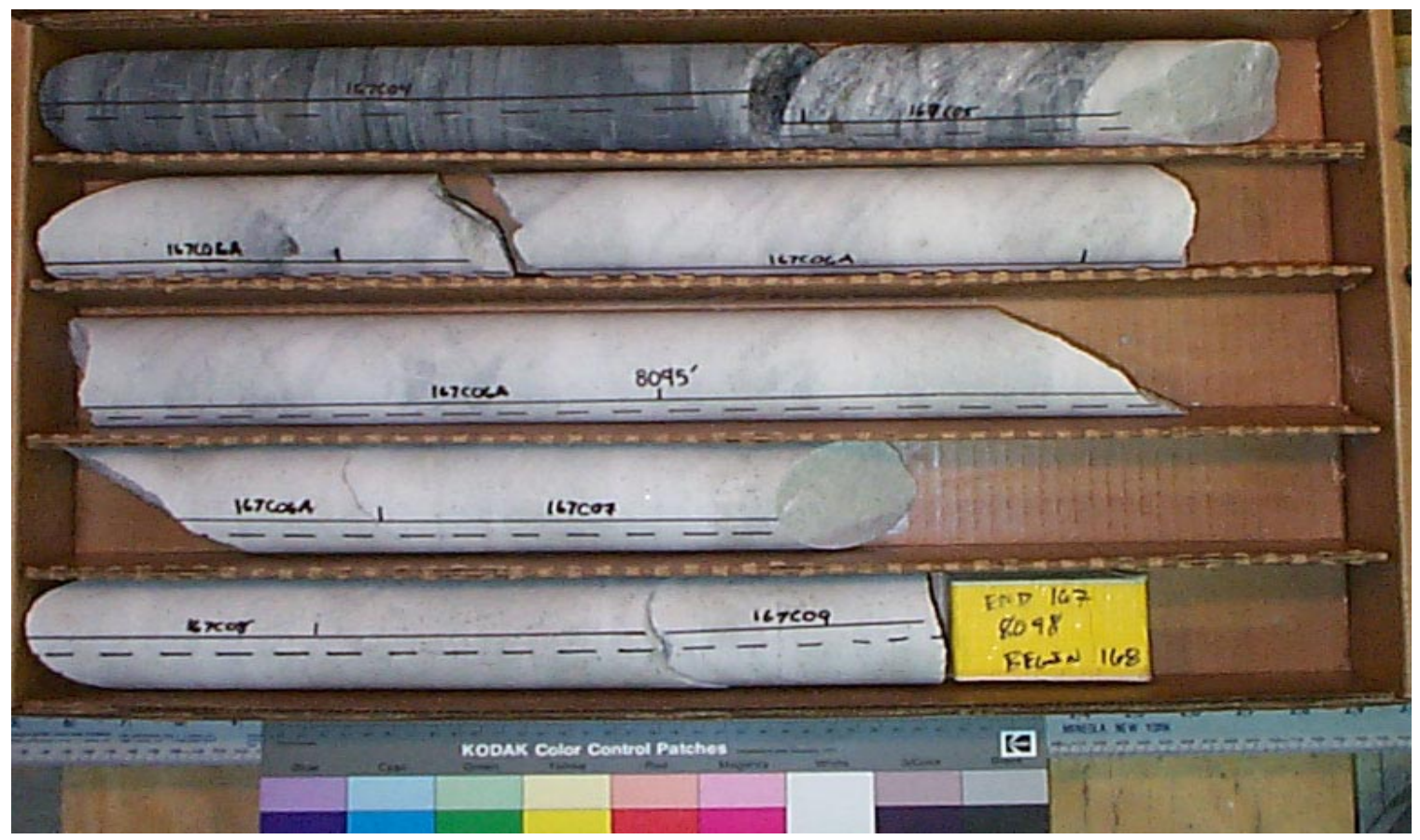

Core Scans included in this box (listed by piece going downhole):

167C0400
$167 \mathrm{C} 0500$
$167 \mathrm{C} 0600$
$167 \mathrm{C} 071 \mathrm{~A}$
$167 \mathrm{C} 072 \mathrm{~A}$
$167 \mathrm{C} 0800$
$167 \mathrm{C} 0900$

See the "reading instructions" section of the introduction for help interpreting core box photos and core piece nomenclature 


\section{LVEW Core Box 258}

Depth Interval 8098.0'-8105.6'

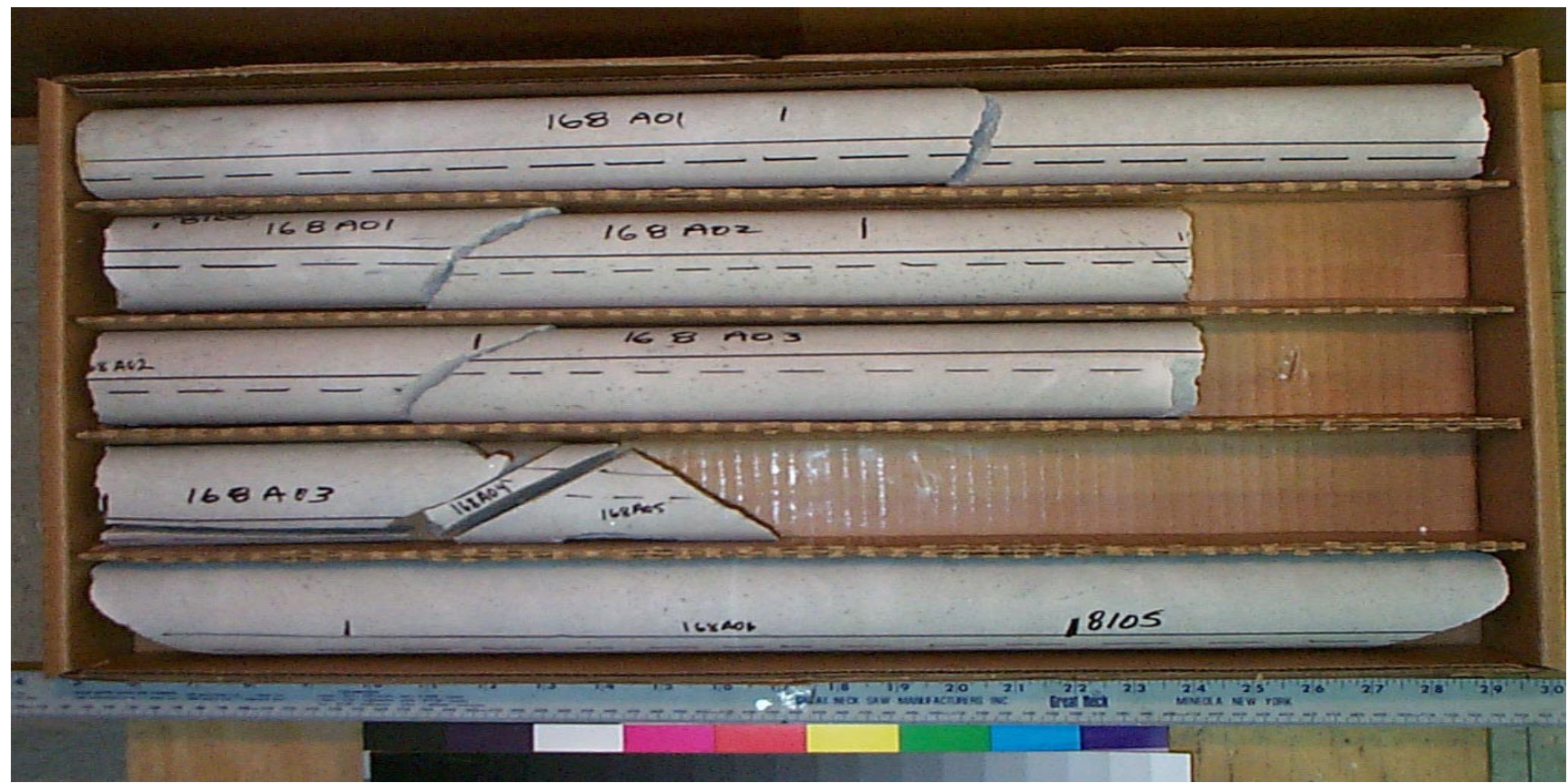

Core Scans included in this box (listed by piece going downhole):

168A010A
168A020A
168A030A
168A0600

See the "reading instructions" section of the introduction for help interpreting core box photos and core piece nomenclature 


\section{LVEW Core Box 259}

Depth Interval 8105.6'-8113.3'

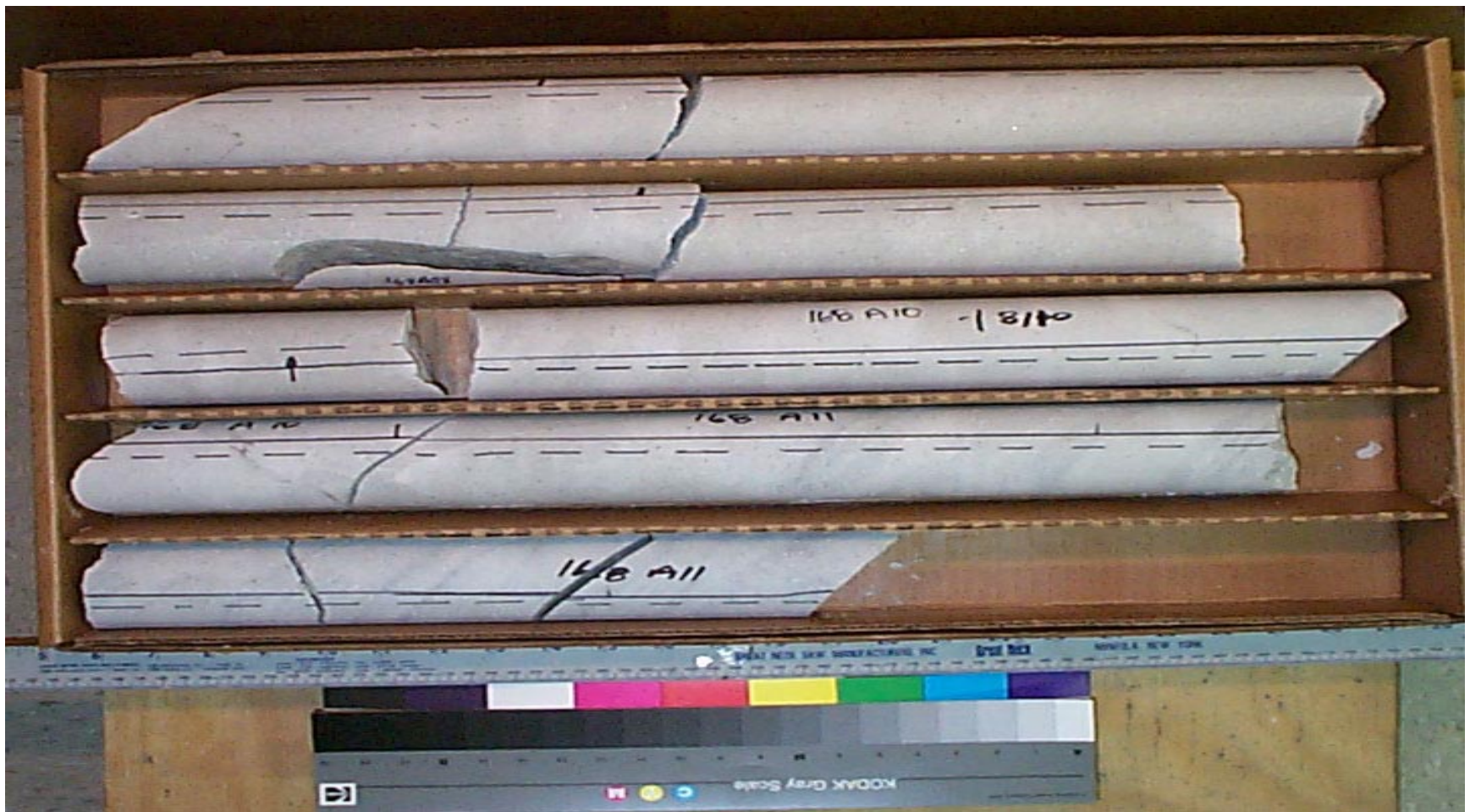

Core Scans included in this box (listed by piece going downhole):
168A070A
168A0900
168A1000
168A1100

See the "reading instructions" section of the introduction for help interpreting core box photos and core piece nomenclature 


\section{LVEW Core Box 260}

Depth Interval 8113.3'-8120.7'

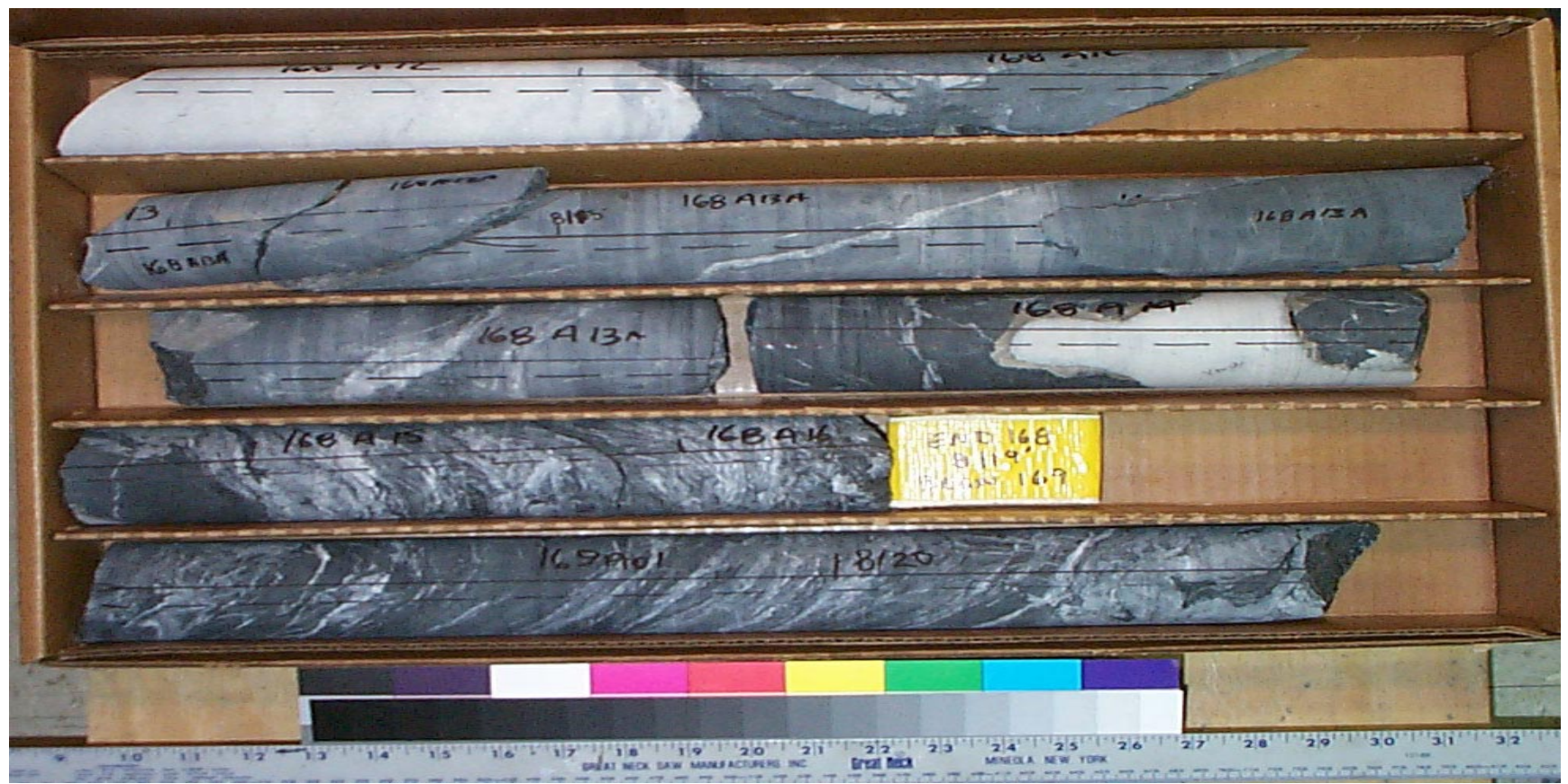

Core Scans included in this box (listed by piece going downhole):

168A1200
168A131A
168A132A
168A1400
168A1500
168A1600
169A0100

See the "reading instructions" section of the introduction for help interpreting core box photos and core piece nomenclature 


\section{LVEW Core Box 261}

\section{Depth Interval 8120.7'-8129.8'}

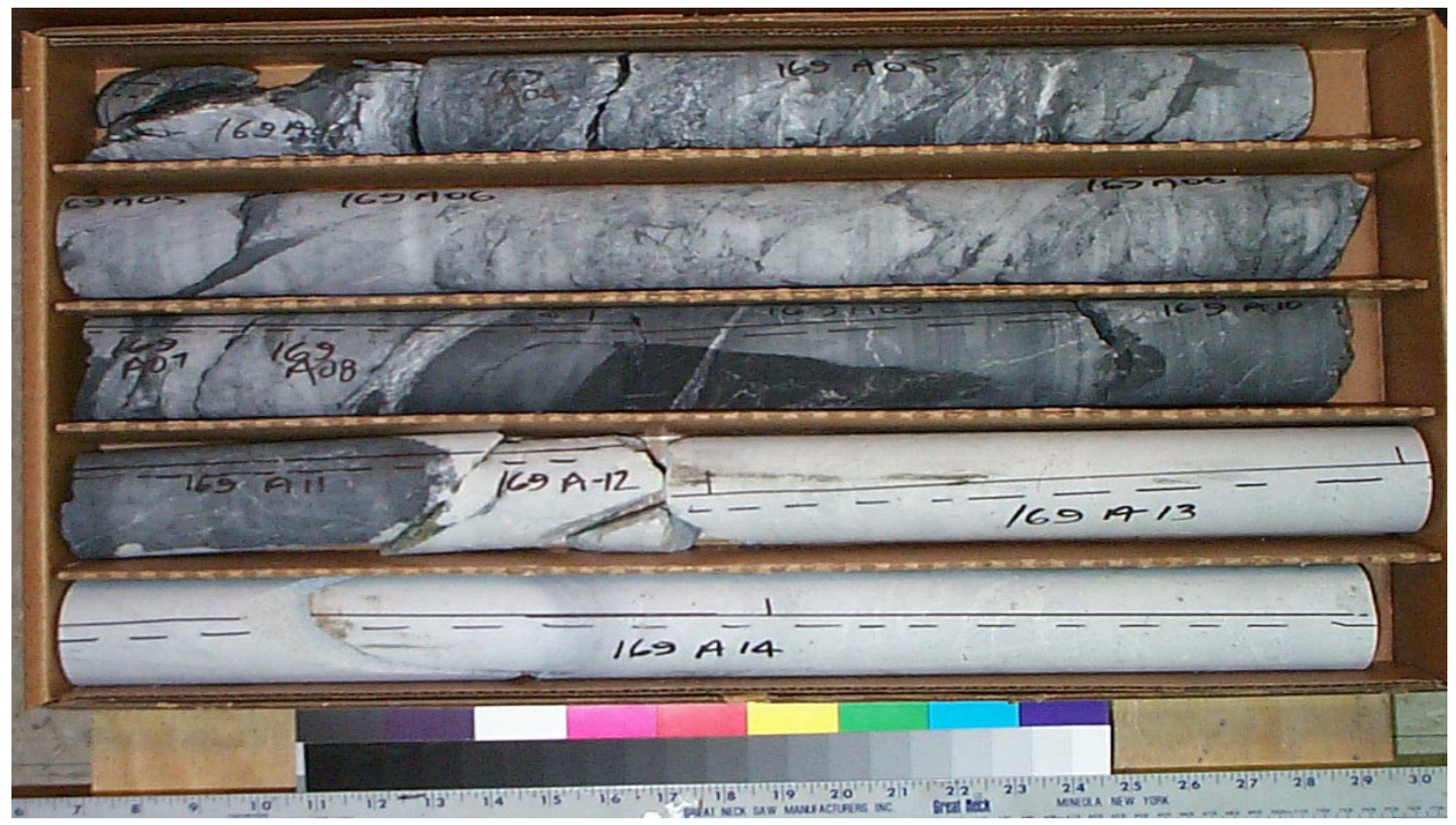

Core Scans included in this box (listed by piece going downhole):

$$
\begin{aligned}
& \text { 169A0400 } \\
& \text { 169A050A } \\
& \text { 169A0600 } \\
& \text { 169A0700 } \\
& \text { 169A0800 } \\
& \text { 169A1000 } \\
& \text { 169A1100 } \\
& \text { 169A1200 } \\
& \text { 169A130A } \\
& \text { 169A140A }
\end{aligned}
$$

See the "reading instructions" section of the introduction for help interpreting core box photos and core piece nomenclature 


\section{LVEW Core Box 262}

Depth Interval 8129.8'-8138.0'

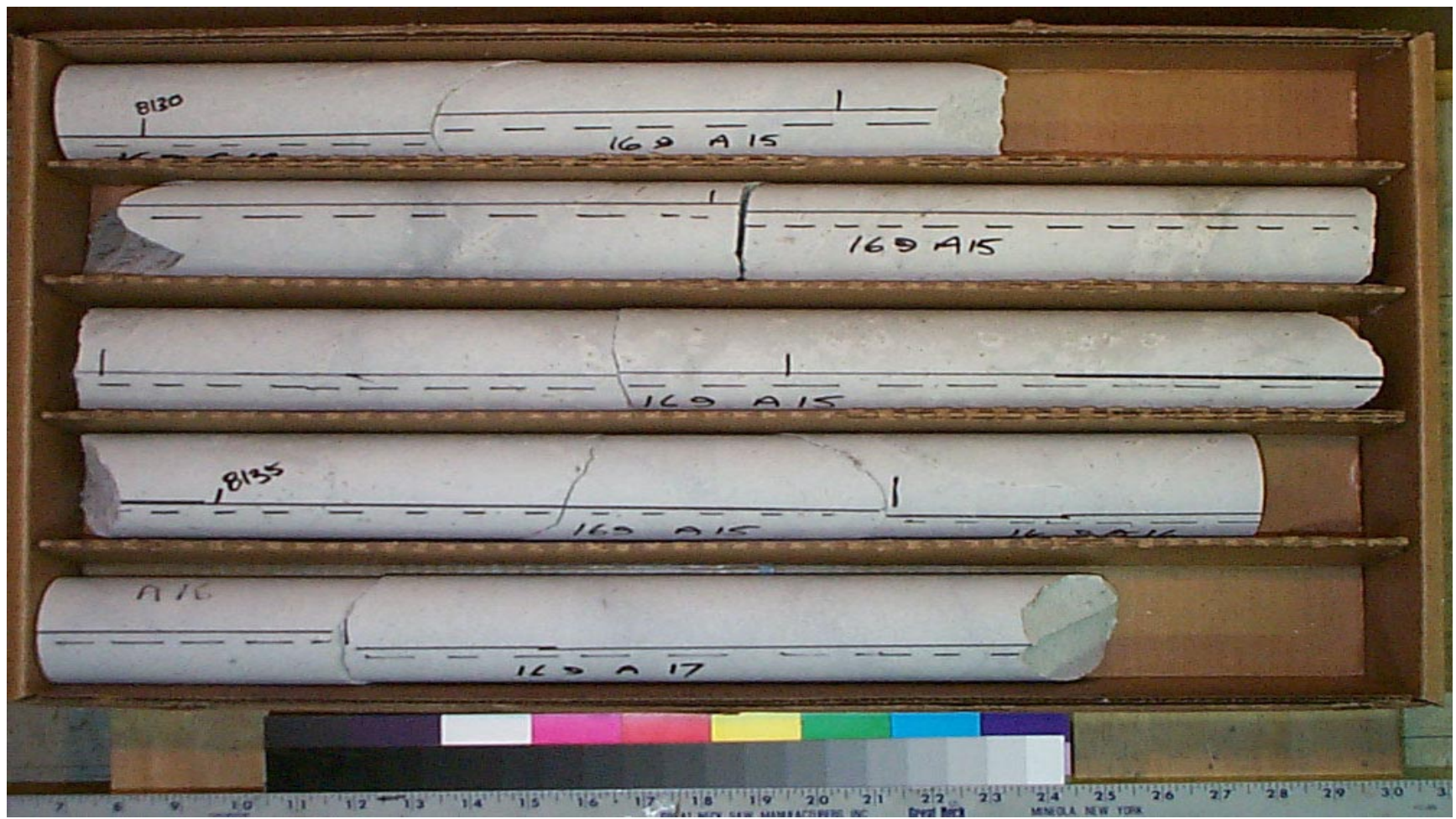

Core Scans included in this box (listed by piece going downhole):

$$
\begin{aligned}
& \text { 169A151A } \\
& \text { 169A152A } \\
& \text { 169A160A } \\
& \text { 169A1700 }
\end{aligned}
$$

See the "reading instructions" section of the introduction for help interpreting core box photos and core piece nomenclature 


\section{LVEW Core Box 263}

Depth Interval 8138.0'-8146.8'

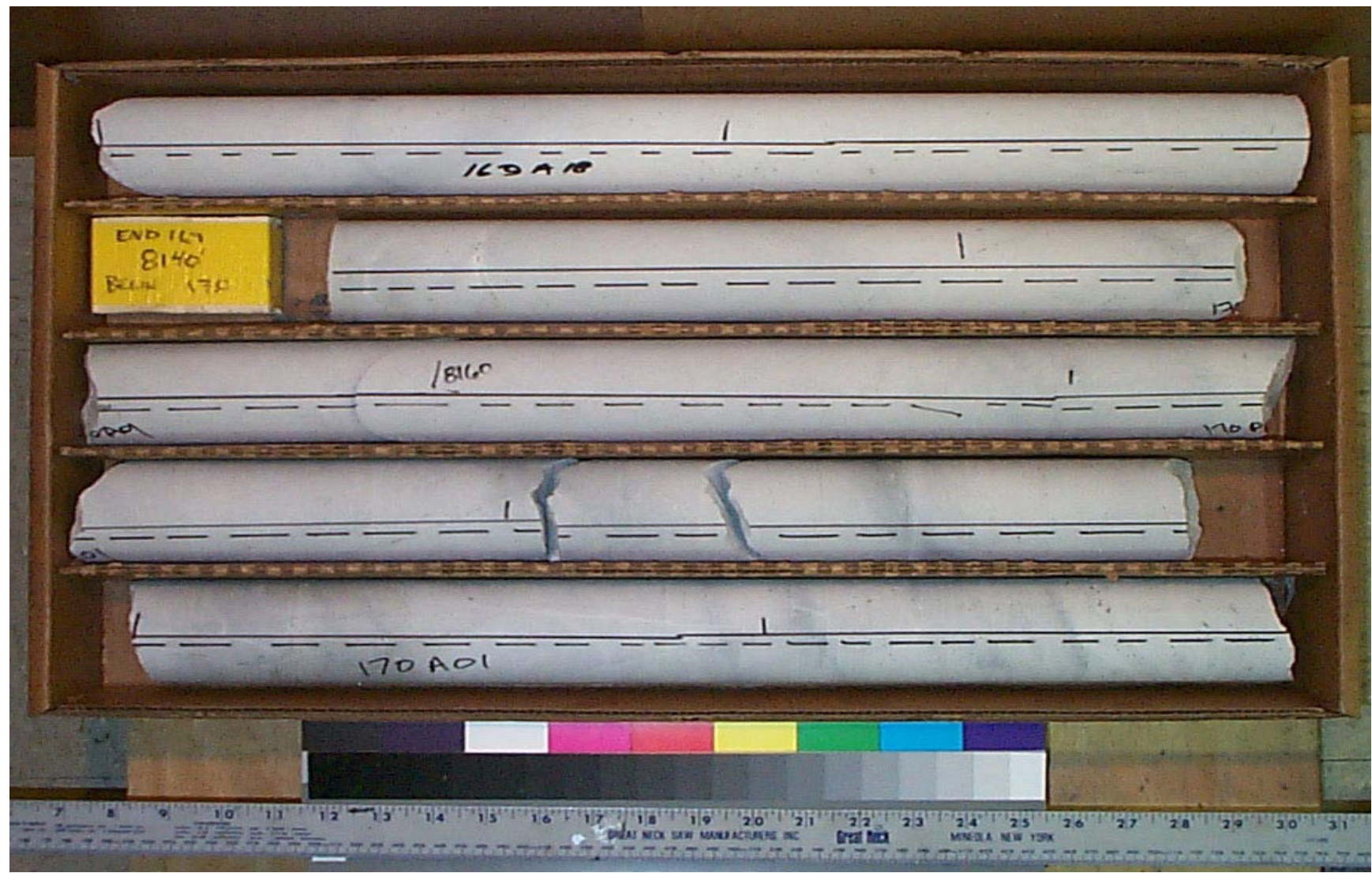

Core Scans included in this box (listed by piece going downhole):

170A011A
170A012A

See the "reading instructions" section of the introduction for help interpreting core box photos and core piece nomenclature 


\section{LVEW Core Box 264}

\section{Depth Interval 8146.8'-8156.0'}

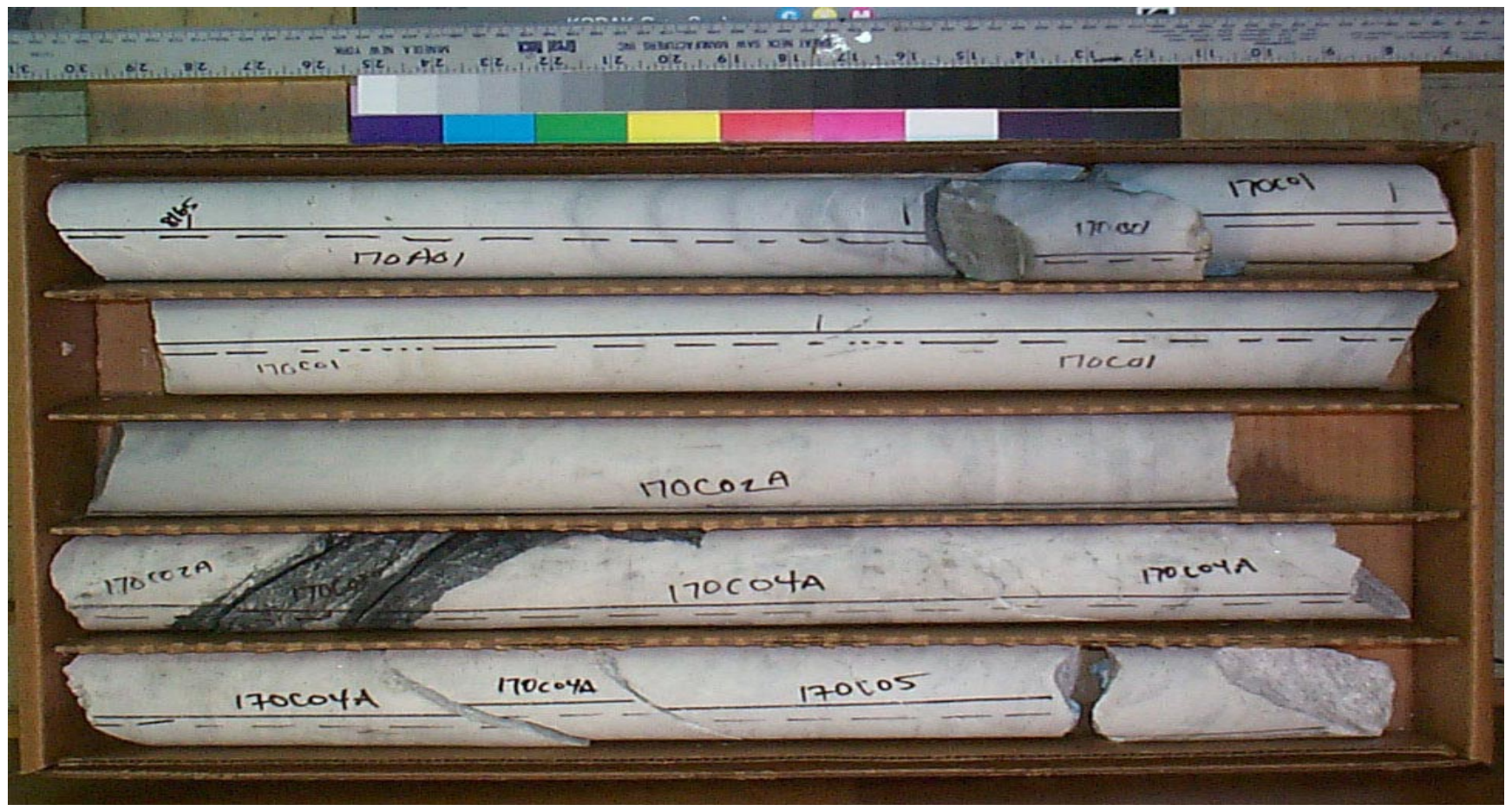

Core Scans included in this box (listed by piece going downhole):
$170 \mathrm{~A} 012 \mathrm{~A}$
$170 \mathrm{C} 0100$
$170 \mathrm{C} 020 \mathrm{~A}$
$170 \mathrm{C} 0300$
$170 \mathrm{C} 040 \mathrm{~A}$
$170 \mathrm{C} 0500$
$170 \mathrm{C0600}$

See the "reading instructions" section of the introduction for help interpreting core box photos and core piece nomenclature 


\section{LVEW Core Box 265}

Depth Interval 8156.0'-8162.6'

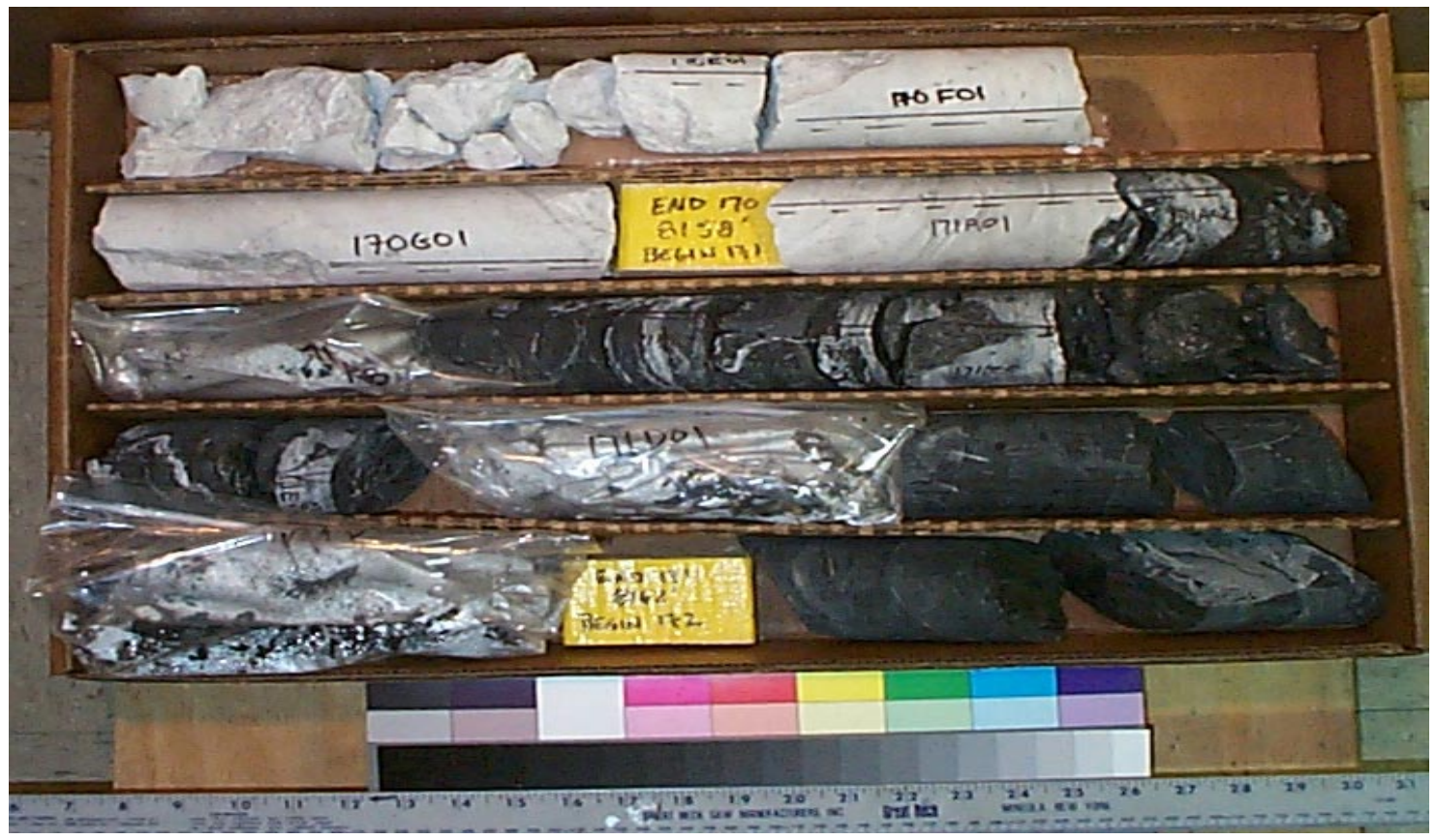

Core Scans included in this box (listed by piece going downhole):
170F0100
$170 \mathrm{G} 0100$
$171 \mathrm{D} 0200$
$171 \mathrm{D} 0300$
$172 \mathrm{~A} 0100$

See the "reading instructions" section of the introduction for help interpreting core box photos and core piece nomenclature 


\section{LVEW Core Box 266}

Depth Interval 8162.6'-8170.1'

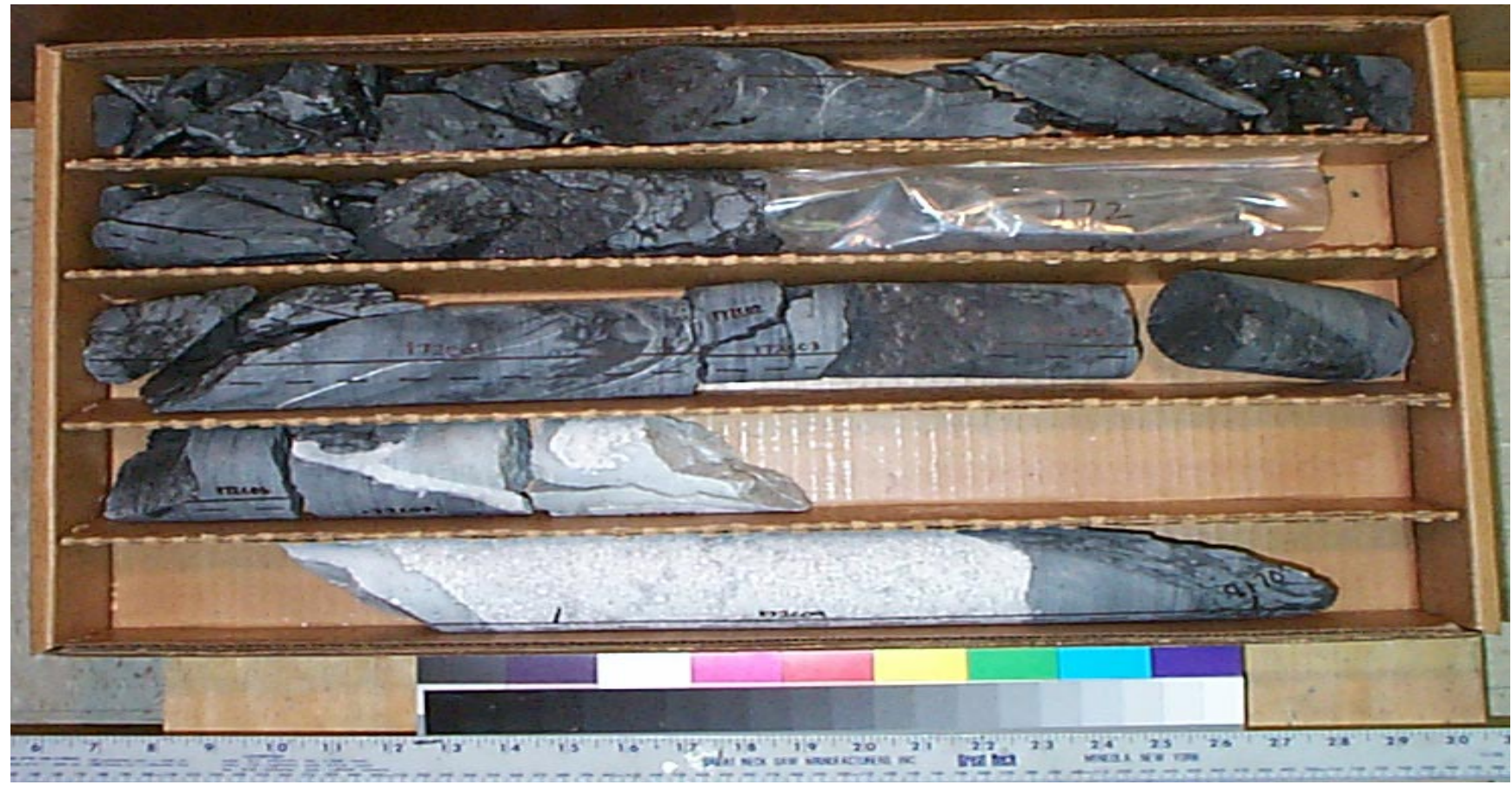

Core Scans included in this box (listed by piece going downhole):
$172 \mathrm{C} 0100$
$172 \mathrm{C} 0400$
$172 \mathrm{C} 0500$
$172 \mathrm{C} 0600$
$172 \mathrm{C} 0700$
$172 \mathrm{C} 0900$

See the "reading instructions" section of the introduction for help interpreting core box photos and core piece nomenclature 


\section{LVEW Core Box 267}

Depth Interval 8170.1'-8176.4'

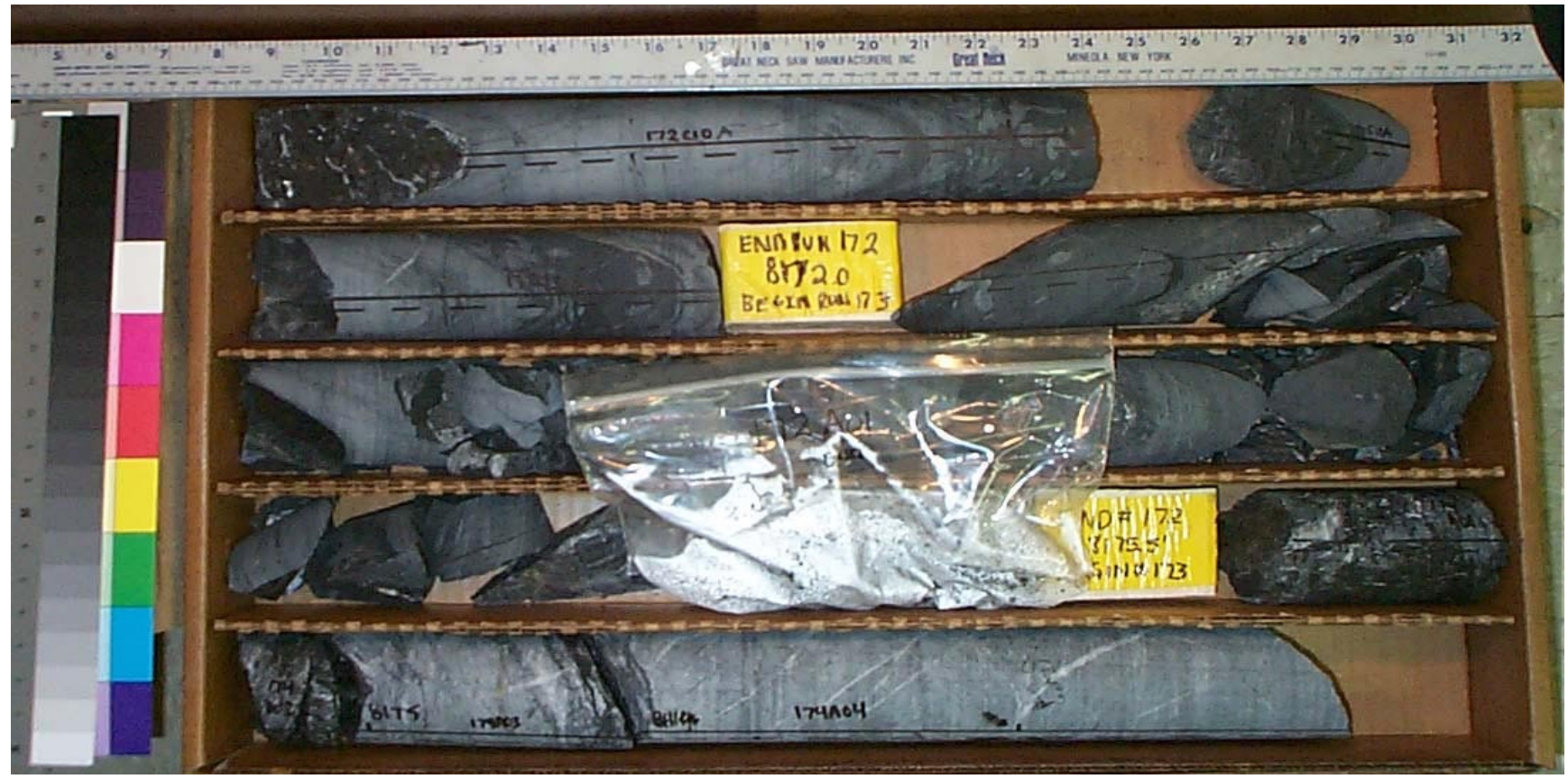

Core Scans included in this box (listed by piece going downhole):

$172 \mathrm{C} 100 \mathrm{~A}$

$174 \mathrm{~A} 0100$

$174 \mathrm{~A} 0300$

$174 \mathrm{~A} 0400$

See the "reading instructions" section of the introduction for help interpreting core box photos and core piece nomenclature 


\section{LVEW Core Box 268}

Depth Interval 8176.4'-8184.3'

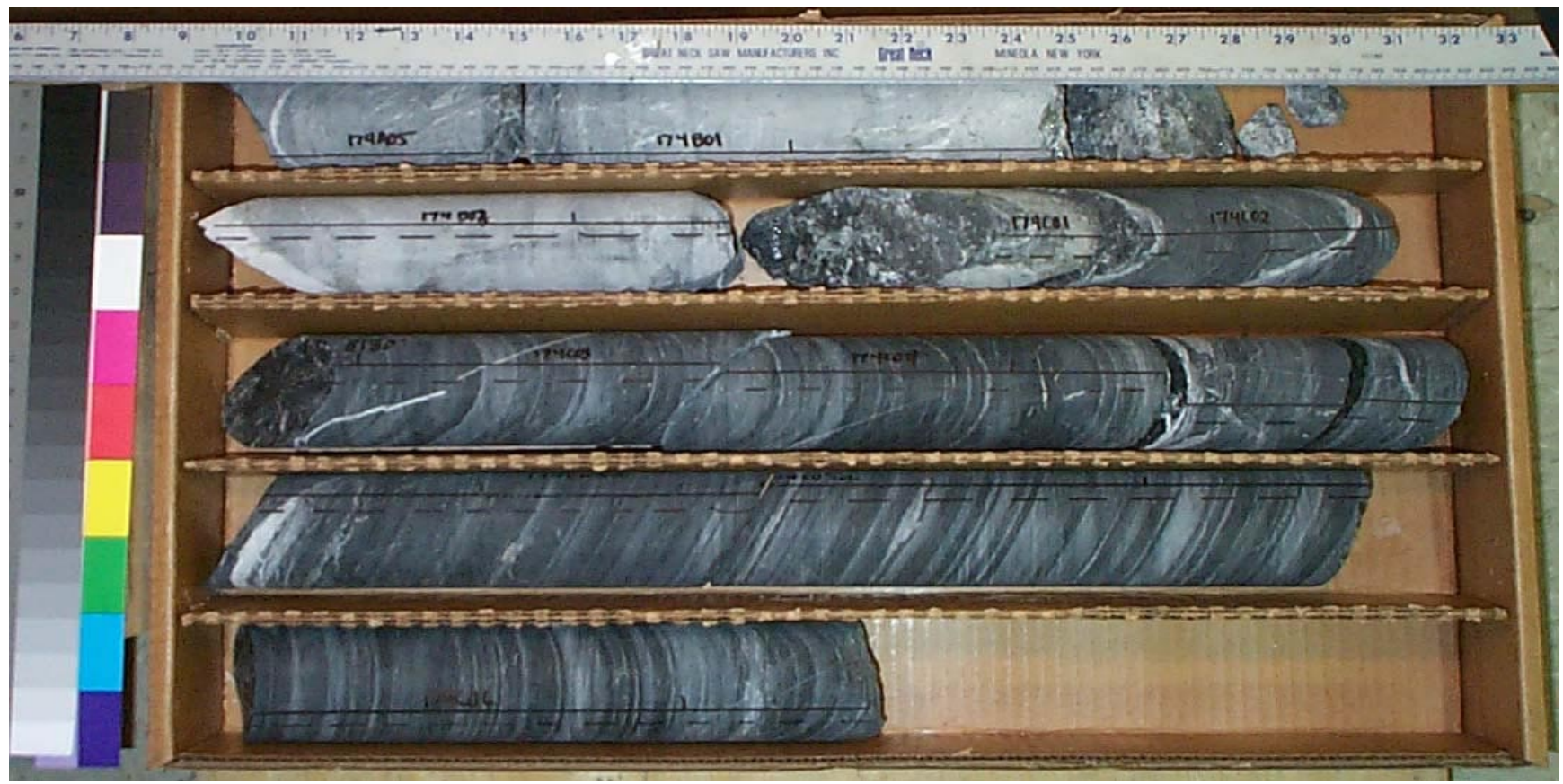

Core Scans included in this box (listed by piece going downhole):
$174 \mathrm{~A} 0500$
174B0100
174B0300
$174 \mathrm{C} 0200$
$174 \mathrm{C} 0300$
$174 \mathrm{C} 0400$
$174 \mathrm{C} 050 \mathrm{~A}$
$174 \mathrm{C} 0600$

See the "reading instructions" section of the introduction for help interpreting core box photos and core piece nomenclature 


\section{LVEW Core Box 269}

Depth Interval 8184.3'-8192.0'

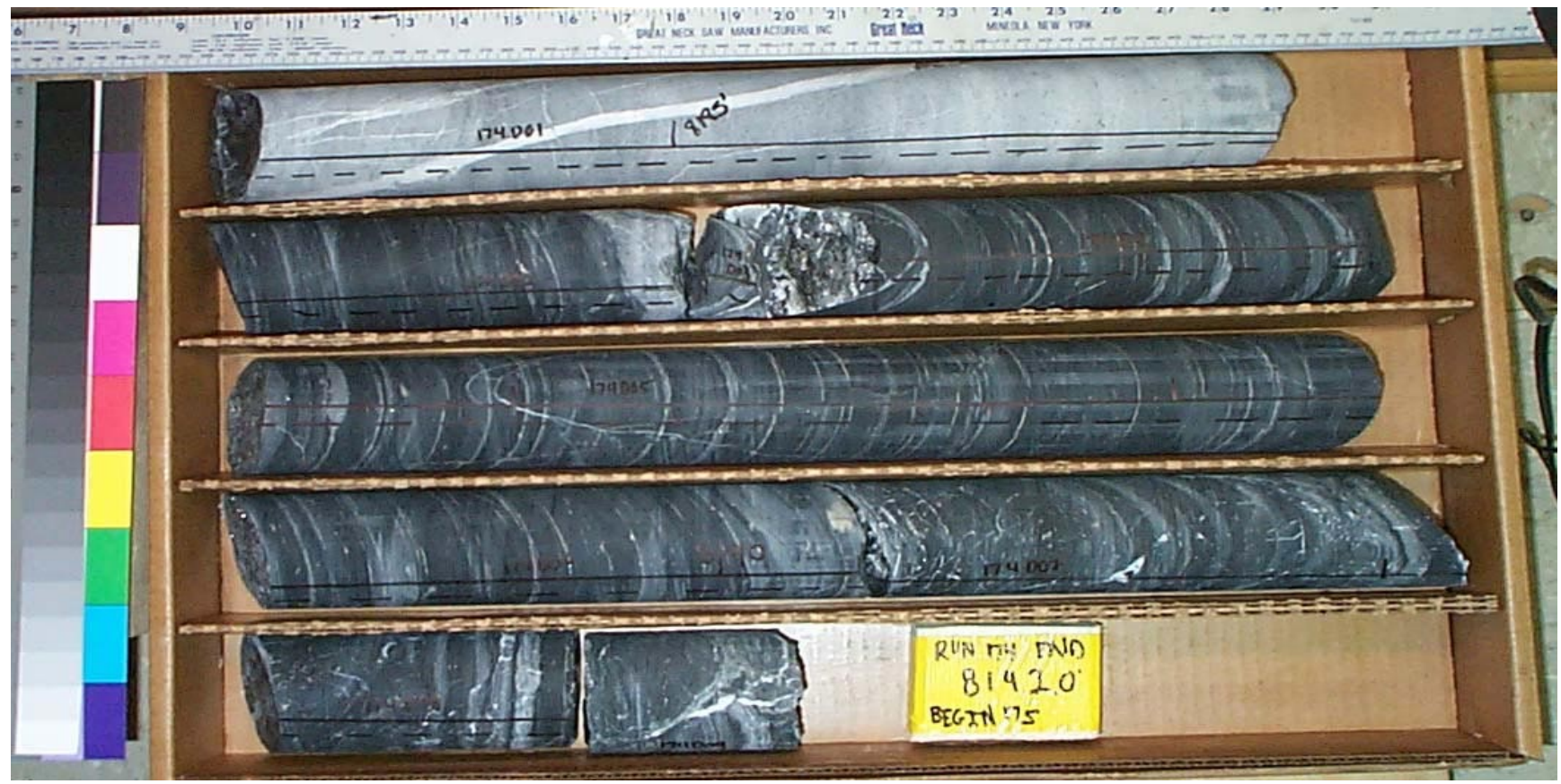

Core Scans included in this box (listed by piece going downhole):

174D0100

174D0200

174D0400

174D0500

174D0600

174D0700

174D0800

174D0900

See the "reading instructions" section of the introduction for help interpreting core box photos and core piece nomenclature 
LVEW Core Box 270

Depth Interval 8192.0'-8199.9'

\section{Missing Core Box}

Core Scans included in this box

(listed by piece going downhole):

175A010A

$175 \mathrm{~A} 0200$

$175 \mathrm{~A} 0300$

$175 \mathrm{~A} 0400$

See the "reading instructions" section of the introduction for help interpreting core box photos and core piece nomenclature 
LVEW Core Box 271

Depth Interval 8199.9'-8206.0'

\section{Missing Core Box}

Core Scans included in this box

(listed by piece going downhole):

\section{$175 \mathrm{~A} 050 \mathrm{~A}$ \\ $175 \mathrm{~A} 0800$ \\ $175 \mathrm{~A} 0900$ \\ $175 \mathrm{~A} 1000$}

See the "reading instructions" section of the introduction for help interpreting core box photos and core piece nomenclature 


\section{LVEW Core Box 272}

Depth Interval 8206.0'-8214.5'

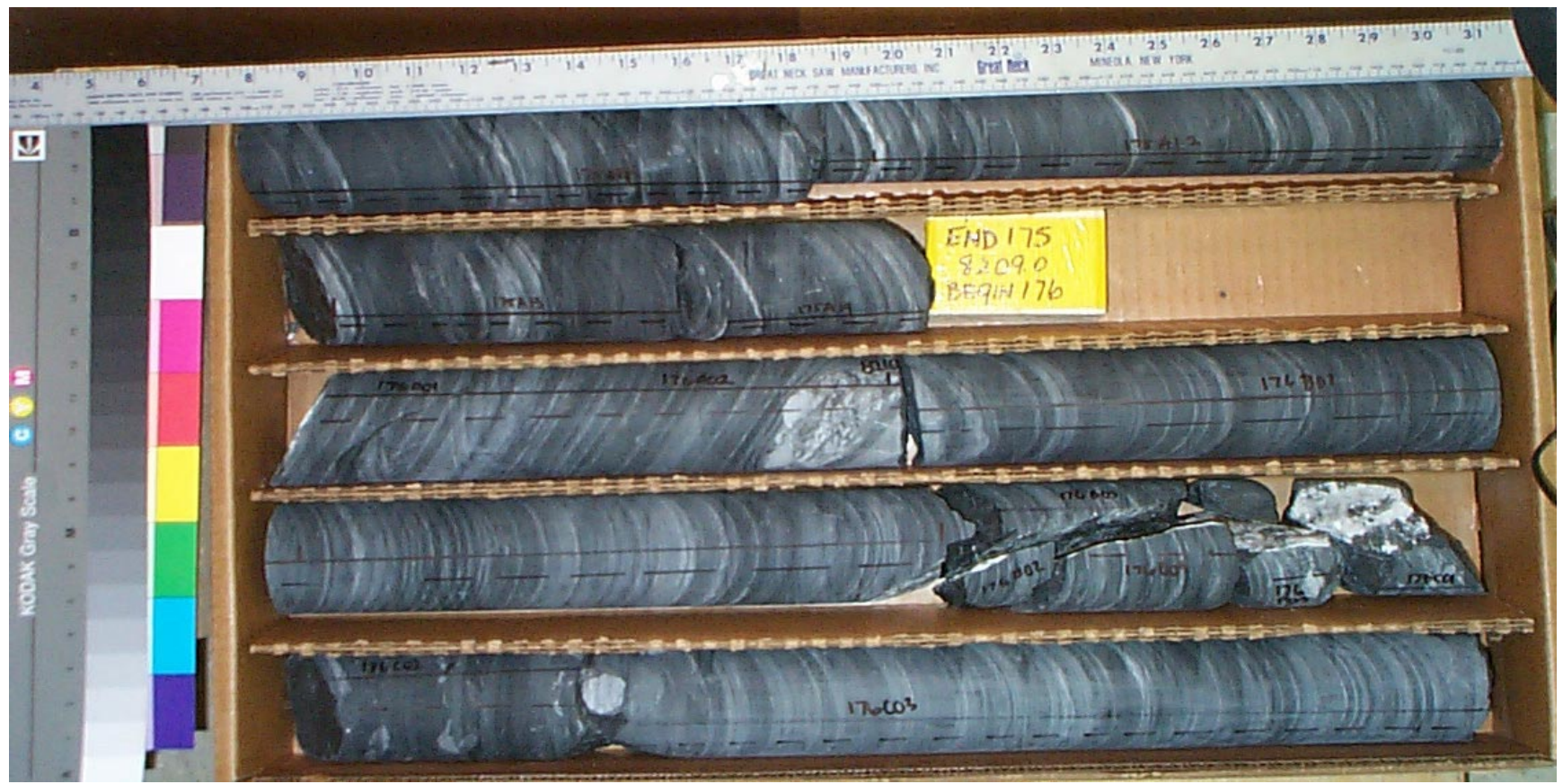

Core Scans included in this box (listed by piece going downhole):
$175 \mathrm{~A} 1100$
$175 \mathrm{~A} 1200$
$175 \mathrm{~A} 1300$
$175 \mathrm{~A} 1400$
$176 \mathrm{~A} 0100$
$176 \mathrm{~A} 0200$
$176 \mathrm{~B} 010 \mathrm{~A}$
$176 \mathrm{C} 0200$
$176 \mathrm{C} 0300$

See the "reading instructions" section of the introduction for help interpreting core box photos and core piece nomenclature 


\section{LVEW Core Box 273}

Depth Interval 8214.5'-8223.0'

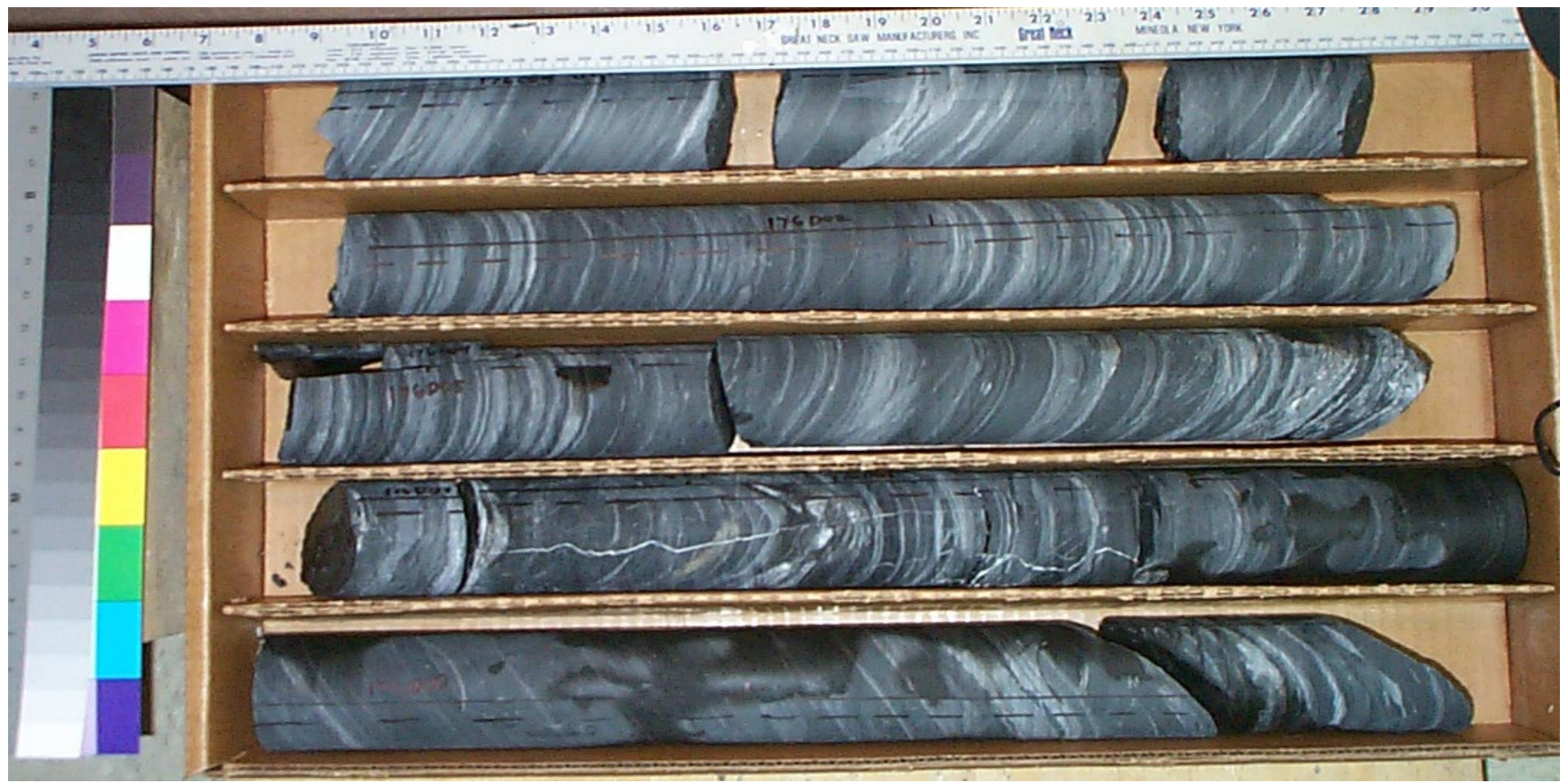

Core Scans included in this box (listed by piece going downhole):
$176 \mathrm{C} 0400$
$176 \mathrm{C} 0500$
$176 \mathrm{D} 0100$
$176 \mathrm{D} 0200$
$176 \mathrm{D} 0600$
$176 \mathrm{D} 0700$
176D0900
176D100A
176D1100

See the "reading instructions" section of the introduction for help interpreting core box photos and core piece nomenclature 


\section{LVEW Core Box 274}

Depth Interval 8223.0'-8231.8'

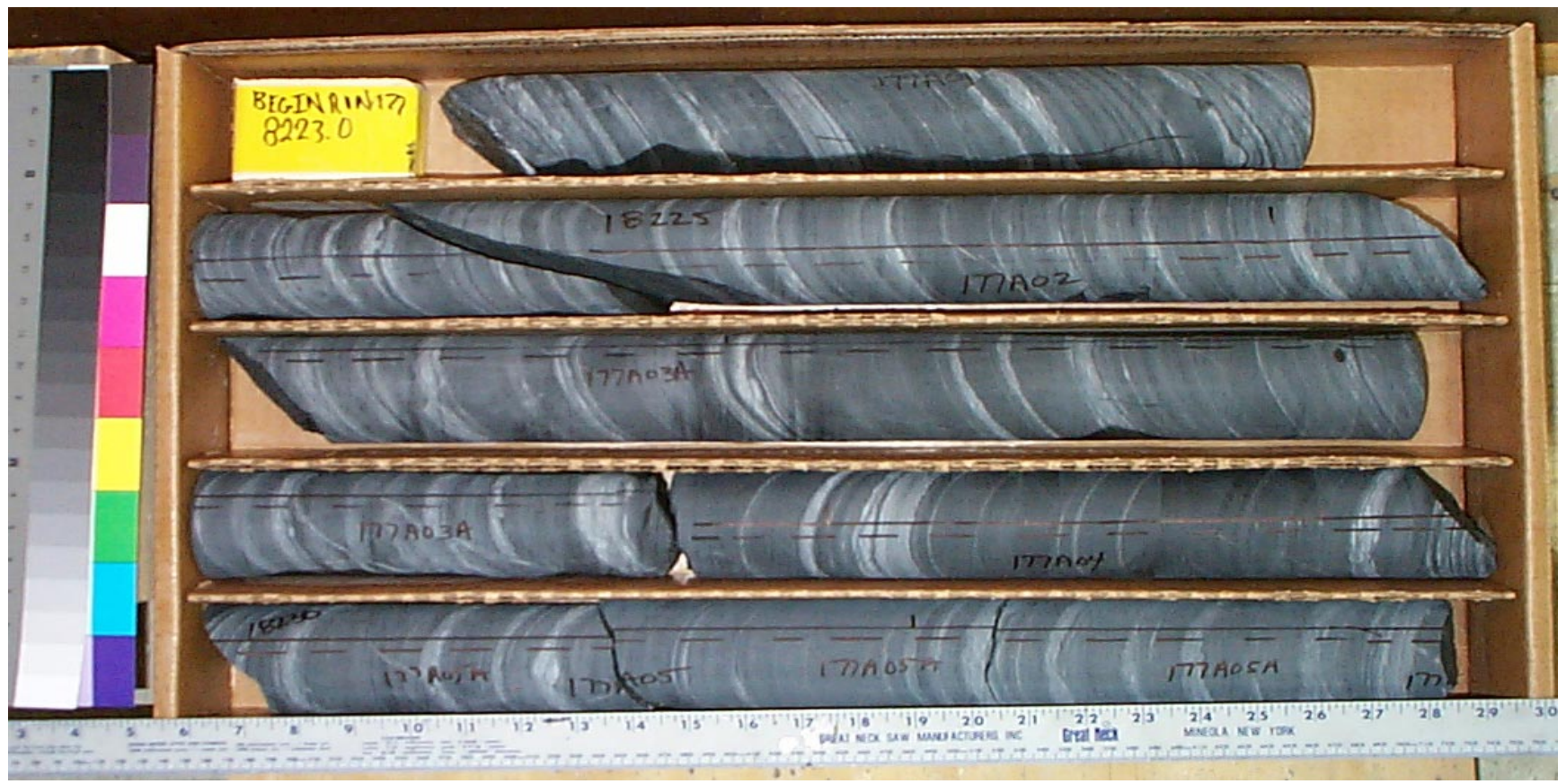

Core Scans included in this box (listed by piece going downhole):
$177 \mathrm{~A} 010 \mathrm{~A}$
$177 \mathrm{~A} 0200$
$177 \mathrm{~A} 0300$
$177 \mathrm{~A} 0400$
177A051A

See the "reading instructions" section of the introduction for help interpreting core box photos and core piece nomenclature 


\section{LVEW Core Box 275}

\section{Depth Interval 8231.8'-8240.2'}

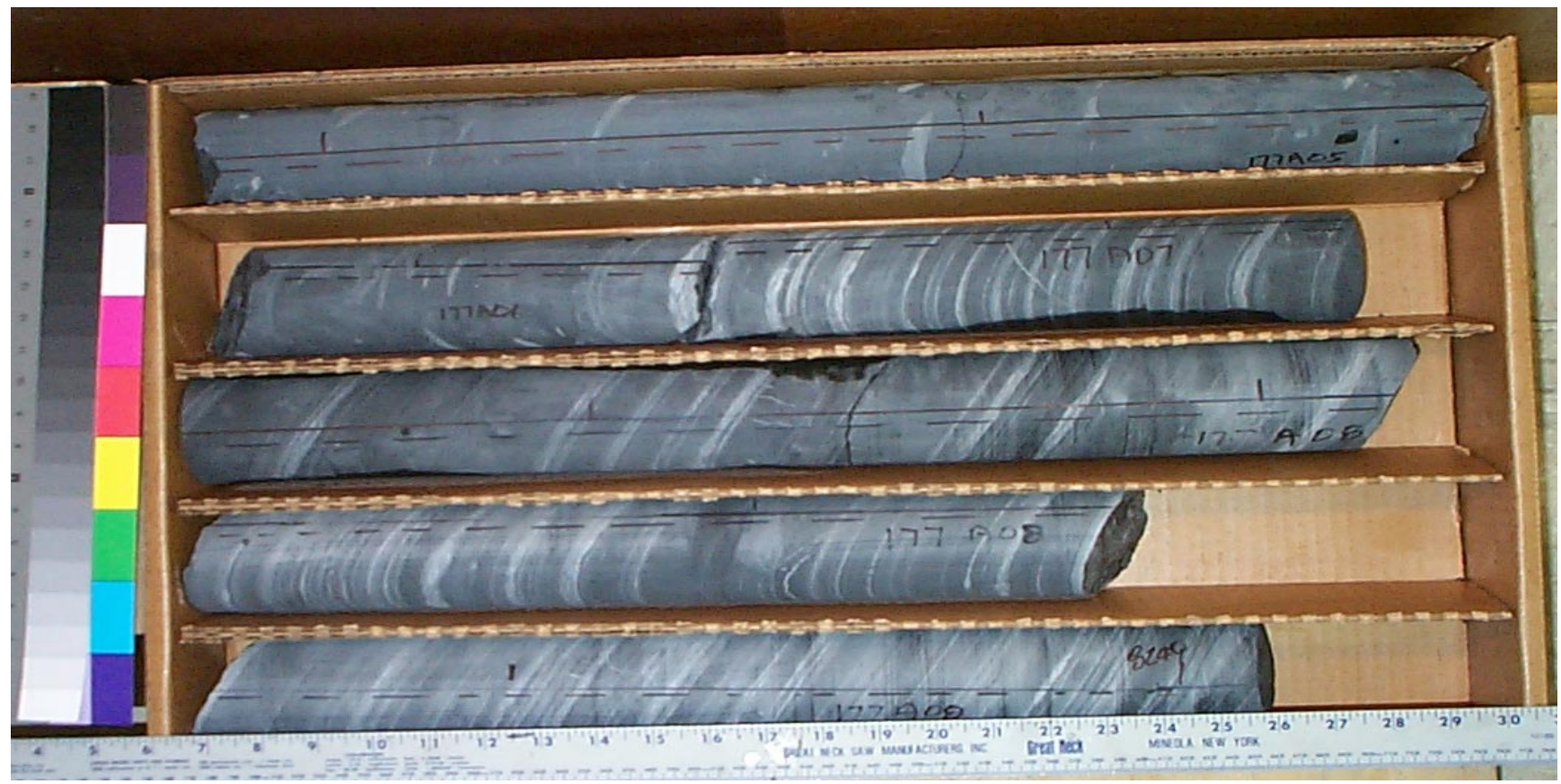

Core Scans included in this box (listed by piece going downhole):
$177 \mathrm{~A} 052 \mathrm{~A}$
$177 \mathrm{~A} 0600$
$177 \mathrm{~A} 070 \mathrm{~A}$
$177 \mathrm{~A} 081 \mathrm{~A}$
177A082A

See the "reading instructions" section of the introduction for help interpreting core box photos and core piece nomenclature 


\section{LVEW Core Box 276}

Depth Interval 8240.2'-8248.7'

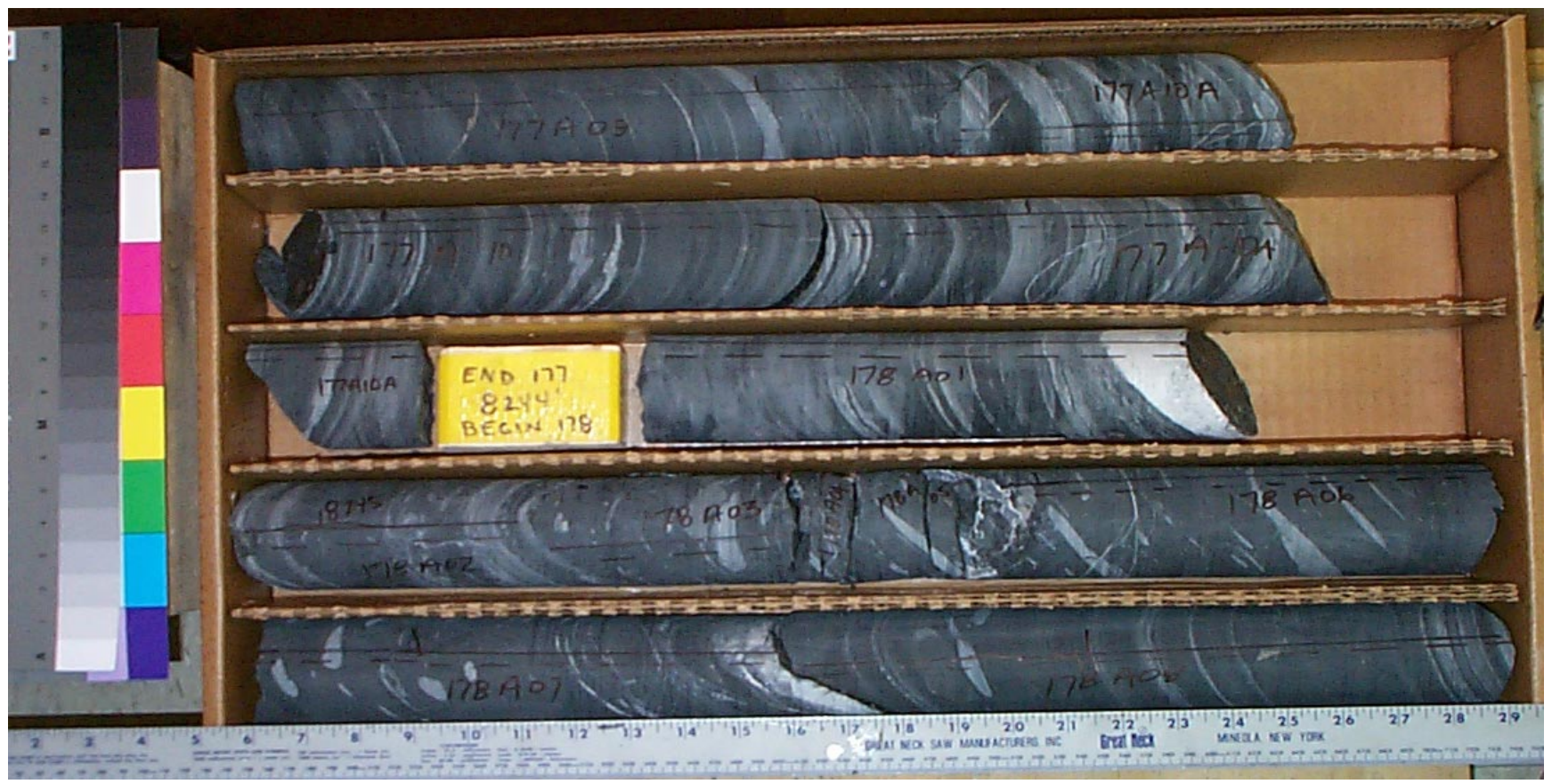

Core Scans included in this box (listed by piece going downhole):
$177 \mathrm{~A} 0900$
177A100A
$178 \mathrm{~A} 0100$
$178 \mathrm{~A} 0200$
178A0600
$178 \mathrm{~A} 0700$
178A0800

See the "reading instructions" section of the introduction for help interpreting core box photos and core piece nomenclature 


\section{LVEW Core Box 277}

\section{Depth Interval 8248.7'-8257.0'}

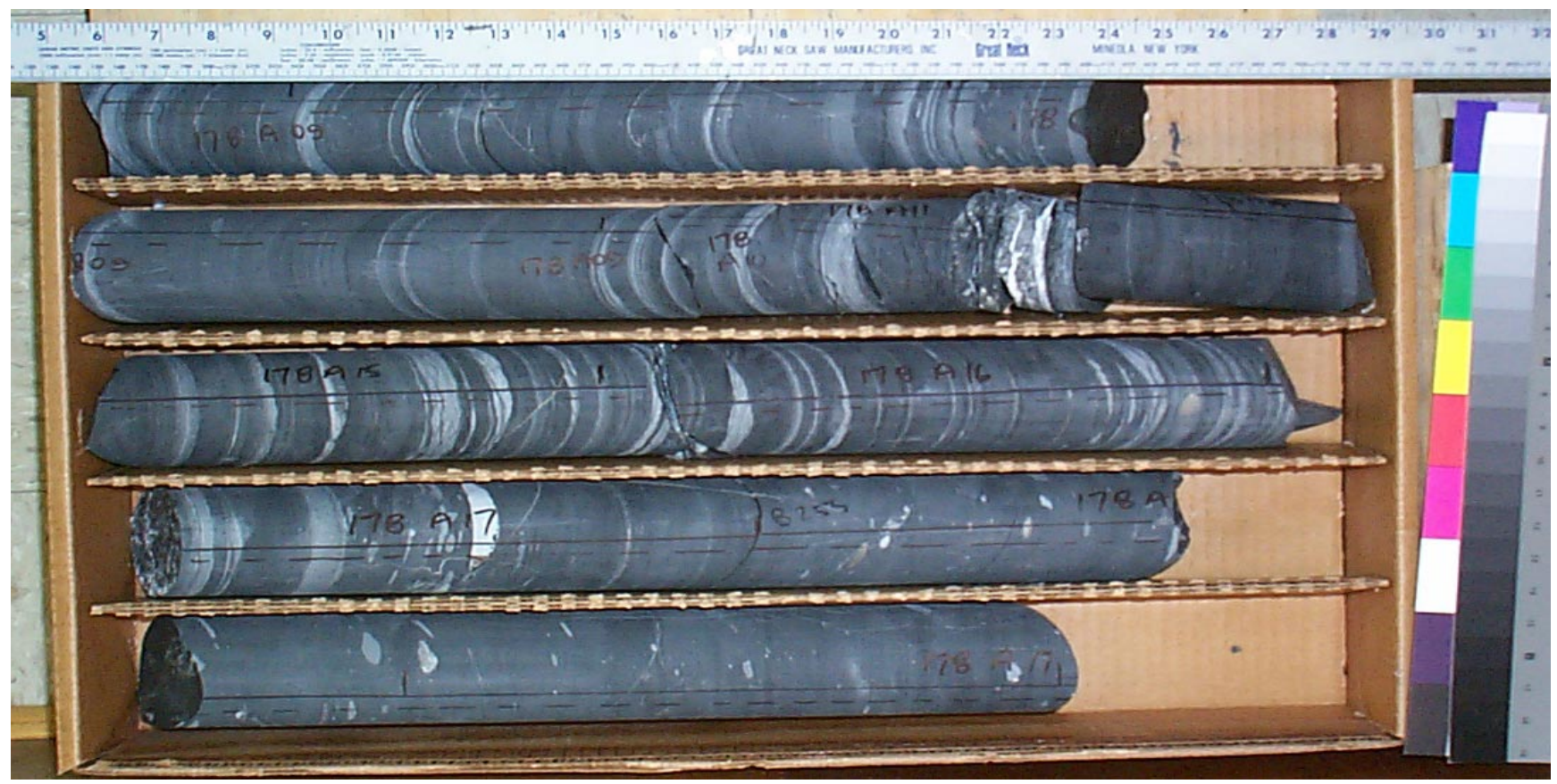

Core Scans included in this box (listed by piece going downhole):

178A090A

$178 \mathrm{~A} 1000$

$178 \mathrm{~A} 1400$

178A 1500

$178 \mathrm{~A} 1600$

$178 \mathrm{~A} 1700$

178A181A

See the "reading instructions" section of the introduction for help interpreting core box photos and core piece nomenclature 


\section{LVEW Core Box 278}

Depth Interval 8257.0'-8263.1'

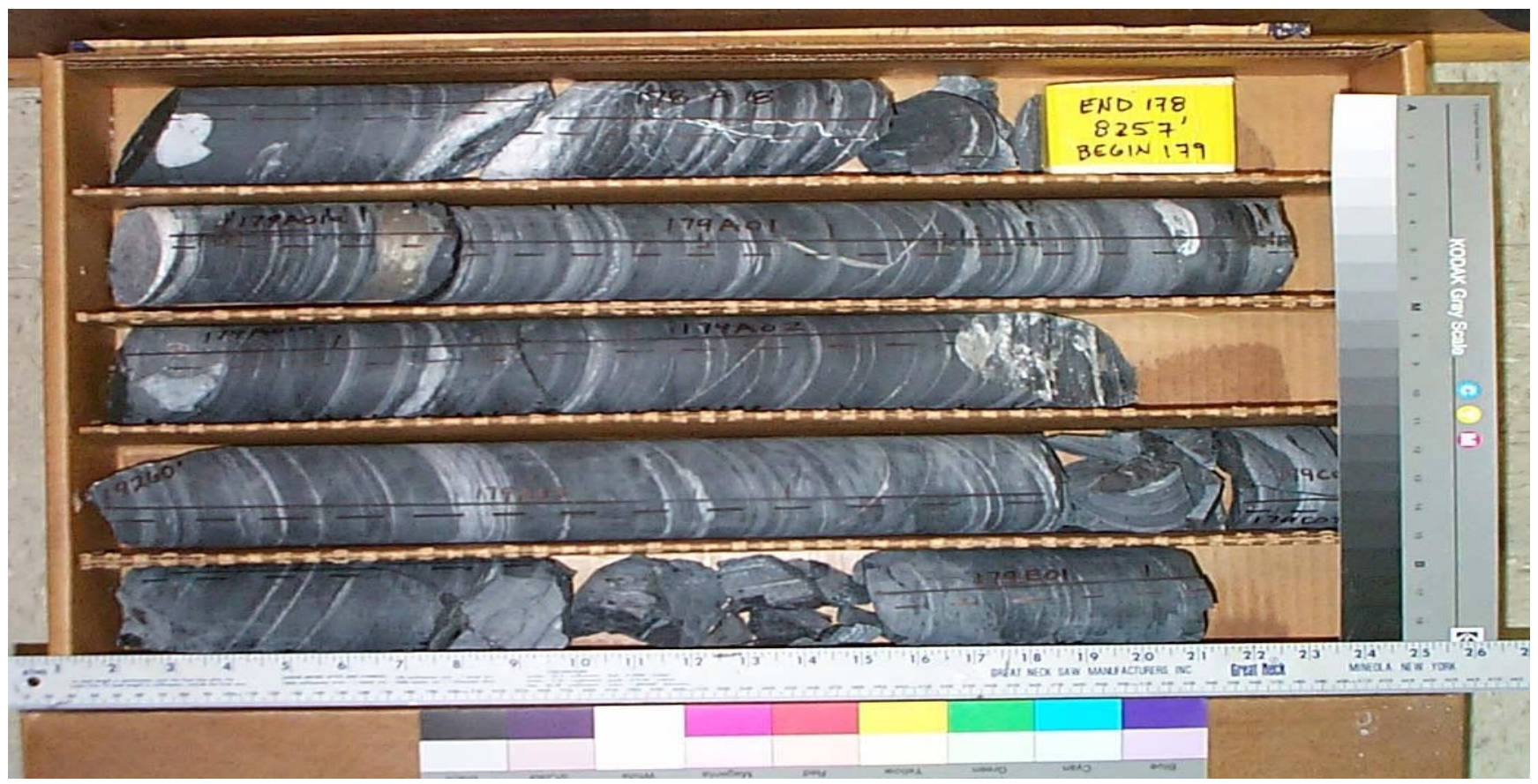

Core Scans included in this box (listed by piece going downhole):
$178 \mathrm{~A} 182 \mathrm{~A}$
$179 \mathrm{~A} 0100$
$179 \mathrm{~A} 0200$
179A0300
$179 \mathrm{C} 0300$
179E0100

See the "reading instructions" section of the introduction for help interpreting core box photos and core piece nomenclature 


\section{LVEW Core Box 279}

Depth Interval 8263.1'-8271.9'

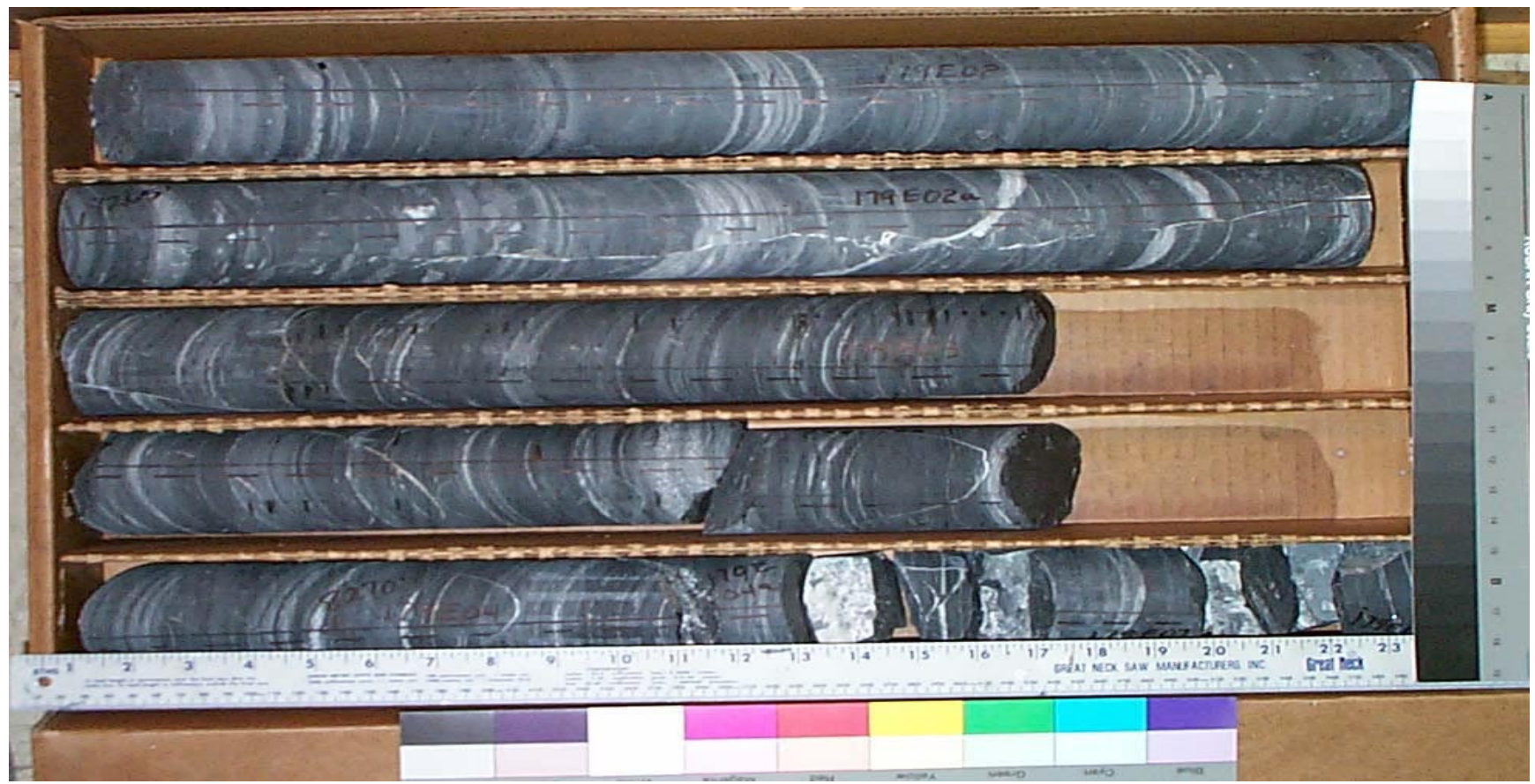

Core Scans included in this box (listed by piece going downhole):

179E021A
179E022A
179E030A
179E040A

See the "reading instructions" section of the introduction for help interpreting core box photos and core piece nomenclature 


\section{LVEW Core Box 280}

Depth Interval 8271.9'-8280.4'

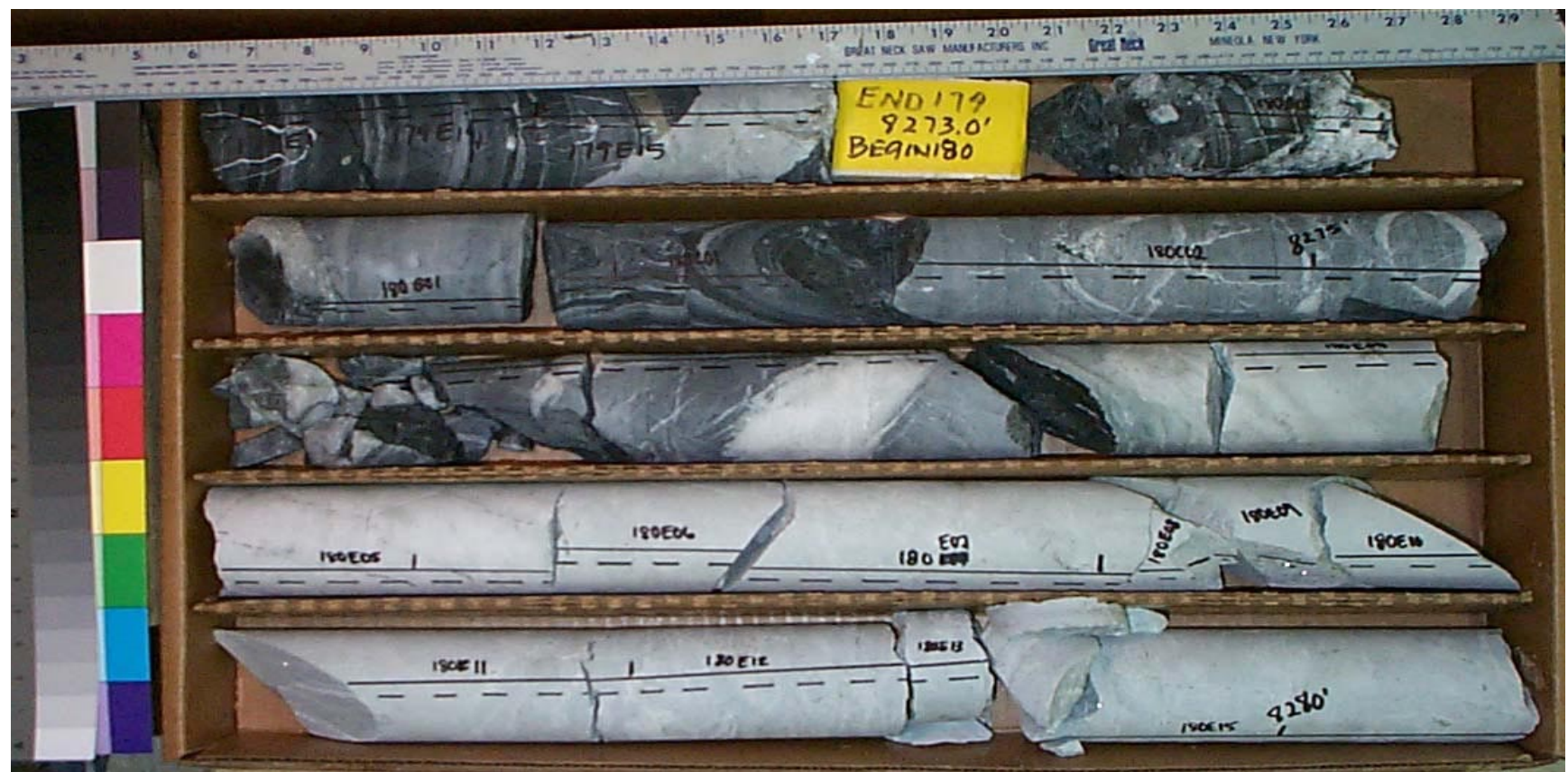

Core Scans included in this box (listed by piece going downhole):
179E1300
180B0100
$180 \mathrm{C} 0100$
$180 \mathrm{C0} 200$
180E0100
180E0400
$180 \mathrm{E} 0500$
180E0600
180E0700
180E1100
180E1200
180E1500

See the "reading instructions" section of the introduction for help interpreting core box photos and core piece nomenclature 


\section{LVEW Core Box 281}

Depth Interval 8280.4'-8285.2'

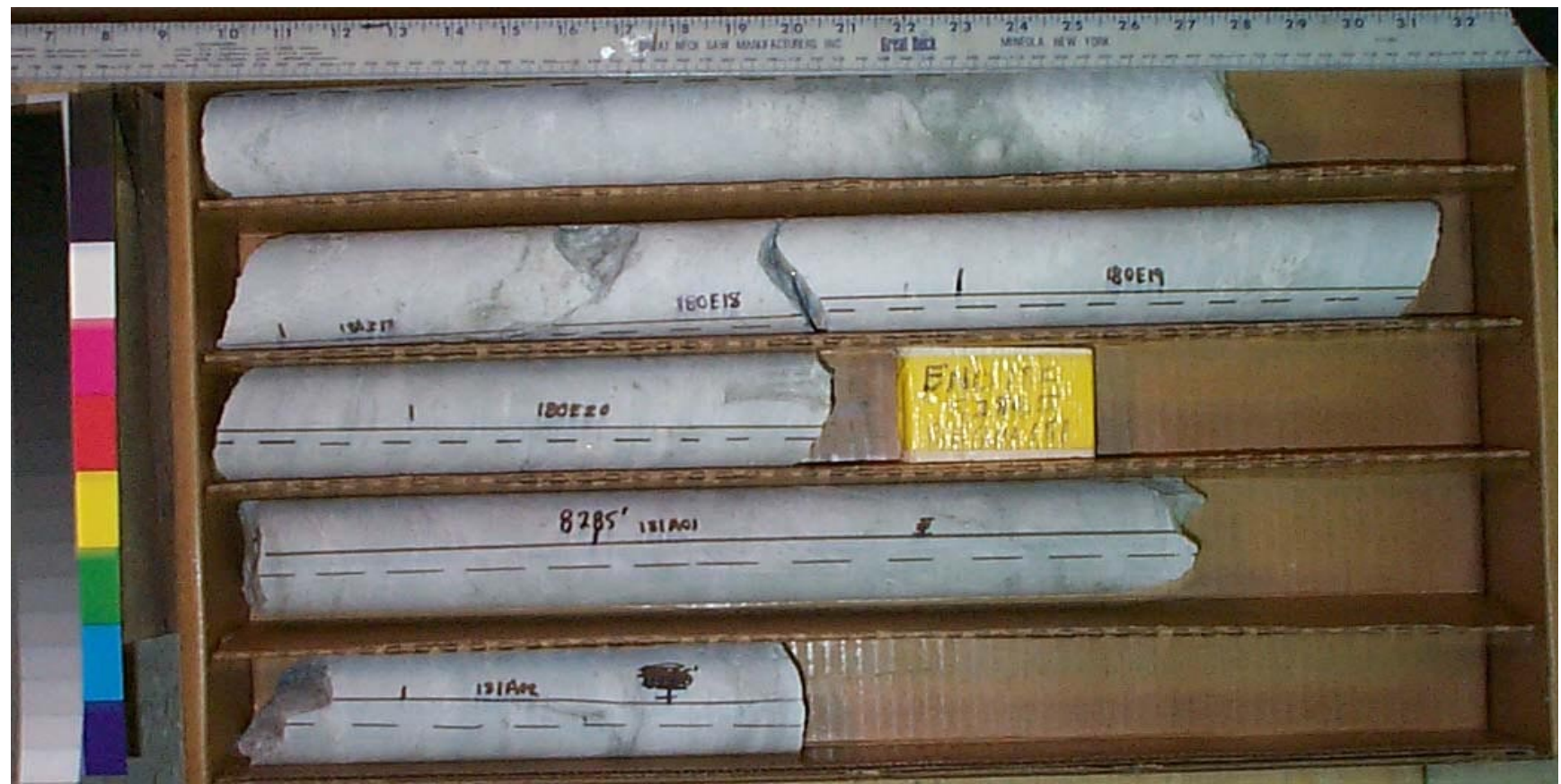

Core Scans included in this box (listed by piece going downhole):

180E1600

$180 \mathrm{E} 1700$

$180 \mathrm{E} 1900$

180E2000

$181 \mathrm{~A} 0100$

$181 \mathrm{~A} 0200$

See the "reading instructions" section of the introduction for help interpreting core box photos and core piece nomenclature 


\section{LVEW Core Box 282}

Depth Interval 8285.2'-8594.8'

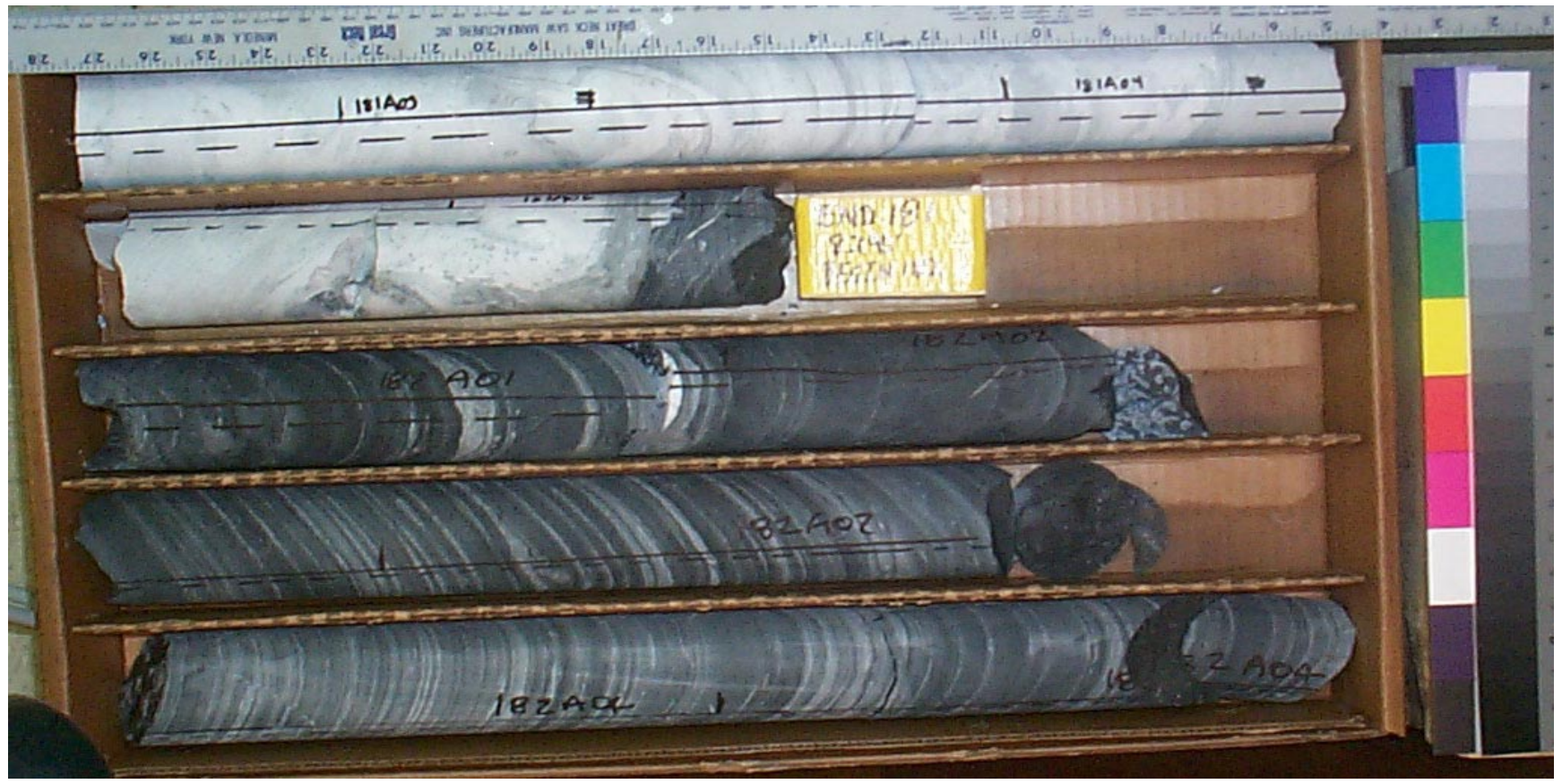

Core Scans included in this box (listed by piece going downhole):

$181 \mathrm{~A} 0300$

$181 \mathrm{~A} 0400$

$181 \mathrm{~A} 0500$

$181 \mathrm{~A} 0600$

$182 \mathrm{~A} 0100$

$182 \mathrm{~A} 020 \mathrm{~A}$

$182 \mathrm{~A} 041 \mathrm{~A}$

See the "reading instructions" section of the introduction for help interpreting core box photos and core piece nomenclature 


\section{LVEW Core Box 283}

Depth Interval 8294.8'-8303.7'

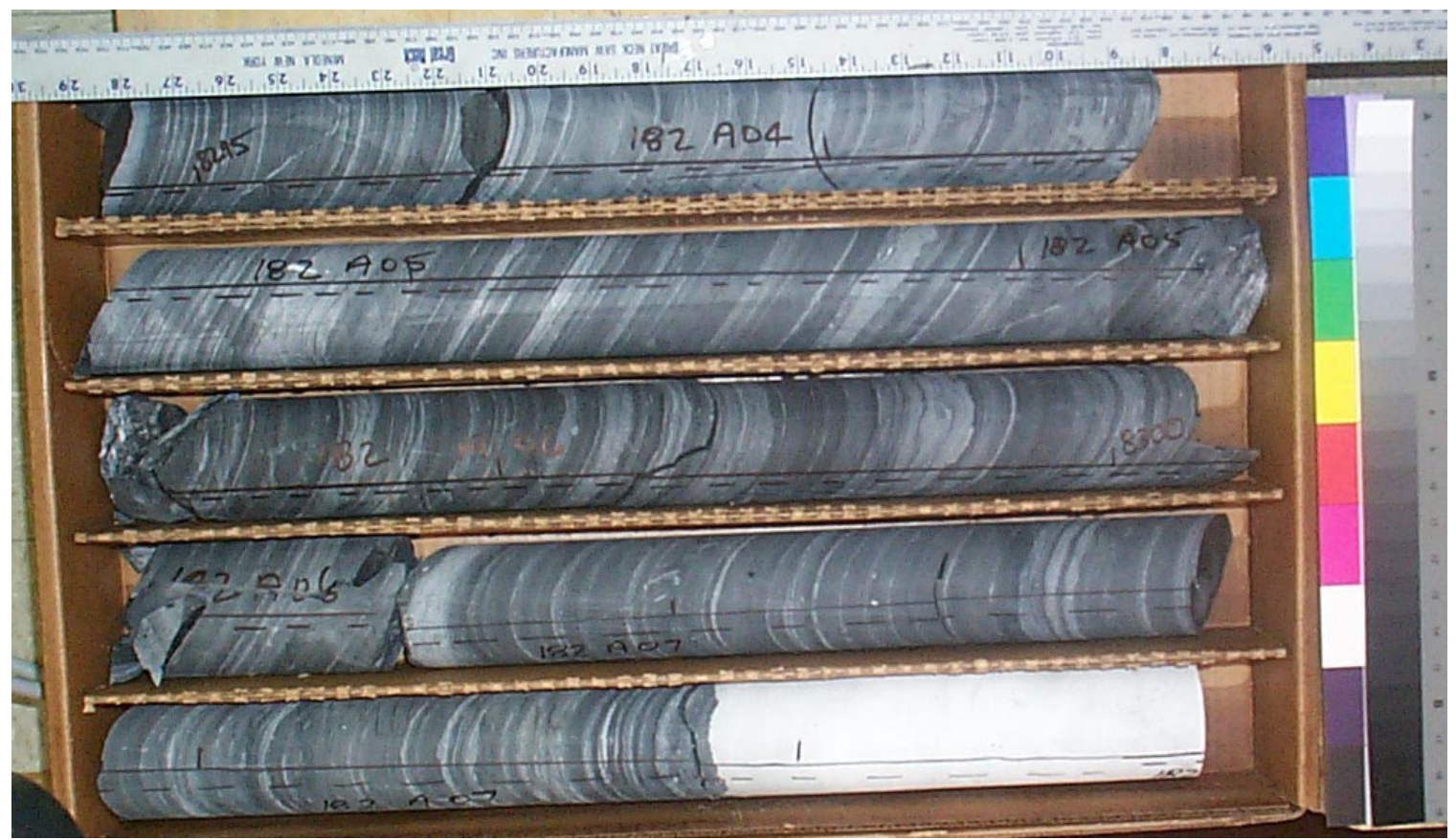

Core Scans included in this box (listed by piece going downhole):
$182 \mathrm{~A} 042 \mathrm{~A}$
$182 \mathrm{~A} 0500$
$182 \mathrm{~A} 060 \mathrm{~A}$
$182 \mathrm{~A} 071 \mathrm{~A}$
182A072A

See the "reading instructions" section of the introduction for help interpreting core box photos and core piece nomenclature 


\section{LVEW Core Box 284}

Depth Interval 8303.7'-8311.2'

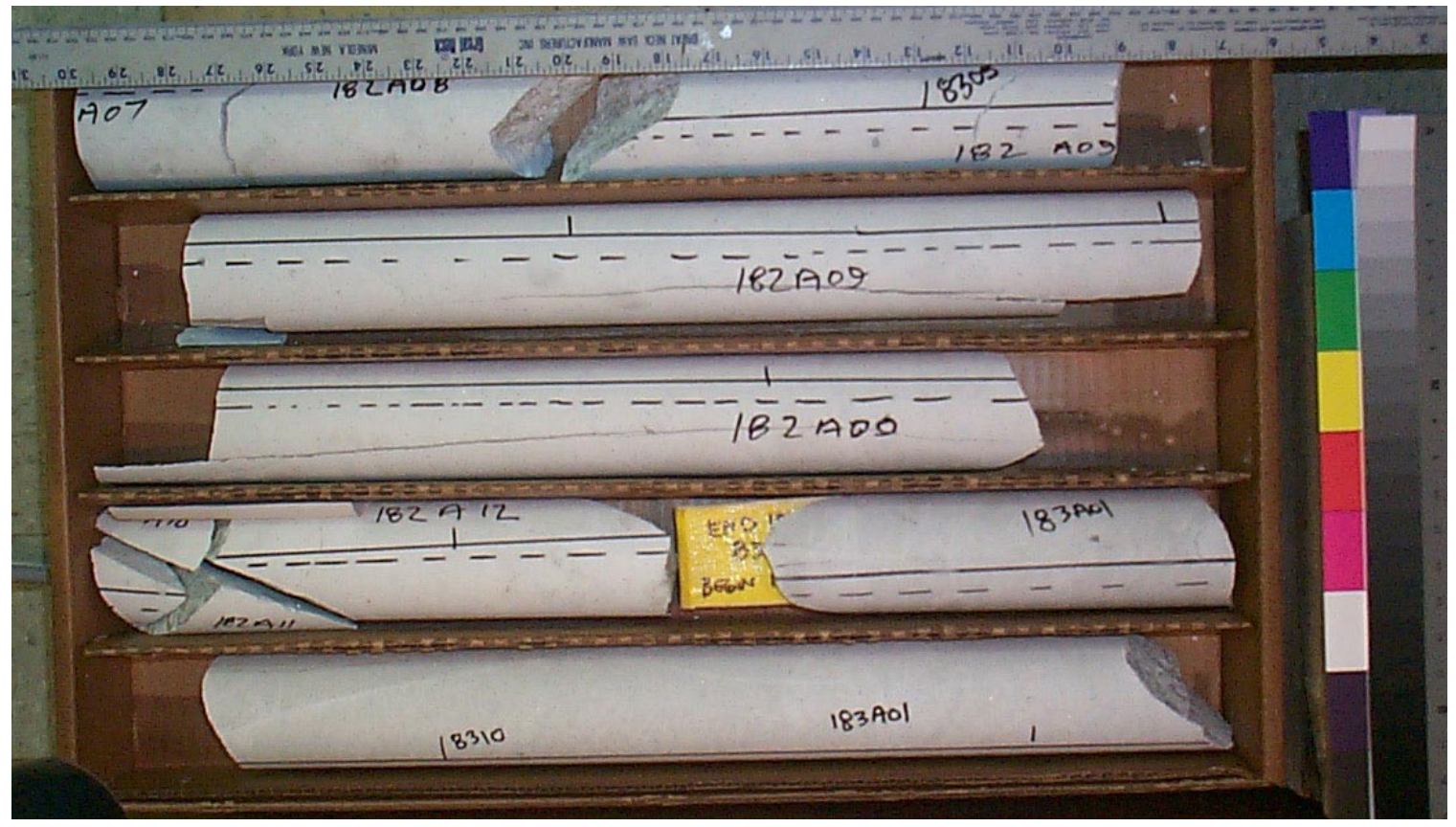

Core Scans included in this box (listed by piece going downhole):
182A072A
$182 \mathrm{~A} 0800$
$182 \mathrm{~A} 091 \mathrm{~A}$
$182 \mathrm{~A} 092 \mathrm{~A}$
$182 \mathrm{~A} 1200$
$183 \mathrm{~A} 0100$

See the "reading instructions" section of the introduction for help interpreting core box photos and core piece nomenclature 


\section{LVEW Core Box 285}

Depth Interval 8311.2'-8319.3'

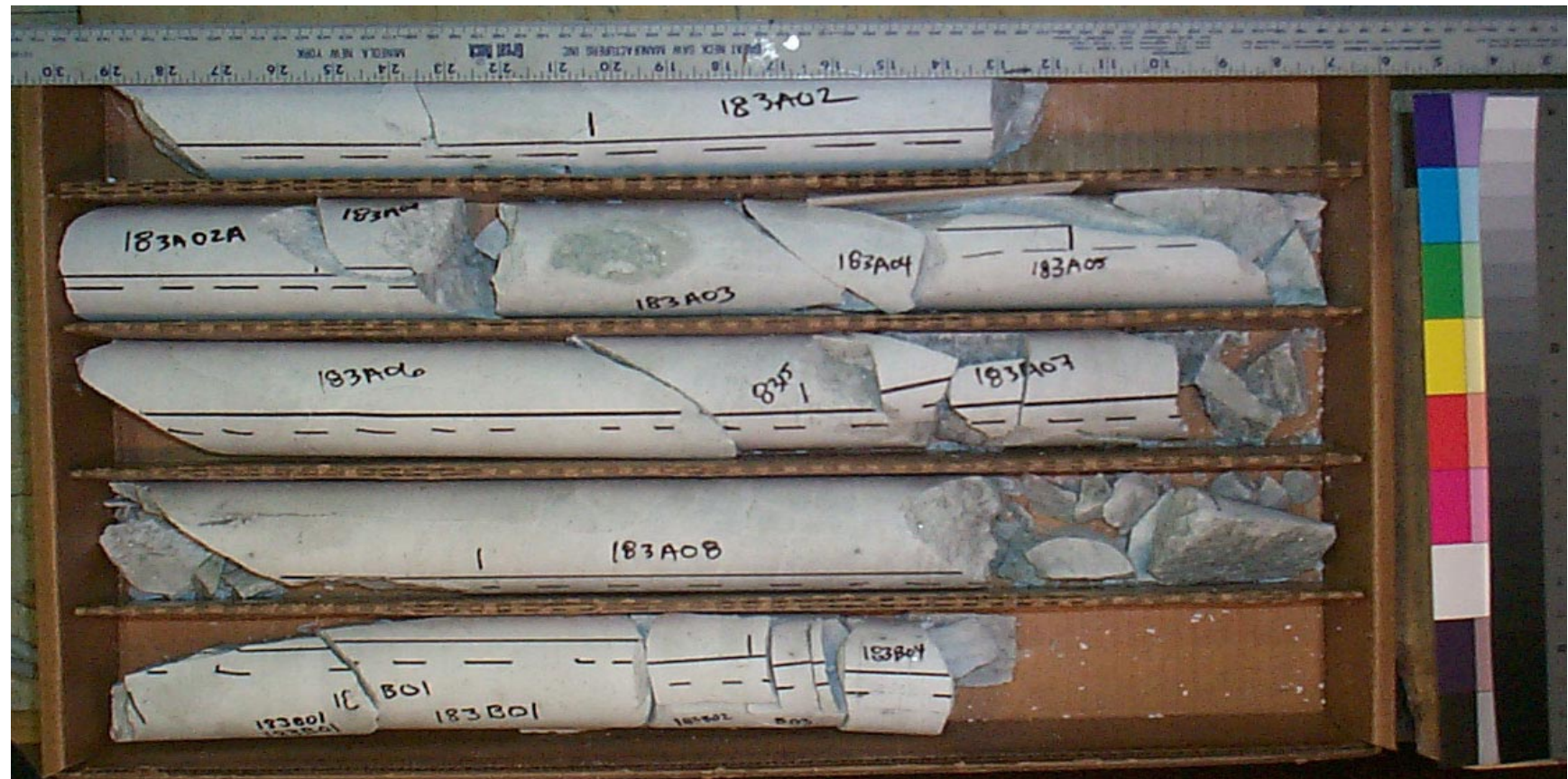

Core Scans included in this box (listed by piece going downhole):

183A020A
183A0300
183A0600
183A0700
$183 A 0800$

See the "reading instructions" section of the introduction for help interpreting core box photos and core piece nomenclature 


\section{LVEW Core Box 286}

Depth Interval 8319.3'-8324.6'

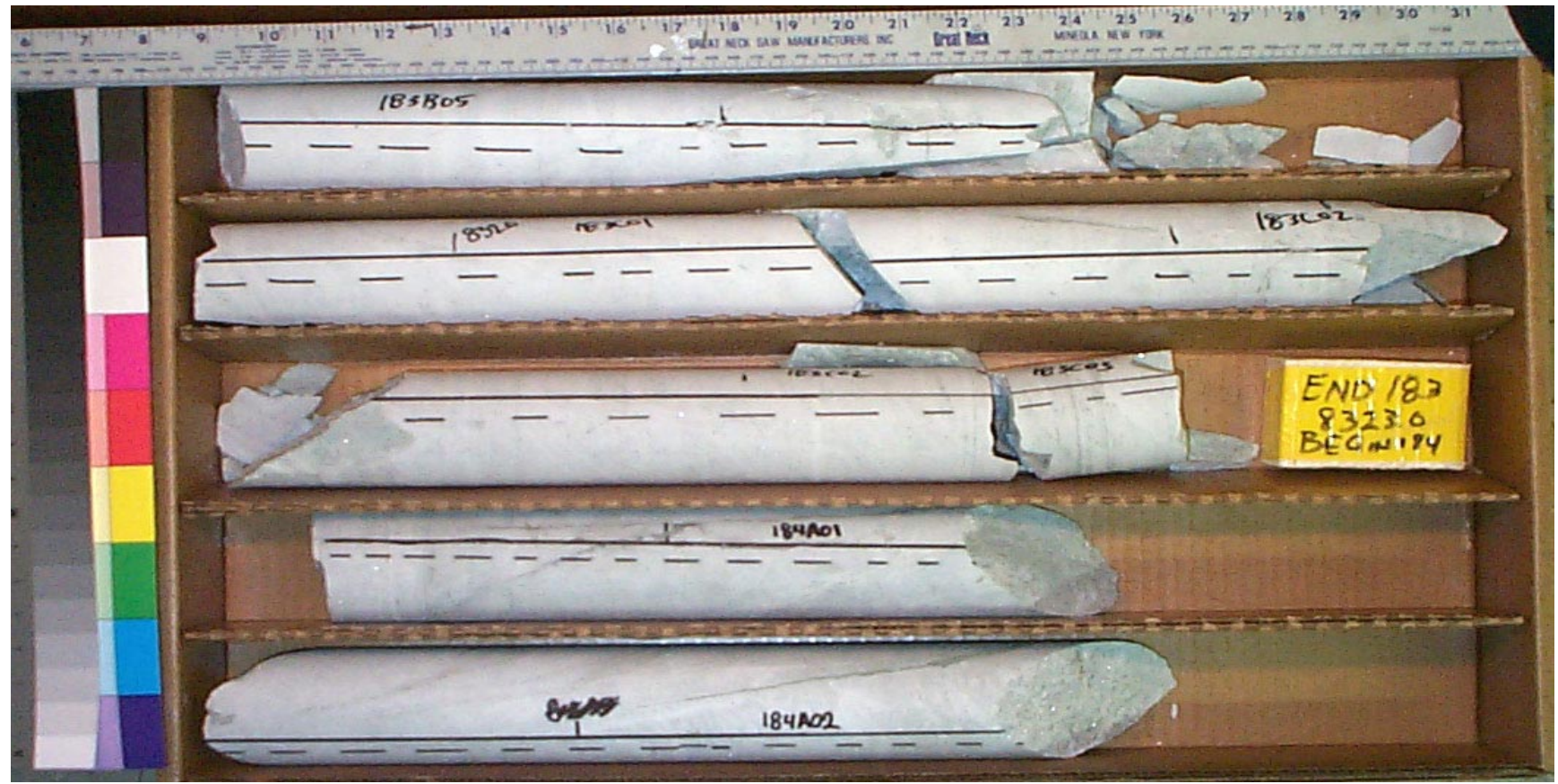

Core Scans included in this box (listed by piece going downhole):
183B0500
$183 \mathrm{C} 0100$
$183 \mathrm{C} 021 \mathrm{~A}$
$183 \mathrm{C} 022 \mathrm{~A}$
$183 \mathrm{C} 0300$
$184 \mathrm{~A} 0100$
$184 \mathrm{~A} 0200$

See the "reading instructions" section of the introduction for help interpreting core box photos and core piece nomenclature 


\section{LVEW Core Box 287}

Depth Interval 8324.6'-8332.9'

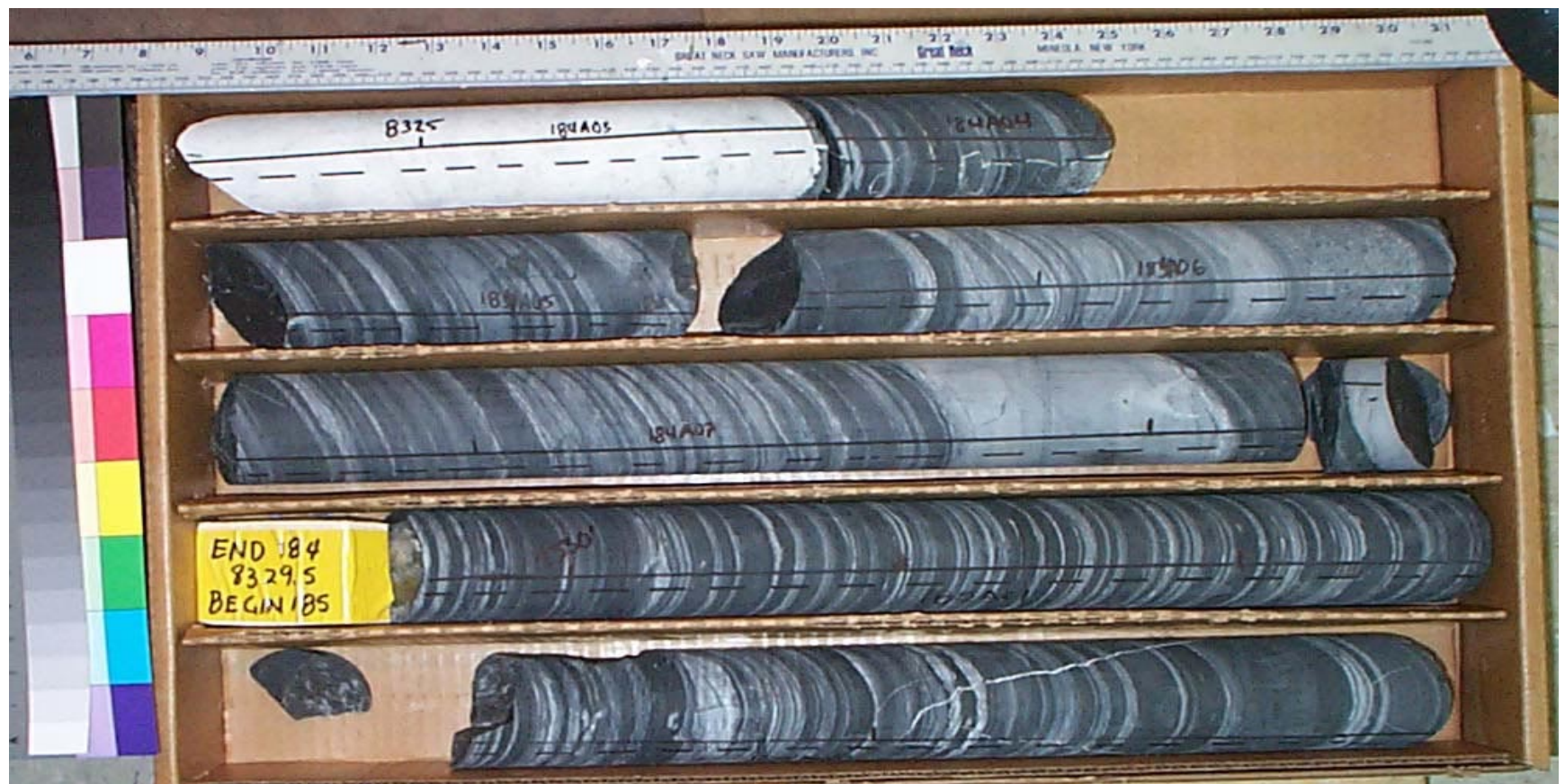

Core Scans included in this box (listed by piece going downhole):

184A0300
$184 \mathrm{~A} 0400$
184A0500
184A0600
184A0700
184A0800
185A0100
185A0200

See the "reading instructions" section of the introduction for help interpreting core box photos and core piece nomenclature 


\section{LVEW Core Box 288}

Depth Interval 8332.9'-8340.7'

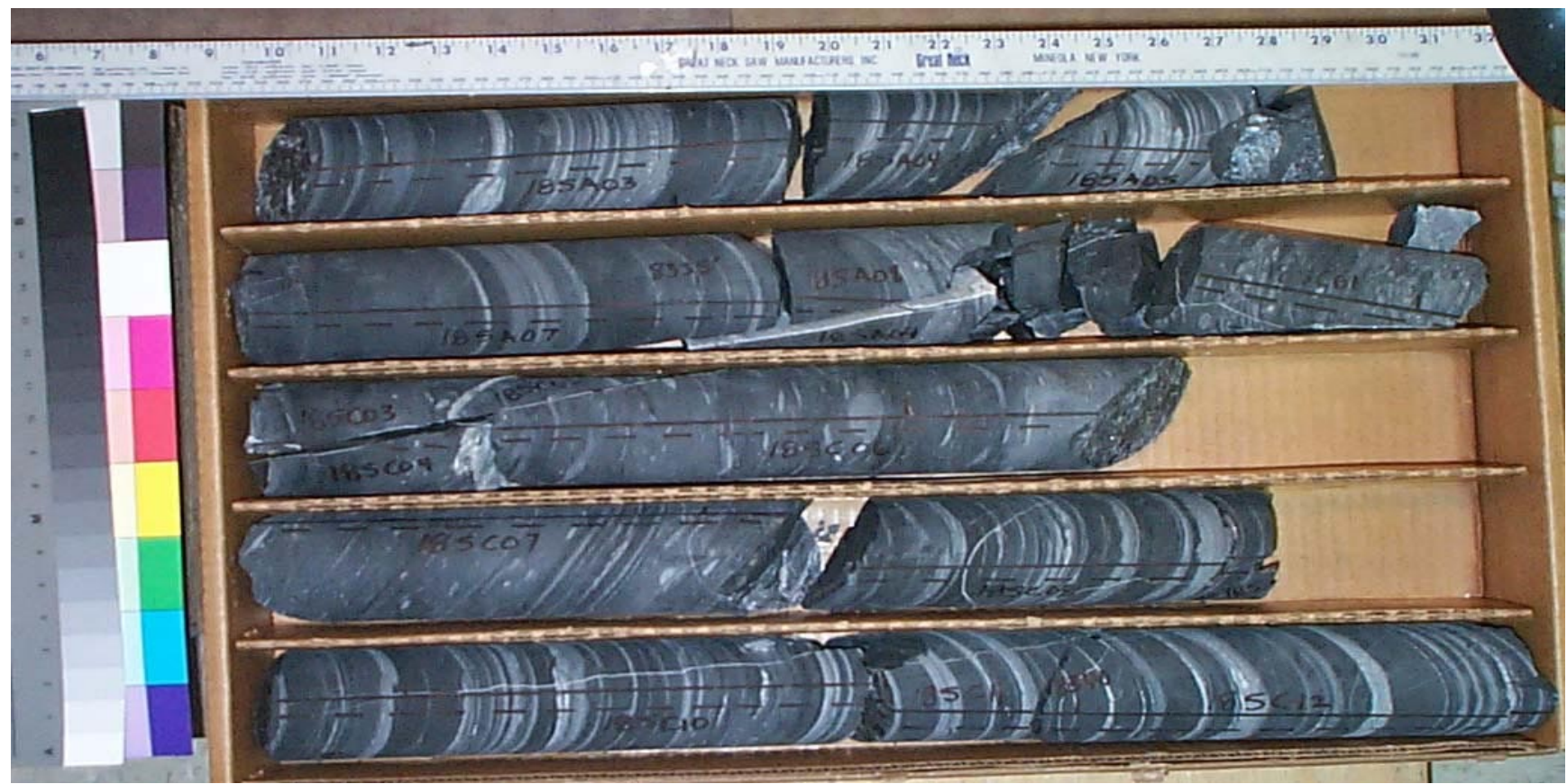

Core Scans included in this box (listed by piece going downhole):

185A0300
$185 A 0400$
$185 A 0500$
$185 A 0700$
$185 C 0600$
$185 C 0700$
$185 C 0800$
$185 C 1000$
$185 C 1100$
$185 C 1200$

See the "reading instructions" section of the introduction for help interpreting core box photos and core piece nomenclature 


\section{LVEW Core Box 289}

Depth Interval 8340.7'-8347.4'

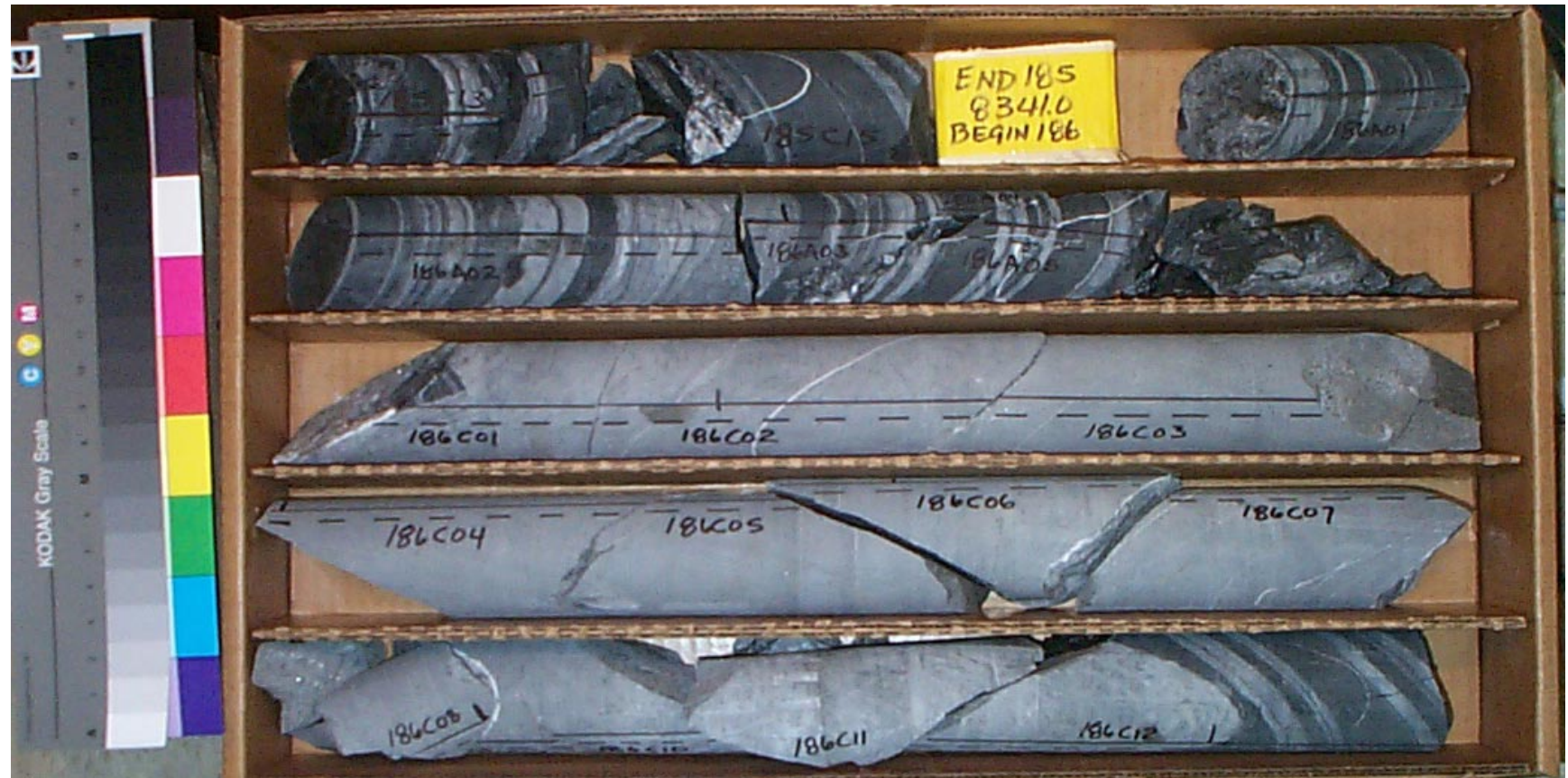

Core Scans included in this box (listed by piece going downhole):
$185 \mathrm{C} 1300$
$185 \mathrm{C} 1500$
$186 \mathrm{~A} 0100$
$186 \mathrm{~A} 0200$
$186 \mathrm{C} 0100$
$186 \mathrm{C} 0200$
$186 \mathrm{C} 0300$
$186 \mathrm{C} 0400$
$186 \mathrm{C} 0500$
$186 \mathrm{C} 0700$
$186 \mathrm{C} 1200$

See the "reading instructions" section of the introduction for help interpreting core box photos and core piece nomenclature 


\section{LVEW Core Box 290}

Depth Interval 8347.4'-8355.7'

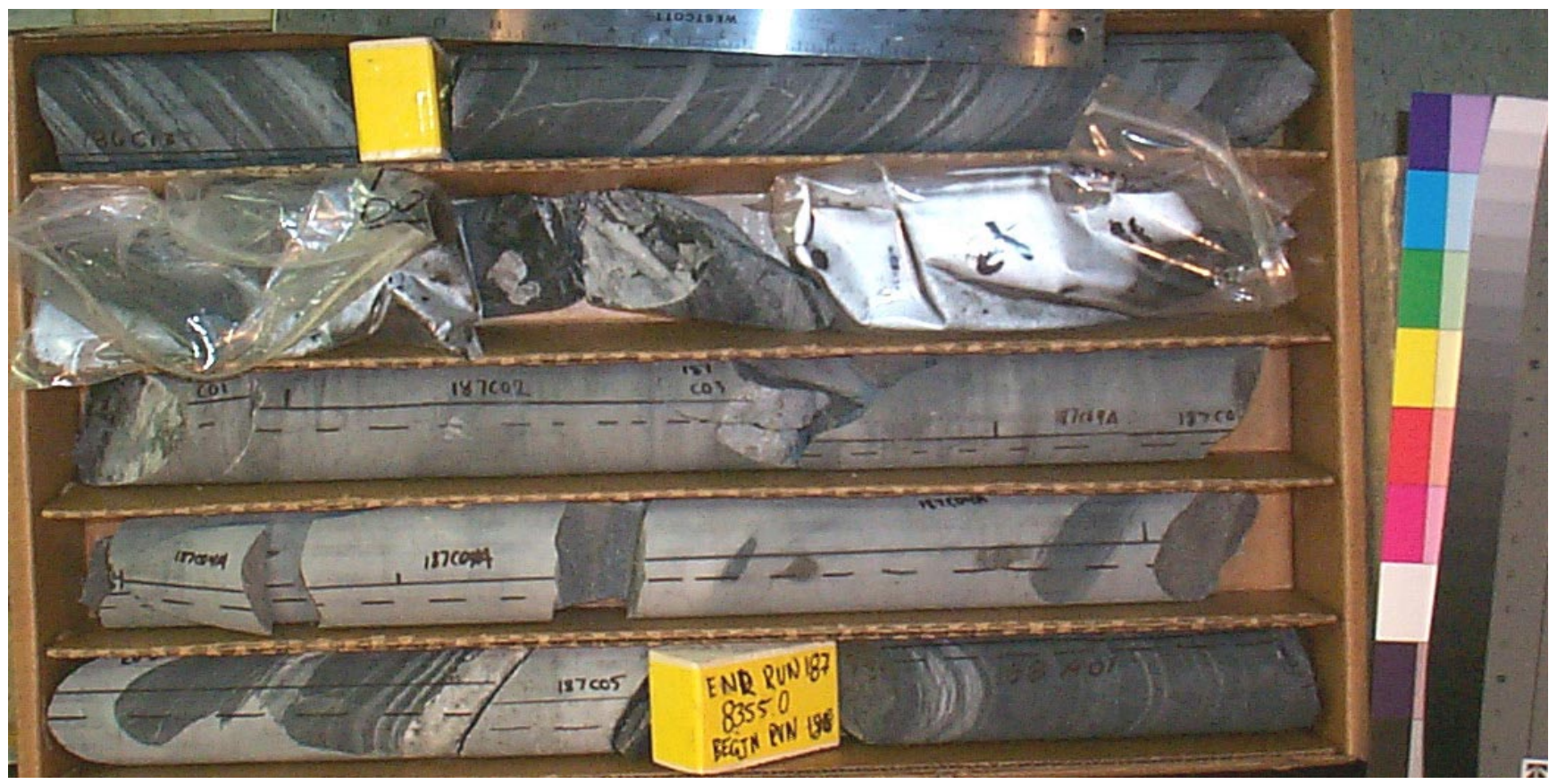

Core Scans included in this box (listed by piece going downhole):

$186 \mathrm{C} 1300$

$187 \mathrm{~A} 0100$

$187 \mathrm{C} 0100$

$187 \mathrm{C} 041 \mathrm{~A}$

$187 \mathrm{C} 042 \mathrm{~A}$

$187 \mathrm{C} 0500$

$188 \mathrm{~A} 0100$

See the "reading instructions" section of the introduction for help interpreting core box photos and core piece nomenclature 


\section{LVEW Core Box 291}

Depth Interval 8355.7'-8364.0'

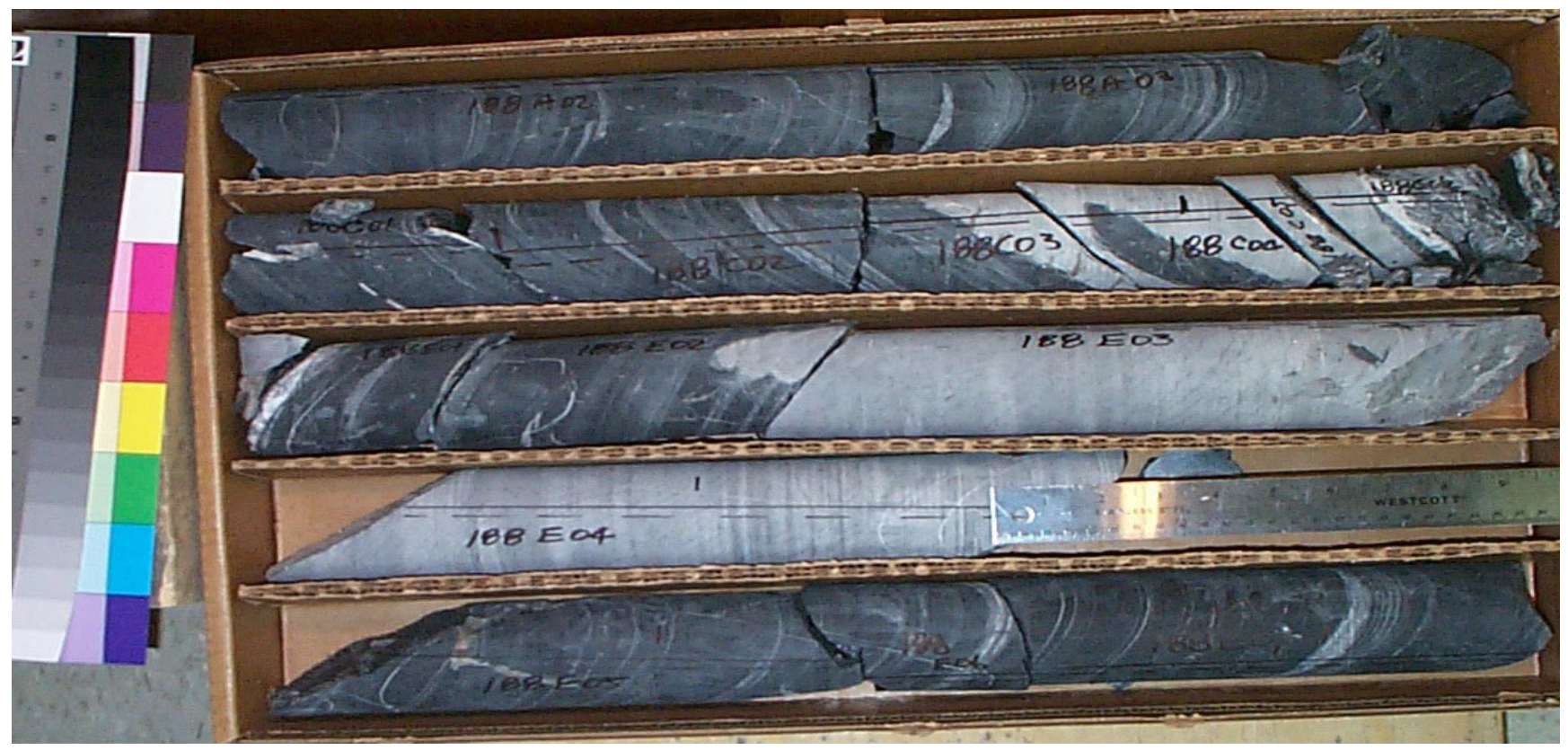

Core Scans included in this box (listed by piece going downhole):
188A0200
$188 \mathrm{~A} 0300$
$188 \mathrm{C} 0200$
$188 \mathrm{C} 0300$
$188 \mathrm{C} 0400$
$188 \mathrm{C} 0600$
$188 \mathrm{E} 0100$
188E0200
$188 \mathrm{E} 0300$
$188 \mathrm{E} 0400$
$188 \mathrm{E} 0500$
$188 \mathrm{E} 0600$
188E0700

See the "reading instructions" section of the introduction for help interpreting core box photos and core piece nomenclature 


\section{LVEW Core Box 292}

Depth Interval 8364.0'-8371.1'

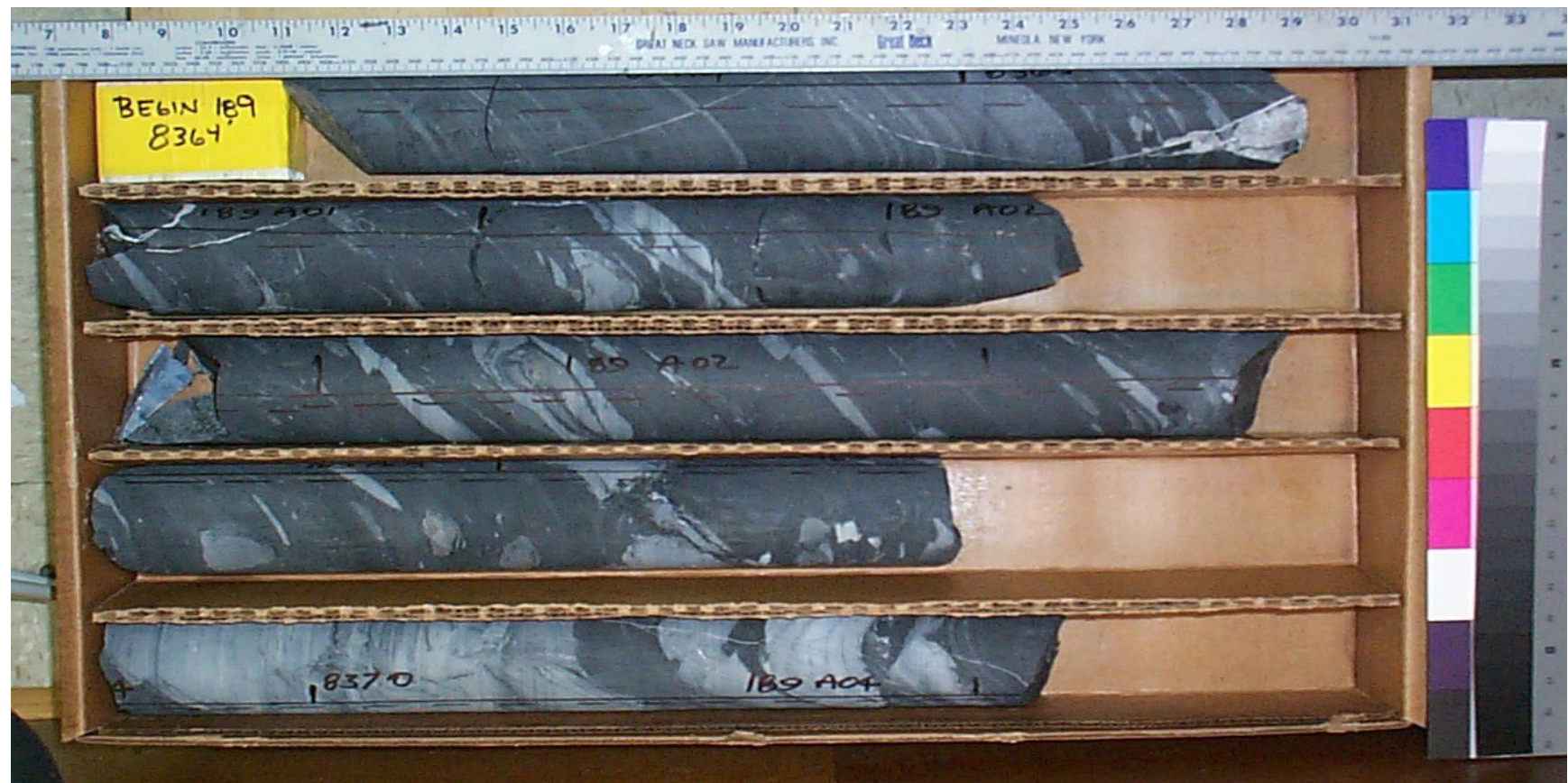

Core Scans included in this box (listed by piece going downhole):

189A010A
189A020A
189A0300
189A040A

See the "reading instructions" section of the introduction for help interpreting core box photos and core piece nomenclature 


\section{LVEW Core Box 293}

Depth Interval 8371.1'-8379.2'

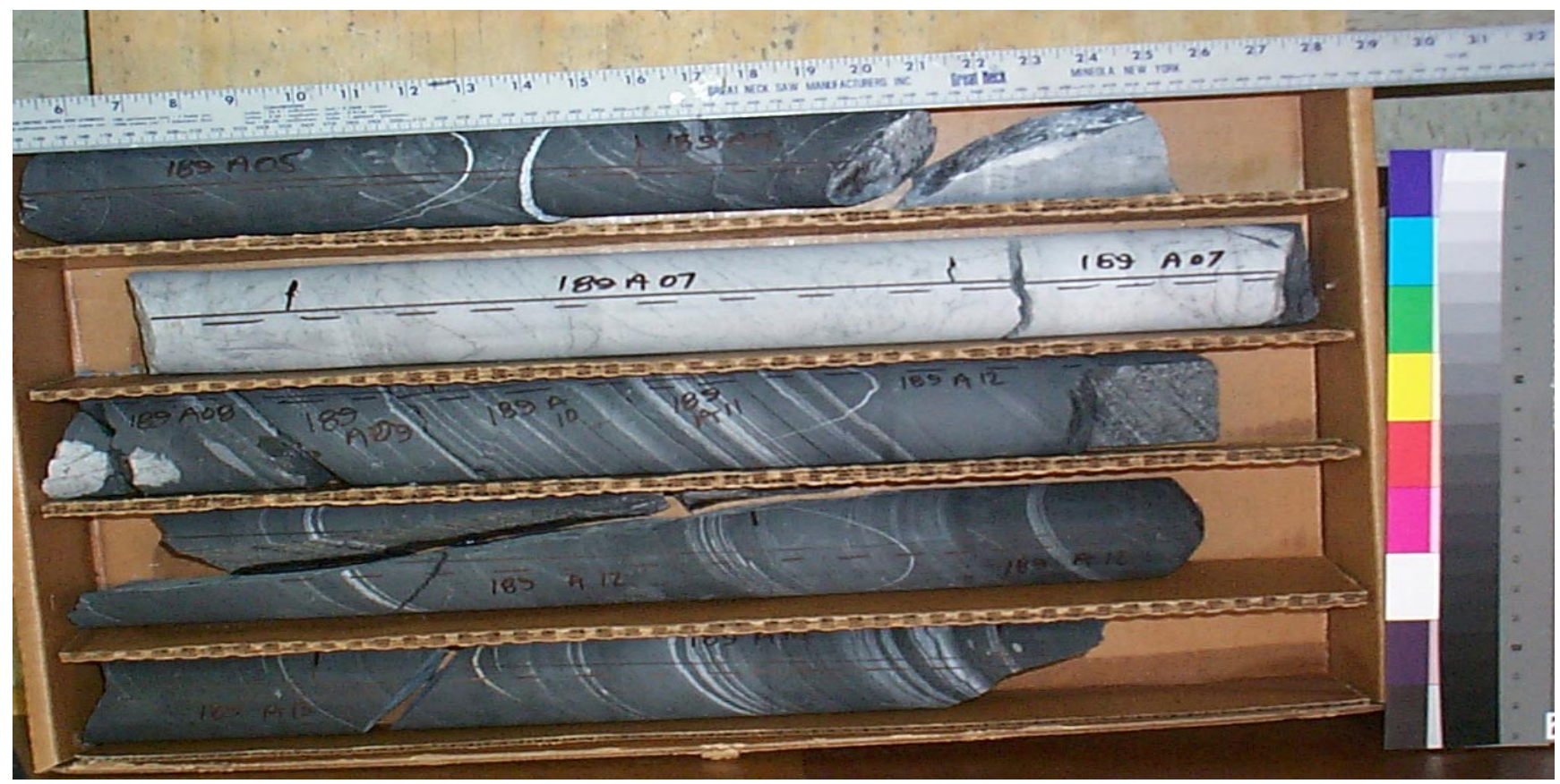

Core Scans included in this box (listed by piece going downhole):

189A0500
189A0600
189A070A
189A0800
189A0900
189A1000
189A1100
189A120A
189A1300
189A1400

See the "reading instructions" section of the introduction for help interpreting core box photos and core piece nomenclature 


\section{LVEW Core Box 294}

Depth Interval 8379.2'-8387.7'

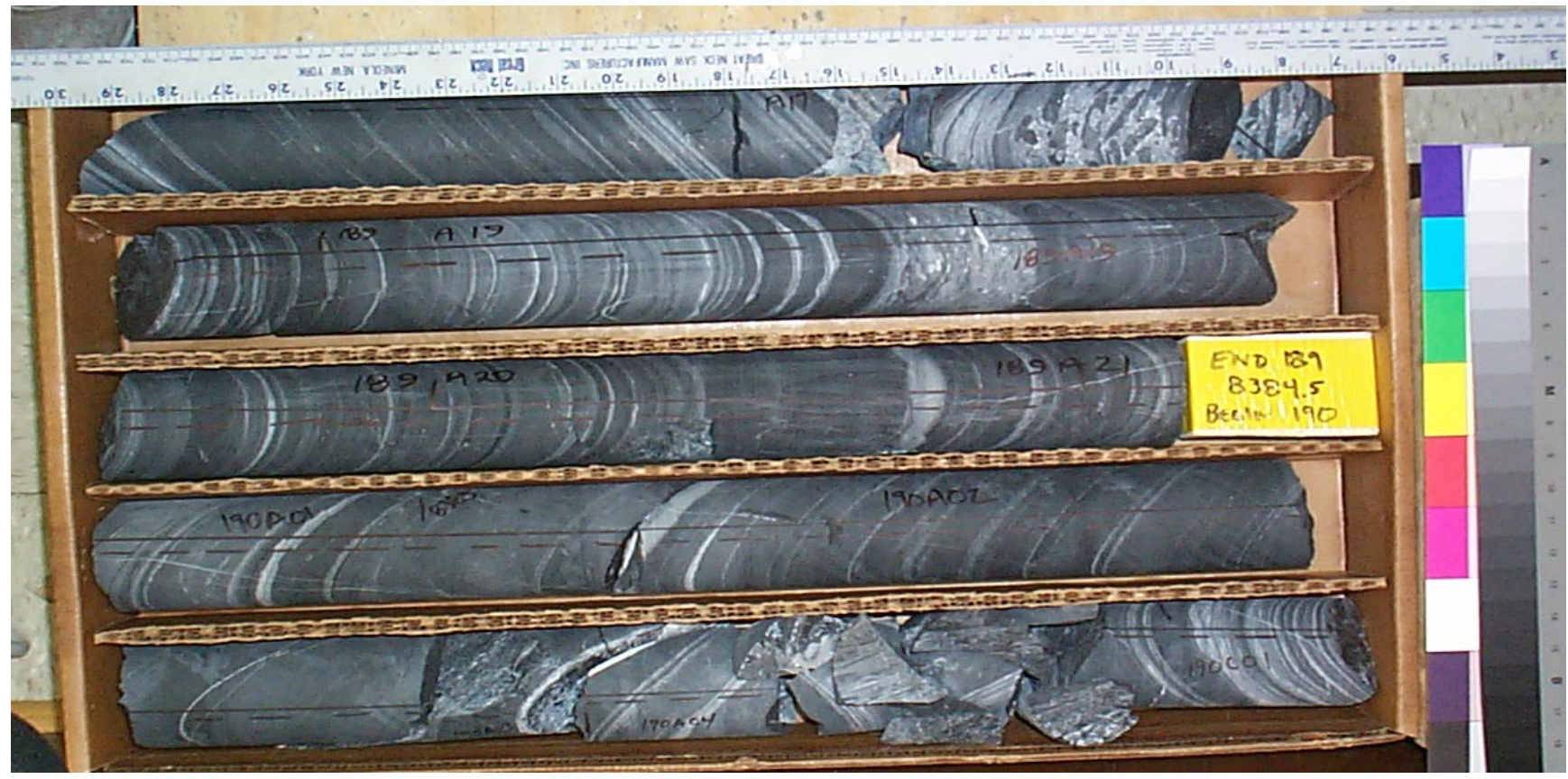

Core Scans included in this box (listed by piece going downhole):
189A1500
189A1800
189A1900
189A2000
189A2100
$190 \mathrm{~A} 0100$
190A020A
$190 \mathrm{C} 0100$

See the "reading instructions" section of the introduction for help interpreting core box photos and core piece nomenclature 


\section{LVEW Core Box 295}

Depth Interval 8387.7'-8396.1'

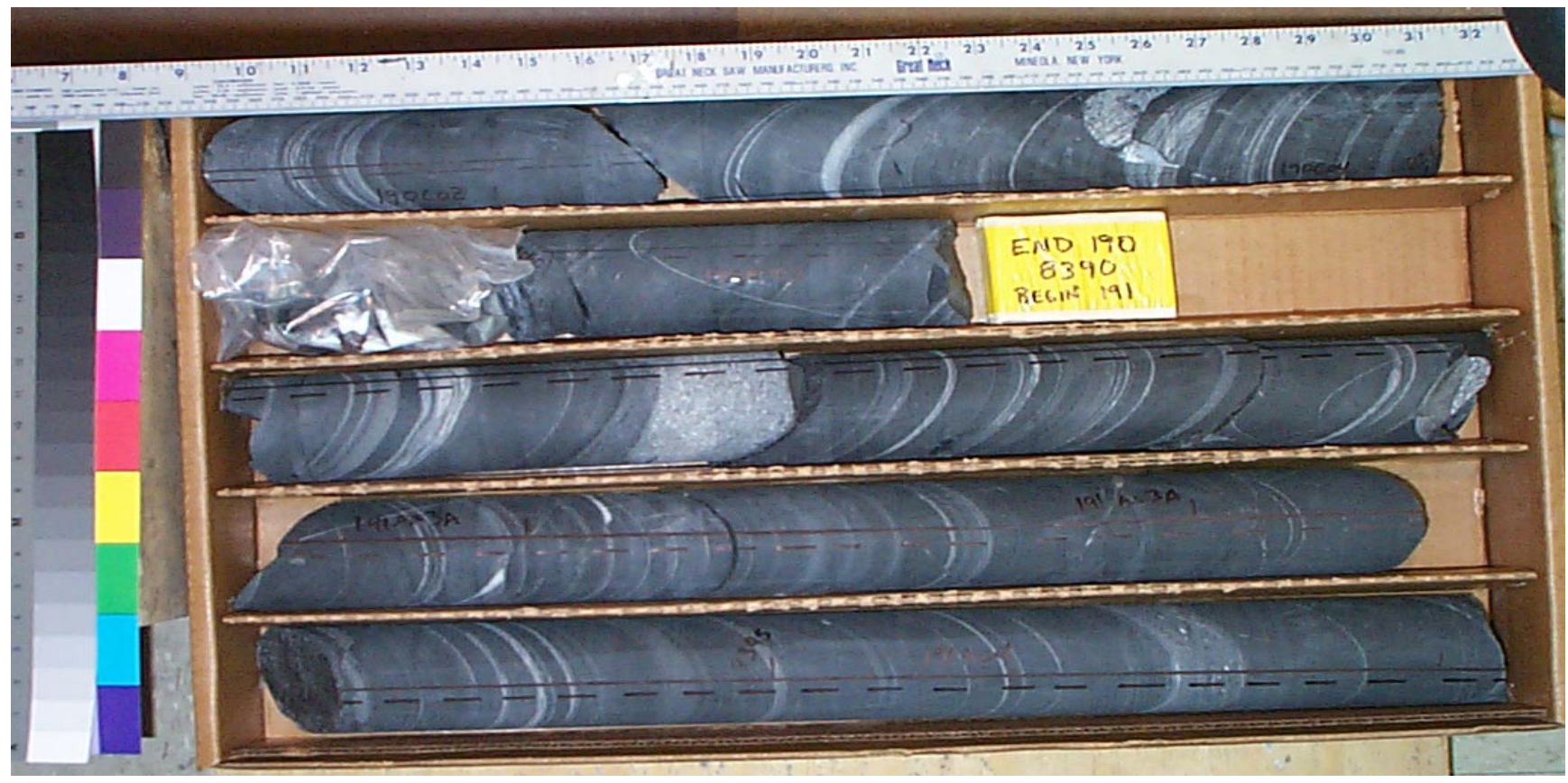

Core Scans included in this box

(listed by piece going downhole):
$190 \mathrm{C02} 200$
$190 \mathrm{C0} 300$
190E0200
$191 \mathrm{~A} 0100$
191A020A
191A030A
$191 \mathrm{~A} 0400$

See the "reading instructions" section of the introduction for help interpreting core box photos and core piece nomenclature 


\section{LVEW Core Box 296}

Depth Interval 8396.1'-8404.4'

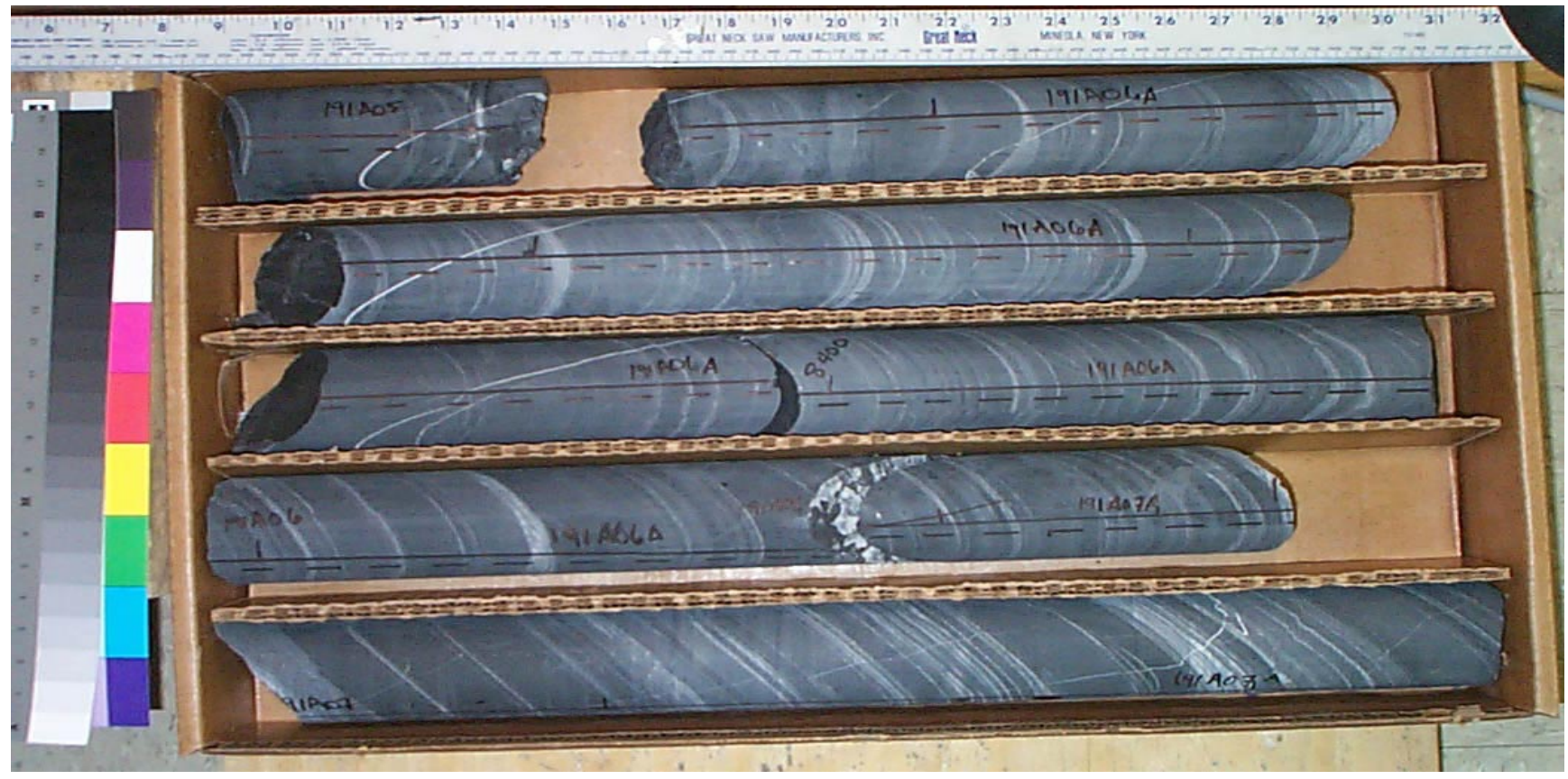

Core Scans included in this box (listed by piece going downhole):

191A0500
191A061A
191A062A
191A070A

See the "reading instructions" section of the introduction for help interpreting core box photos and core piece nomenclature 


\section{LVEW Core Box 297}

\section{Depth Interval 8404.4'-8412.2}

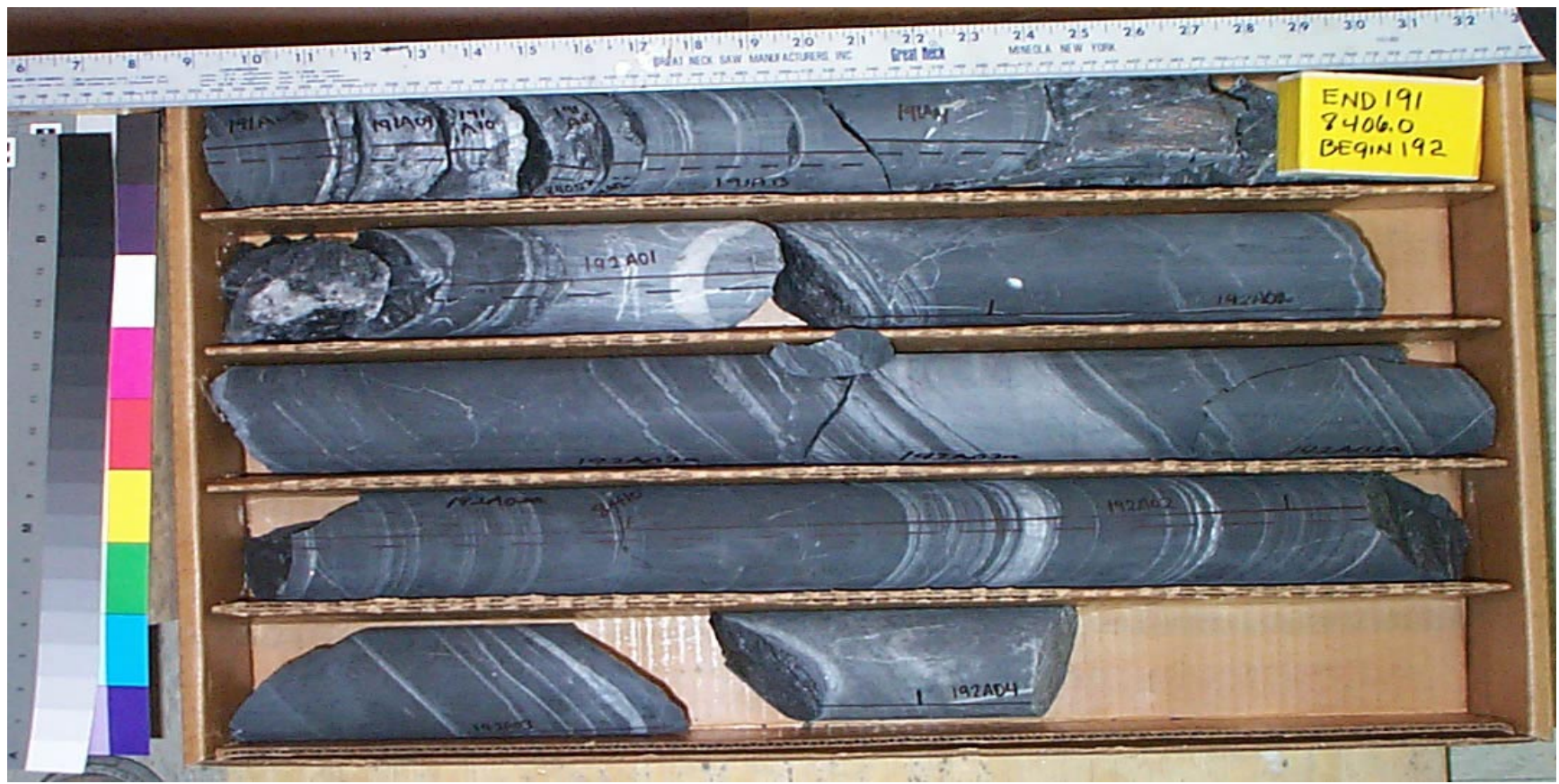

Core Scans included in this box (listed by piece going downhole):

191A0800
$191 A 1300$
192A0100
192A021A
192A022A
192A023A
192A0300
192A0400

See the "reading instructions" section of the introduction for help interpreting core box photos and core piece nomenclature 


\section{LVEW Core Box 298}

Depth Interval 8412.2'-8420.1'

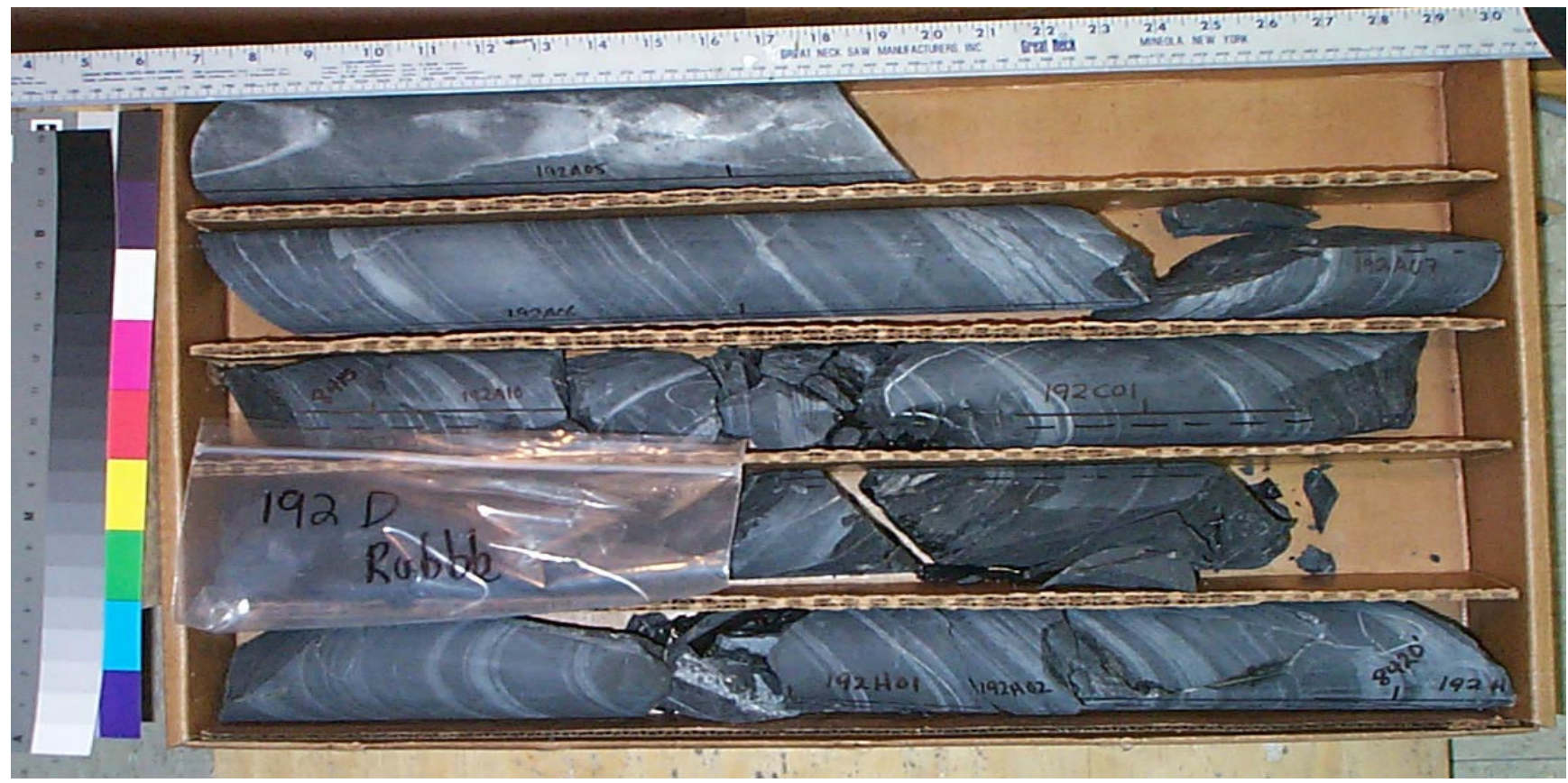

Core Scans included in this box (listed by piece going downhole):

192A0500
192A0600
192C0100
192G0100
192H040A

See the "reading instructions" section of the introduction for help interpreting core box photos and core piece nomenclature 


\section{LVEW Core Box 299}

Depth Interval 8420.1'-8427.5'

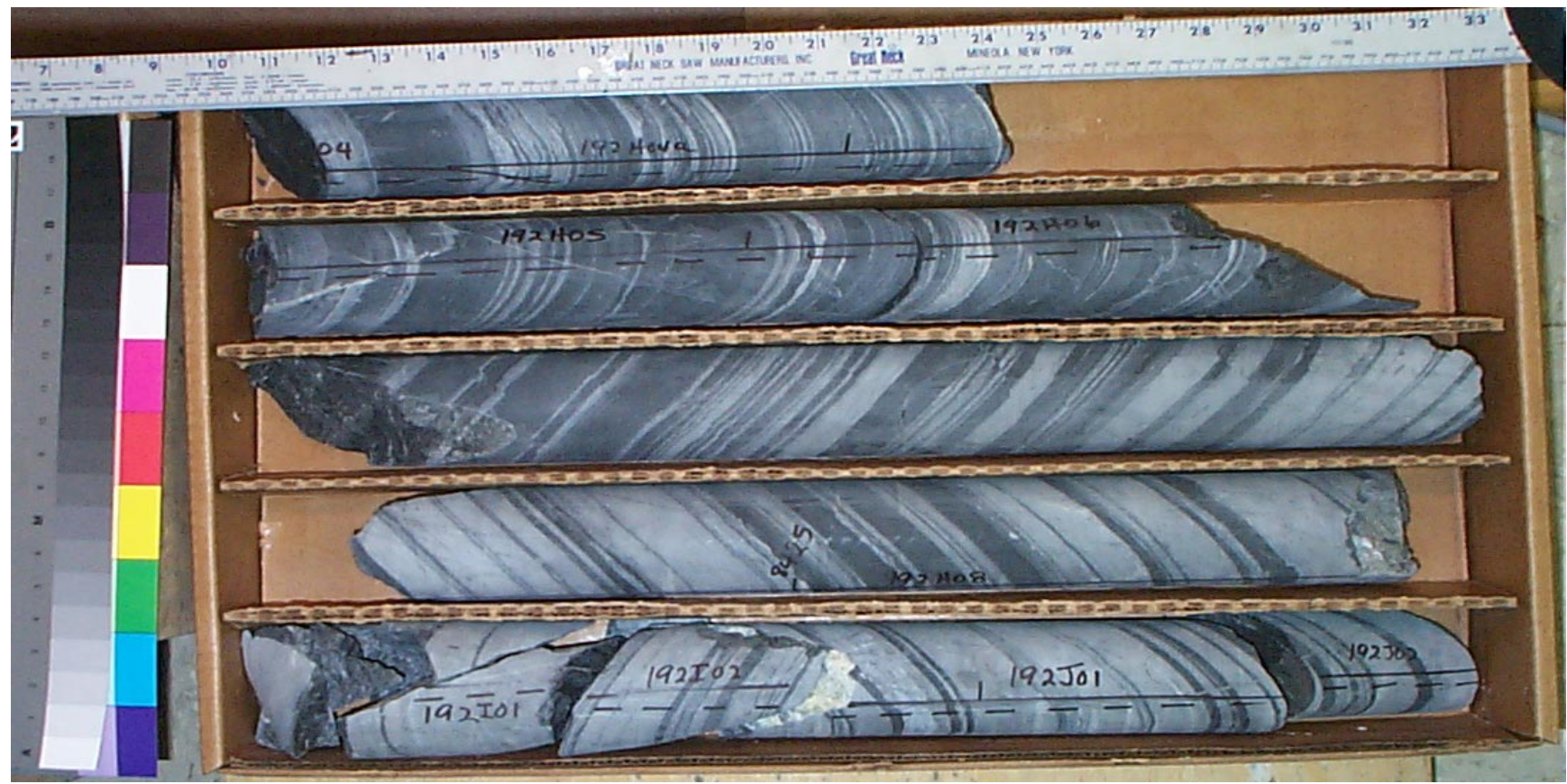

Core Scans included in this box (listed by piece going downhole):
$192 \mathrm{H} 040 \mathrm{~A}$
$192 \mathrm{H} 0500$
$192 \mathrm{H} 0600$
$192 \mathrm{H} 0700$
$192 \mathrm{H} 0800$
192J0100

See the "reading instructions" section of the introduction for help interpreting core box photos and core piece nomenclature 


\section{LVEW Core Box 300}

Depth Interval 8427.5'-8435.1'

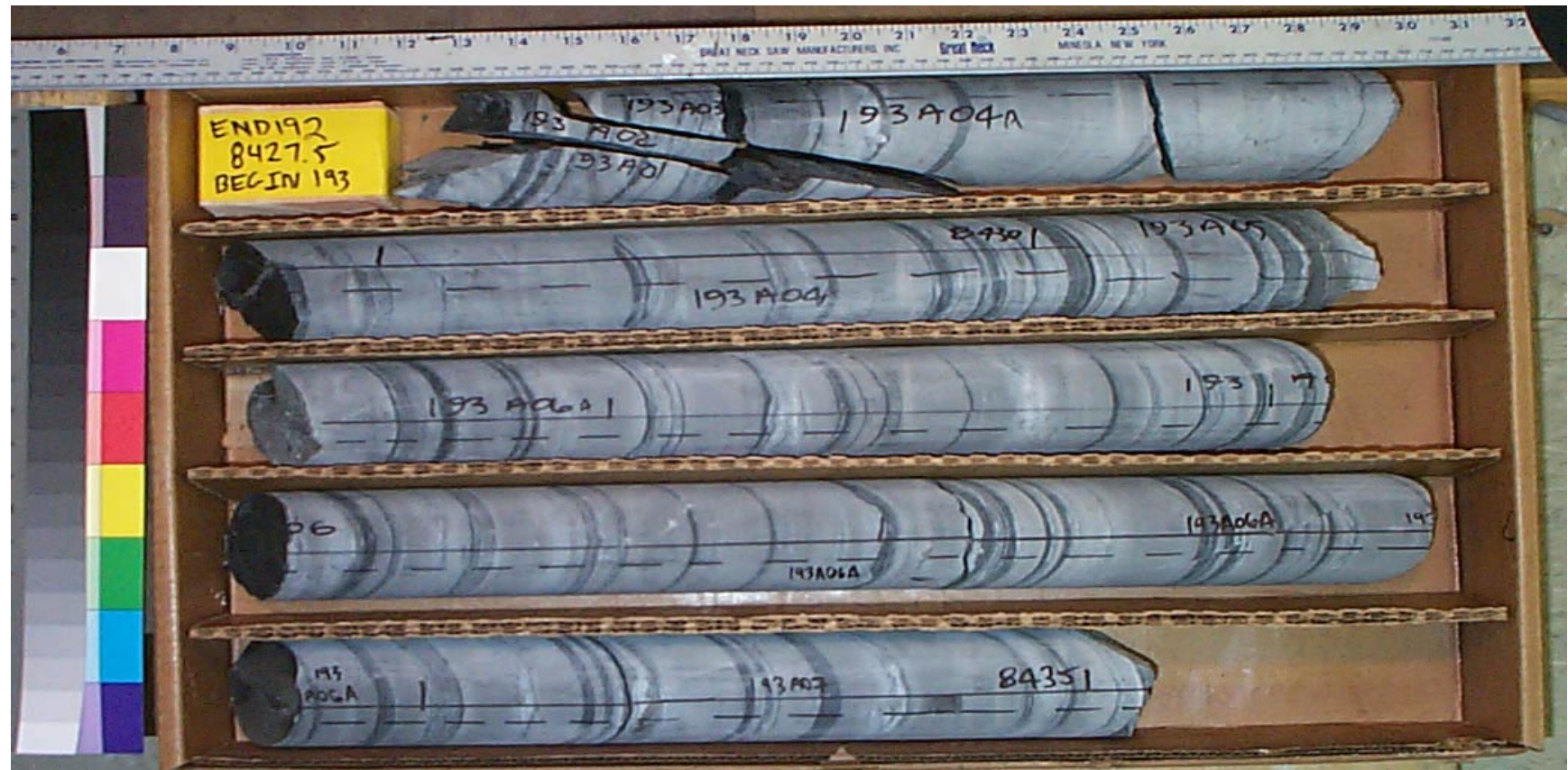

Core Scans included in this box (listed by piece going downhole):

193A040A
193A0500
193A061A
193A062A
193A0700

See the "reading instructions" section of the introduction for help interpreting core box photos and core piece nomenclature 


\section{LVEW Core Box 301}

\section{Depth Interval 8435.1'-8444.0'}

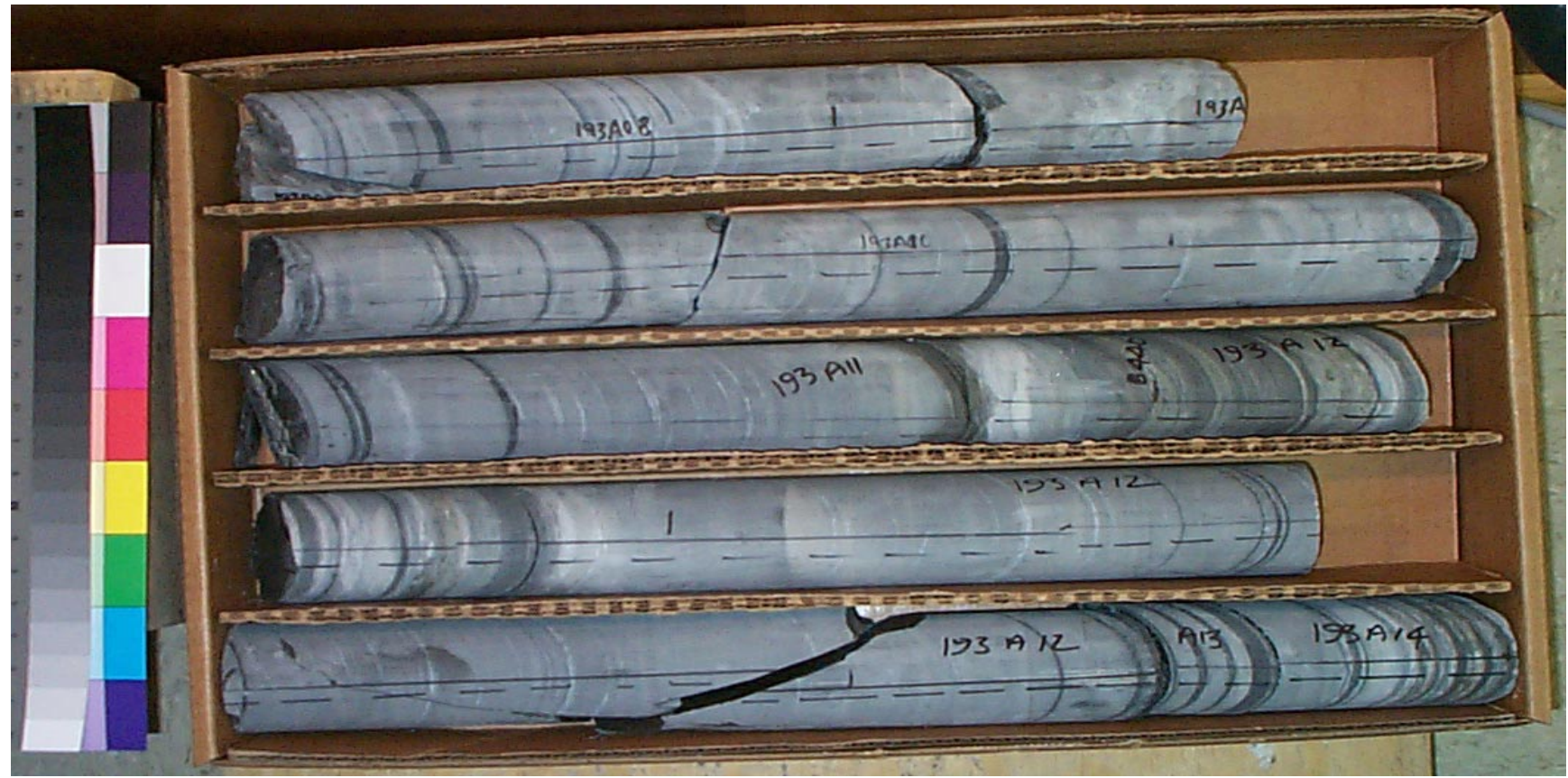

Core Scans included in this box (listed by piece going downhole):

$$
\begin{aligned}
& \text { 193A0800 } \\
& \text { 193A090A } \\
& \text { 193A1000 } \\
& \text { 193A1100 } \\
& \text { 193A1200 } \\
& \text { 193A1400 }
\end{aligned}
$$

See the "reading instructions" section of the introduction for help interpreting core box photos and core piece nomenclature 


\section{LVEW Core Box 302}

Depth Interval 8444.0'-8452.6'

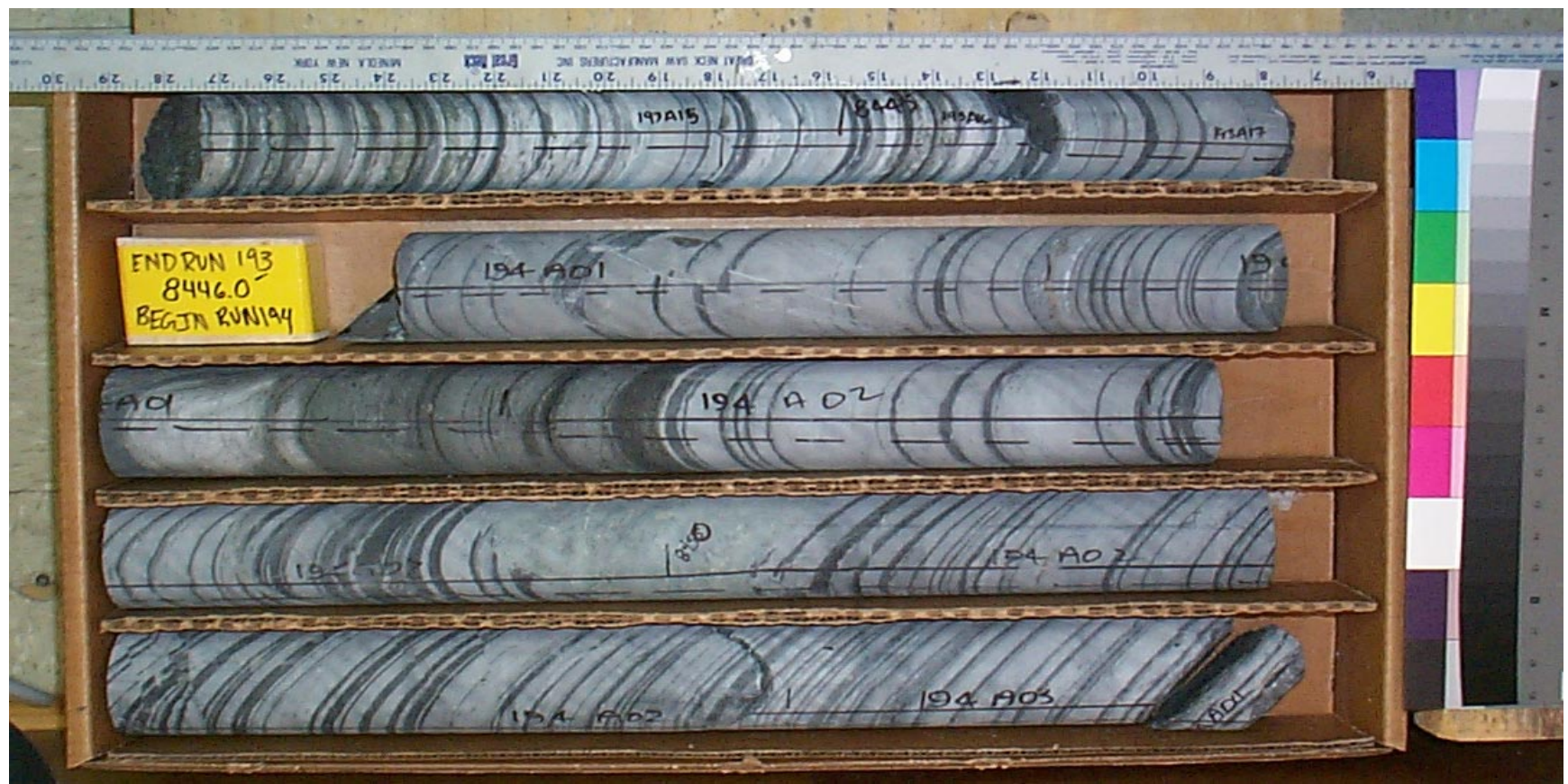

Core Scans included in this box (listed by piece going downhole):

193A1500
193A1600
193A1700
194A010A
194A021A
194A022A
194A0300

See the "reading instructions" section of the introduction for help interpreting core box photos and core piece nomenclature 


\section{LVEW Core Box 303}

Depth Interval 8452.6'-8460.5'

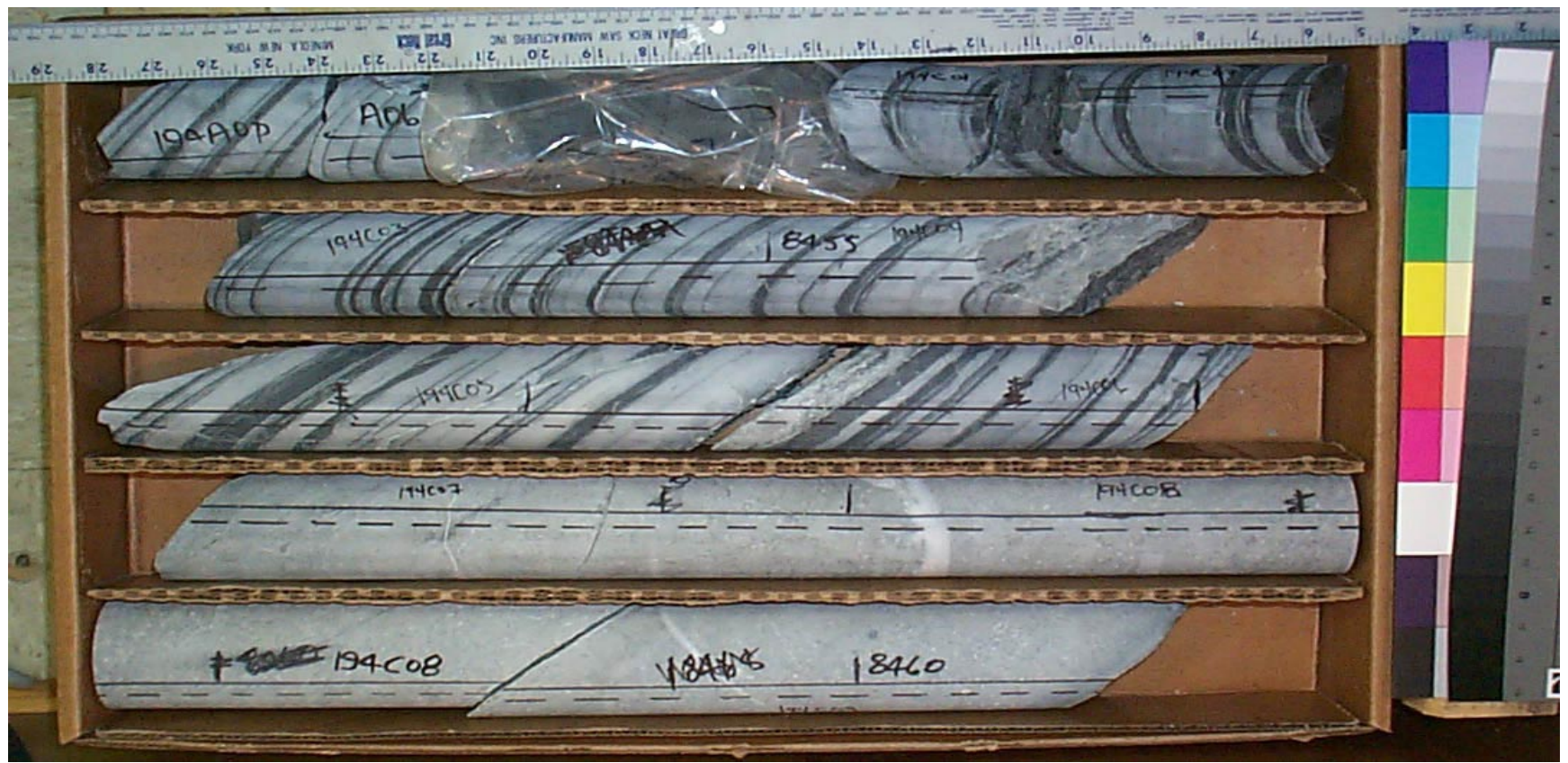

Core Scans included in this box (listed by piece going downhole):

194A0500
$194 A 0600$
$194 C 0200$
$194 C 0300$
$194 C 0400$
$194 C 0500$
$194 C 0600$
$194 C 0700$
$194 C 0800$
$194 C 0900$

See the "reading instructions" section of the introduction for help interpreting core box photos and core piece nomenclature 


\section{LVEW Core Box 304}

Depth Interval 8460.5'-8468.3'

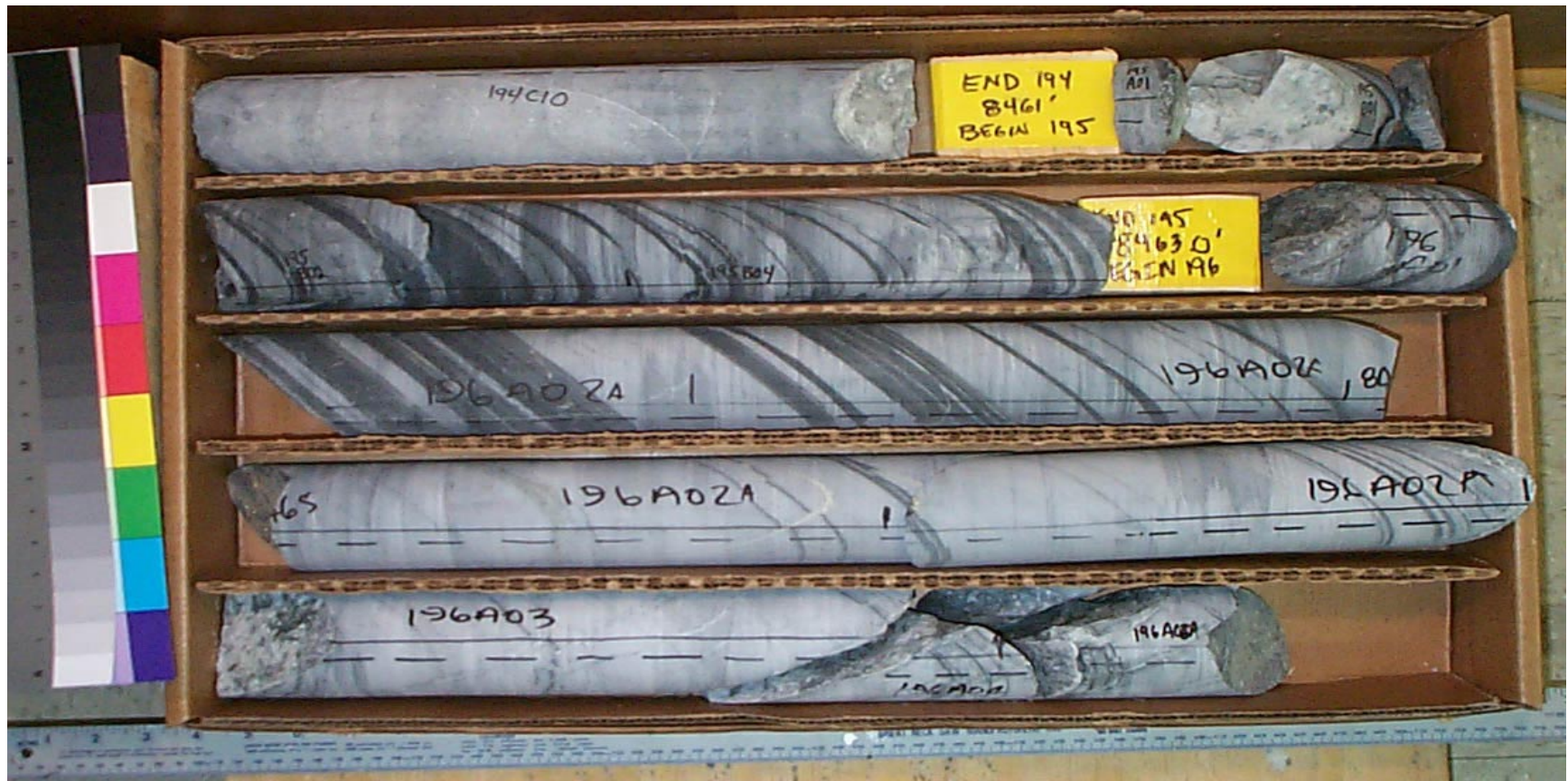

Core Scans included in this box (listed by piece going downhole):

194C1000
195B0400
196A021A
196A022A
196A0300
196A060A

See the "reading instructions" section of the introduction for help interpreting core box photos and core piece nomenclature 


\section{LVEW Core Box 305}

Depth Interval 8468.3'-8475.5'

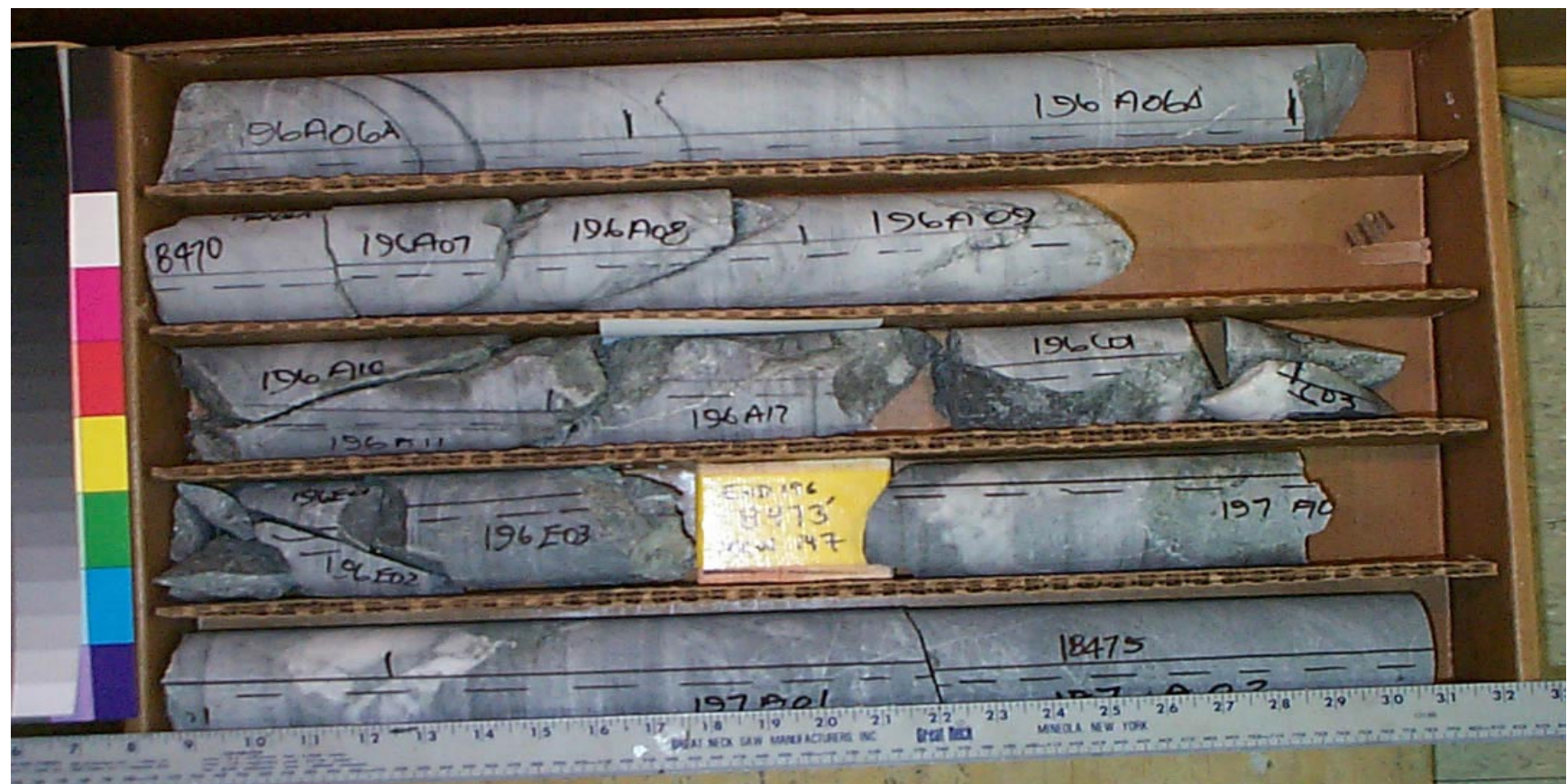

Core Scans included in this box (listed by piece going downhole):
196A060A
$196 \mathrm{~A} 0700$
$197 \mathrm{~A} 0100$
197A0200

See the "reading instructions" section of the introduction for help interpreting core box photos and core piece nomenclature 


\section{LVEW Core Box 306}

Depth Interval 8475.5'-8483.3'

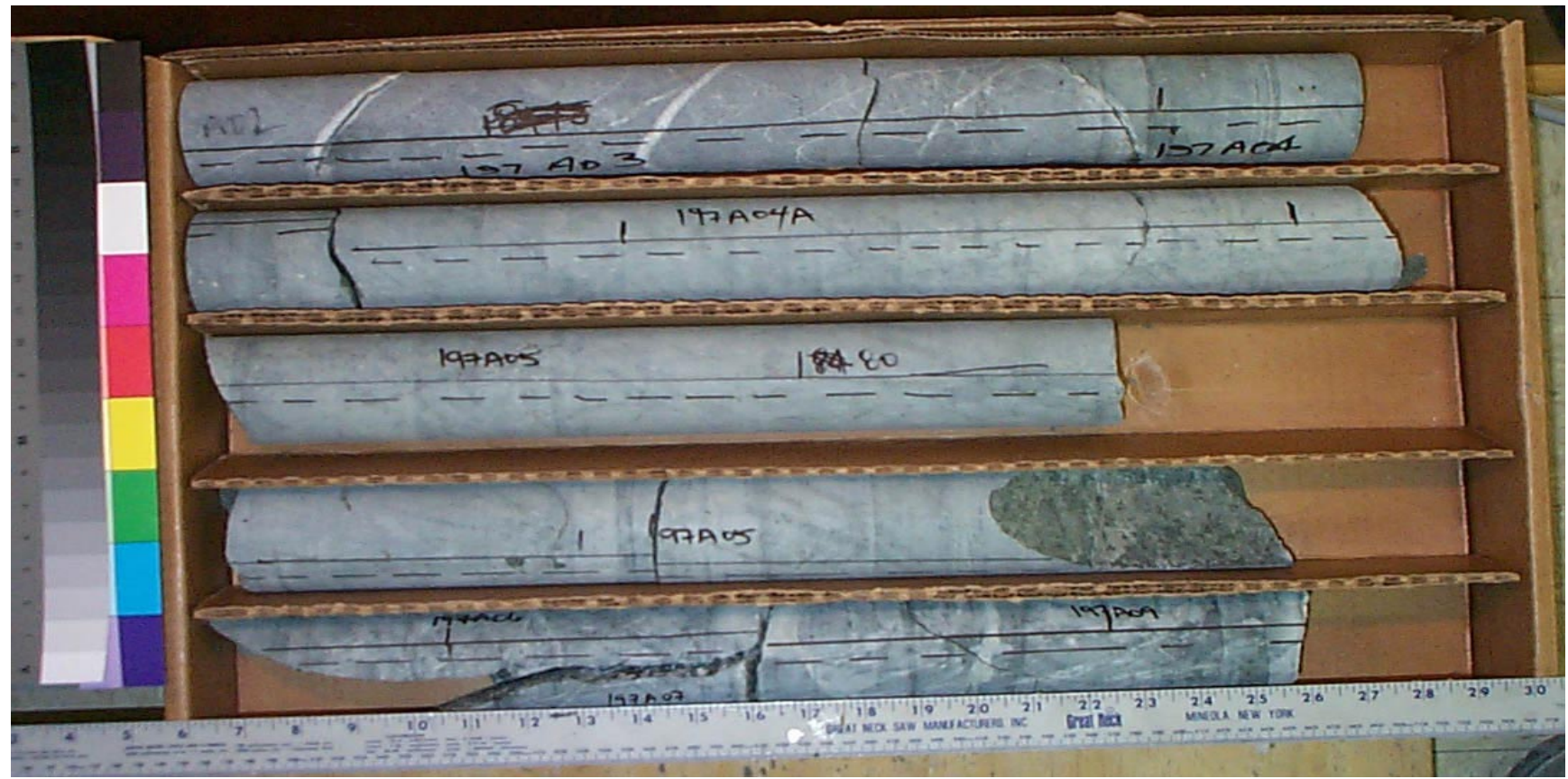

Core Scans included in this box (listed by piece going downhole):

197A0300
197A040A
197A0500
197A090A

See the "reading instructions" section of the introduction for help interpreting core box photos and core piece nomenclature 


\section{LVEW Core Box 307}

Depth Interval 8483.3'-8493.0'

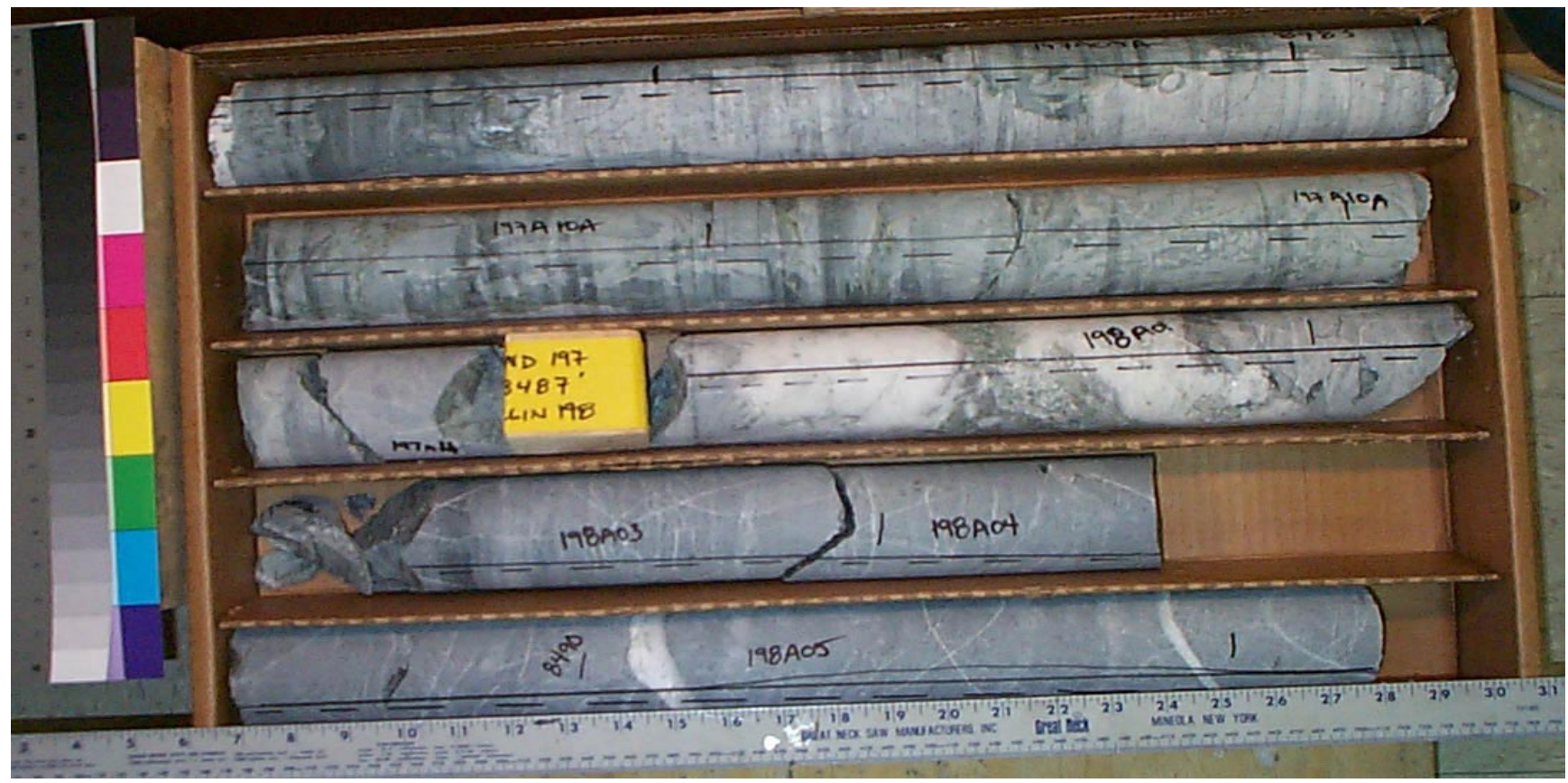

Core Scans included in this box (listed by piece going downhole):
197A090A
197A100A
197A1100
198A0100
198A0300
198A0400
198A0500

See the "reading instructions" section of the introduction for help interpreting core box photos and core piece nomenclature 


\section{LVEW Core Box 308}

Depth Interval 8493.0'-8498.9'

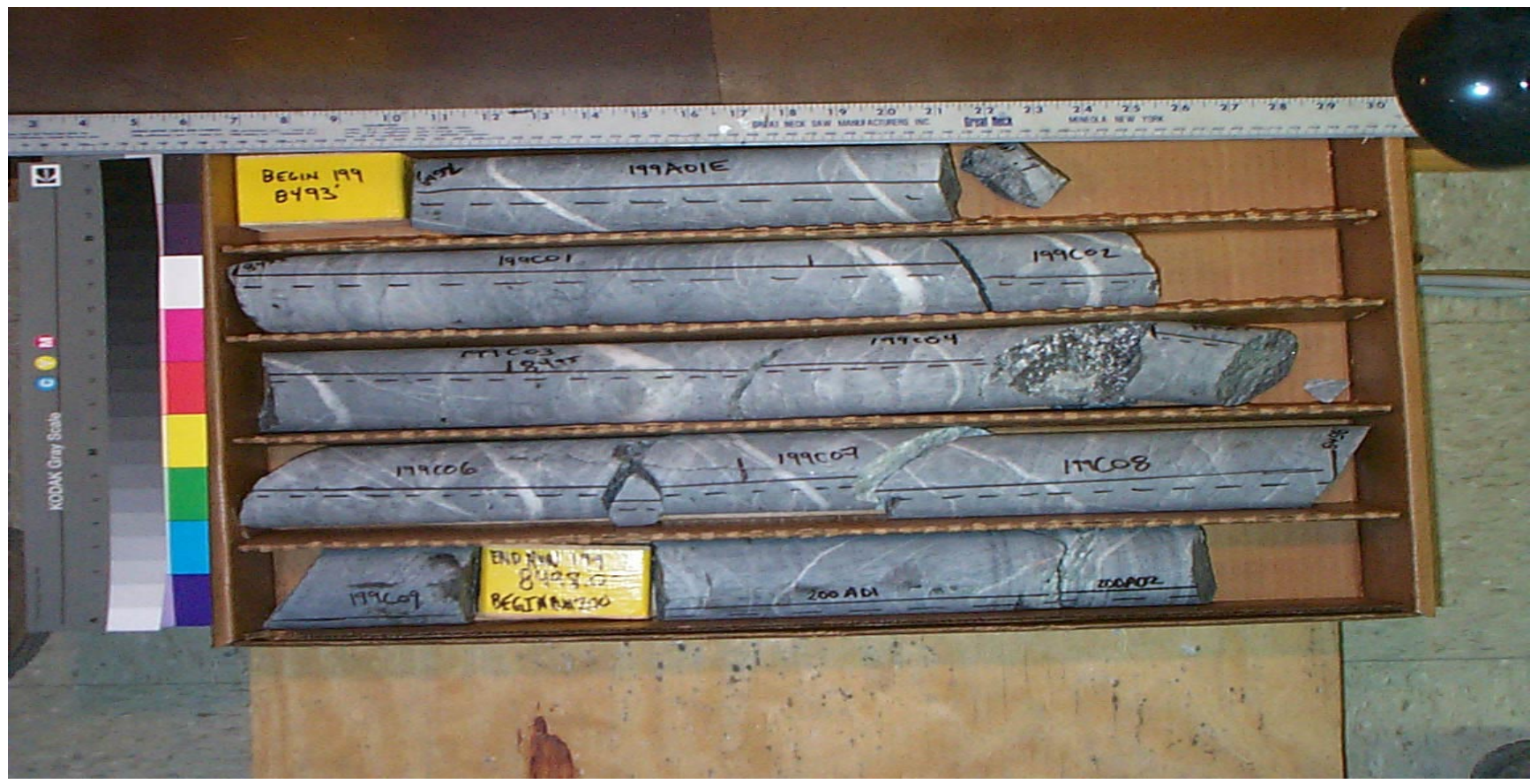

Core Scans included in this box (listed by piece going downhole):
$199 C 0100$
$199 \mathrm{C0200}$
$199 \mathrm{C0300}$
$199 \mathrm{C0400}$
199C0600
$199 \mathrm{C0700}$
19960800
199C0900
200A0100
200A0200

See the "reading instructions" section of the introduction for help interpreting core box photos and core piece nomenclature 


\section{Stratigraphic Column for LVEW Phase III, page 4}

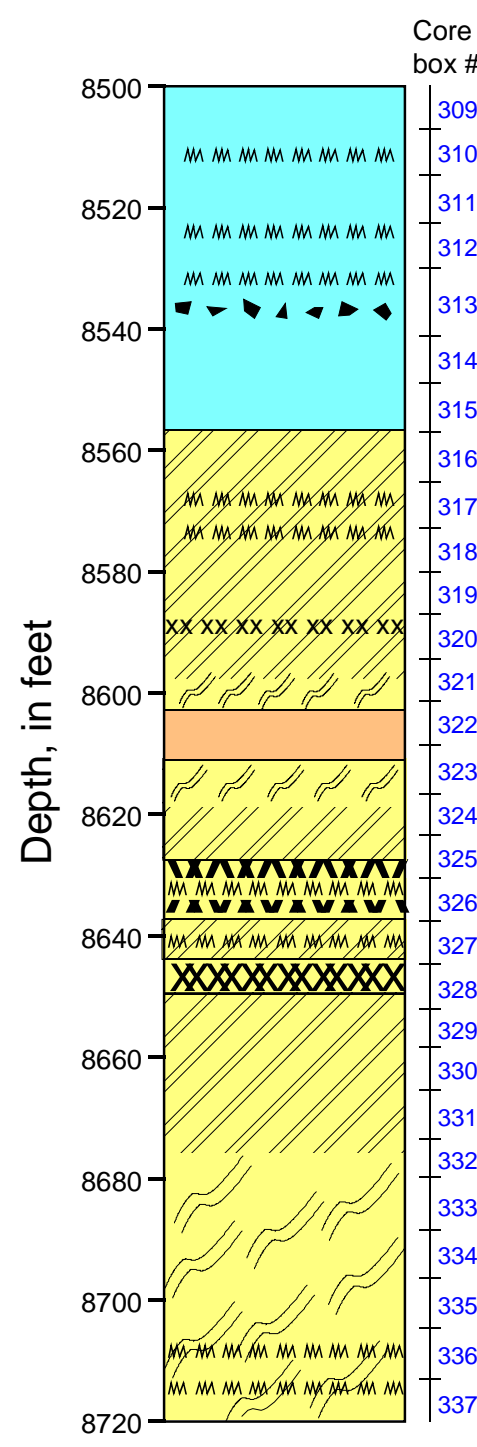

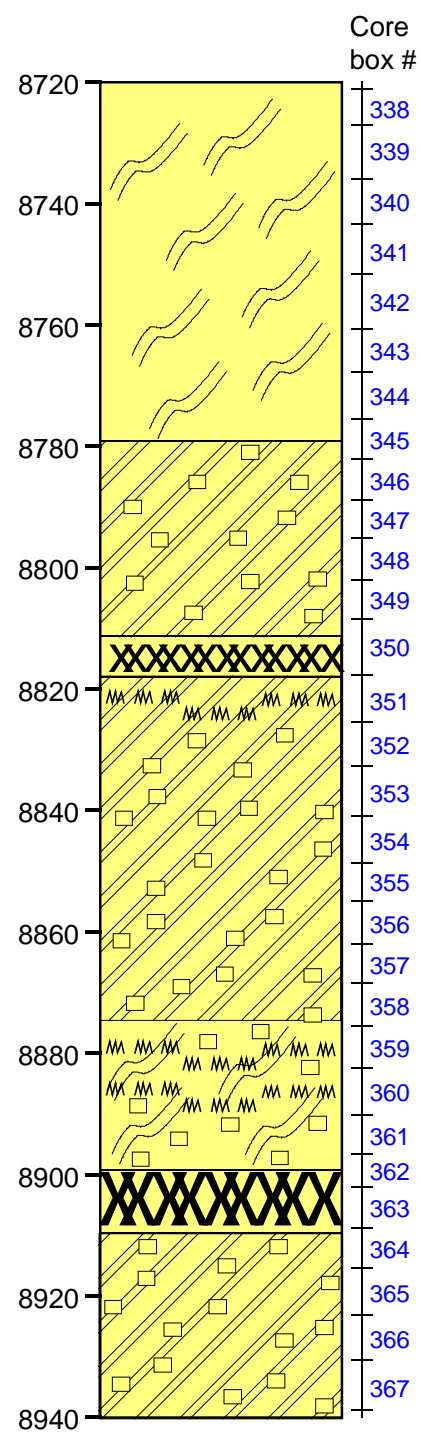

\section{fault gouge}

hydrothermal crystallization, mylotinization fault gouge

banded metapelite - dip $\sim 40^{\circ}-50^{\circ}$

severe deformation - veins of calcite, chlorite, epidote, pyrite

Core

quartzite - massive

open hydrothermal veins - fresh, breccia - healed with massive

metapelite - graphitic, siliceous

high grade hydrothermal zone

fault gouge calcareous meta-sandstone banding begins ductile folding due to healed

\section{Explanation}

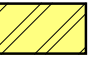

Metapelite with banding

Hornfels

Metapelite with ductile deformation

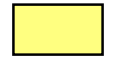

Metapelite no banding

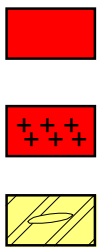

Quartzite

Calc-silicate
Intrusion

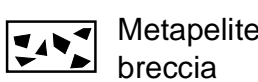

Intrusion-

metamorphosed

Boudinage

deformation severe deformation

increase in metamorphic grade to banded pelitic hornfels - garnet, hornblende, wollastonite

\section{fault gouge}

hydrothermal fractures abundant andalucite(?), marcasite in fractures

\section{fracturing/folding}

hydrothermal veining -

calcite, epidote, chlorite, quartz

open veining and fault gouge
M M M Hydrothermal veins/fractures

$x x x x$ Fault gouge

口 2nd generation garnets 


\section{LVEW Core Box 309}

Depth Interval 8498.9'-8507.0'

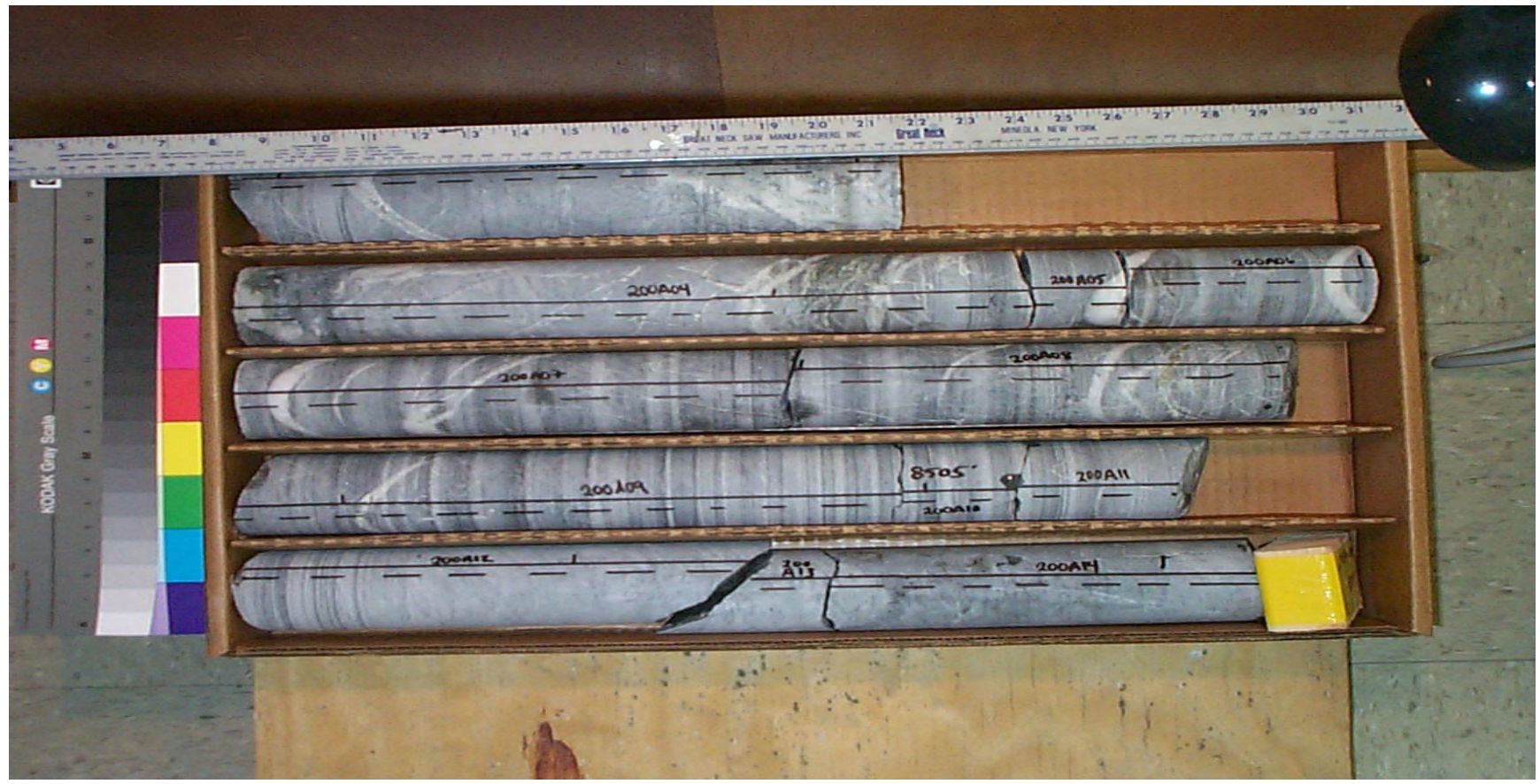

Core Scans included in this box (listed by piece going downhole):
200A0300
200A0400
200A0500
200A0600
200A0700
200A0800
200A0900
200A1000
200A1100
200A1200
$200 A 1400$

See the "reading instructions" section of the introduction for help interpreting core box photos and core piece nomenclature 


\section{LVEW Core Box 310}

Depth Interval 8507.0'-8514.4'

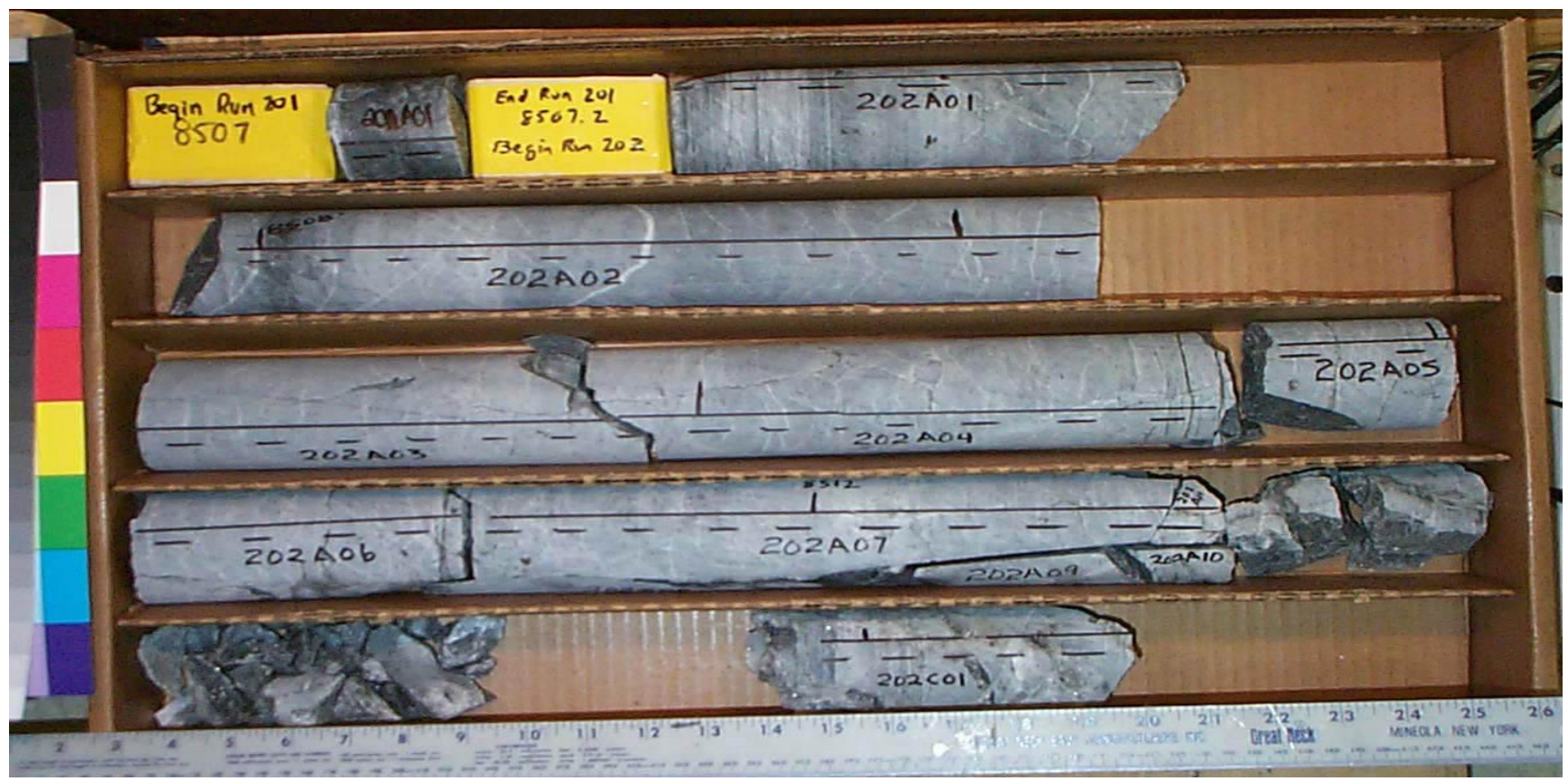

Core Scans included in this box (listed by piece going downhole):
202A0100
202A0200
202A0300
202A0400
202A0500
202A0600
202C0100

See the "reading instructions" section of the introduction for help interpreting core box photos and core piece nomenclature 


\section{LVEW Core Box 311}

Depth Interval 8514.4'-8522.3'

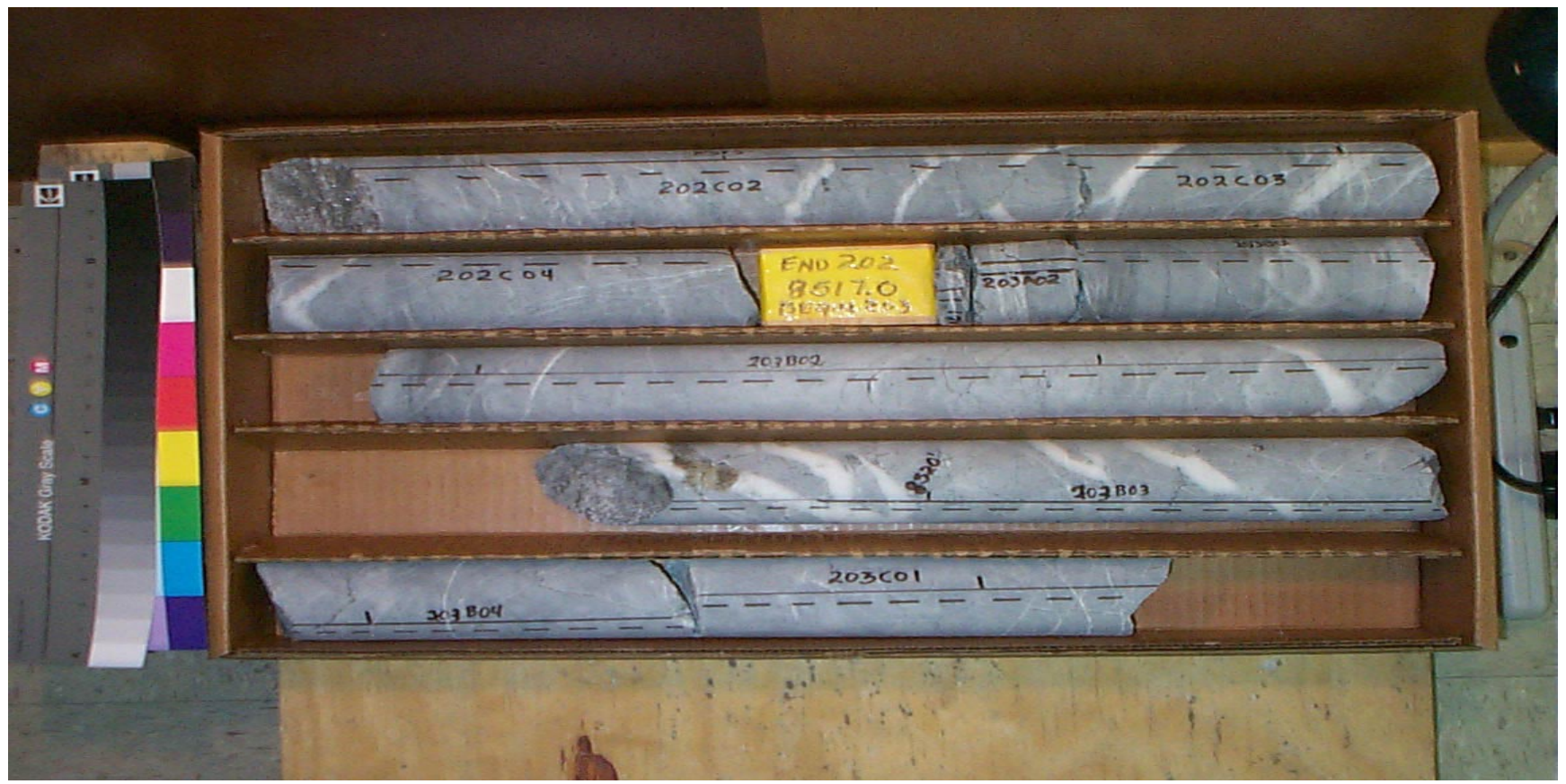

Core Scans included in this box (listed by piece going downhole):
202C0200
$202 \mathrm{C} 0300$
202C0400
203A0200
203B0100
203B0200
203B0300
203B0400
203C0100

See the "reading instructions" section of the introduction for help interpreting core box photos and core piece nomenclature 


\section{LVEW Core Box 312}

Depth Interval 8522.3'-8530.0'

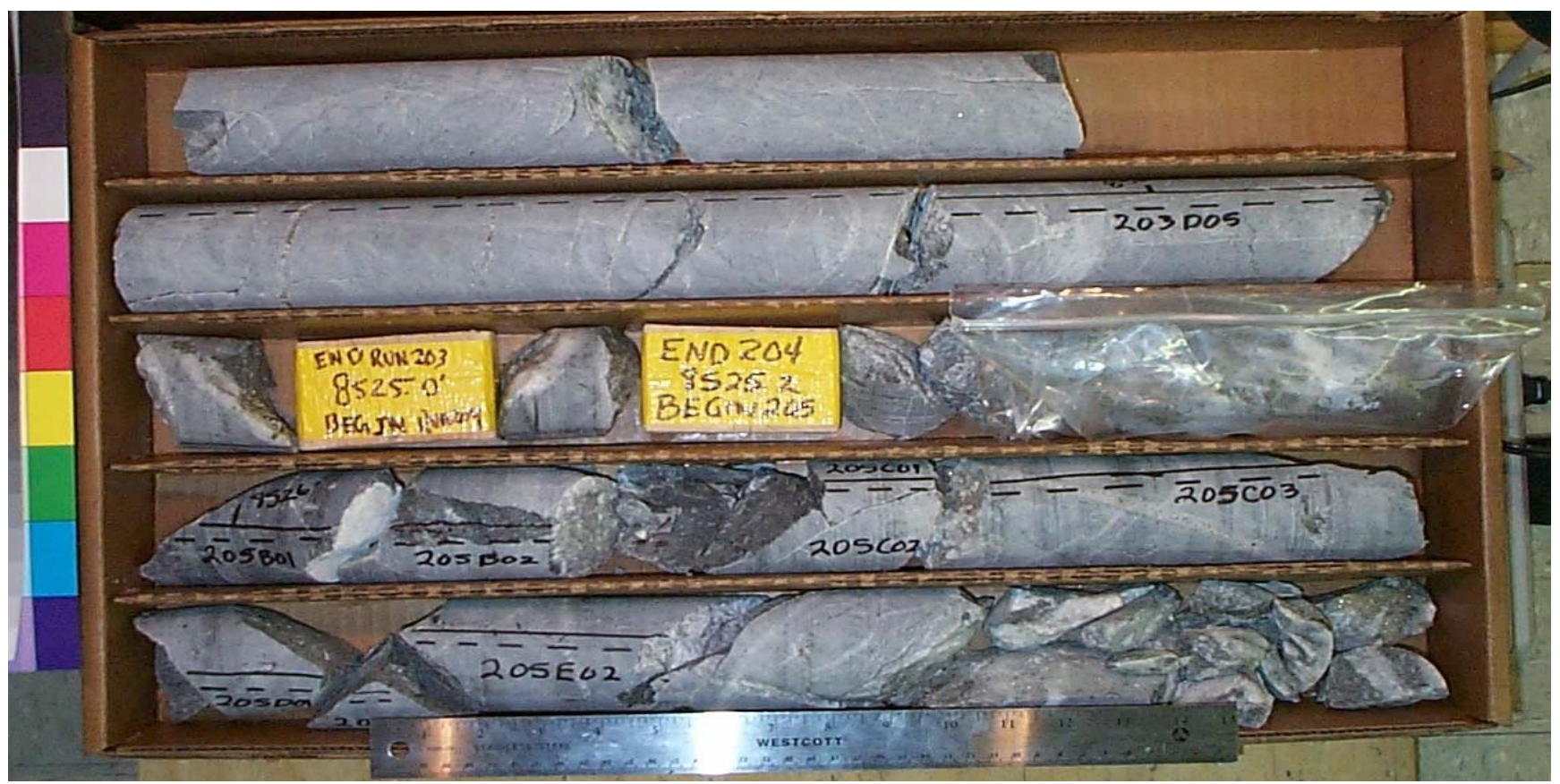

Core Scans included in this box (listed by piece going downhole):
203C0200
203D0100
203D0200
203D0300
203D0500
203E0100
205B0200
205C0300
205D0100
205E0200

See the "reading instructions" section of the introduction for help interpreting core box photos and core piece nomenclature 


\section{LVEW Core Box 313}

Depth Interval 8530.0'-8541.0'

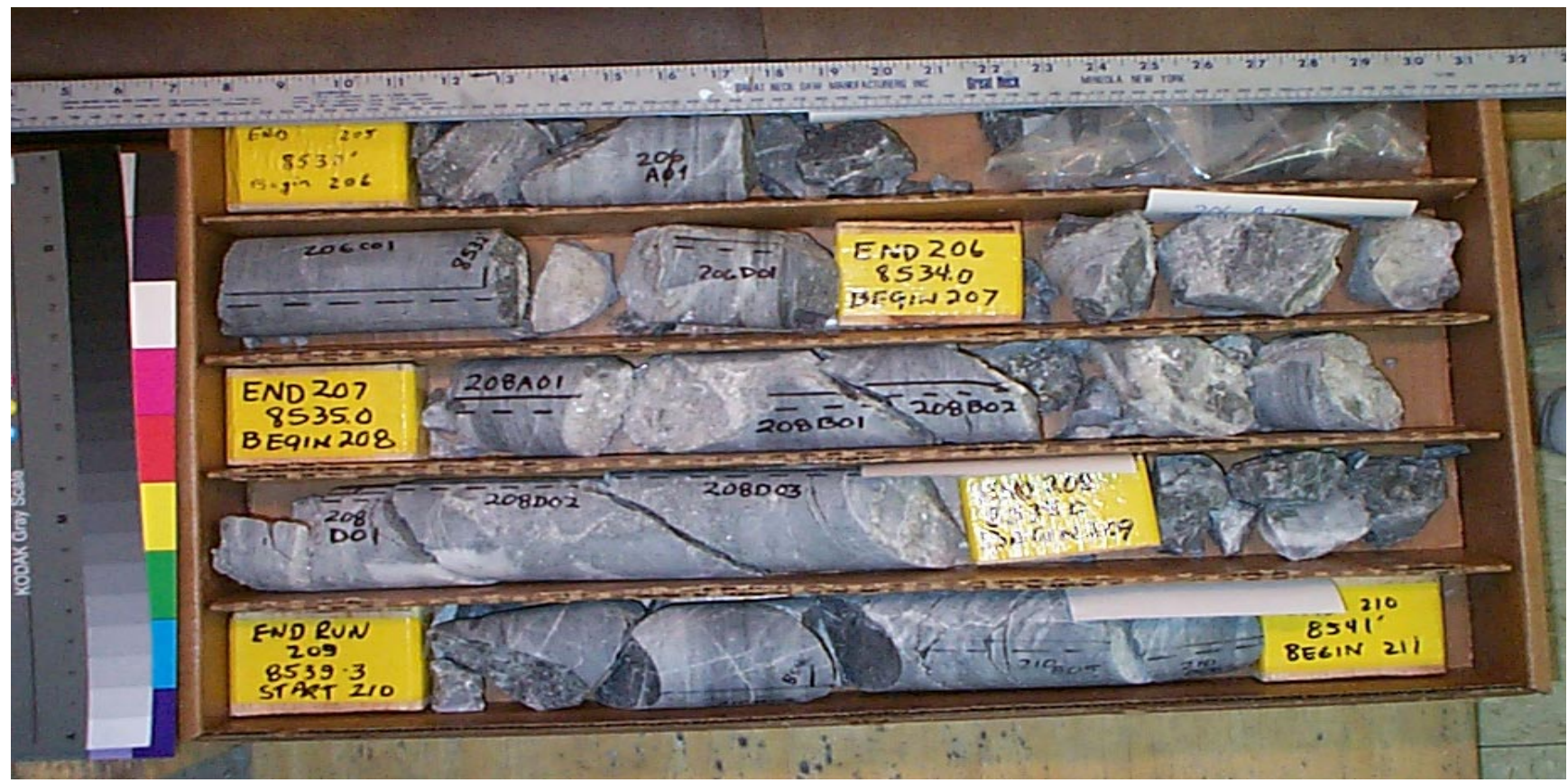

Core Scans included in this box (listed by piece going downhole):
206A010R 206C0100 206D010R 208B0100 208D0100 208D0200 208D0300
210B0200 210B0400 210B0500

See the "reading instructions" section of the introduction for help interpreting core box photos and core piece nomenclature 


\section{LVEW Core Box 314}

Depth Interval 8541.0'-8548.8'

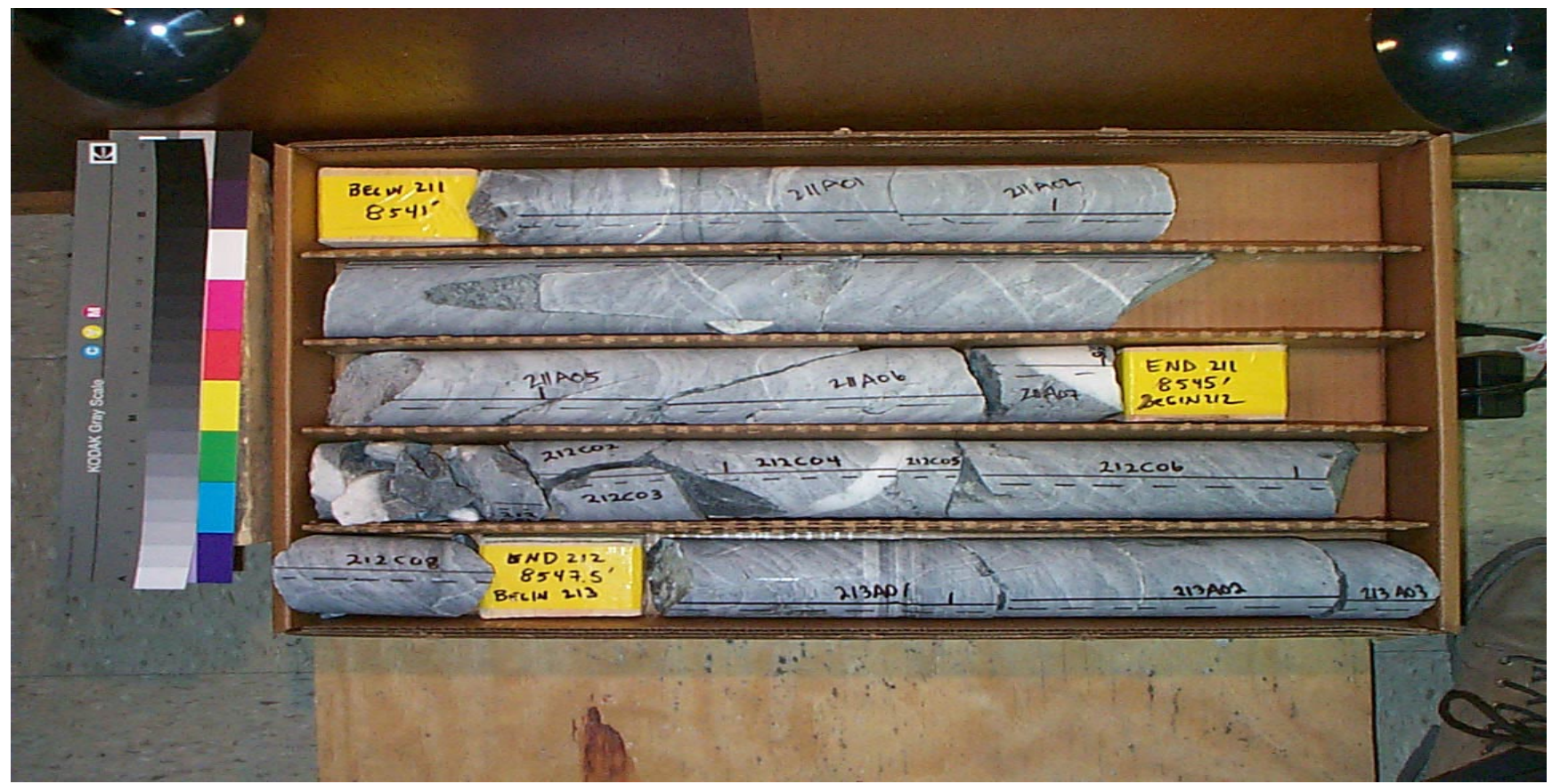

Core Scans included in this box (listed by piece going downhole):
$211 \mathrm{~A} 0100$
$211 \mathrm{~A} 0200$
$211 \mathrm{~A} 0300$
$211 \mathrm{~A} 0400$
$211 \mathrm{~A} 0500$
$211 \mathrm{~A} 0700$
212C0400
$212 \mathrm{C} 0600$
$212 \mathrm{C} 0800$
213A0100
213A0200
213A0300

See the "reading instructions" section of the introduction for help interpreting core box photos and core piece nomenclature 


\section{LVEW Core Box 315}

Depth Interval 8548.8'-8557.1'

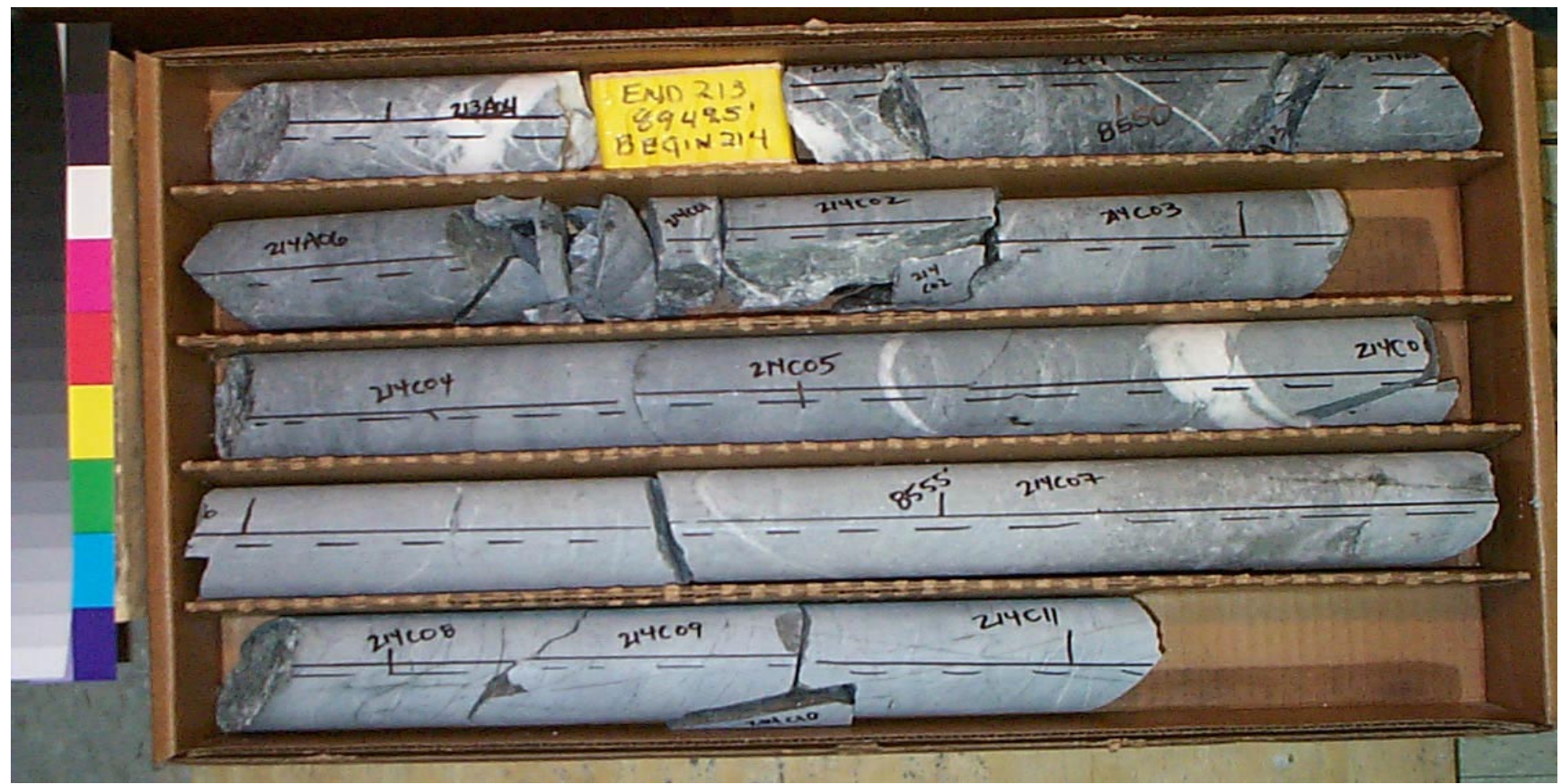

Core Scans included in this box (listed by piece going downhole):

$213 A 0400$
$214 A 0100$
$214 A 0200$
$214 A 0500$
$214 A 0600$
$214 C 0100$
$214 C 0300$

214C0400

$214 \mathrm{C} 0500$

214C060A

$214 \mathrm{C} 0700$

214C0800

214C0900

214C1100

See the "reading instructions" section of the introduction for help interpreting core box photos and core piece nomenclature 


\section{LVEW Core Box 316}

Depth Interval 8557.1'-8565.1'

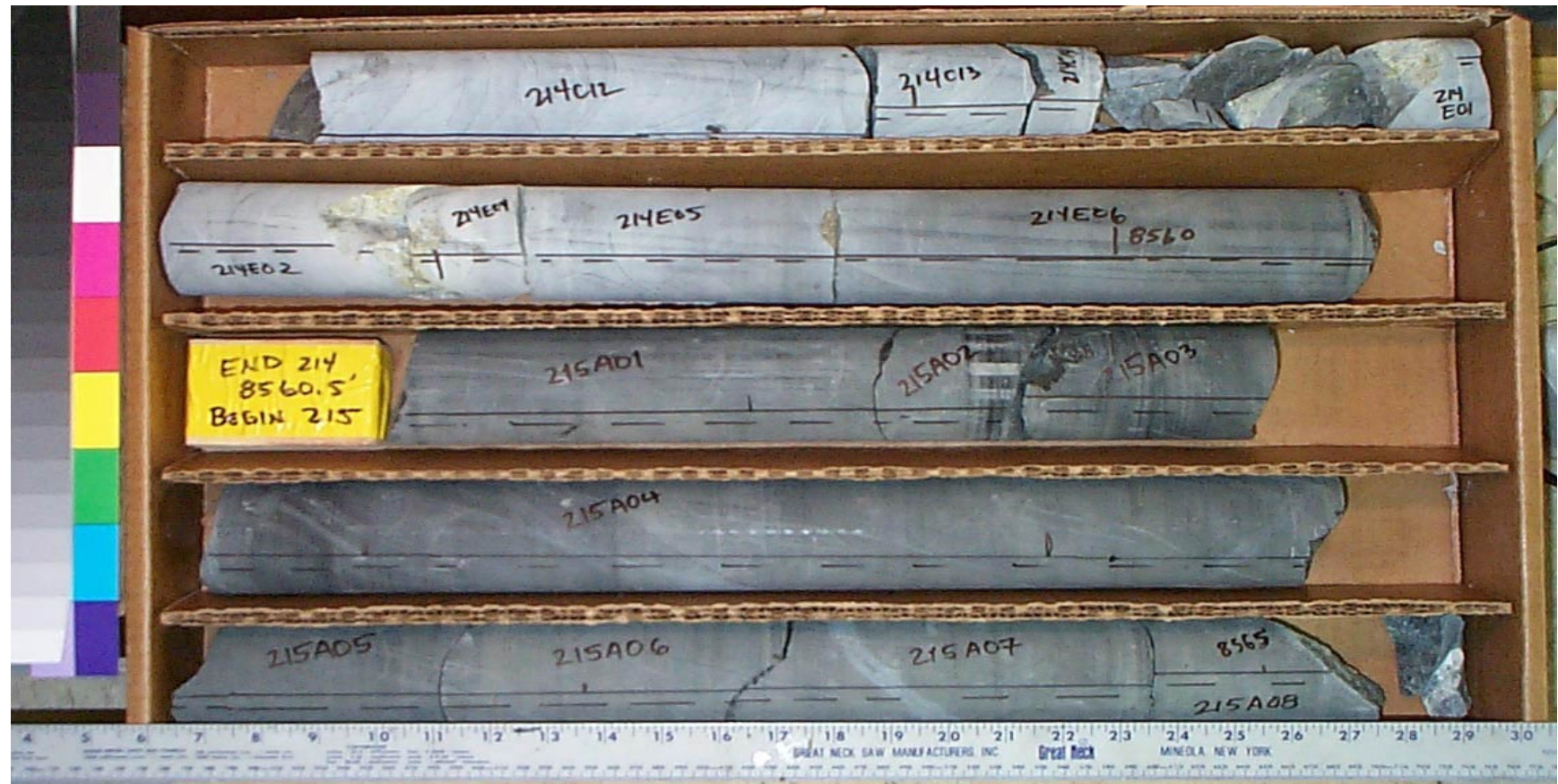

Core Scans included in this box (listed by piece going downhole):
214C1200
214C1300
214E0100
214E0200
214E0500
214E0600
215A0100

$215 A 0200$
$215 A 0300$
$215 A 0400$
$215 A 0500$
$215 A 0600$
$215 A 0700$
$215 A 0800$

See the "reading instructions" section of the introduction for help interpreting core box photos and core piece nomenclature 


\section{LVEW Core Box 317}

\section{Depth Interval 8565.1'-8572.8'}

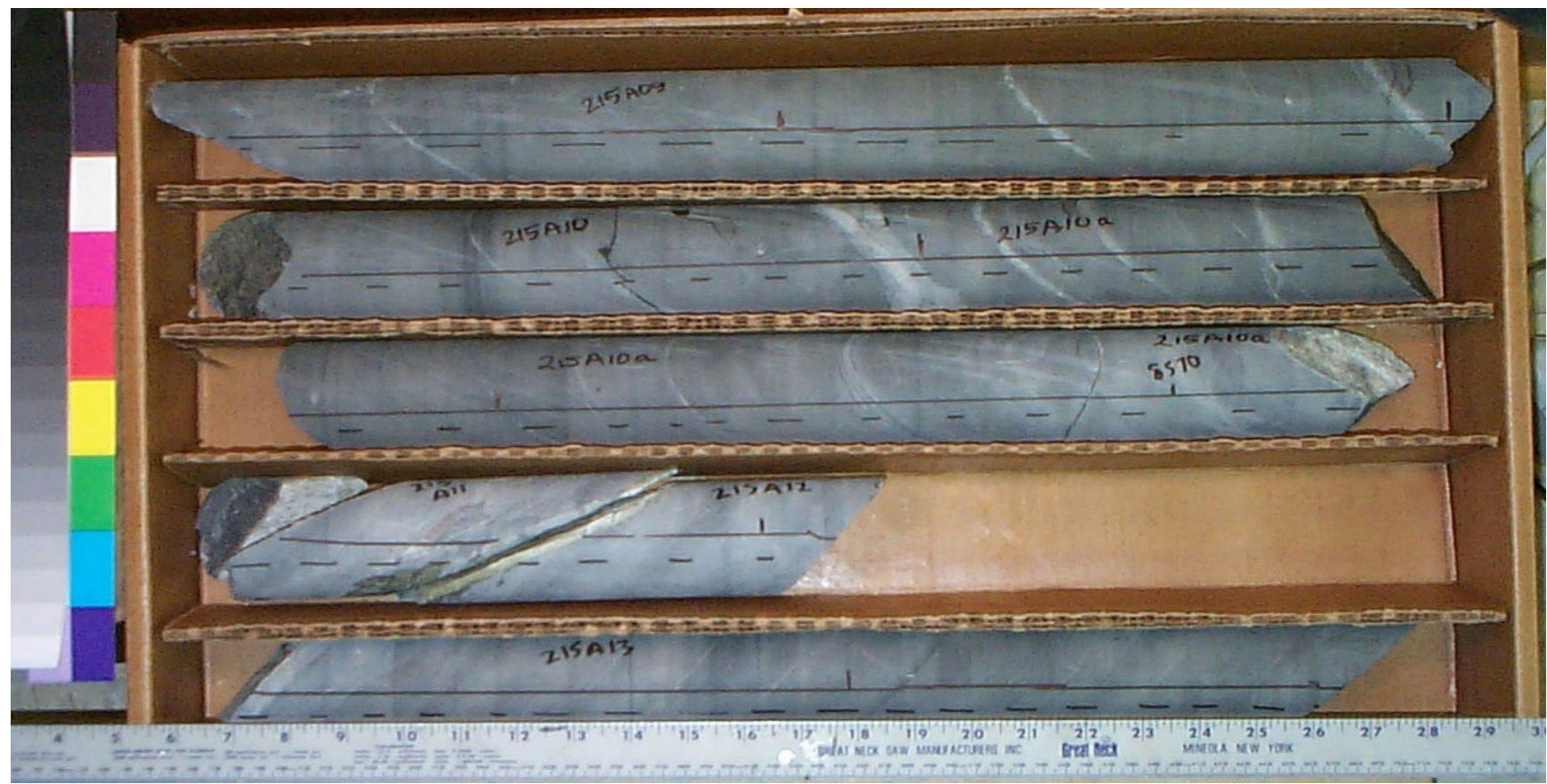

Core Scans included in this box (listed by piece going downhole):
$215 A 0900$
215A101A
215A102A
$215 \mathrm{~A} 1100$
215A1300

See the "reading instructions" section of the introduction for help interpreting core box photos and core piece nomenclature 


\section{LVEW Core Box 318}

Depth Interval 8572.8'-8580.0'

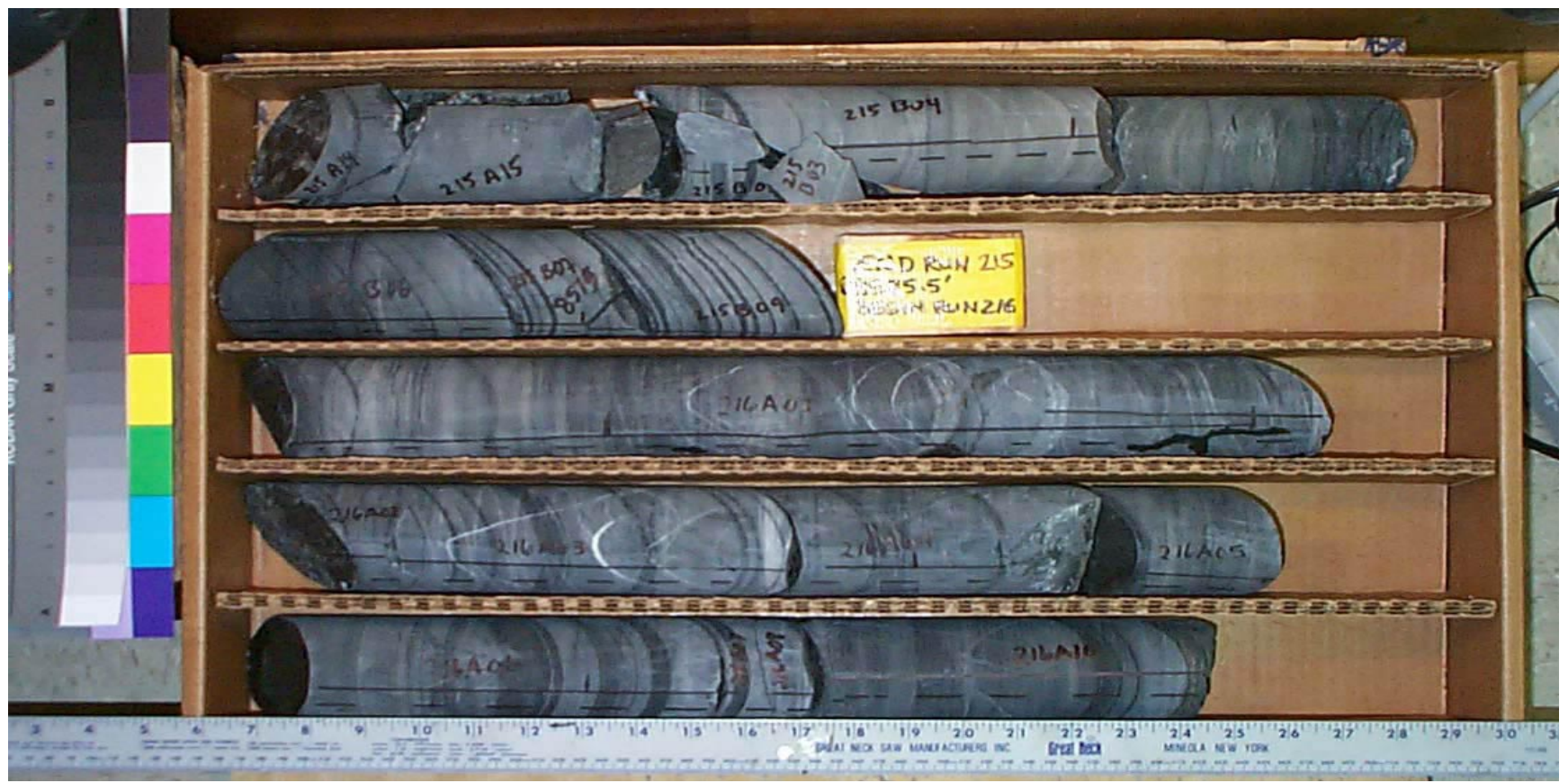

Core Scans included in this box (listed by piece going downhole):
215B0500
215B0600
215B0700
215B0900
$216 \mathrm{~A} 0100$
216A0200
216A0400
$216 \mathrm{~A} 0500$
$216 \mathrm{~A} 0600$
216A1000

See the "reading instructions" section of the introduction for help interpreting core box photos and core piece nomenclature 


\section{LVEW Core Box 319}

Depth Interval 8580.0'-8587.2'

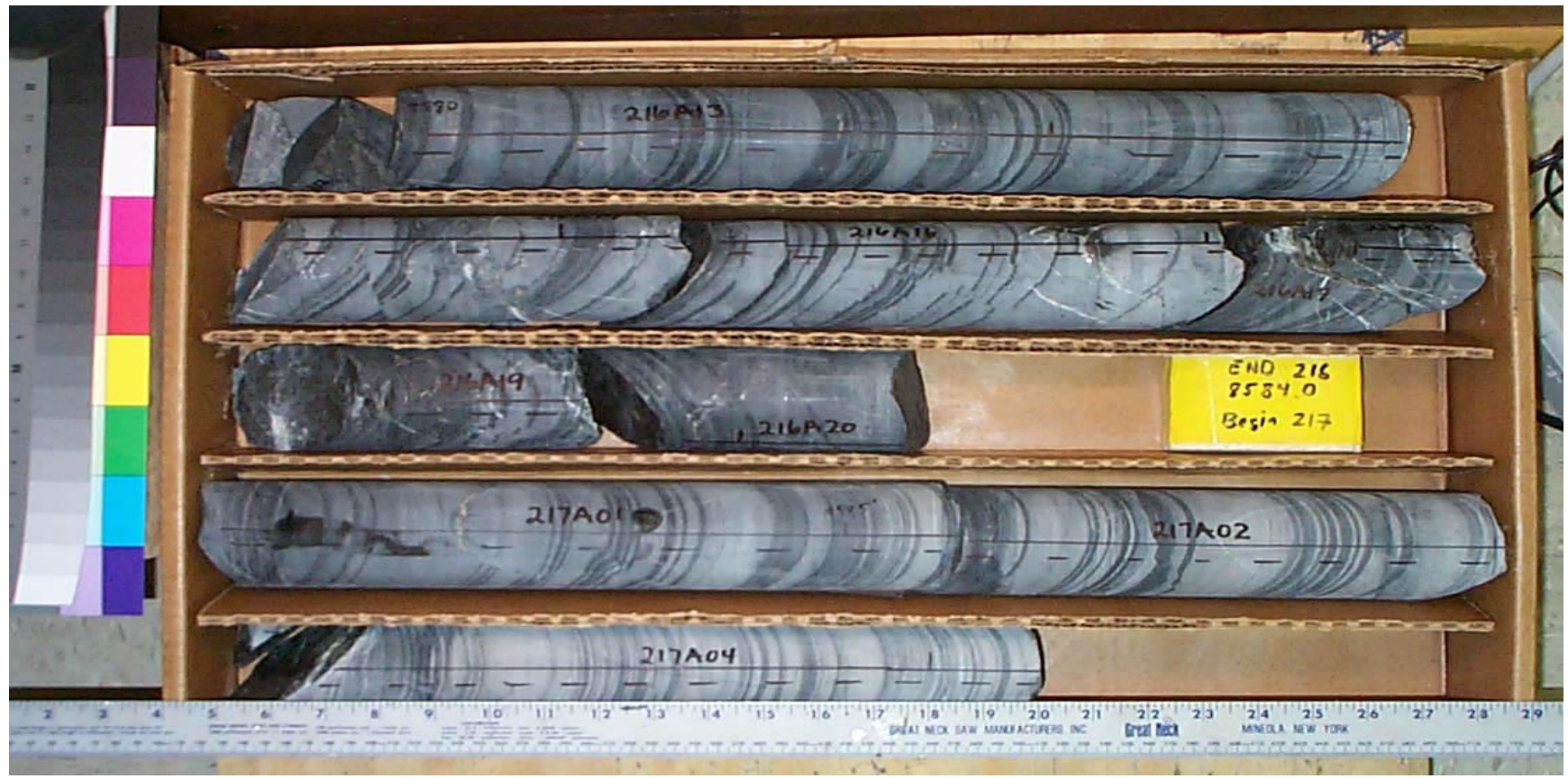

Core Scans included in this box (listed by piece going downhole):
216A1300
216A1400
216A1600
216A1900
216A2000
$217 \mathrm{~A} 0100$
$217 \mathrm{~A} 0200$
217A0400

See the "reading instructions" section of the introduction for help interpreting core box photos and core piece nomenclature 


\section{LVEW Core Box 320}

\section{Depth Interval 8587.2'-8594.2'}

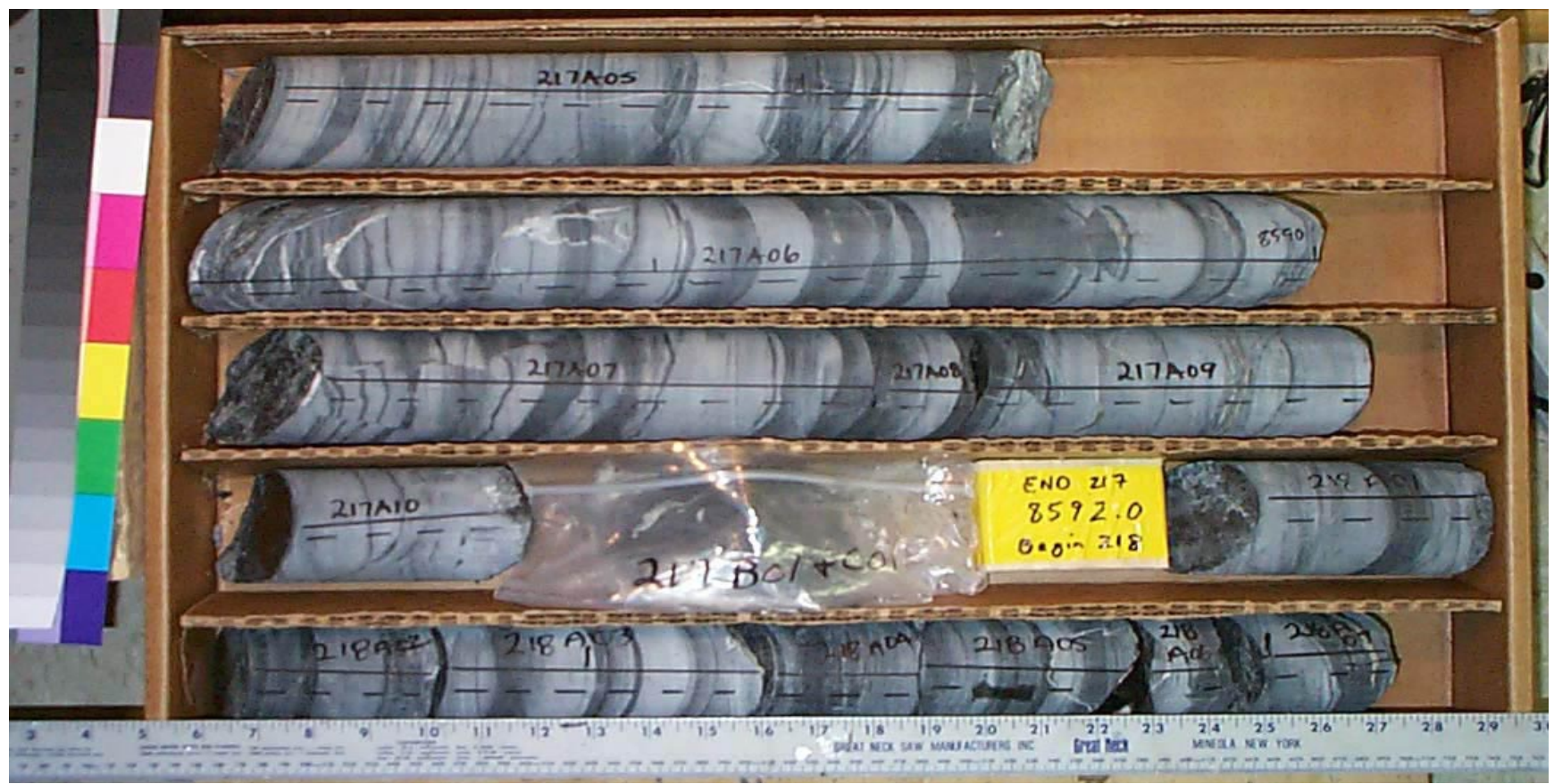

Core Scans included in this box (listed by piece going downhole):

$217 \mathrm{~A} 0500$
$217 \mathrm{~A} 0600$
$217 \mathrm{~A} 0700$
$217 \mathrm{~A} 0900$
$217 \mathrm{~A} 1000$
$217 \mathrm{C} 0100$
$218 \mathrm{~A} 0100$

218A0200

218A0300

218A0400

218A0500

218A0700

218A0800

218A0900

See the "reading instructions" section of the introduction for help interpreting core box photos and core piece nomenclature 


\section{LVEW Core Box 321}

\section{Depth Interval 8594.2'-8601.5'}

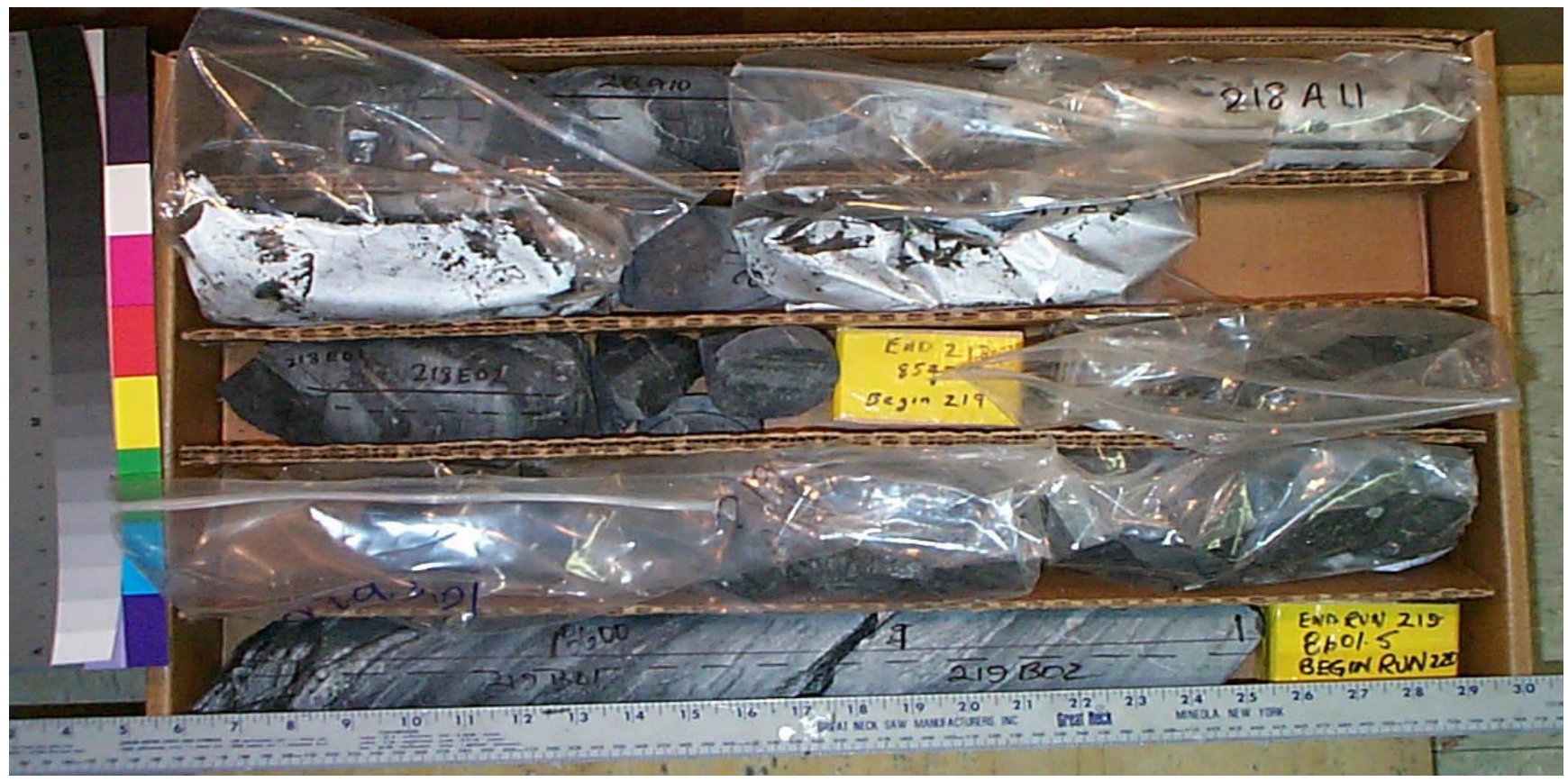

Core Scans included in this box (listed by piece going downhole):
$218 \mathrm{~A} 1000$
$218 \mathrm{~A} 1100$
218B0700
218E0200
219B0100
219B0200

See the "reading instructions" section of the introduction for help interpreting core box photos and core piece nomenclature 


\section{LVEW Core Box 322}

Depth Interval 9601.5'-8608.5'

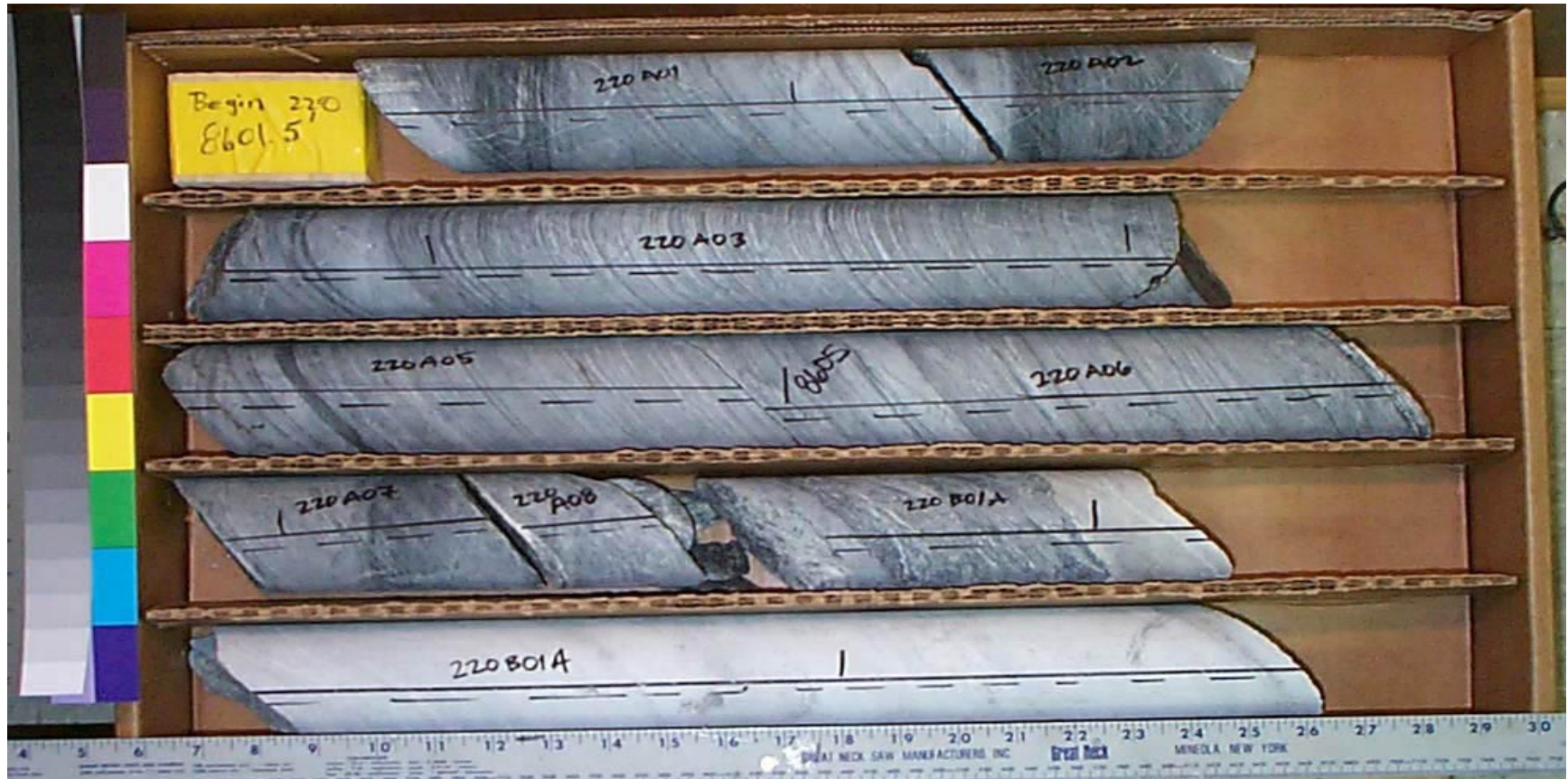

Core Scans included in this box (listed by piece going downhole):

$220 A 0100$
$220 A 0200$
$220 A 0300$
$220 A 0500$
$220 A 0600$
$220 A 0700$
$220 B 011 A$

See the "reading instructions" section of the introduction for help interpreting core box photos and core piece nomenclature 


\section{LVEW Core Box 323}

\section{Depth Interval 8608.5'-8616.4'}

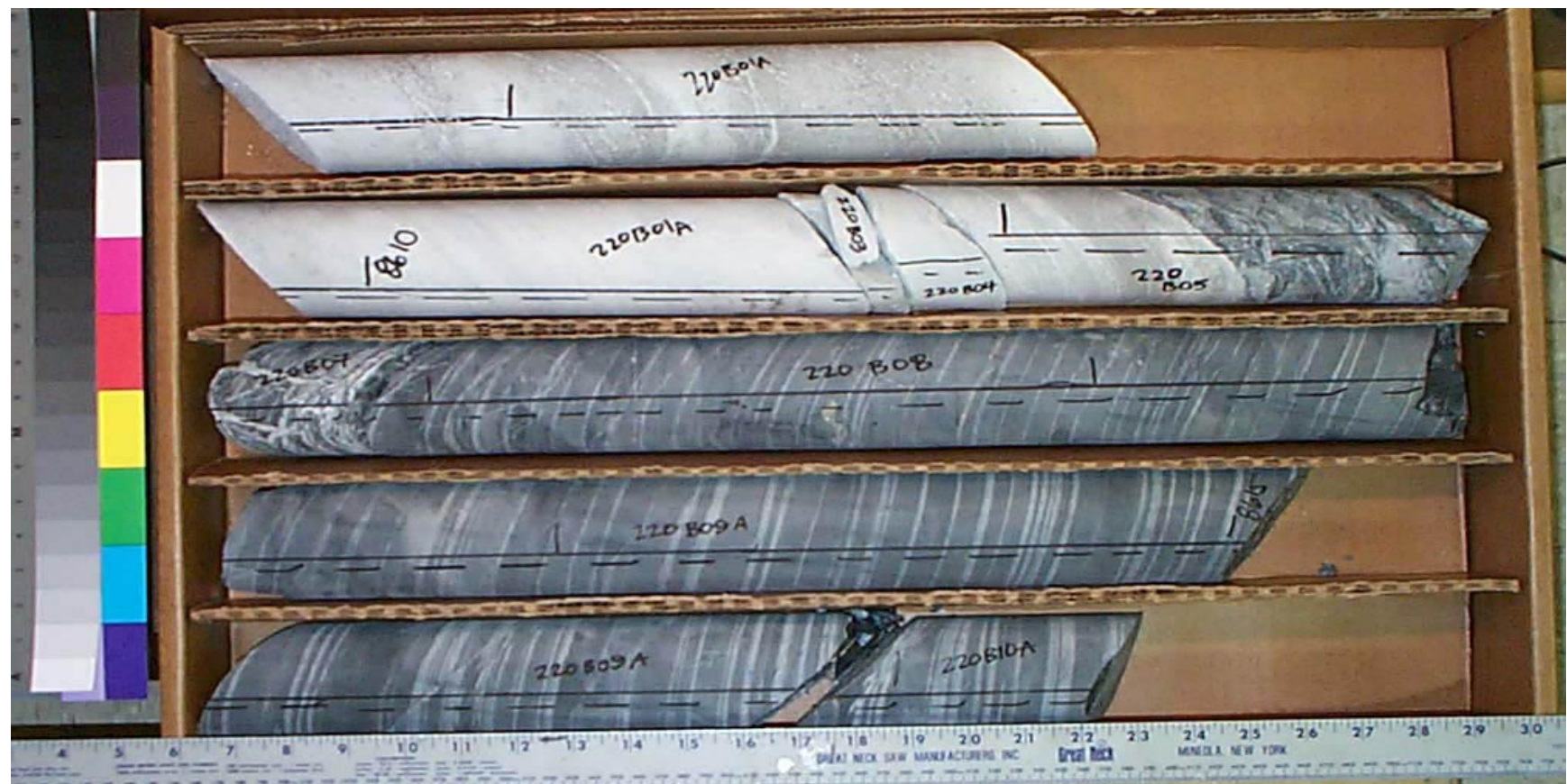

Core Scans included in this box (listed by piece going downhole):
220B012A
220B0400
220B0500
220B0800
220B090A
220B100A

See the "reading instructions" section of the introduction for help interpreting core box photos and core piece nomenclature 


\section{LVEW Core Box 324}

Depth Interval 8616.4'-8623.5'

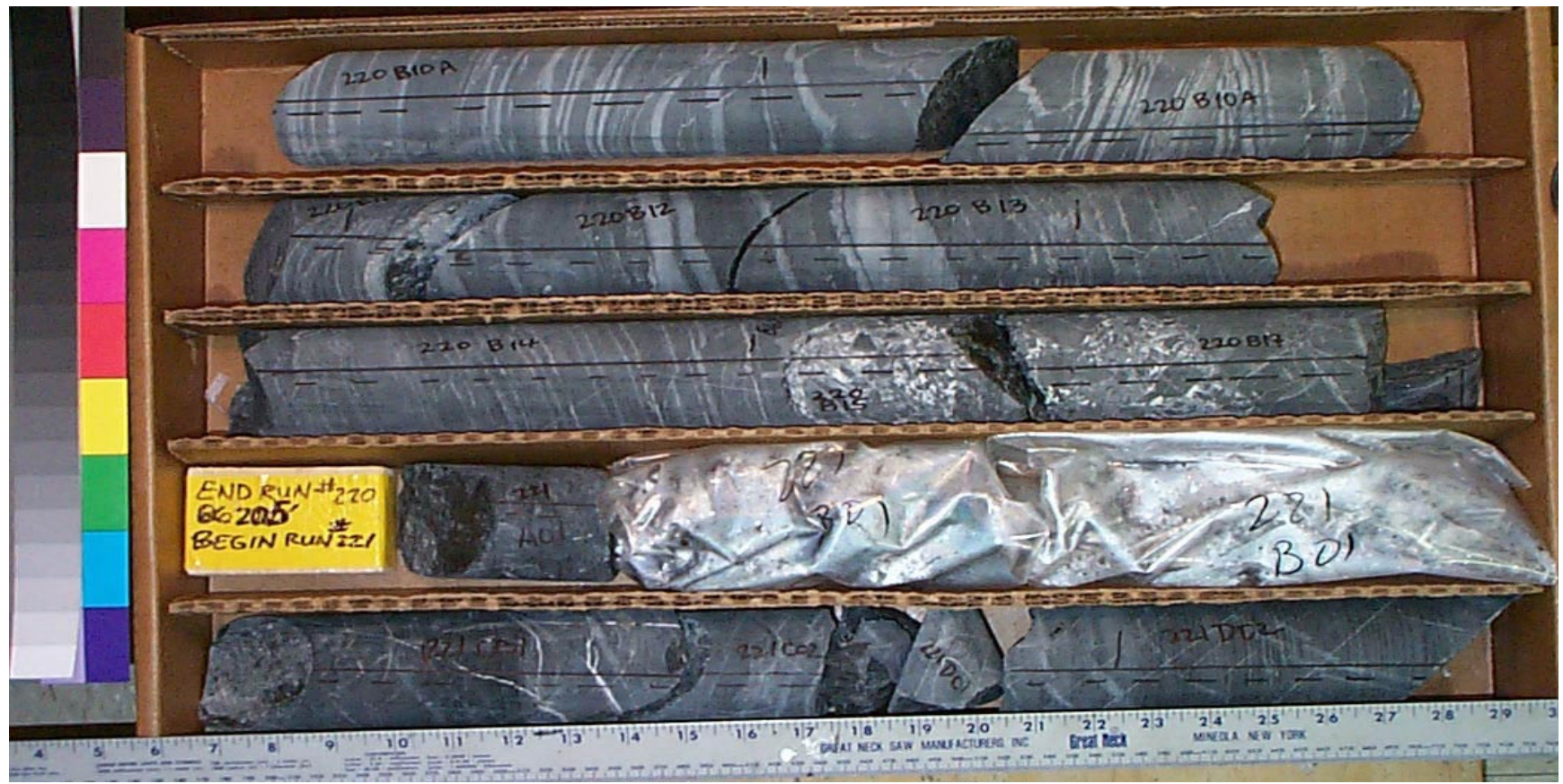

Core Scans included in this box (listed by piece going downhole):

220B100A
$220 B 1100$
$220 B 1200$
$220 B 1300$
$220 B 1400$
$220 B 1700$
$221 A 0100$
$221 C 0100$
$221 C 0200$
$221 D 0100$

See the "reading instructions" section of the introduction for help interpreting core box photos and core piece nomenclature 


\section{LVEW Core Box 325}

Depth Interval 8623.5'-8630.2'

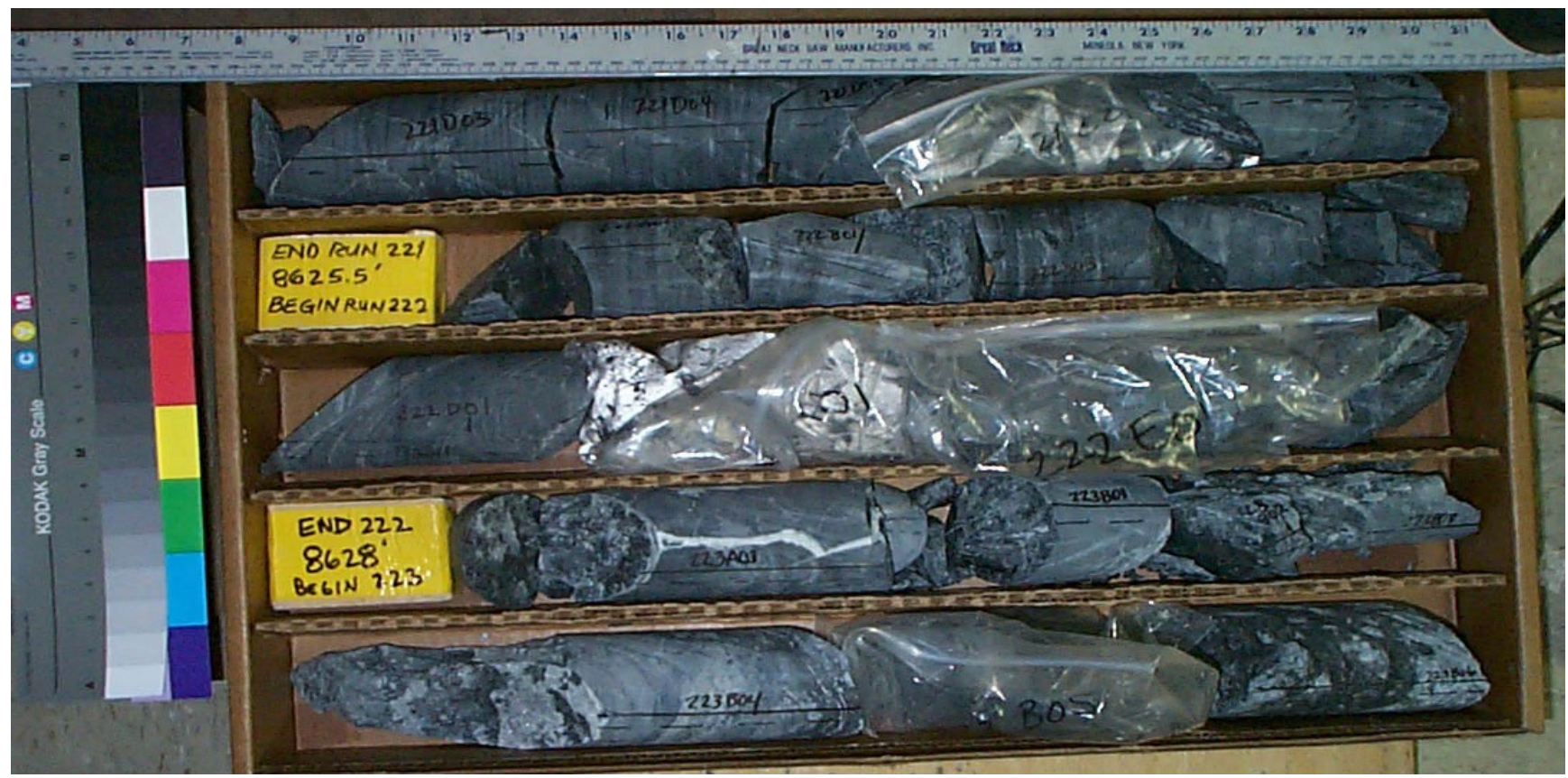

Core Scans included in this box (listed by piece going downhole):
221D0300
221D0400
222A0200
222B0300
222D0100
223A0300
223B0400
223B0600

See the "reading instructions" section of the introduction for help interpreting core box photos and core piece nomenclature 


\section{LVEW Core Box 326}

Depth Interval 8630.2'-8637.7'

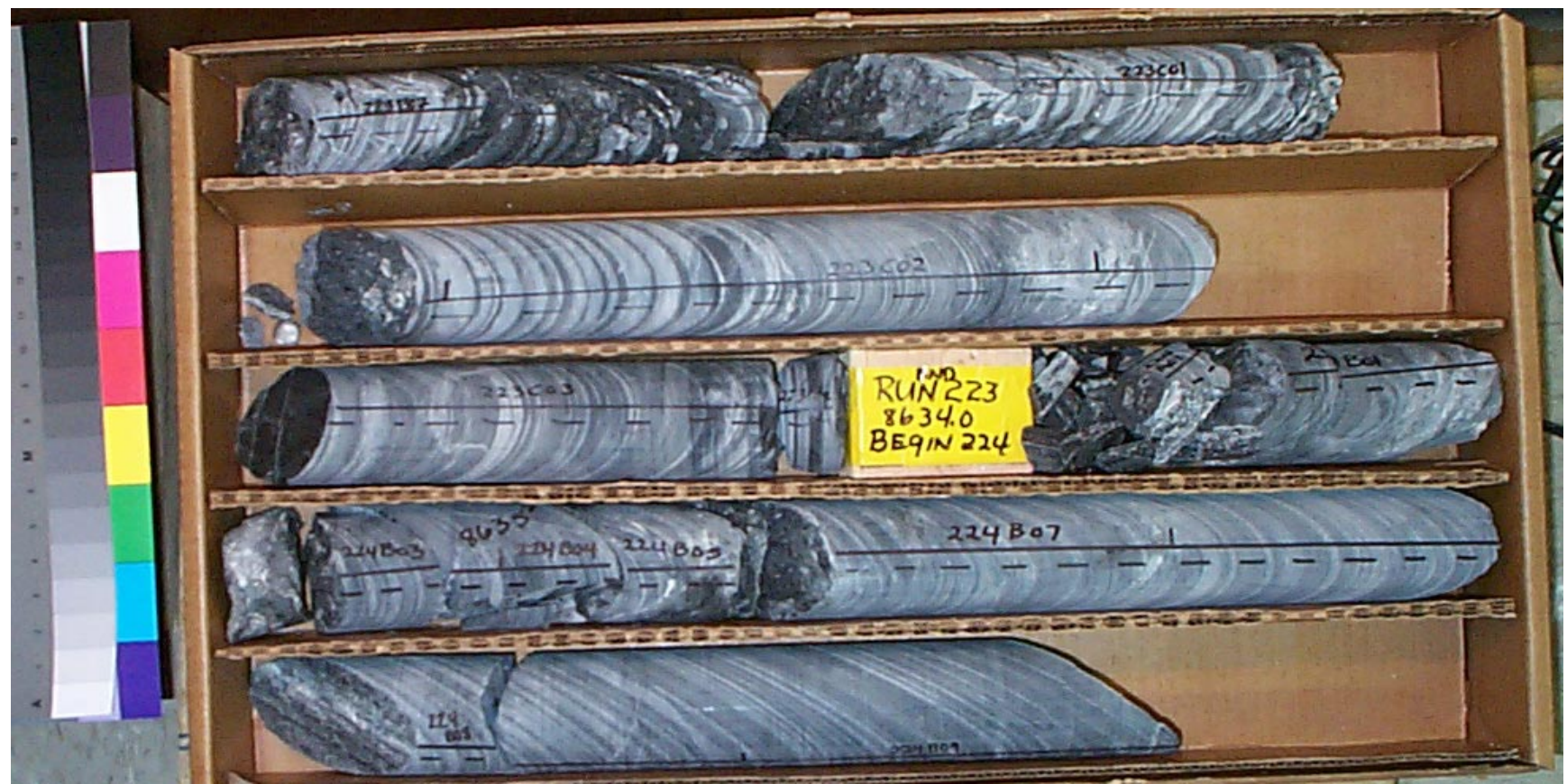

Core Scans included in this box (listed by piece going downhole):
223B0700
223B0800
223C0100
223C0200
223C0300
224B0100
224B0700
224B0900

See the "reading instructions" section of the introduction for help interpreting core box photos and core piece nomenclature 


\section{LVEW Core Box 327}

\section{Depth Interval 8637.7'-8644.5'}

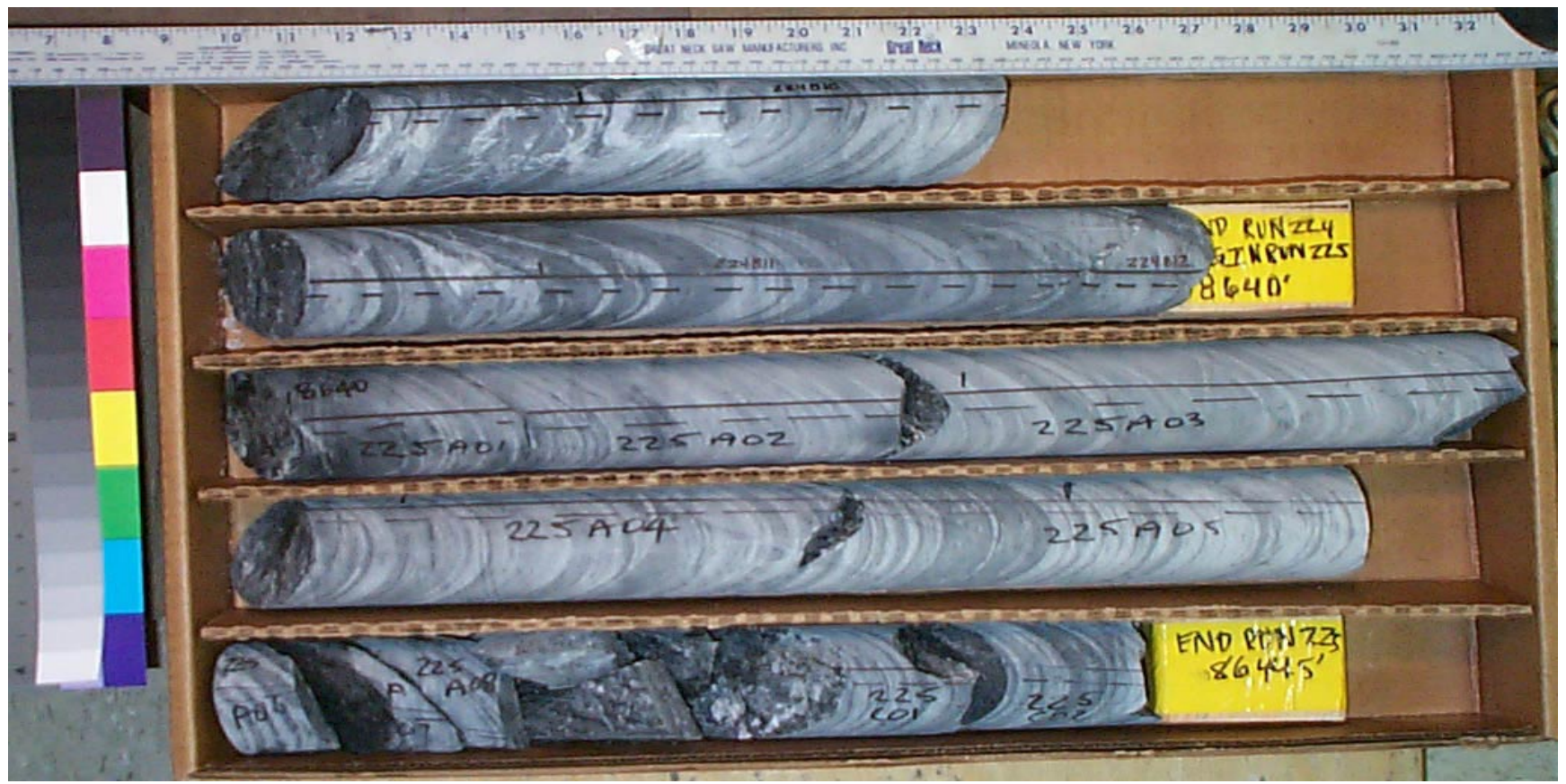

Core Scans included in this box (listed by piece going downhole):
224B1000
225A 0100
225A0200
225A0300
225A0400
225A0500

See the "reading instructions" section of the introduction for help interpreting core box photos and core piece nomenclature 


\section{LVEW Core Box 328}

Depth Interval 8644.5'-8652.0'

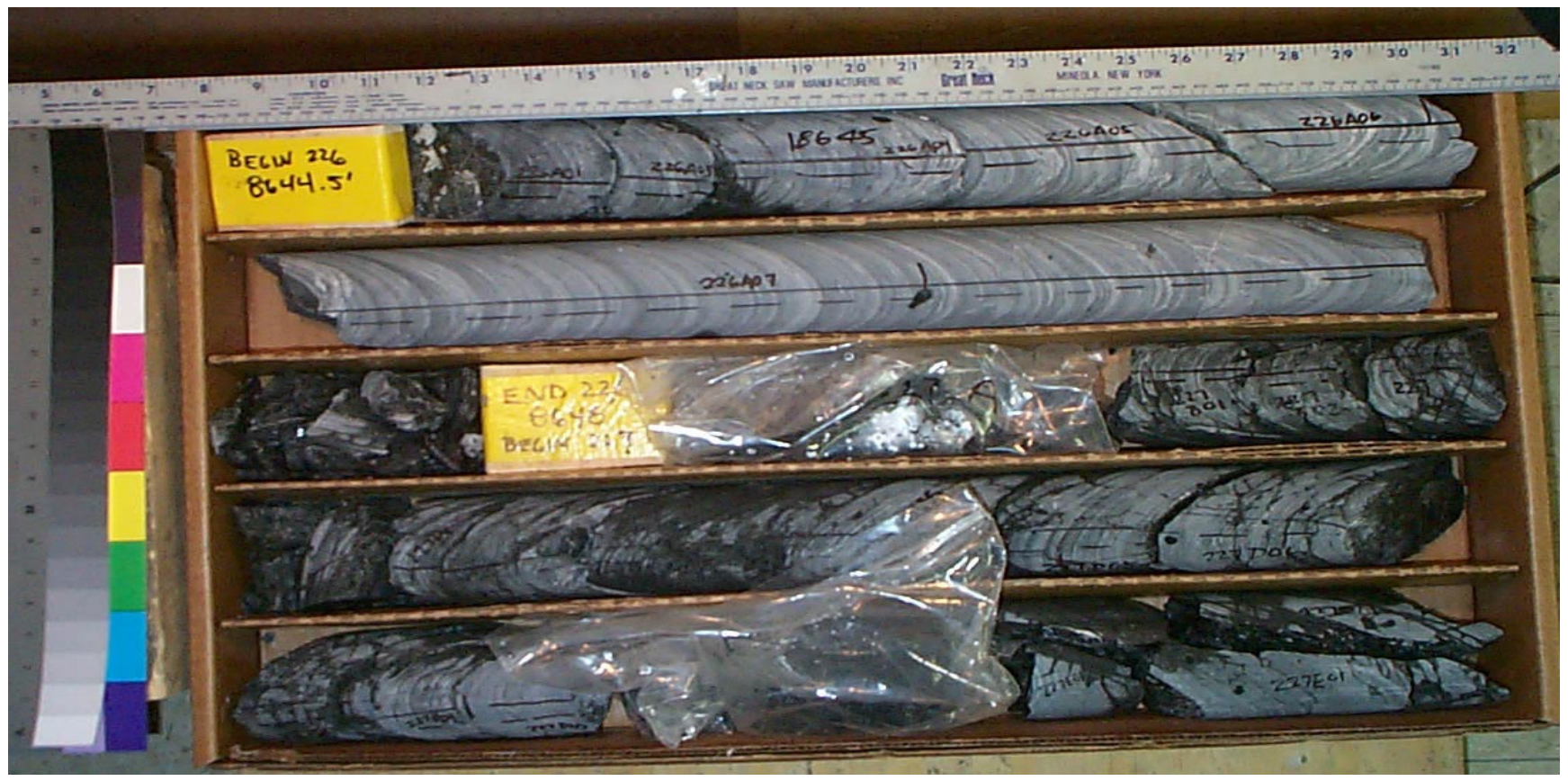

Core Scans included in this box (listed by piece going downhole):
226A0400
226A0500
226A0600
226A0700
227D0500

See the "reading instructions" section of the introduction for help interpreting core box photos and core piece nomenclature 


\section{LVEW Core Box 329}

Depth Interval 8652.0'-8658.2'

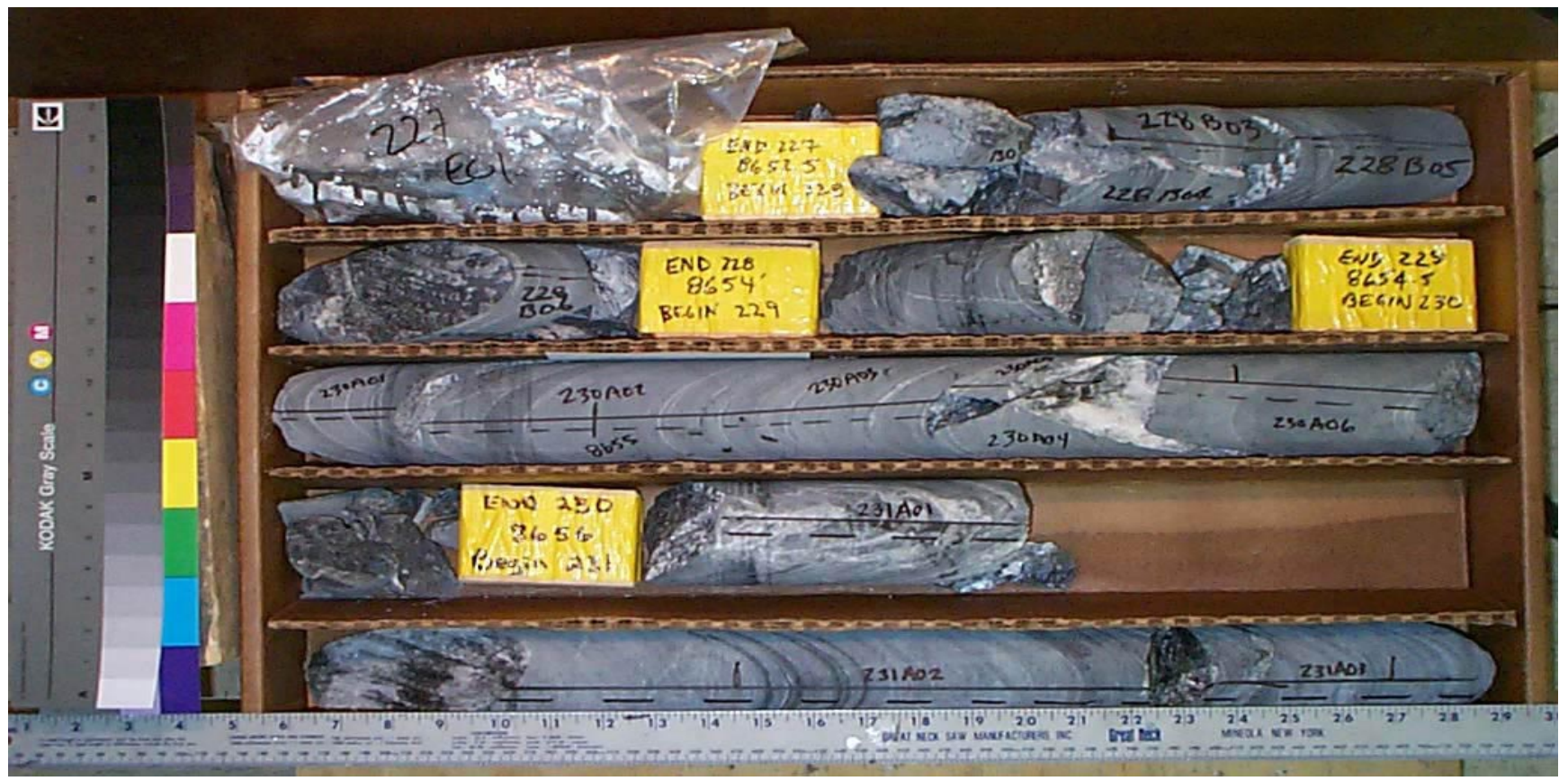

Core Scans included in this box (listed by piece going downhole):

\section{A0100 \\ 230A0200 \\ 230A0300 \\ $231 \mathrm{~A} 0100$ \\ $231 \mathrm{~A} 0200$ \\ $231 \mathrm{~A} 0300$}

See the "reading instructions" section of the introduction for help interpreting core box photos and core piece nomenclature 


\section{LVEW Core Box 330}

Depth Interval 8658.2'-8665.6'

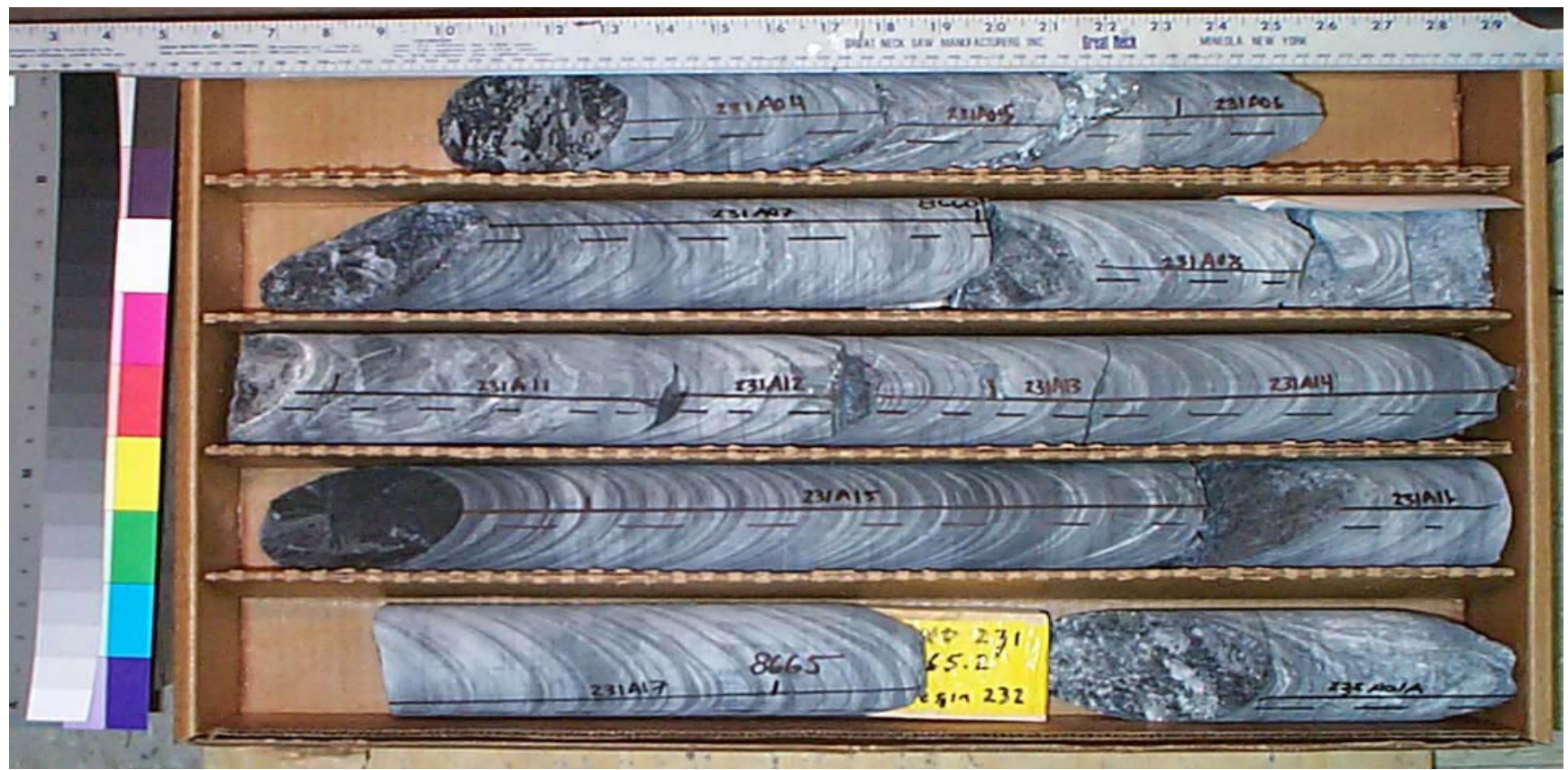

Core Scans included in this box (listed by piece going downhole):

231A0400
231A0600
231A0700
231A0800
$231 A 1100$
$231 A 1200$
231A1400
231A1500
231A1600
231A1700
232A010A

See the "reading instructions" section of the introduction for help interpreting core box photos and core piece nomenclature 


\section{LVEW Core Box 331}

\section{Depth Interval 8665.6'-8673.4'}

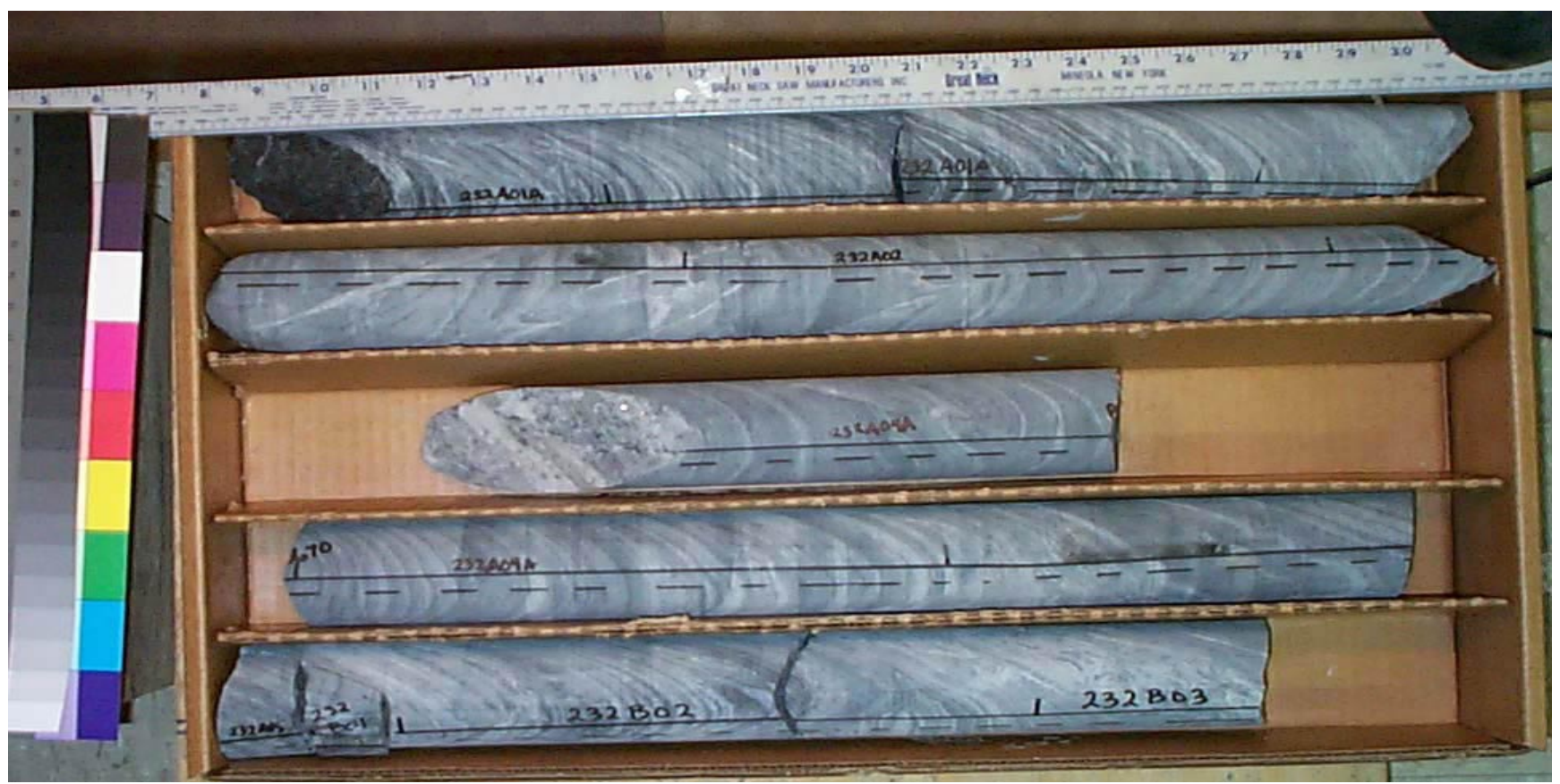

Core Scans included in this box (listed by piece going downhole):

$$
\begin{aligned}
& \text { 232A010A } \\
& 232 A 0200 \\
& 232 A 040 A \\
& 232 B 0200 \\
& 232 B 0300
\end{aligned}
$$

See the "reading instructions" section of the introduction for help interpreting core box photos and core piece nomenclature 


\section{LVEW Core Box 332}

\section{Depth Interval 8673.4'-8679.9'}

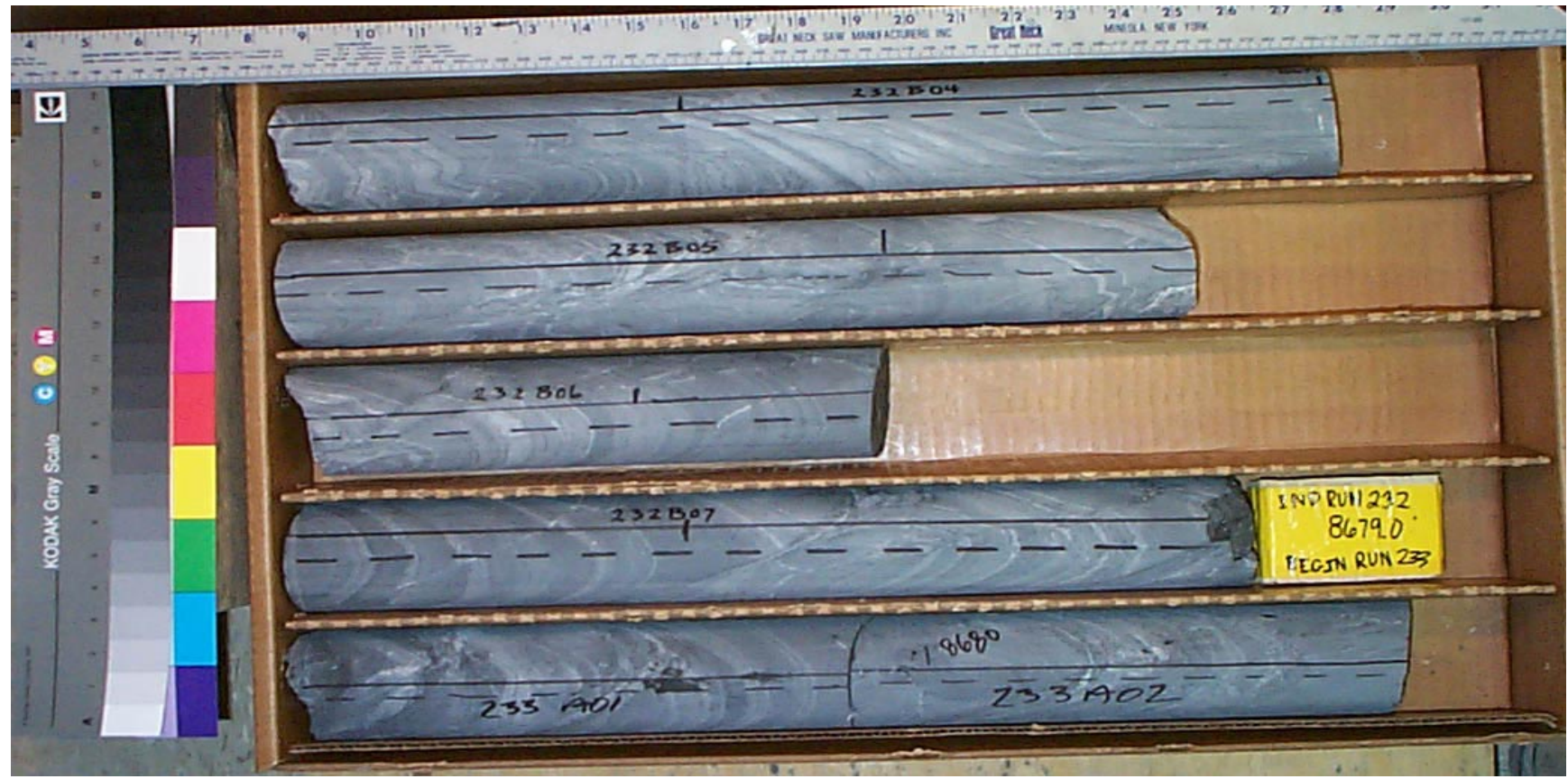

Core Scans included in this box (listed by piece going downhole):

\section{B0400 \\ 232B0500 \\ 232B0600 \\ 232B0700 \\ 233A0100 \\ 233A0200}

See the "reading instructions" section of the introduction for help interpreting core box photos and core piece nomenclature 


\section{LVEW Core Box 333}

Depth Interval 8679.9'-8688.4'

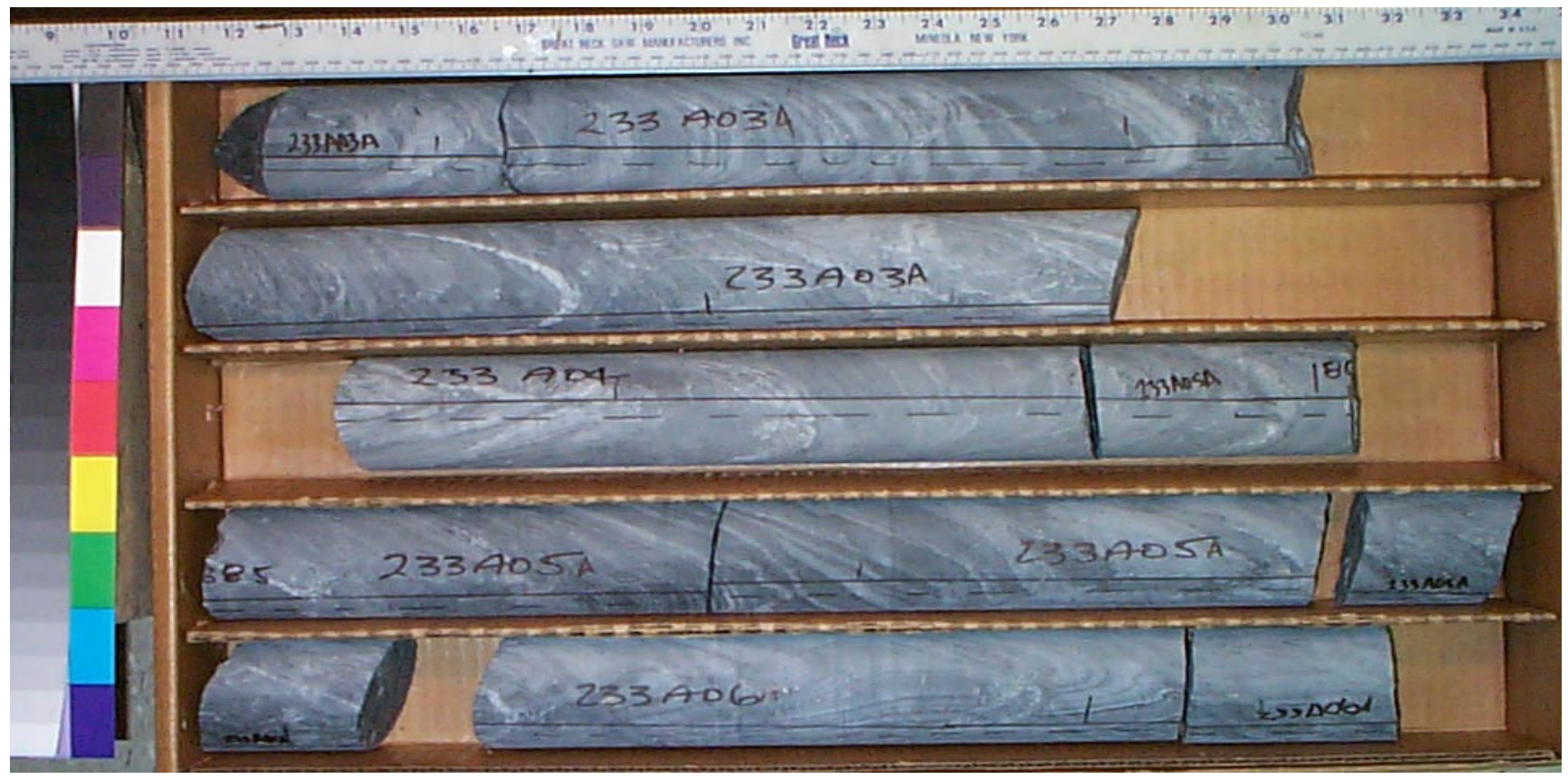

Core Scans included in this box (listed by piece going downhole):
233A030A
233A0400
233A050A
233A060A

See the "reading instructions" section of the introduction for help interpreting core box photos and core piece nomenclature 


\section{LVEW Core Box 334}

Depth Interval 8688.4'-8696.1'

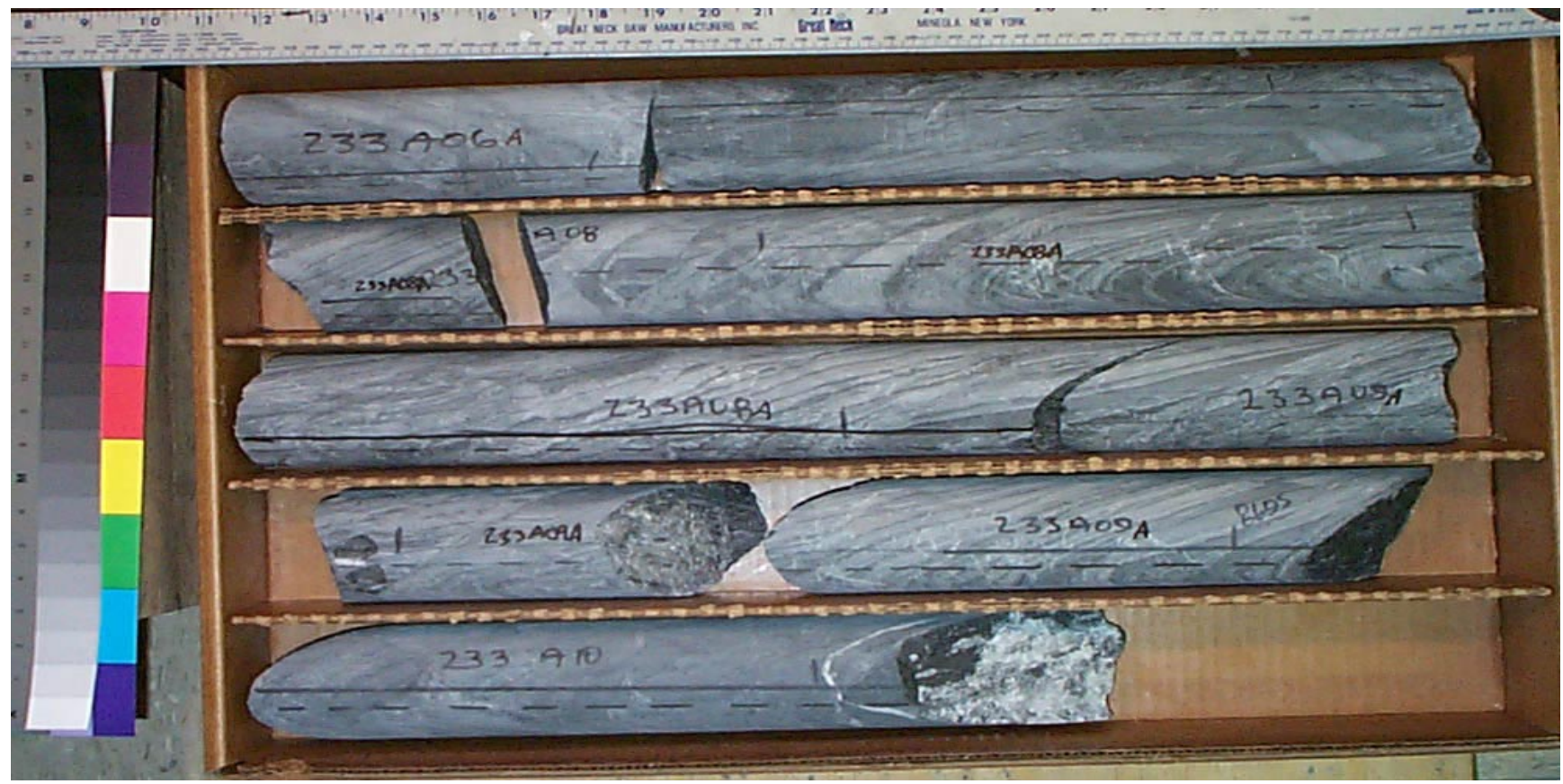

Core Scans included in this box (listed by piece going downhole):
233A060A
233A070A
233A081A
233A082A
233A090A
$233 \mathrm{~A} 1000$

See the "reading instructions" section of the introduction for help interpreting core box photos and core piece nomenclature 


\section{LVEW Core Box 335}

\section{Depth Interval 8696.1'-8704.3'}

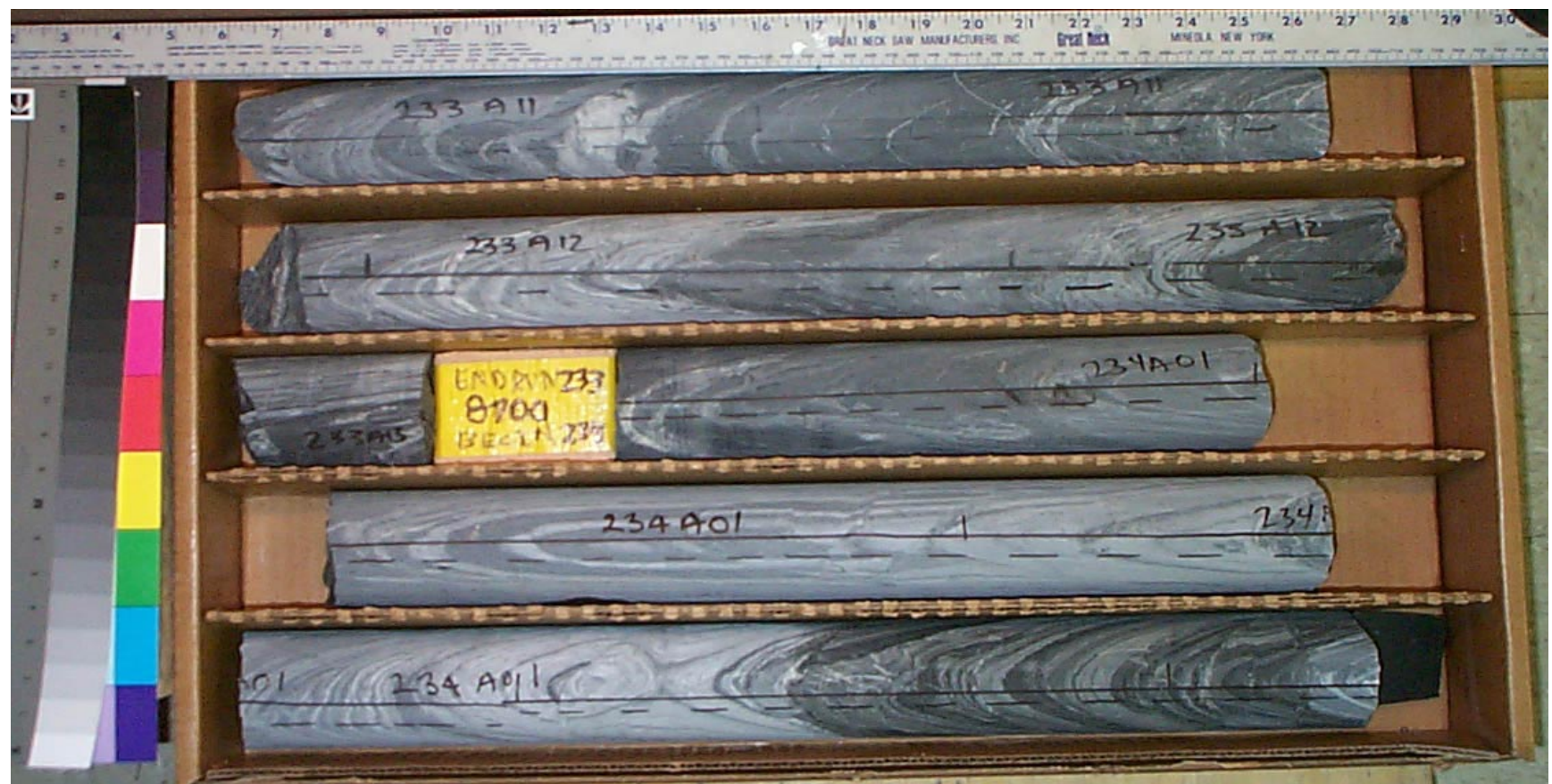

Core Scans included in this box (listed by piece going downhole):

$$
\begin{aligned}
& 233 A 1100 \\
& 233 A 1200 \\
& 233 A 1300 \\
& 234 A 011 A \\
& 234 A 012 A \\
& 234 A 013 A
\end{aligned}
$$

See the "reading instructions" section of the introduction for help interpreting core box photos and core piece nomenclature 


\section{LVEW Core Box 336}

Depth Interval 8704.3'-8713.0'

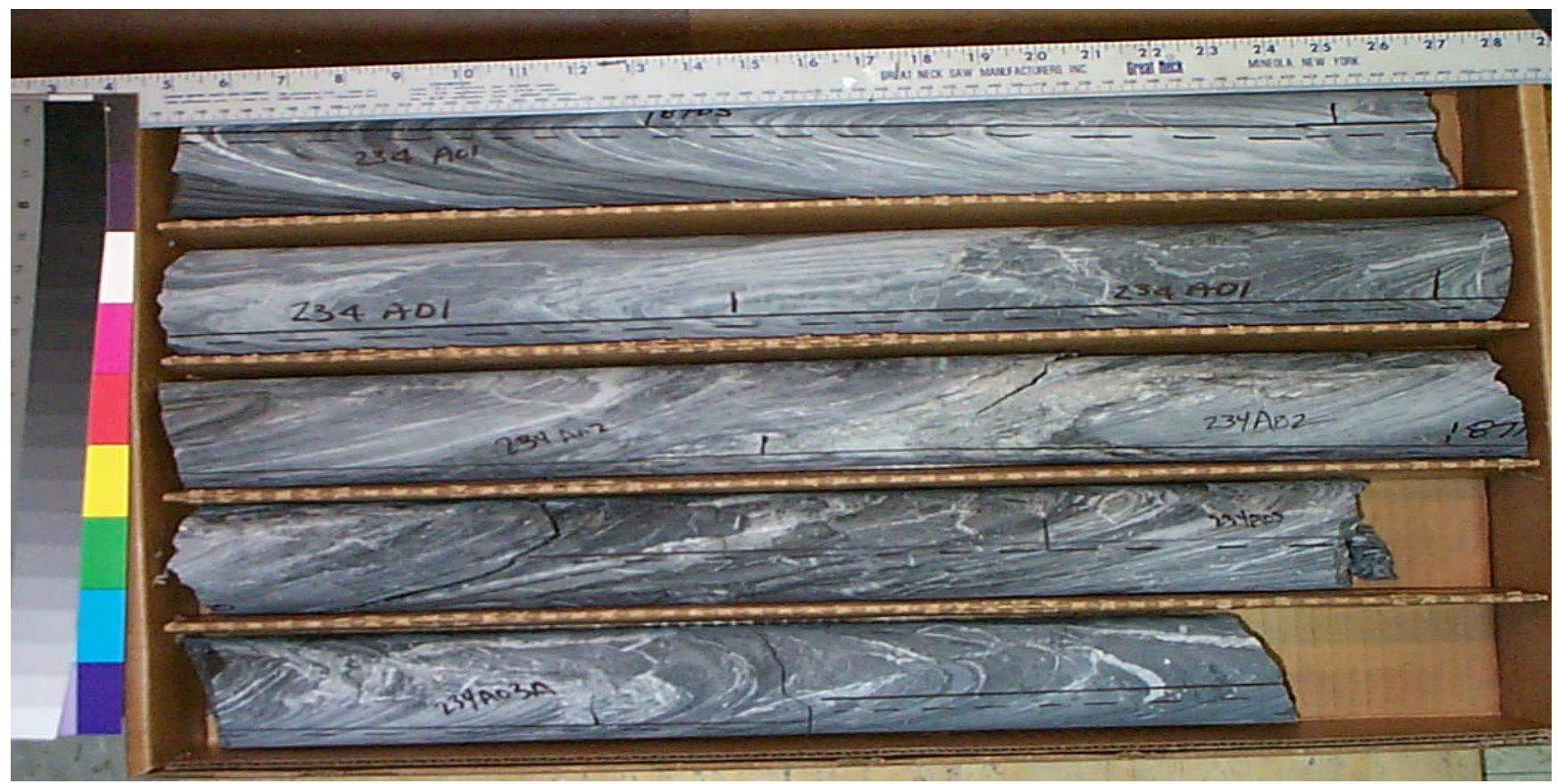

Core Scans included in this box (listed by piece going downhole):
234A012A
234A013A
234A014A
234A020A
234A030A

See the "reading instructions" section of the introduction for help interpreting core box photos and core piece nomenclature 


\section{LVEW Core Box 337}

Depth Interval 8713.0'-8721.0'

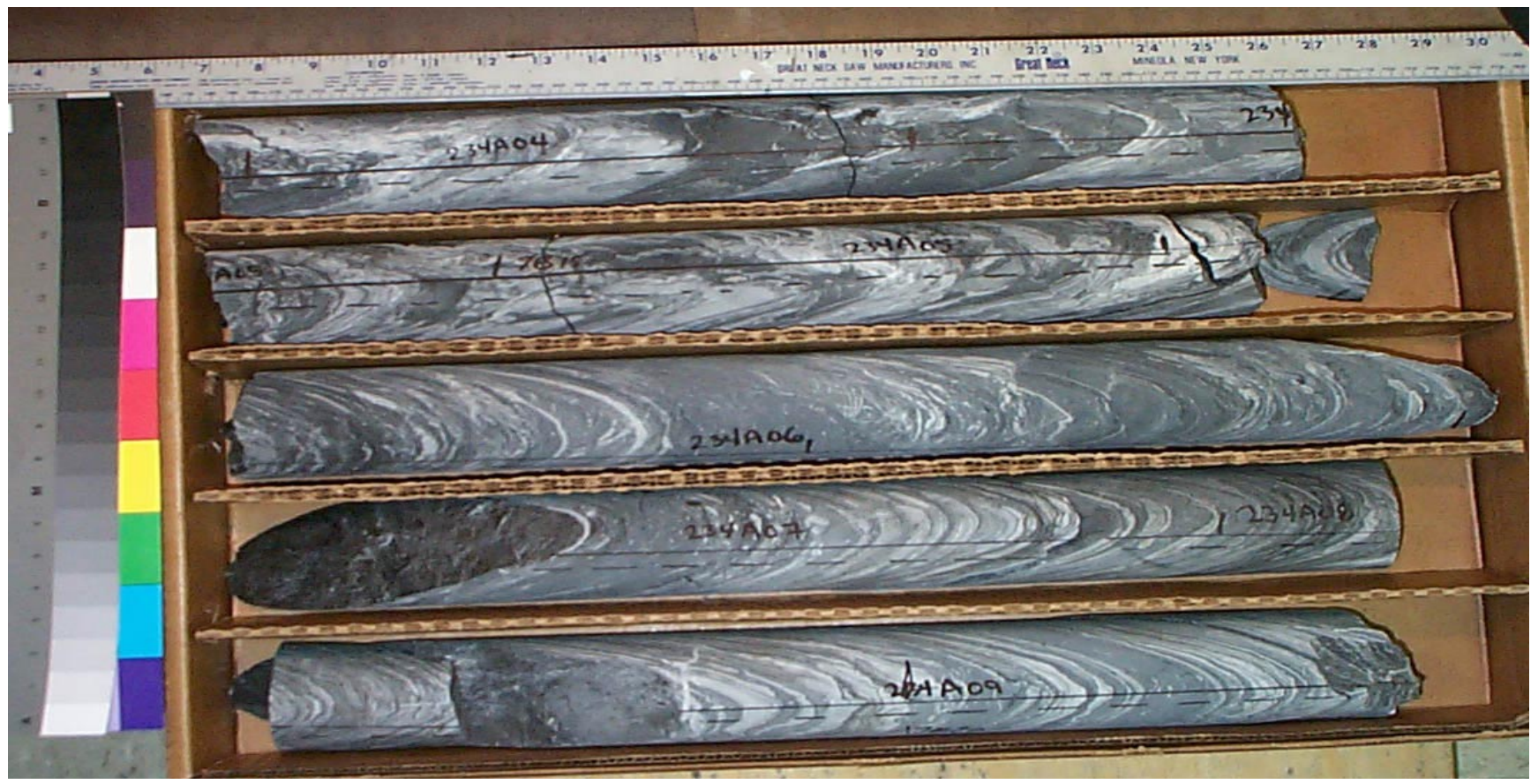

Core Scans included in this box (listed by piece going downhole):
234A040A
234A050A
234A0600
234A0700
234A0800
234A0900

See the "reading instructions" section of the introduction for help interpreting core box photos and core piece nomenclature 


\section{LVEW Core Box 338}

Depth Interval 8721.0'-8727.2'

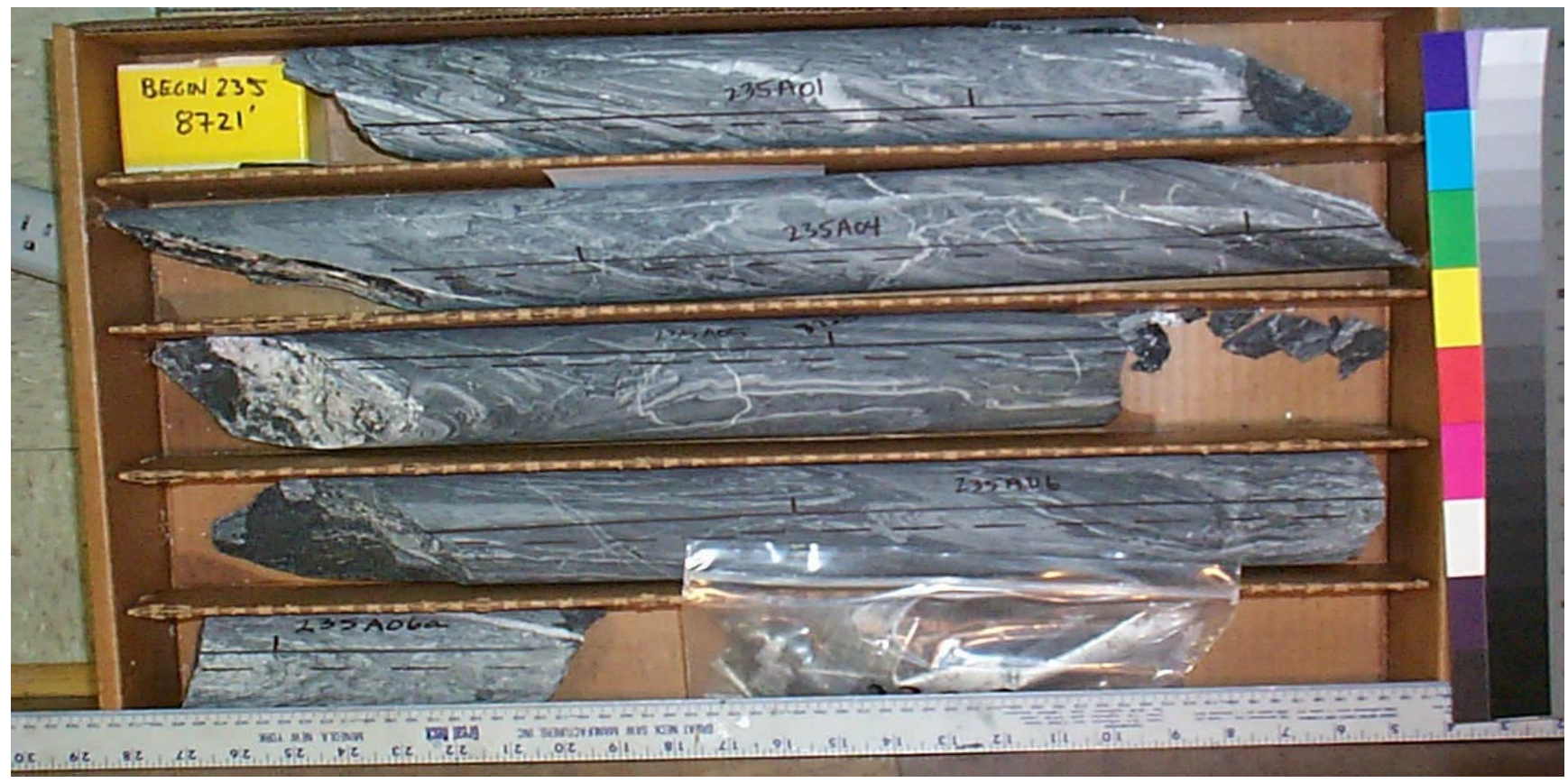

Core Scans included in this box (listed by piece going downhole):
235A0100
235A 0400
235A0500
235A060A

See the "reading instructions" section of the introduction for help interpreting core box photos and core piece nomenclature 


\section{LVEW Core Box 339}

Depth Interval 8727.2'-8735.9'

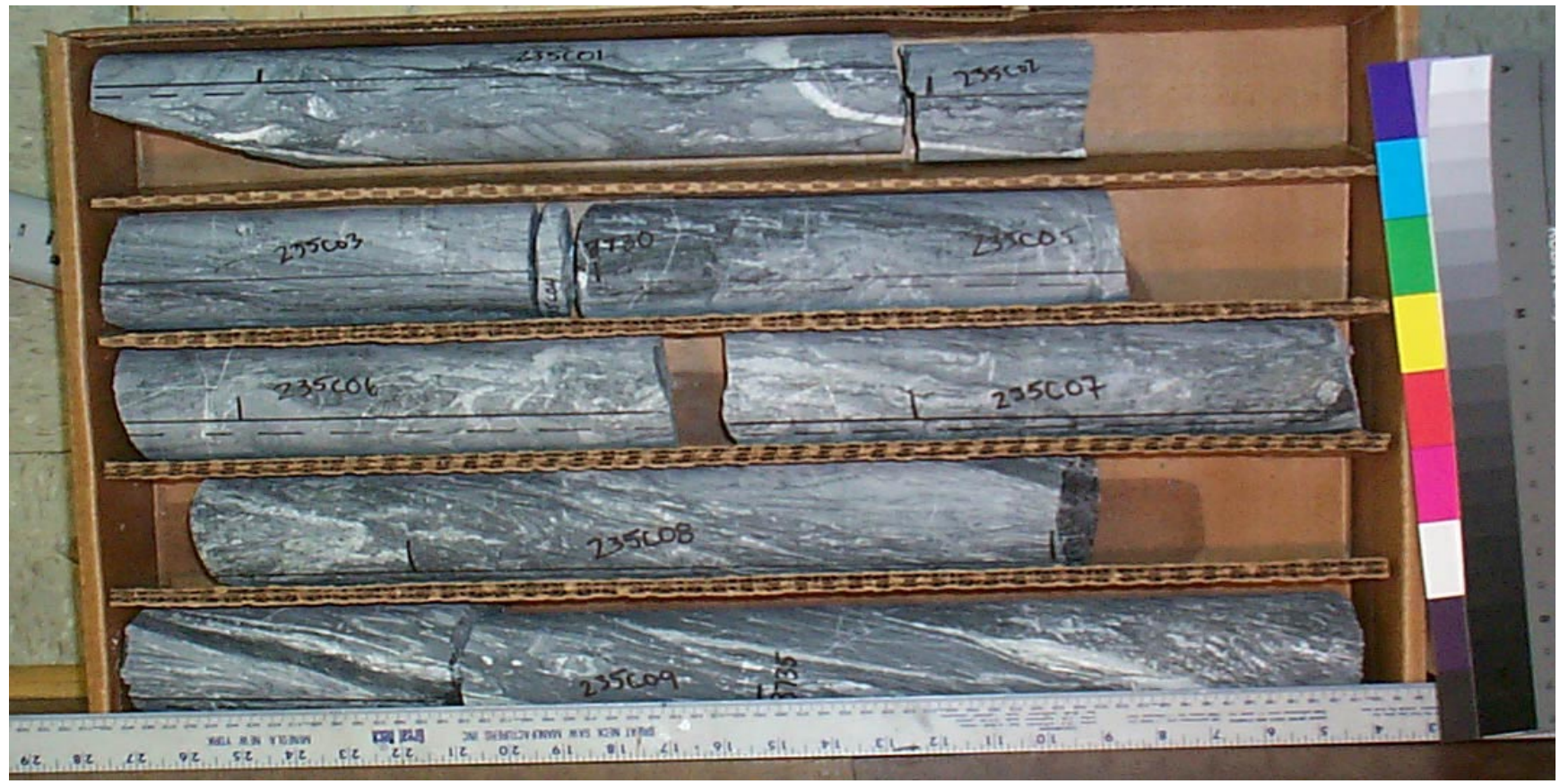

Core Scans included in this box (listed by piece going downhole):
235C0100
235C0200
$235 \mathrm{C} 0300$
235C0400
235C0500
235C0600
235C0700
$235 \mathrm{C} 0800$
235C091A

See the "reading instructions" section of the introduction for help interpreting core box photos and core piece nomenclature 


\section{LVEW Core Box 340}

Depth Interval 8735.9'-8743.6'

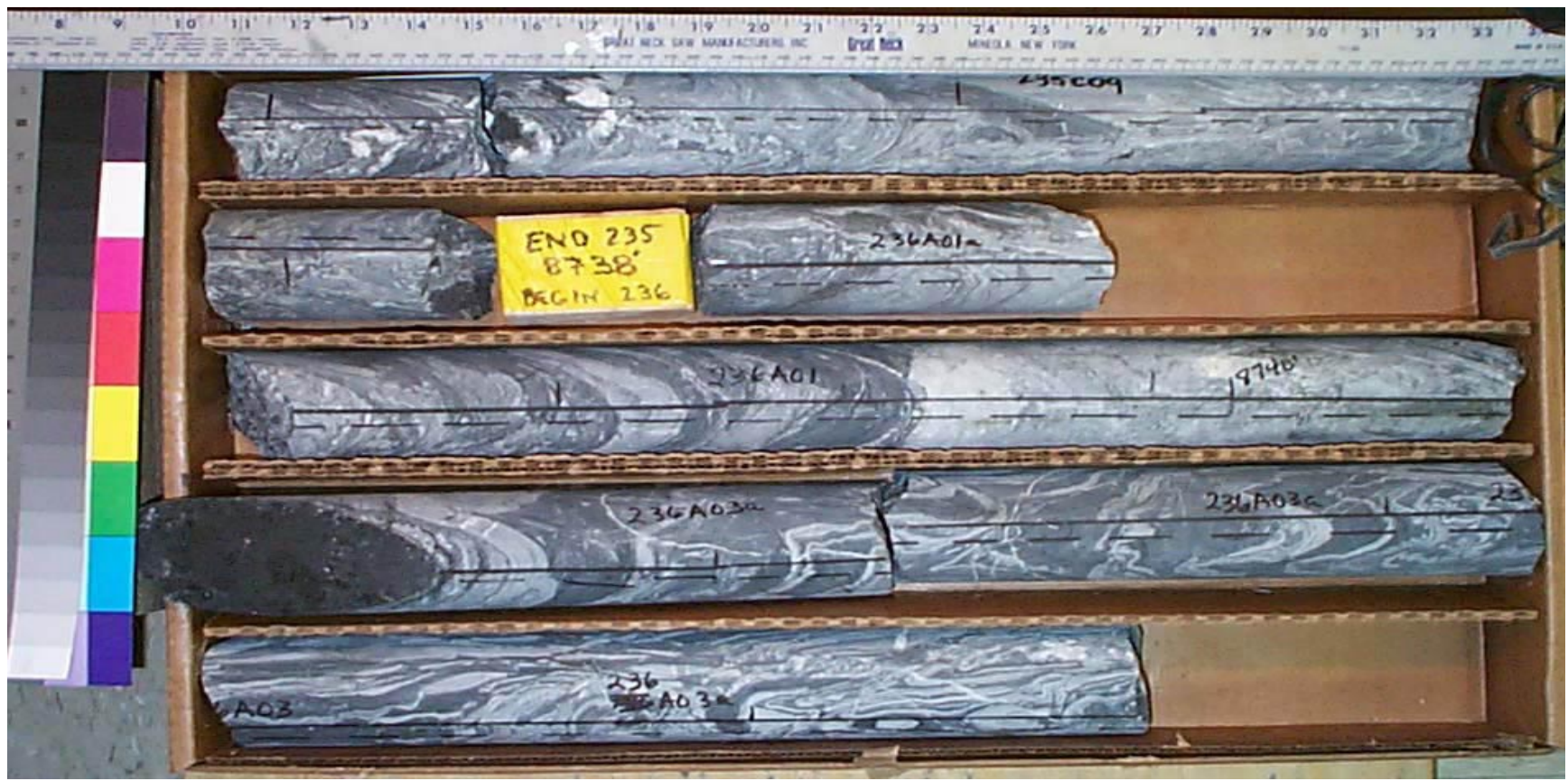

Core Scans included in this box (listed by piece going downhole):

\section{$235 \mathrm{C} 092 \mathrm{~A}$ 236A010A 236A030A}

See the "reading instructions" section of the introduction for help interpreting core box photos and core piece nomenclature 


\section{LVEW Core Box 341}

Depth Interval 8743.6'-8751.4'

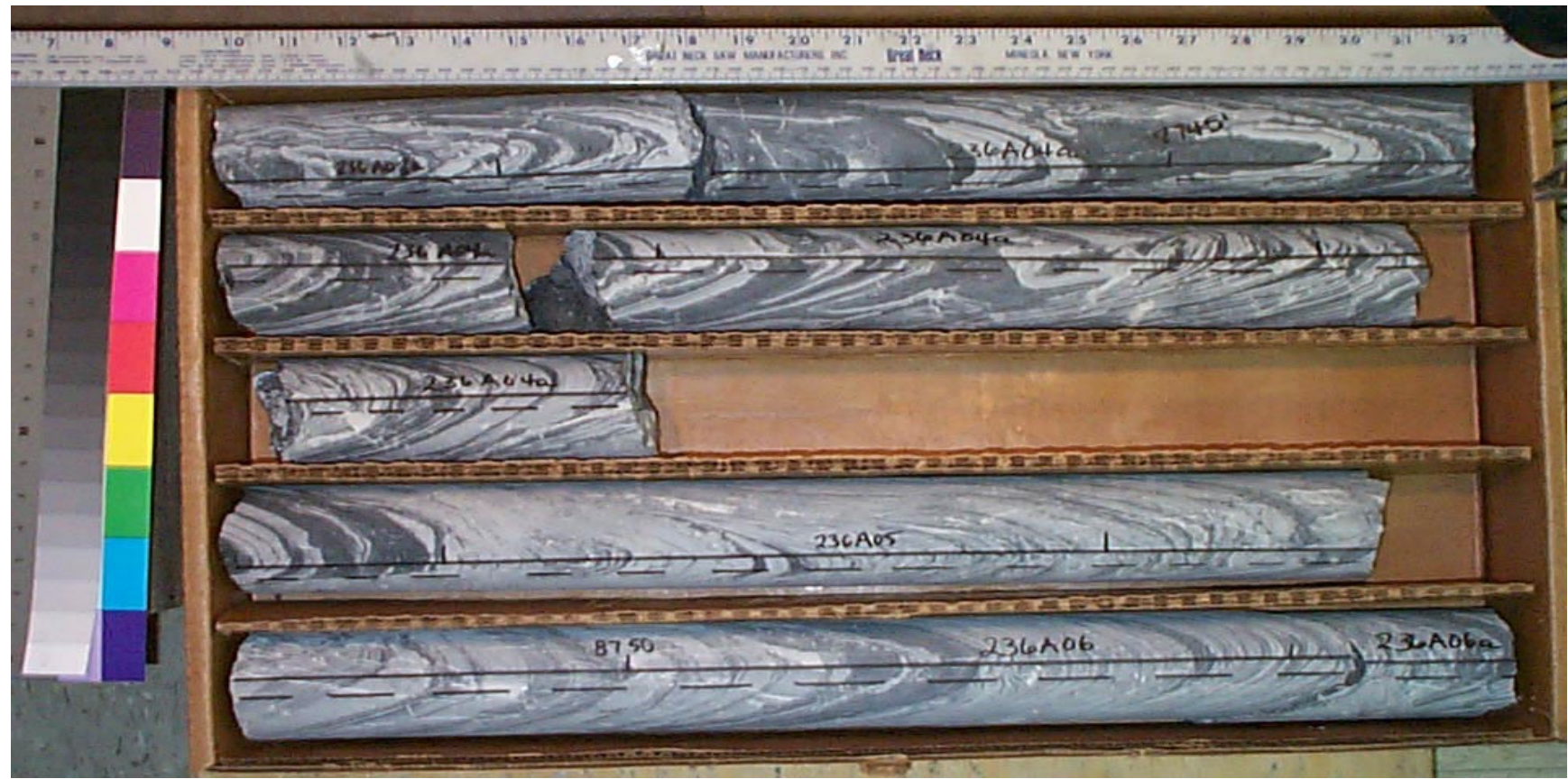

Core Scans included in this box (listed by piece going downhole):

\section{A030A 236A041A 236A042A $236 \mathrm{~A} 0500$ 236A061A}

See the "reading instructions" section of the introduction for help interpreting core box photos and core piece nomenclature 


\section{LVEW Core Box 342}

Depth Interval 8751.4'-8760.8'

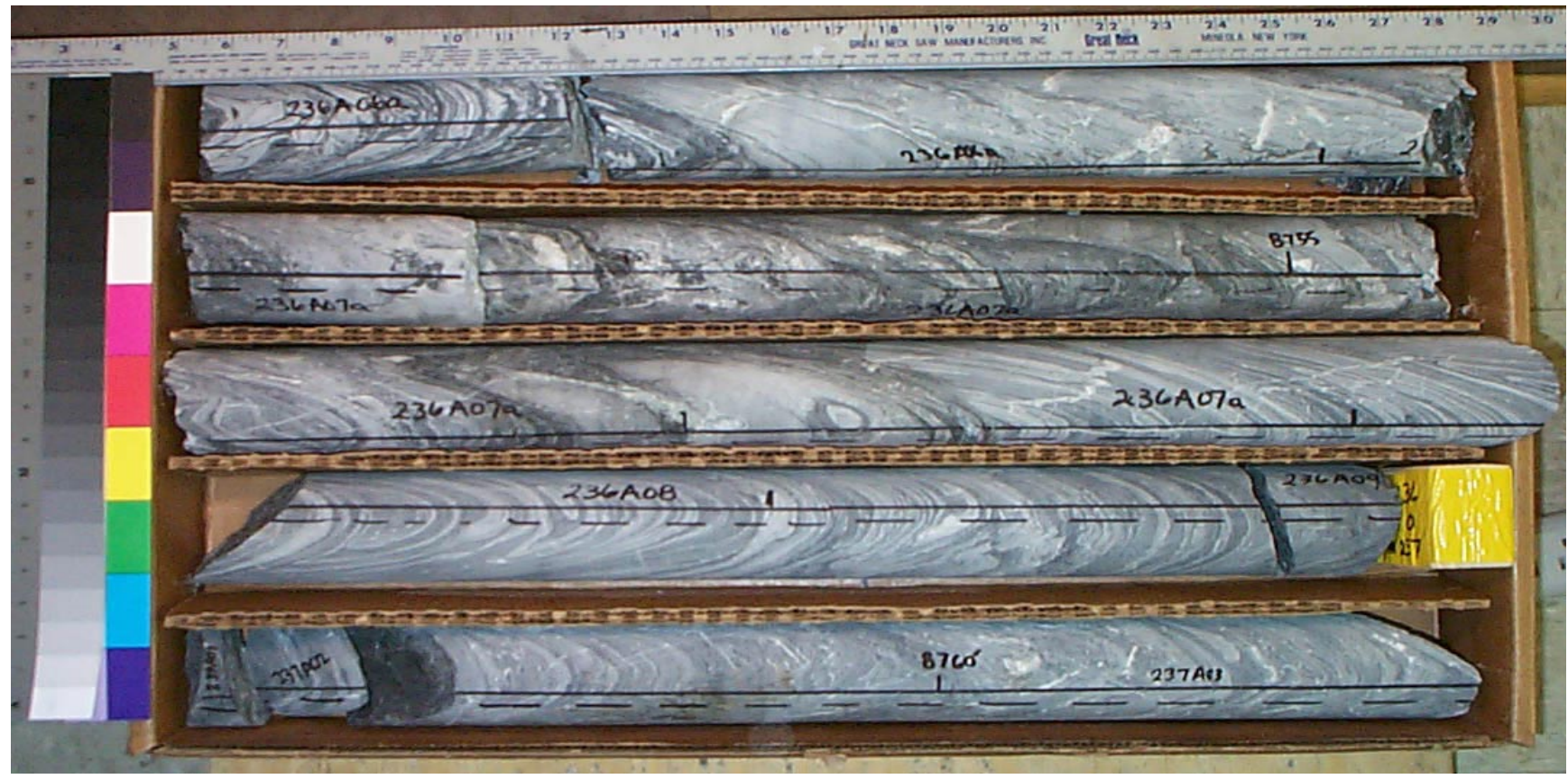

Core Scans included in this box (listed by piece going downhole):
236A062A
236A071A
236A072A
$236 \mathrm{~A} 0800$
$236 \mathrm{~A} 0900$
$237 \mathrm{~A} 0100$
$237 \mathrm{~A} 0300$

See the "reading instructions" section of the introduction for help interpreting core box photos and core piece nomenclature 


\section{LVEW Core Box 343}

Depth Interval 8760.8'-8767.8'

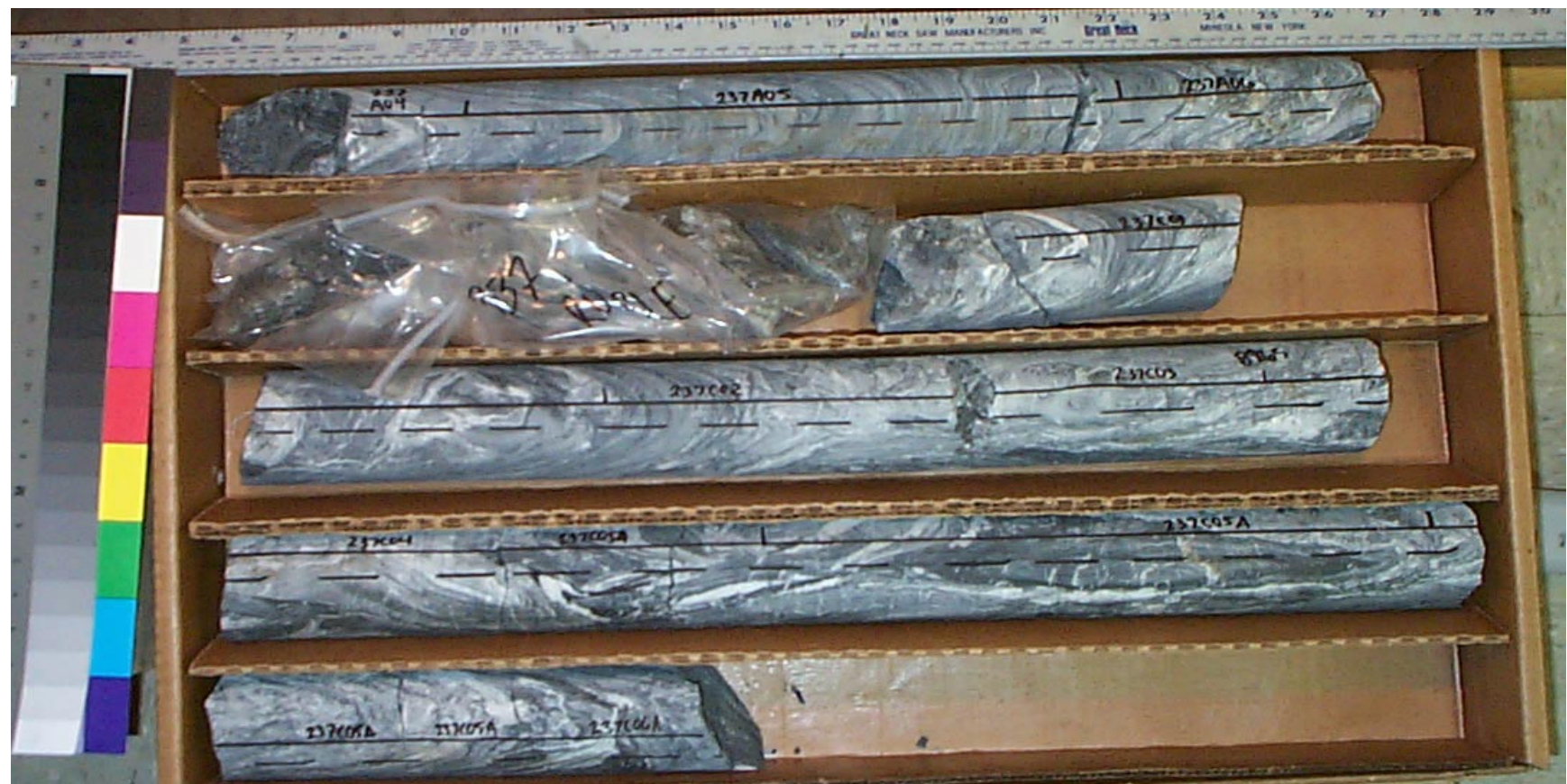

Core Scans included in this box (listed by piece going downhole):

$237 \mathrm{~A} 0400$
$237 \mathrm{~A} 0500$
$237 \mathrm{~A} 0600$
$237 \mathrm{C} 0100$
$237 \mathrm{C} 0200$
$237 \mathrm{C} 0300$
$237 \mathrm{C} 0400$
$237 \mathrm{C} 050 \mathrm{~A}$
$237 \mathrm{C} 060 \mathrm{~A}$

See the "reading instructions" section of the introduction for help interpreting core box photos and core piece nomenclature 


\section{LVEW Core Box 344}

Depth Interval 8767.8'-8775.8'

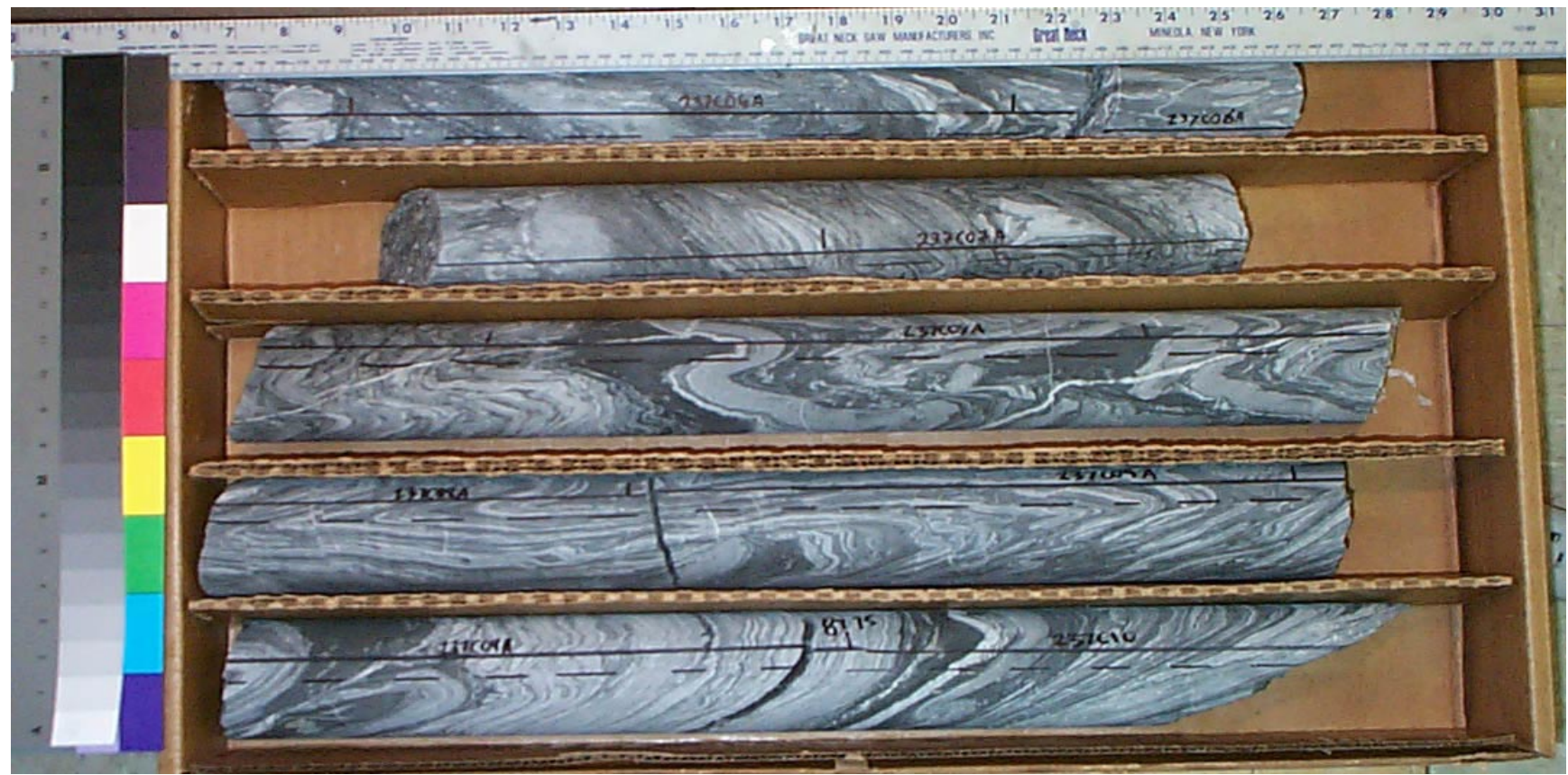

Core Scans included in this box (listed by piece going downhole):
$237 \mathrm{C060A}$
$237 \mathrm{C} 0700$
$237 \mathrm{C} 080 \mathrm{~A}$
$237 \mathrm{C} 090 \mathrm{~A}$
$237 \mathrm{C} 1000$

See the "reading instructions" section of the introduction for help interpreting core box photos and core piece nomenclature 


\section{LVEW Core Box 345}

Depth Interval 8775.8'-8781.9'

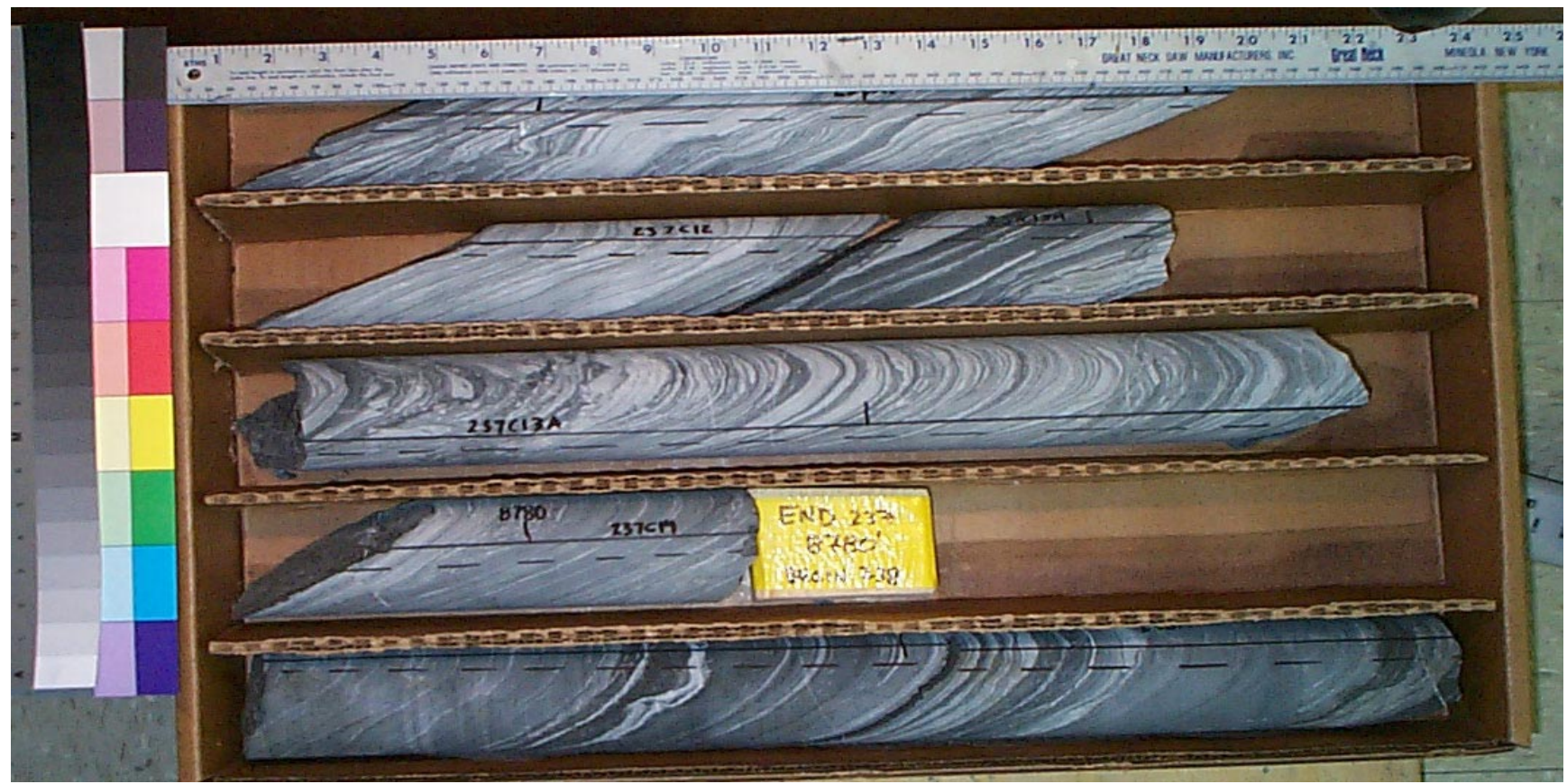

Core Scans included in this box (listed by piece going downhole):
237C1100
$237 \mathrm{C} 1200$
$237 \mathrm{C} 130 \mathrm{~A}$
$237 \mathrm{C} 1400$
238A0100
238A0200

See the "reading instructions" section of the introduction for help interpreting core box photos and core piece nomenclature 


\section{LVEW Core Box 346}

Depth Interval 8781.9'-8788.8'

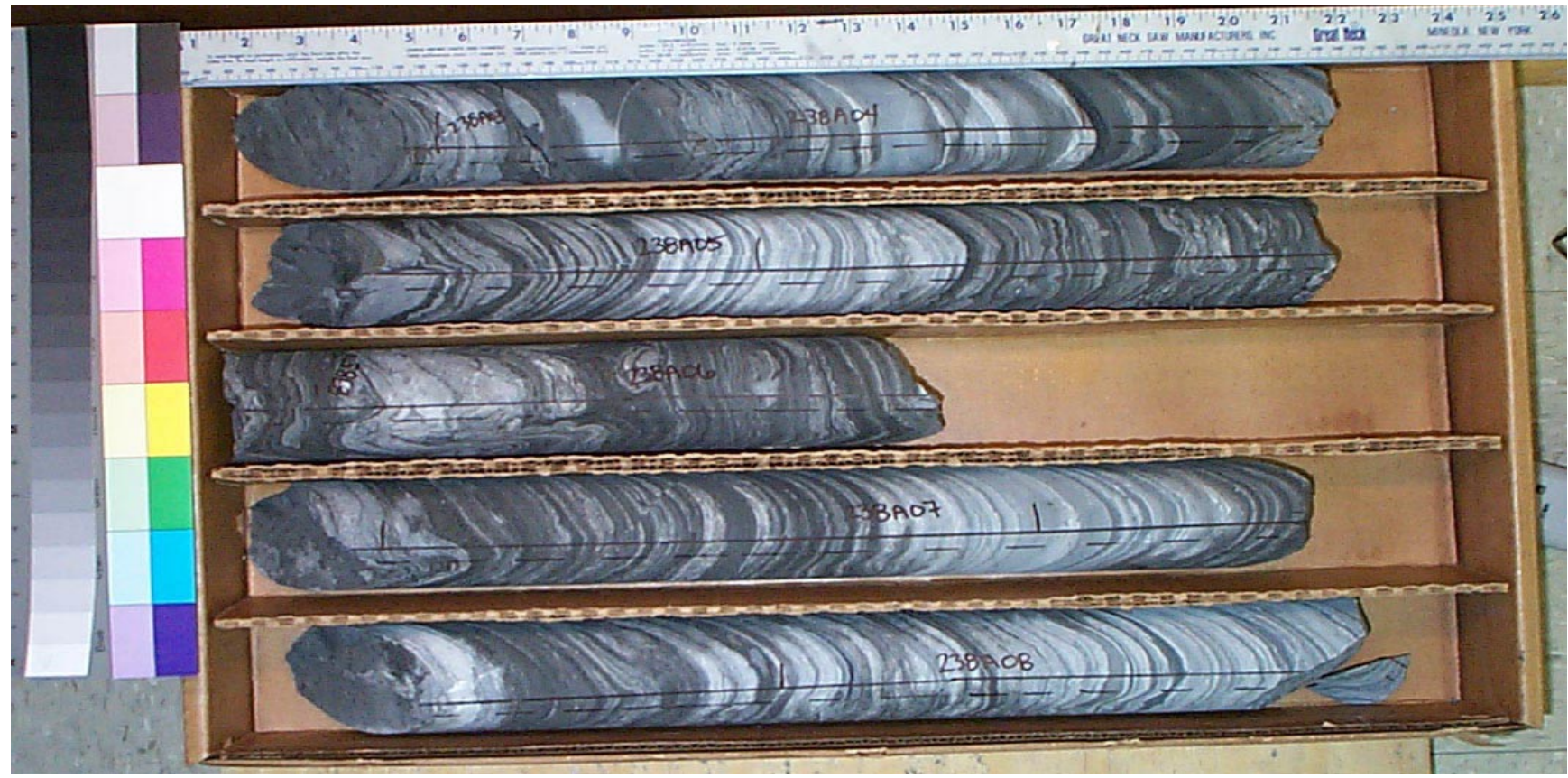

Core Scans included in this box (listed by piece going downhole):
238A0300
238A0400
238A050A
238A0600
238A0700
238A080A

See the "reading instructions" section of the introduction for help interpreting core box photos and core piece nomenclature 


\section{LVEW Core Box 347}

Depth Interval 8788.8'-8795.0'

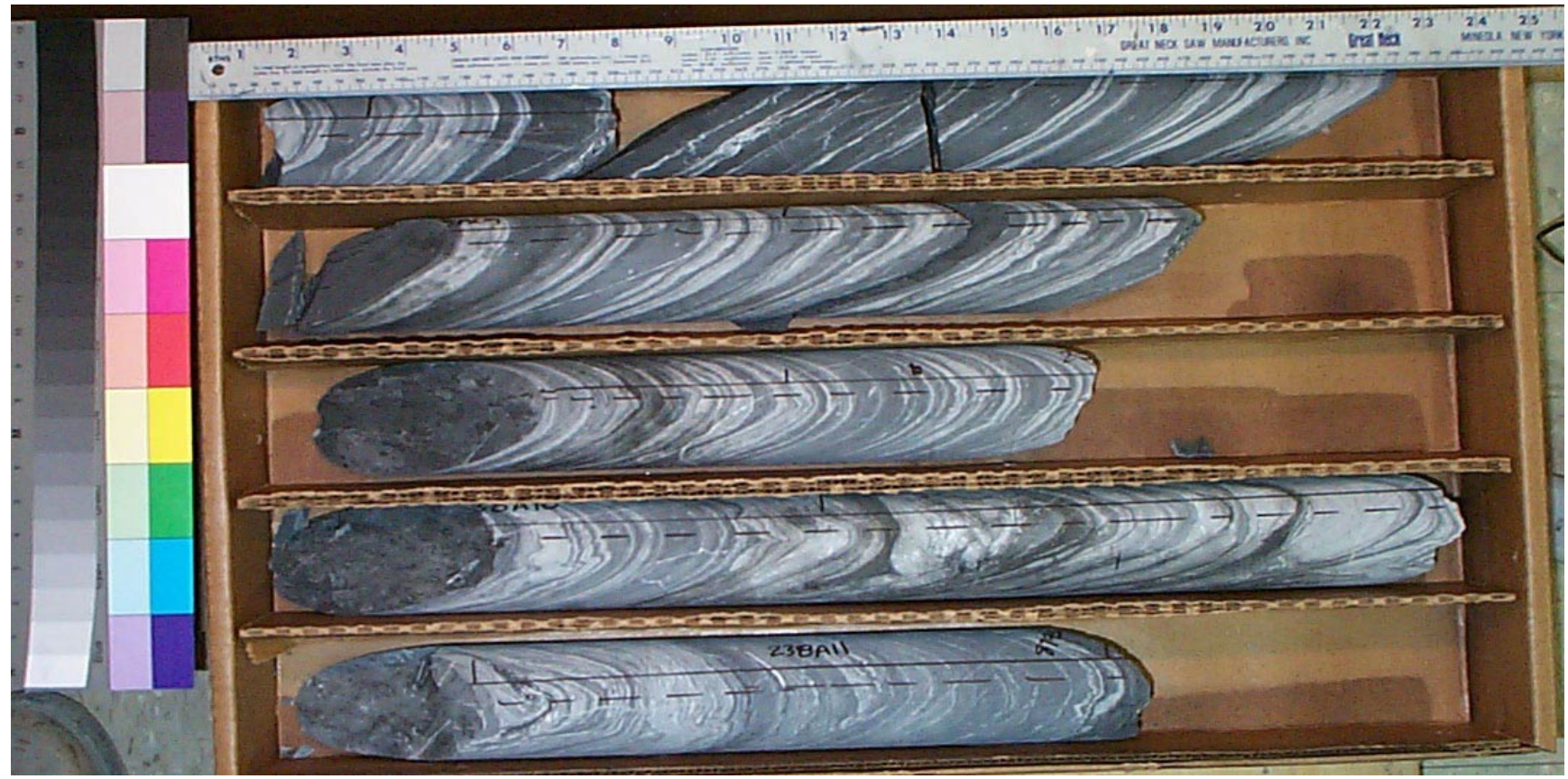

Core Scans included in this box (listed by piece going downhole):

\section{A090A 238A100A 238A1100}

See the "reading instructions" section of the introduction for help interpreting core box photos and core piece nomenclature 


\section{LVEW Core Box 348}

Depth Interval 8795.0'-8802.0'

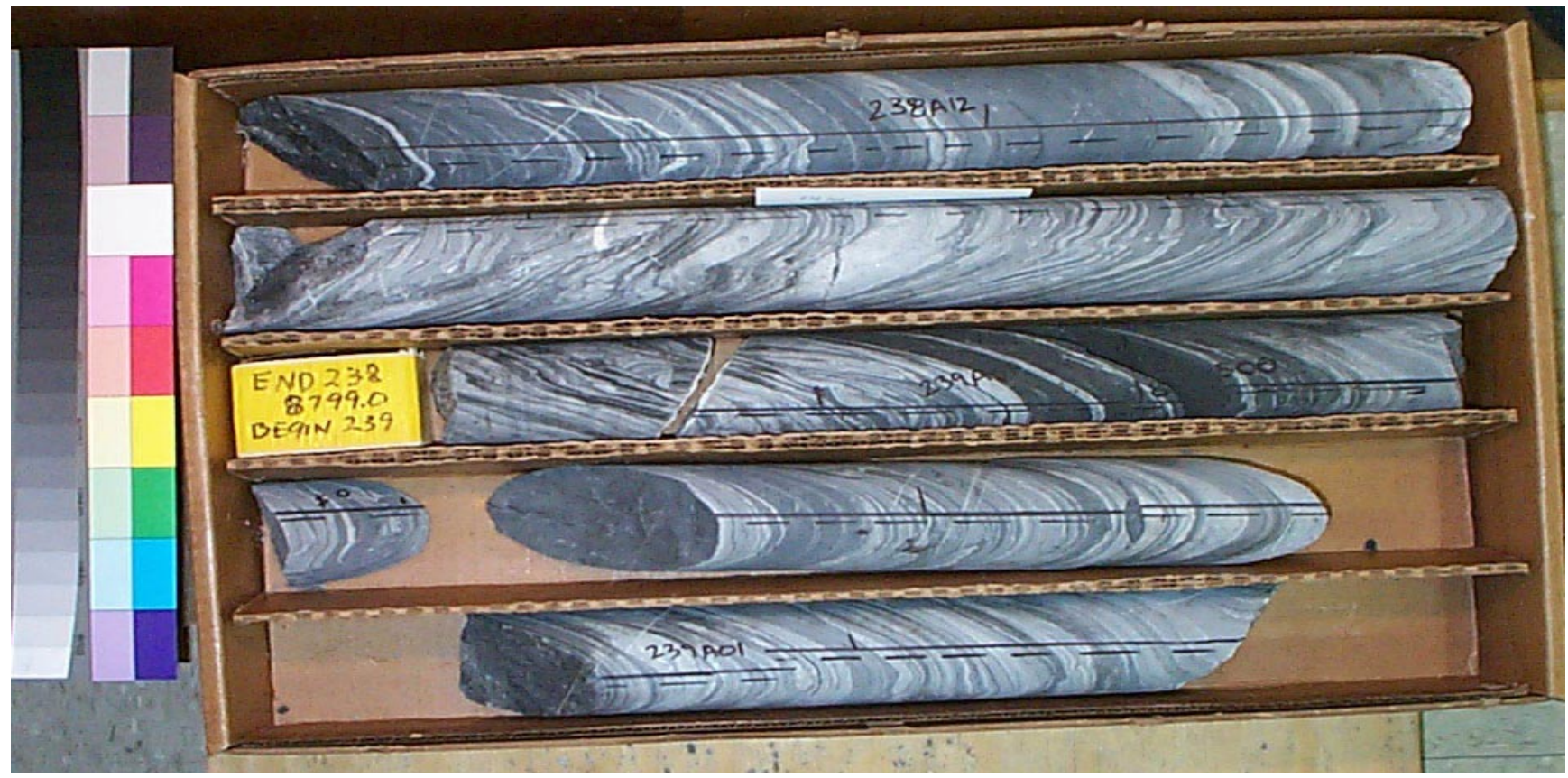

Core Scans included in this box (listed by piece going downhole):
238A 1200
238A 1300
238A 1400
239A011A
239A012A

See the "reading instructions" section of the introduction for help interpreting core box photos and core piece nomenclature 


\section{LVEW Core Box 349}

Depth Interval 8802.0'-8808.5'

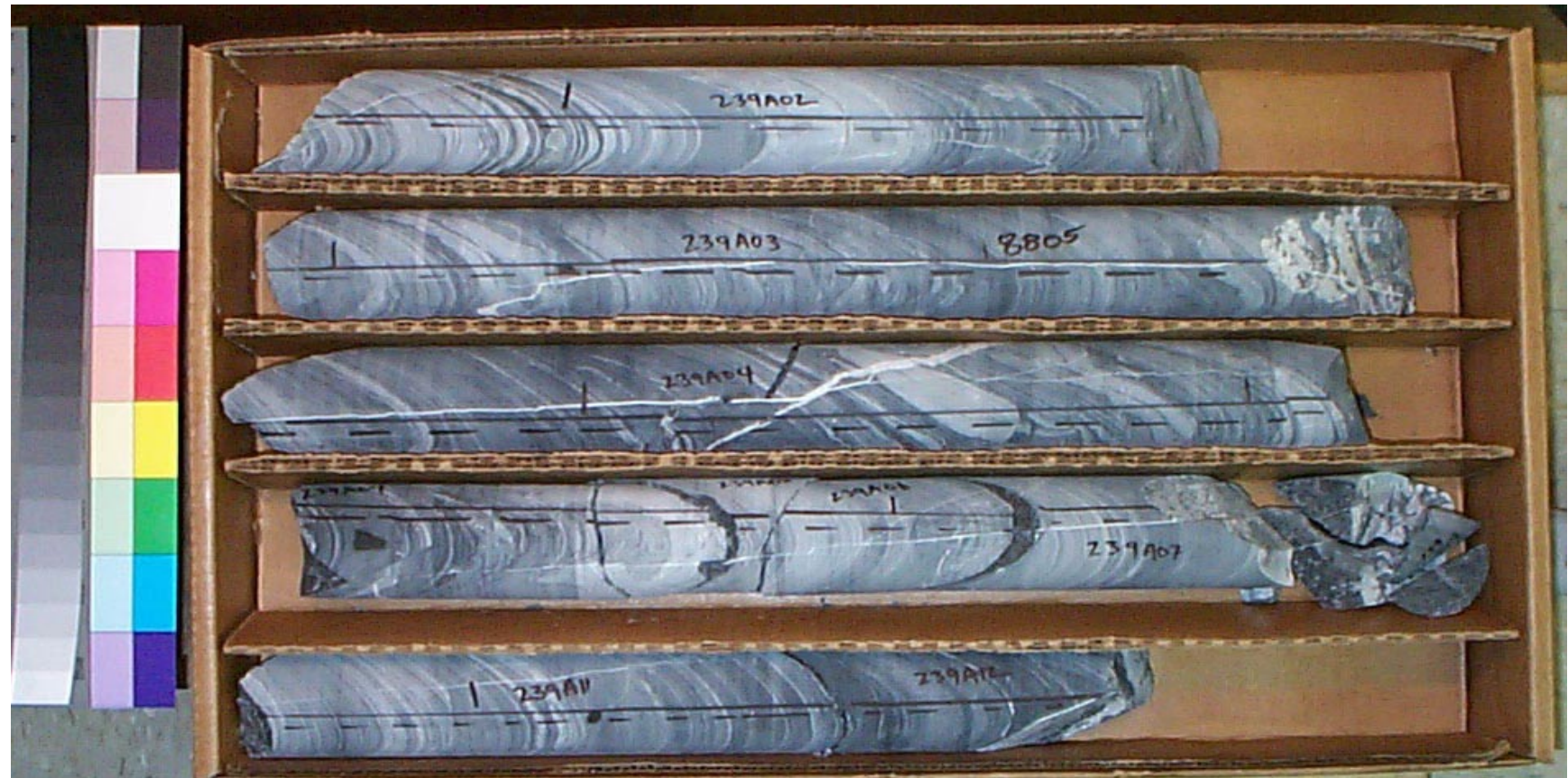

Core Scans included in this box (listed by piece going downhole):

$$
\begin{aligned}
& \text { 239A0200 } \\
& \text { 239A0300 } \\
& 239 A 0400 \\
& \text { 239A0700 } \\
& \text { 239A1100 } \\
& \text { 239A1200 }
\end{aligned}
$$

See the "reading instructions" section of the introduction for help interpreting core box photos and core piece nomenclature 


\section{LVEW Core Box 350}

Depth Interval 8808.5'-8817.9'

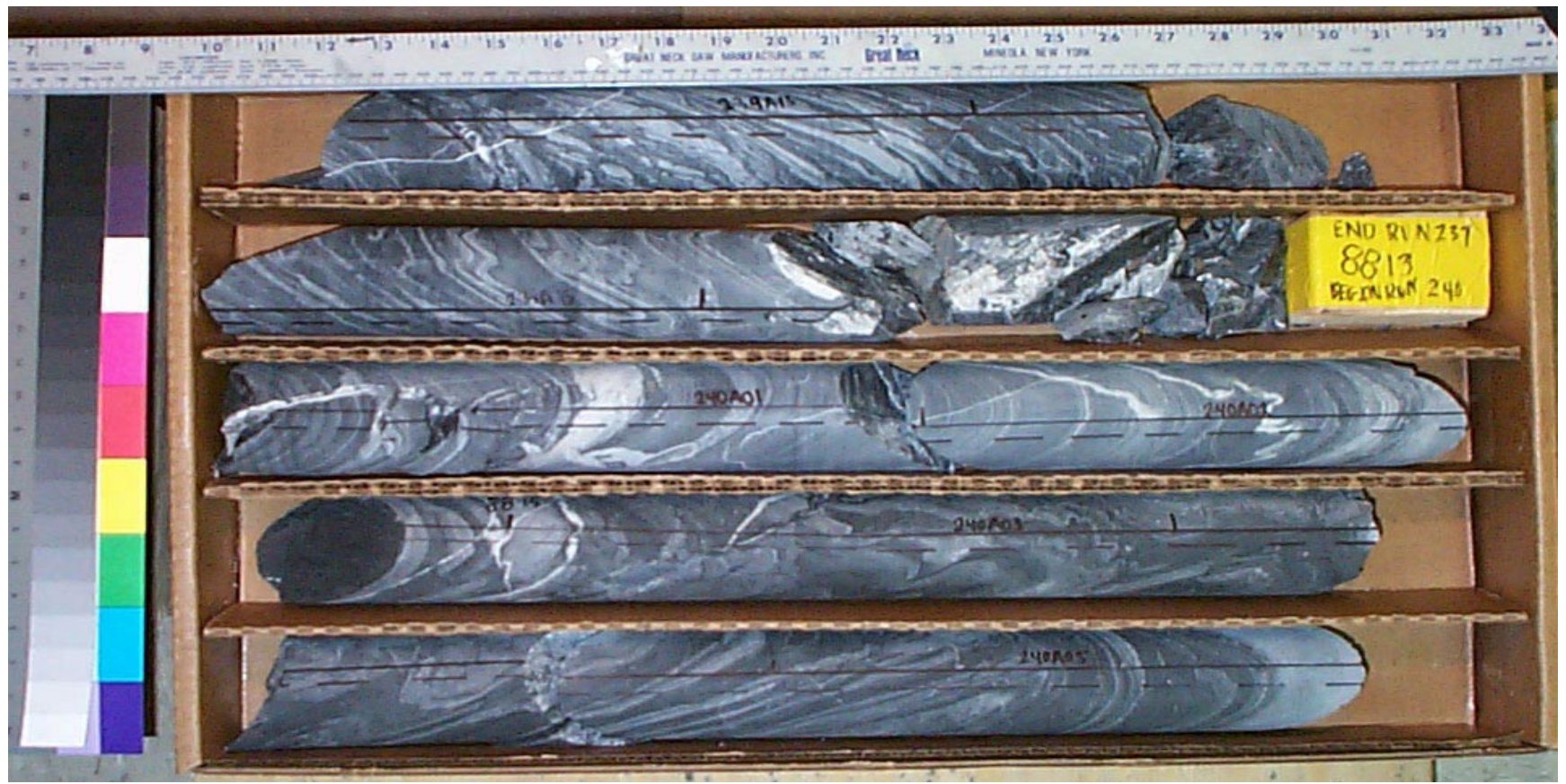

Core Scans included in this box (listed by piece going downhole):
239A 1300
239A 1500
$240 \mathrm{~A} 0100$
240A0200
$240 \mathrm{~A} 030 \mathrm{~A}$
$240 \mathrm{~A} 0500$

See the "reading instructions" section of the introduction for help interpreting core box photos and core piece nomenclature 


\section{LVEW Core Box 351}

Depth Interval 8817.9'-8825.3'

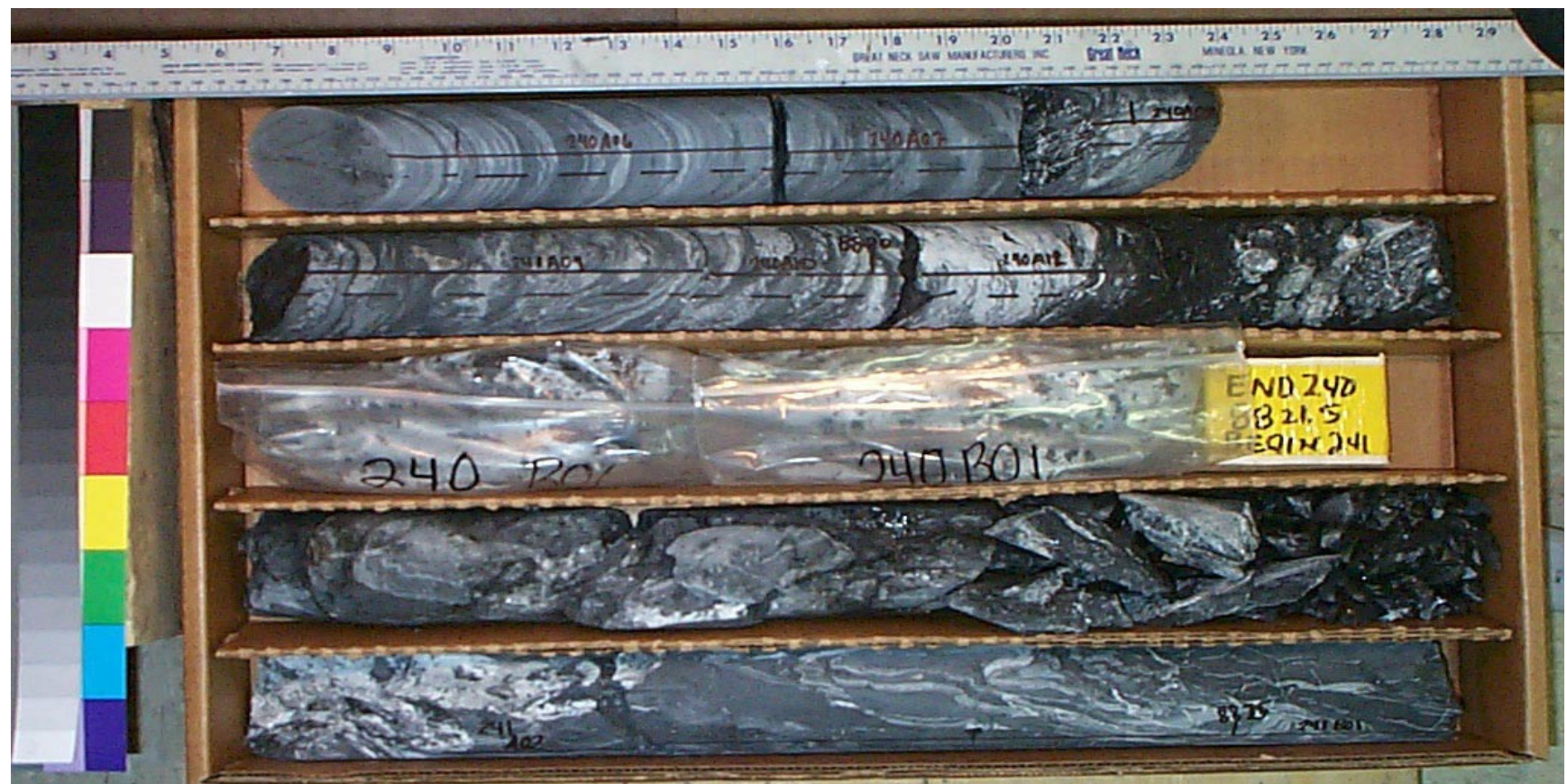

Core Scans included in this box (listed by piece going downhole):

\section{$240 \mathrm{~A} 0600$ \\ $240 \mathrm{~A} 0700$ \\ $240 \mathrm{~A} 0800$ \\ 240A0900 \\ $240 \mathrm{~A} 1000$ \\ 241B011A}

See the "reading instructions" section of the introduction for help interpreting core box photos and core piece nomenclature 


\section{LVEW Core Box 352}

Depth Interval 8825.3'-8832.7'

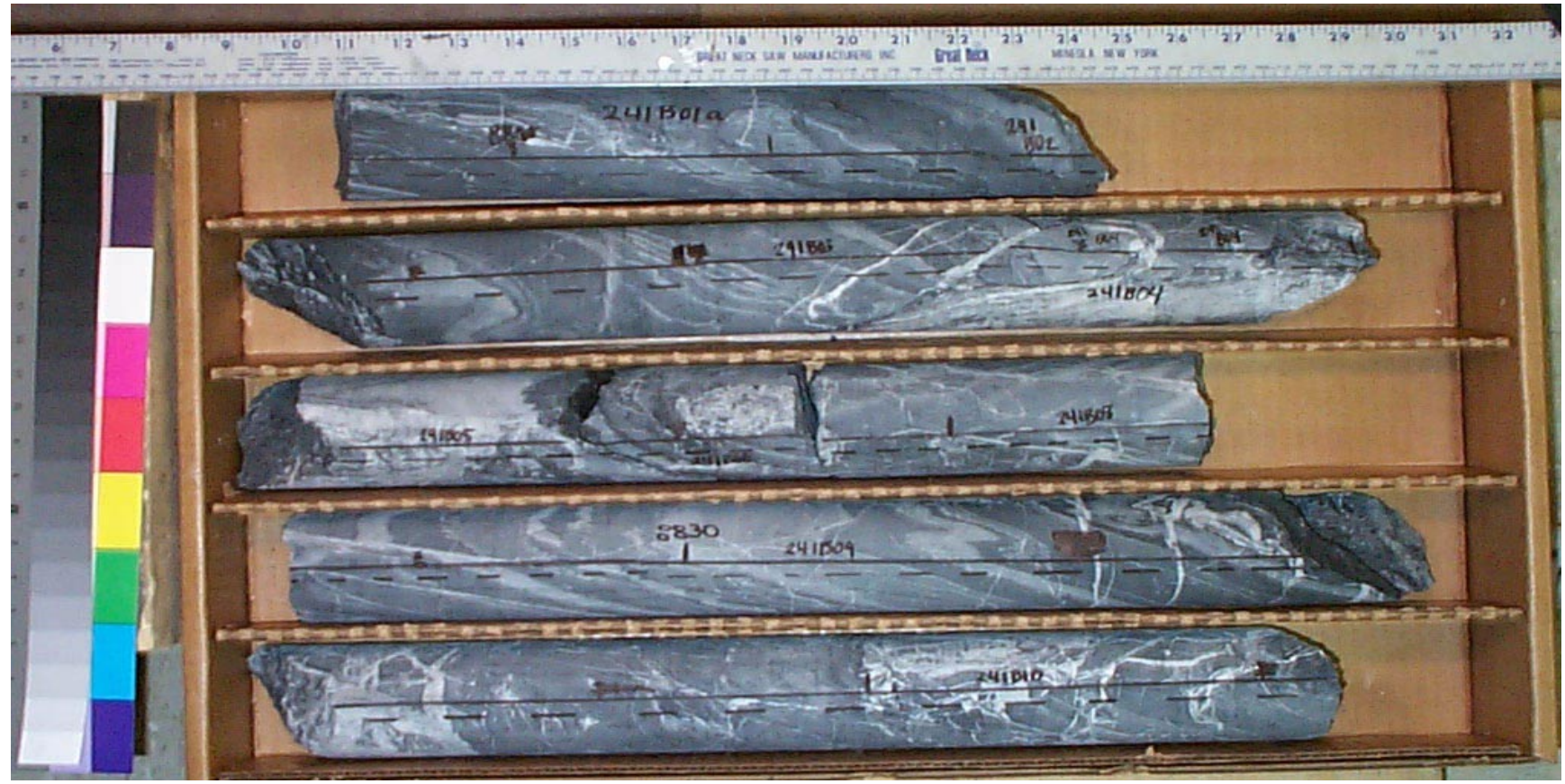

Core Scans included in this box (listed by piece going downhole):

241B011A

241B0300

241B0500

241B0800

241B0900

241B1000

See the "reading instructions" section of the introduction for help interpreting core box photos and core piece nomenclature 


\section{LVEW Core Box 353}

Depth Interval 8832.7'-8840.7'

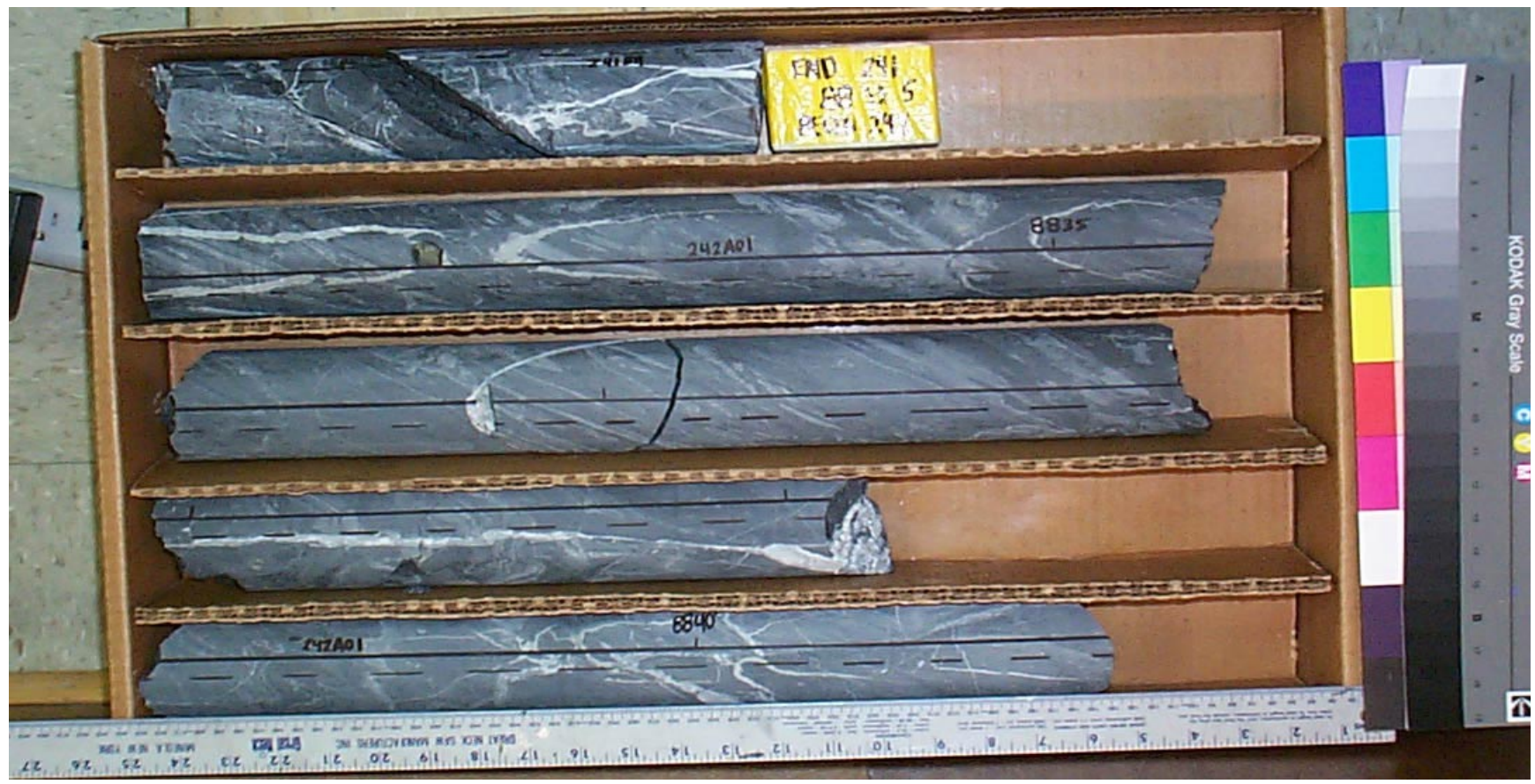

Core Scans included in this box (listed by piece going downhole):

\section{B1100 \\ 242A011A \\ 242A012A \\ 242A013A}

See the "reading instructions" section of the introduction for help interpreting core box photos and core piece nomenclature 


\section{LVEW Core Box 354}

\section{Depth Interval 8840.7'-8848.6'}

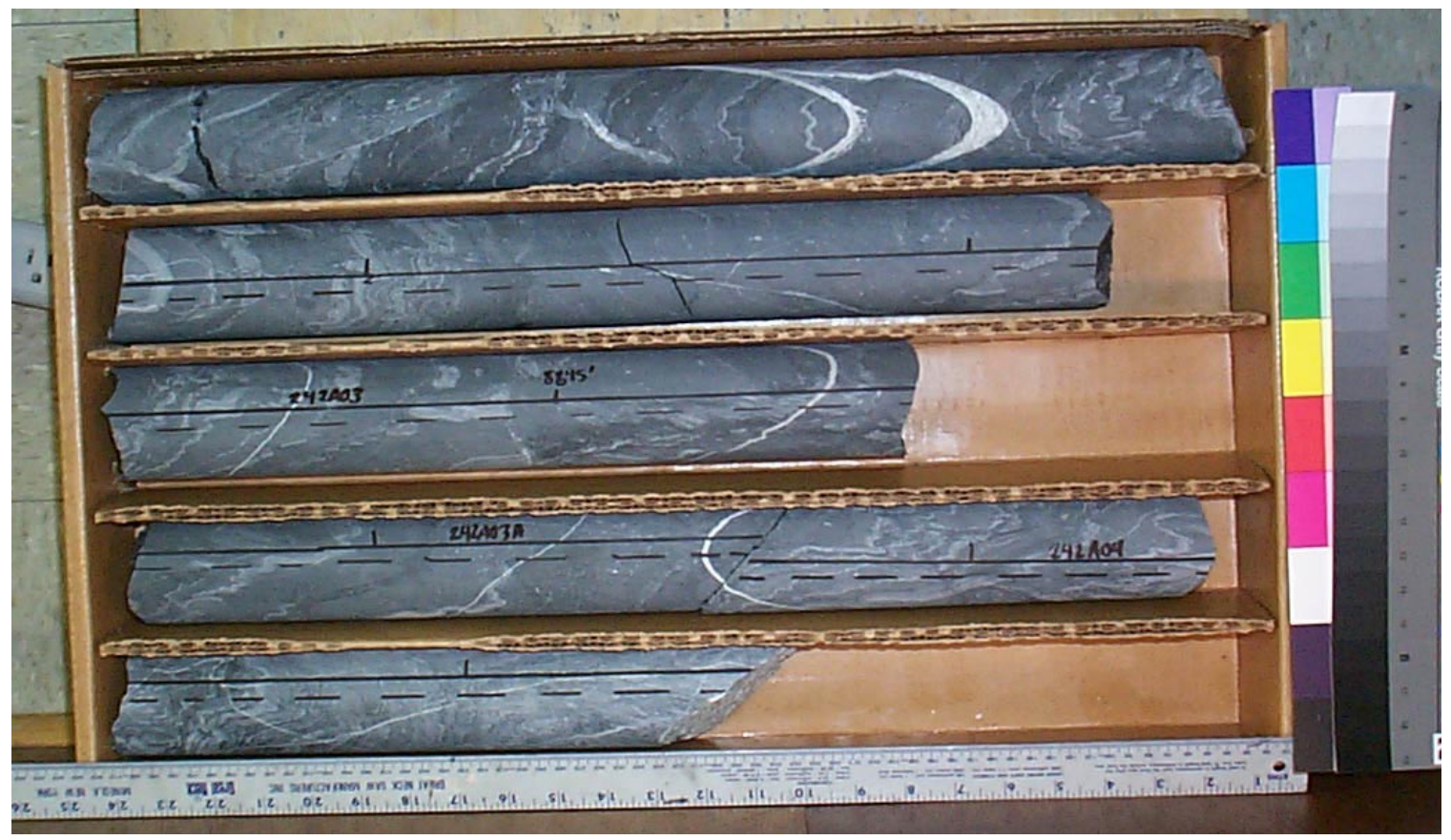

Core Scans included in this box (listed by piece going downhole):
242A021A
242A022A
$242 \mathrm{~A} 030 \mathrm{~A}$
242A040A

See the "reading instructions" section of the introduction for help interpreting core box photos and core piece nomenclature 


\section{LVEW Core Box 355}

Depth Interval 8848.6'-8855.0'

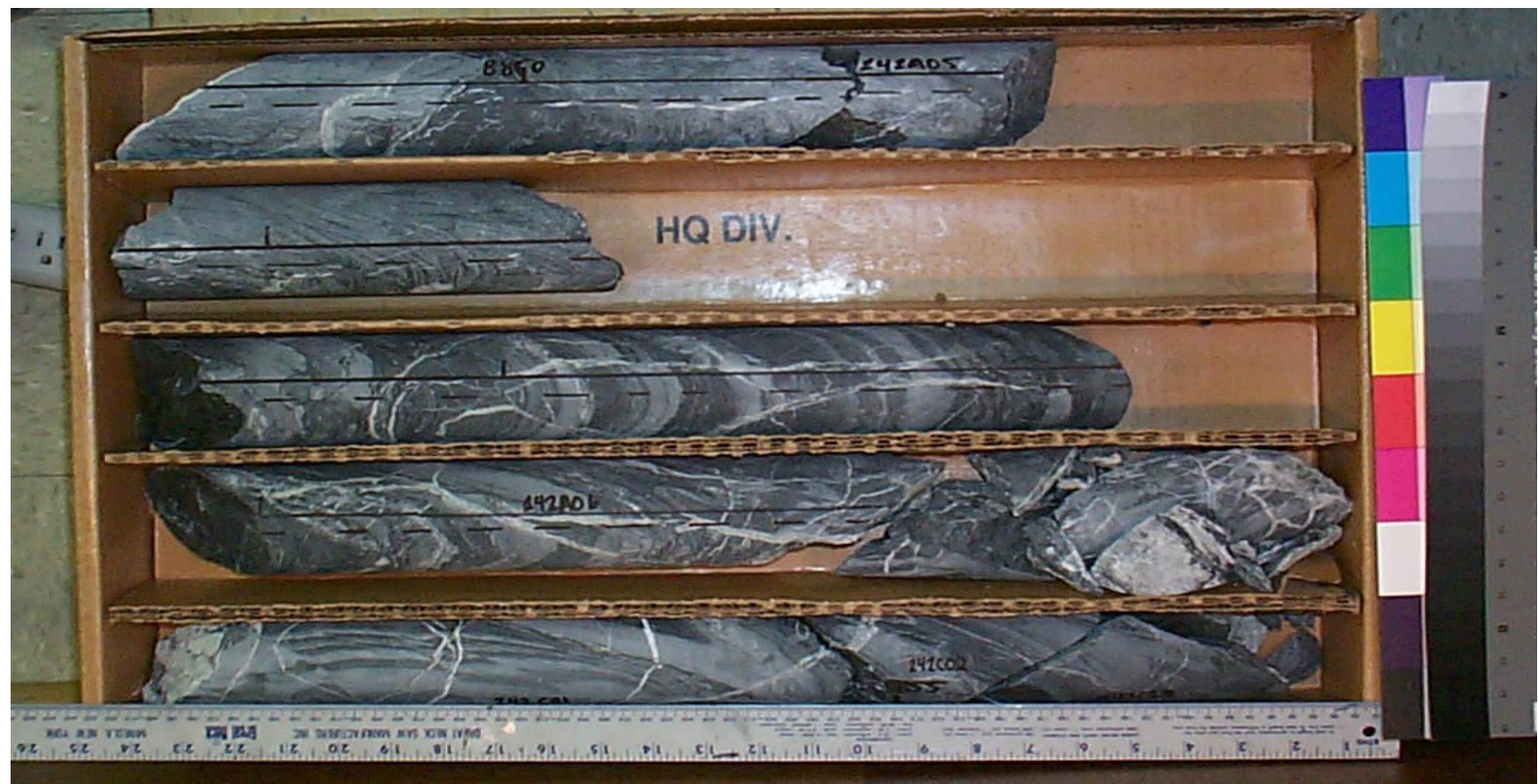

Core Scans included in this box (listed by piece going downhole):

\section{A050A 242A060A \\ $242 \mathrm{C} 0100$ 242C0200}

See the "reading instructions" section of the introduction for help interpreting core box photos and core piece nomenclature 


\section{LVEW Core Box 356}

Depth Interval 8855.0'-8861.9'

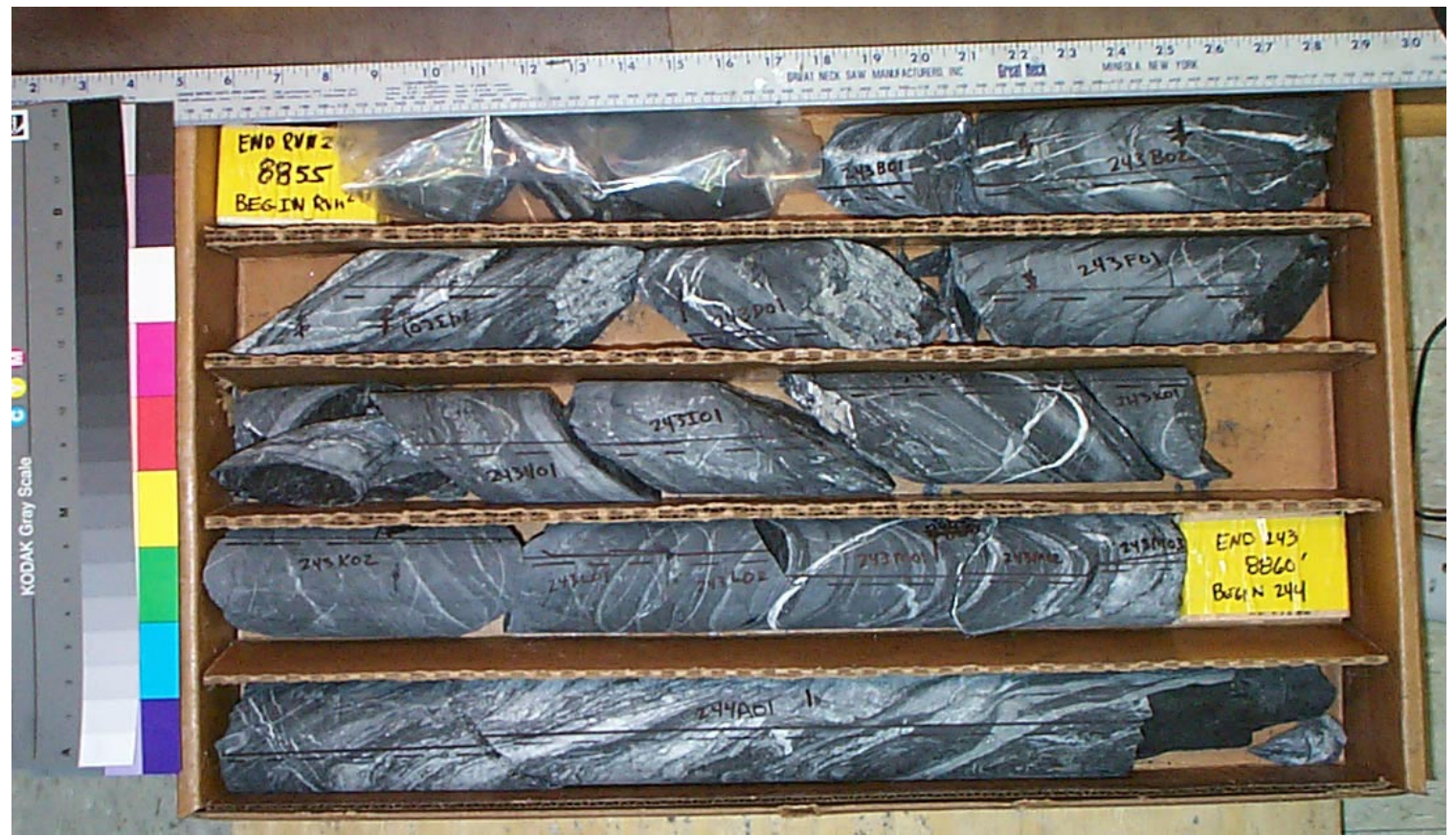

Core Scans included in this box (listed by piece going downhole):

\section{B0200 \\ 243C0100 \\ 243D0100 \\ 243F0100 \\ $243 \mathrm{H} 0100$ \\ 24310100 \\ 243J0100 \\ 243K0100 \\ 243L0100 \\ 243M0100 \\ $243 \mathrm{M} 0300$ \\ 244A010A}

See the "reading instructions" section of the introduction for help interpreting core box photos and core piece nomenclature 


\section{LVEW Core Box 357}

Depth Interval 8861.9'-8868.3'

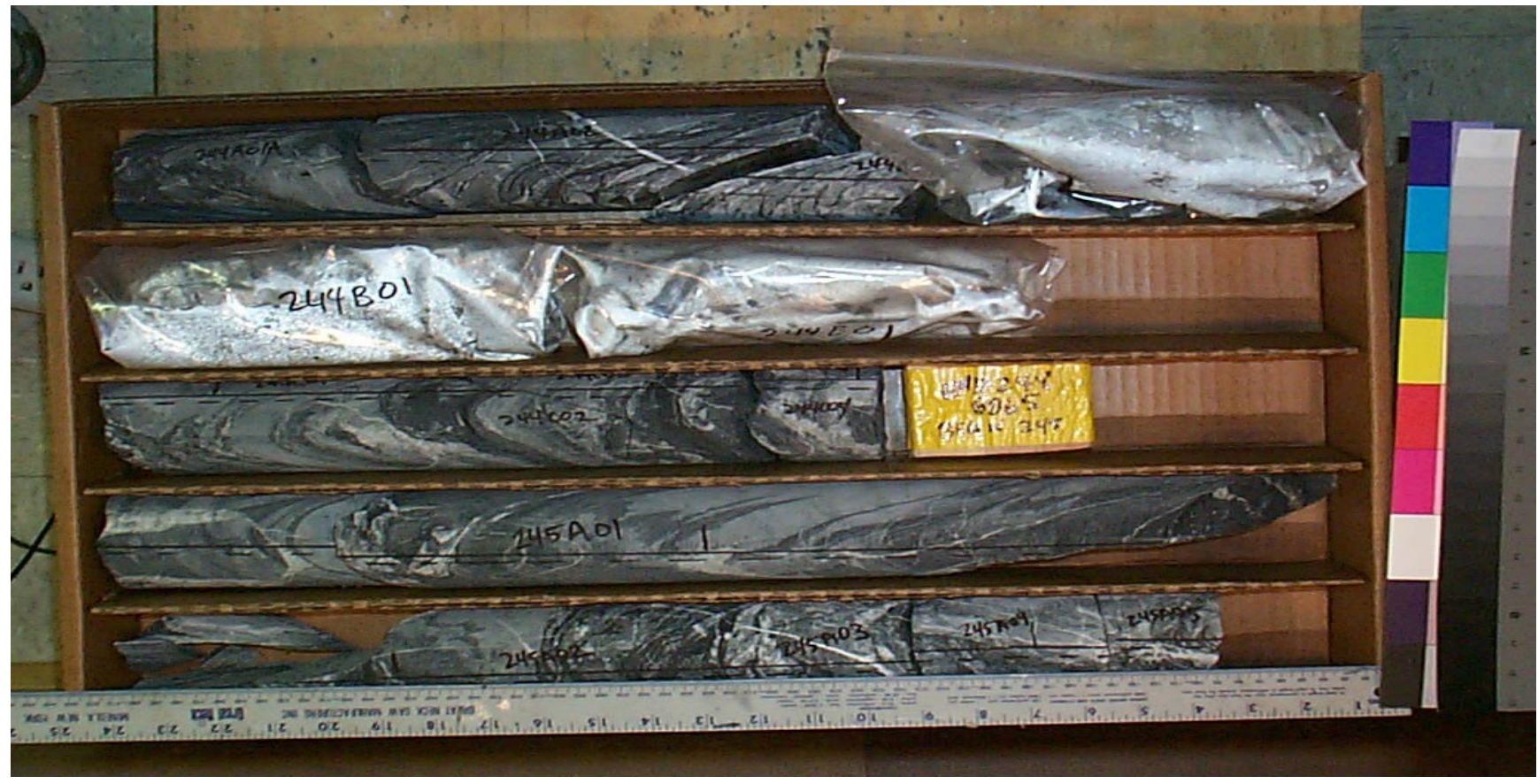

Core Scans included in this box (listed by piece going downhole):
244A0200
244C0100
244C0300
244C0400
245A010A
245A0200
245A0300
245A0400
$245 \mathrm{~A} 0500$

See the "reading instructions" section of the introduction for help interpreting core box photos and core piece nomenclature 


\section{LVEW Core Box 358}

Depth Interval 8868.3'-8875.5'

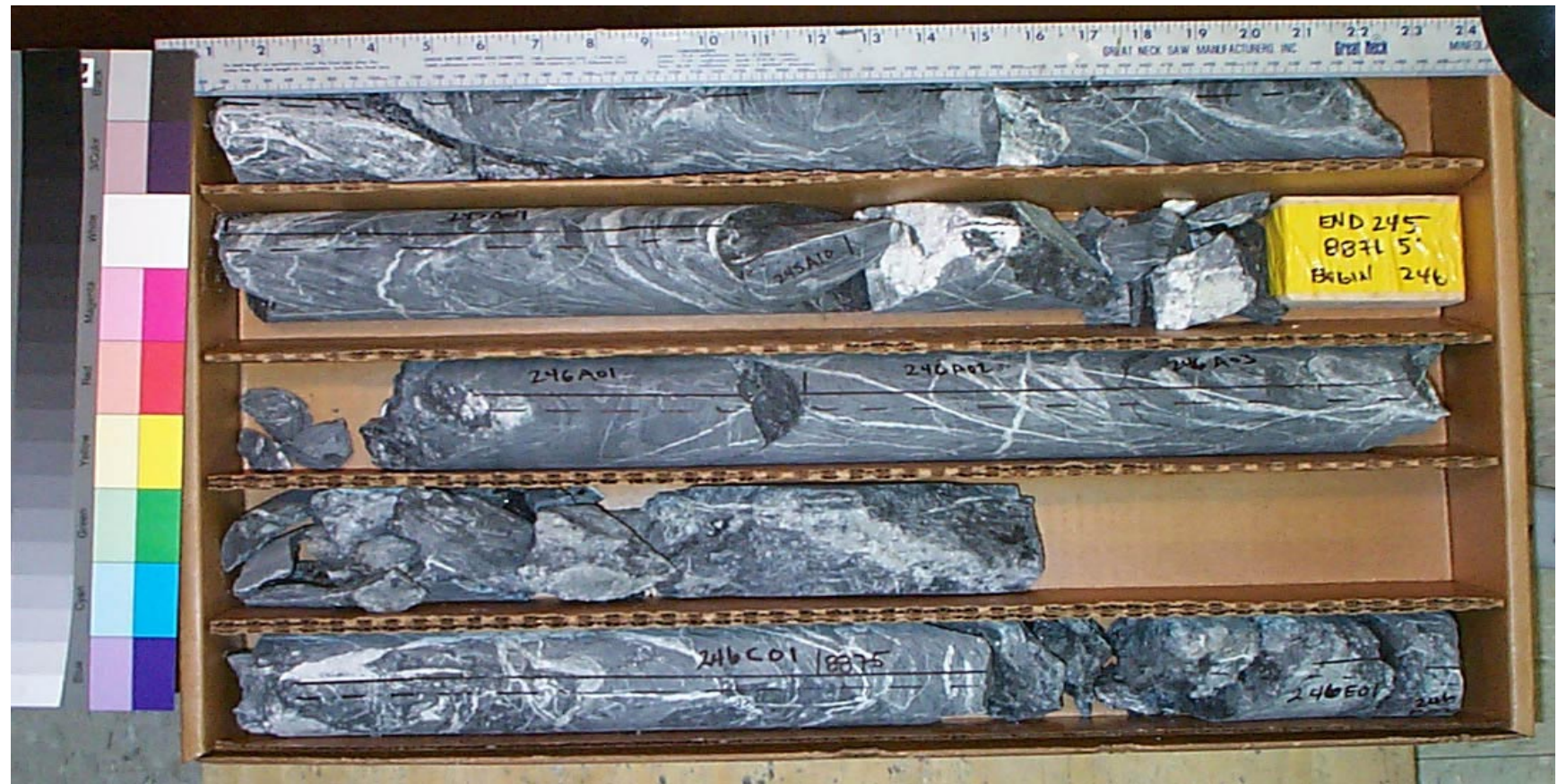

Core Scans included in this box (listed by piece going downhole):
$245 \mathrm{~A} 0600$
245A0800
245A0900
246A0200
$246 \mathrm{C} 0100$
246E0100

See the "reading instructions" section of the introduction for help interpreting core box photos and core piece nomenclature 


\section{LVEW Core Box 359}

Depth Interval 8875.5'-8882.3'

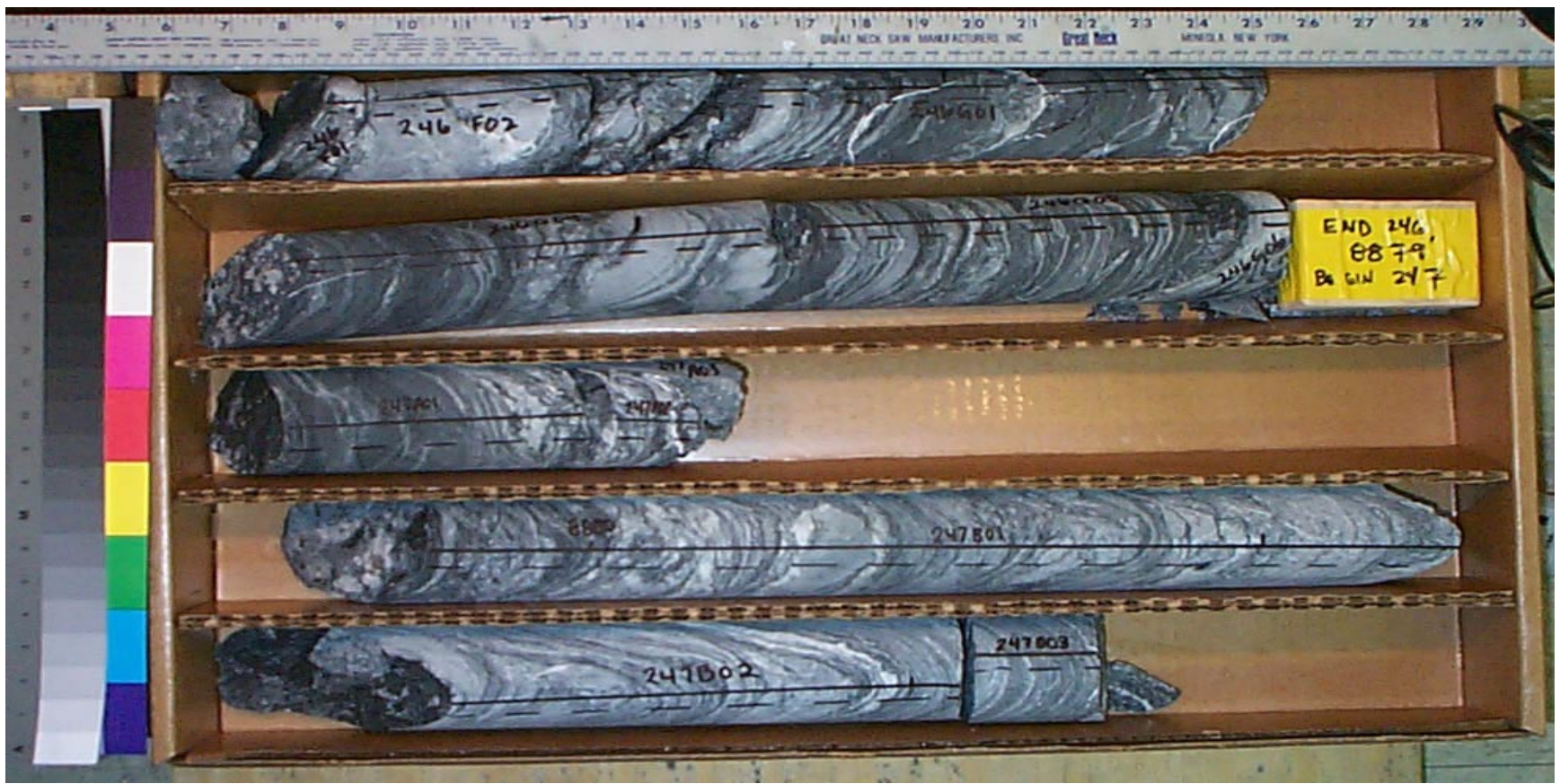

Core Scans included in this box (listed by piece going downhole):

246F0200

246G0100

246G0400

246G0500

247A0100

247B0100

247B0200

247B0300

See the "reading instructions" section of the introduction for help interpreting core box photos and core piece nomenclature 


\section{LVEW Core Box 360}

Depth Interval 8882.3'-8890.1'

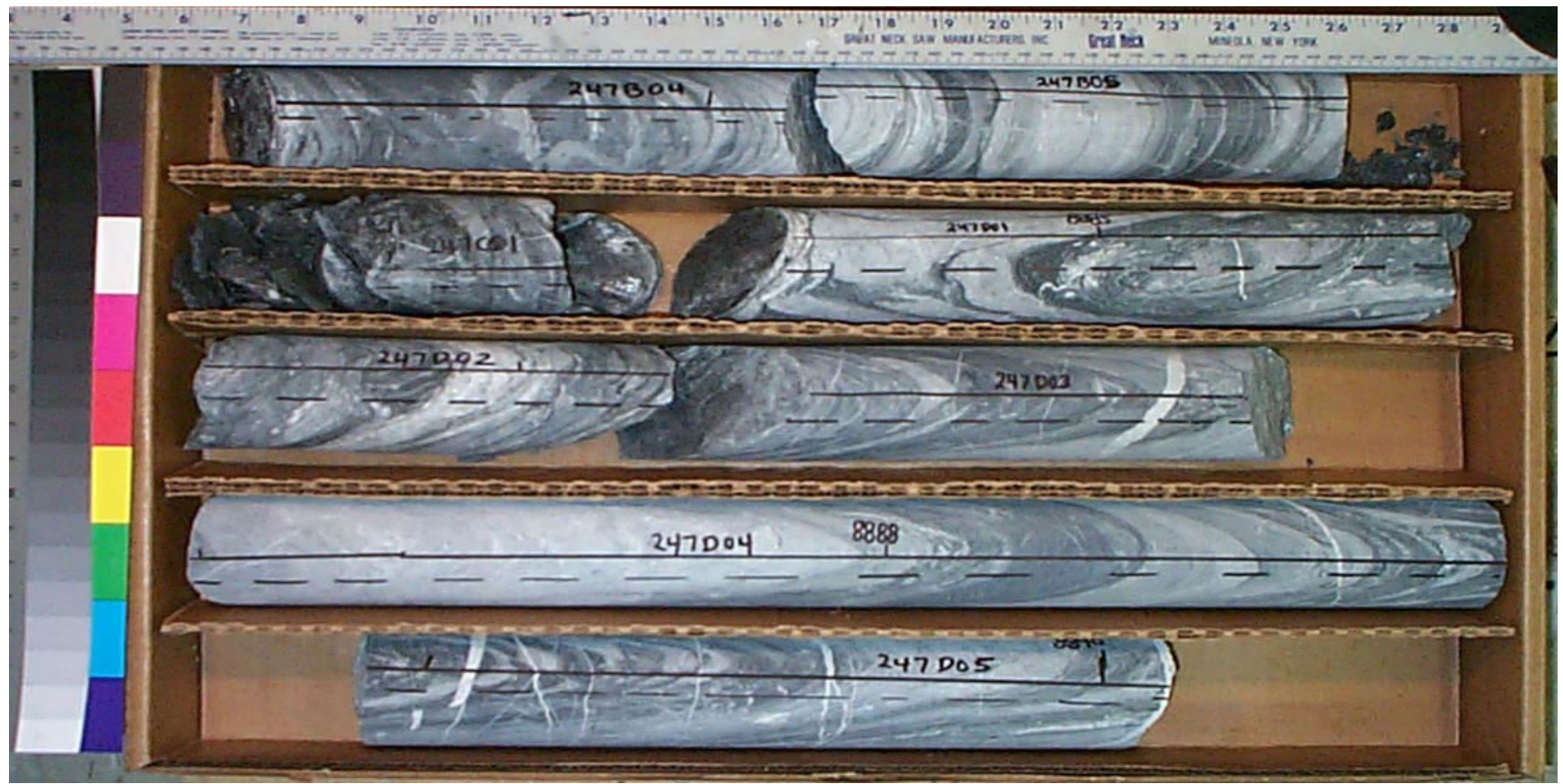

Core Scans included in this box (listed by piece going downhole):
247B0400
247B0500
$247 \mathrm{C} 0100$
247D0100
247D0200
247D0300
247D0400
247D0500

See the "reading instructions" section of the introduction for help interpreting core box photos and core piece nomenclature 


\section{LVEW Core Box 361}

\section{Depth Interval 8890.1'-8896.3'}

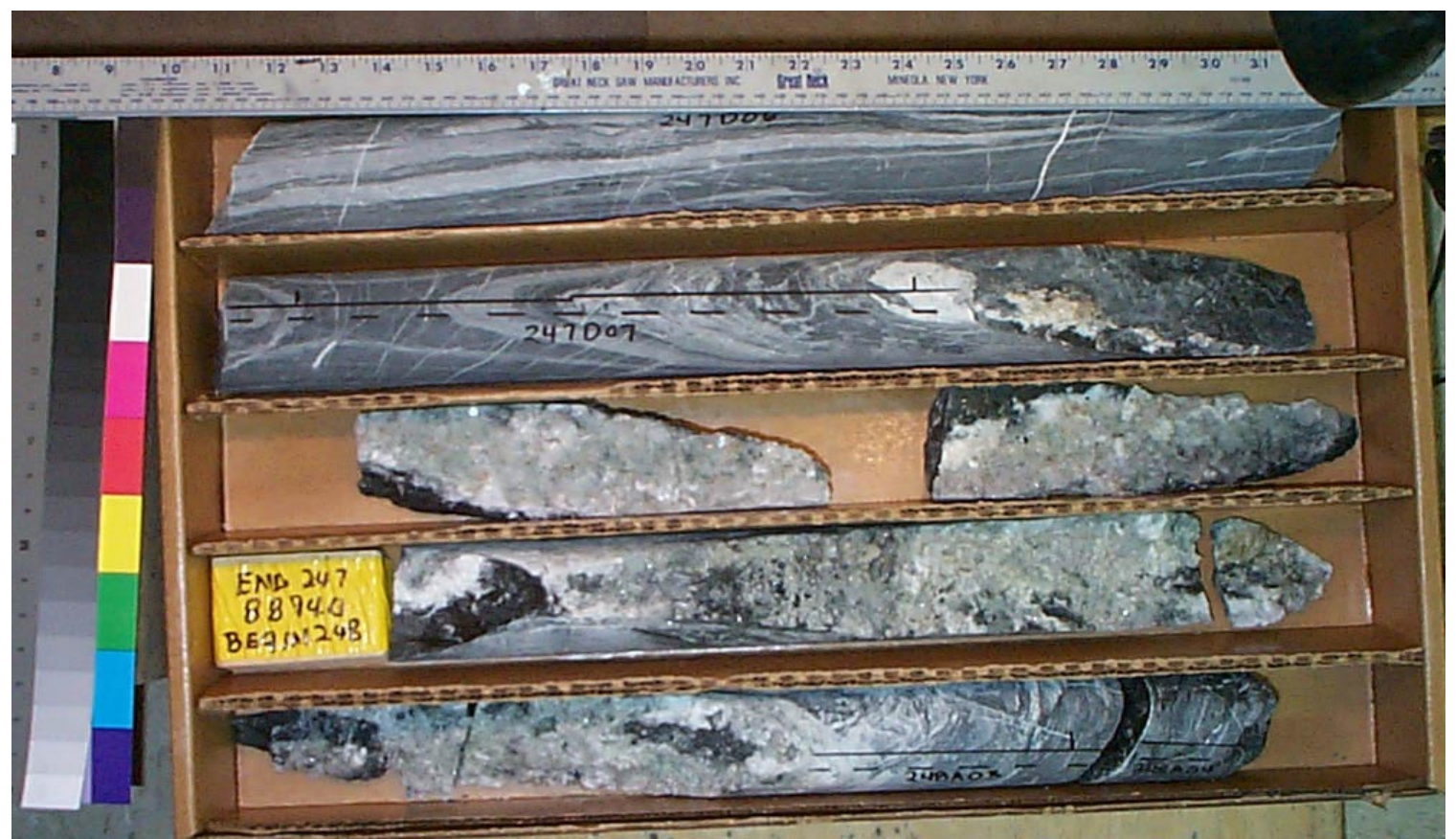

Core Scans included in this box (listed by piece going downhole):

\section{D0600 \\ 247D0700}

See the "reading instructions" section of the introduction for help interpreting core box photos and core piece nomenclature 


\section{LVEW Core Box 362}

Depth Interval 8896.3'-8902.1'

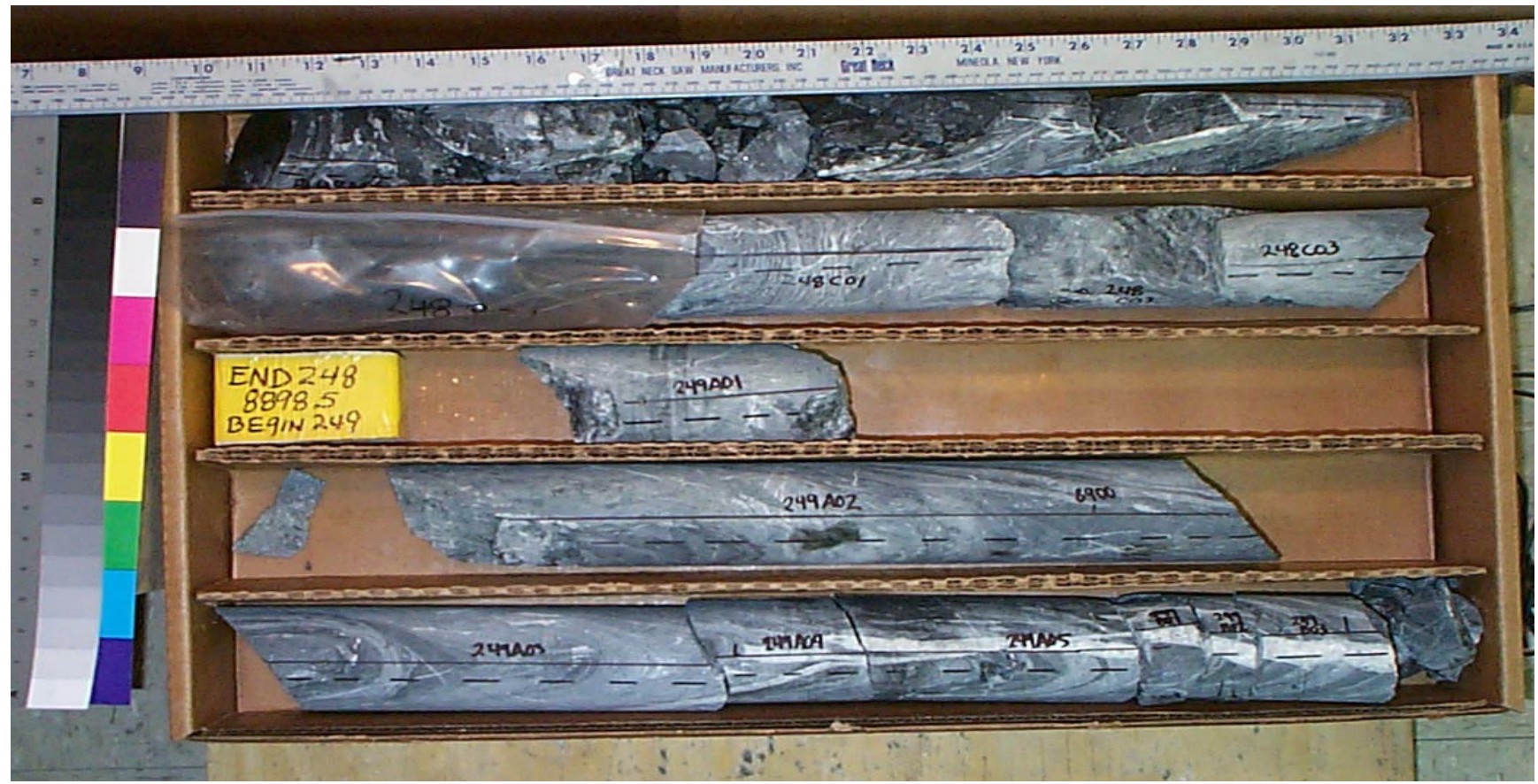

Core Scans included in this box (listed by piece going downhole):

\section{A0100 \\ 249A0200 \\ 249A0300 \\ 249A0400 \\ 249B0300}

See the "reading instructions" section of the introduction for help interpreting core box photos and core piece nomenclature 


\section{LVEW Core Box 363}

Depth Interval 8902.1'-8908.8'

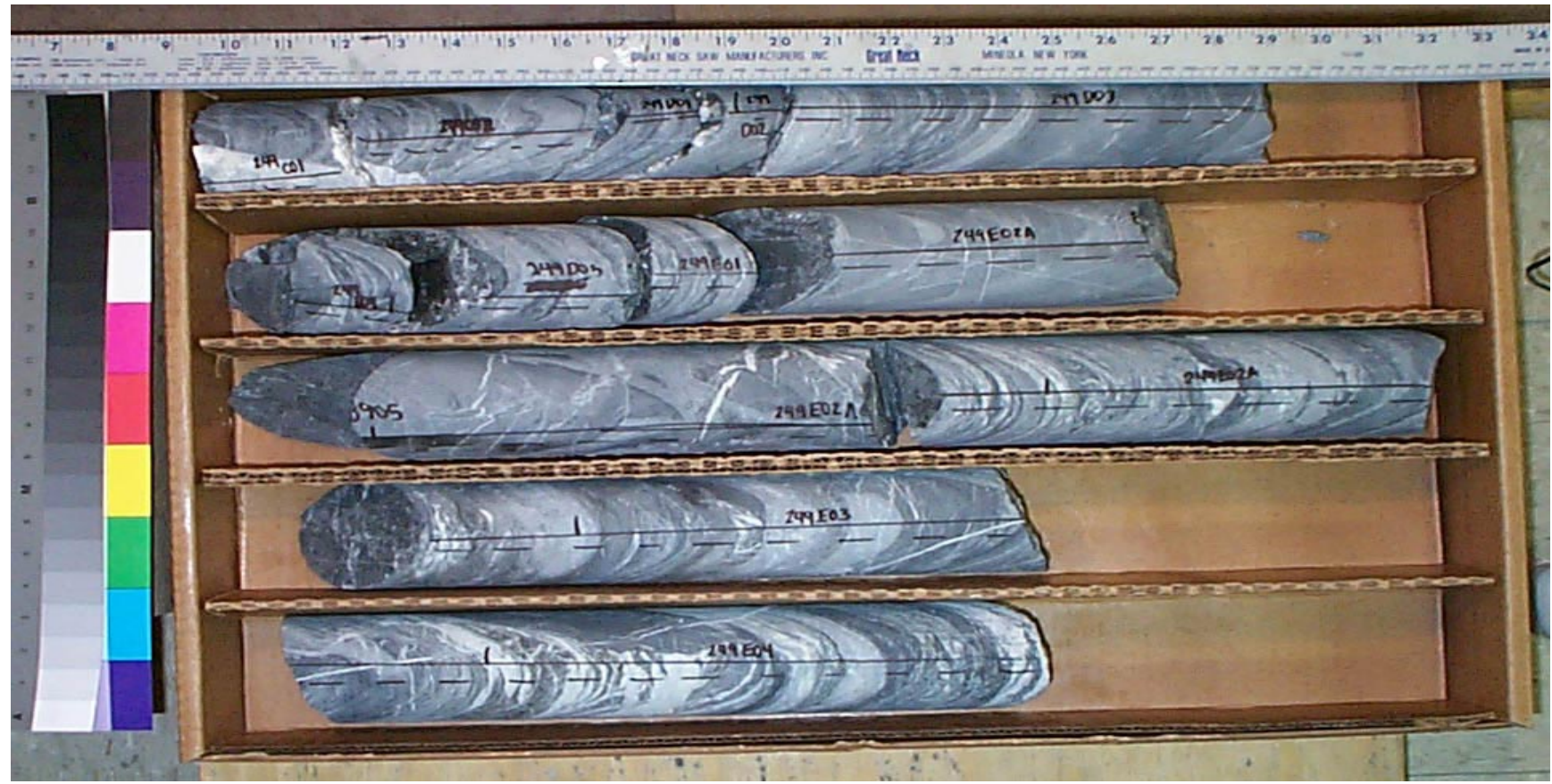

Core Scans included in this box (listed by piece going downhole):
$249 \mathrm{C} 0100$
249D0300
249E0300
249E0400

See the "reading instructions" section of the introduction for help interpreting core box photos and core piece nomenclature 


\section{LVEW Core Box 364}

\section{Depth Interval 8908.8'-8915.3'}

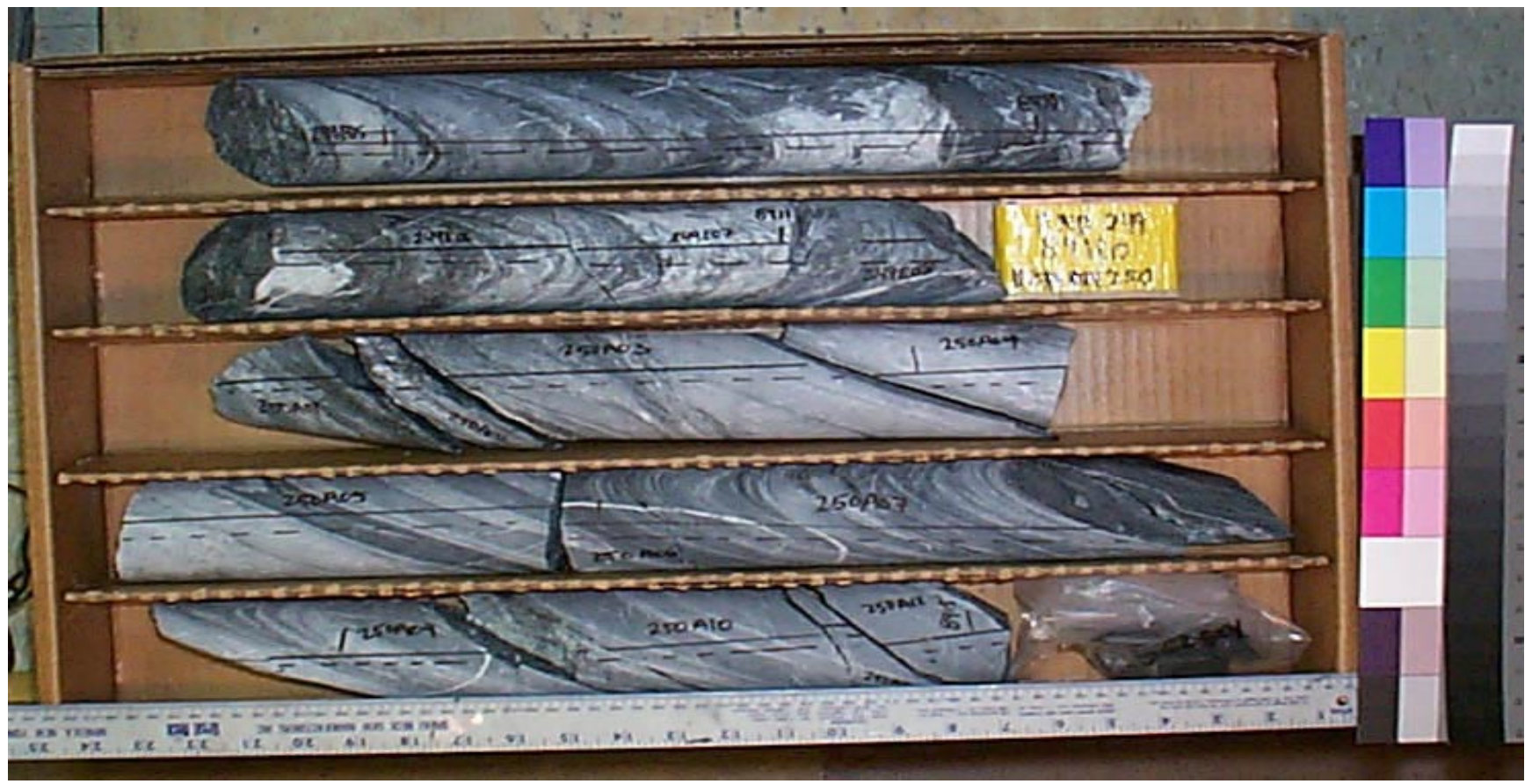

Core Scans included in this box (listed by piece going downhole):

\section{E0500 \\ 249E0600 \\ $250 \mathrm{~A} 0300$ \\ $250 \mathrm{~A} 0500$ \\ $250 \mathrm{~A} 0600$ \\ $250 \mathrm{~A} 0700$ \\ $250 A 0900$ \\ $250 \mathrm{~A} 1000$ \\ $250 \mathrm{~A} 1200$}

See the "reading instructions" section of the introduction for help interpreting core box photos and core piece nomenclature 


\section{LVEW Core Box 365}

\section{Depth Interval 8915.3'-8923.1'}

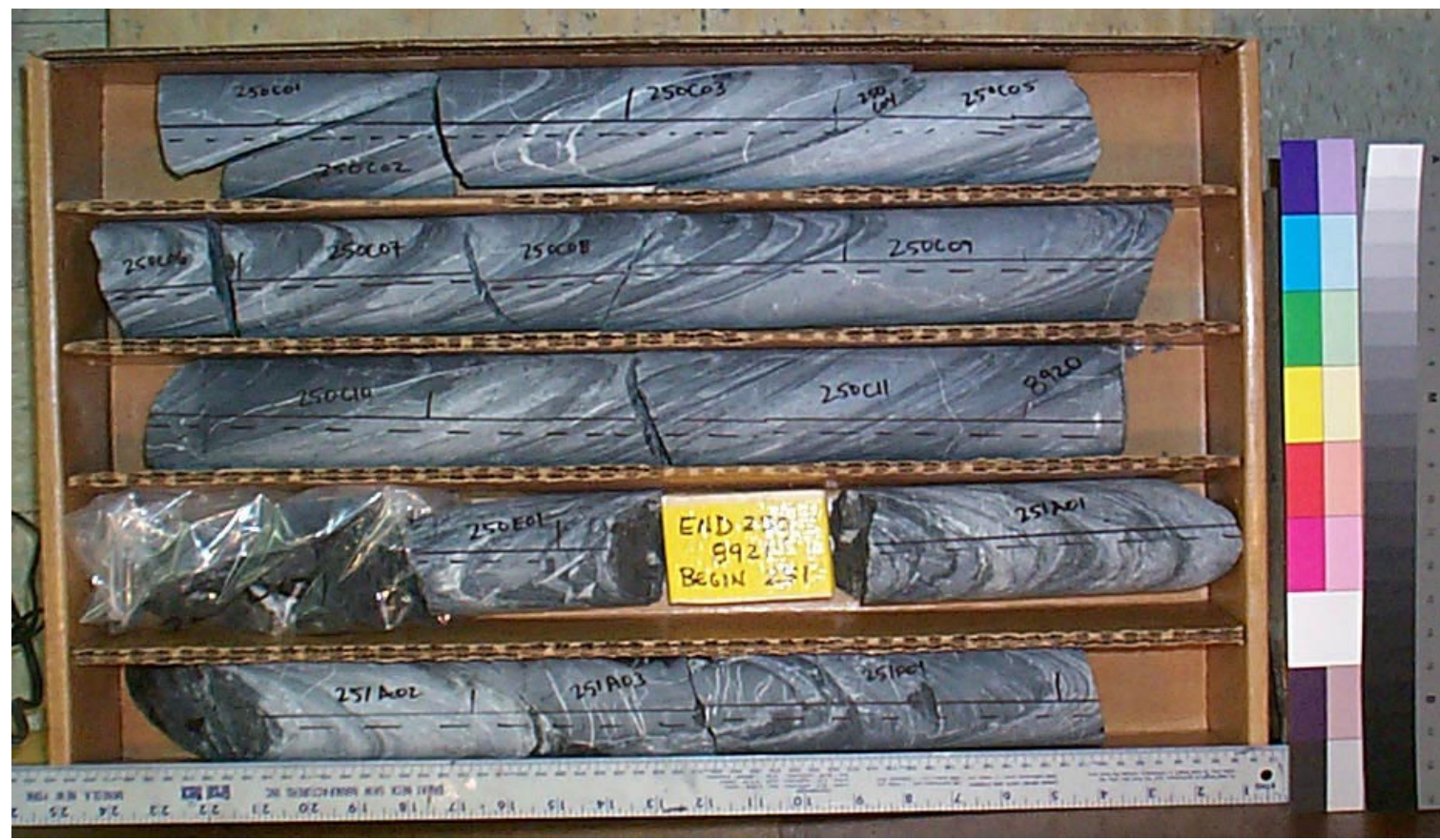

Core Scans included in this box (listed by piece going downhole):
$250 \mathrm{C} 0100$
$250 \mathrm{C} 0300$
$250 \mathrm{C} 0500$
$250 \mathrm{C} 0600$
$250 \mathrm{C} 0700$
$250 \mathrm{C} 0800$
250C1000
$250 \mathrm{C} 1100$
$251 \mathrm{~A} 0100$
$251 \mathrm{~A} 0200$
$251 \mathrm{~A} 0300$
$251 \mathrm{~A} 0400$

See the "reading instructions" section of the introduction for help interpreting core box photos and core piece nomenclature 


\section{LVEW Core Box 366}

Depth Interval 8923.1'-8930.5'

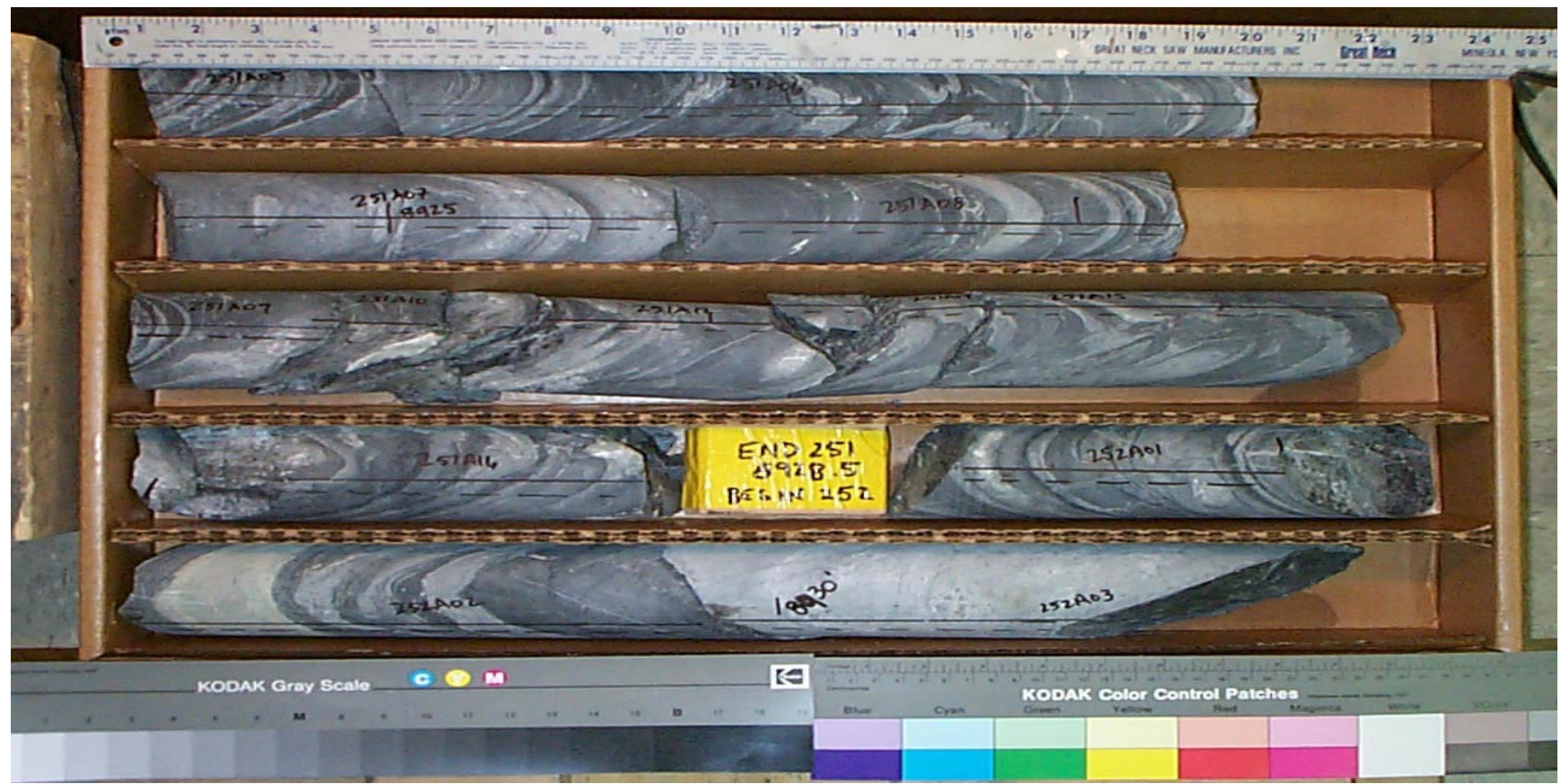

Core Scans included in this box (listed by piece going downhole):
$251 \mathrm{~A} 0500$
$251 \mathrm{~A} 0600$
251A0700
251A0800
$251 \mathrm{~A} 1200$
$251 \mathrm{~A} 1400$
$251 \mathrm{~A} 1500$
$251 \mathrm{~A} 1600$
252A0100
252A0200
252A0300

See the "reading instructions" section of the introduction for help interpreting core box photos and core piece nomenclature 


\title{
LVEW Core Box 367
}

Depth Interval 8930.5'-8939.0'

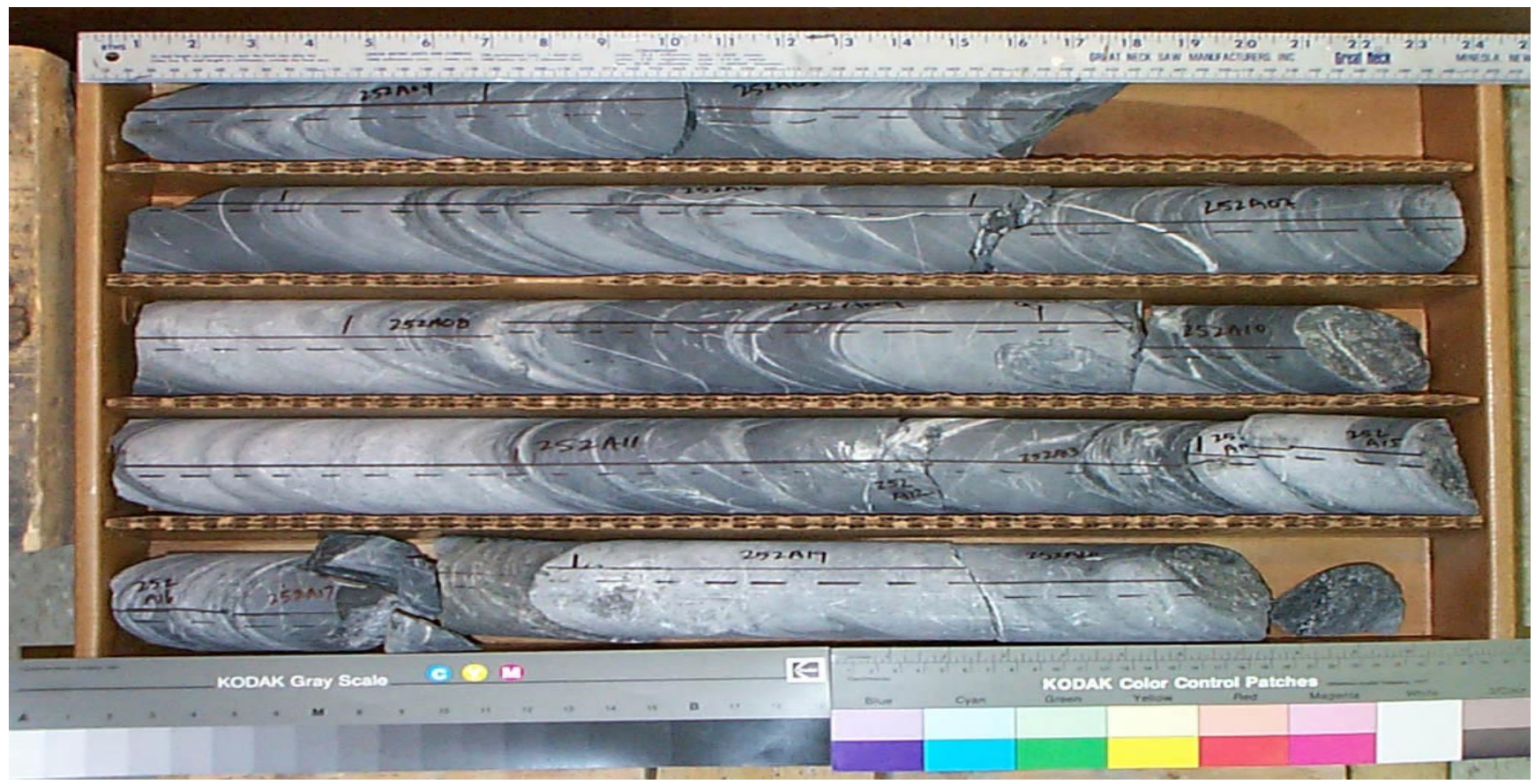

Core Scans included in this box (listed by piece going downhole):
252A0400
252A0500
252A0600
252A0700
252A0800
252A0900
252A 1000

\begin{abstract}
252A 1100
252A 1300

252A 1400

252A 1600

252A 1900

252A2000
\end{abstract}

See the "reading instructions" section of the introduction for help interpreting core box photos and core piece nomenclature 


\section{Stratigraphic Column for LVEW Phase III, page 5}

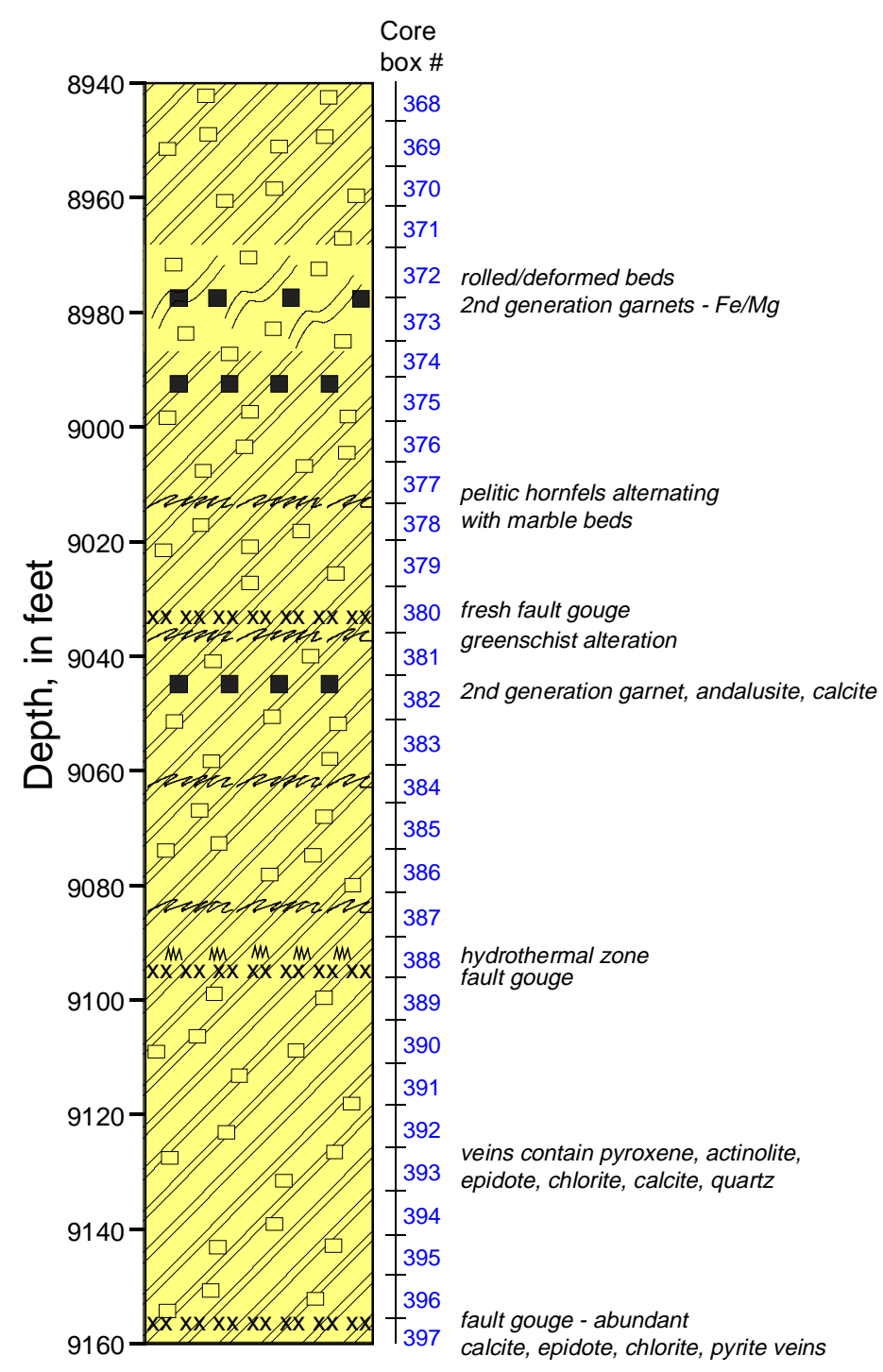

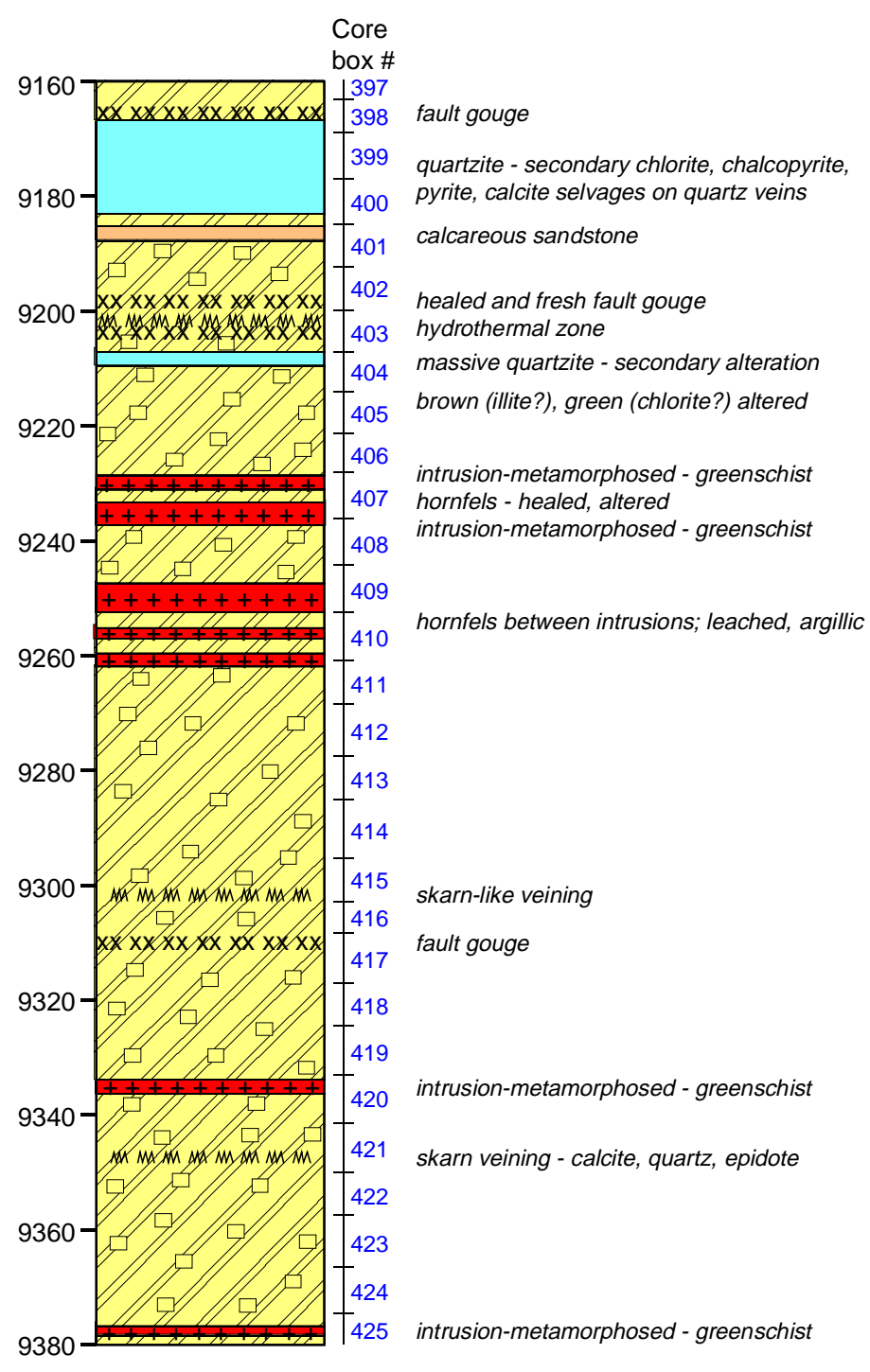

\section{Explanation}

Metapelite with banding

Hornfels

Metapelite with ductile deformation
Metapelite no banding

Quartzite

Calc-silicate

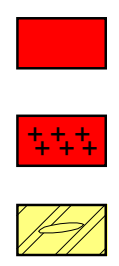

Intrusion

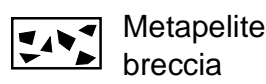

Intrusion-

metamorphosed

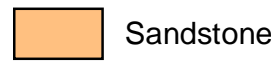

Boudinage deformation
M M M Hydrothermal veins/fractures

\begin{tabular}{|l|l}
$x x x x$ & Fault gouge
\end{tabular} 2nd generation garnets 


\section{LVEW Core Box 368}

Depth Interval 8939.0'-8946.5'

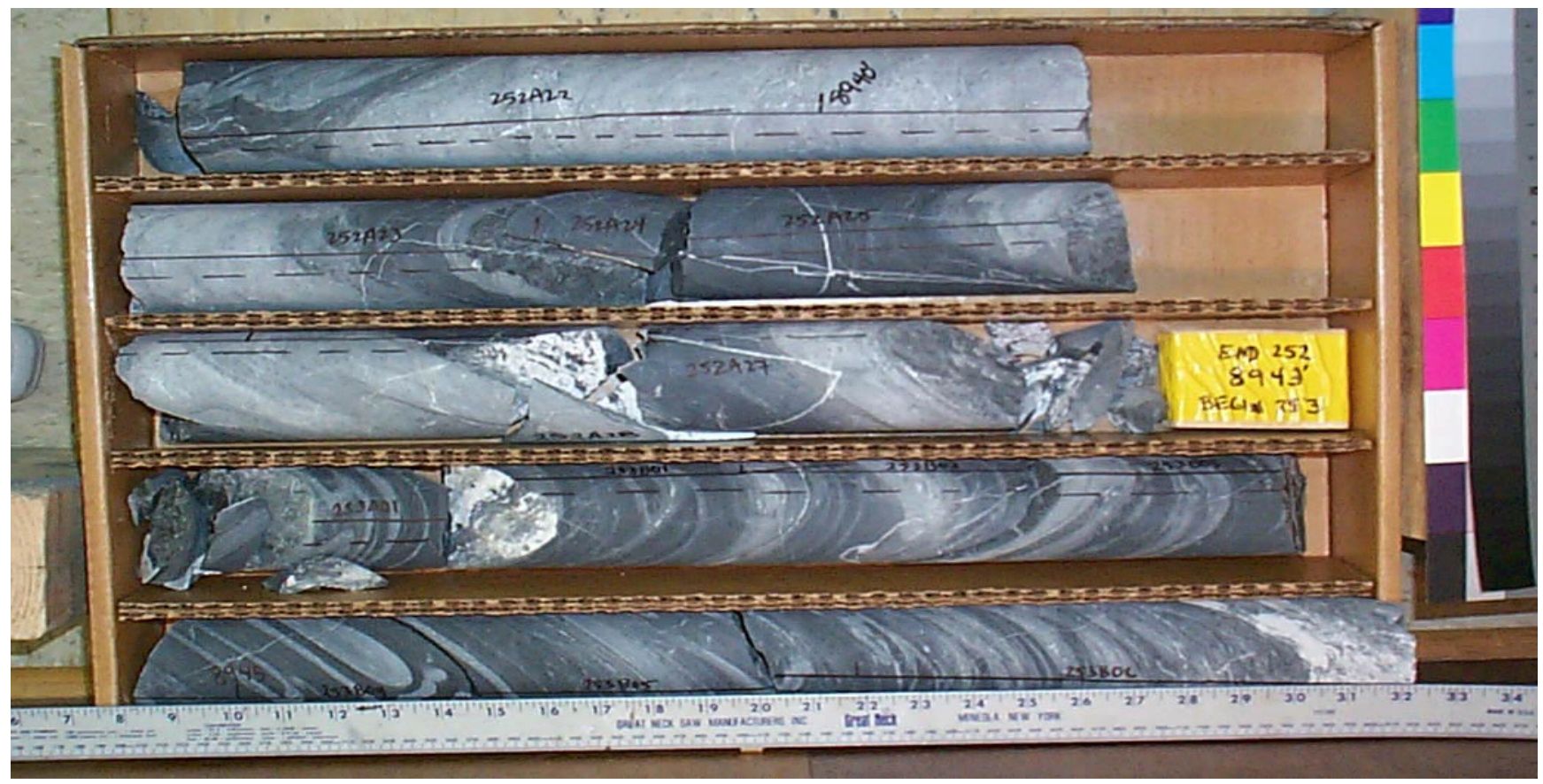

Core Scans included in this box (listed by piece going downhole):

$252 A 2200$
$252 A 2300$
$252 A 2500$
$252 A 2600$
$252 A 2700$
$253 A 0100$

See the "reading instructions" section of the introduction for help interpreting core box photos and core piece nomenclature 


\section{LVEW Core Box 369}

\section{Depth Interval 8946.5'-8954.6'}

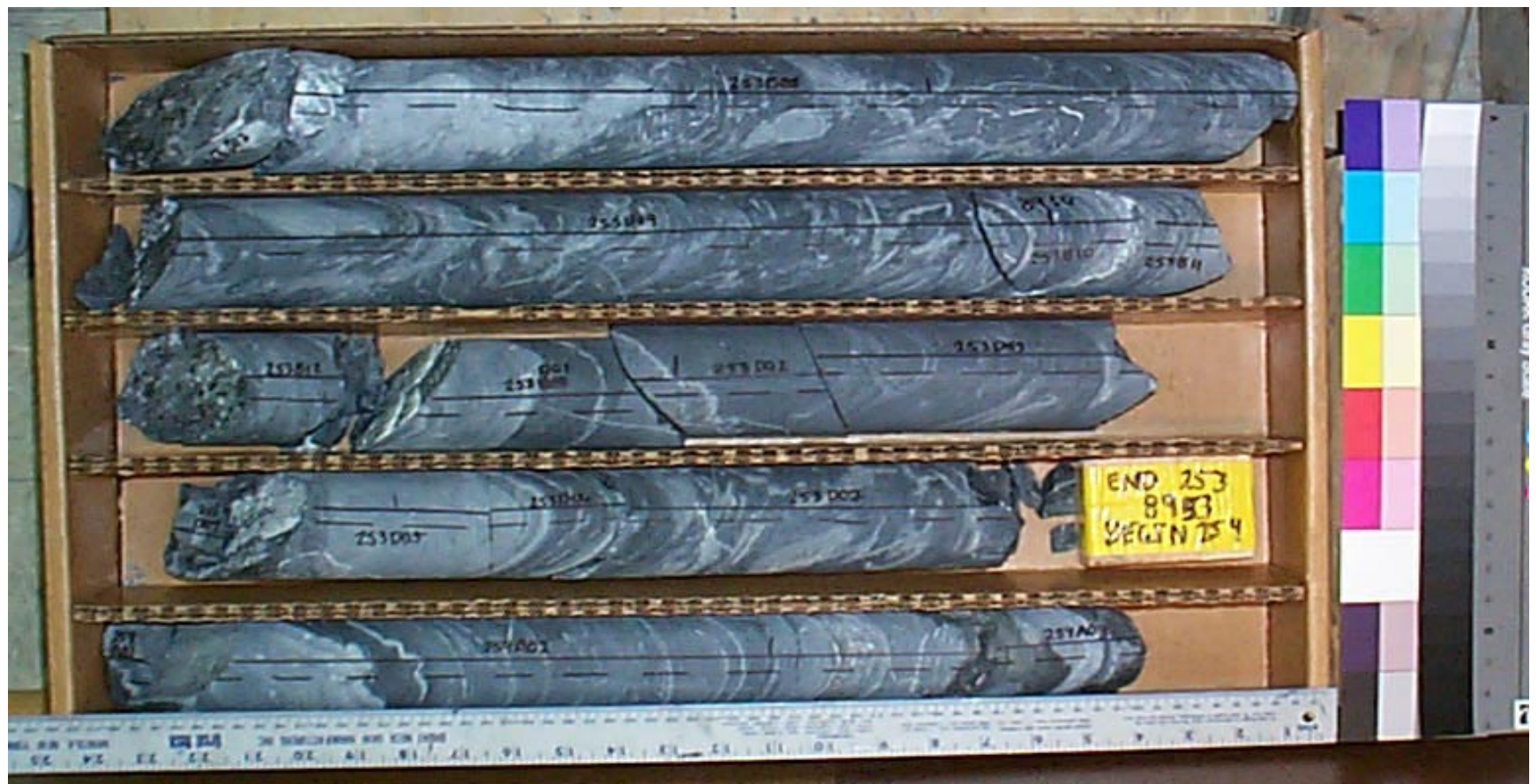

Core Scans included in this box (listed by piece going downhole):
253B0800
253B0900
253B1200
253D0100
253D0200
253D0300
253D0500
253D0700
$254 \mathrm{~A} 0200$
$254 \mathrm{~A} 0300$

See the "reading instructions" section of the introduction for help interpreting core box photos and core piece nomenclature 


\section{LVEW Core Box 370}

Depth Interval 8954.6'-8961.5'

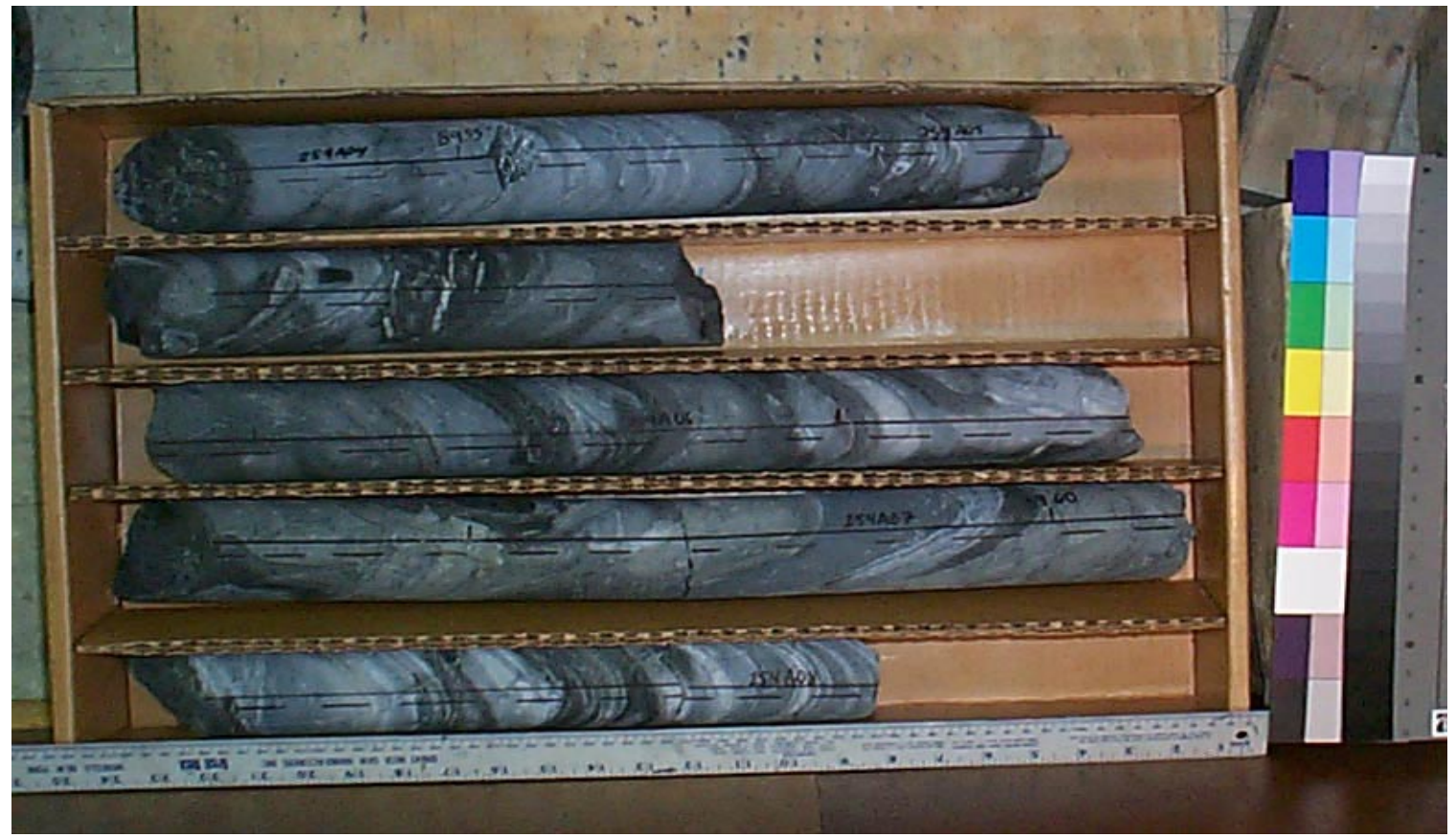

Core Scans included in this box (listed by piece going downhole):
$254 \mathrm{~A} 0400$
254A050A
254A0600
254A070A
$254 \mathrm{~A} 0800$

See the "reading instructions" section of the introduction for help interpreting core box photos and core piece nomenclature 


\section{LVEW Core Box 371}

\section{Depth Interval 8961.5'-8968.6'}

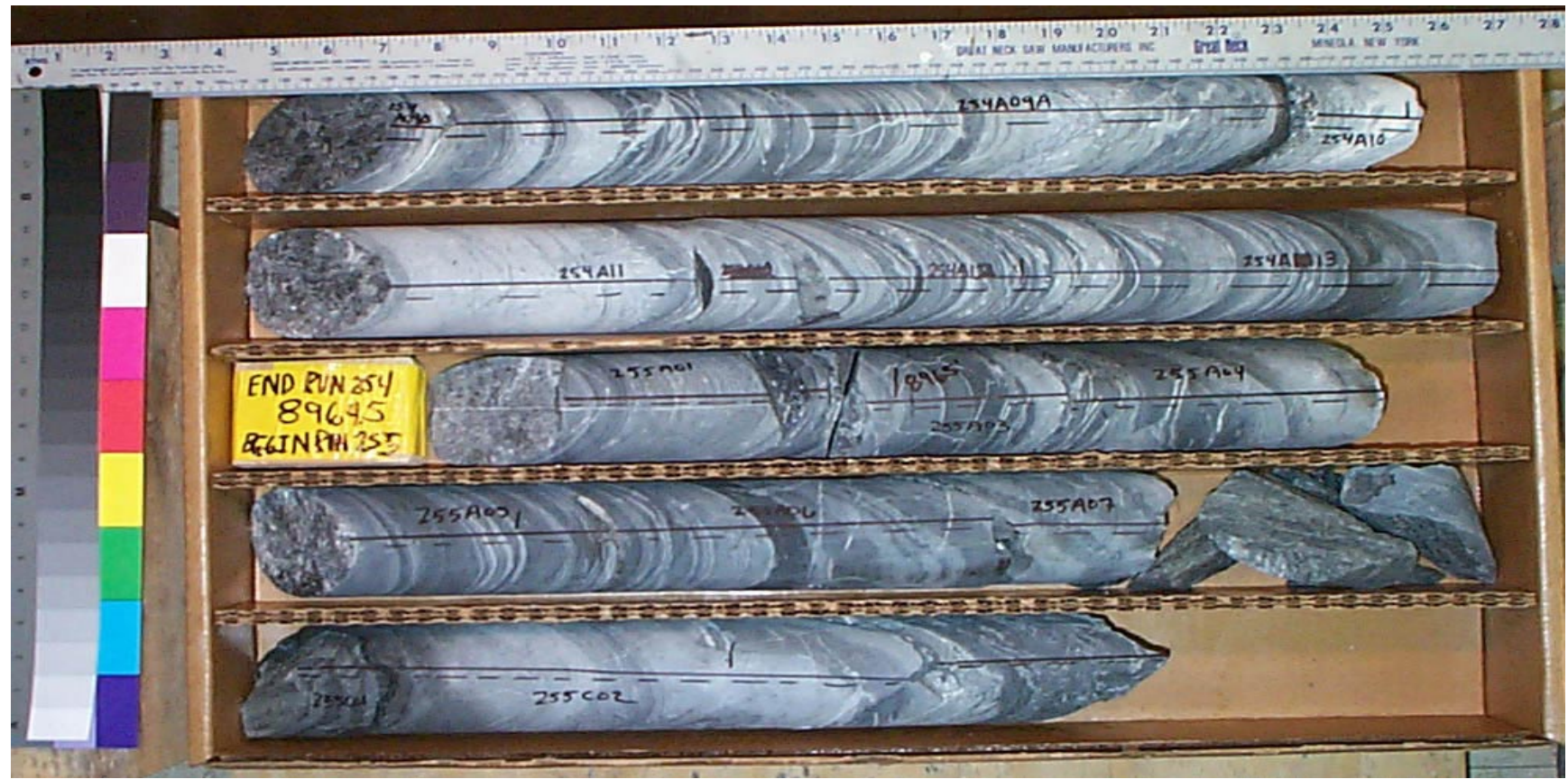

Core Scans included in this box (listed by piece going downhole):

254A090A
$254 A 1100$
$254 A 1200$
$254 A 1300$
$255 A 0100$
$255 A 0200$
$255 A 0300$
$255 A 0400$
$255 A 0500$
$255 A 0600$
$255 A 0700$
$255 C 0200$

See the "reading instructions" section of the introduction for help interpreting core box photos and core piece nomenclature 


\section{LVEW Core Box 372}

Depth Interval 8968.6'-8977.5'

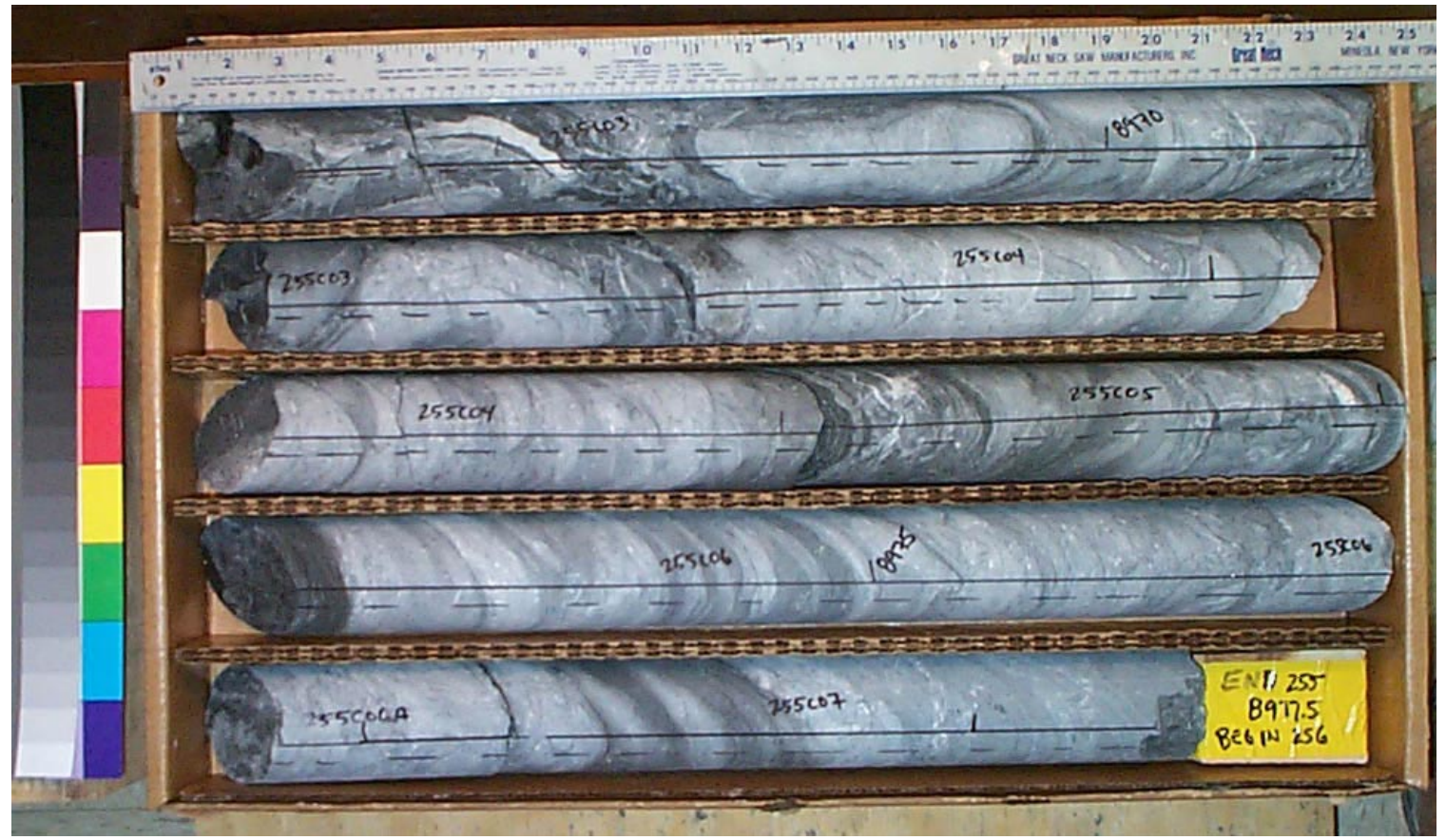

Core Scans included in this box (listed by piece going downhole):

\section{$255 \mathrm{C} 030 \mathrm{~A}$ $255 \mathrm{C} 040 \mathrm{~A}$ $255 \mathrm{C} 0500$ $255 \mathrm{C} 060 \mathrm{~A}$ $255 \mathrm{C} 0700$}

See the "reading instructions" section of the introduction for help interpreting core box photos and core piece nomenclature 


\section{LVEW Core Box 373}

Depth Interval 8977.5'-8985.0'

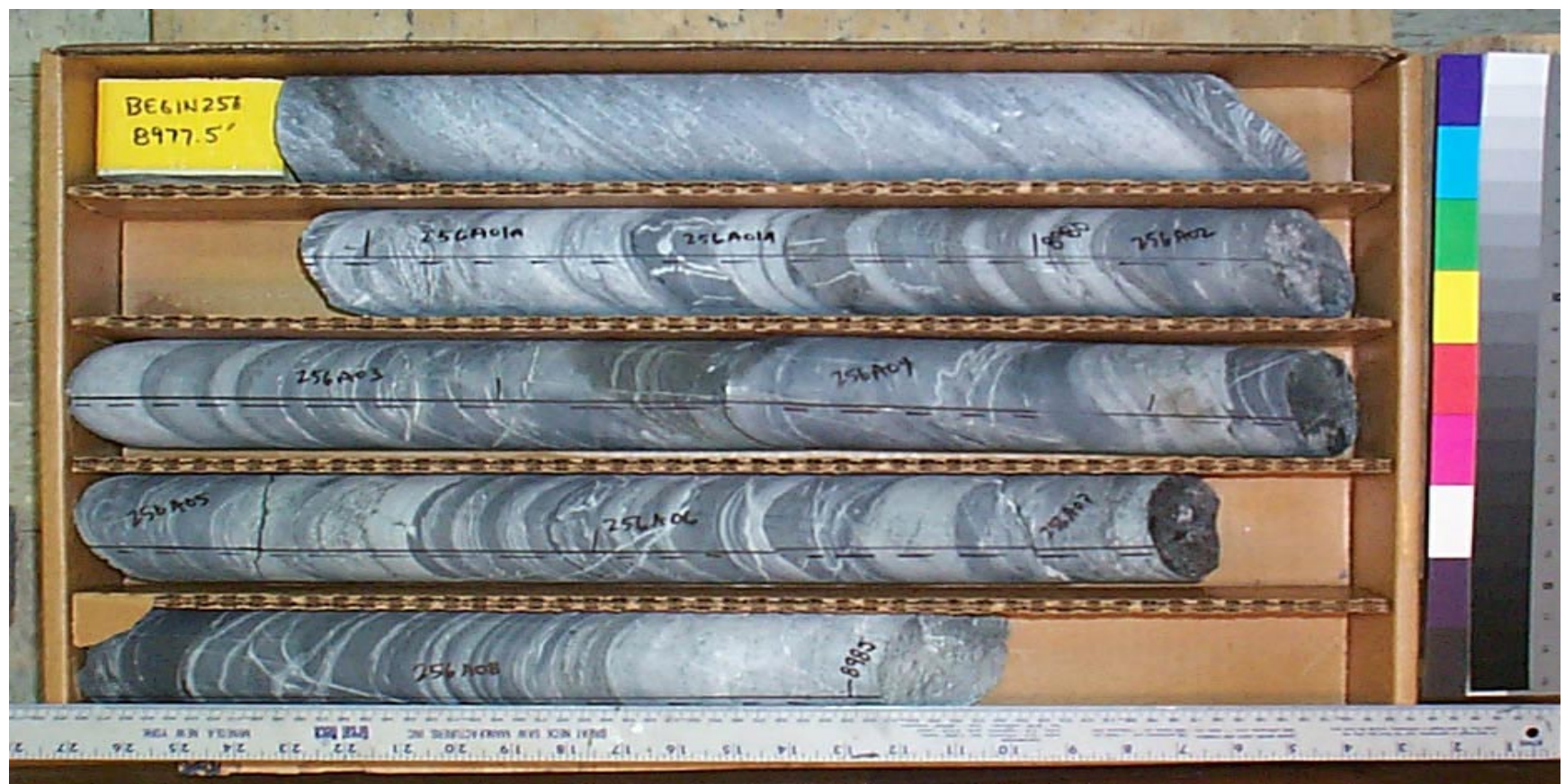

Core Scans included in this box (listed by piece going downhole):
256A010A
$256 \mathrm{~A} 0200$
$256 \mathrm{~A} 0300$
$256 \mathrm{~A} 0400$
$256 \mathrm{~A} 0500$
$256 \mathrm{~A} 0600$
$256 \mathrm{~A} 0700$
$256 \mathrm{~A} 0800$

See the "reading instructions" section of the introduction for help interpreting core box photos and core piece nomenclature 


\section{LVEW Core Box 374}

\section{Depth Interval 8985.0'-8991.3'}

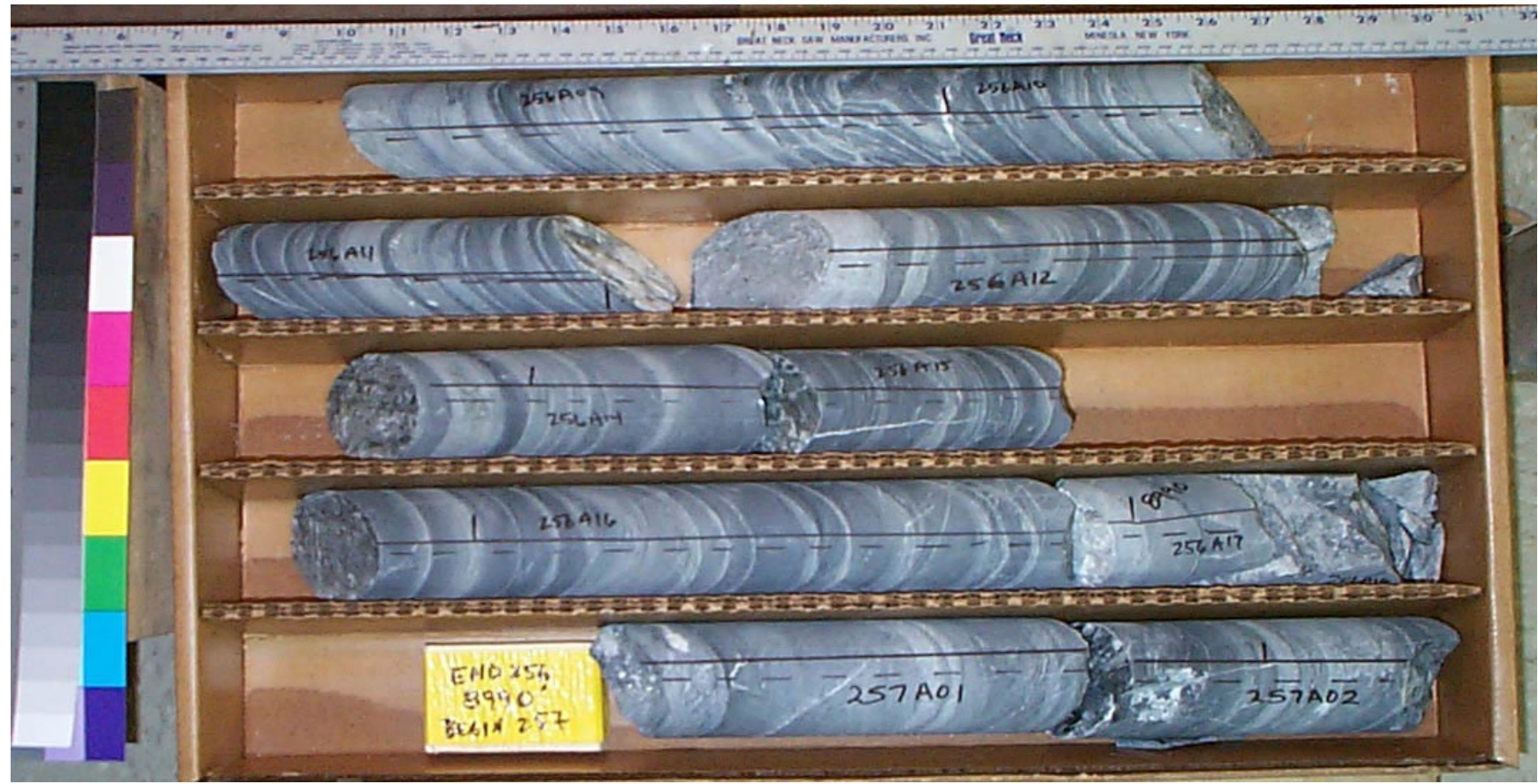

Core Scans included in this box (listed by piece going downhole):

$$
\begin{aligned}
& \text { 256A0900 } \\
& \text { 256A1000 } \\
& \text { 256A1100 } \\
& 256 A 1200 \\
& 256 A 1400 \\
& 256 A 1500 \\
& 256 A 1600 \\
& 257 A 0100 \\
& \text { 257A } 0200
\end{aligned}
$$

See the "reading instructions" section of the introduction for help interpreting core box photos and core piece nomenclature 


\section{LVEW Core Box 375}

\section{Depth Interval 8991.3'-8998.8'}

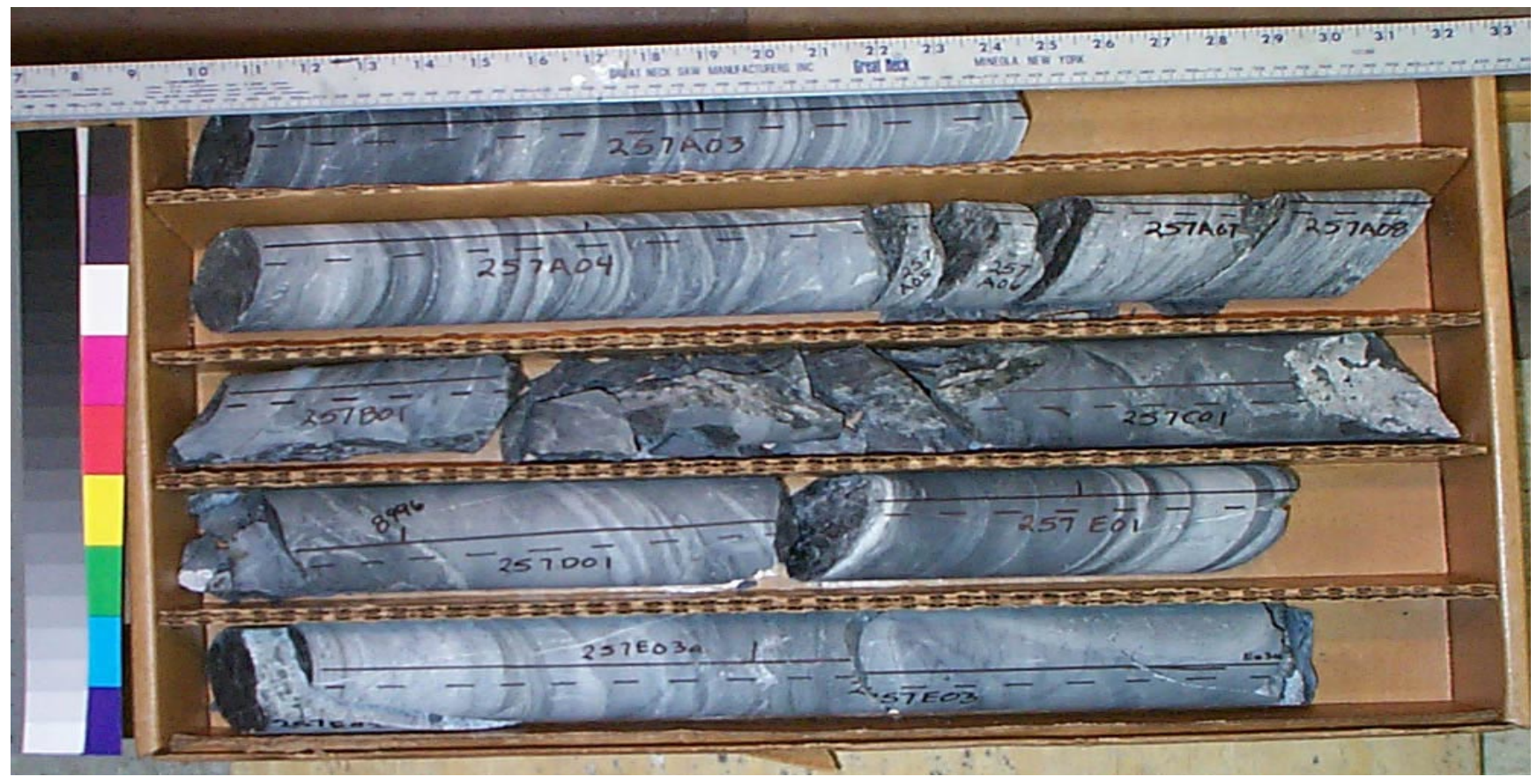

Core Scans included in this box (listed by piece going downhole):
$257 \mathrm{~A} 0300$
257A0400
257A0700
257A0800
$257 \mathrm{C} 0100$
257D0100
257E0100
257E030A

See the "reading instructions" section of the introduction for help interpreting core box photos and core piece nomenclature 


\section{LVEW Core Box 376}

Depth Interval 8998.8'-9006.0'

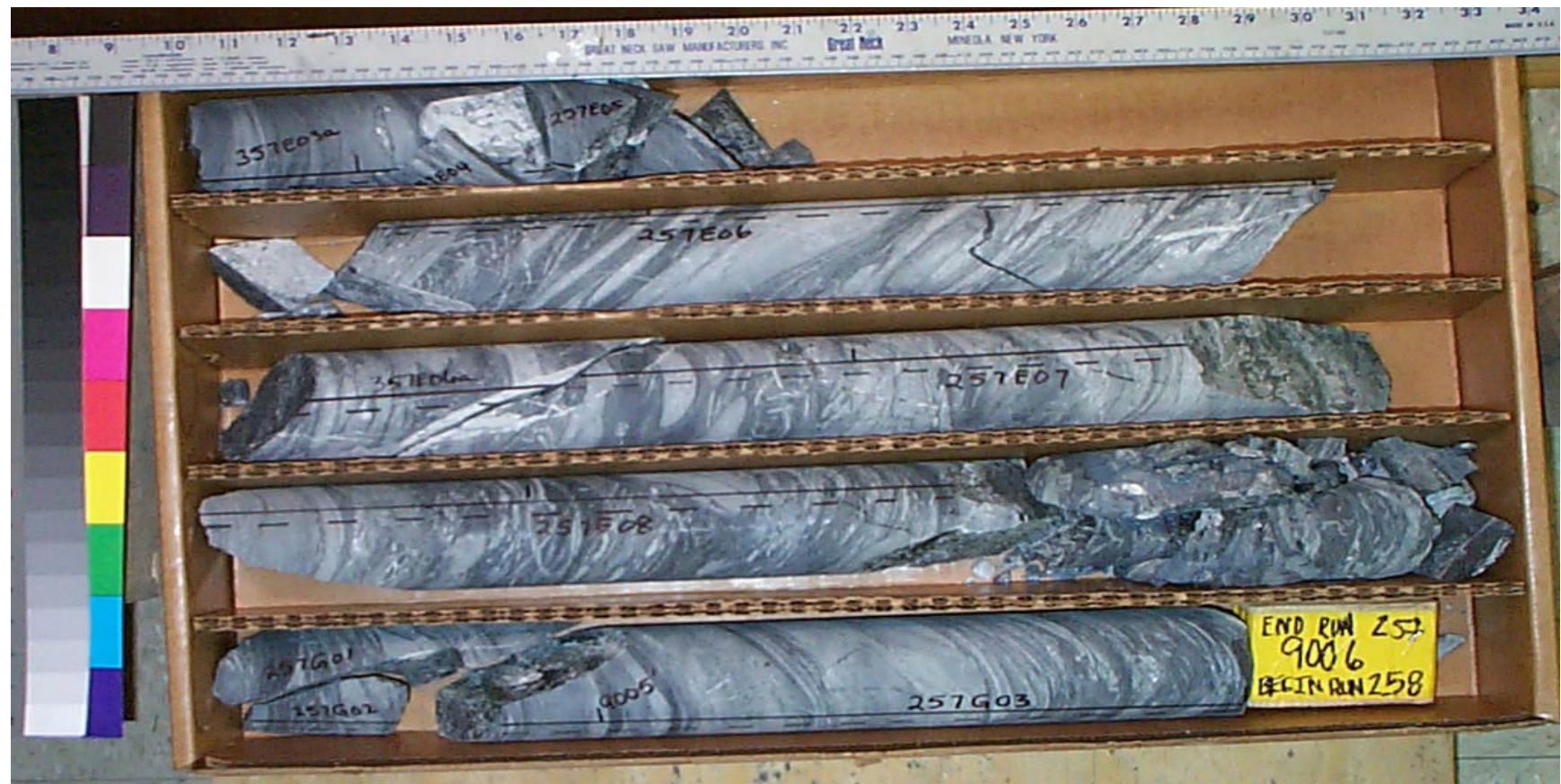

Core Scans included in this box (listed by piece going downhole):
257E030A
257E060A
257E0700
257E0800
257G0300

See the "reading instructions" section of the introduction for help interpreting core box photos and core piece nomenclature 


\section{LVEW Core Box 377}

Depth Interval 9006.0'-9013.3'

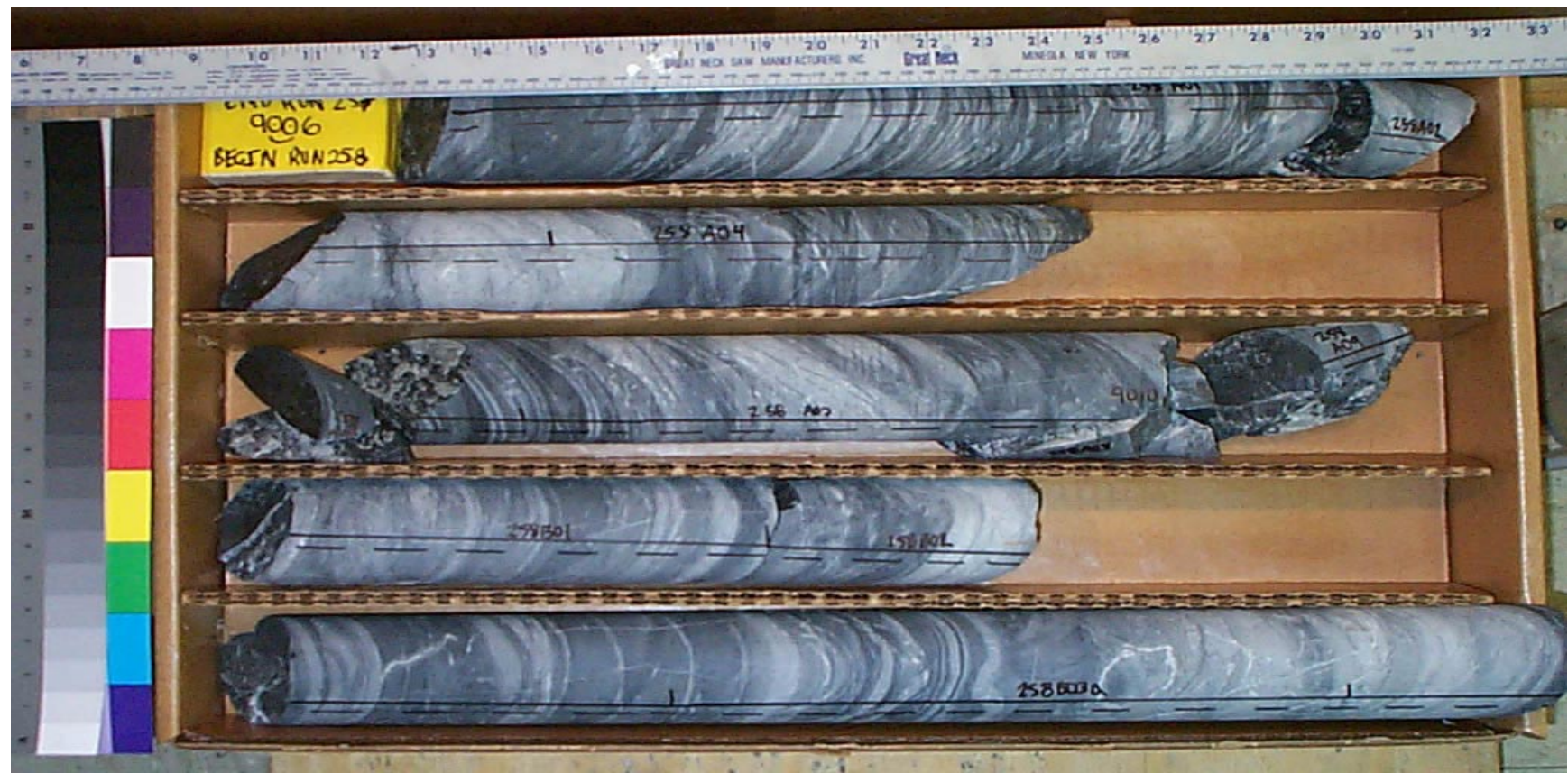

Core Scans included in this box (listed by piece going downhole):
258A0100
258A0400
258A0700
258B0100
258B0200
258B031A

See the "reading instructions" section of the introduction for help interpreting core box photos and core piece nomenclature 


\section{LVEW Core Box 378}

Depth Interval 9013.3'-9019.8'

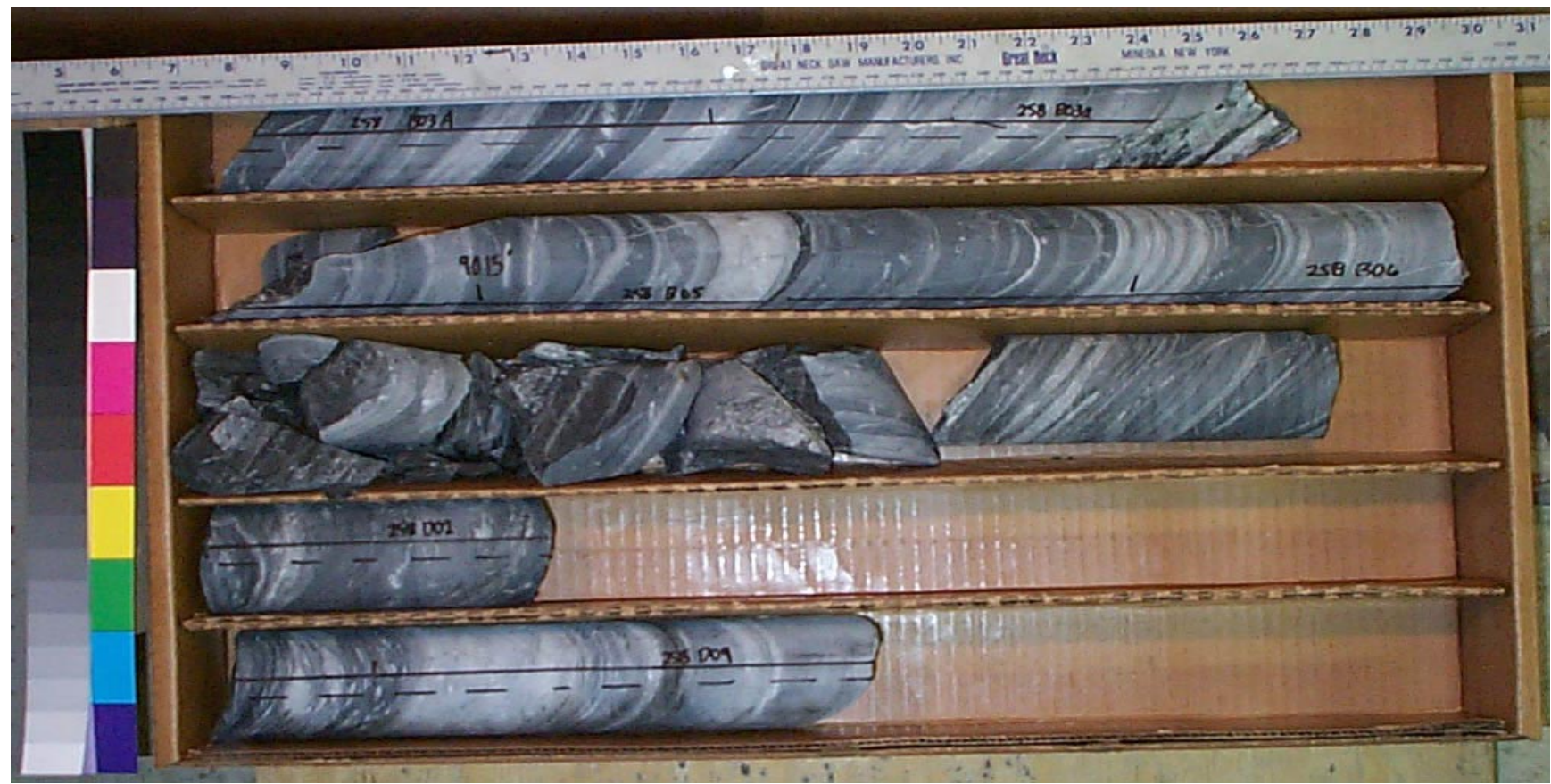

Core Scans included in this box

(listed by piece going downhole):
258B032A
258B0500
258B0600
258D0100
258D0200
258D0300
258D0400

See the "reading instructions" section of the introduction for help interpreting core box photos and core piece nomenclature 


\section{LVEW Core Box 379}

Depth Interval 9019.8'-9028.0'

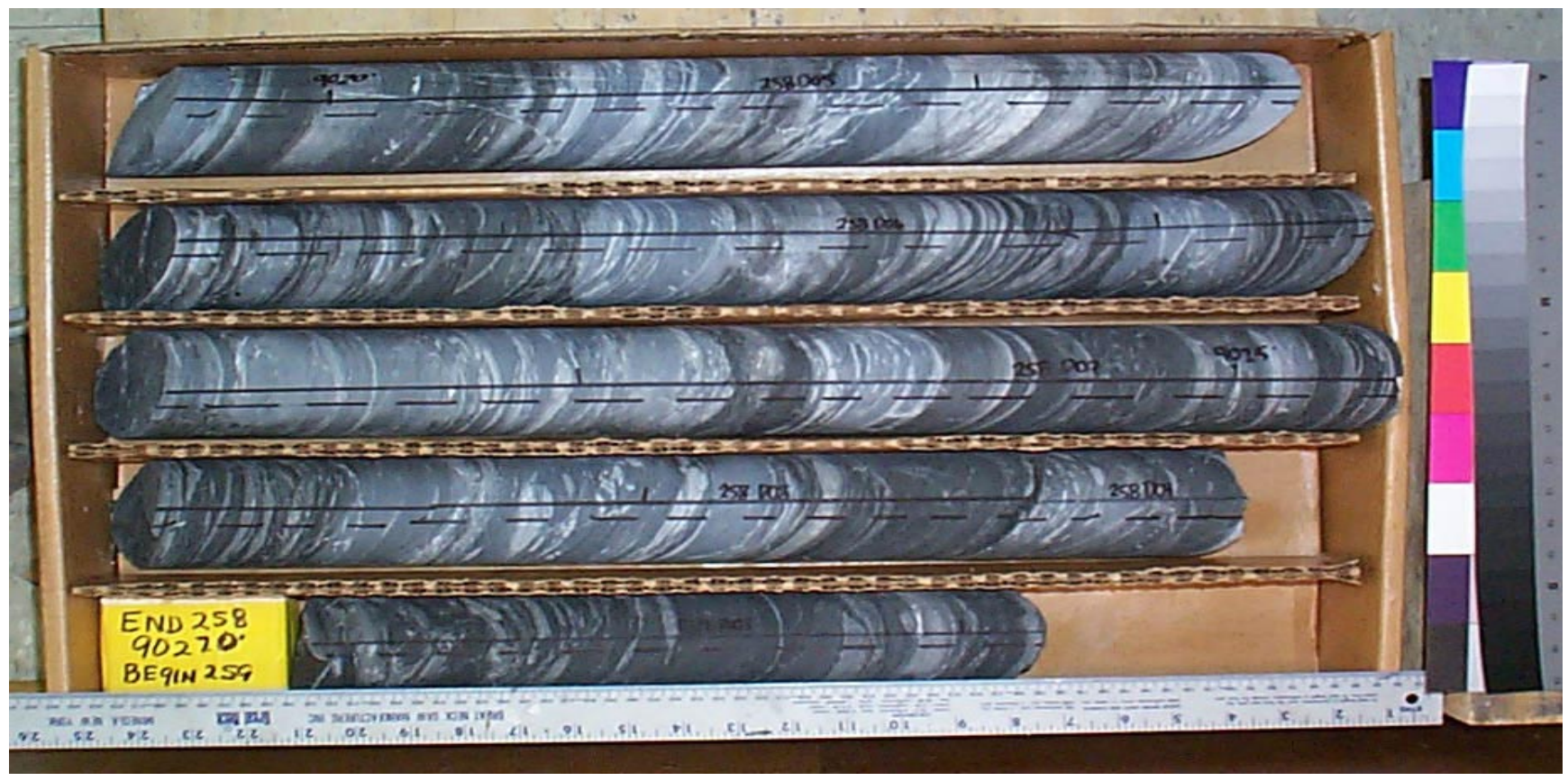

Core Scans included in this box (listed by piece going downhole):
258D0500
258D0600
258D0700
258D0800
258D0900
259A0100

See the "reading instructions" section of the introduction for help interpreting core box photos and core piece nomenclature 


\title{
LVEW Core Box 380
}

Depth Interval 9028.0'-9036.0'

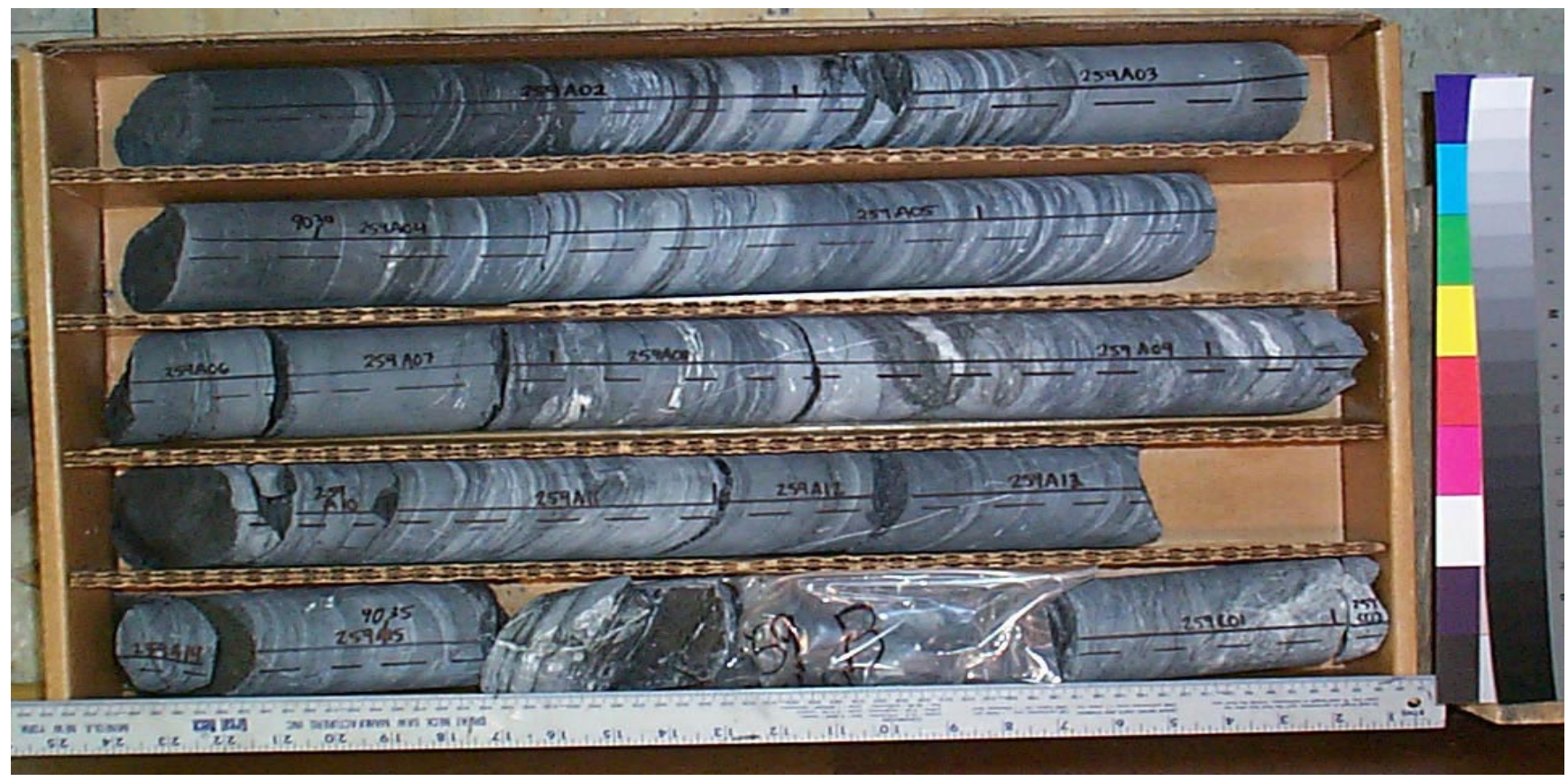

Core Scans included in this box (listed by piece going downhole):
259A0200
259A0300
259A0400
259A0500
259A0600
259A0700
259A0800

\begin{abstract}
259A0900
259A 1000

259A1200

259A1300

259A 1500

259C0100
\end{abstract}

See the "reading instructions" section of the introduction for help interpreting core box photos and core piece nomenclature 


\section{LVEW Core Box 381}

\section{Depth Interval 9036.0'-9043.6'}

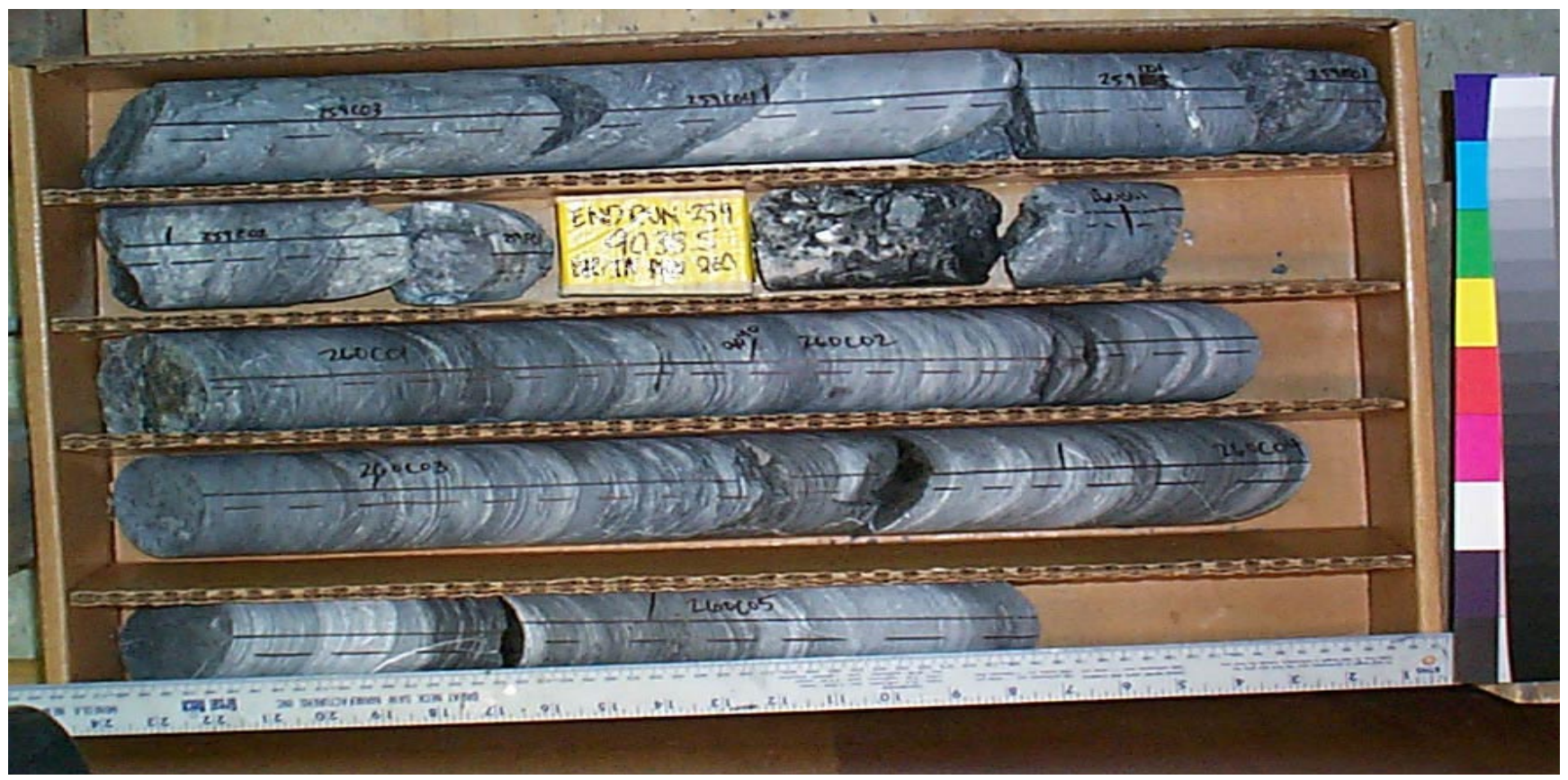

Core Scans included in this box (listed by piece going downhole):
$259 \mathrm{C0} 300$
259C0400
259D0100
259E0100
259E0200
$260 \mathrm{C} 0100$
$260 \mathrm{C} 0200$
260C030A
$260 \mathrm{C} 040 \mathrm{~A}$
$260 \mathrm{C} 0500$

See the "reading instructions" section of the introduction for help interpreting core box photos and core piece nomenclature 


\section{LVEW Core Box 382}

Depth Interval 9043.6'-9050.9'

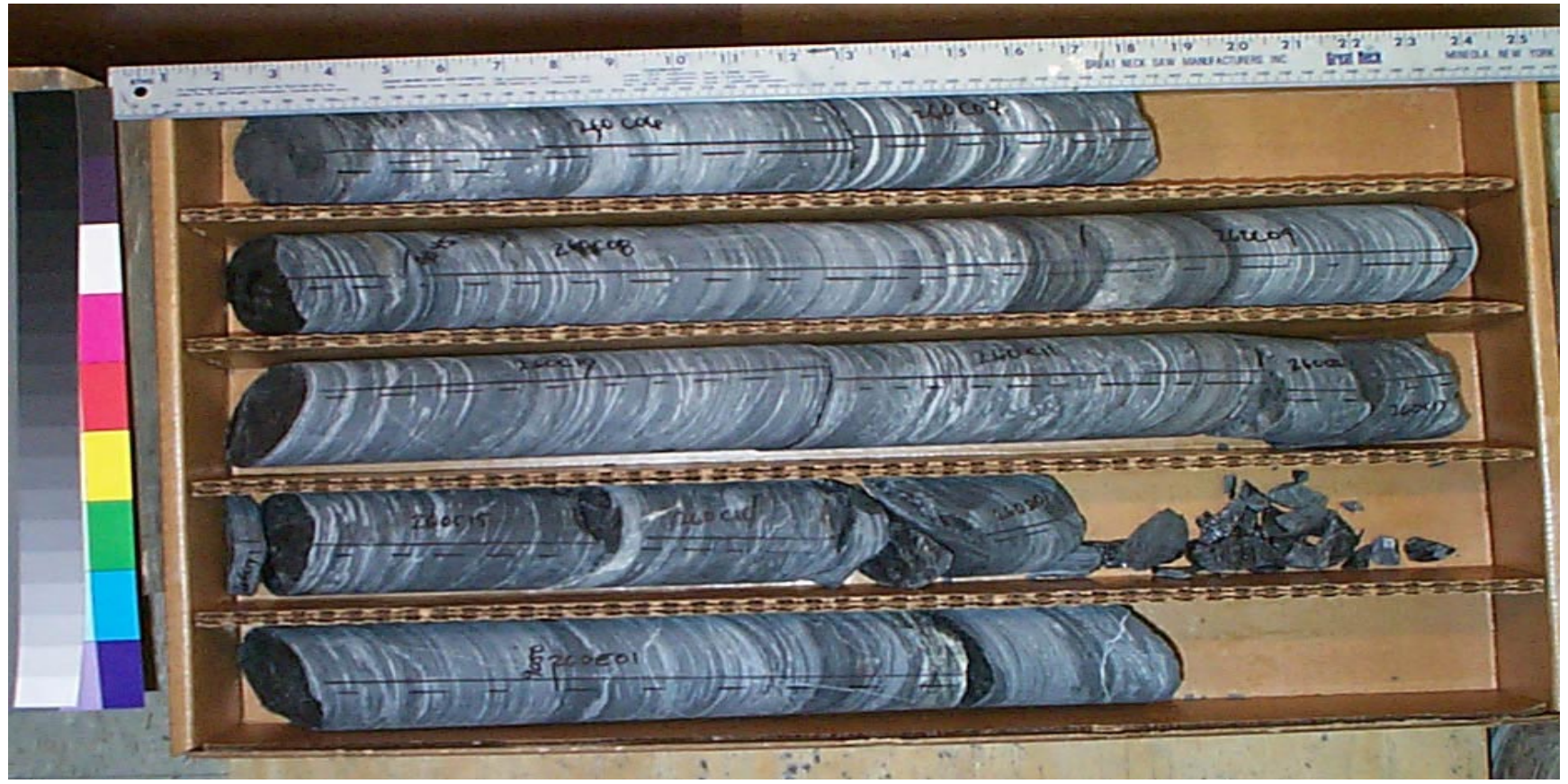

Core Scans included in this box (listed by piece going downhole):

$260 C 0600$
$260 C 0700$
$260 C 0800$
$260 C 0900$
$260 C 1000$
$260 C 1100$
$260 C 1300$
$260 C 1500$
$260 C 1600$
$260 \mathrm{E} 0100$

See the "reading instructions" section of the introduction for help interpreting core box photos and core piece nomenclature 


\section{LVEW Core Box 383}

Depth Interval 9050.9'-9059.0'

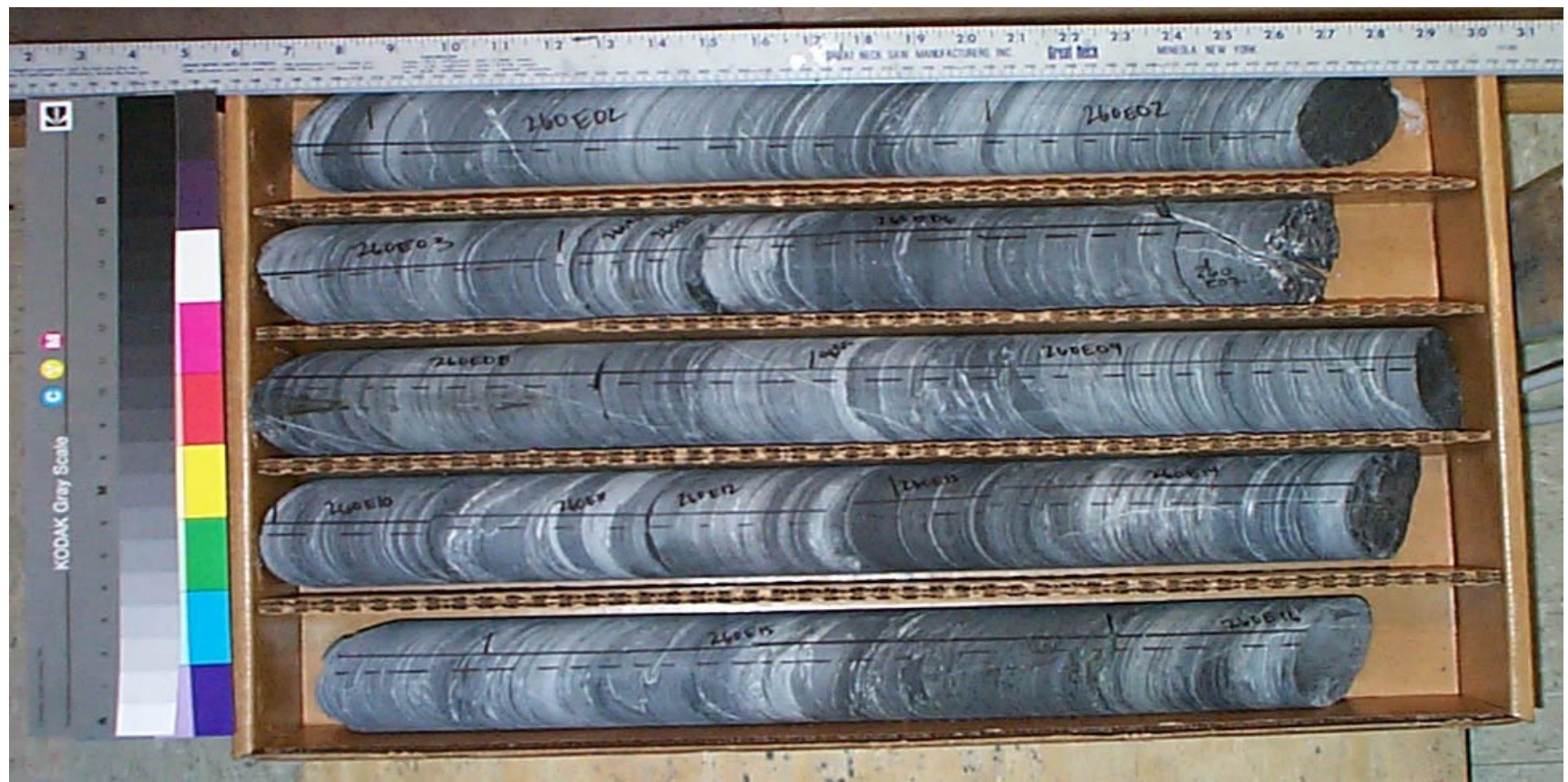

Core Scans included in this box (listed by piece going downhole):
260E0200
260E0300
260E0600
260E0800
260E0900
260E 1000
260E 1100
260E1200
260E 1300
260E1400
260E 1500
260E 1600

See the "reading instructions" section of the introduction for help interpreting core box photos and core piece nomenclature 


\section{LVEW Core Box 384}

Depth Interval 9059.0'-9065.7

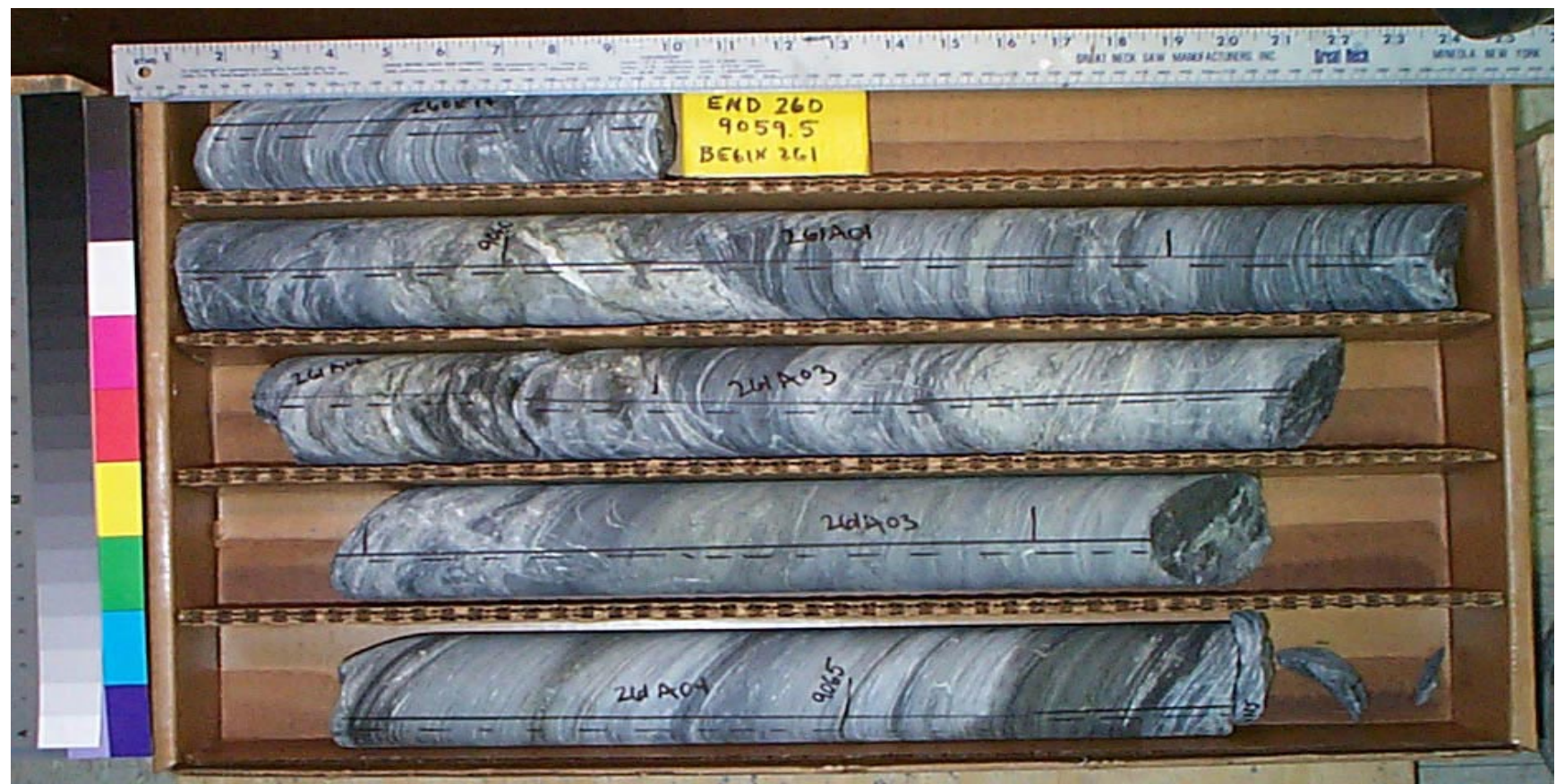

Core Scans included in this box (listed by piece going downhole):

260E1700

$261 \mathrm{~A} 0100$

$261 \mathrm{~A} 0200$

$261 \mathrm{~A} 030 \mathrm{~A}$

$261 \mathrm{~A} 0400$

See the "reading instructions" section of the introduction for help interpreting core box photos and core piece nomenclature 


\section{LVEW Core Box 385}

Depth Interval 9065.7'-9073.6'

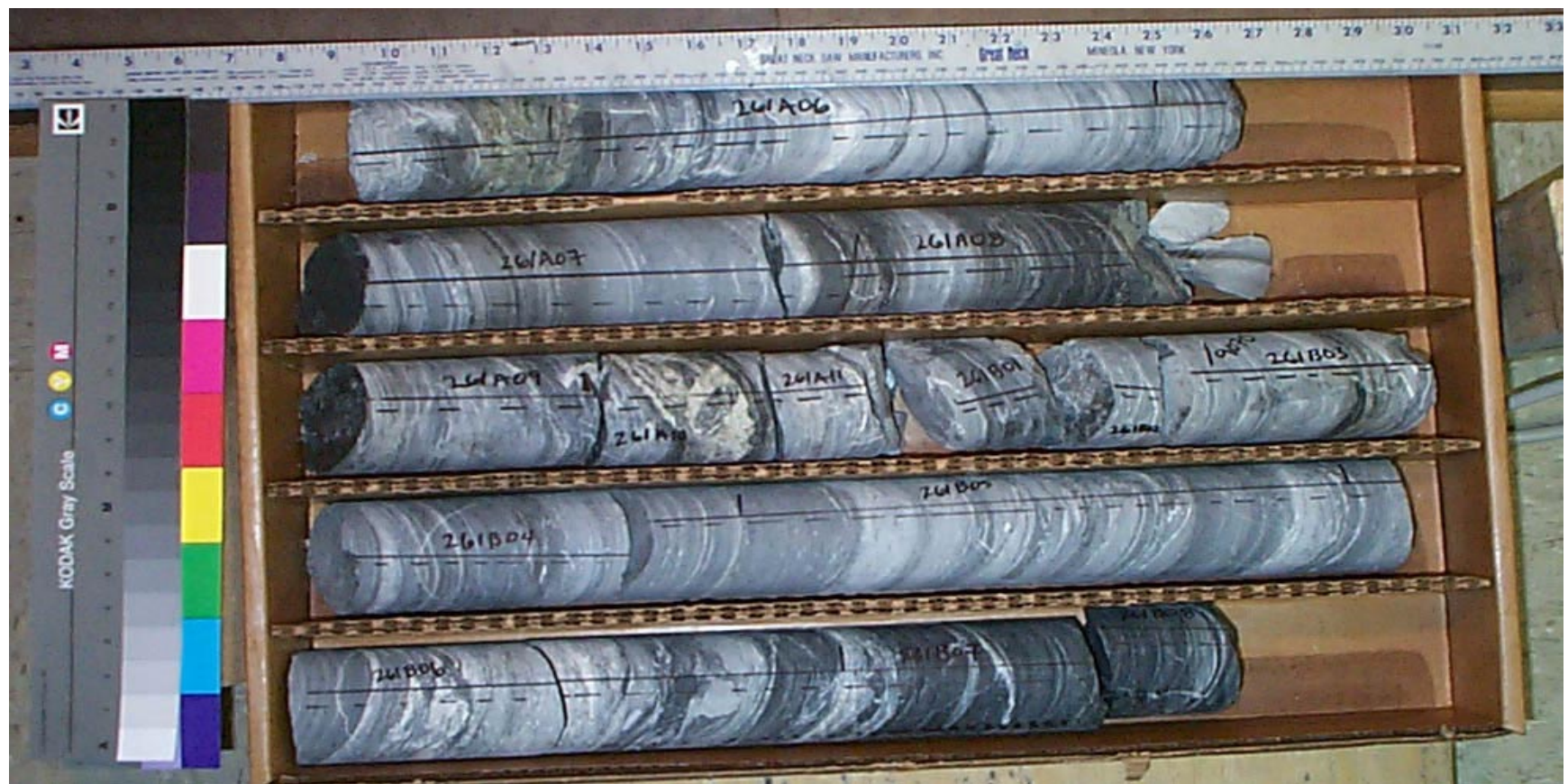

Core Scans included in this box (listed by piece going downhole):

$261 A 0600$
$261 A 0700$
$261 A 0800$
$261 A 0900$
$261 A 1000$
$261 A 1100$
$261 B 0100$

261B0200 261B0300 261B0400 261B0500 261B0600 261B0700 261B0800

See the "reading instructions" section of the introduction for help interpreting core box photos and core piece nomenclature 


\section{LVEW Core Box 386}

Depth Interval 9073.6'-9081.2'

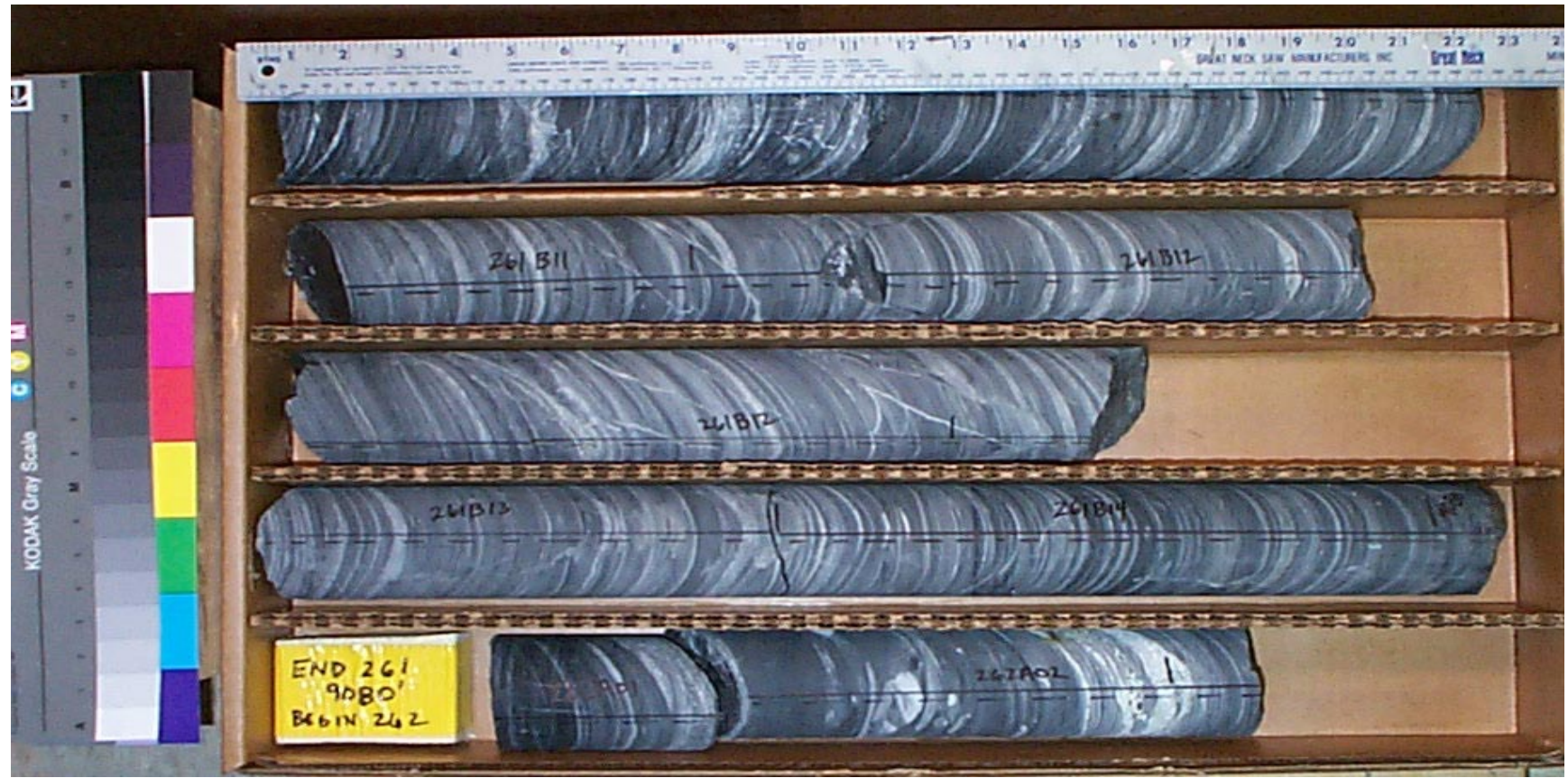

Core Scans included in this box (listed by piece going downhole):
261B0900
261B1000
261B1100
261B1200
261B1300
261B1400
262A0100
262A0200

See the "reading instructions" section of the introduction for help interpreting core box photos and core piece nomenclature 


\section{LVEW Core Box 387}

Depth Interval 9081.2'-9089.1'

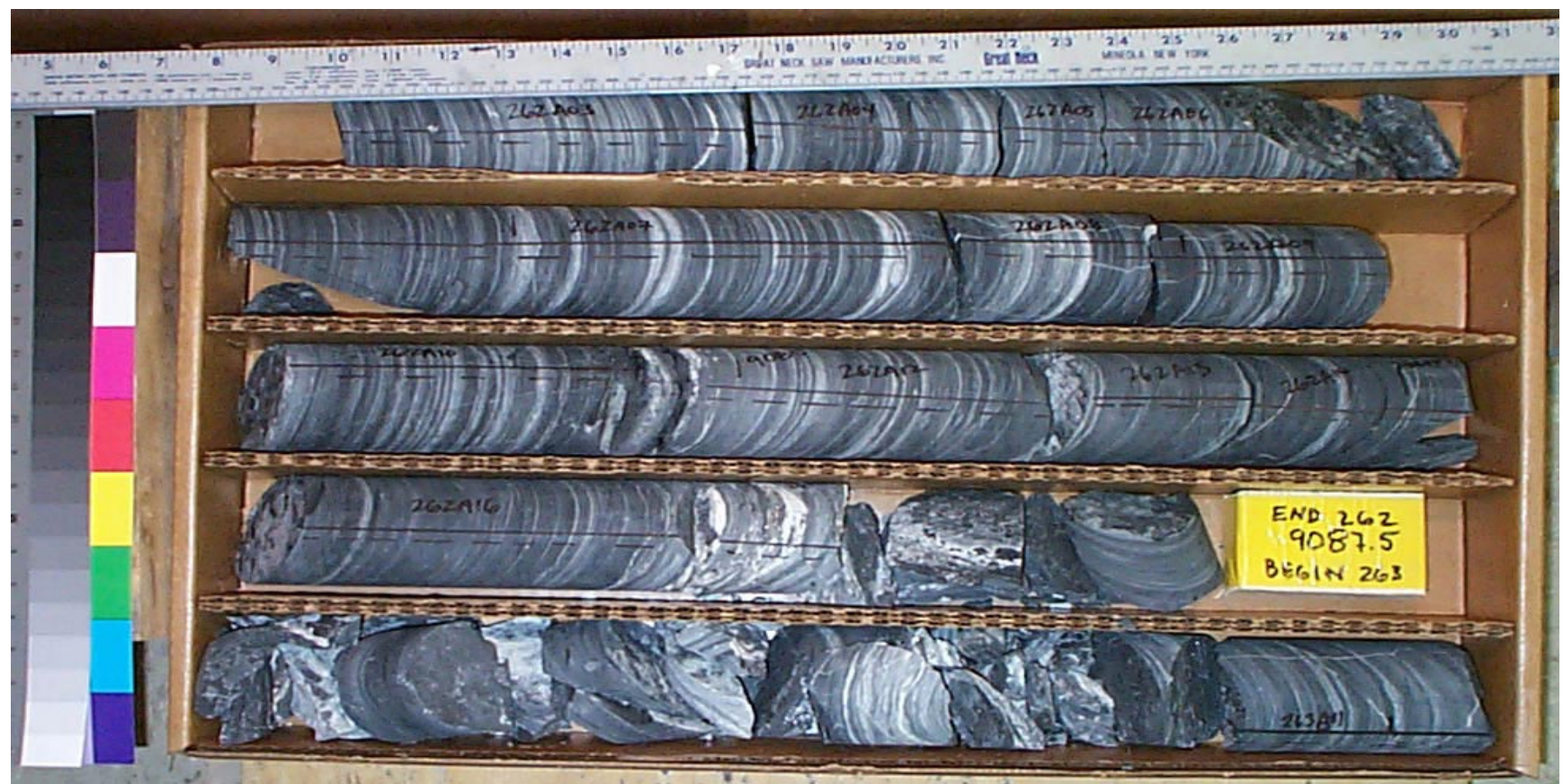

Core Scans included in this box (listed by piece going downhole):

262A0300
$262 A 0400$
$262 A 0500$
$262 A 0600$
$262 A 0700$
$262 A 0800$
$262 A 0900$
$262 A 1000$

$262 \mathrm{~A} 1200$

$262 \mathrm{~A} 1300$

$262 \mathrm{~A} 1400$

$262 \mathrm{~A} 1500$

$262 \mathrm{~A} 1600$

$262 \mathrm{~A} 1700$

263A0100

See the "reading instructions" section of the introduction for help interpreting core box photos and core piece nomenclature 


\section{LVEW Core Box 388}

Depth Interval 9089.1'-9096.1'

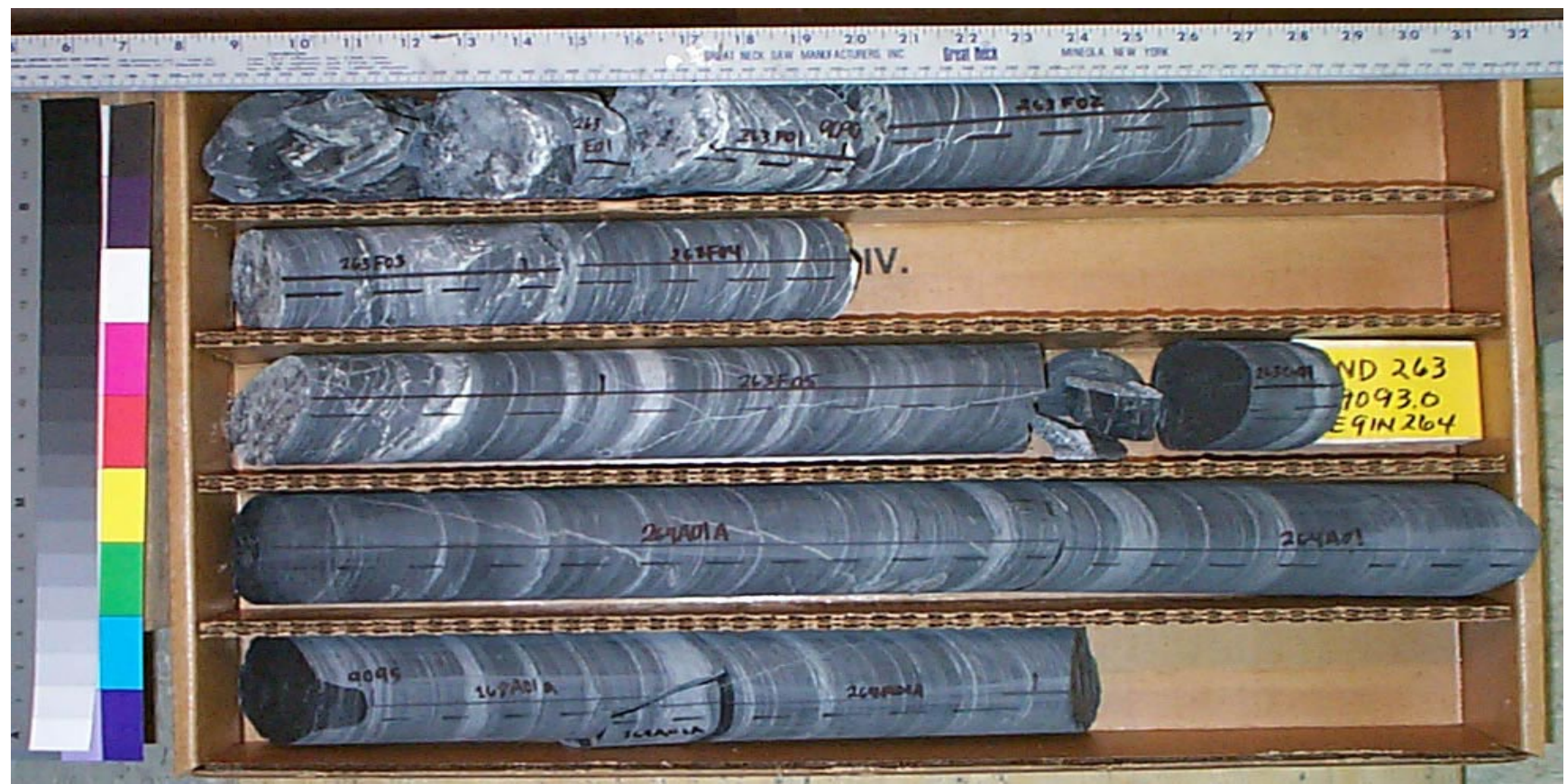

Core Scans included in this box (listed by piece going downhole):

$263 F 0100$
$263 F 0200$
$263 F 0300$
$263 F 0400$
263F0500
264A010A
264A021A

See the "reading instructions" section of the introduction for help interpreting core box photos and core piece nomenclature 


\section{LVEW Core Box 389}

\section{Depth Interval 9096.1'-9103.7'}

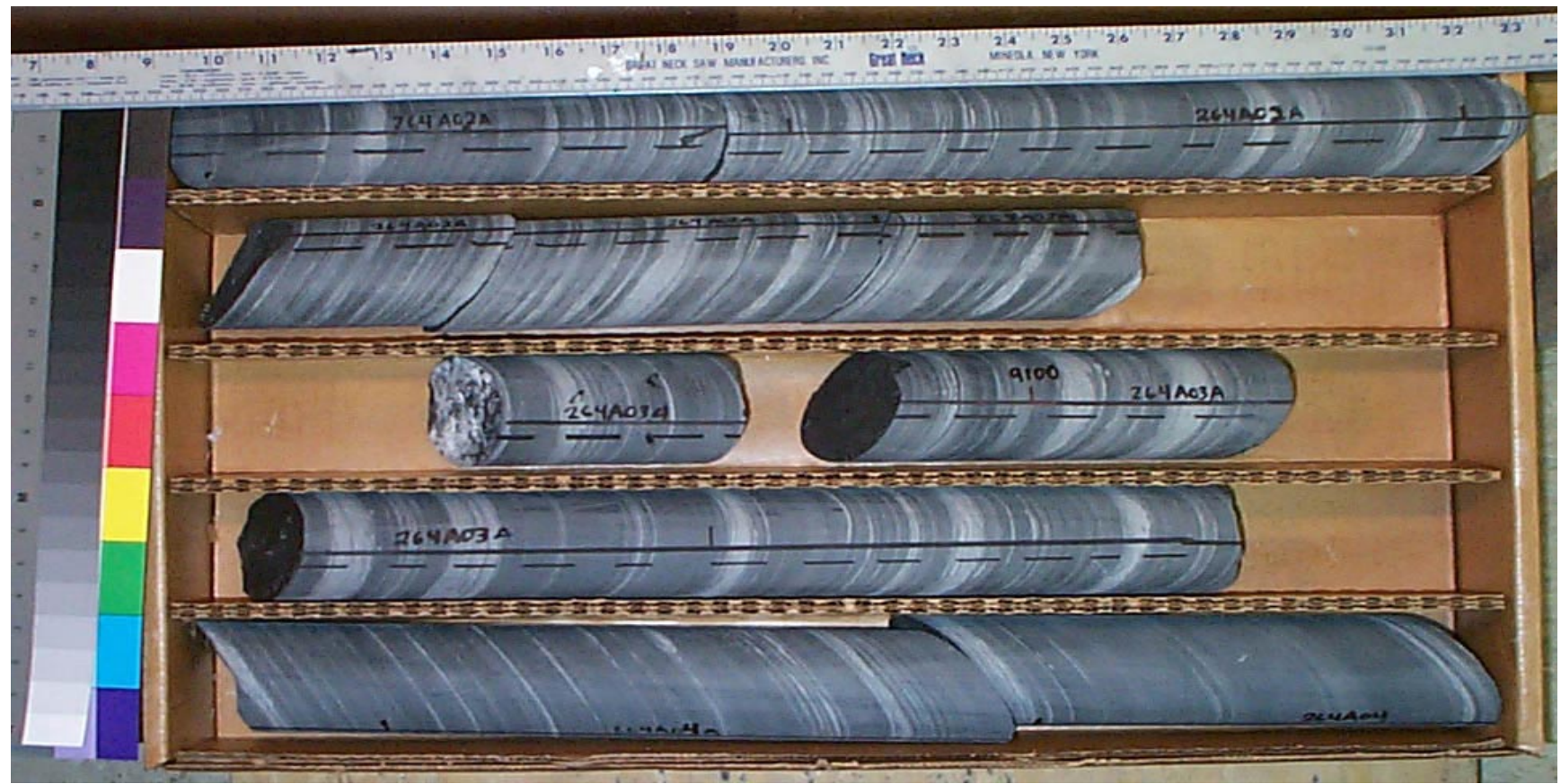

Core Scans included in this box (listed by piece going downhole):

$$
\begin{aligned}
& \text { 264A021A } \\
& \text { 264A022A } \\
& \text { 264A030A } \\
& \text { 264A040A }
\end{aligned}
$$

See the "reading instructions" section of the introduction for help interpreting core box photos and core piece nomenclature 


\section{LVEW Core Box 390}

Depth Interval 9103.7'-9110.9'

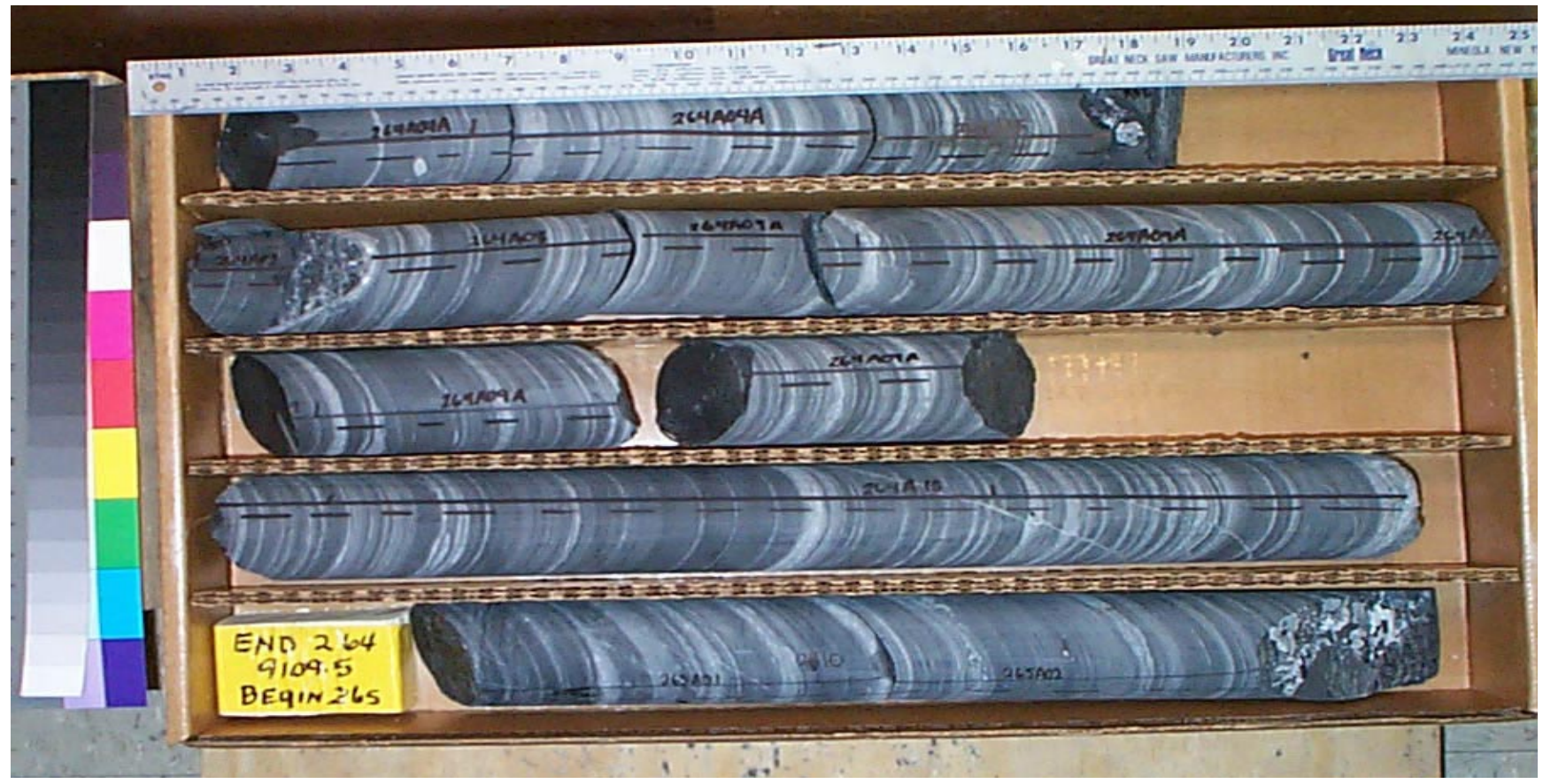

Core Scans included in this box (listed by piece going downhole):
264A0800
264A090A
$264 \mathrm{~A} 1000$
$265 \mathrm{~A} 0100$
265A0200

See the "reading instructions" section of the introduction for help interpreting core box photos and core piece nomenclature 


\section{LVEW Core Box 391}

Depth Interval 9110.9'-9118.2'

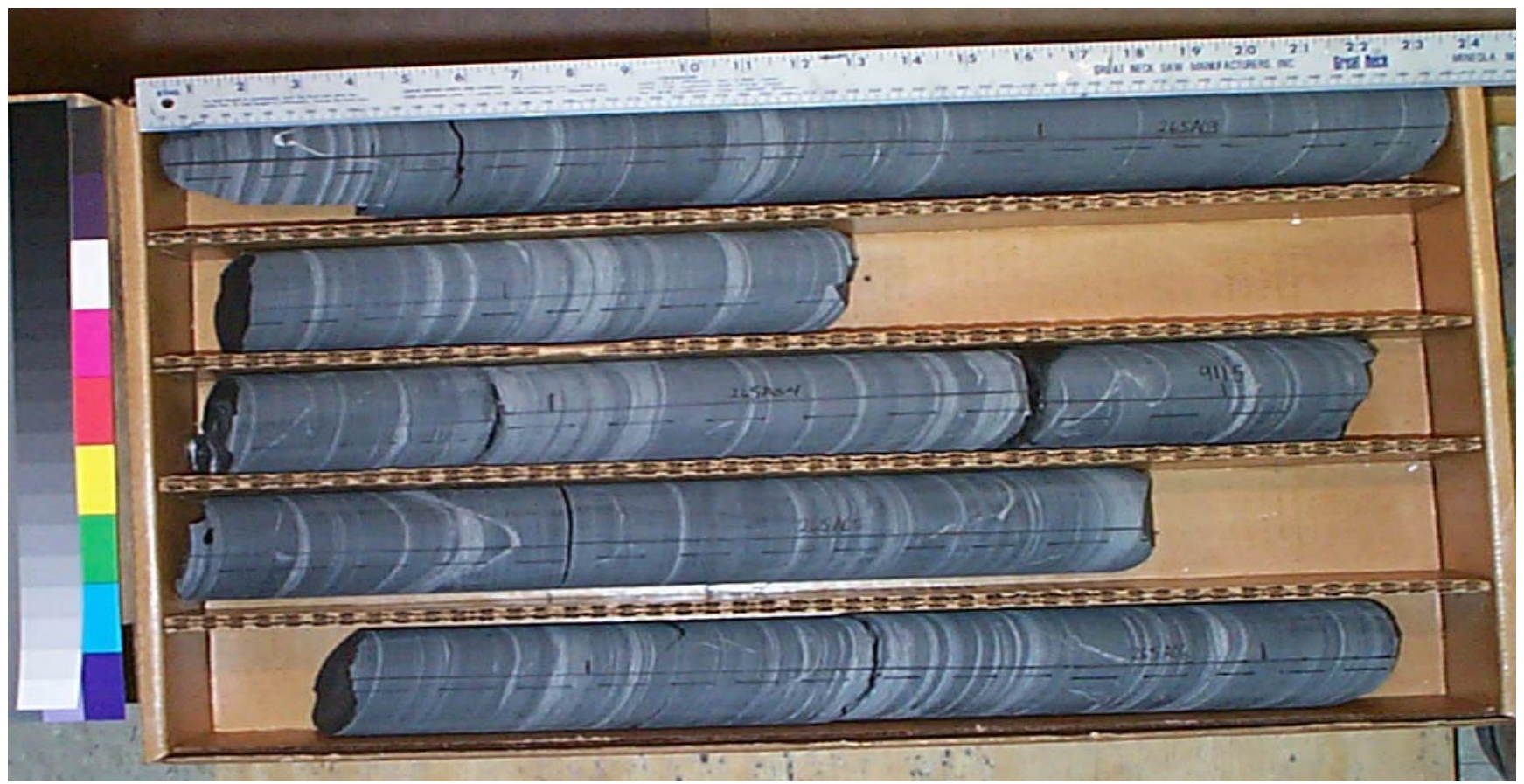

Core Scans included in this box (listed by piece going downhole):

$$
\begin{aligned}
& \text { 265A030A } \\
& \text { 265A040A } \\
& \text { 265A050A } \\
& \text { 265A0600 }
\end{aligned}
$$

See the "reading instructions" section of the introduction for help interpreting core box photos and core piece nomenclature 


\section{LVEW Core Box 392}

Depth Interval 9118.2'-9125.8'

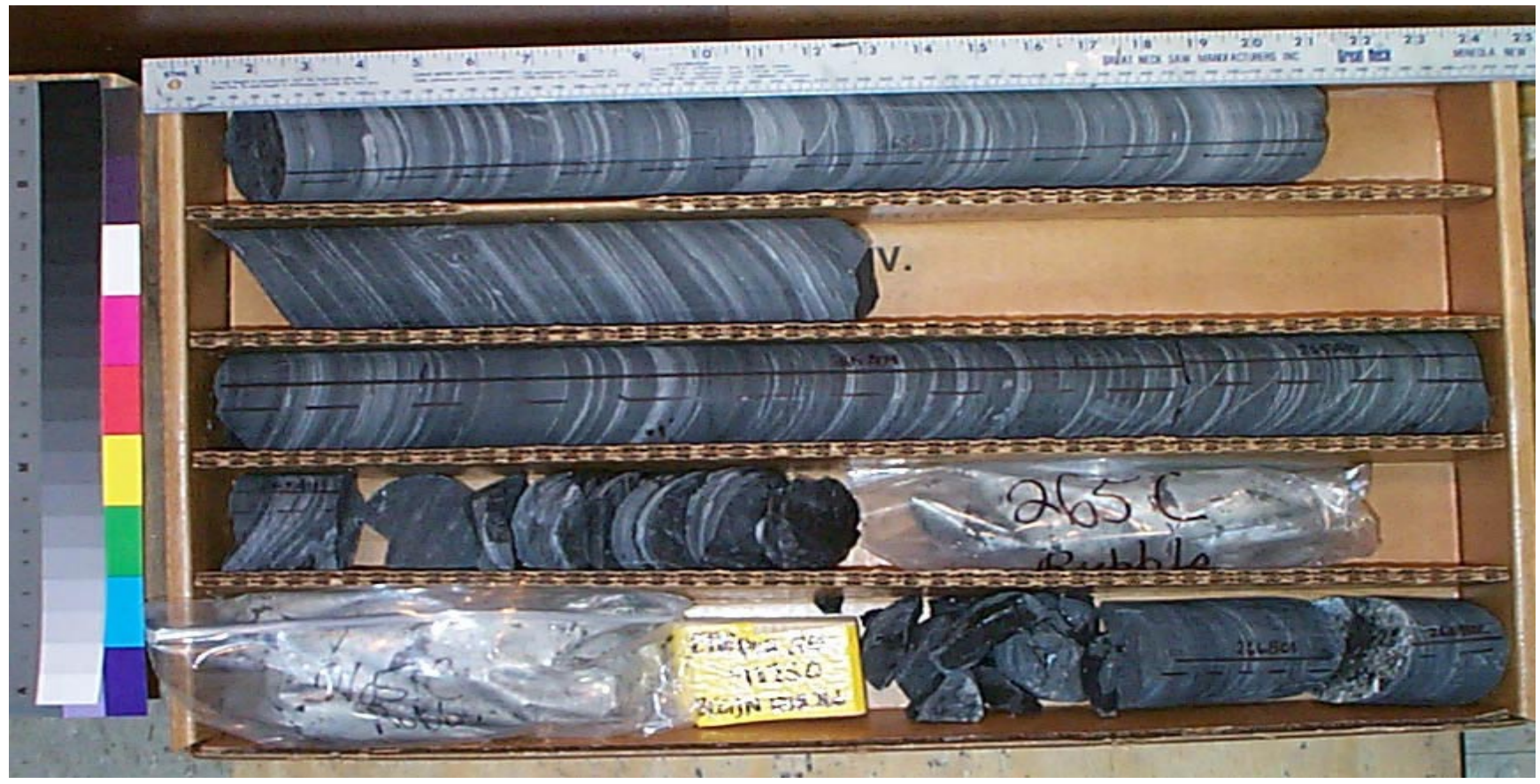

Core Scans included in this box (listed by piece going downhole):
265A0700
265A0800
265A0900
265A 1000
265A 1100
265B0100
266B0200

See the "reading instructions" section of the introduction for help interpreting core box photos and core piece nomenclature 


\section{LVEW Core Box 393}

Depth Interval 9125.8'-9133.5'

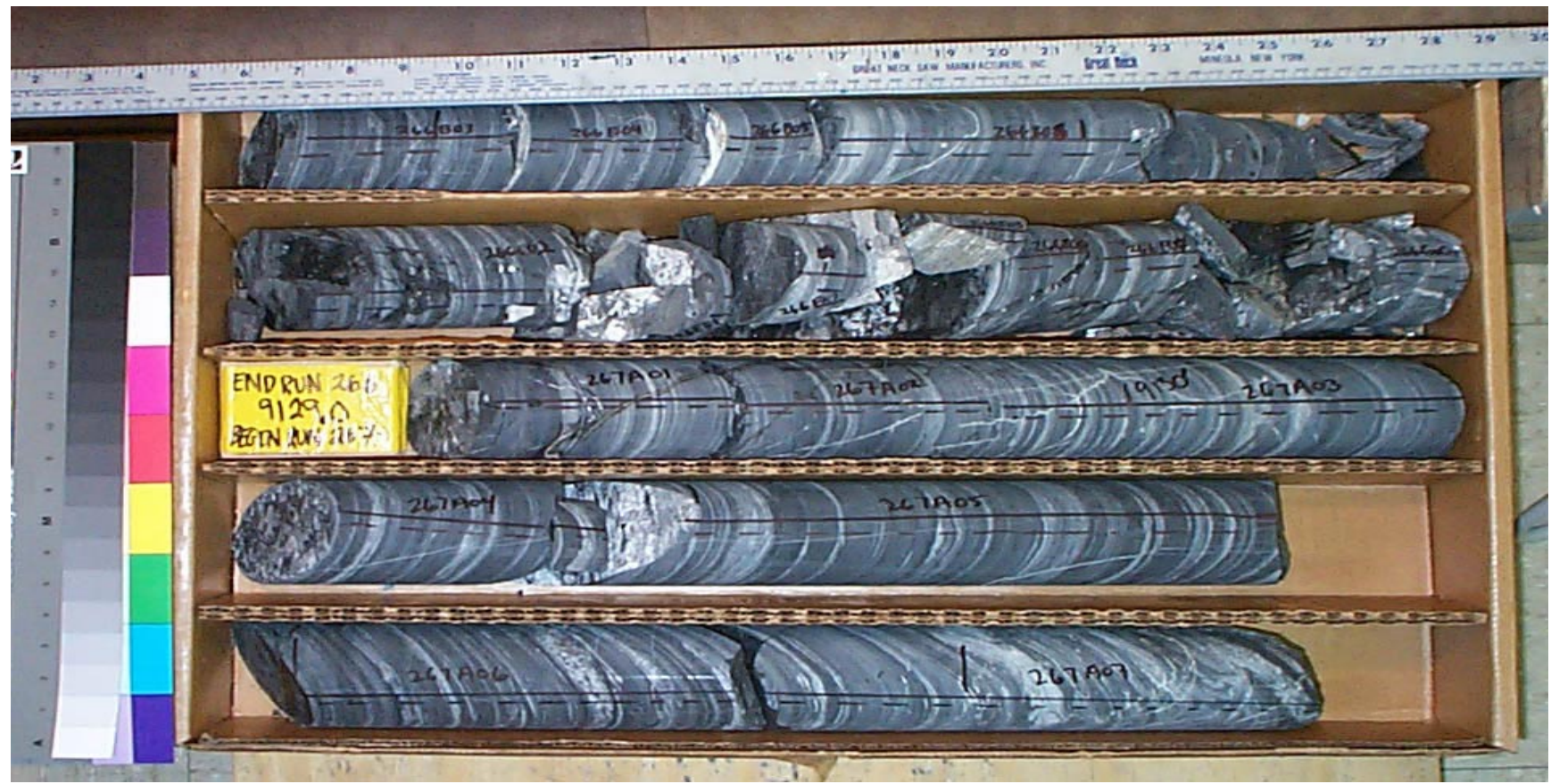

Core Scans included in this box (listed by piece going downhole):
266B0300
266B0400
266B0600
267A0100
267A0200
267A0300
267A0400
267A0500
267A0600
267A0700

See the "reading instructions" section of the introduction for help interpreting core box photos and core piece nomenclature 


\section{LVEW Core Box 394}

Depth Interval 9133.5'-9140.8'

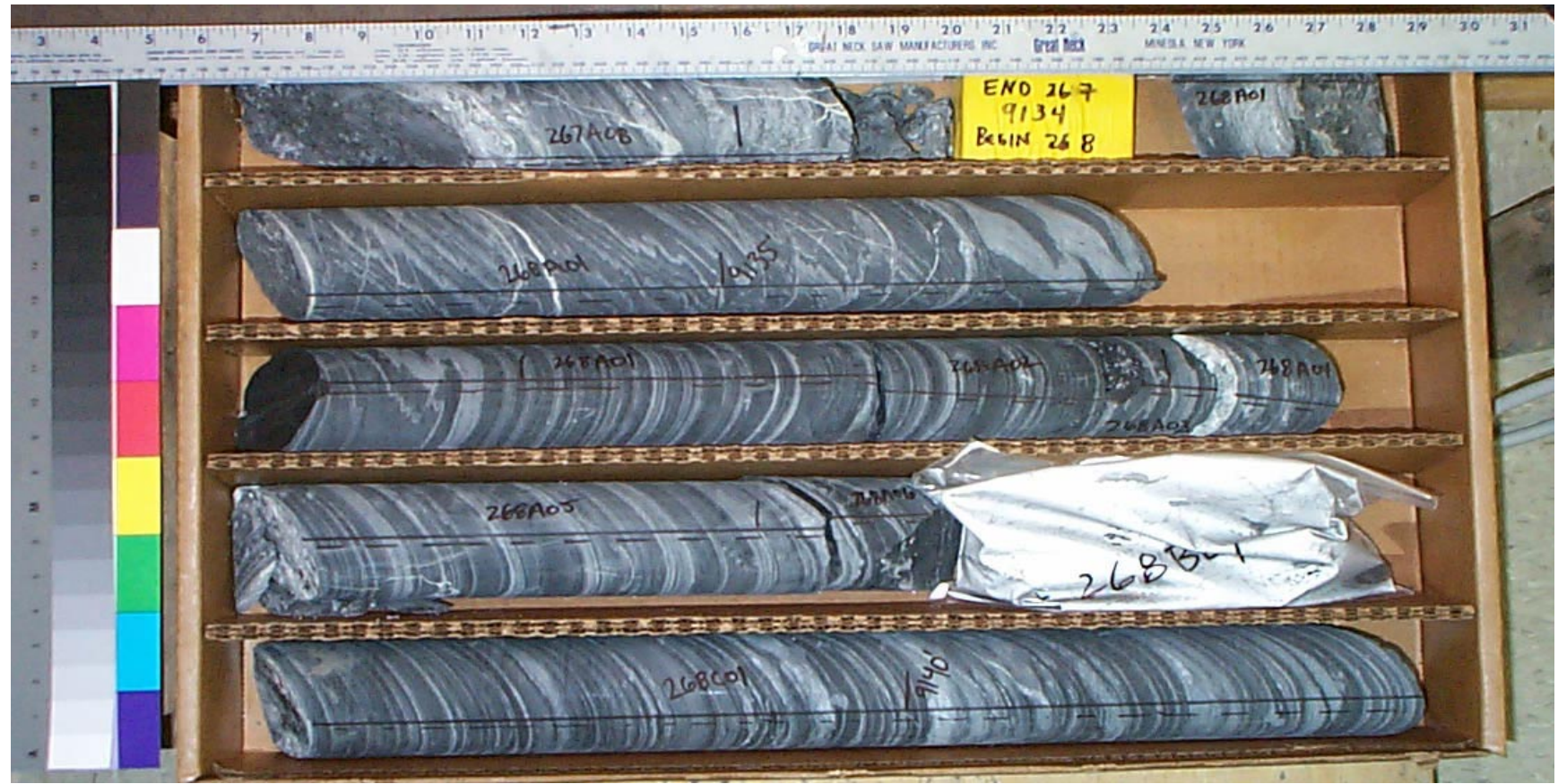

Core Scans included in this box (listed by piece going downhole):
267A0800
268A010A
268A0200
$268 \mathrm{C} 0100$

See the "reading instructions" section of the introduction for help interpreting core box photos and core piece nomenclature 


\section{LVEW Core Box 395}

Depth Interval 9140.8'-9147.9'

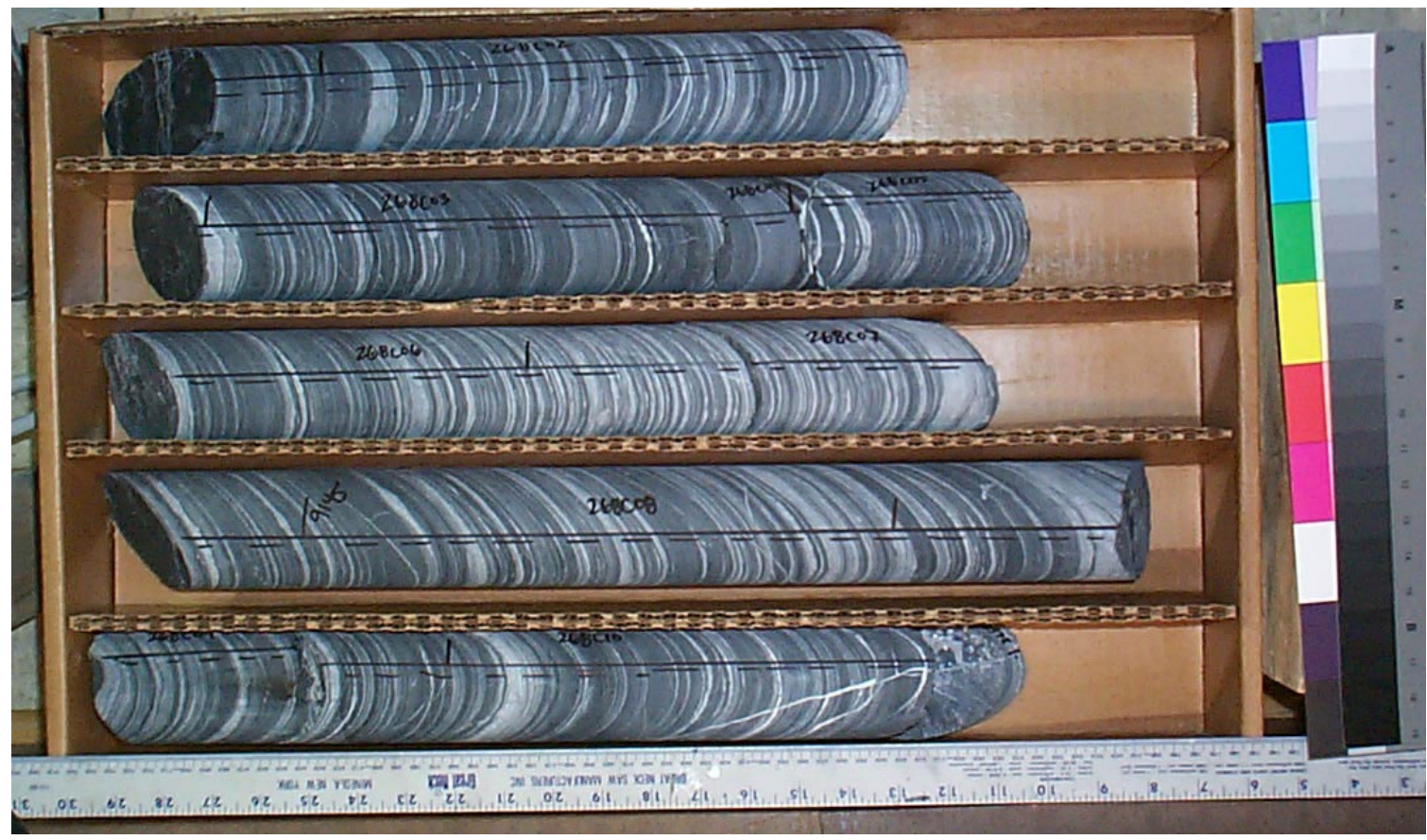

Core Scans included in this box (listed by piece going downhole):

\section{$268 C 0200$ \\ $268 \mathrm{C} 0300$ \\ $268 \mathrm{C} 0400$ \\ $268 \mathrm{C} 0500$ \\ $268 \mathrm{C} 0600$ \\ $268 \mathrm{C} 0700$ \\ $268 \mathrm{C} 0800$ \\ 268C 1000}

See the "reading instructions" section of the introduction for help interpreting core box photos and core piece nomenclature 
LVEW Core Box 396

Depth Interval 9147.9'-9155.3'

\section{Box Photo Missing}

Core Scans included in this box (listed by piece going downhole):

268C1200

269A0100

269B0100

269C010A

269C0200

269C0400

269D0100

269D0200

269D0300

269D0400

See the "reading instructions" section of the introduction for help interpreting core box photos and core piece nomenclature 
LVEW Core Box 397

Depth Interval 9155.3'-9163.0'

\section{Box Photo Missing}

Core Scans included in this box (listed by piece going downhole):

269D0500

269D0600

269D0700

269D0800

269D0900

See the "reading instructions" section of the introduction for help interpreting core box photos and core piece nomenclature 


\section{LVEW Core Box 398}

Depth Interval 9163.0'-9168.8'

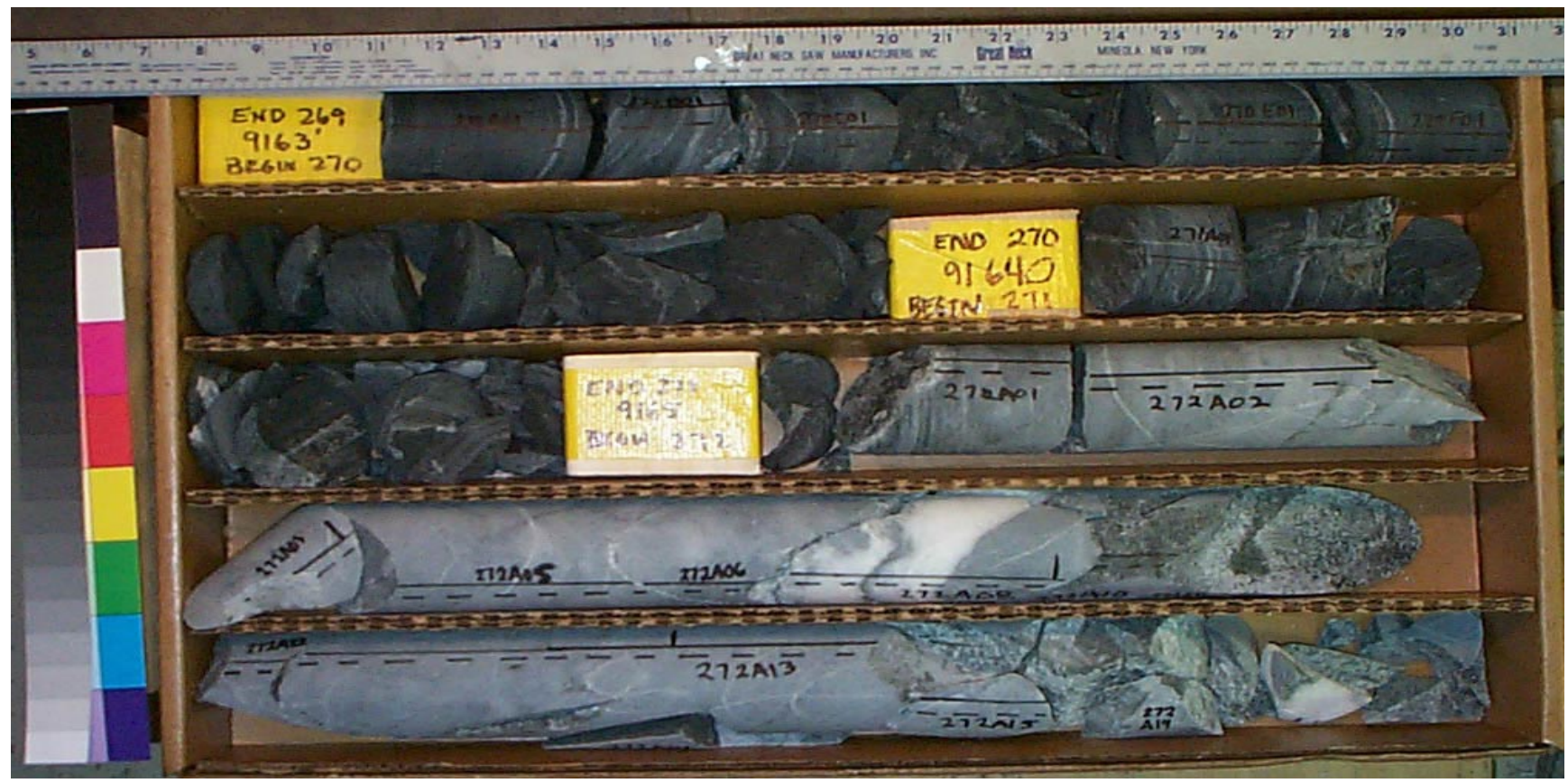

Core Scans included in this box (listed by piece going downhole):
$270 \mathrm{~A} 0100$
270B0100
$270 \mathrm{C} 0100$
270E0100
270F0100
$271 \mathrm{~A} 0100$
272A0100
272A0200
272A0500

See the "reading instructions" section of the introduction for help interpreting core box photos and core piece nomenclature 


\section{LVEW Core Box 399}

Depth Interval 9168.8'-9177.0'

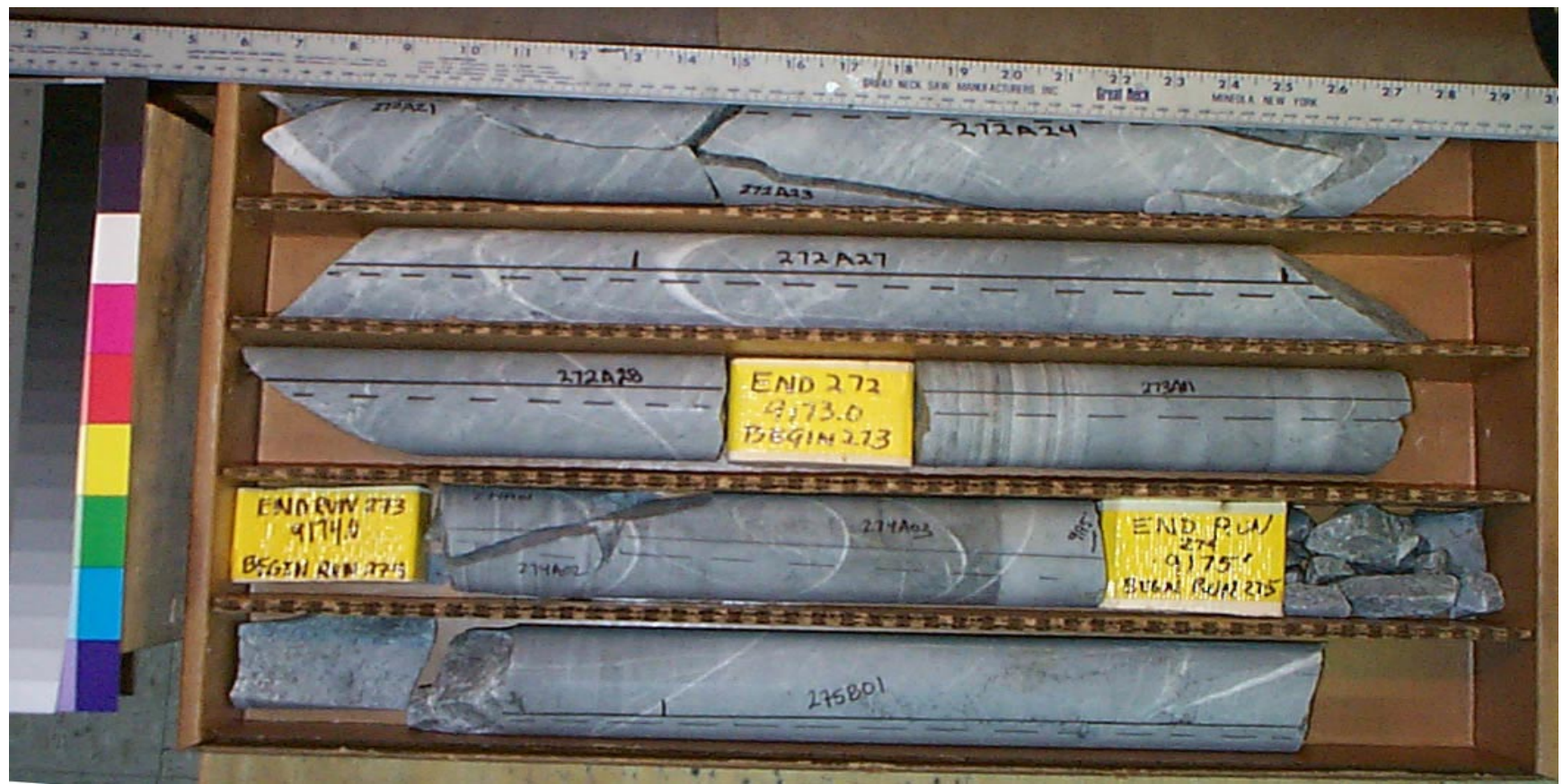

Core Scans included in this box (listed by piece going downhole):
$272 \mathrm{~A} 2700$
272A2800
273A0100
274A0300
275B0100

See the "reading instructions" section of the introduction for help interpreting core box photos and core piece nomenclature 


\section{LVEW Core Box 400}

Depth Interval 9177.0'-9185.0'

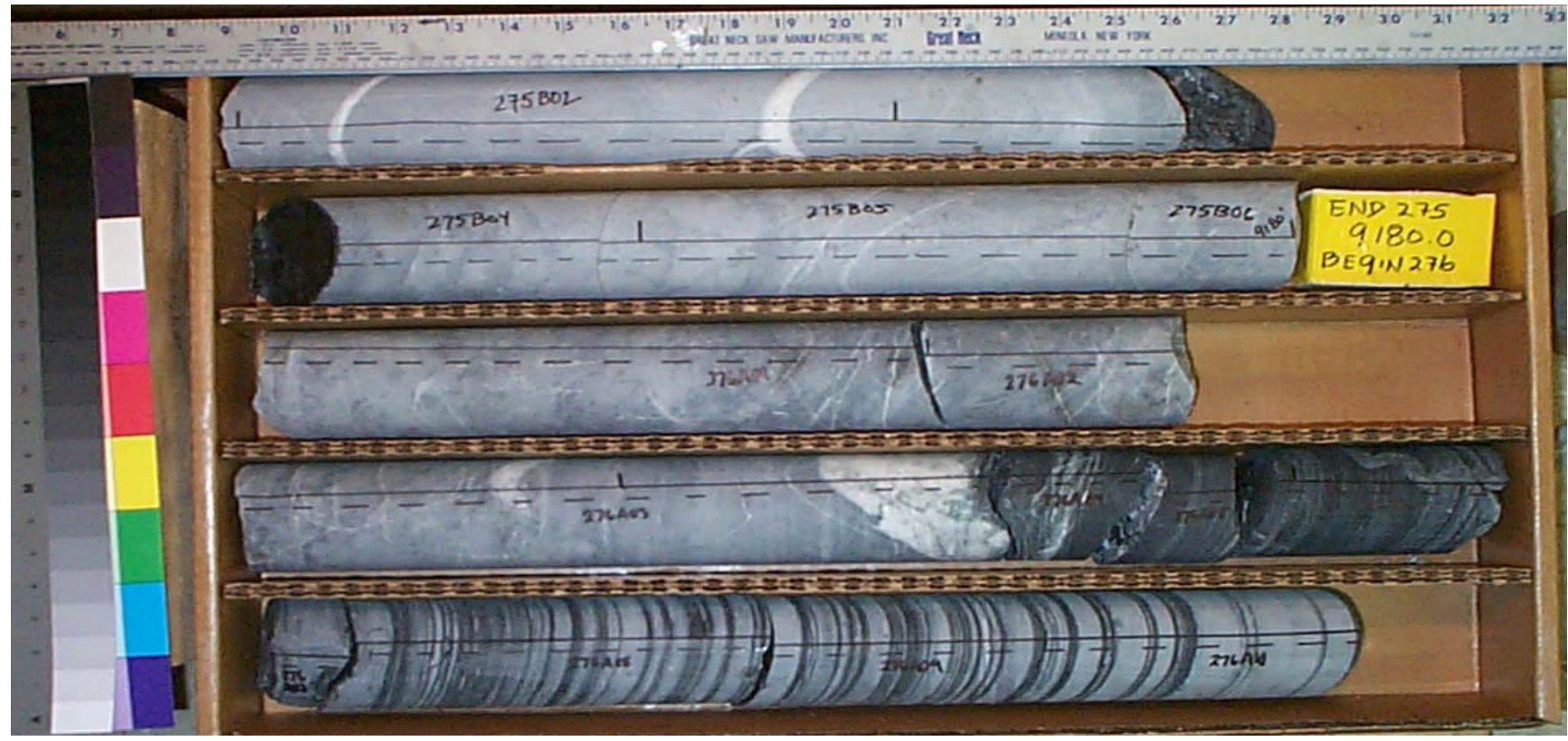

Core Scans included in this box (listed by piece going downhole):
275B0200
275B0400
275B0500
275B0600
276A0100
276A0200
276A0300
276A0400
276A0600
276A0800

See the "reading instructions" section of the introduction for help interpreting core box photos and core piece nomenclature 


\section{LVEW Core Box 401}

\section{Depth Interval 9185.0'-9192.2'}

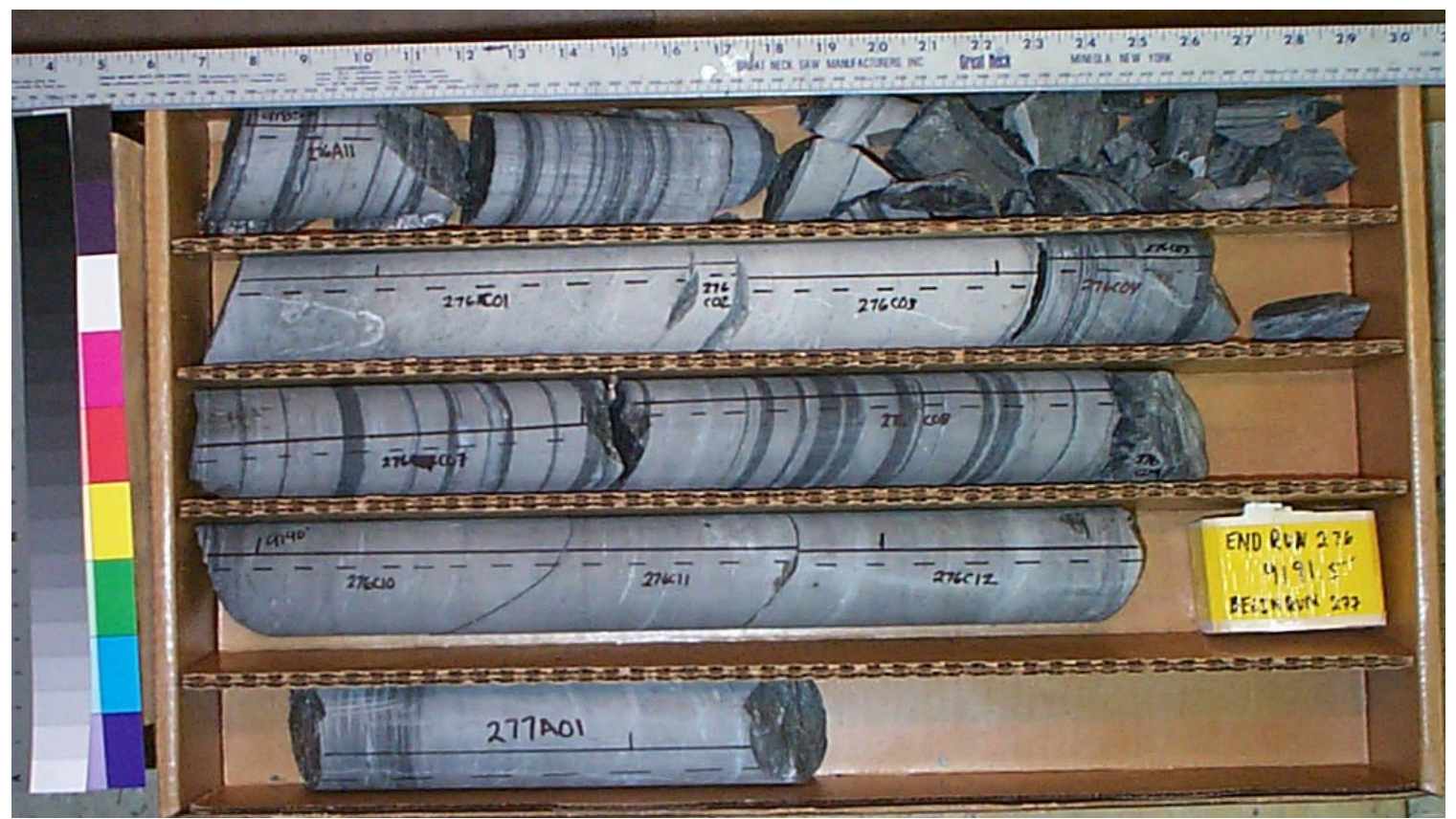

Core Scans included in this box (listed by piece going downhole):
$276 \mathrm{C} 0100$
$276 \mathrm{C} 0300$
$276 \mathrm{C} 0400$
276C0700
$276 \mathrm{C} 0800$
276C1000
276C1100
276C1200
277A0100

See the "reading instructions" section of the introduction for help interpreting core box photos and core piece nomenclature 


\section{LVEW Core Box 402}

Depth Interval 9192.2'-9200.0'

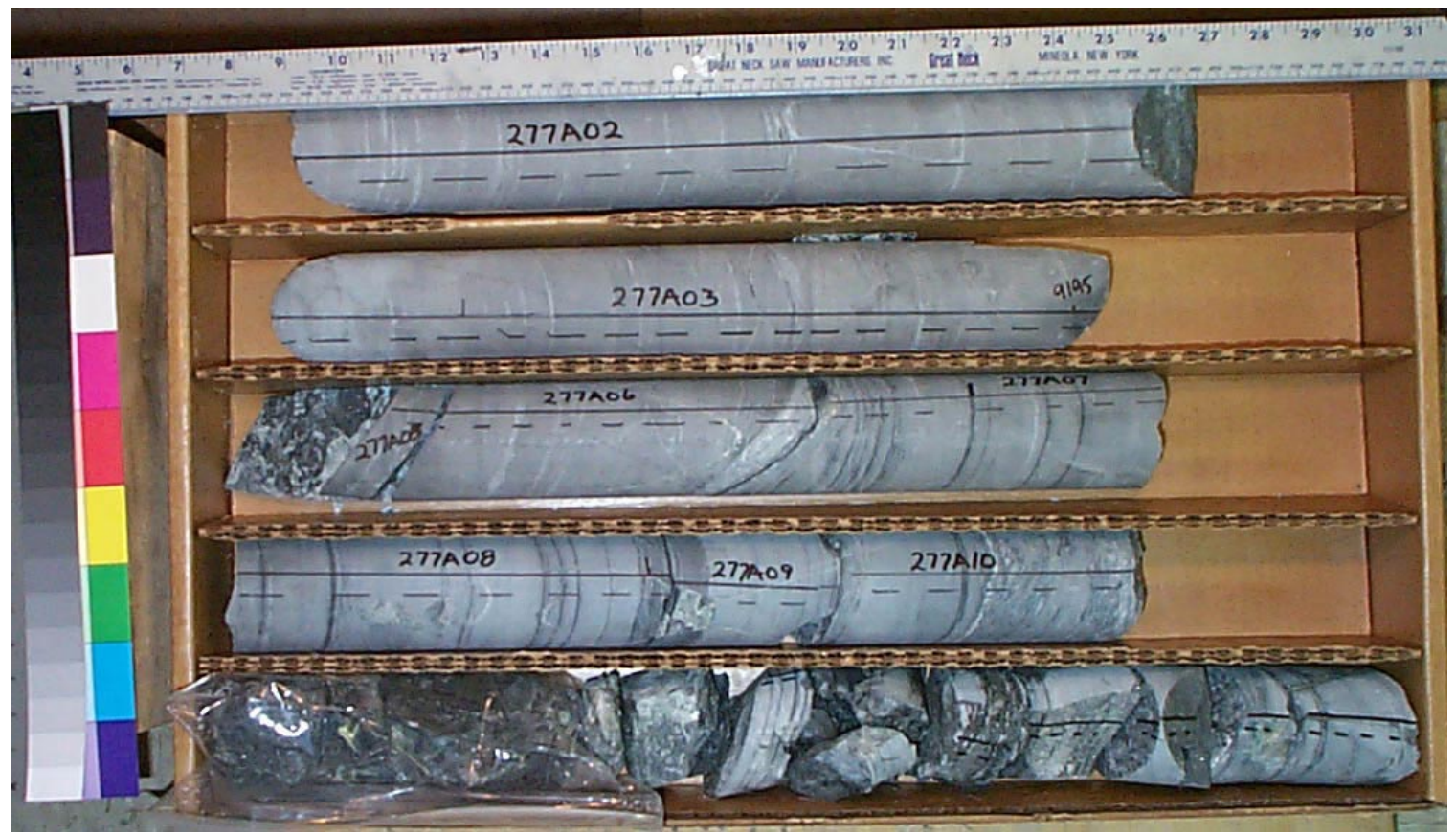

Core Scans included in this box (listed by piece going downhole):
277A0200
277A0300
277A0600
277A0700
277A0800
277A0900
277A1000

See the "reading instructions" section of the introduction for help interpreting core box photos and core piece nomenclature 


\section{LVEW Core Box 403}

Depth Interval 9200.0'-9207.0'

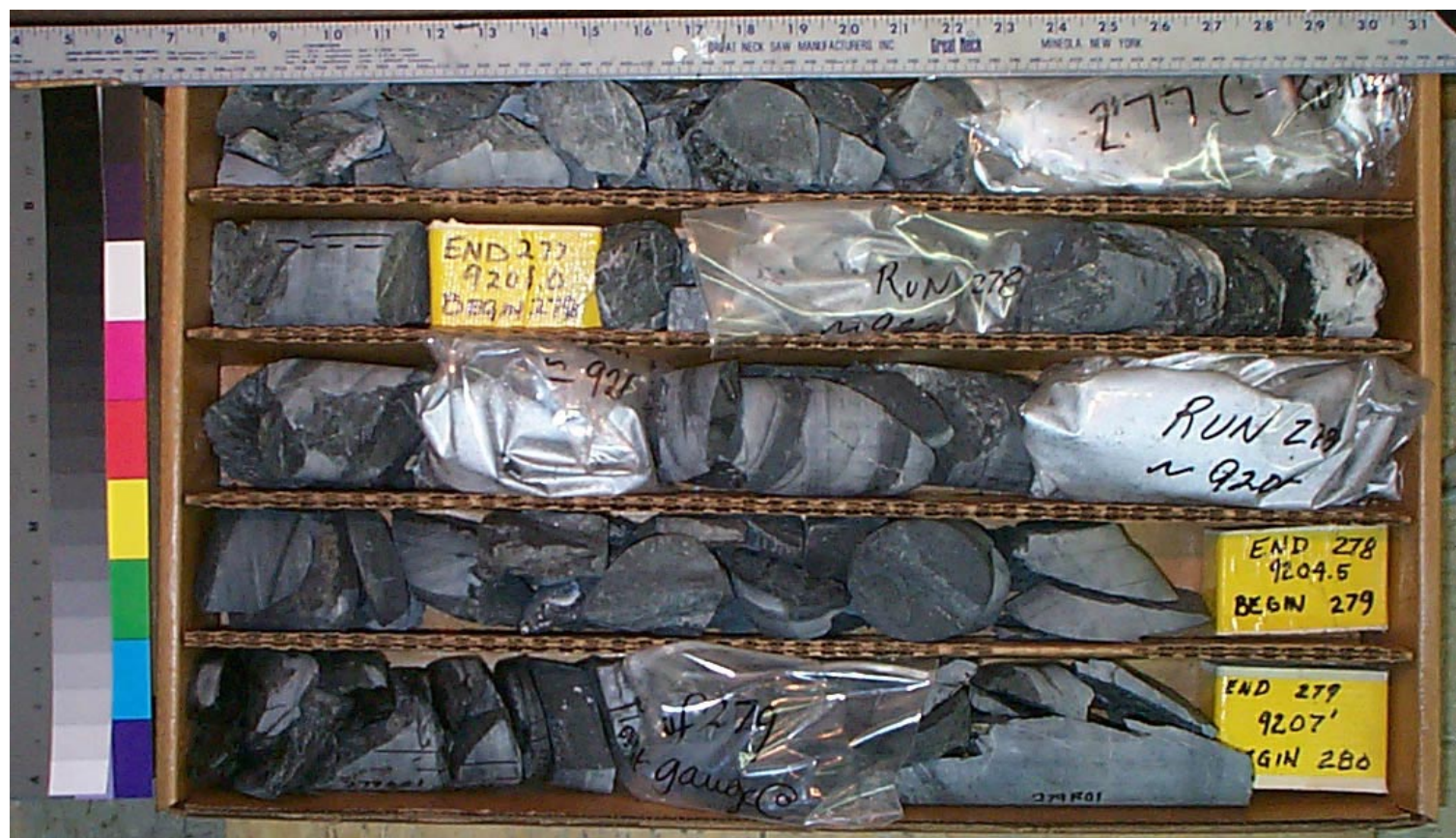

Core Scans included in this box (listed by piece going downhole):

\section{(No Core Scans Included in This Box)}

See the "reading instructions" section of the introduction for help interpreting core box photos and core piece nomenclature 


\section{LVEW Core Box 404}

Depth Interval 9207.0'-9214.0'

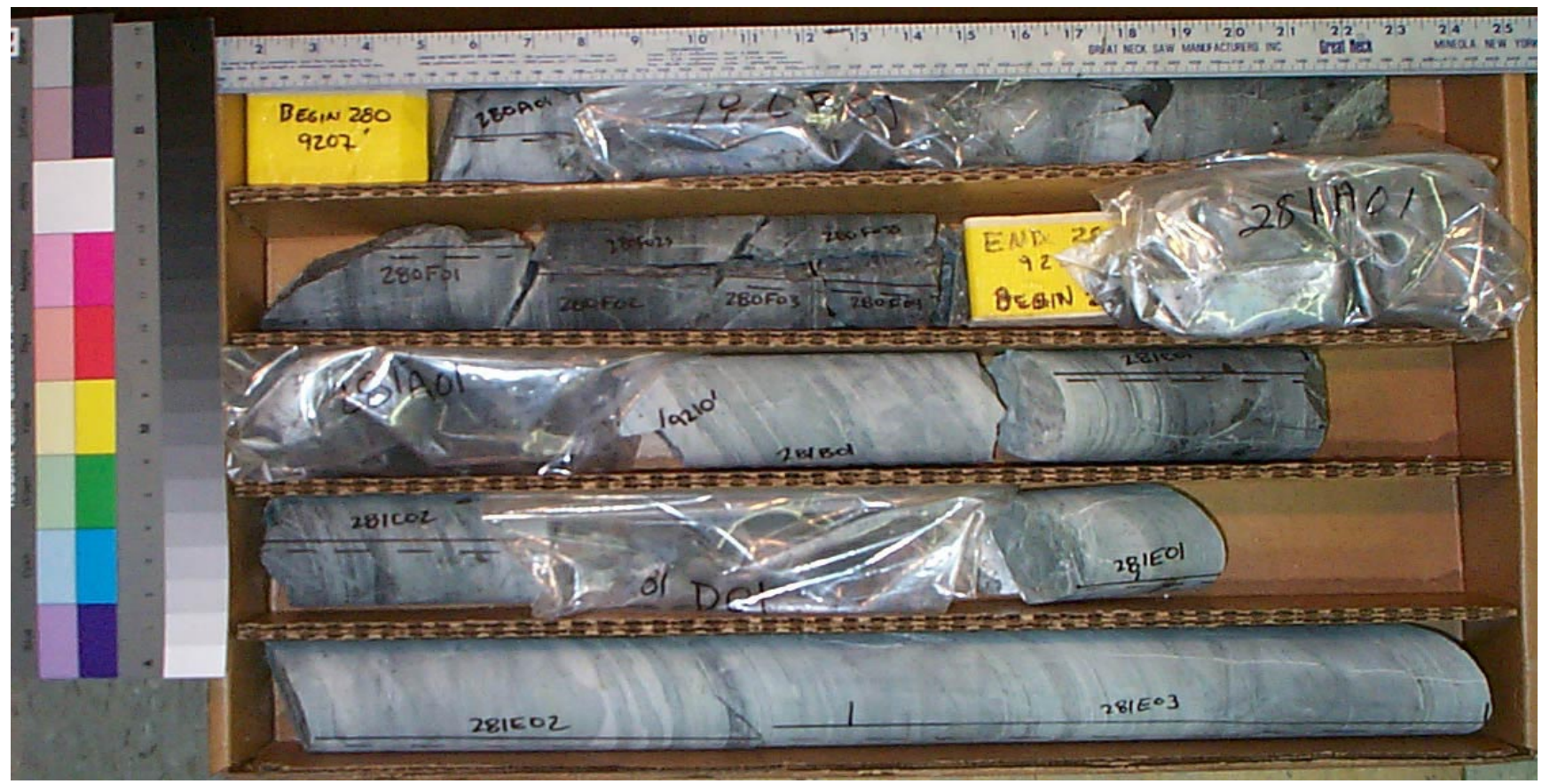

Core Scans included in this box (listed by piece going downhole):
$280 \mathrm{C} 0100$
280E0100
281B0100
281C0100
281C0200
281E0200
281E030A

See the "reading instructions" section of the introduction for help interpreting core box photos and core piece nomenclature 


\section{LVEW Core Box 405}

Depth Interval 9214.0'-9221.3'

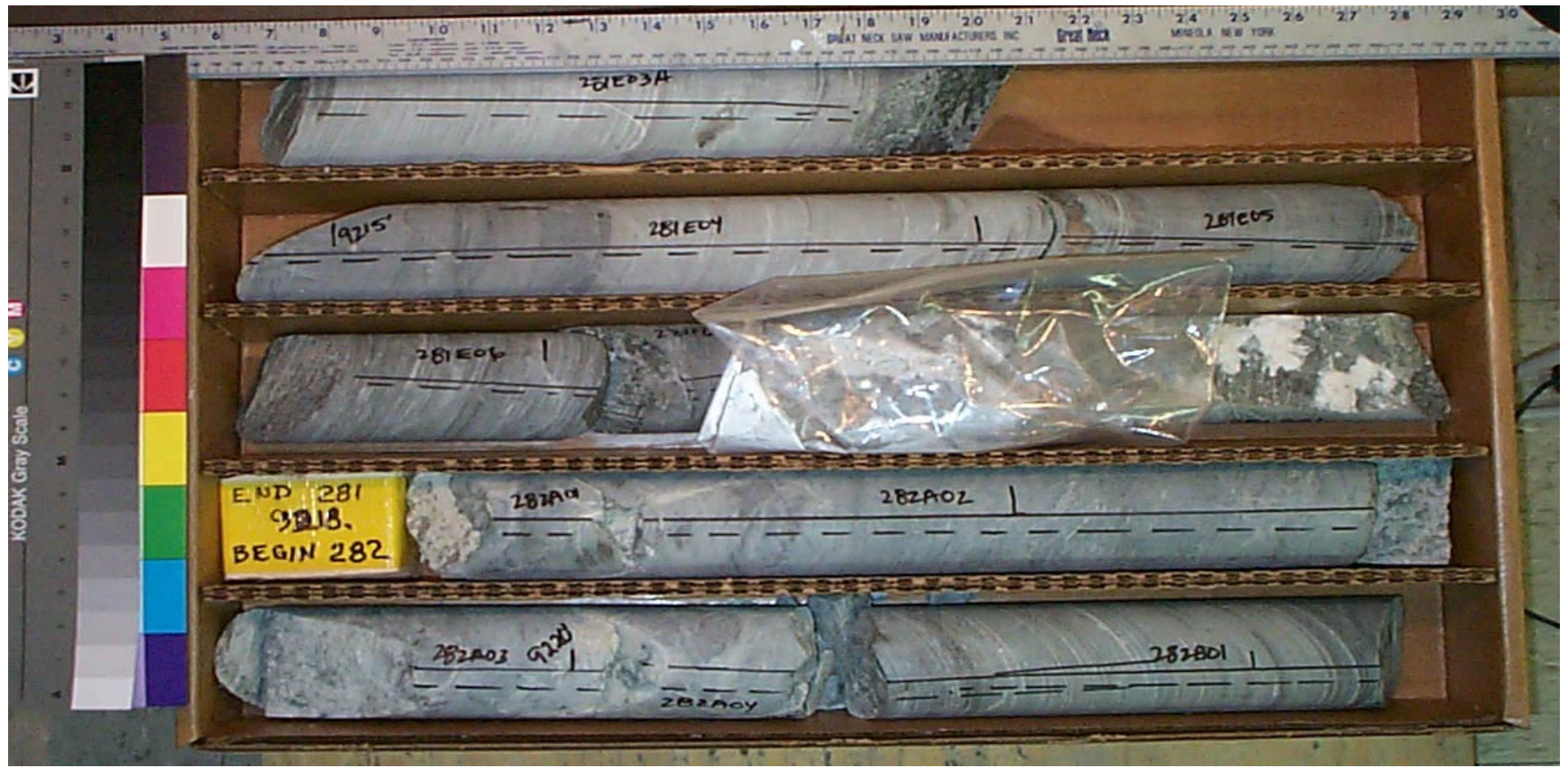

Core Scans included in this box (listed by piece going downhole):
281E030A
281E0400
281E0500
281E0600
281F0100
282A0200
282A0300
282B0100

See the "reading instructions" section of the introduction for help interpreting core box photos and core piece nomenclature 


\section{LVEW Core Box 406}

Depth Interval 9221.3'-9228.0'

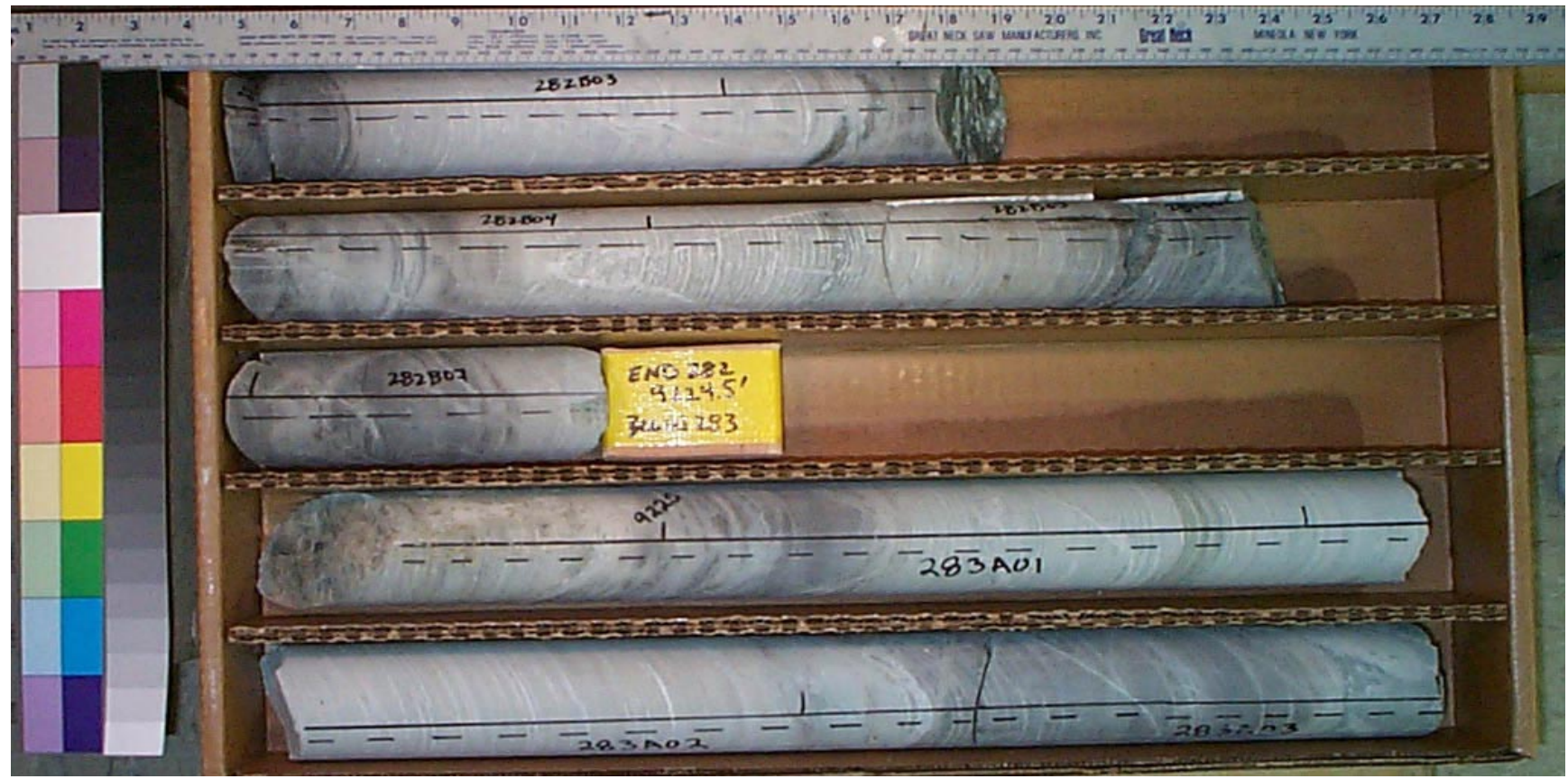

Core Scans included in this box (listed by piece going downhole):

\section{B0300 \\ 282B0400 \\ 282B0700 \\ 283A0100 \\ 283A0200 \\ 283A0300}

See the "reading instructions" section of the introduction for help interpreting core box photos and core piece nomenclature 


\section{LVEW Core Box 407}

Depth Interval 9228.0'-9236.2'

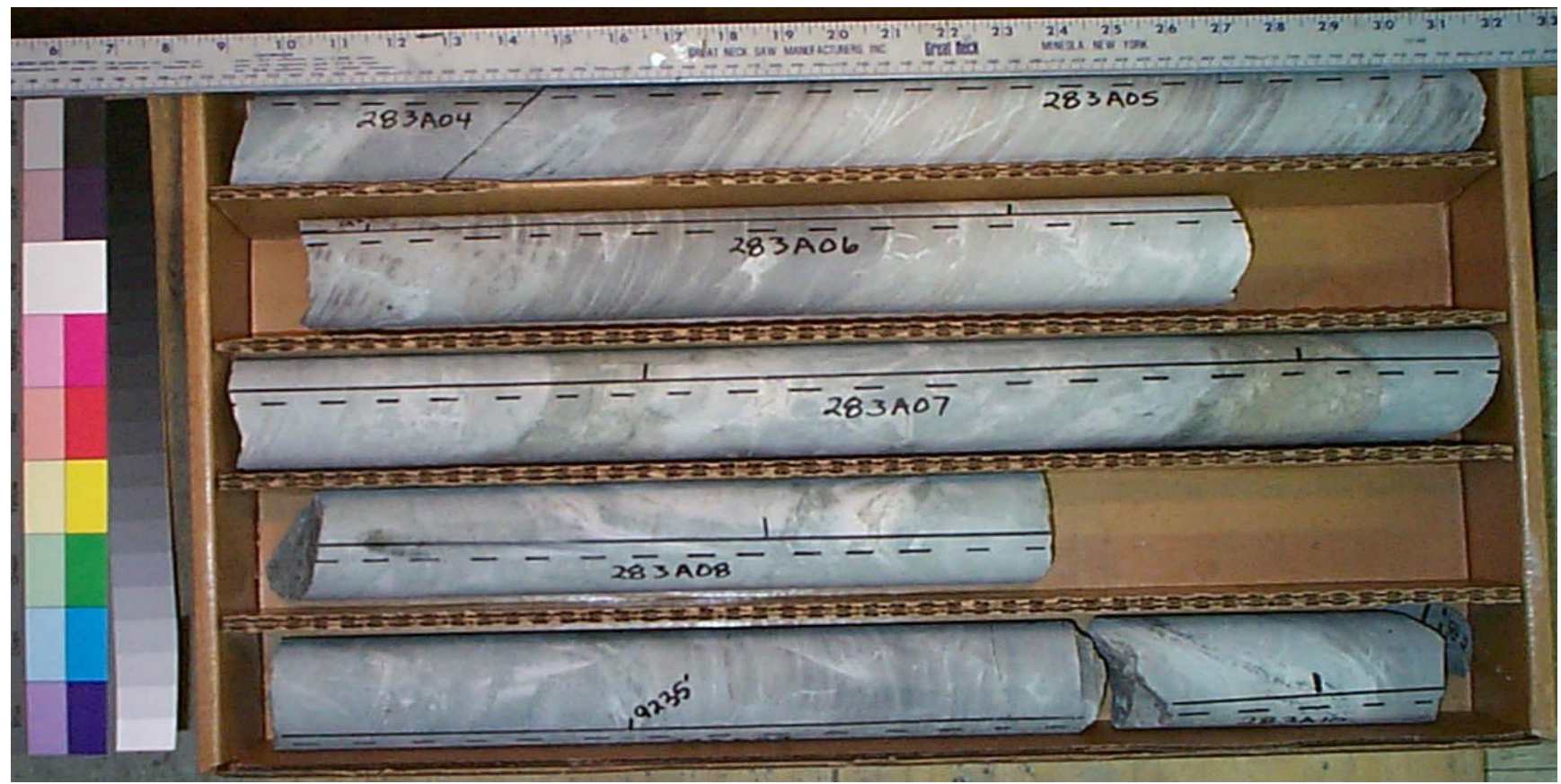

Core Scans included in this box (listed by piece going downhole):
283A0400
283A0500
283A0600
283A0700
283A0800
283A0900
283A1000

See the "reading instructions" section of the introduction for help interpreting core box photos and core piece nomenclature 


\section{LVEW Core Box 408}

Depth Interval 9236.2'-9244.1'

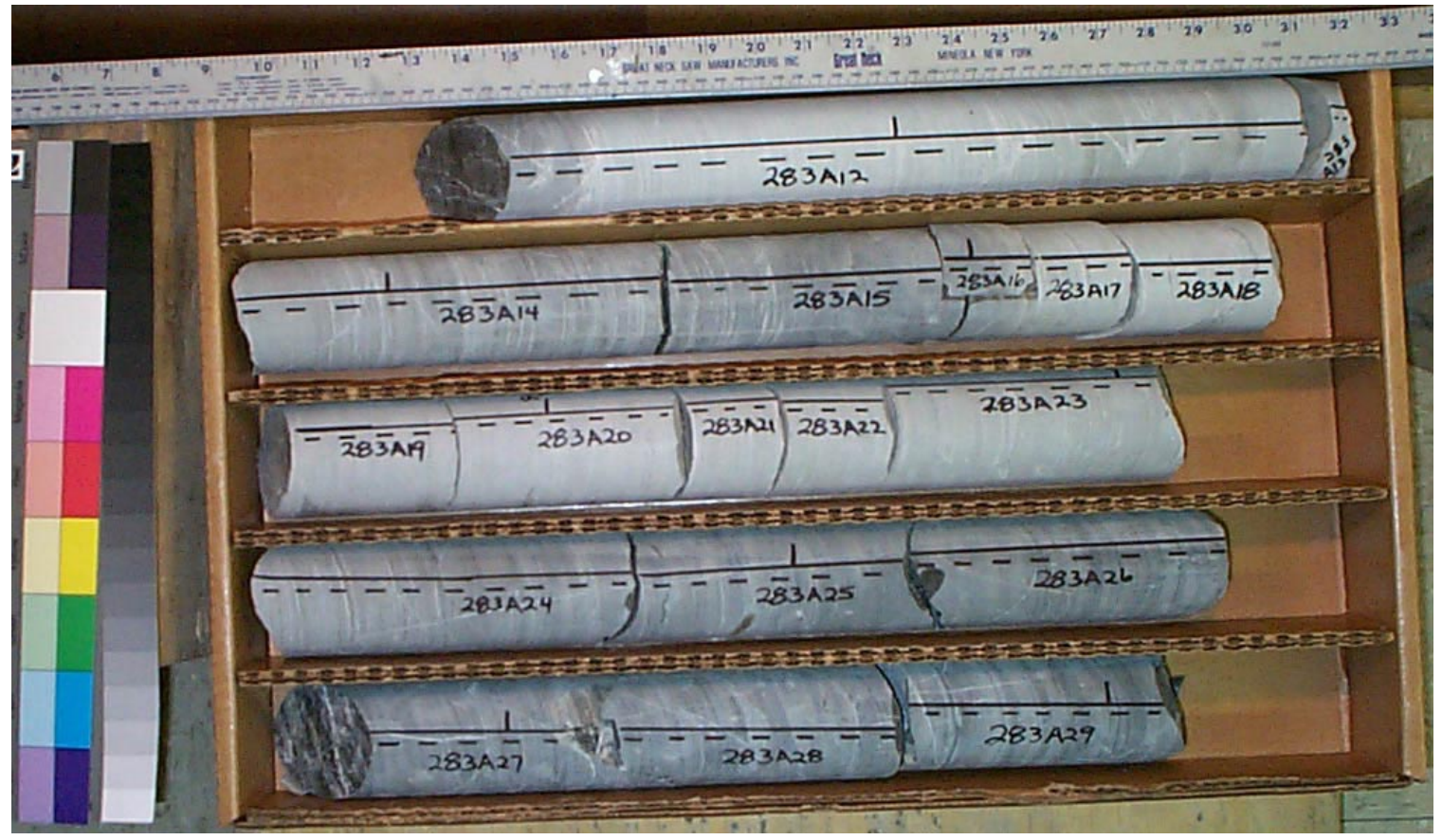

Core Scans included in this box (listed by piece going downhole):

$$
\begin{aligned}
& 283 A 1200 \\
& 283 A 1400 \\
& 283 A 1500 \\
& 283 A 1700 \\
& 283 A 1800 \\
& 283 A 1900 \\
& 283 A 2000 \\
& 283 A 2100
\end{aligned}
$$

283A2200
$283 A 2300$
$283 A 2400$
$283 A 2500$
$283 A 2600$
$283 A 2700$
$283 A 2800$
$283 A 2900$

See the "reading instructions" section of the introduction for help interpreting core box photos and core piece nomenclature 


\section{LVEW Core Box 409}

Depth Interval 9244.1'-9252.2'

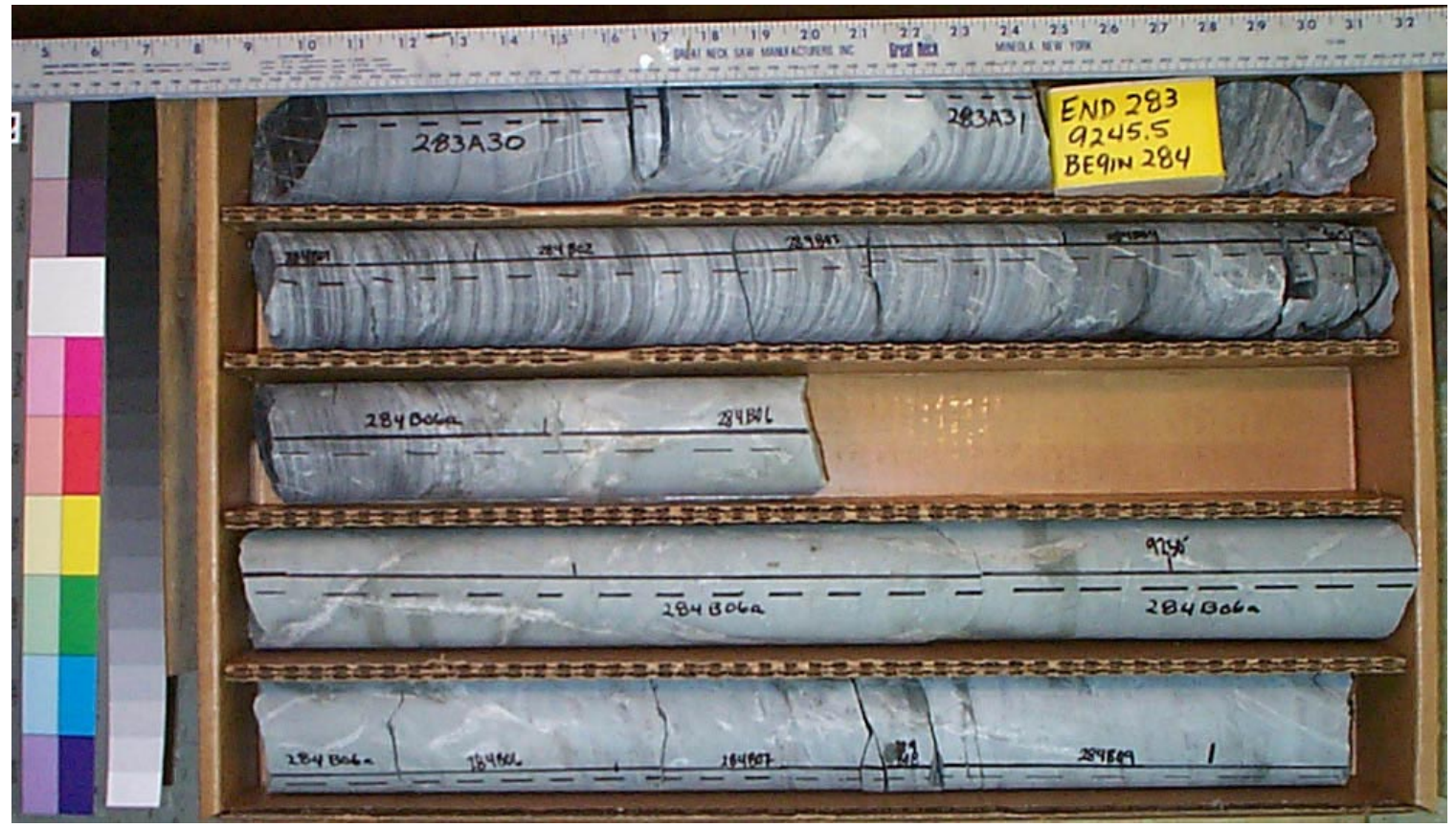

Core Scans included in this box (listed by piece going downhole):
283A3000
283A3100
284B0100
284B0200
284B0300
284B0400
284B061A
284B062A
284B0700
284B0900

See the "reading instructions" section of the introduction for help interpreting core box photos and core piece nomenclature 


\section{LVEW Core Box 410}

Depth Interval 9252.2'-9261.0'

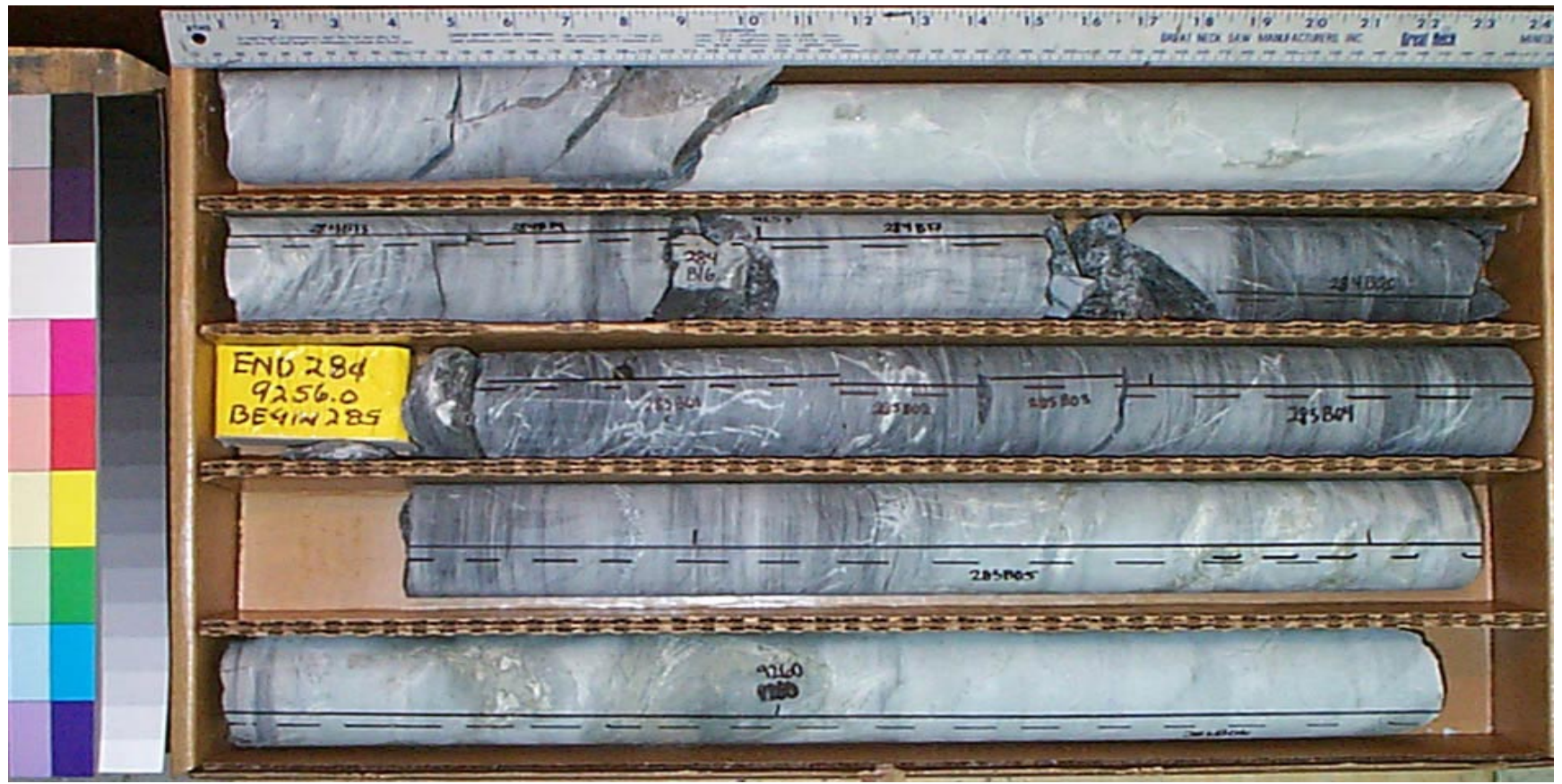

Core Scans included in this box (listed by piece going downhole):
284B100A
284B1100
284B1200
284B 1300
284B1400
284B 1700
284B2000

$285 B 0100$
$285 B 0200$
$285 B 0300$
$285 B 0400$
$285 B 0500$
$285 B 060 A$

See the "reading instructions" section of the introduction for help interpreting core box photos and core piece nomenclature 


\section{LVEW Core Box 411}

\section{Depth Interval 9261.0'-9268.4'}

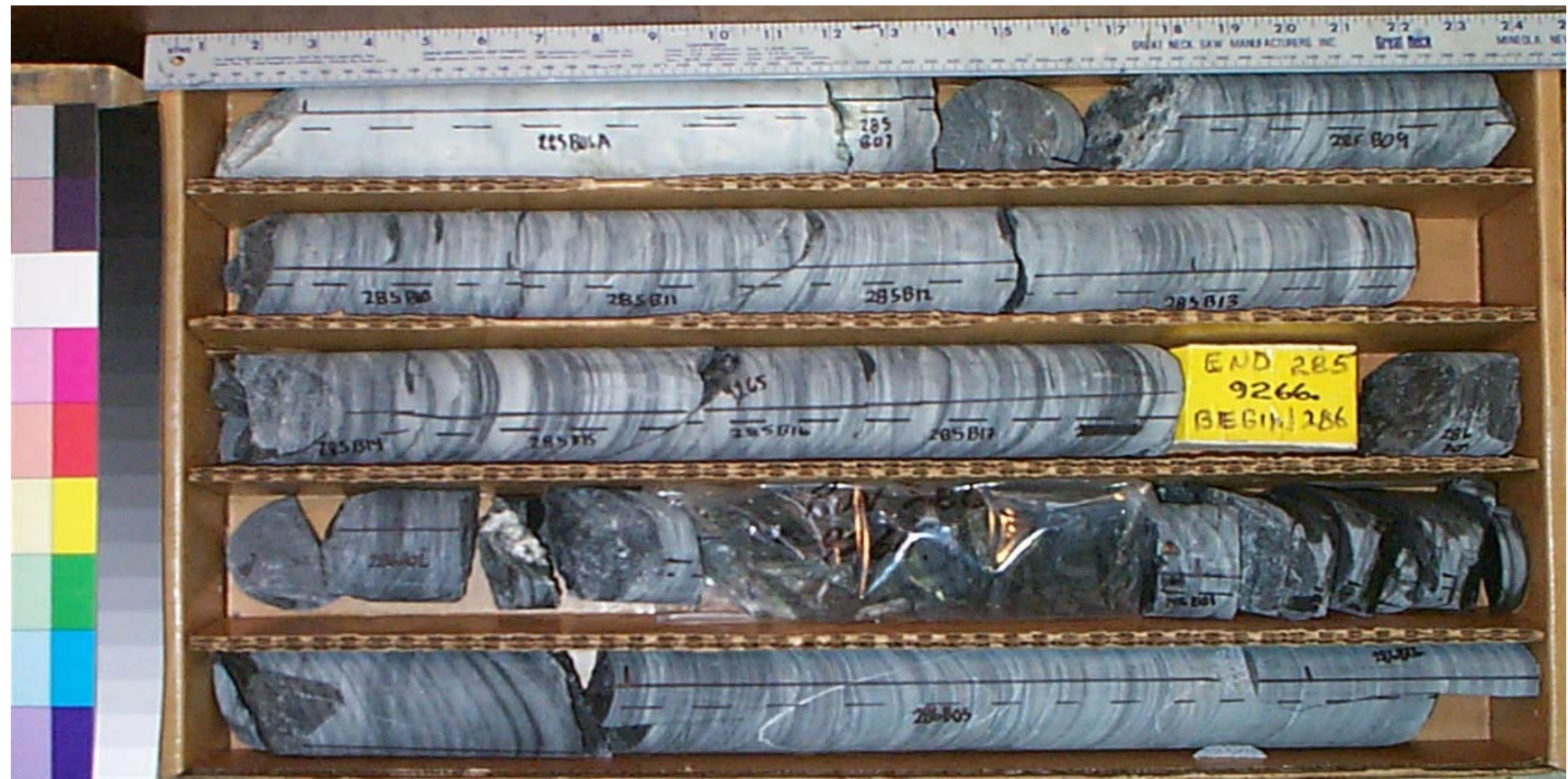

Core Scans included in this box (listed by piece going downhole):
285B060A
285B0700
285B0900
285B1000
285B1100
285B1200
285B1300

285B1400

285B1500

285B1600

285B 1700

286A0200

286B0500

See the "reading instructions" section of the introduction for help interpreting core box photos and core piece nomenclature 


\section{LVEW Core Box 412}

\section{Depth Interval 9268.4'-9277.5'}

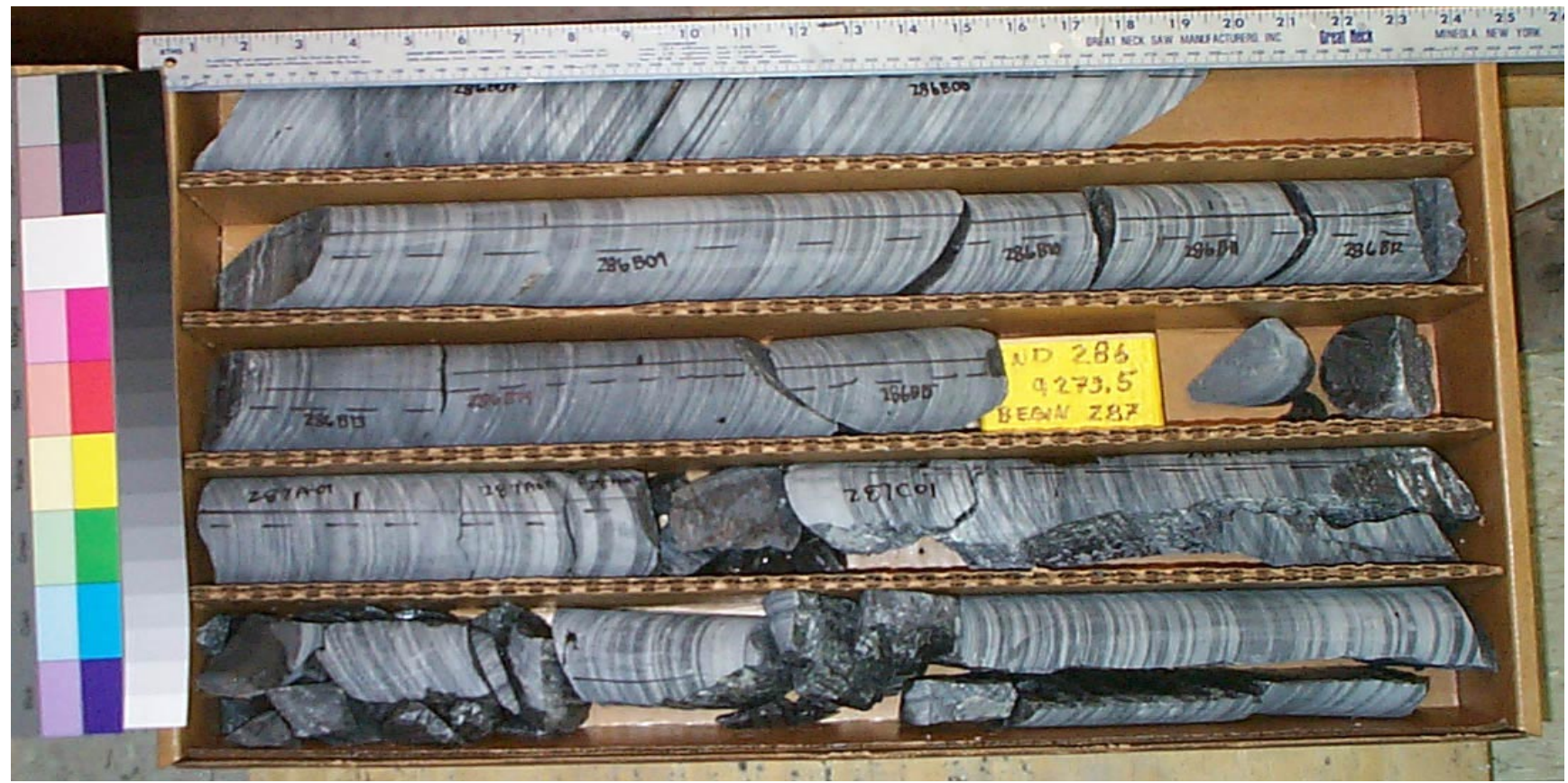

Core Scans included in this box (listed by piece going downhole):
286B0700
286B0800
286B0900
286B1000
286B1100
286B1200
286B1300
286B1400
$287 \mathrm{~A} 0100$
287A0200

See the "reading instructions" section of the introduction for help interpreting core box photos and core piece nomenclature 


\section{LVEW Core Box 413}

Depth Interval 9277.5'-9285.0'

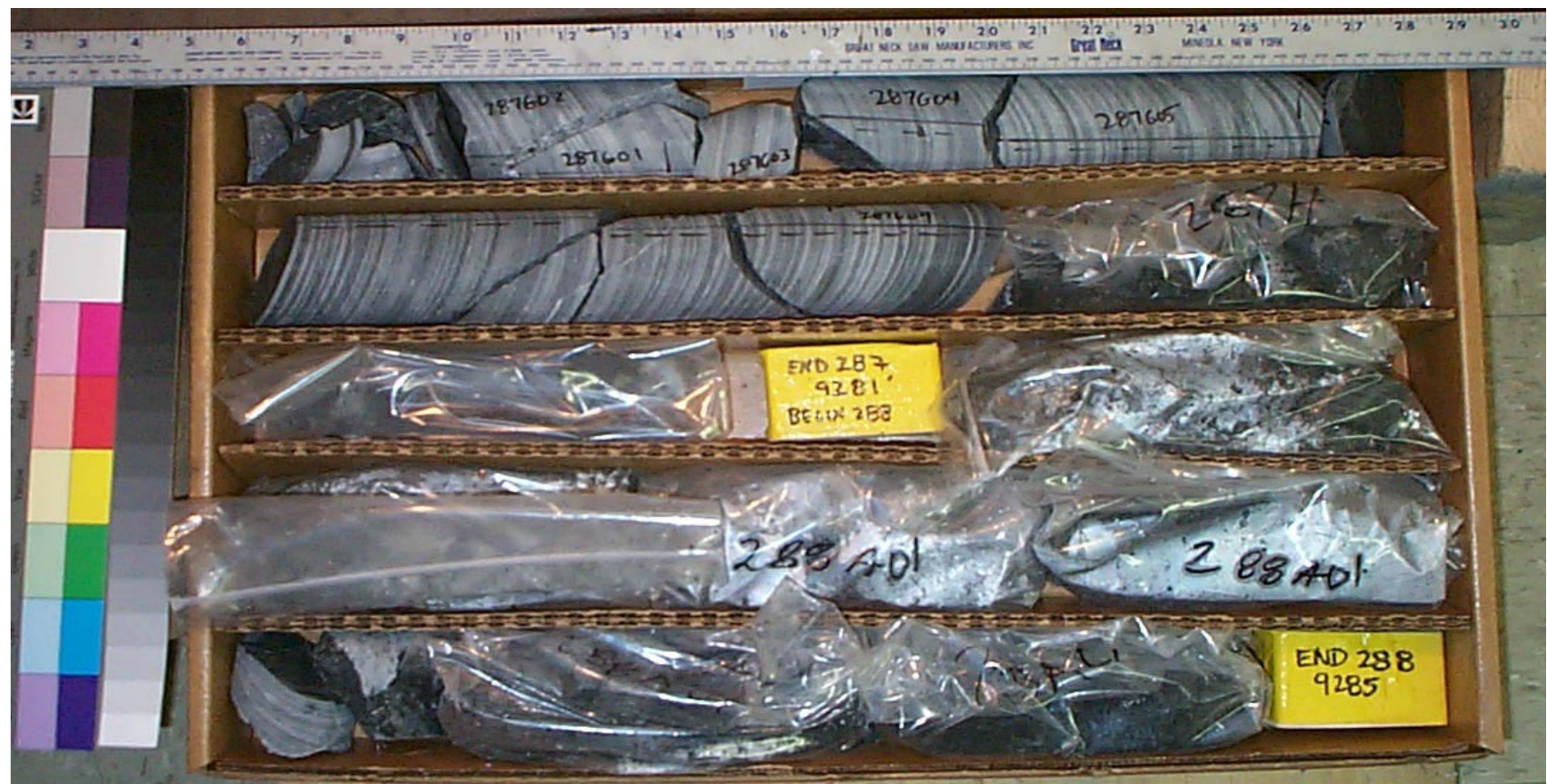

Core Scans included in this box (listed by piece going downhole):
$287 \mathrm{G} 0400$
$287 \mathrm{G} 0500$
287G0700
$287 \mathrm{G} 0800$
287G0900

See the "reading instructions" section of the introduction for help interpreting core box photos and core piece nomenclature 


\section{LVEW Core Box 414}

Depth Interval 9285.0'-9295.0'

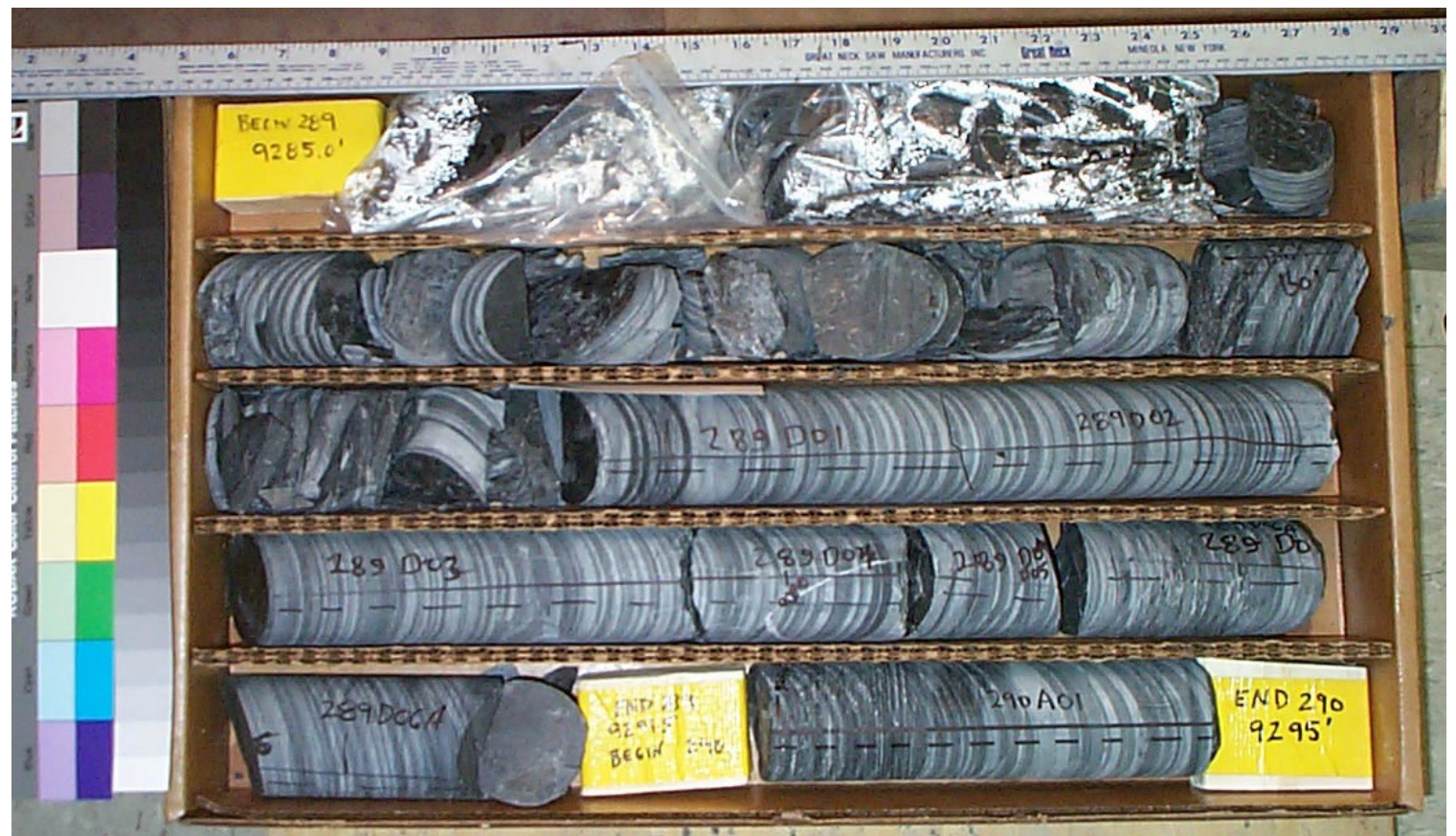

Core Scans included in this box (listed by piece going downhole):
289B0100
289D0100
289D0200
289D0300
289D0400
289D0500
289D0600

See the "reading instructions" section of the introduction for help interpreting core box photos and core piece nomenclature 


\section{LVEW Core Box 415}

Depth Interval 9295.0'-9302.8'

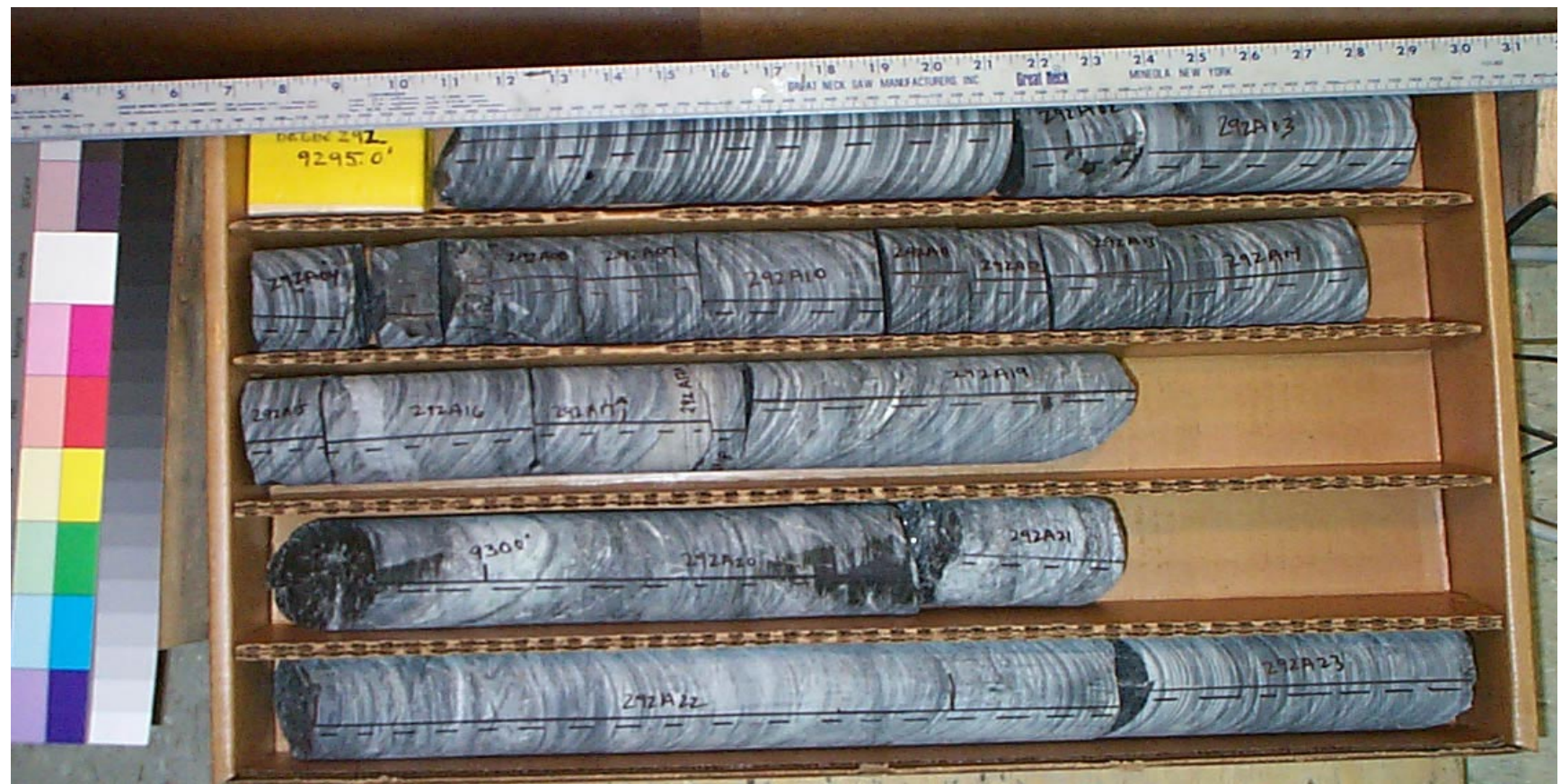

Core Scans included in this box (listed by piece going downhole):

291A0100
$292 A 0100$
$292 A 0300$
$292 A 0400$
$292 A 0700$
$292 A 0900$
$292 A 1000$
$292 A 1100$
$292 A 1200$
$292 A 1300$

292A1400

292A1500

292A 1600

292A1700

292A1900

292A2000

292A2100

292A2200

292A2300

See the "reading instructions" section of the introduction for help interpreting core box photos and core piece nomenclature 


\section{LVEW Core Box 416}

Depth Interval 9302.8'-9308.2'

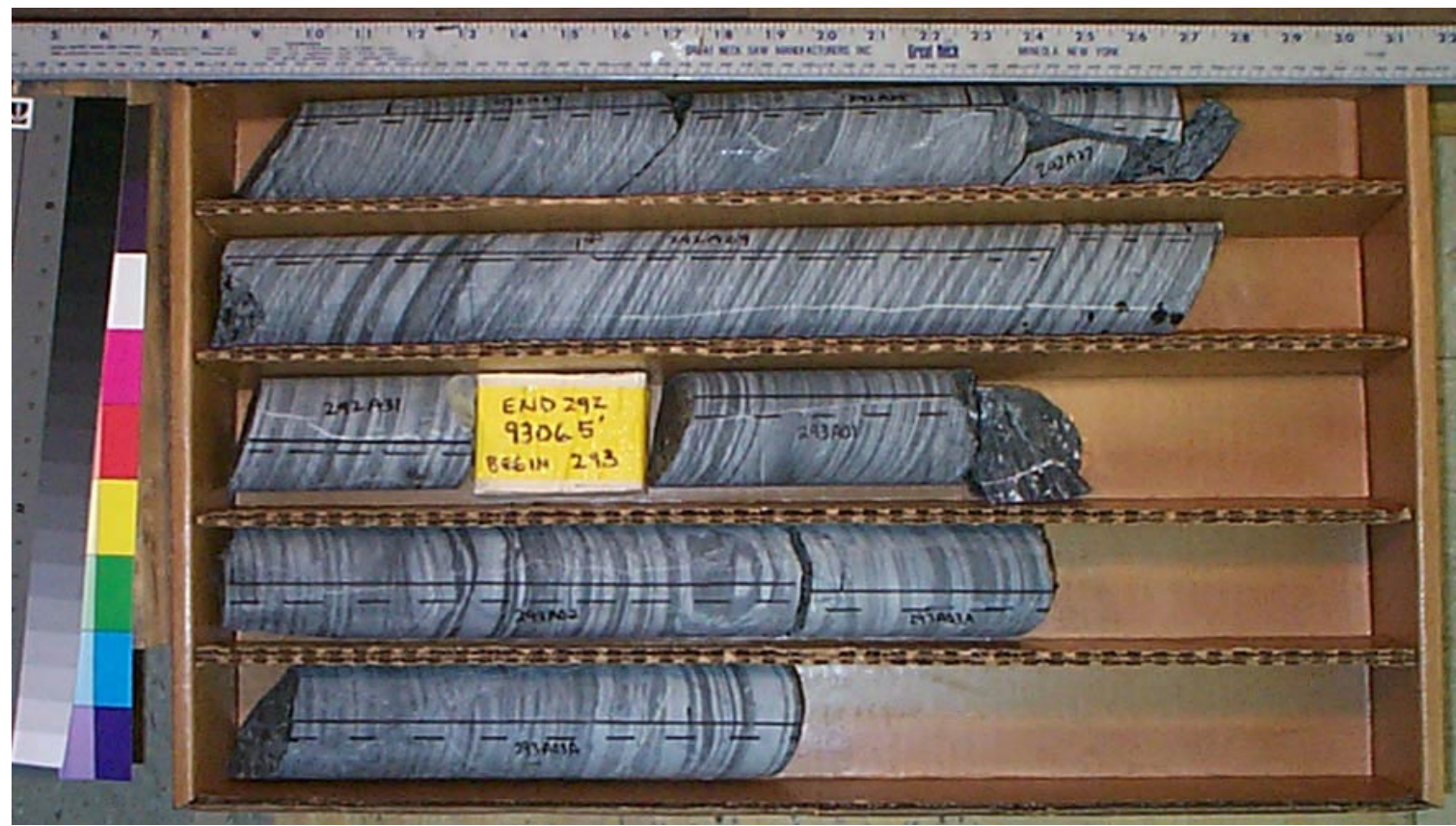

Core Scans included in this box (listed by piece going downhole):
292A2400
292A2500
292A2900
292A3000
292A3100
293A0100
293A0200
293A030A

See the "reading instructions" section of the introduction for help interpreting core box photos and core piece nomenclature 


\section{LVEW Core Box 417}

Depth Interval 9308.2'-9317.2'

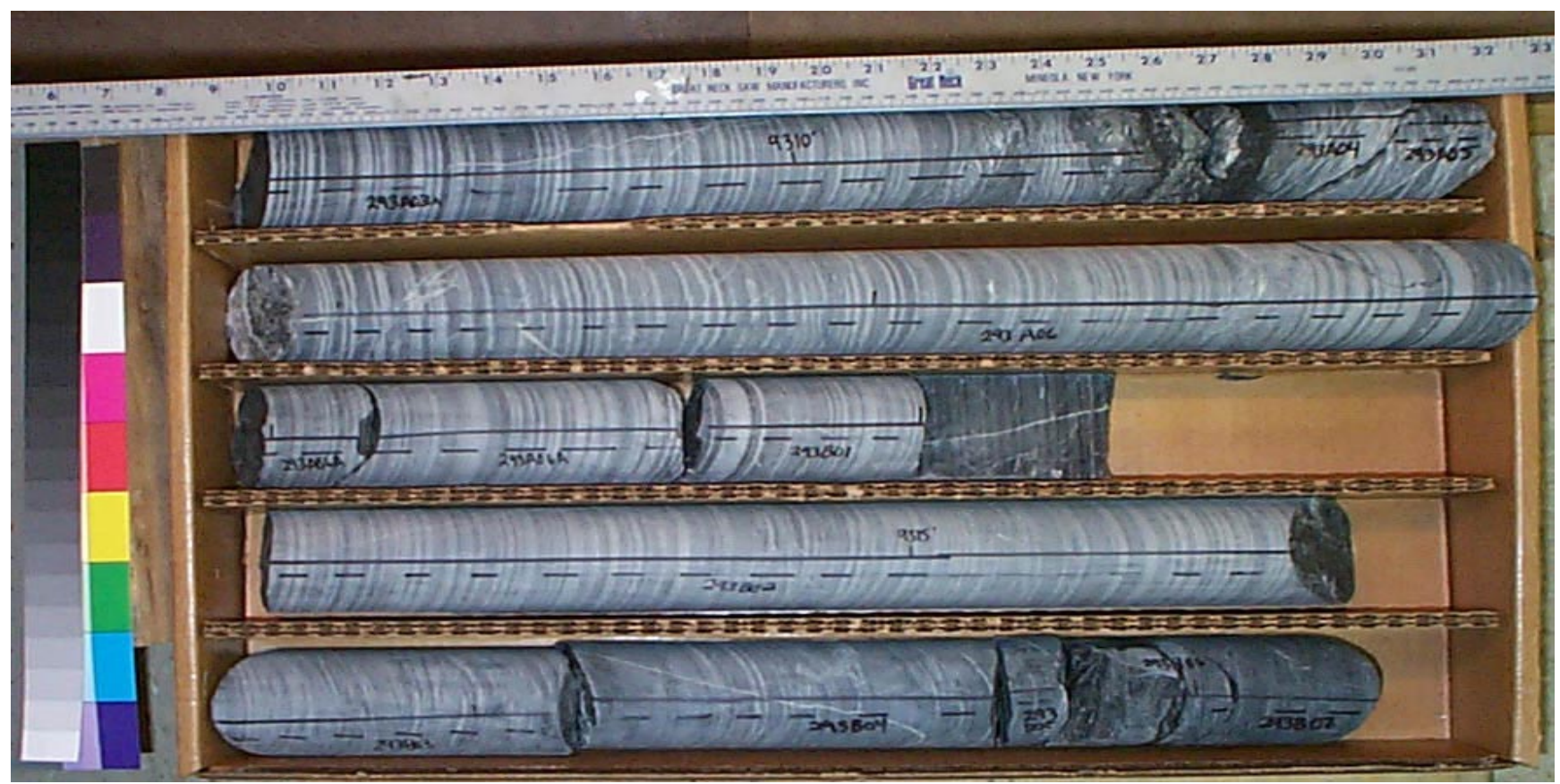

Core Scans included in this box (listed by piece going downhole):
293A030A
293A0600
293B0100
293B0300
293B0400
293B0700

See the "reading instructions" section of the introduction for help interpreting core box photos and core piece nomenclature 


\section{LVEW Core Box 418}

Depth Interval 9317.2'-9324.6'

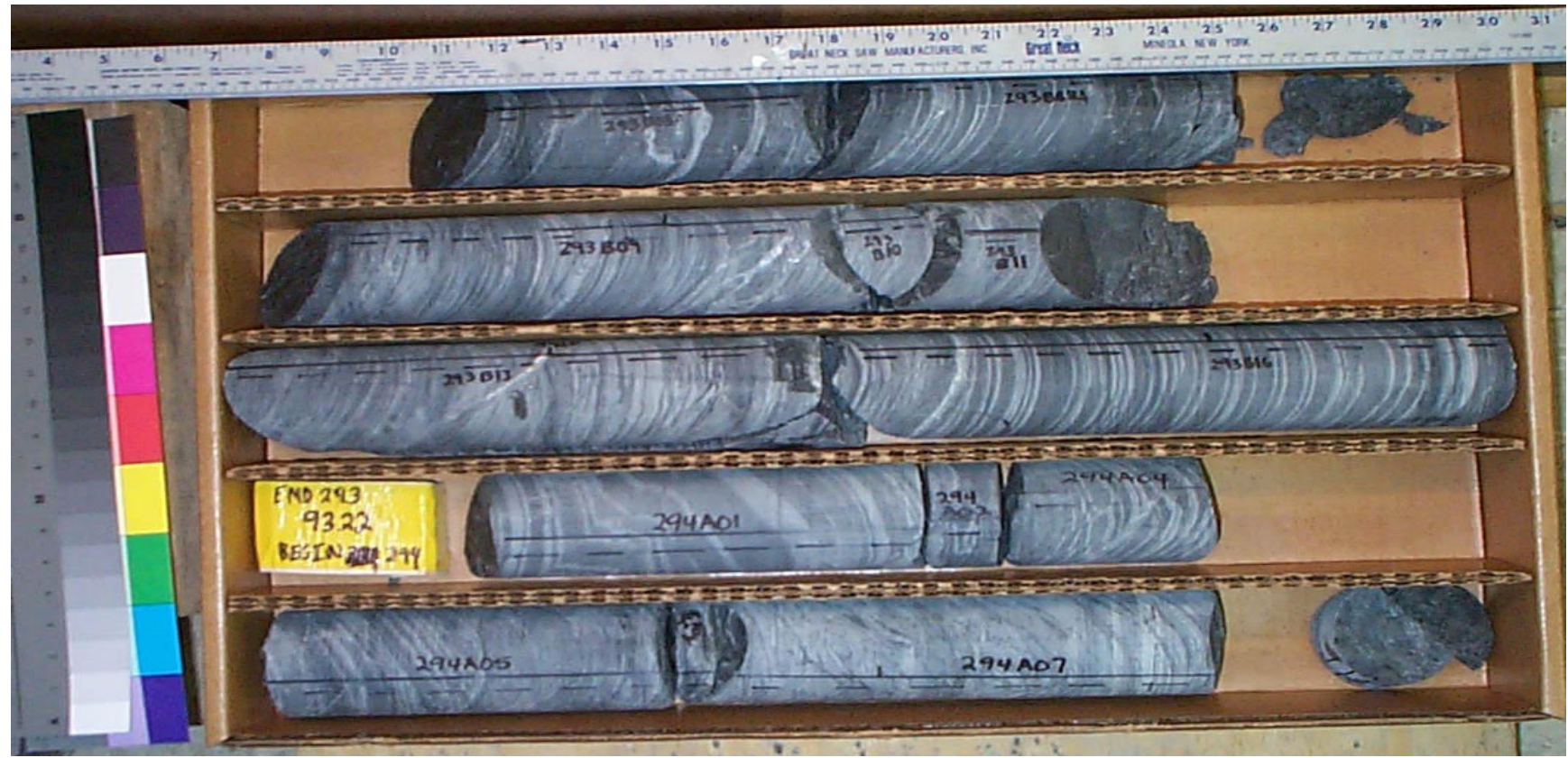

Core Scans included in this box (listed by piece going downhole):

\section{B0800 \\ 293B0900 \\ 293B1600 \\ 294A0100 \\ 294A0400 \\ 294A0500 \\ 294A0700}

See the "reading instructions" section of the introduction for help interpreting core box photos and core piece nomenclature 


\section{LVEW Core Box 419}

Depth Interval 9324.6'-9333.0'

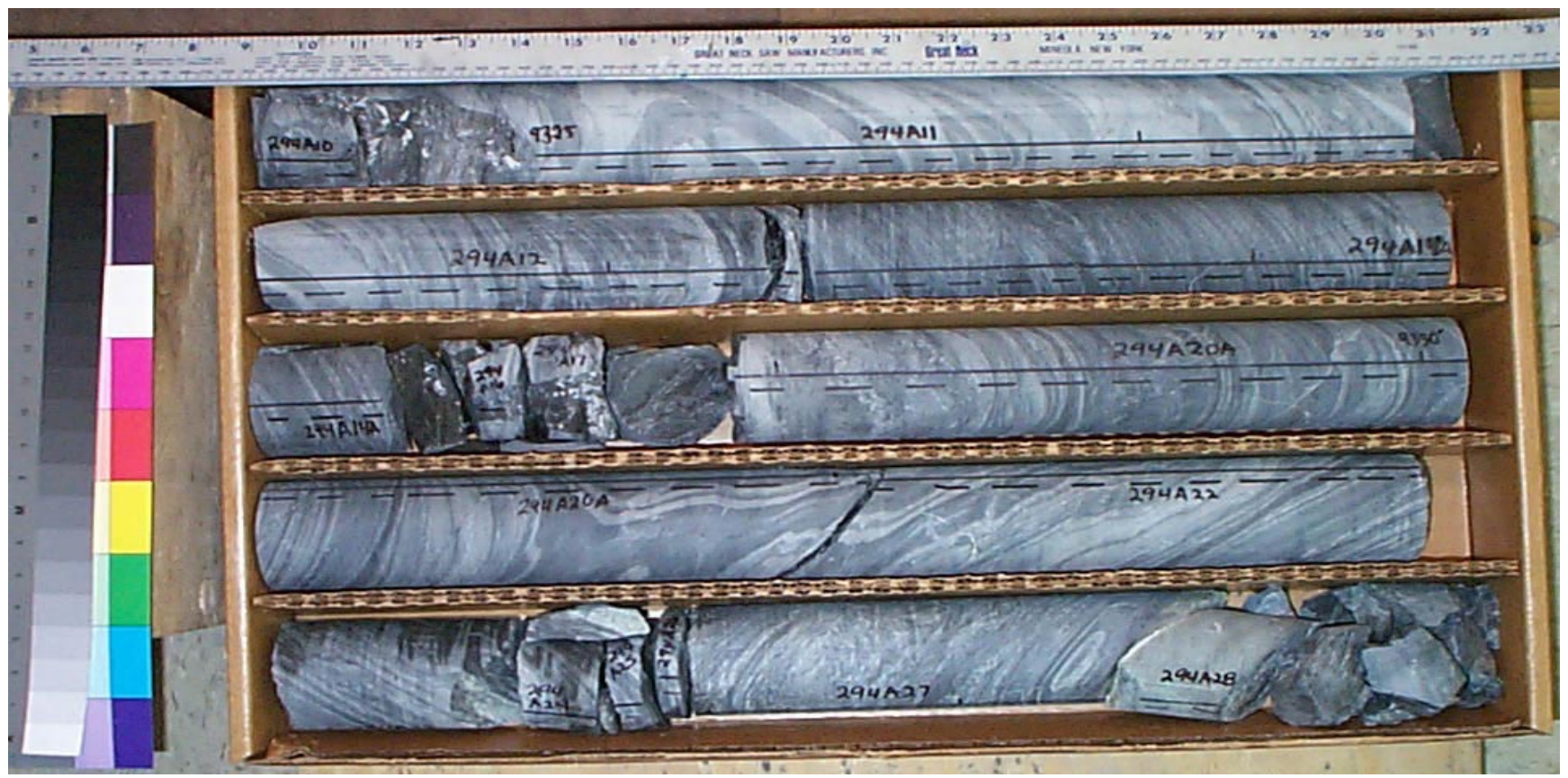

Core Scans included in this box (listed by piece going downhole):
294A1100
294A1200
294A1900
294A201A
294A202A
294A2300
294A2700

See the "reading instructions" section of the introduction for help interpreting core box photos and core piece nomenclature 


\section{LVEW Core Box 420}

\section{Depth Interval 9333.0'-9314.6'}

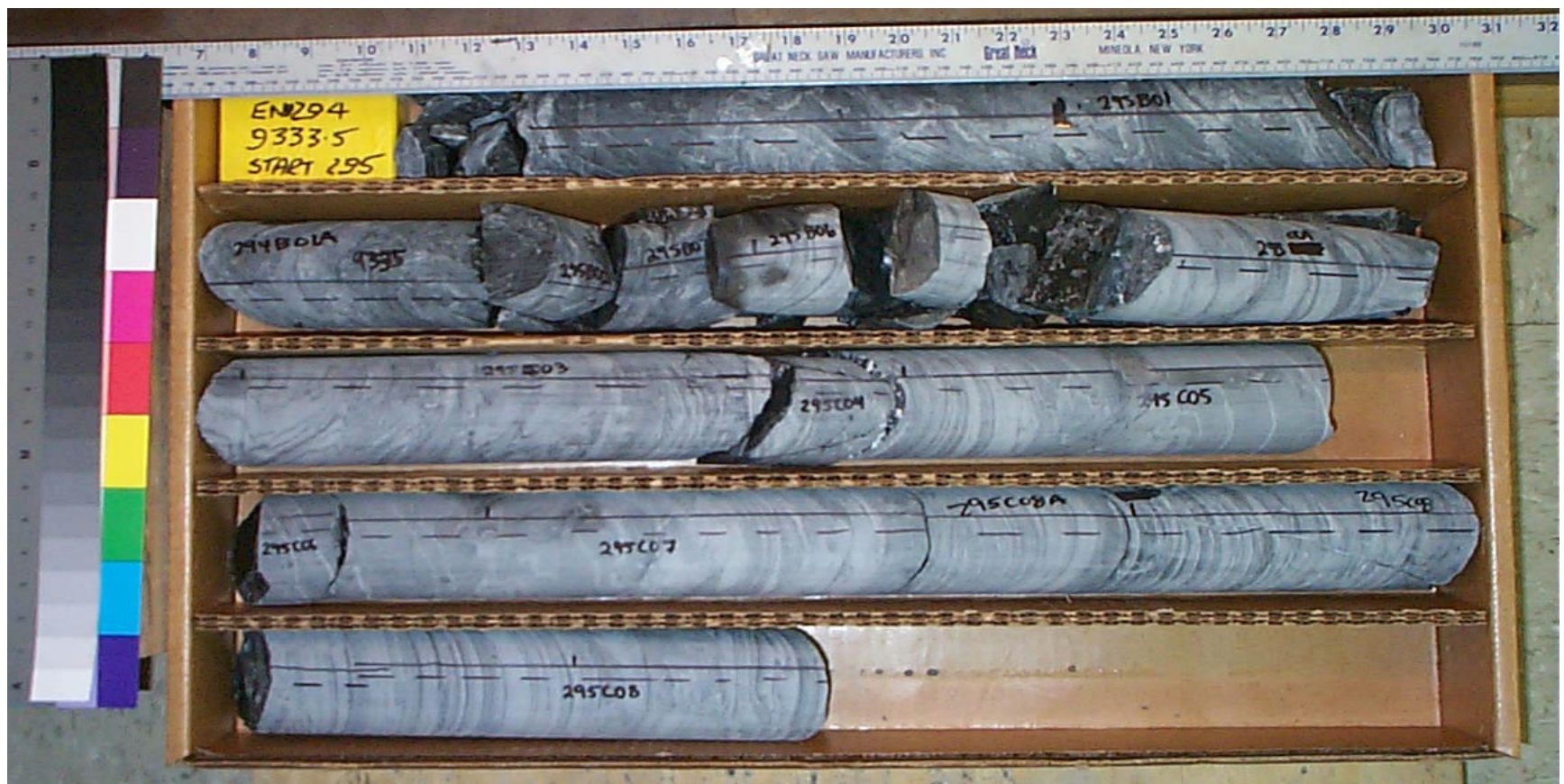

Core Scans included in this box (listed by piece going downhole):

295B010A

295B0400

295C0300

295C0500

295C0600

295C0700 295C081A

See the "reading instructions" section of the introduction for help interpreting core box photos and core piece nomenclature 


\section{LVEW Core Box 421}

\section{Depth Interval 9341.6'-9350.0'}

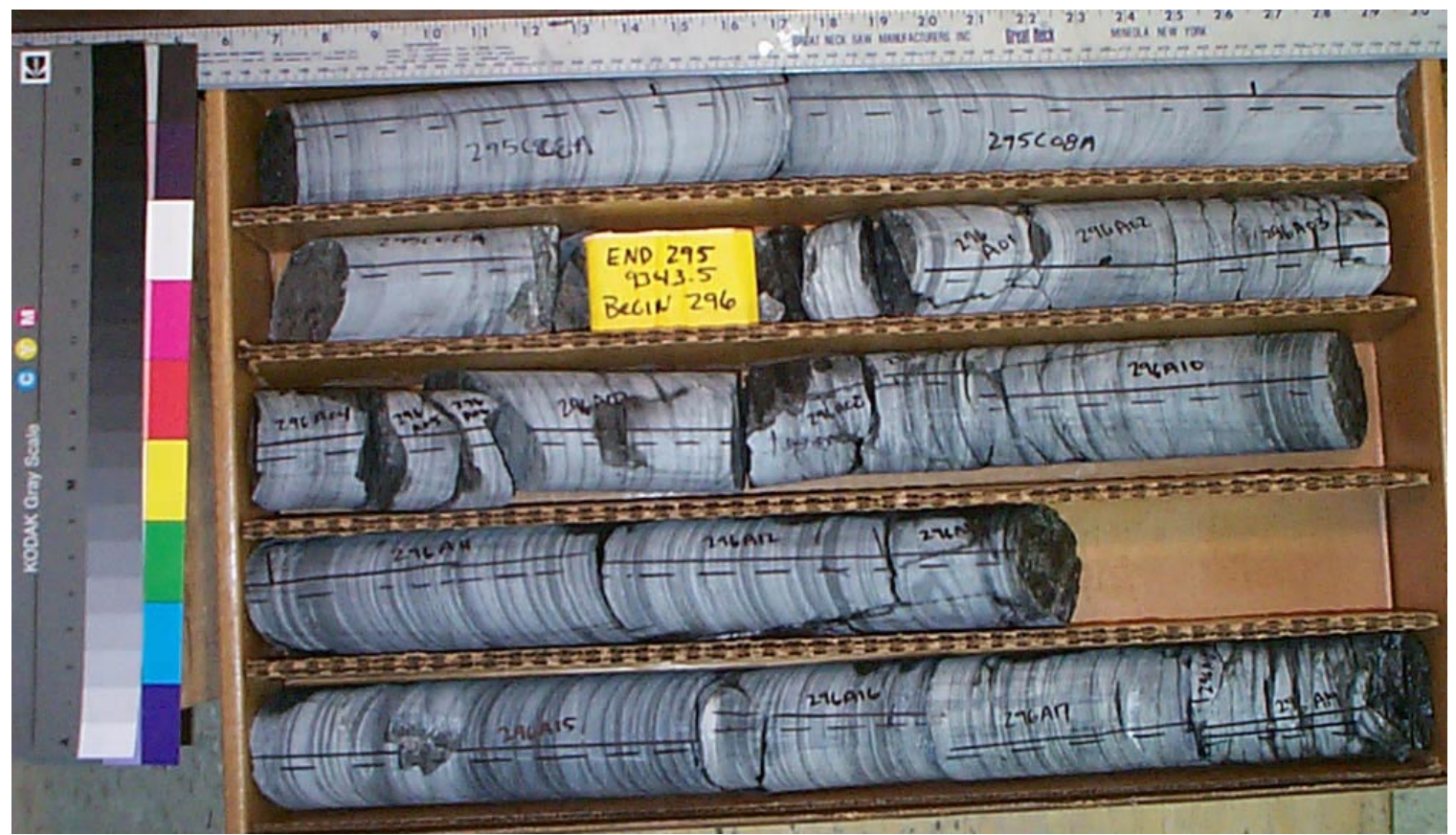

Core Scans included in this box (listed by piece going downhole):

295C082A
$296 A 0100$
$296 A 0200$
$296 A 0300$
$296 A 0400$
$296 A 0700$
$296 A 0800$
$296 A 0900$

296A1000

296A1100

296A1400

296A1500

296A 1600

296A1700

296A1900

See the "reading instructions" section of the introduction for help interpreting core box photos and core piece nomenclature 


\section{LVEW Core Box 422}

Depth Interval 9350.0'-9357.4'

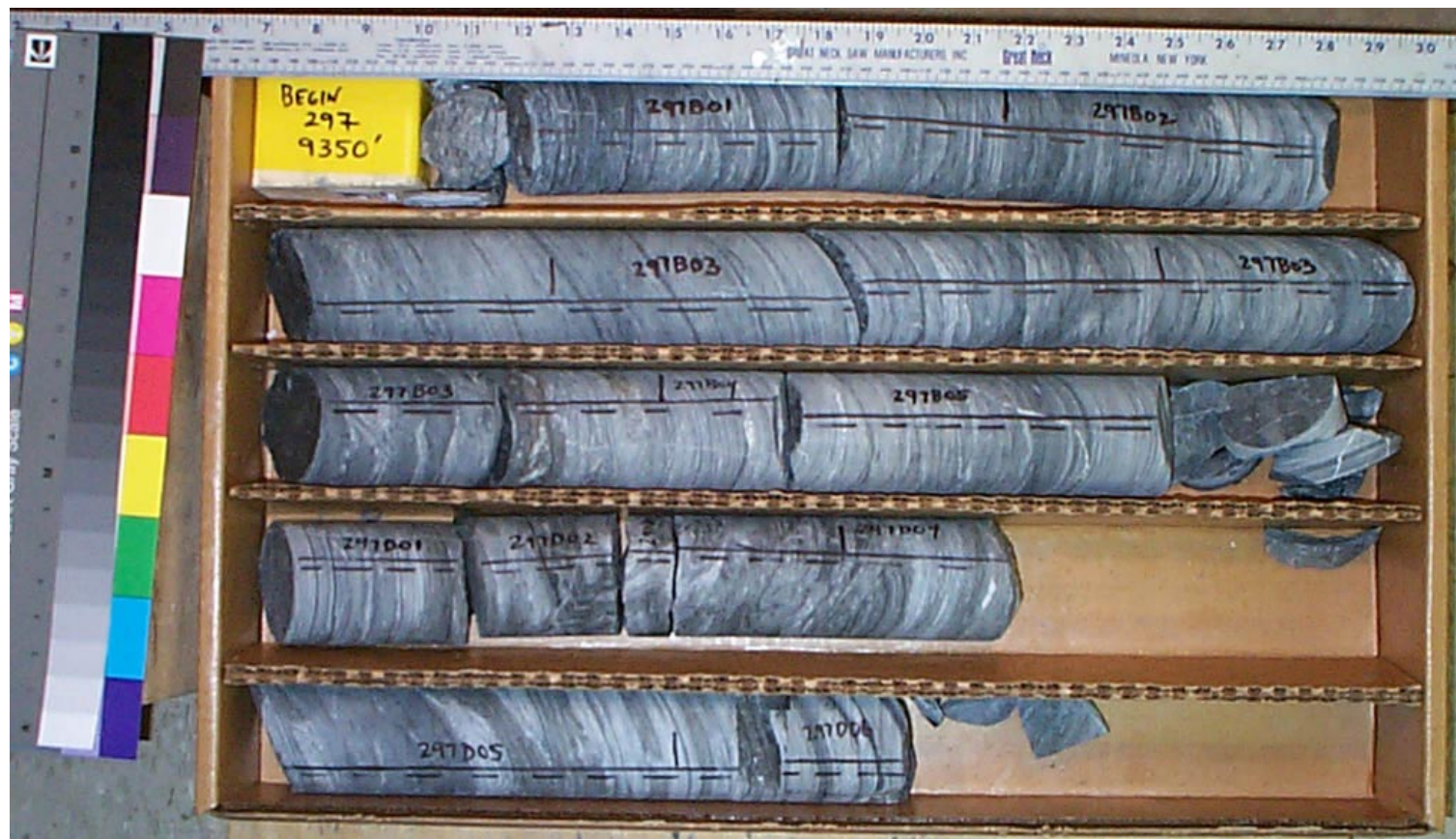

Core Scans included in this box (listed by piece going downhole):
297B0100
297B0200
297B030A
297B0400
297B0500
297D0100
297D0200
297D0300
297D0400
297D0500
297D0600

See the "reading instructions" section of the introduction for help interpreting core box photos and core piece nomenclature 


\section{LVEW Core Box 423}

Depth Interval 9357.4'-9366.3'

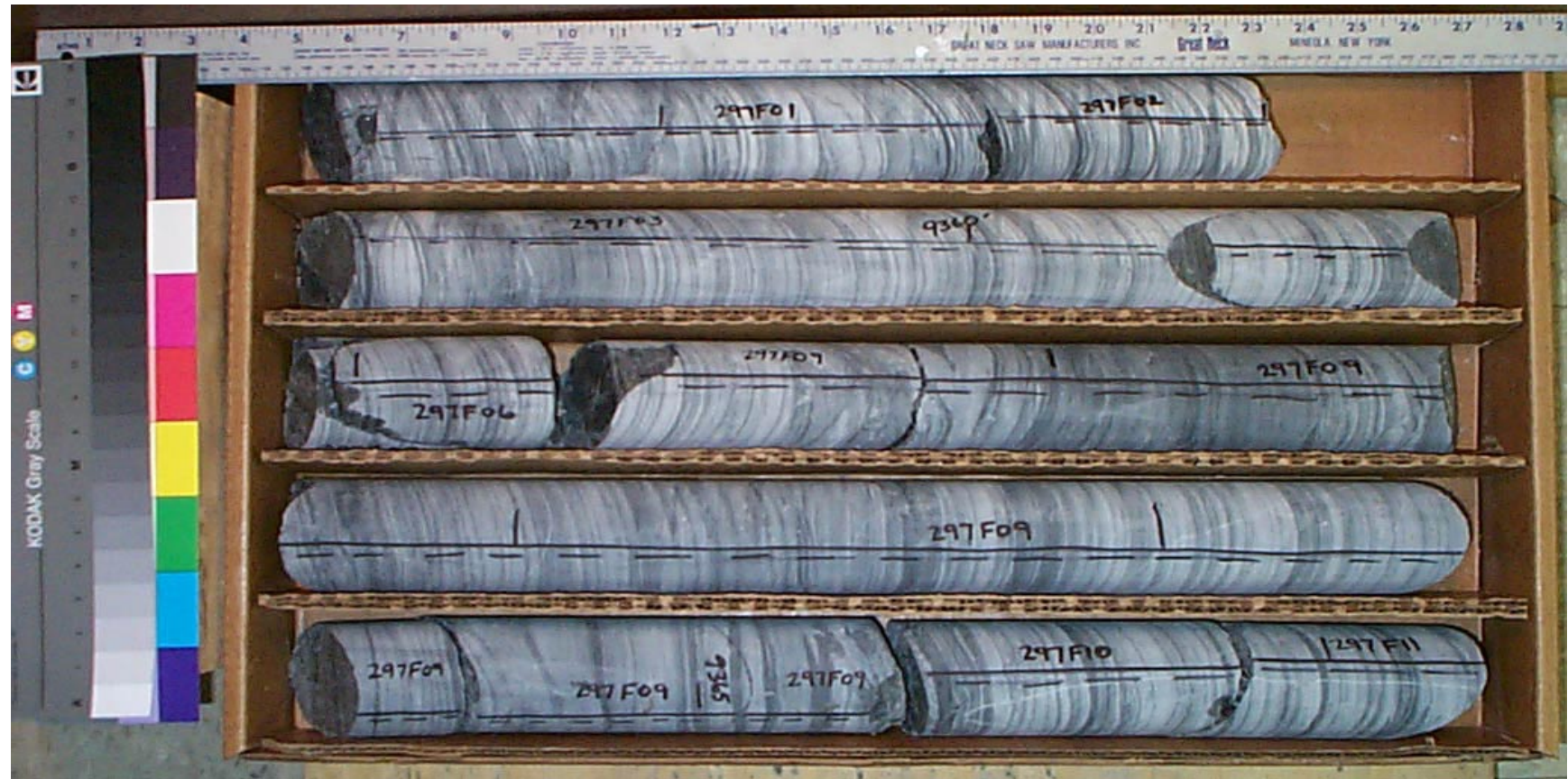

Core Scans included in this box (listed by piece going downhole):
297F0100
297F0200
297F0300
297F091A
297F092A
297F1000
297F1100

See the "reading instructions" section of the introduction for help interpreting core box photos and core piece nomenclature 


\section{LVEW Core Box 424}

Depth Interval 9366.3'-9374.3'

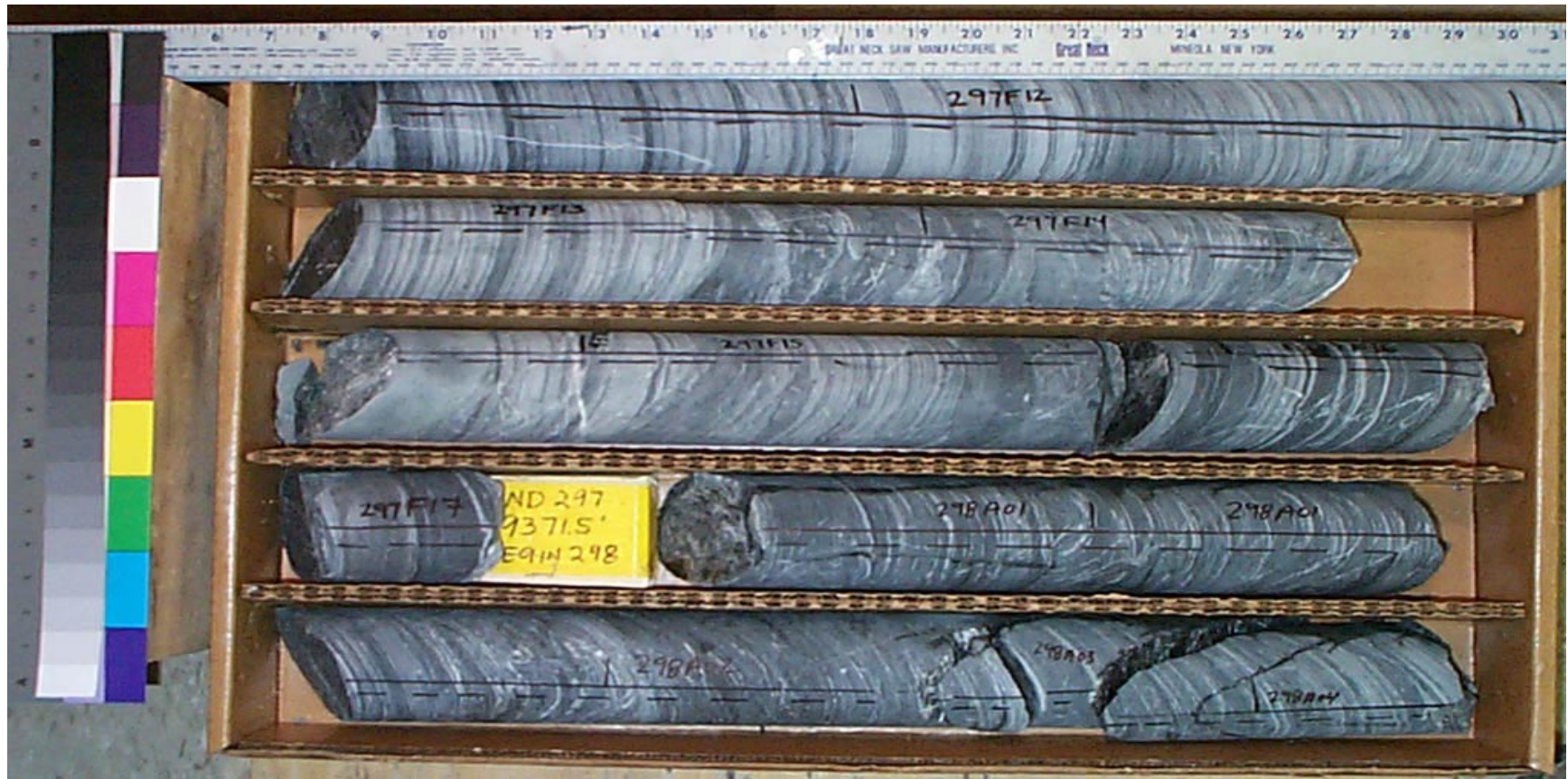

Core Scans included in this box (listed by piece going downhole):
297F1200
297F1300
297F1400
297F1500
297F1600
297F1700
298A0100
298A0200

See the "reading instructions" section of the introduction for help interpreting core box photos and core piece nomenclature 


\section{LVEW Core Box 425}

Depth Interval 9374.3'-9381.2'

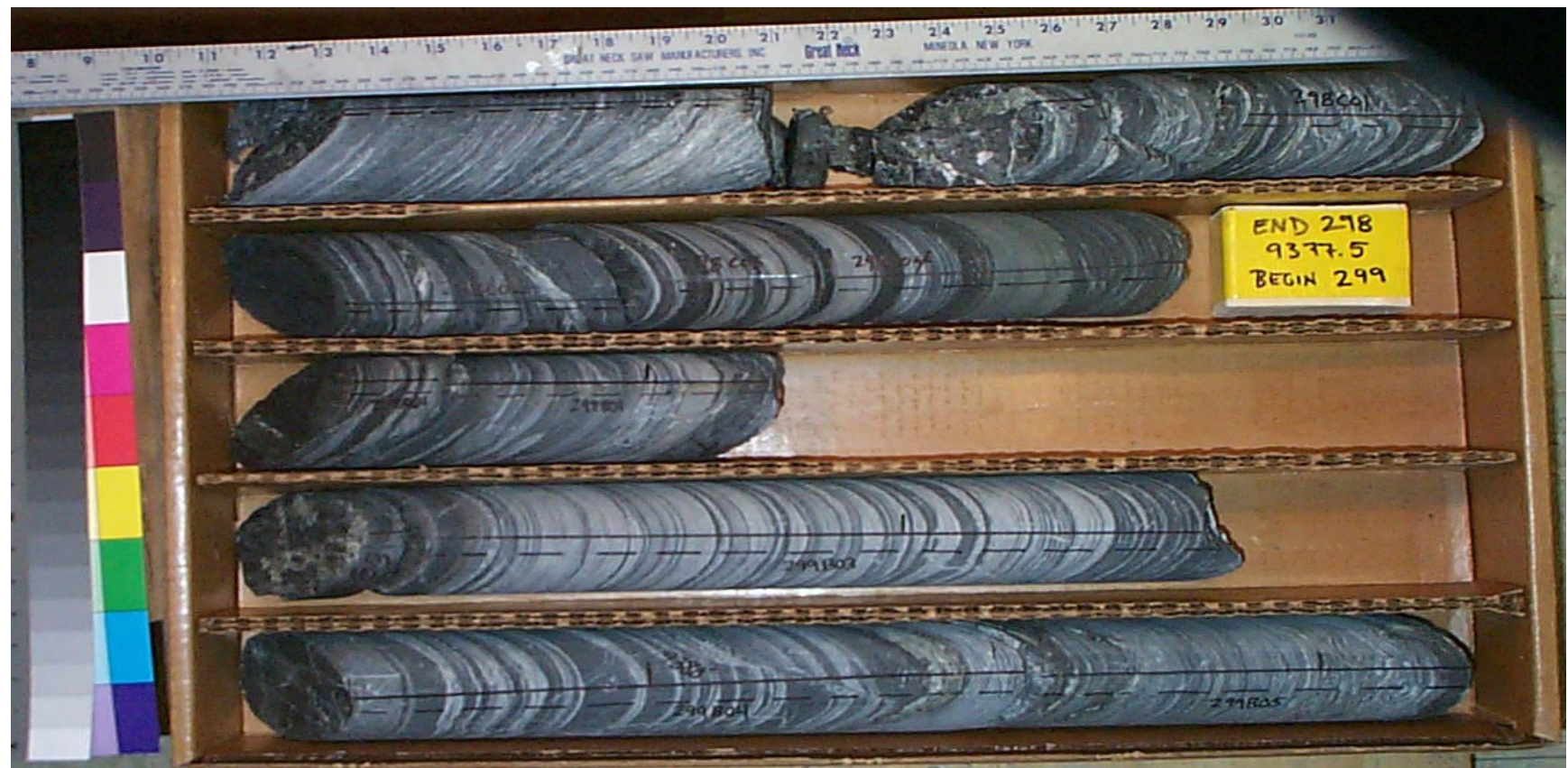

Core Scans included in this box (listed by piece going downhole):
298B0100
298B0200
298C0100
298C0200
298C0300
298C0400
299B0100
299B0300
299B0400
299B0500

See the "reading instructions" section of the introduction for help interpreting core box photos and core piece nomenclature 


\section{Stratigraphic Column for LVEW Phase III, page 6}

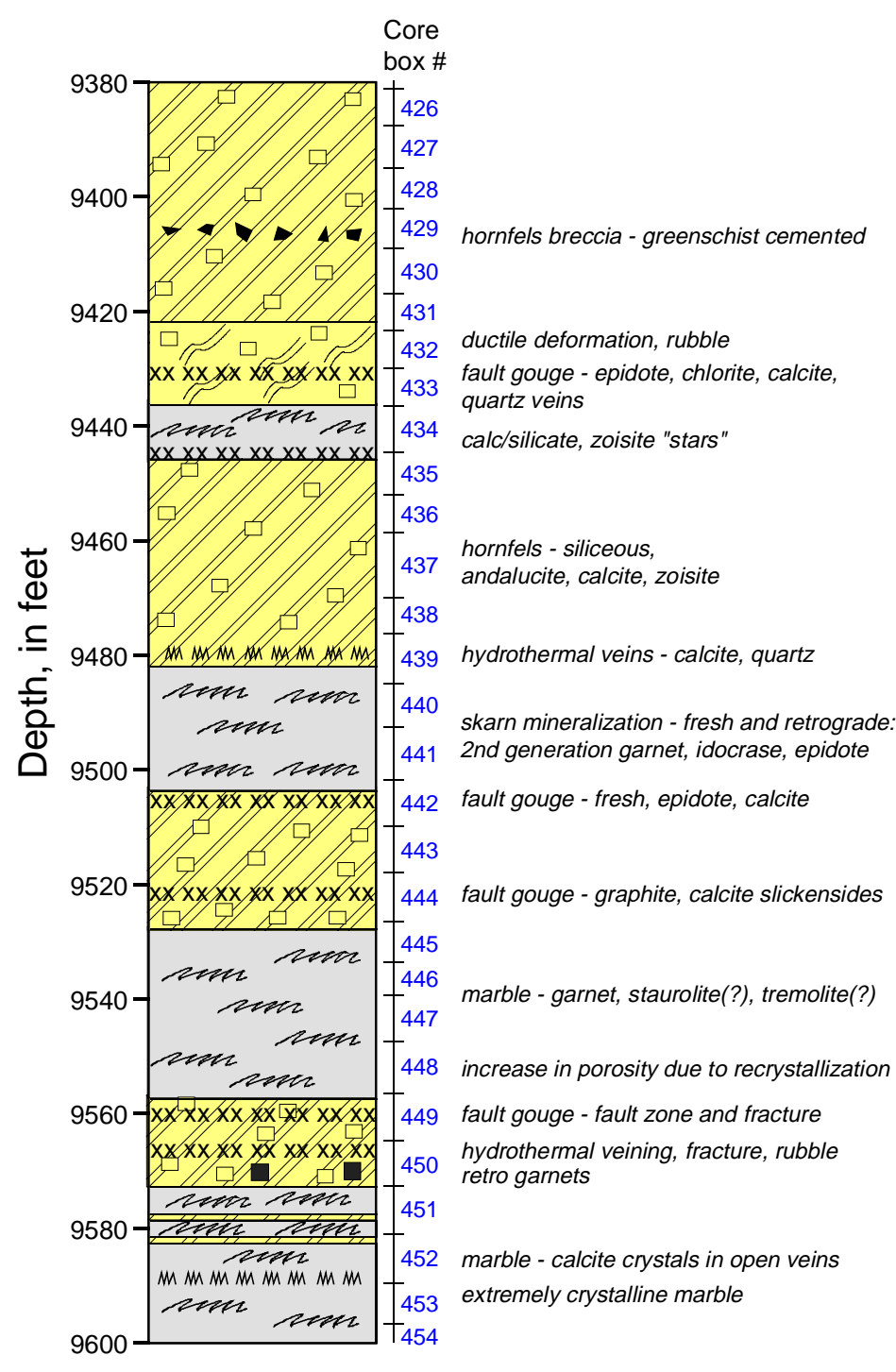

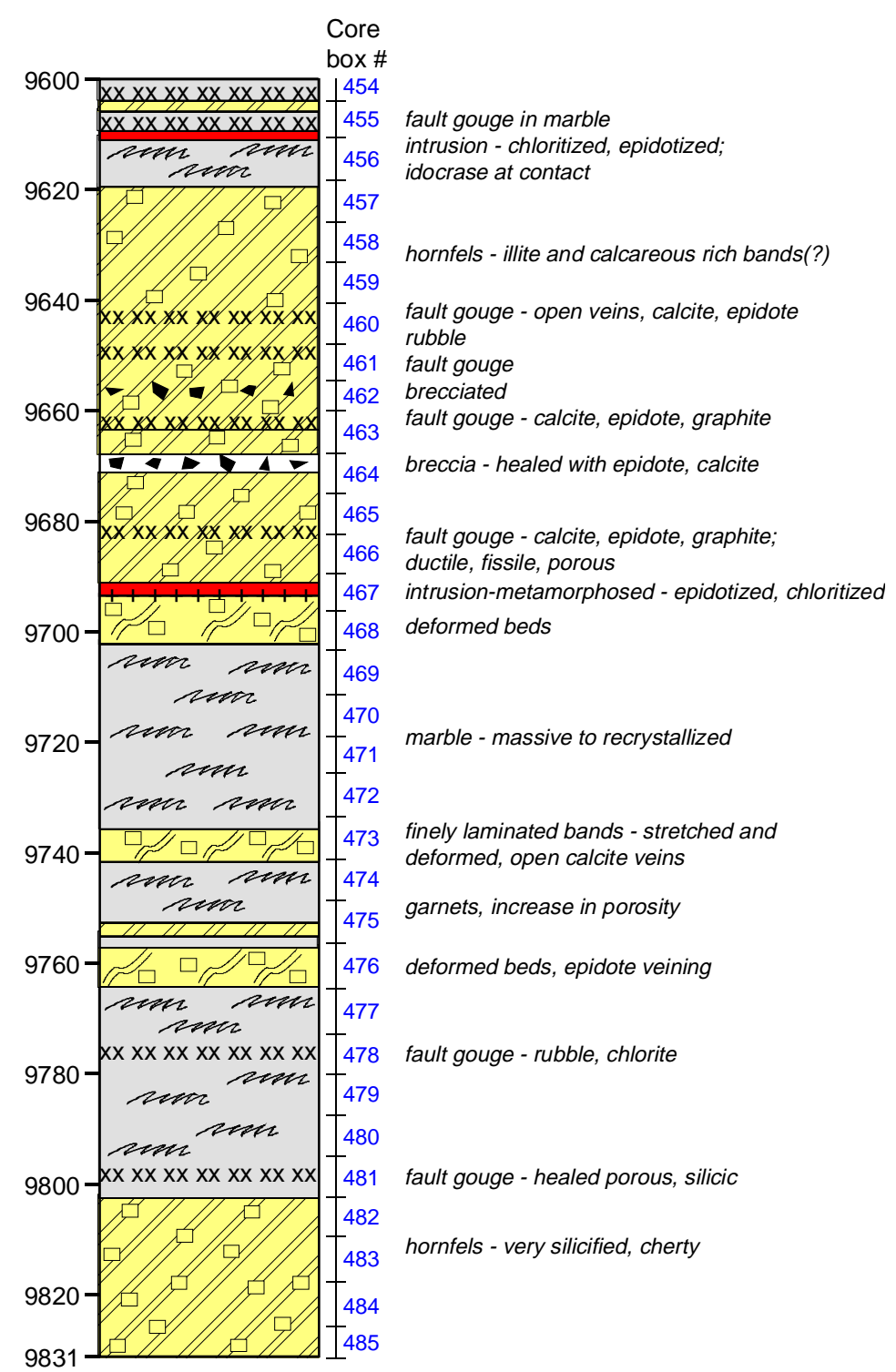

stratigraphy by Vicki McConnell 1-99

\section{Explanation}

Metapelite with banding

Hornfels

Metapelite with ductile deformation
Metapelite no banding

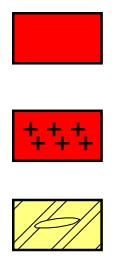

Intrusion

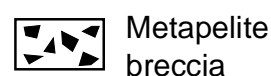

Quartzite

rant Calc-silicate
Intrusionmetamorphosed

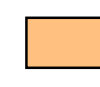

Sandstone deformation
M M M Hydrothermal veins/fractures

$x x x x$ Fault gouge

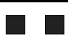

2nd generation garnets 


\section{LVEW Core Box 426}

Depth Interval 9381.3'-9387.8'

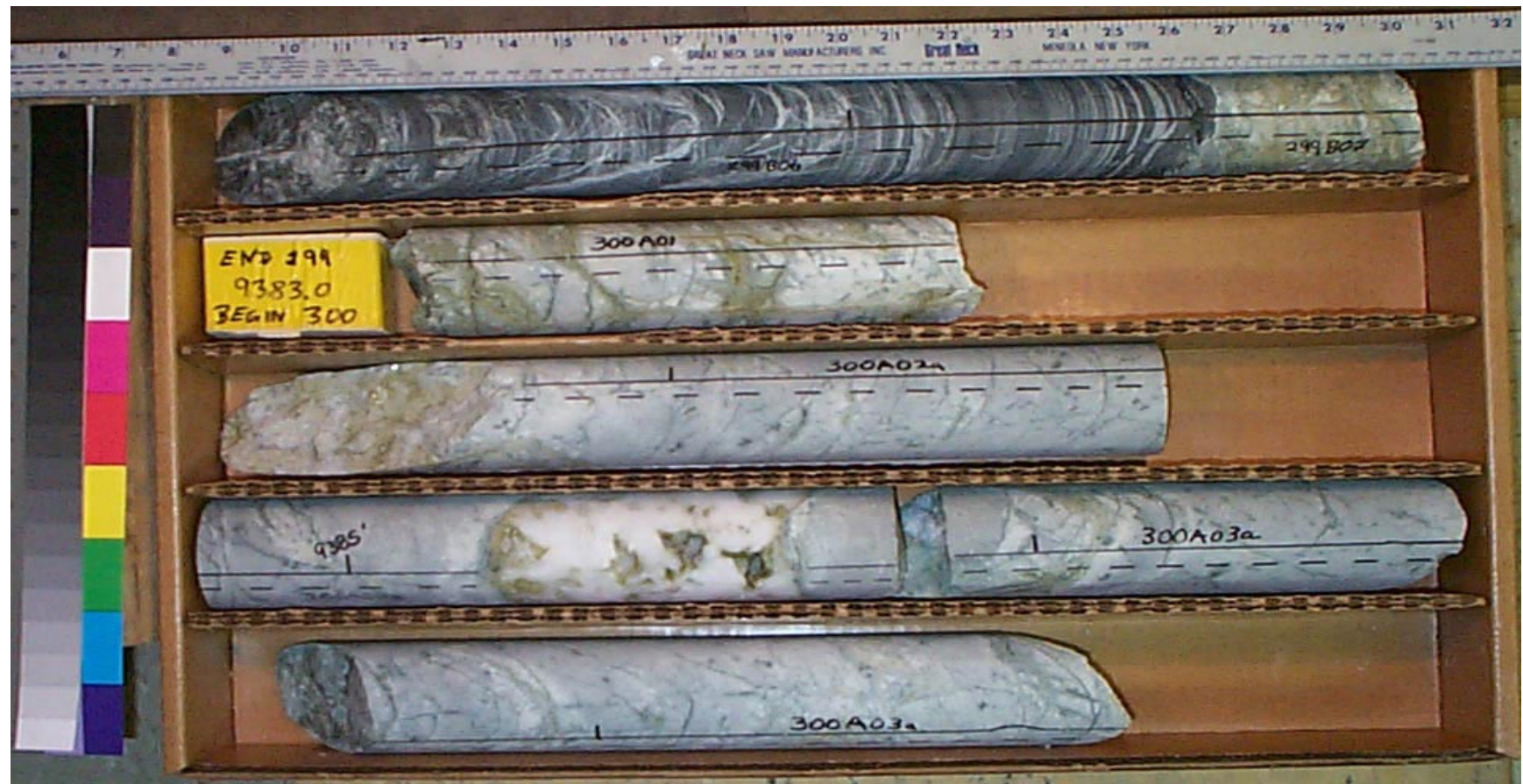

Core Scans included in this box (listed by piece going downhole):

299B0600
$299 B 0700$
300A0100
300A021A
300A022A
300A031A
300A032A

See the "reading instructions" section of the introduction for help interpreting core box photos and core piece nomenclature 


\section{LVEW Core Box 427}

Depth Interval 9387.8'-9394.9'

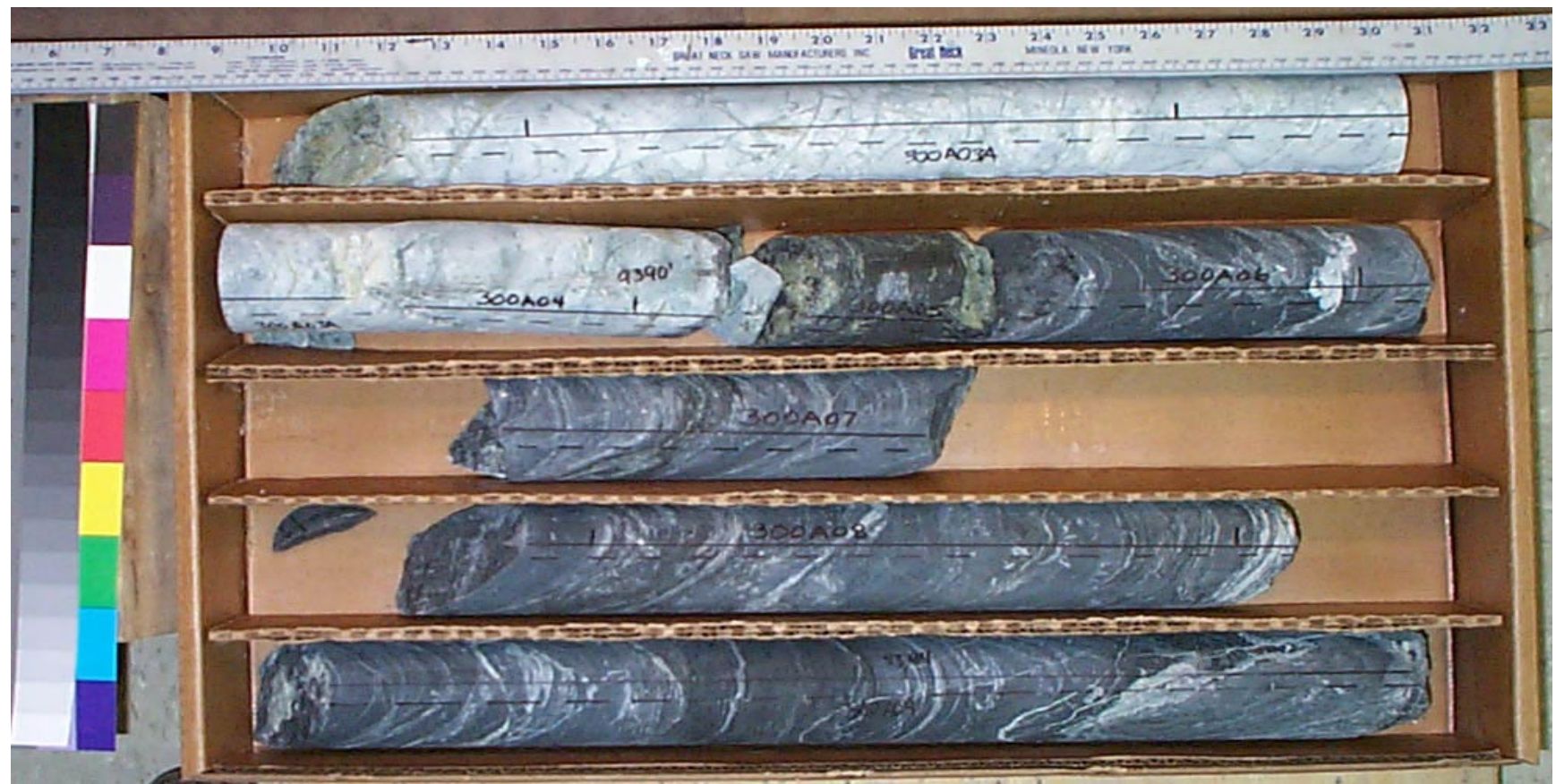

Core Scans included in this box

(listed by piece going downhole):
300A032A
300A033A
$300 A 0500$
$300 \mathrm{~A} 0600$
$300 \mathrm{~A} 0700$
$300 \mathrm{~A} 0800$
$300 \mathrm{~A} 0900$

See the "reading instructions" section of the introduction for help interpreting core box photos and core piece nomenclature 


\section{LVEW Core Box 428}

Depth Interval 9394.9'-9402.0'

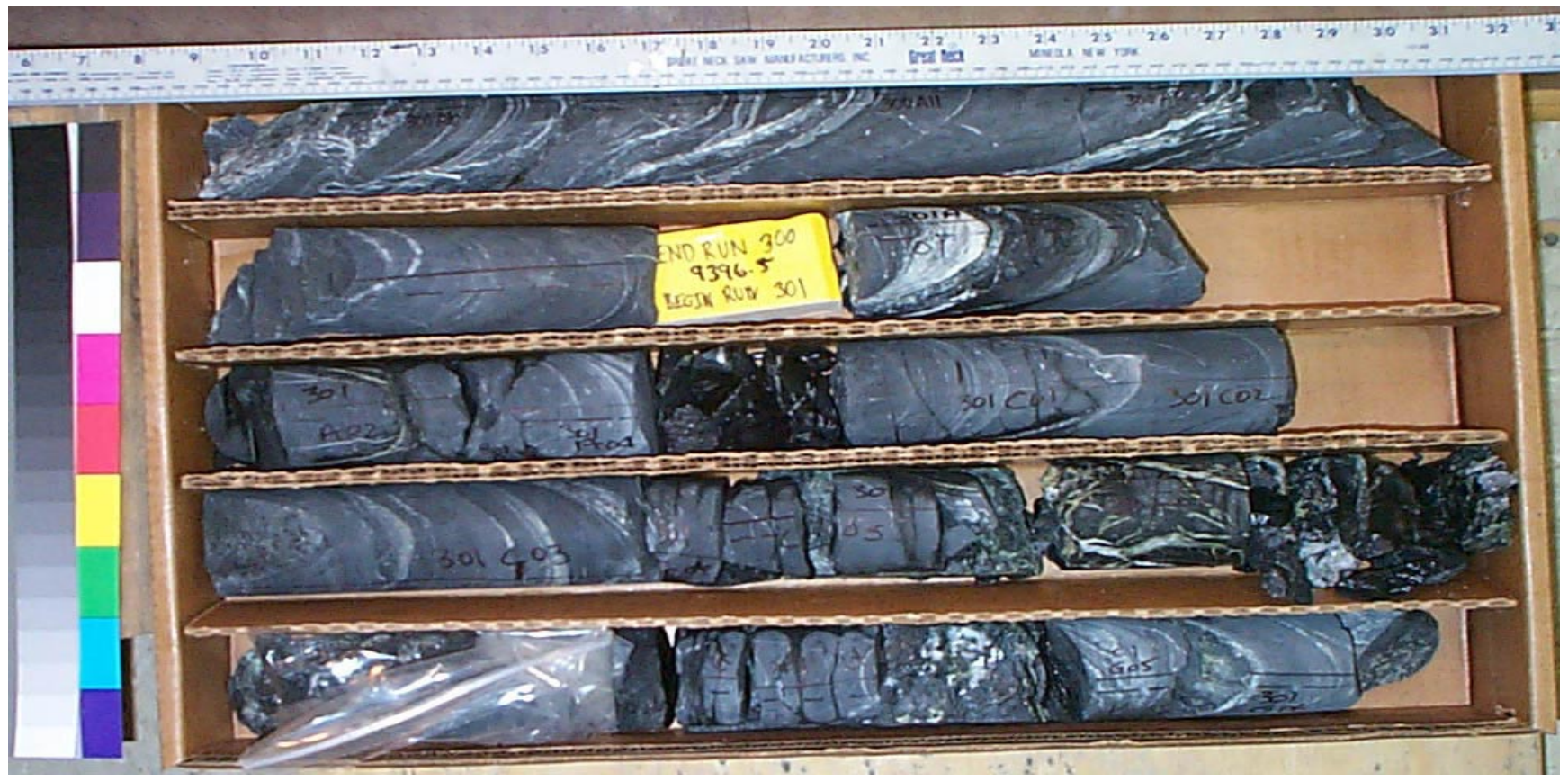

Core Scans included in this box (listed by piece going downhole):

$$
\begin{aligned}
& 300 A 1000 \\
& 300 A 1100 \\
& 301 C 0300 \\
& 301 F 0100
\end{aligned}
$$

See the "reading instructions" section of the introduction for help interpreting core box photos and core piece nomenclature 


\section{LVEW Core Box 429}

\section{Depth Interval 9402.0'-9409.2'}

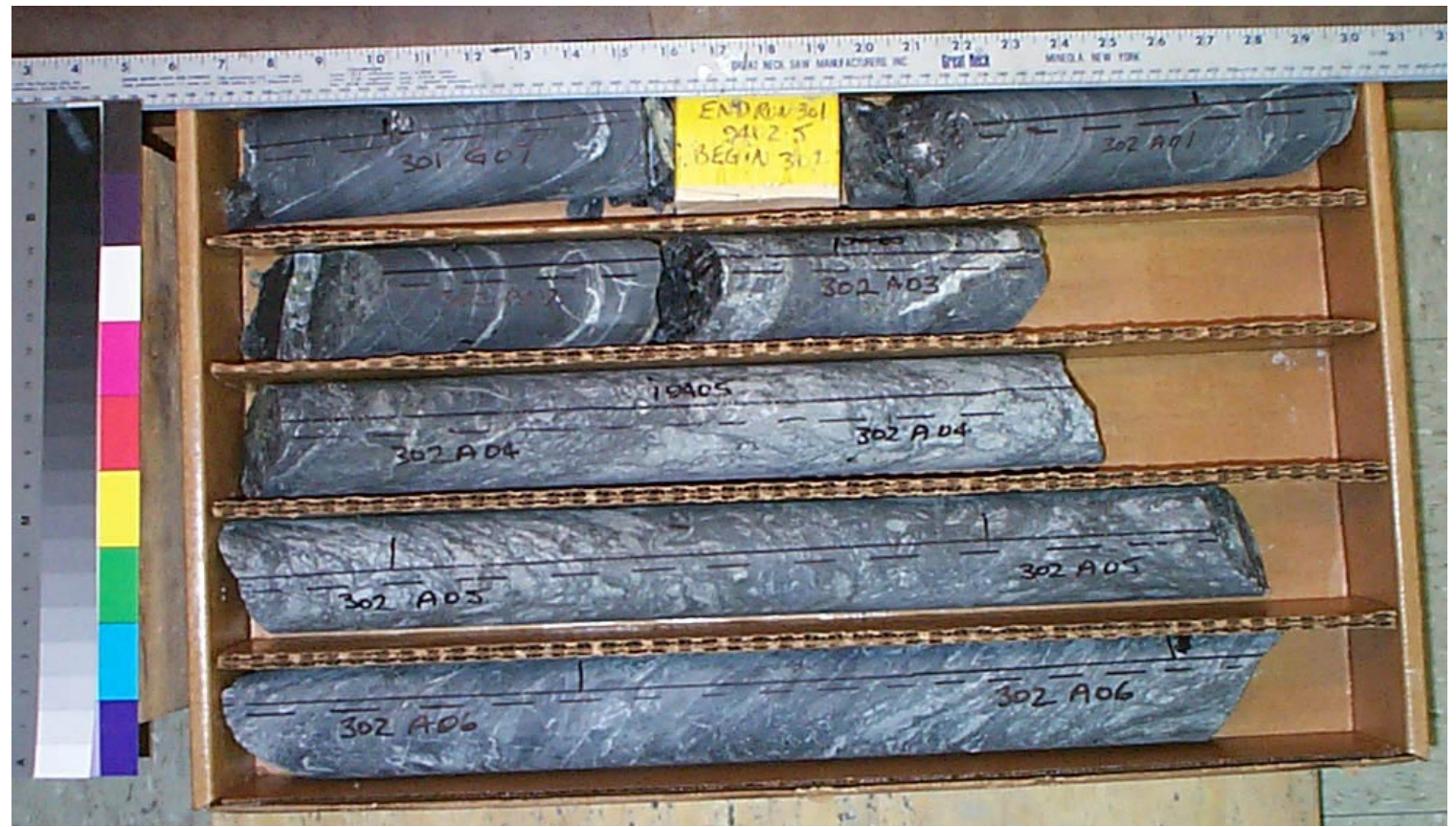

Core Scans included in this box (listed by piece going downhole):
$301 \mathrm{G} 0100$ $302 \mathrm{~A} 0100$ $302 \mathrm{~A} 0200$ $302 \mathrm{~A} 0300$ $302 \mathrm{~A} 0400$ $302 \mathrm{~A} 0500$ $302 \mathrm{~A} 0600$

See the "reading instructions" section of the introduction for help interpreting core box photos and core piece nomenclature 


\section{LVEW Core Box 430}

Depth Interval 9409.2'-9416.8'

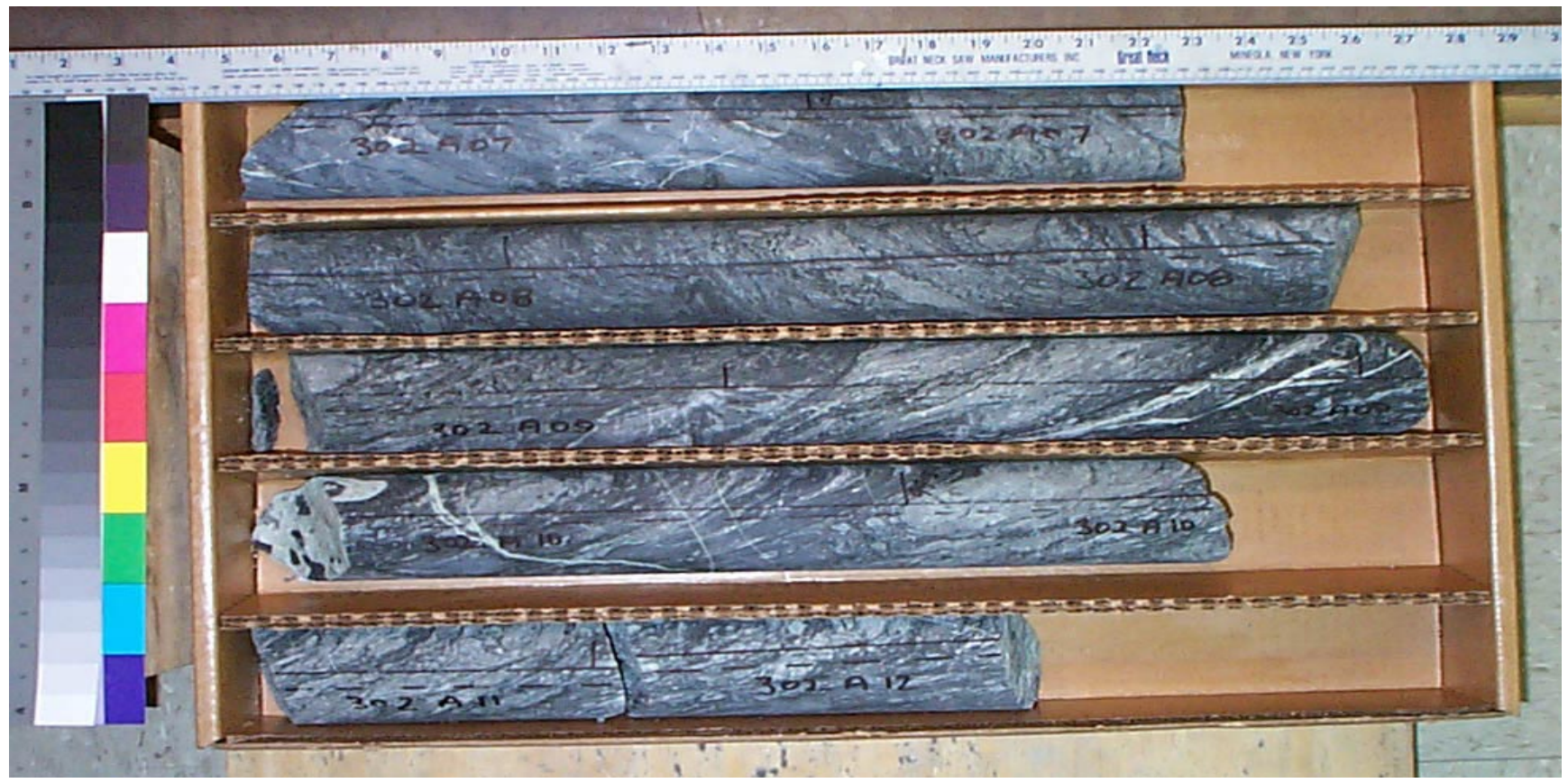

Core Scans included in this box (listed by piece going downhole):
$302 \mathrm{~A} 0700$
$302 \mathrm{~A} 0800$
$302 \mathrm{~A} 0900$
$302 \mathrm{~A} 1000$
$302 \mathrm{~A} 1100$
$302 \mathrm{~A} 1200$

See the "reading instructions" section of the introduction for help interpreting core box photos and core piece nomenclature 


\section{LVEW Core Box 431}

\section{Depth Interval 9416.8'-9423.5'}

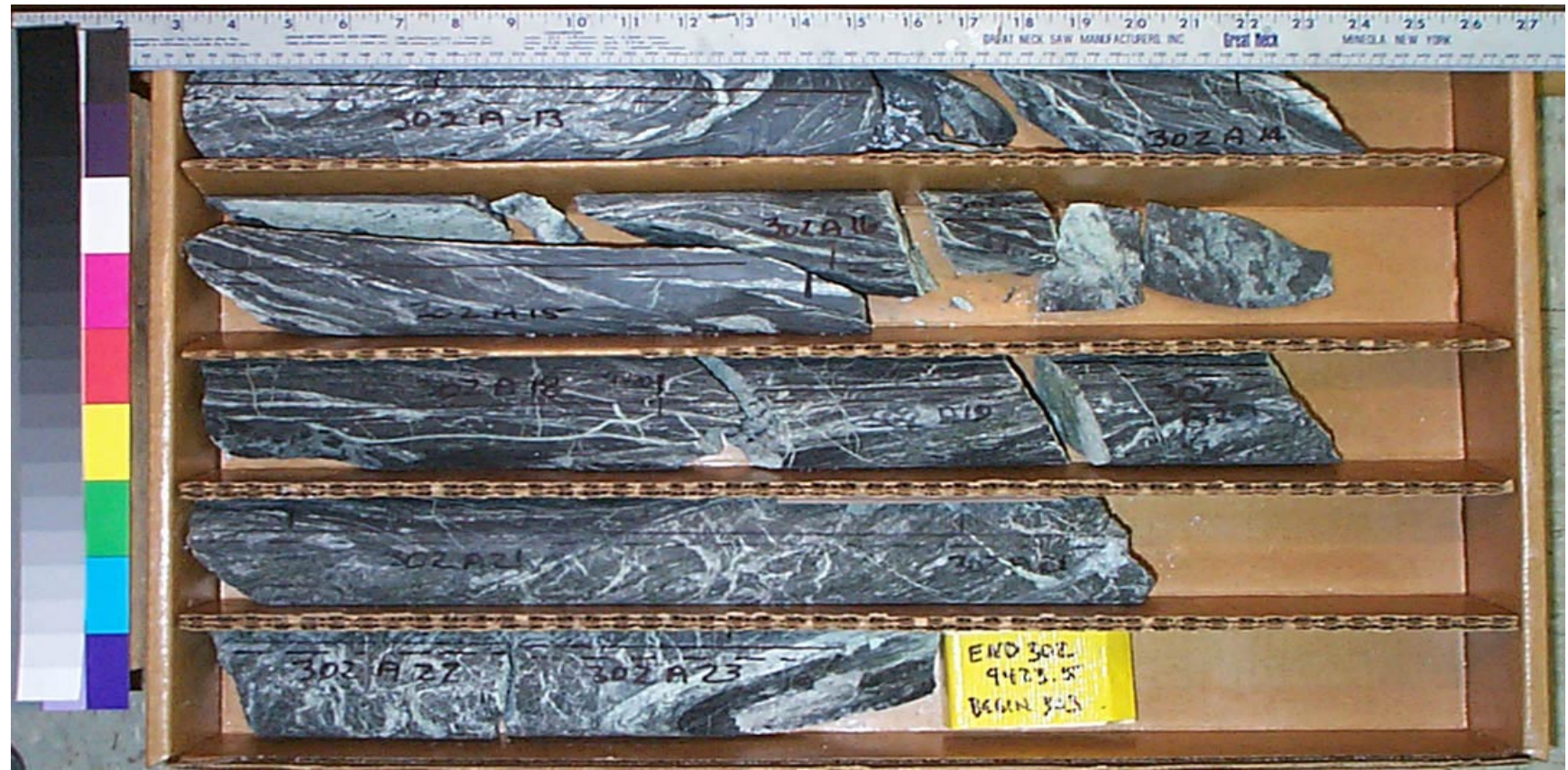

Core Scans included in this box (listed by piece going downhole):

$$
\begin{aligned}
& 302 A 1300 \\
& 302 A 1400 \\
& 302 A 1800 \\
& 302 A 1900 \\
& 302 A 2000 \\
& 302 A 2100 \\
& 302 A 2200 \\
& \text { 302A2300 }
\end{aligned}
$$

See the "reading instructions" section of the introduction for help interpreting core box photos and core piece nomenclature 


\section{LVEW Core Box 432}

Depth Interval 9423.5'-9430.0'

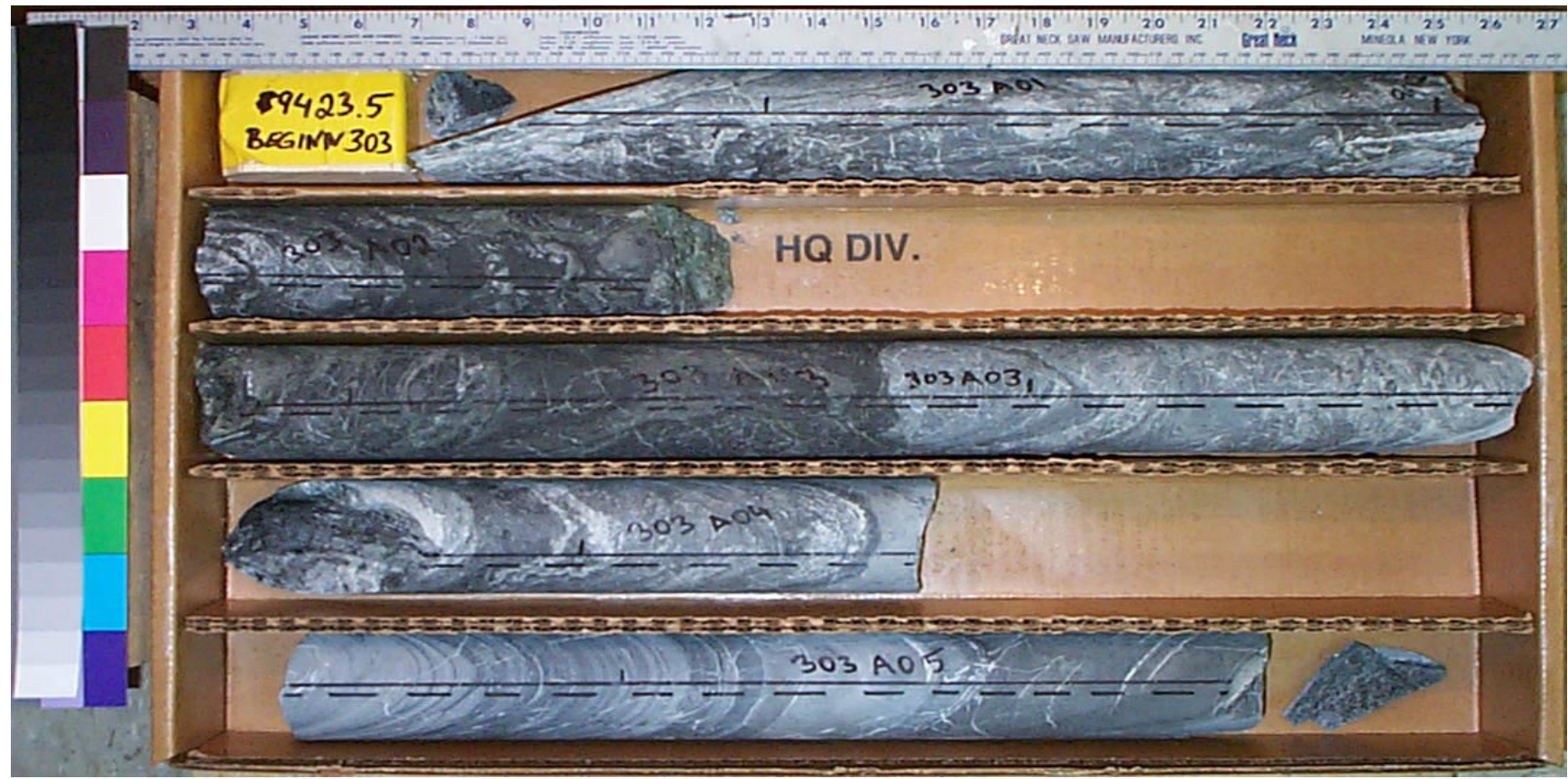

Core Scans included in this box (listed by piece going downhole):

$$
\begin{aligned}
& 303 A 0100 \\
& 303 A 0200 \\
& 303 A 0300 \\
& 303 A 0400 \\
& 303 A 0500
\end{aligned}
$$

See the "reading instructions" section of the introduction for help interpreting core box photos and core piece nomenclature 


\section{LVEW Core Box 433}

Depth Interval 9430.0'-9436.3'

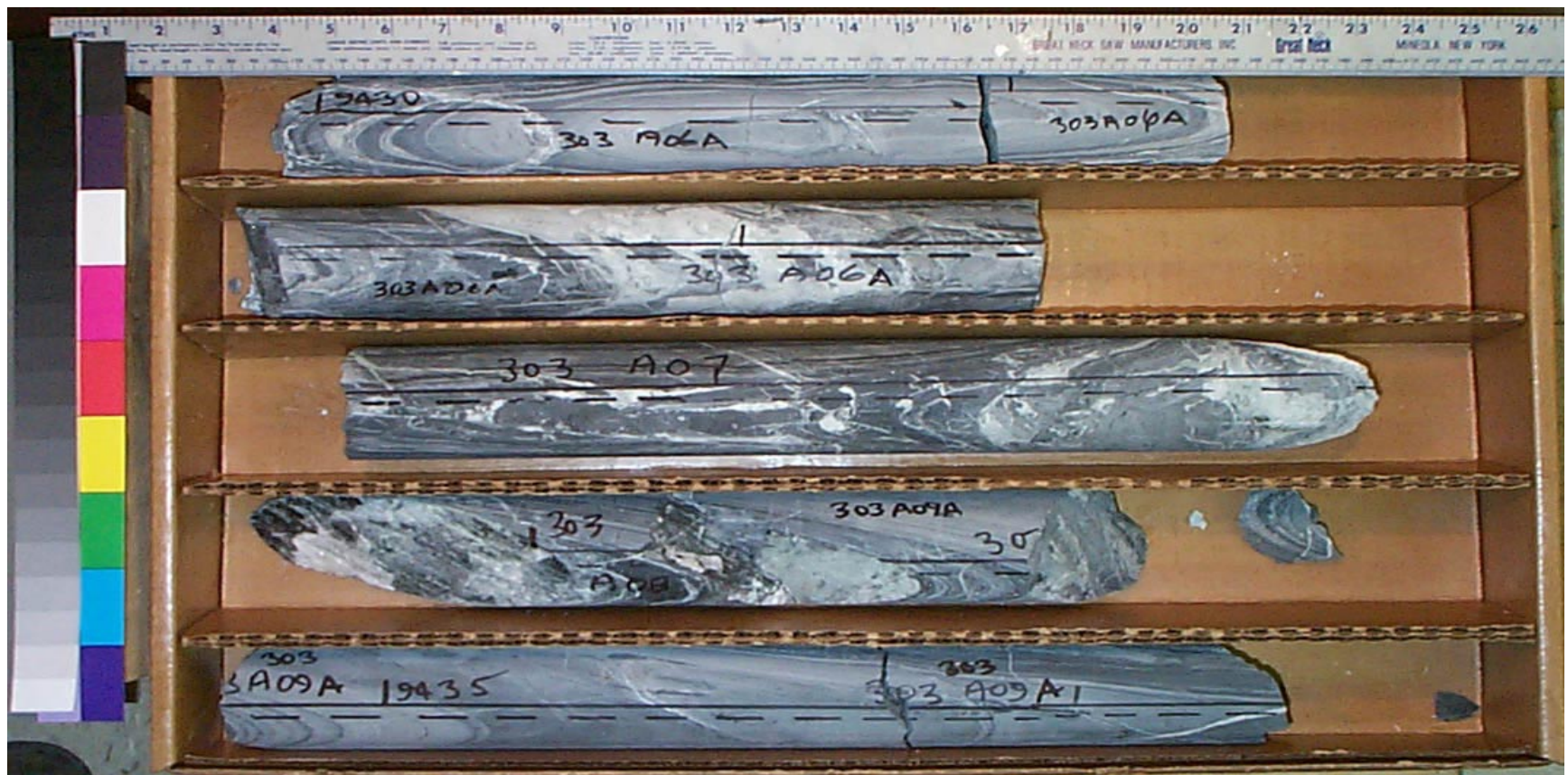

Core Scans included in this box (listed by piece going downhole):
303A060A
303A0700
303A0800
303A091A
303A092A

See the "reading instructions" section of the introduction for help interpreting core box photos and core piece nomenclature 


\section{LVEW Core Box 434}

\section{Depth Interval 9436.3'-9444.6'}

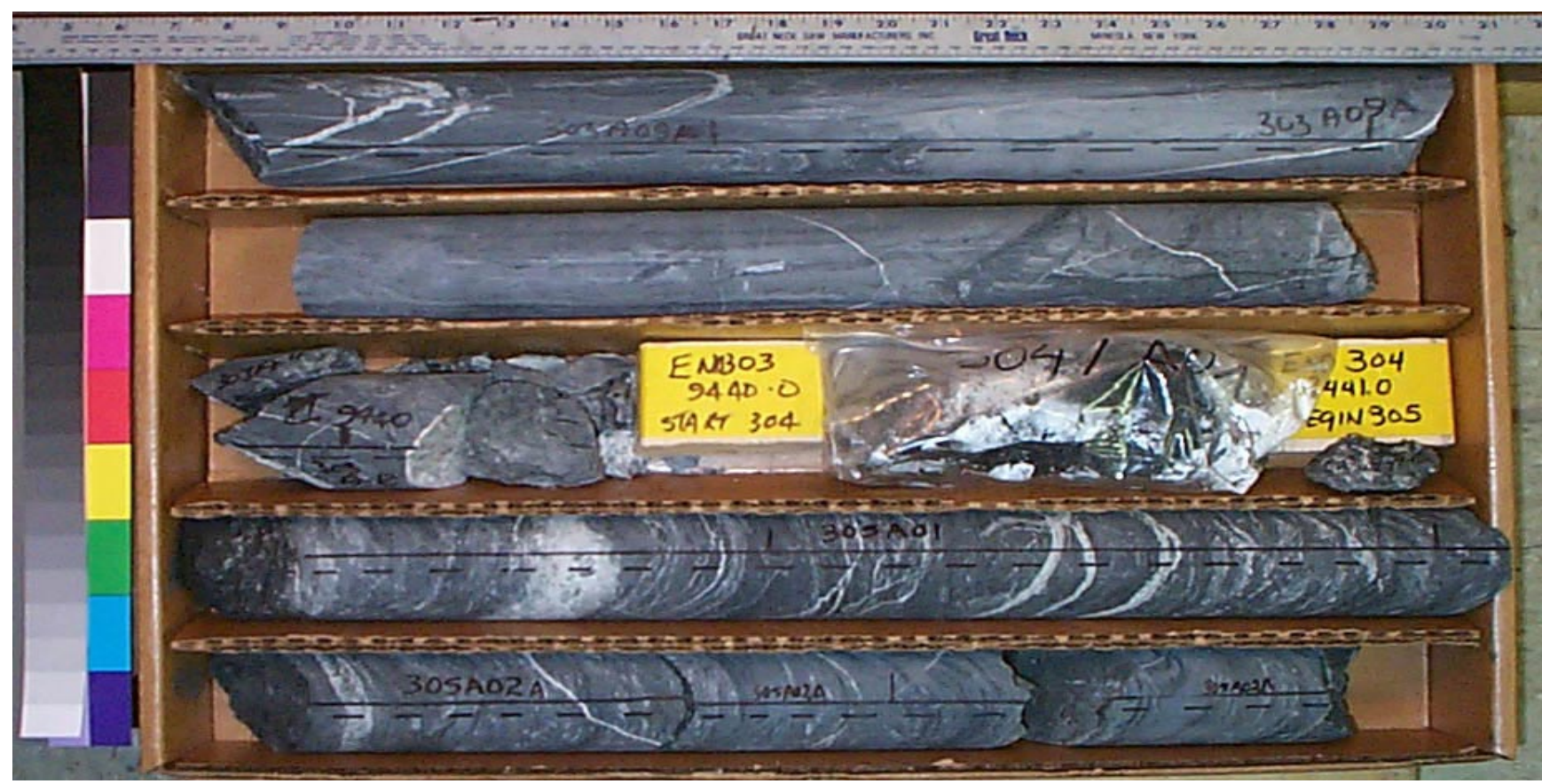

Core Scans included in this box (listed by piece going downhole):
303A092A
$303 \mathrm{~A} 1000$
$303 \mathrm{~A} 1200$
$305 \mathrm{~A} 0100$
305A0200
305A030A

See the "reading instructions" section of the introduction for help interpreting core box photos and core piece nomenclature 


\section{LVEW Core Box 435}

Depth Interval 9444.6'-9452.0'

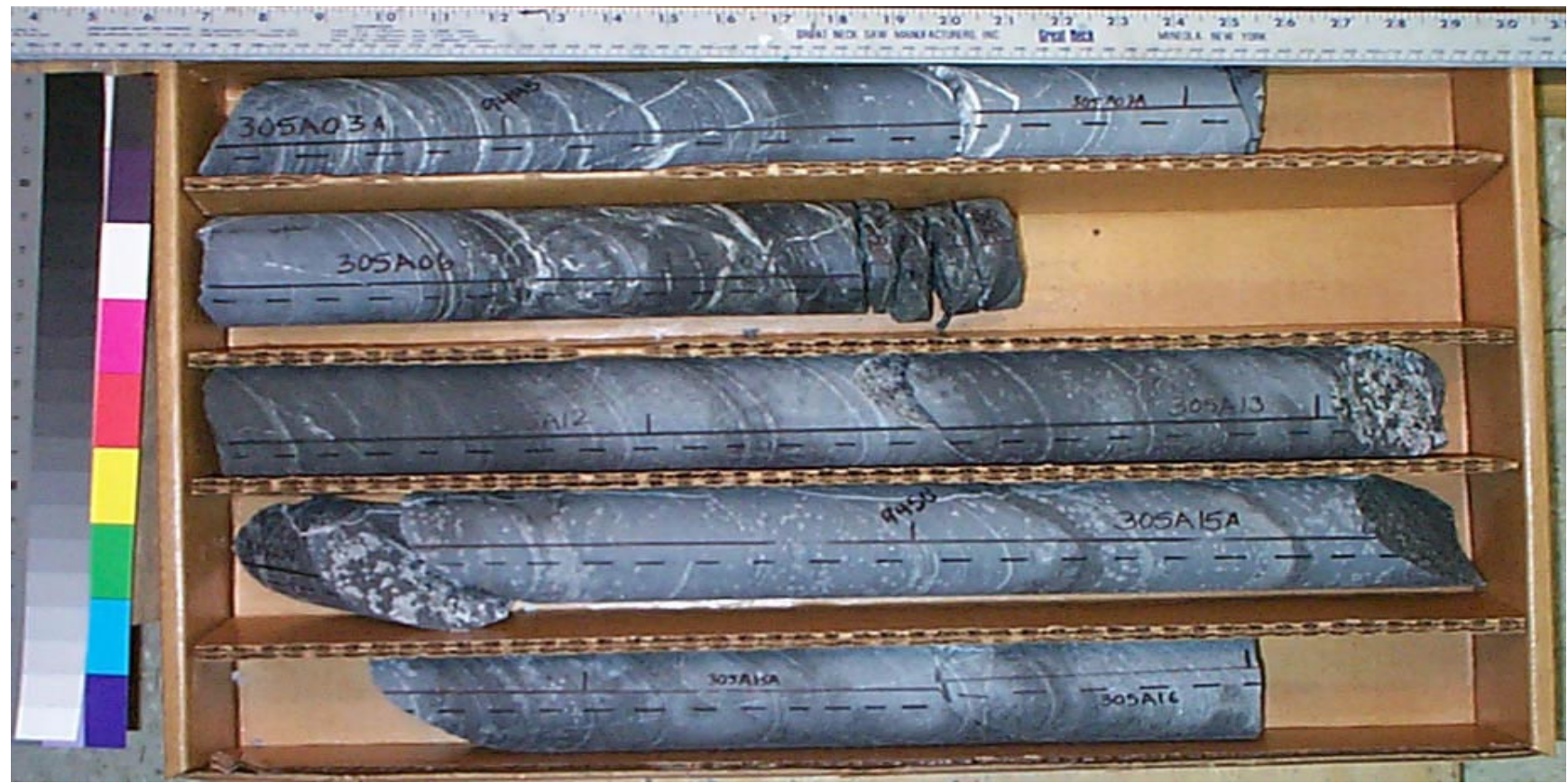

Core Scans included in this box (listed by piece going downhole):

305A030A
305A0600
305A1200
305A1300
305A150A
305A160A

See the "reading instructions" section of the introduction for help interpreting core box photos and core piece nomenclature 


\section{LVEW Core Box 436}

Depth Interval 9452.0'-9458.7'

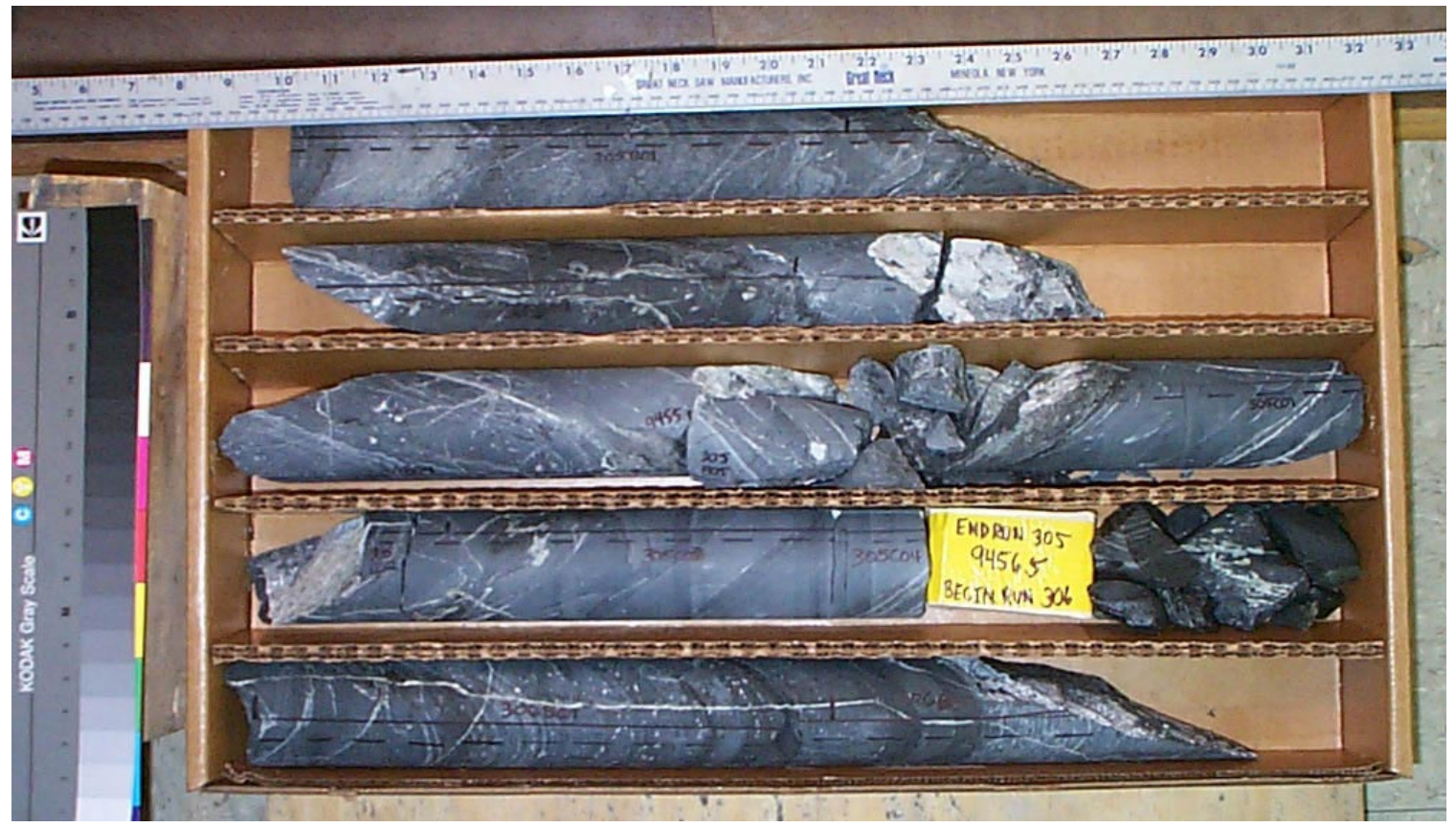

Core Scans included in this box (listed by piece going downhole):
305B0100
305B0200
305B0400
$305 \mathrm{C} 0100$
$305 \mathrm{C} 0300$
306B0100
306B0200

See the "reading instructions" section of the introduction for help interpreting core box photos and core piece nomenclature 


\section{LVEW Core Box 437}

Depth Interval 9458.7'-9470.0'

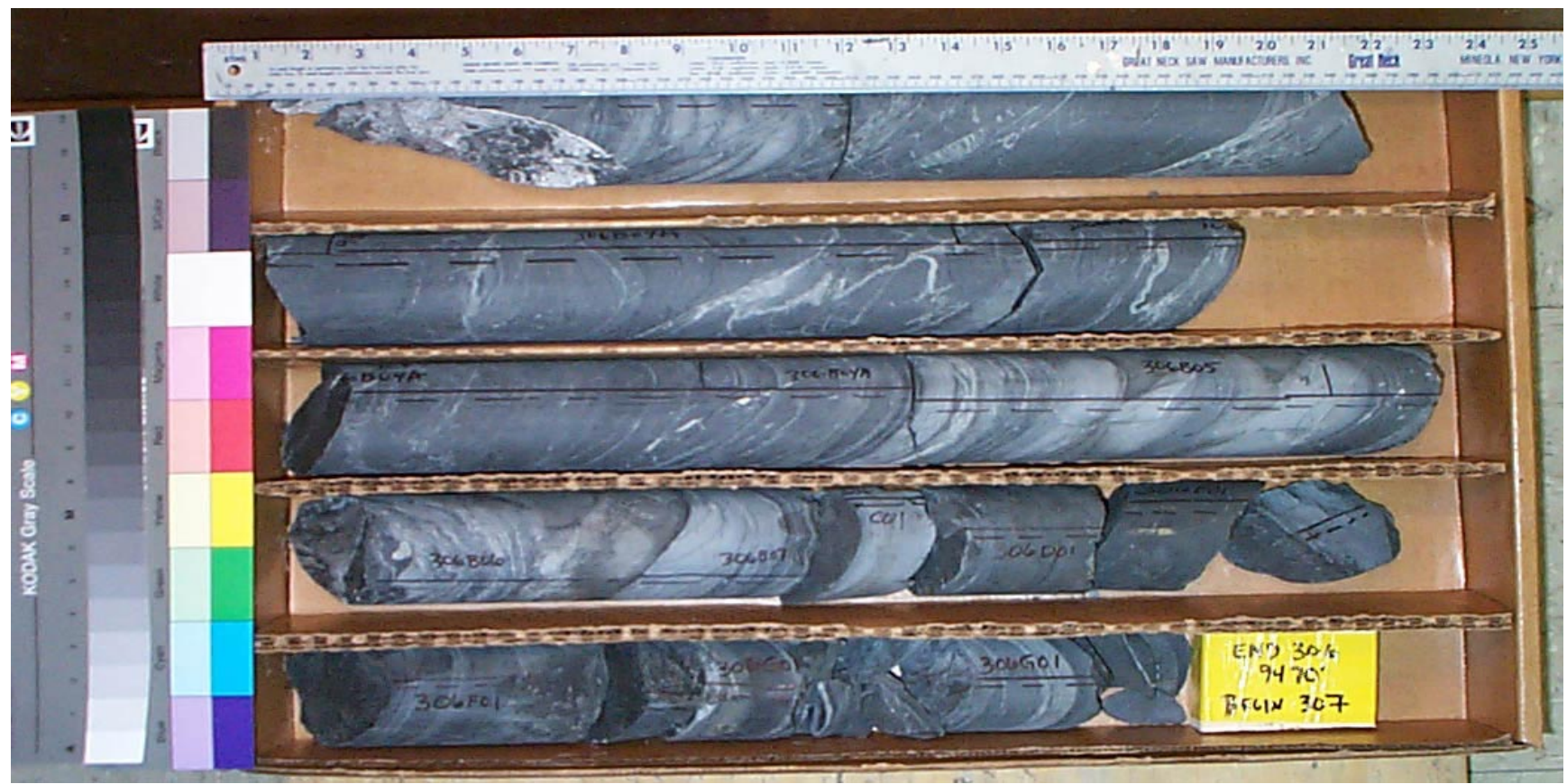

Core Scans included in this box (listed by piece going downhole):
306B0300
306B040A
306B0500
306B0600
306B0700
306C010R
306D010R
306F010R
306G010R

See the "reading instructions" section of the introduction for help interpreting core box photos and core piece nomenclature 


\section{LVEW Core Box 438}

Depth Interval 9470.0'-9476.2'

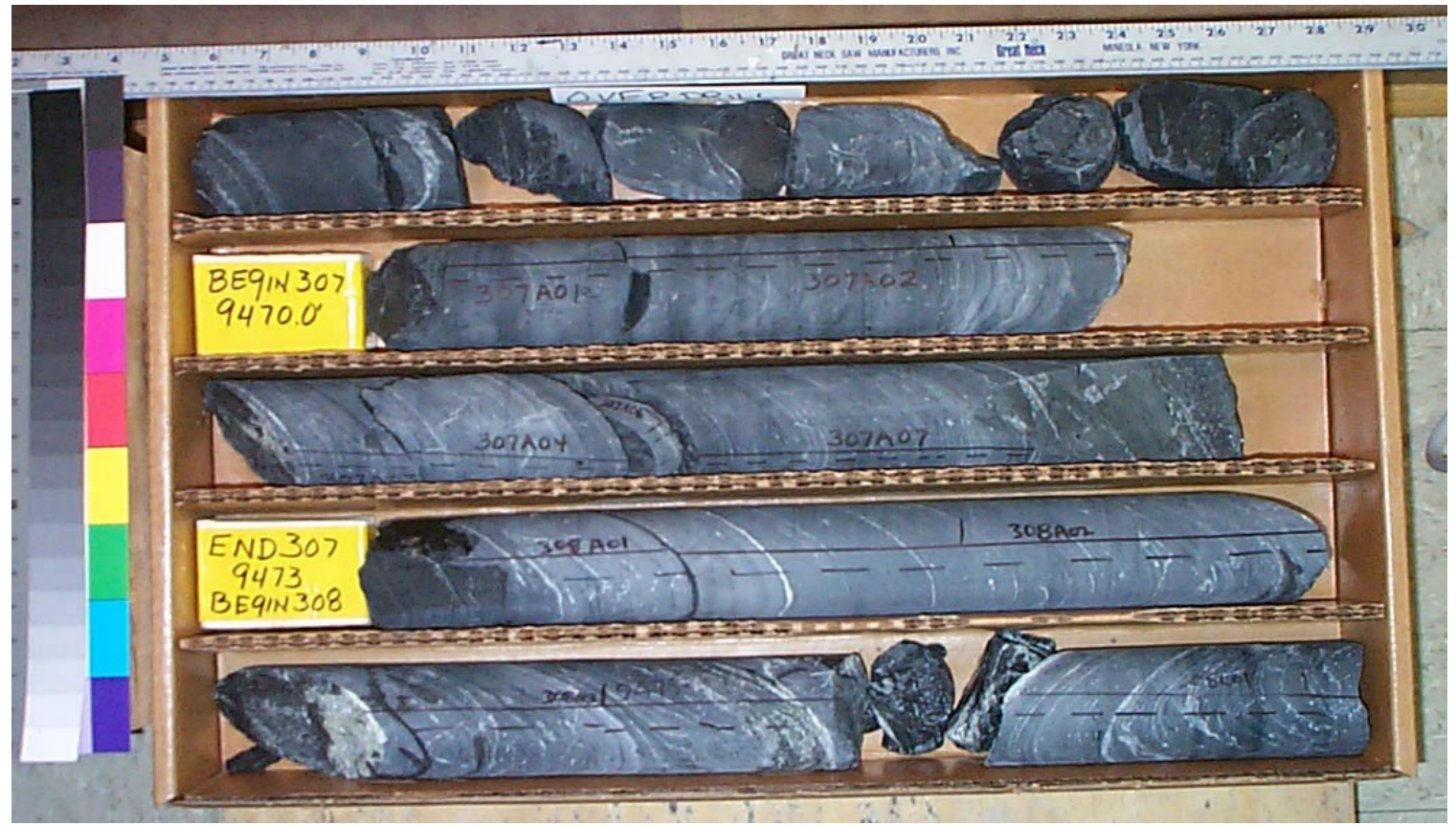

Core Scans included in this box (listed by piece going downhole):
$307 \mathrm{~A} 0100$
$307 \mathrm{~A} 0200$
$307 \mathrm{~A} 0300$
$307 \mathrm{~A} 0700$
308A0100
308A0200
308A0300
$308 \mathrm{C} 0100$

See the "reading instructions" section of the introduction for help interpreting core box photos and core piece nomenclature 


\section{LVEW Core Box 439}

\section{Depth Interval 9476.2'-9484.8'}

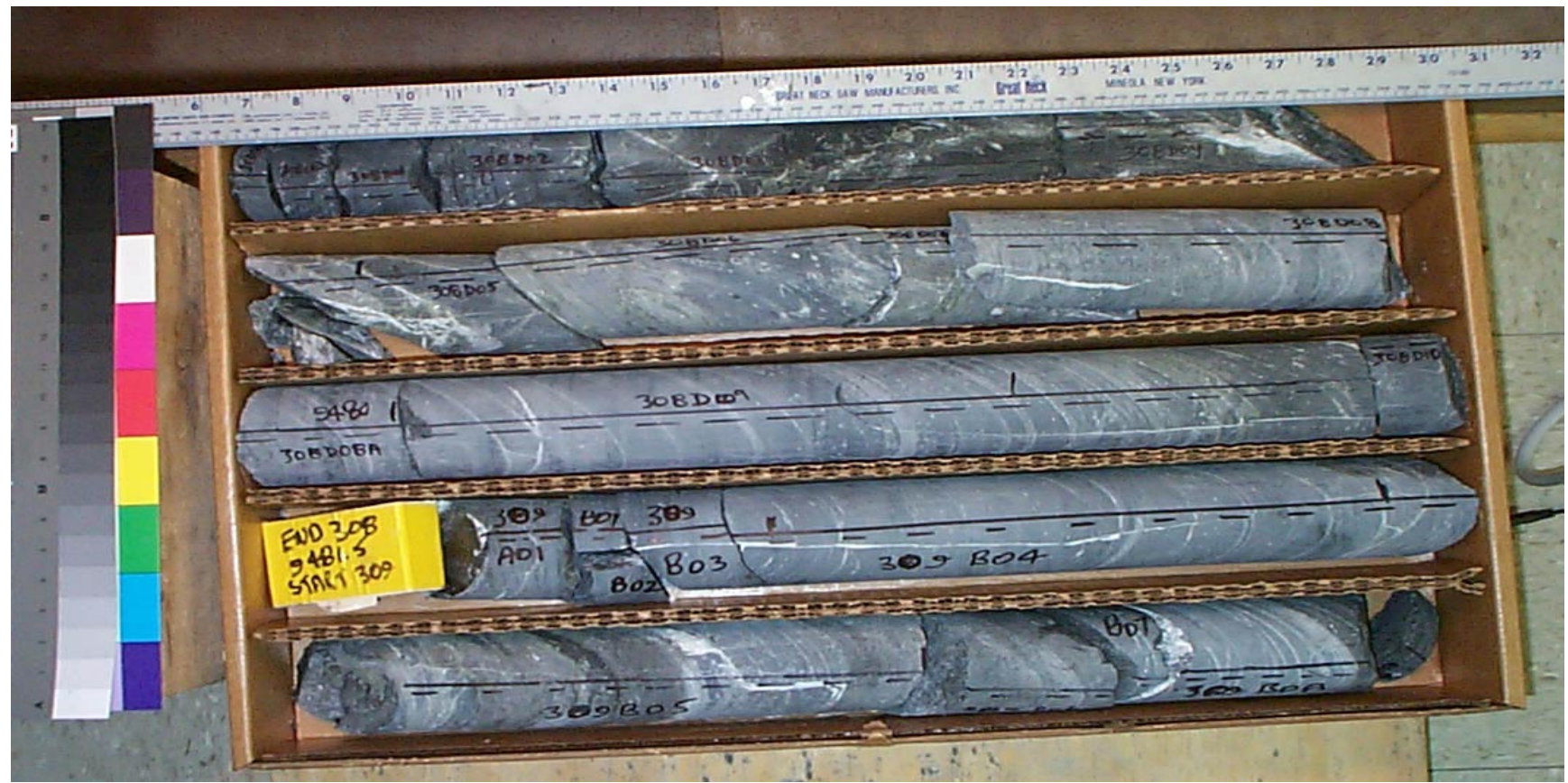

Core Scans included in this box (listed by piece going downhole):

$308 C 0200$
$308 C 0300$
$308 D 0100$
$308 D 0200$
$308 D 0300$
$308 D 0500$
$308 D 0600$
308D0700

308D0800 308D0900 309A010R 309B0300 309B0400 309B0500 309B0600 309B0800

See the "reading instructions" section of the introduction for help interpreting core box photos and core piece nomenclature 


\section{LVEW Core Box 440}

Depth Interval 9484.8'-9492.6'

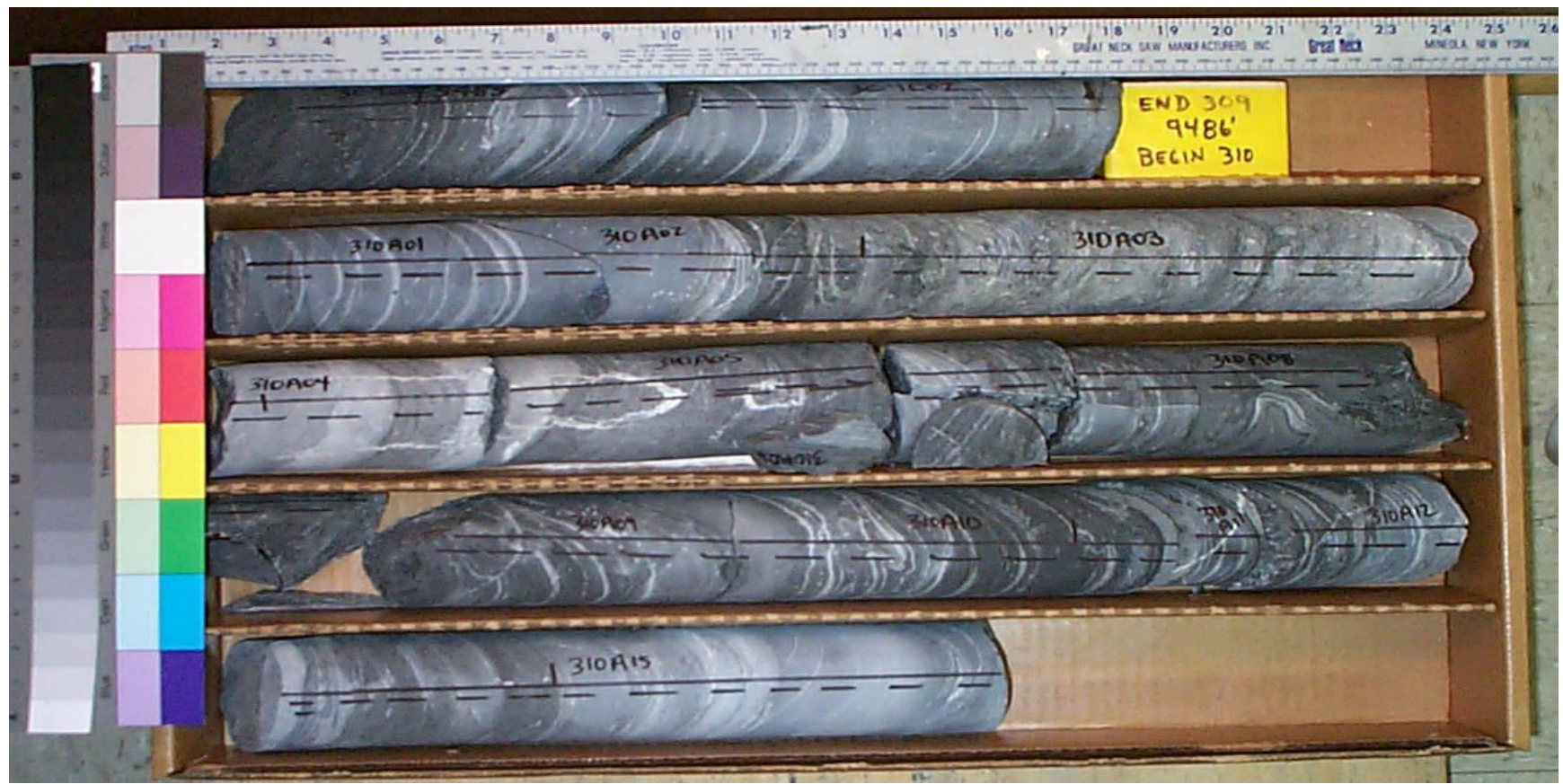

Core Scans included in this box (listed by piece going downhole):

$309 C 0100$
$309 C 0200$
$310 A 0100$
$310 A 0300$
$310 A 0400$
$310 A 0500$
$310 A 0800$
$310 A 0900$
310A1000
310A1100
310A1500

See the "reading instructions" section of the introduction for help interpreting core box photos and core piece nomenclature 


\section{LVEW Core Box 441}

\section{Depth Interval 9492.6'-9501.8'}

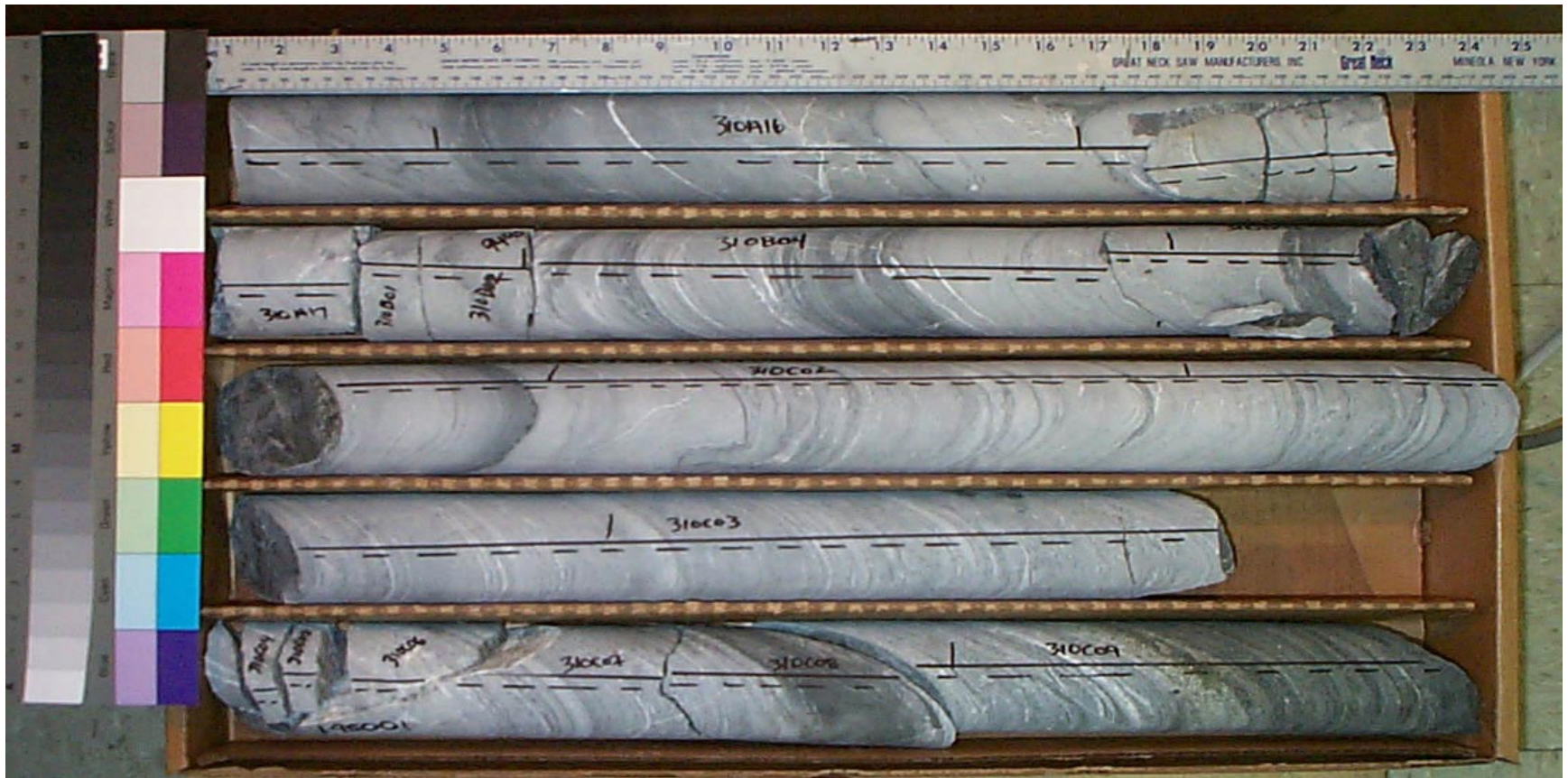

Core Scans included in this box (listed by piece going downhole):

$310 A 1600$
$310 B 0400$
$310 B 0500$
$310 C 0200$
$310 C 0300$
$310 C 0700$
$310 C 0800$

See the "reading instructions" section of the introduction for help interpreting core box photos and core piece nomenclature 


\section{LVEW Core Box 442}

Depth Interval 9501.8'-9509.9'

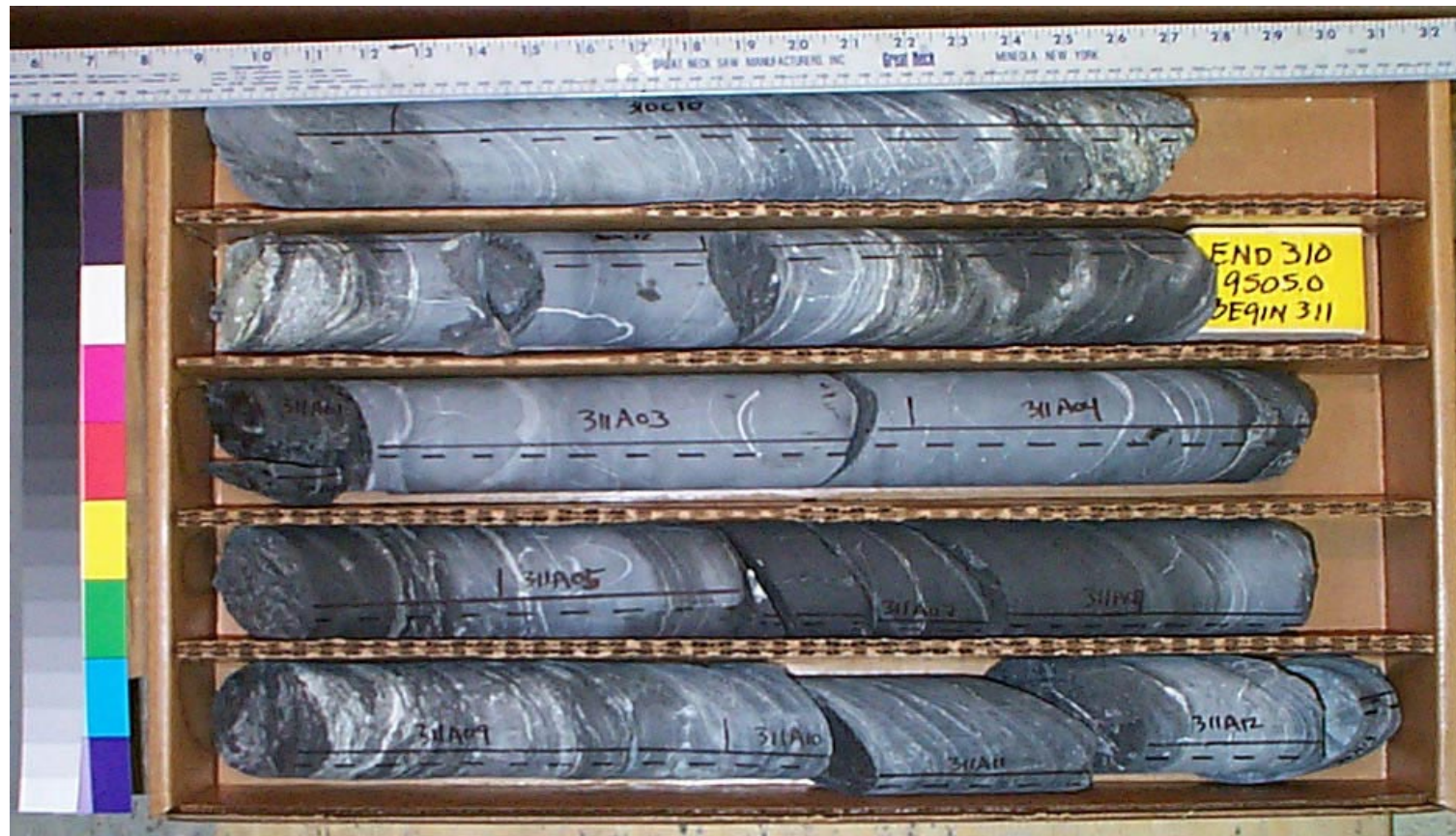

Core Scans included in this box (listed by piece going downhole):
$310 \mathrm{C} 1000$
$310 \mathrm{C} 1100$
$310 \mathrm{C} 1200$
$310 \mathrm{C} 1300$
$311 \mathrm{~A} 0300$
$311 \mathrm{~A} 0400$
$311 \mathrm{~A} 0500$

$311 A 070 A$
$311 A 0800$
$311 A 0900$
$311 A 1000$
$311 A 1100$
$311 A 1200$

See the "reading instructions" section of the introduction for help interpreting core box photos and core piece nomenclature 


\section{LVEW Core Box 443}

Depth Interval 9409.9'-9517.8'

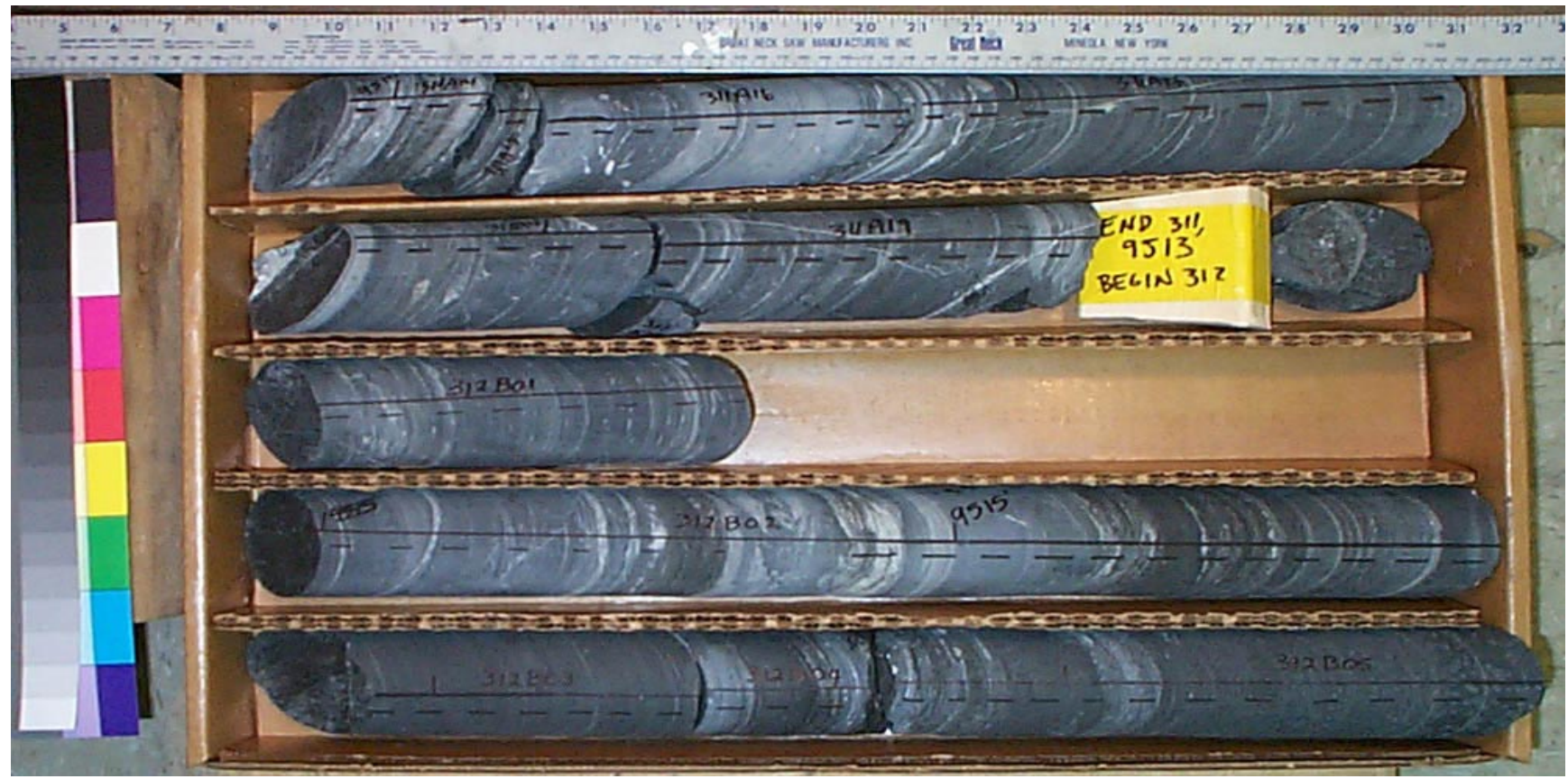

Core Scans included in this box (listed by piece going downhole):
$311 \mathrm{~A} 1400$
$311 \mathrm{~A} 1500$
$311 \mathrm{~A} 1700$
$311 \mathrm{~A} 1800$
$311 \mathrm{~A} 1900$
312B0100
312B0200
312B0300
312B0400
312B0500
312B0600

See the "reading instructions" section of the introduction for help interpreting core box photos and core piece nomenclature 


\section{LVEW Core Box 444}

Depth Interval 9517.8'-9526.4'

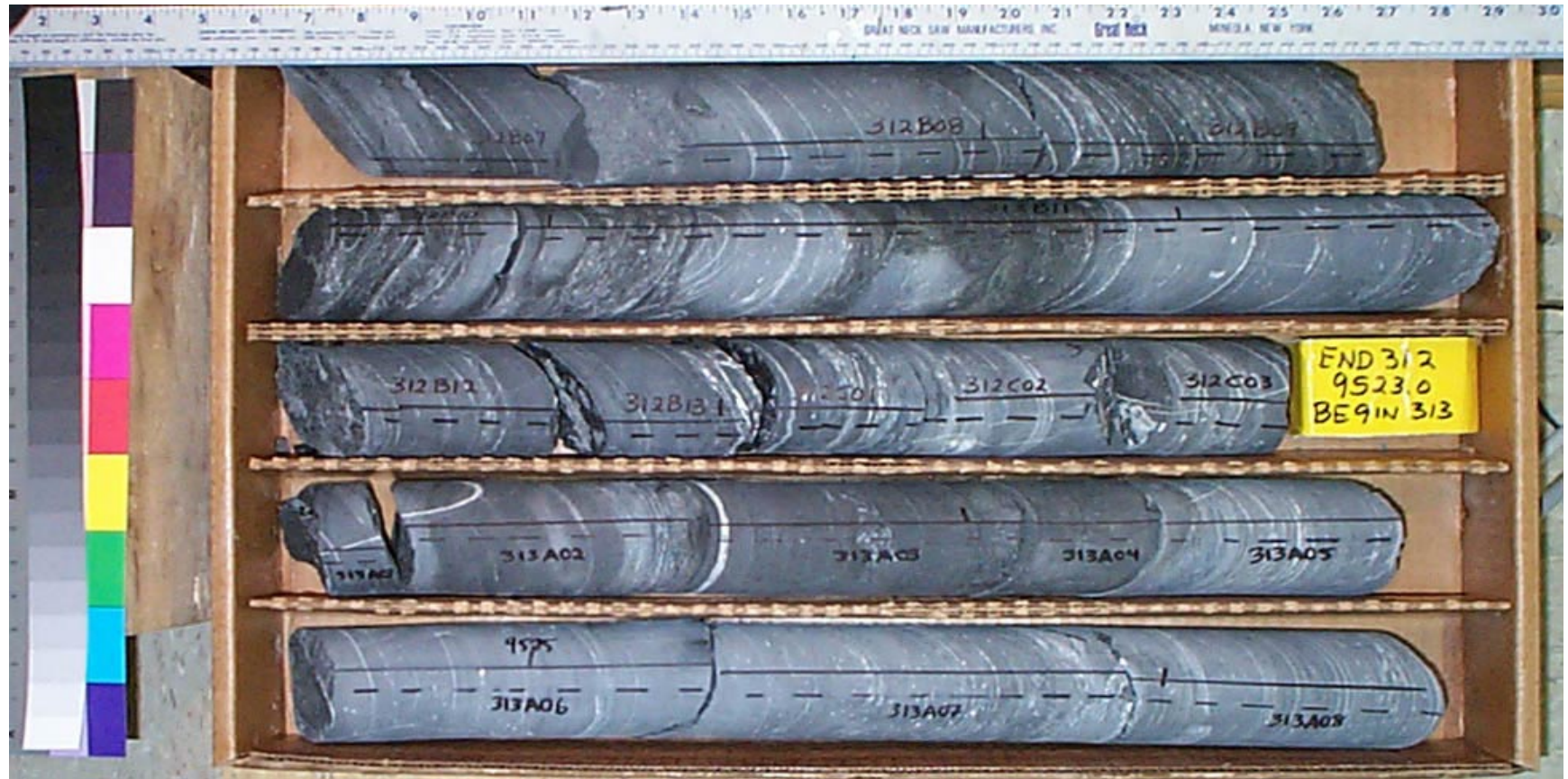

Core Scans included in this box (listed by piece going downhole):

$312 \mathrm{~B} 0700$
$312 \mathrm{~B} 0800$
$312 \mathrm{~B} 0900$
$312 \mathrm{~B} 1000$
$312 \mathrm{~B} 1100$
$312 \mathrm{~B} 1200$
$312 \mathrm{~B} 1300$
312C0100

$312 \mathrm{C} 0200$

$312 \mathrm{C} 0300$

$313 \mathrm{~A} 0100$

$313 \mathrm{~A} 0300$

313A0500

313A0600

313A0700

313A0800

See the "reading instructions" section of the introduction for help interpreting core box photos and core piece nomenclature 


\section{LVEW Core Box 445}

Depth Interval 9526.4'-9533.8'

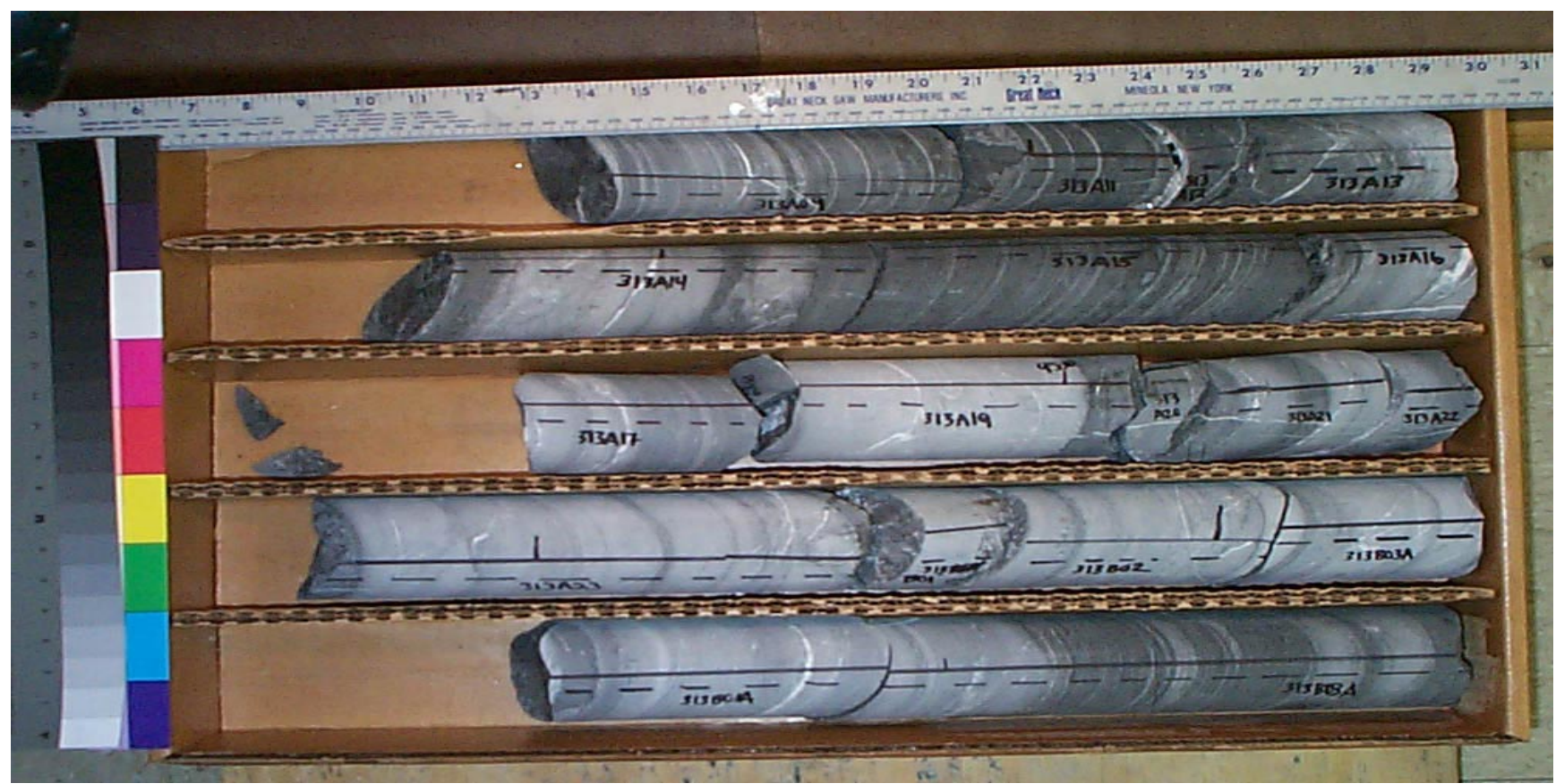

Core Scans included in this box (listed by piece going downhole):

313A0900
$313 A 1100$
$313 A 1300$
$313 A 1400$
$313 A 1500$
$313 A 1600$
$313 A 1700$
$313 A 190 A$
$313 A 2100$
$313 A 2300$
313B0100
313B030A

See the "reading instructions" section of the introduction for help interpreting core box photos and core piece nomenclature 


\section{LVEW Core Box 446}

Depth Interval 9533.8'-9539.4'

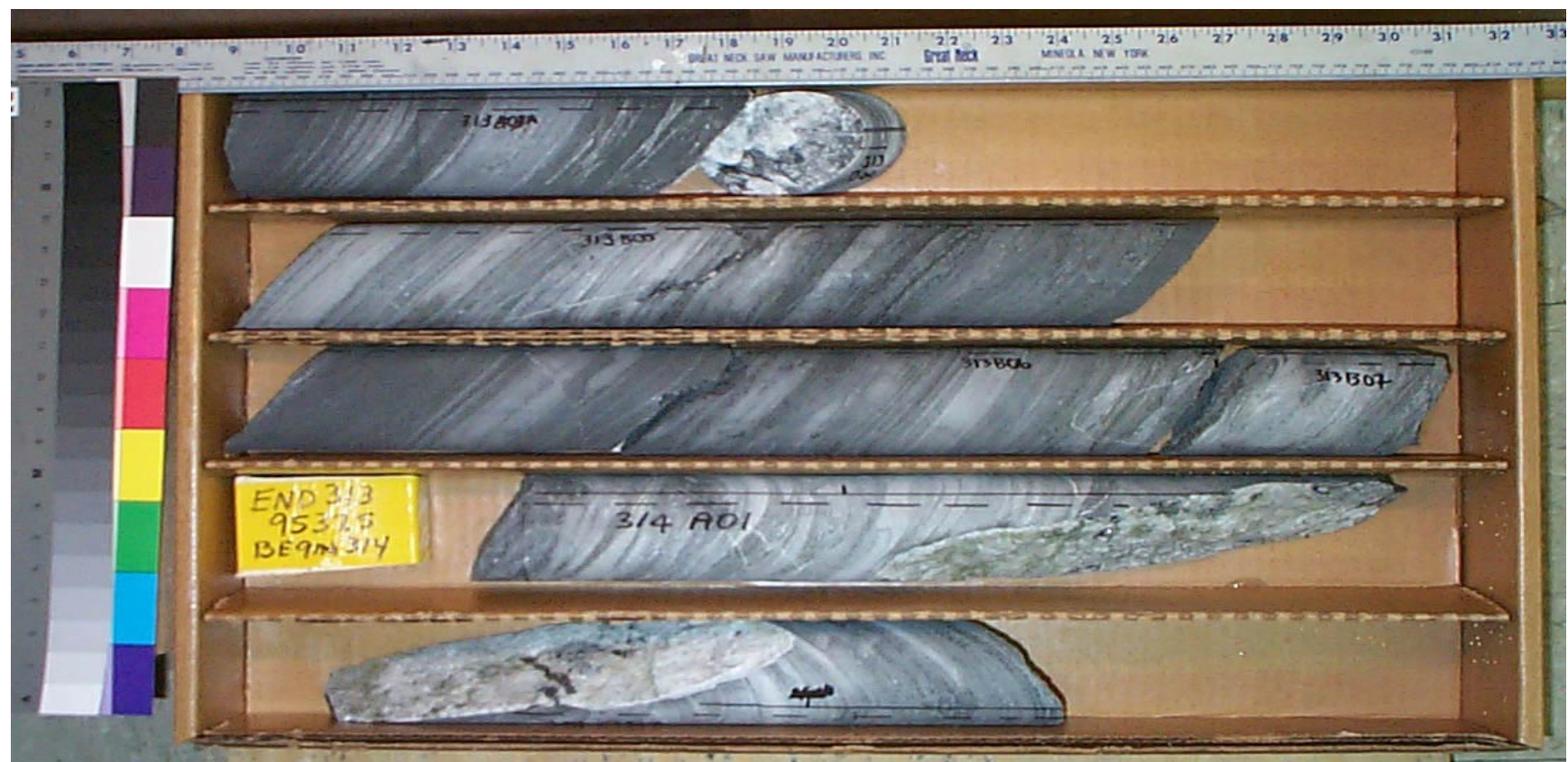

Core Scans included in this box (listed by piece going downhole):
313B030A
313B0500
313B0600
313B0700

See the "reading instructions" section of the introduction for help interpreting core box photos and core piece nomenclature 


\section{LVEW Core Box 447}

Depth Interval 9539.4'-9547.3'

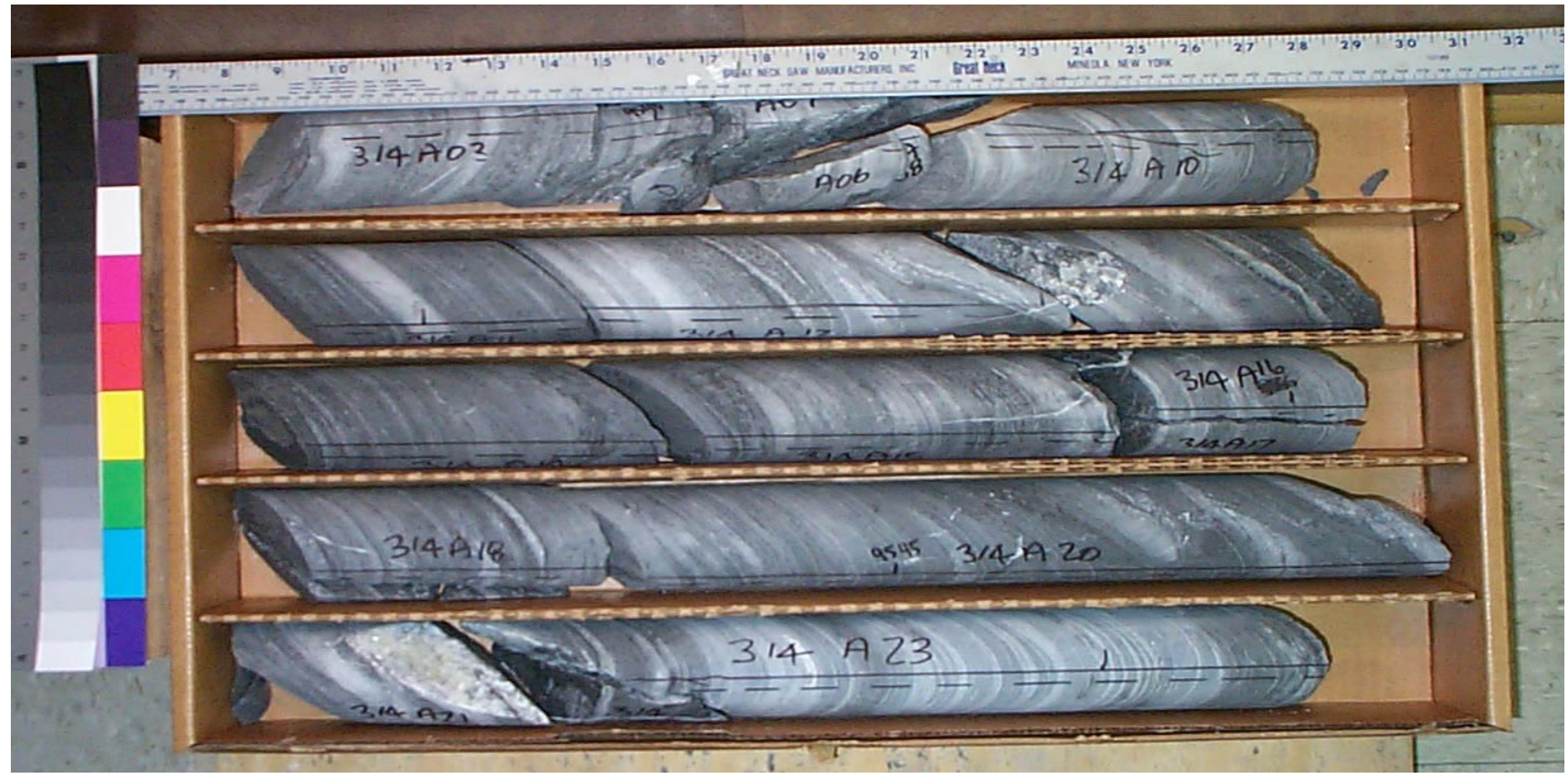

Core Scans included in this box (listed by piece going downhole):
$314 \mathrm{~A} 0300$
$314 \mathrm{~A} 1000$
$314 \mathrm{~A} 1100$
$314 \mathrm{~A} 1200$
$314 \mathrm{~A} 1300$
$314 \mathrm{~A} 1400$
$314 \mathrm{~A} 1500$
$314 \mathrm{~A} 2000$
$314 \mathrm{~A} 2100$
$314 \mathrm{~A} 2300$

See the "reading instructions" section of the introduction for help interpreting core box photos and core piece nomenclature 


\section{LVEW Core Box 448}

Depth Interval 9547.3'-9556.5'

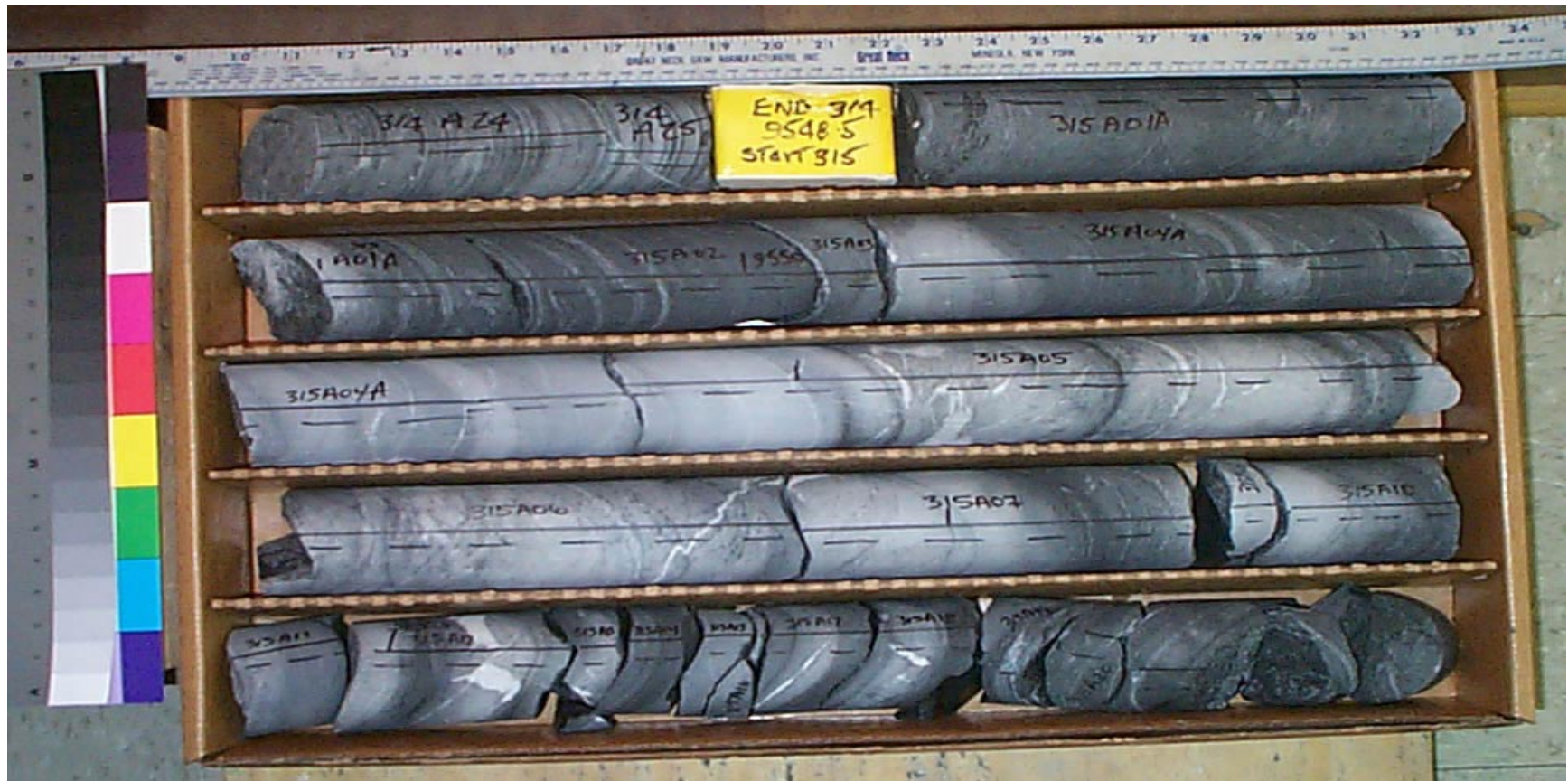

Core Scans included in this box (listed by piece going downhole):

314A2400
314A2500
315A010A
315A0200
315A0300
315A040A
315A0500
315A0600

$315 \mathrm{~A} 0700$

$315 \mathrm{~A} 1000$

$315 \mathrm{~A} 1100$

$315 \mathrm{~A} 1200$

$315 \mathrm{~A} 1400$

$315 \mathrm{~A} 1700$

$315 A 1800$

See the "reading instructions" section of the introduction for help interpreting core box photos and core piece nomenclature 


\section{LVEW Core Box 449}

Depth Interval 9556.5'-9564.7'

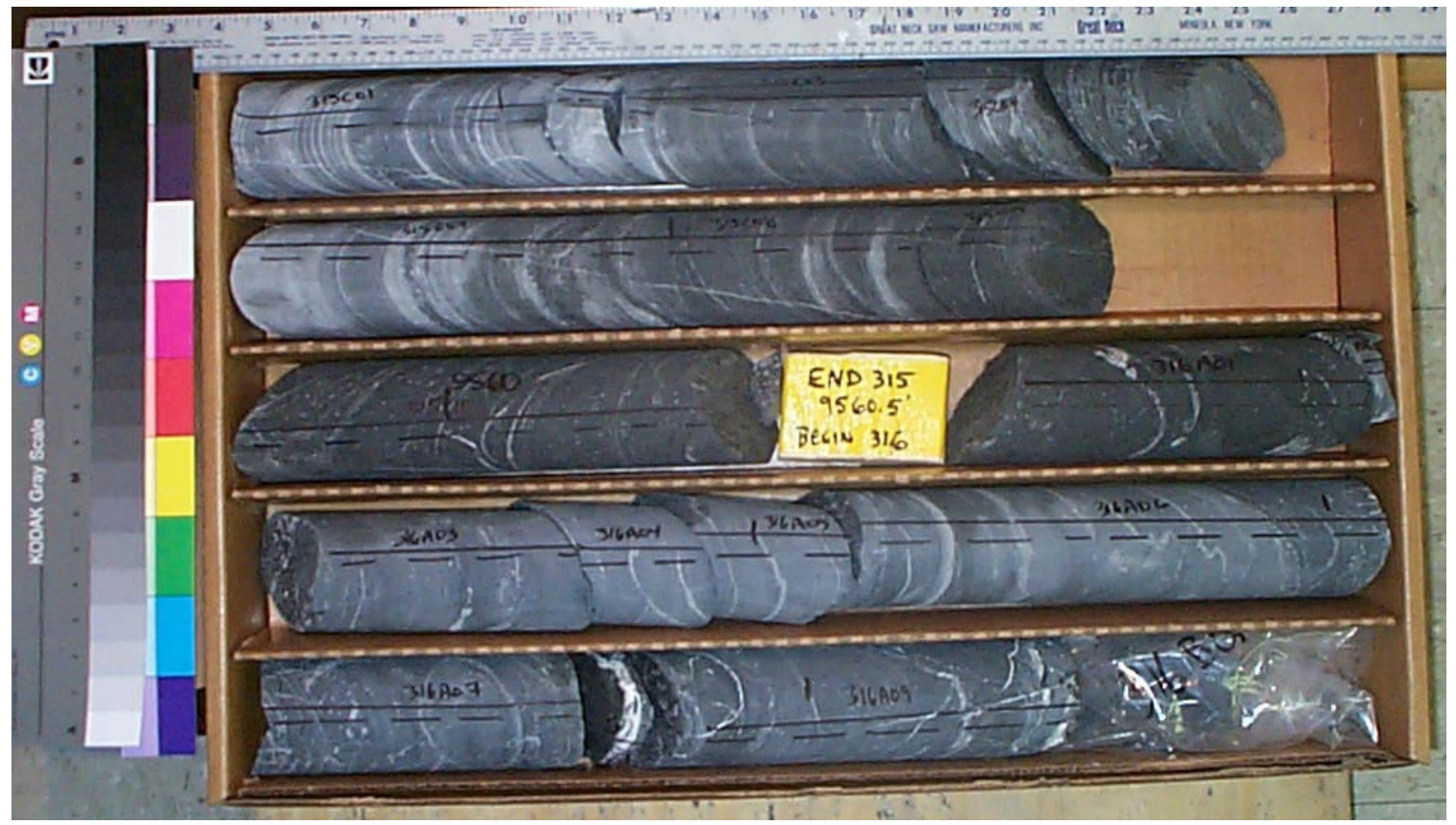

Core Scans included in this box (listed by piece going downhole):
$315 \mathrm{C} 0100$
$315 \mathrm{C} 0300$
$315 \mathrm{C} 0600$
$315 \mathrm{C} 0700$
$315 \mathrm{C} 0800$
$315 \mathrm{C} 0900$
$315 \mathrm{C} 1000$

316A0100
316A0300
316A0400
316A0500
316A0600
316A0700
316A0900

See the "reading instructions" section of the introduction for help interpreting core box photos and core piece nomenclature 


\section{LVEW Core Box 450}

Depth Interval 9564.7'-9572.5'

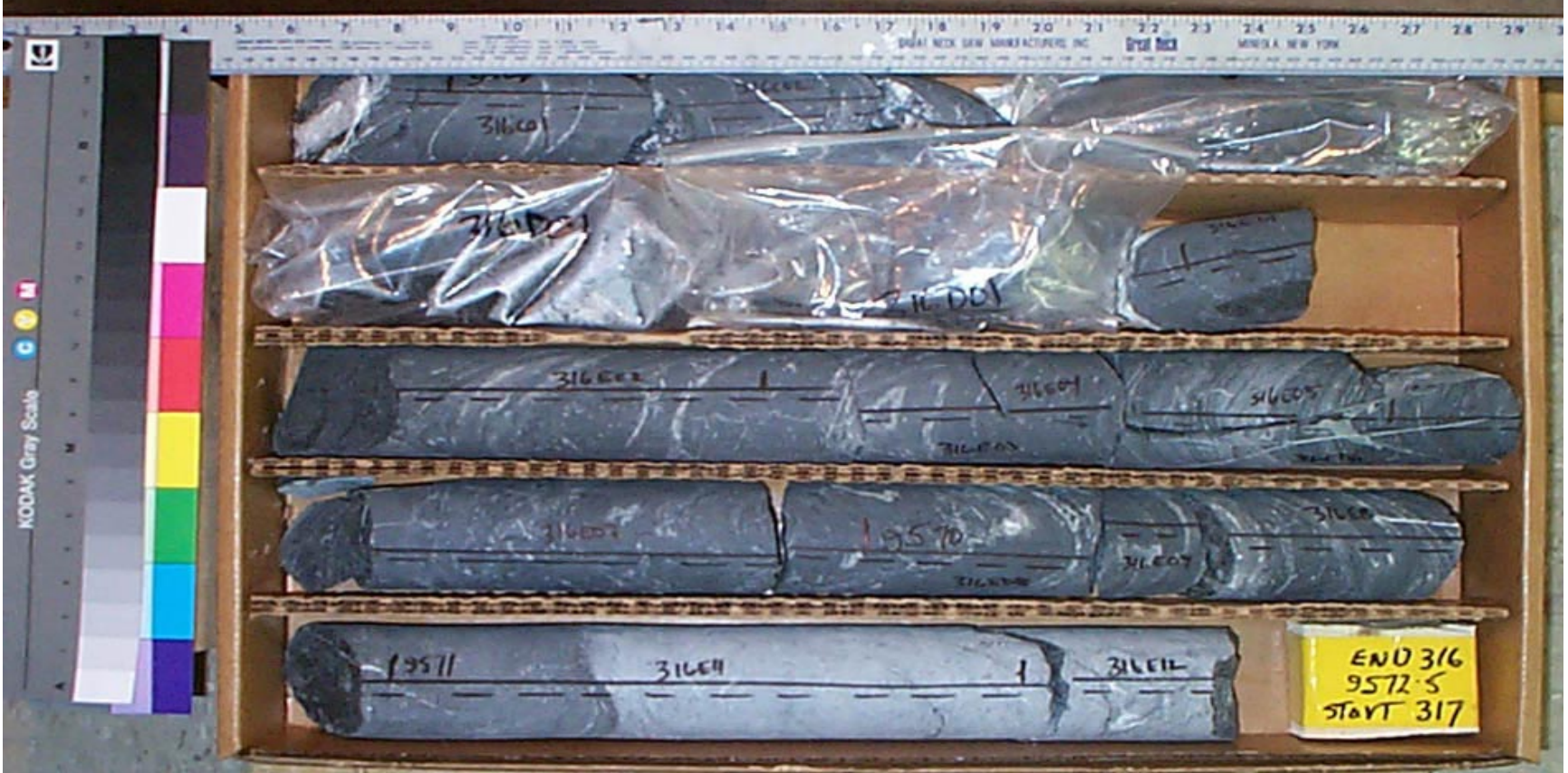

Core Scans included in this box (listed by piece going downhole):
$316 \mathrm{C} 0100$
$316 \mathrm{C} 0200$
$316 \mathrm{E} 0200$
$316 \mathrm{E} 0300$
$316 \mathrm{E} 0600$
$316 \mathrm{E} 0700$
$316 \mathrm{E} 0800$
$316 \mathrm{E} 1000$
$316 \mathrm{E} 1100$
$316 \mathrm{E} 1200$

See the "reading instructions" section of the introduction for help interpreting core box photos and core piece nomenclature 


\section{LVEW Core Box 451}

Depth Interval 9572.5'-9581.0'

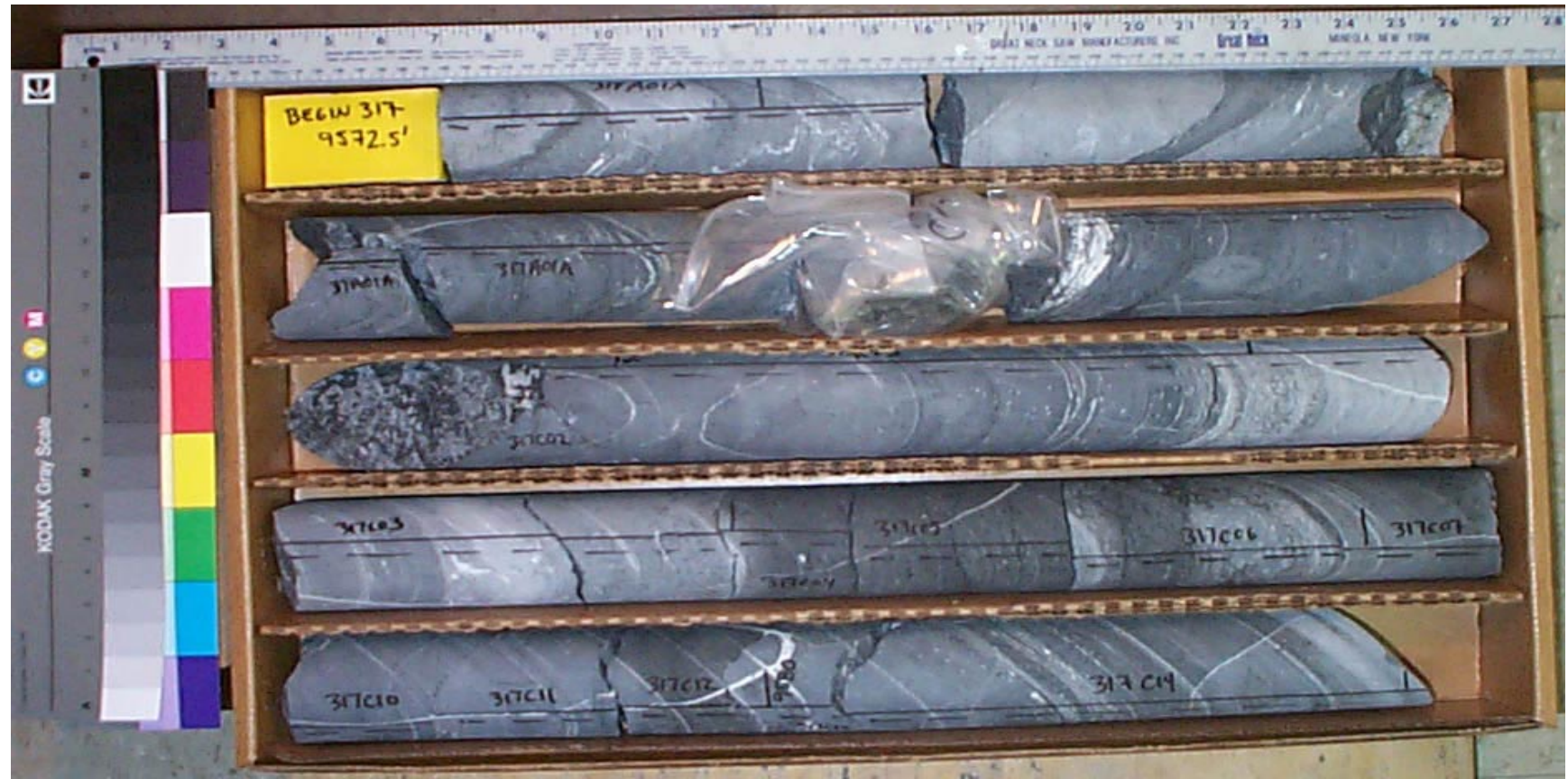

Core Scans included in this box (listed by piece going downhole):

$317 \mathrm{~A} 010 \mathrm{~A}$
$317 \mathrm{C} 0100$
$317 \mathrm{C} 0200$
$317 \mathrm{C} 030 \mathrm{~A}$
$317 \mathrm{C} 0400$
$317 \mathrm{C} 0500$
$317 \mathrm{C} 0600$
$317 \mathrm{C} 0700$
$317 \mathrm{C} 1000$
$317 \mathrm{C} 1100$
$317 \mathrm{C} 1200$
$317 \mathrm{C} 1400$

See the "reading instructions" section of the introduction for help interpreting core box photos and core piece nomenclature 


\section{LVEW Core Box 452}

Depth Interval 9581.0'-9589.4'

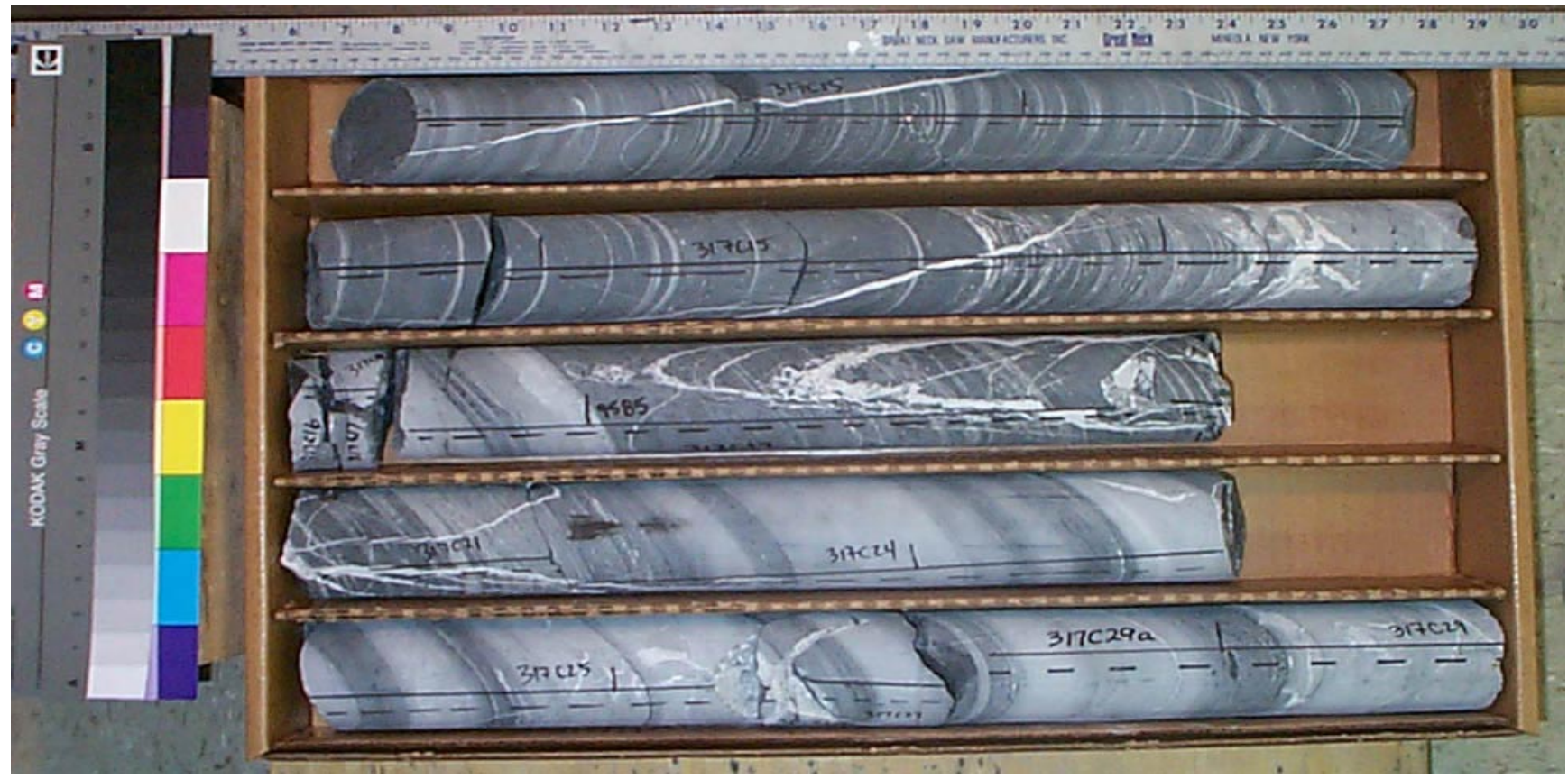

Core Scans included in this box (listed by piece going downhole):
$317 \mathrm{C} 151 \mathrm{~A}$
$317 \mathrm{C} 152 \mathrm{~A}$
$317 \mathrm{C} 1900$
$317 \mathrm{C} 2400$
$317 \mathrm{C} 2500$
$317 \mathrm{C} 290 \mathrm{~A}$

See the "reading instructions" section of the introduction for help interpreting core box photos and core piece nomenclature 


\section{LVEW Core Box 453}

Depth Interval 9589.4'-9596.4'

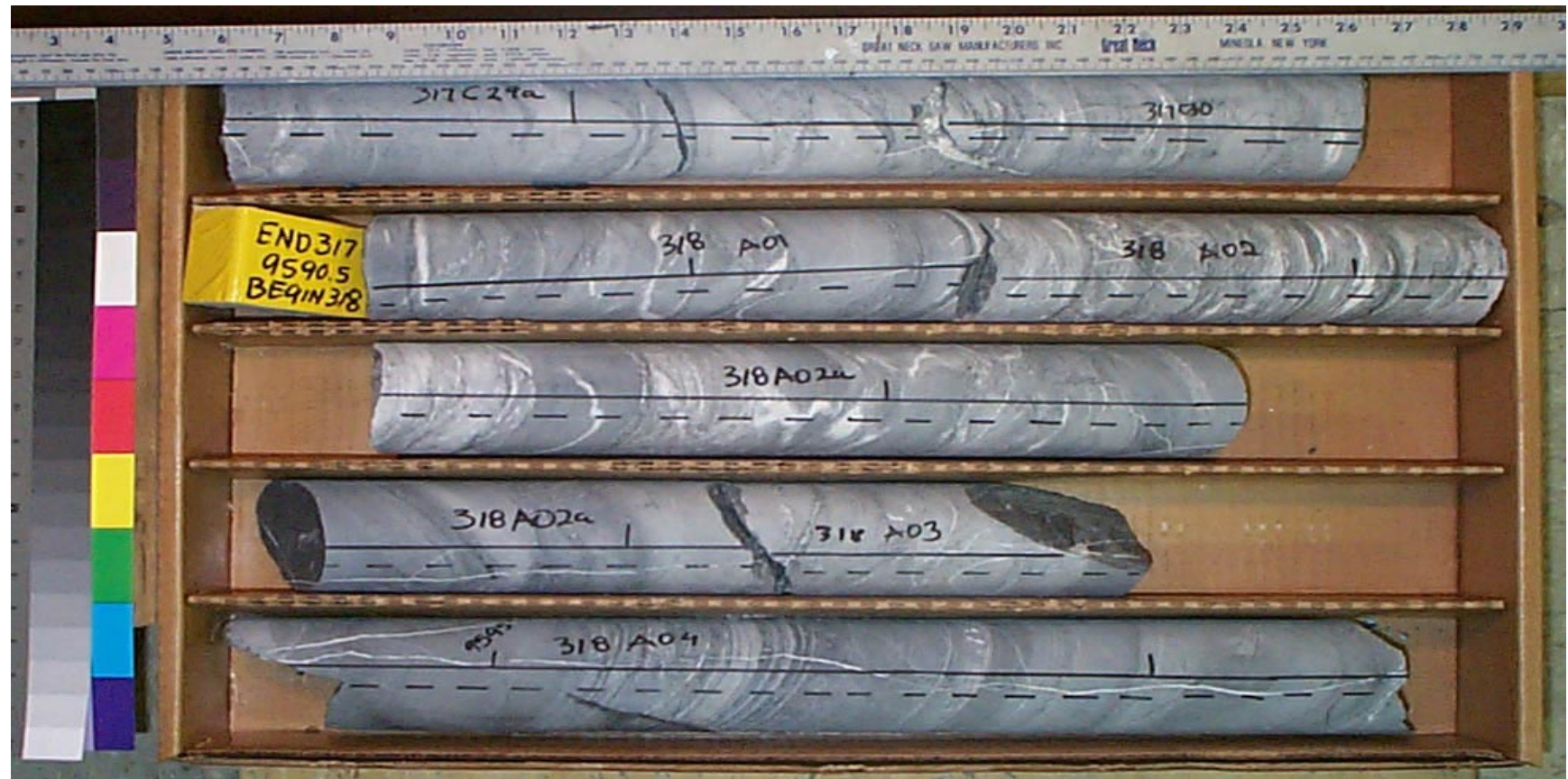

Core Scans included in this box (listed by piece going downhole):

317C290A
318A0100
318A020A
318A0300
318A040A

See the "reading instructions" section of the introduction for help interpreting core box photos and core piece nomenclature 


\section{LVEW Core Box 454}

Depth Interval 9596.4'-9603.8'

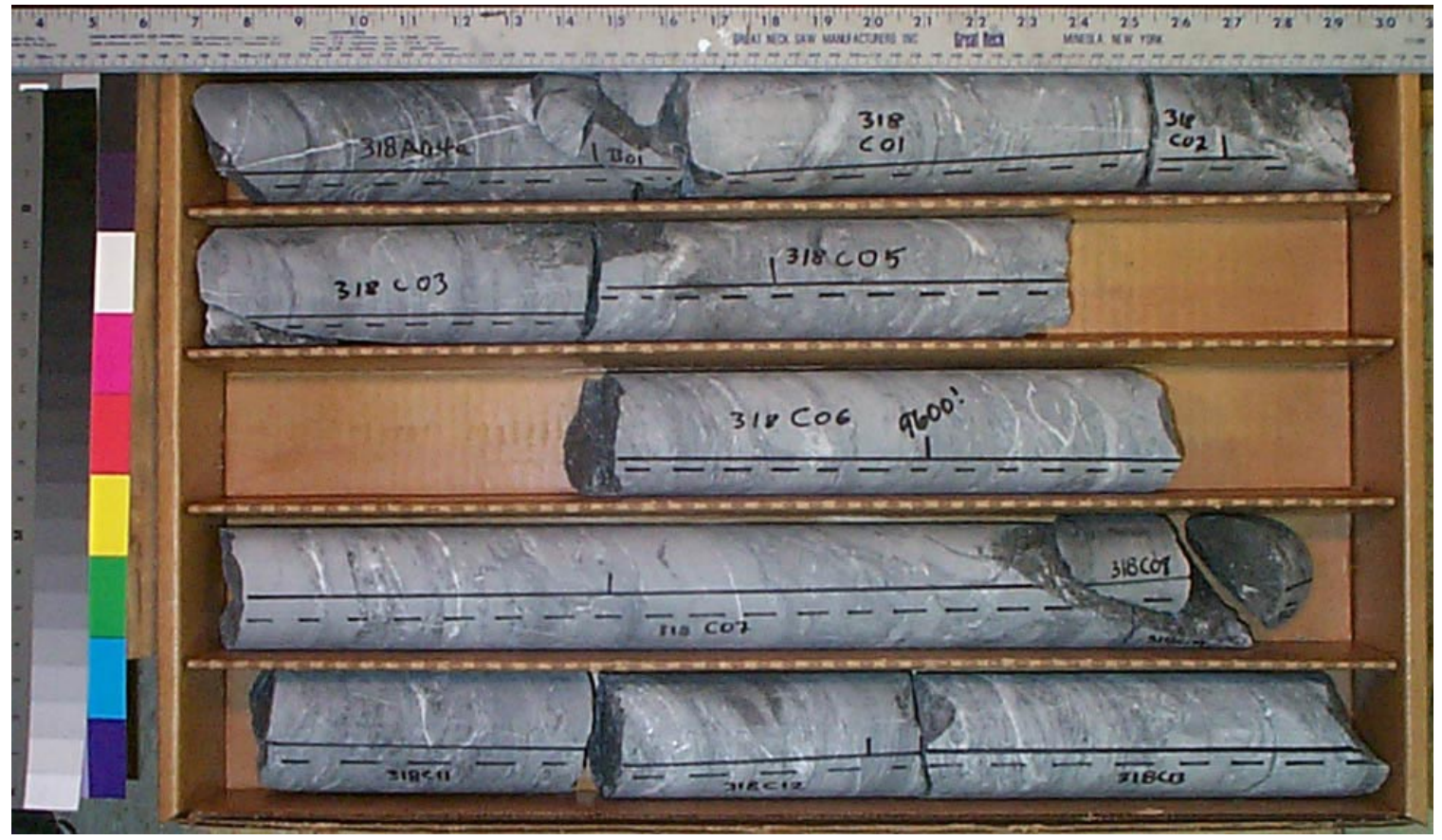

Core Scans included in this box (listed by piece going downhole):
318A040A
$318 \mathrm{C} 0100$
$318 \mathrm{C} 0500$
$318 \mathrm{C} 0600$
$318 \mathrm{C} 0700$
$318 \mathrm{C} 1100$
$318 \mathrm{C} 1200$
$318 \mathrm{C} 1300$

See the "reading instructions" section of the introduction for help interpreting core box photos and core piece nomenclature 


\section{LVEW Core Box 455}

Depth Interval 9603.8'-9610.3'

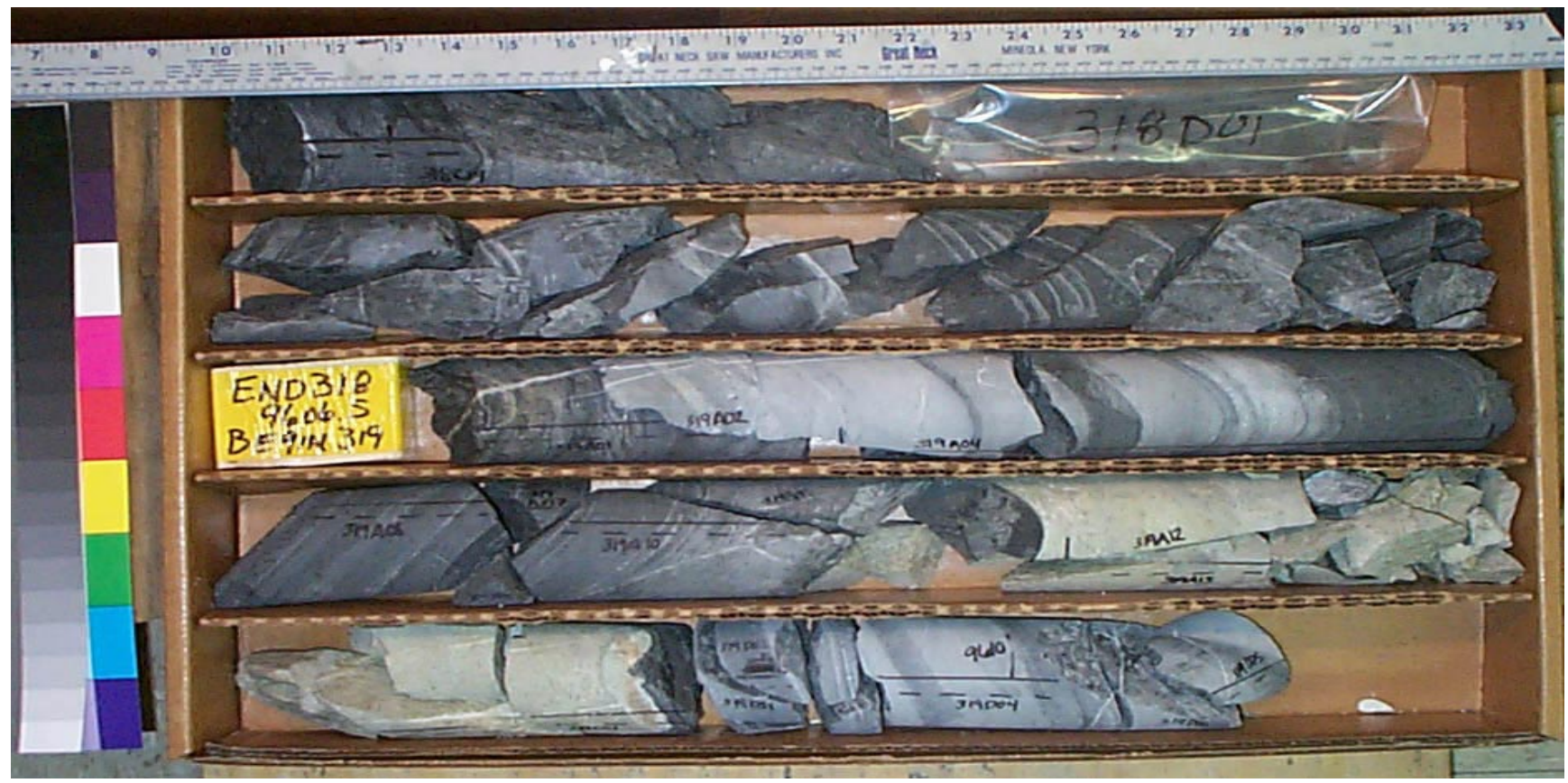

Core Scans included in this box (listed by piece going downhole):
319A0100
319A0500
319A0600
$319 \mathrm{C} 0100$
319D0400

See the "reading instructions" section of the introduction for help interpreting core box photos and core piece nomenclature 


\section{LVEW Core Box 456}

Depth Interval 9610.3'-9618.3'

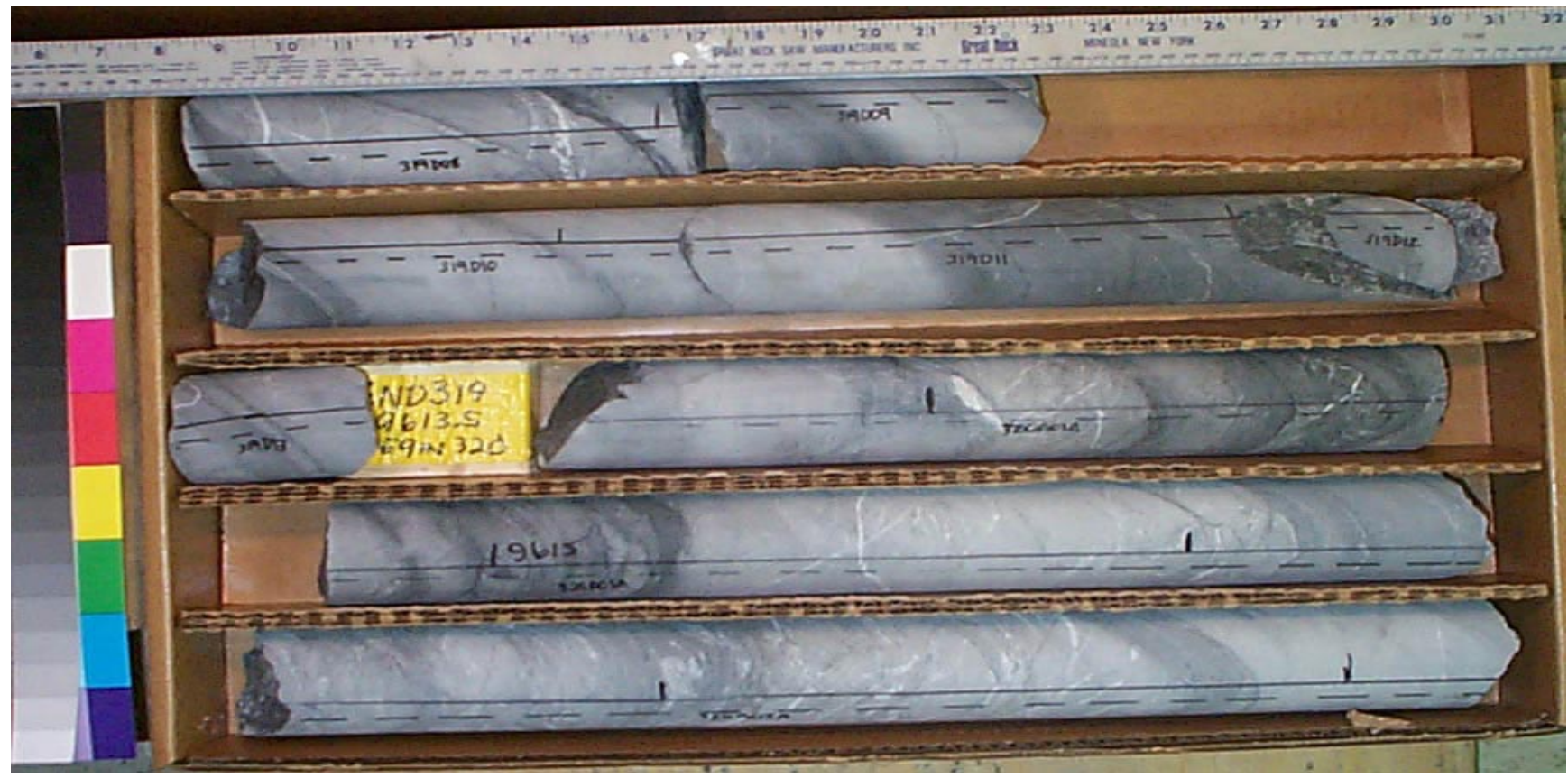

Core Scans included in this box (listed by piece going downhole):
319D0800
319D0900
319D1000
319D1100
$320 \mathrm{~A} 010 \mathrm{~A}$ 320A021A

See the "reading instructions" section of the introduction for help interpreting core box photos and core piece nomenclature 


\section{LVEW Core Box 457}

Depth Interval 9618.3'-9625.8'

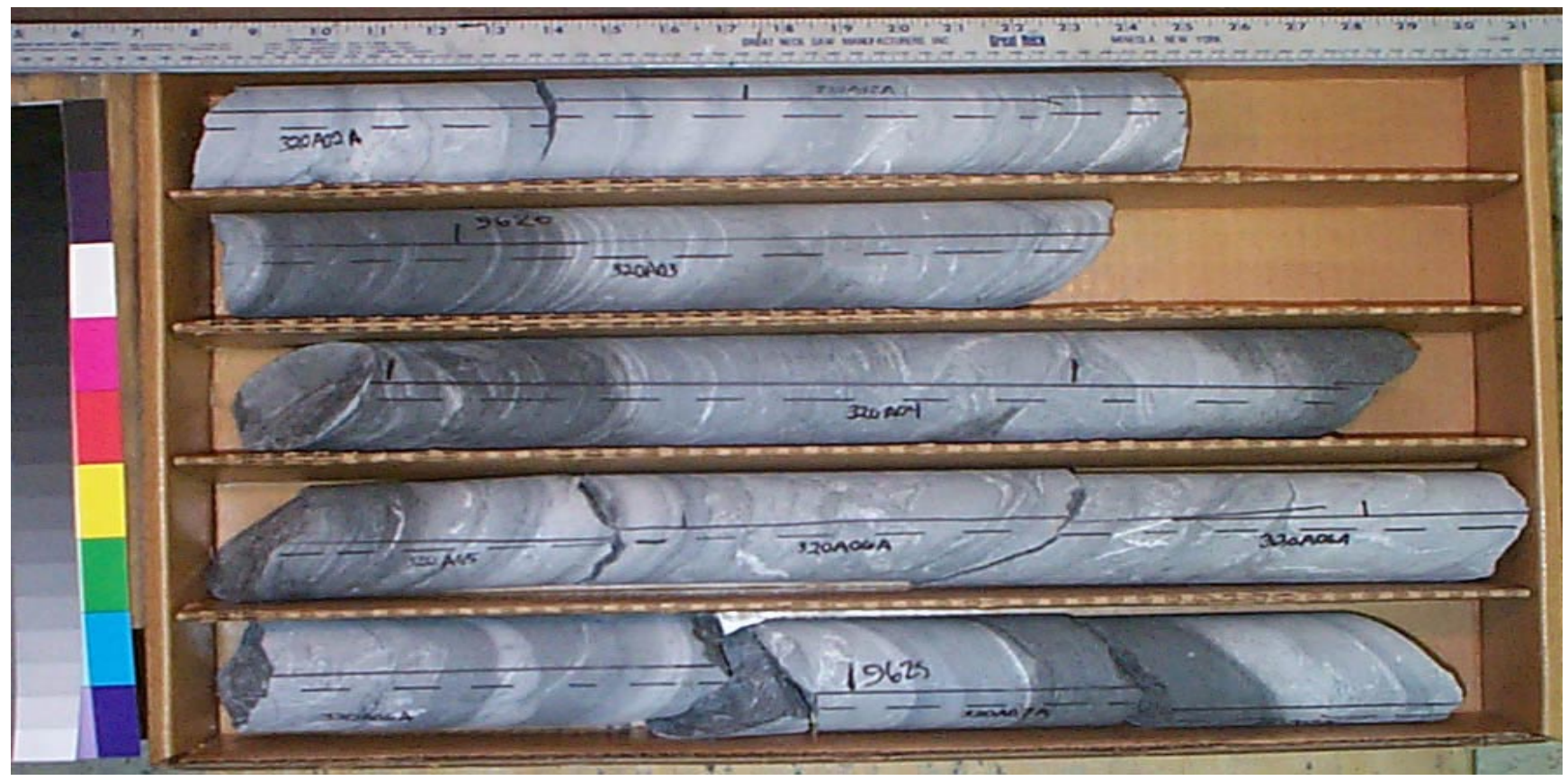

Core Scans included in this box (listed by piece going downhole):
$320 \mathrm{~A} 022 \mathrm{~A}$
$320 \mathrm{~A} 0300$
$320 \mathrm{~A} 0400$
$320 \mathrm{~A} 0500$
320A060A

See the "reading instructions" section of the introduction for help interpreting core box photos and core piece nomenclature 


\section{LVEW Core Box 458}

Depth Interval 9625.8'-9632.9'

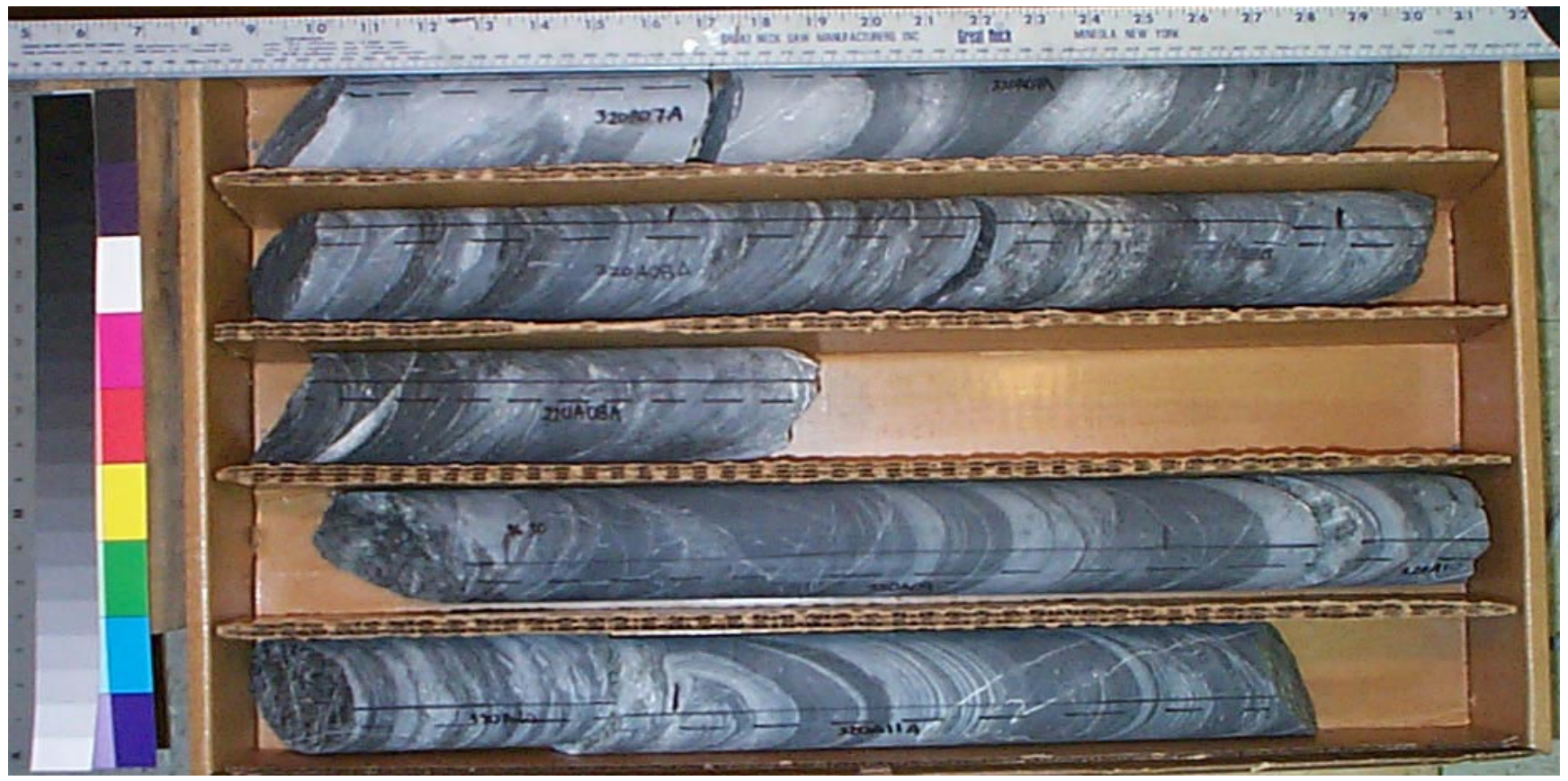

Core Scans included in this box (listed by piece going downhole):

320A070A
320A080A
320A0900
320A100A
320A111A

See the "reading instructions" section of the introduction for help interpreting core box photos and core piece nomenclature 


\section{LVEW Core Box 459}

Depth Interval 9632.9'-9640.5'

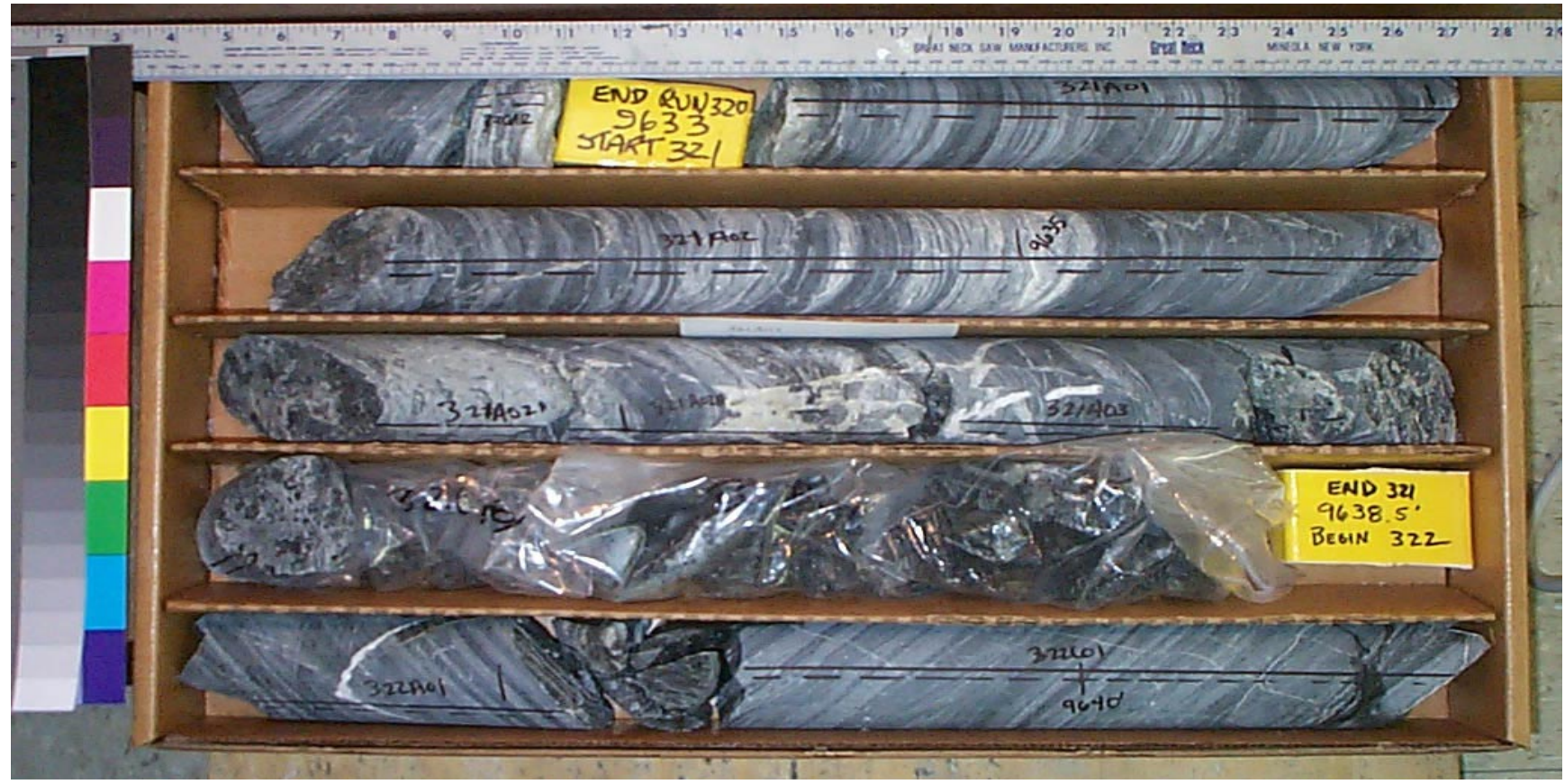

Core Scans included in this box (listed by piece going downhole):
$320 \mathrm{~A} 112 \mathrm{~A}$
$320 A 1200$
$321 \mathrm{~A} 0100$
$321 \mathrm{~A} 020 \mathrm{~A}$
$321 \mathrm{~A} 0300$
$322 \mathrm{C} 0100$

See the "reading instructions" section of the introduction for help interpreting core box photos and core piece nomenclature 


\section{LVEW Core Box 460}

Depth Interval 9640.5'-9648.0'

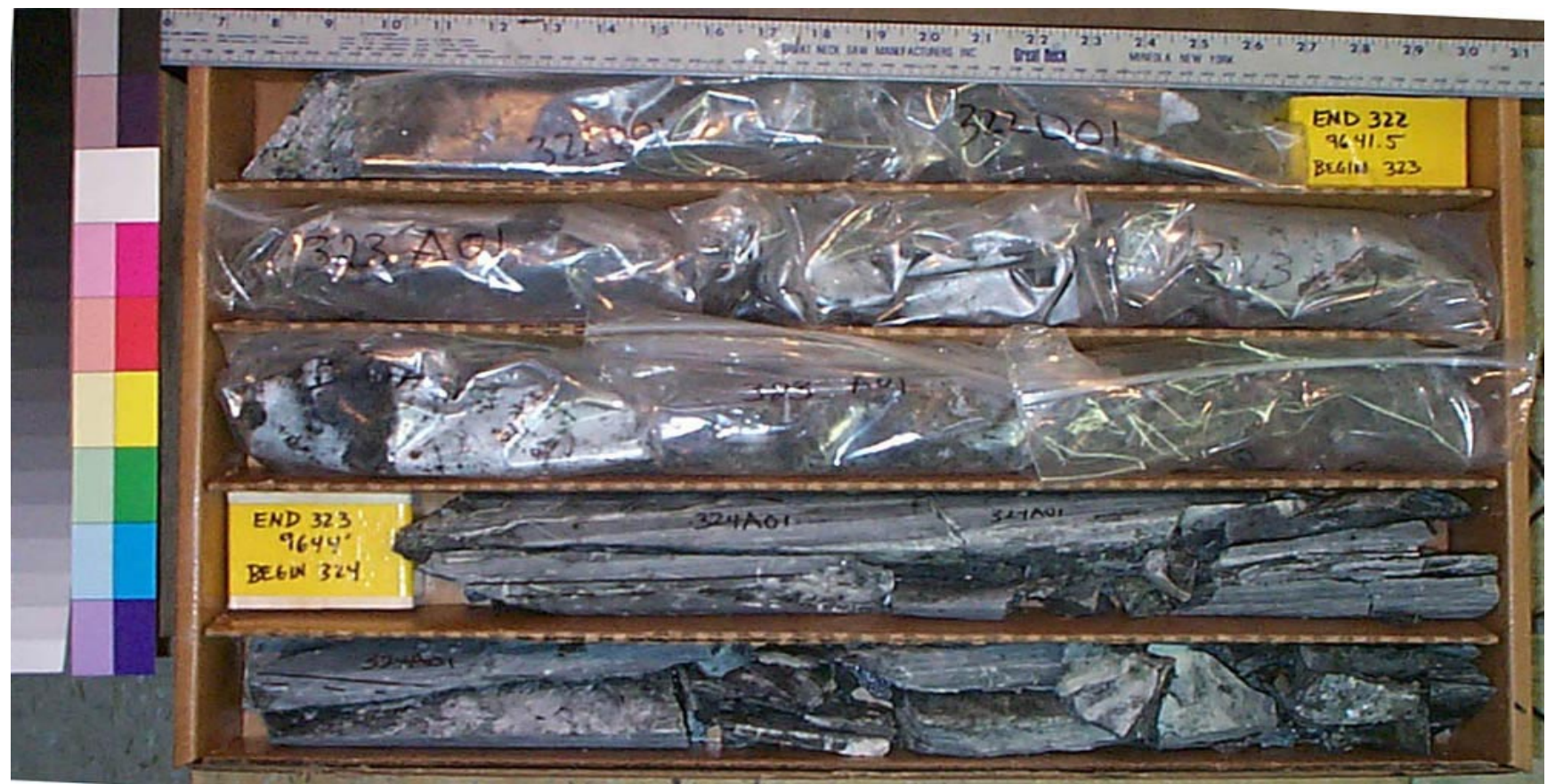

Core Scans included in this box (listed by piece going downhole):

\section{(No Core Scans Included in This Box)}

See the "reading instructions" section of the introduction for help interpreting core box photos and core piece nomenclature 
LVEW Core Box 461

Depth Interval 9648.0'-9654.5'

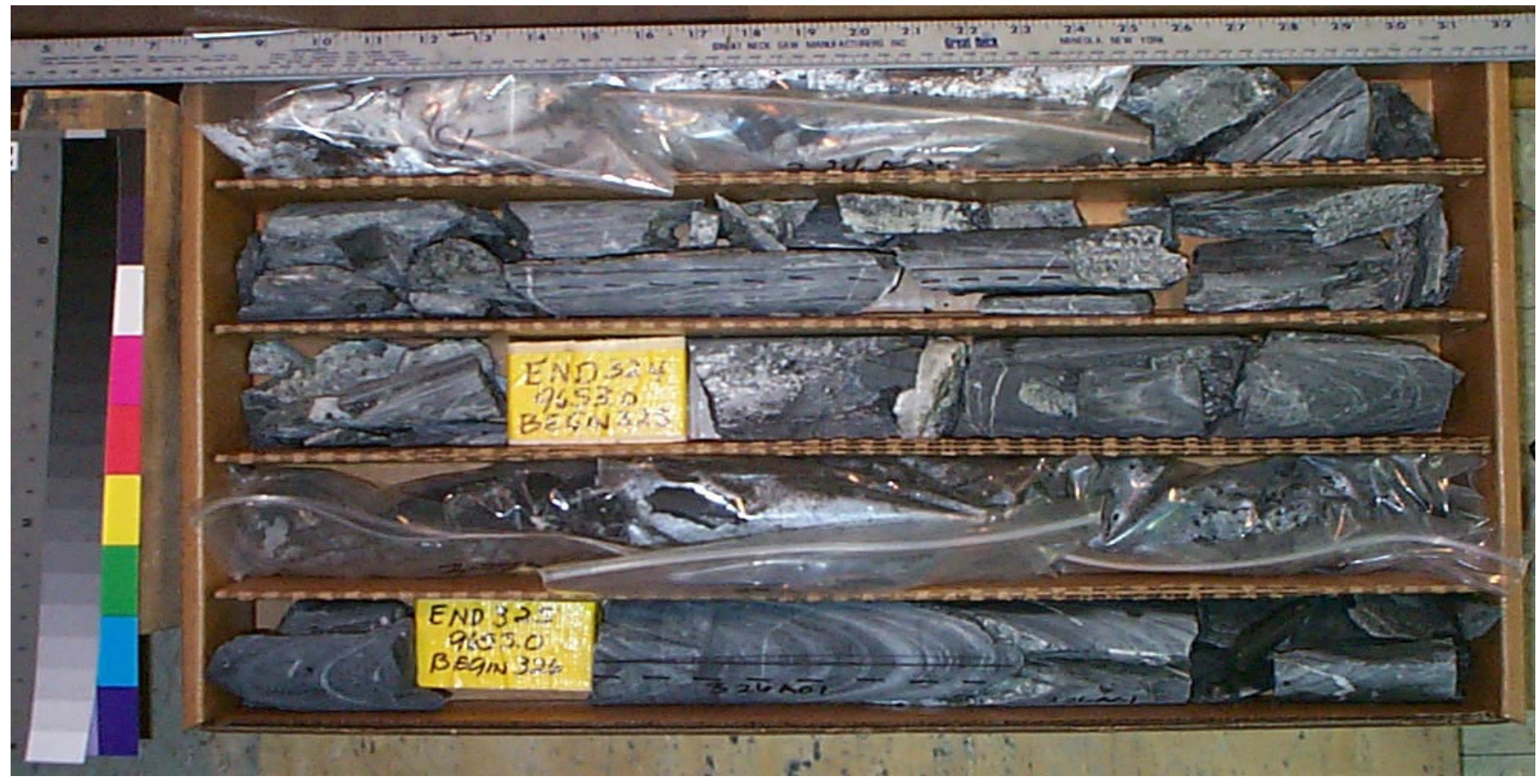

Core Scans included in this box (listed by piece going downhole):

(No Core Scans Included in This Box)

See the "reading instructions" section of the introduction for help interpreting core box photos and core piece nomenclature 


\section{LVEW Core Box 462}

Depth Interval 9654.5'-9660.0'

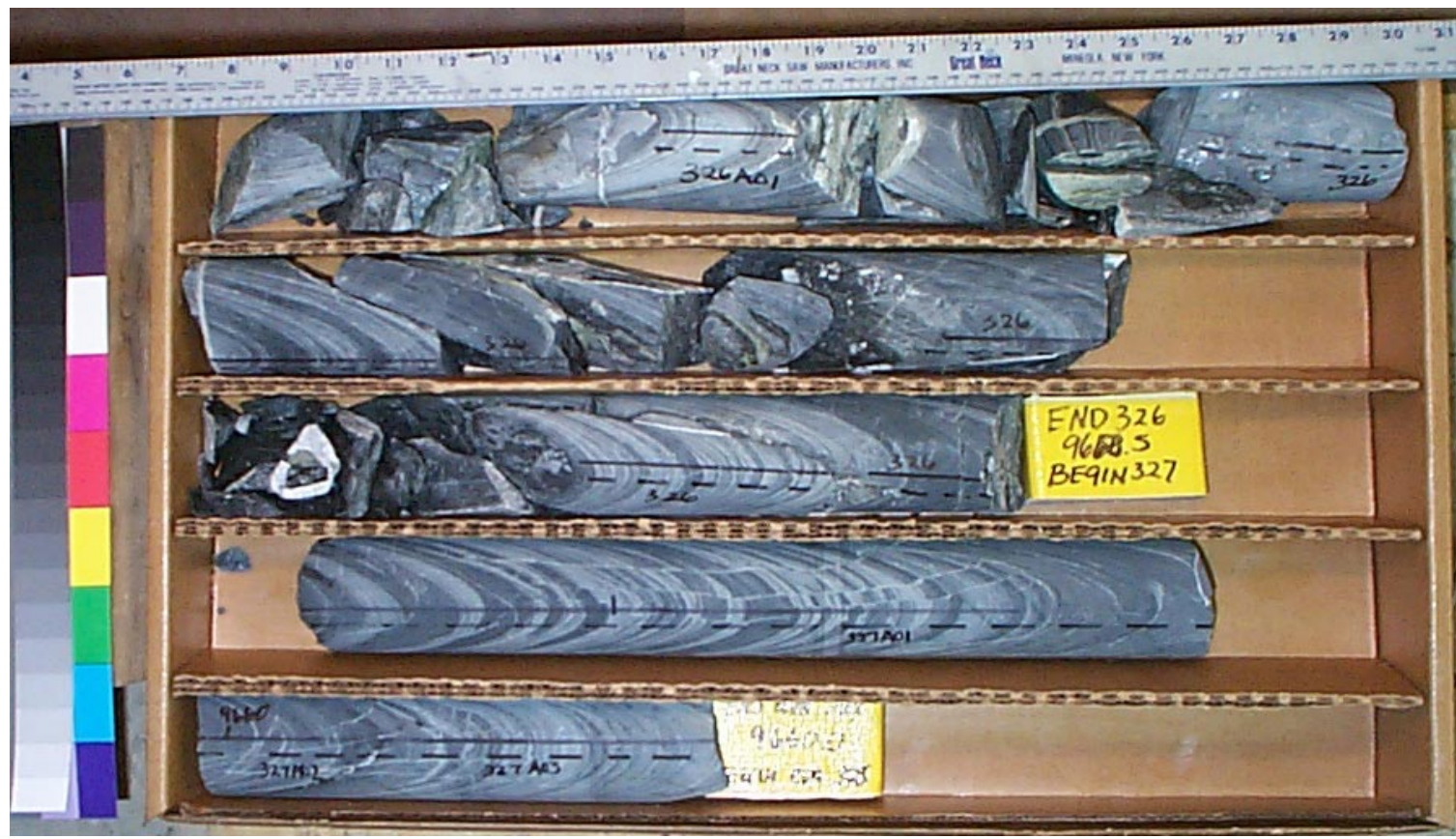

Core Scans included in this box (listed by piece going downhole):

\section{$327 \mathrm{~A} 0100$ \\ $327 \mathrm{~A} 0300$}

See the "reading instructions" section of the introduction for help interpreting core box photos and core piece nomenclature 


\section{LVEW Core Box 463}

Depth Interval 9660.0'-9667.8'

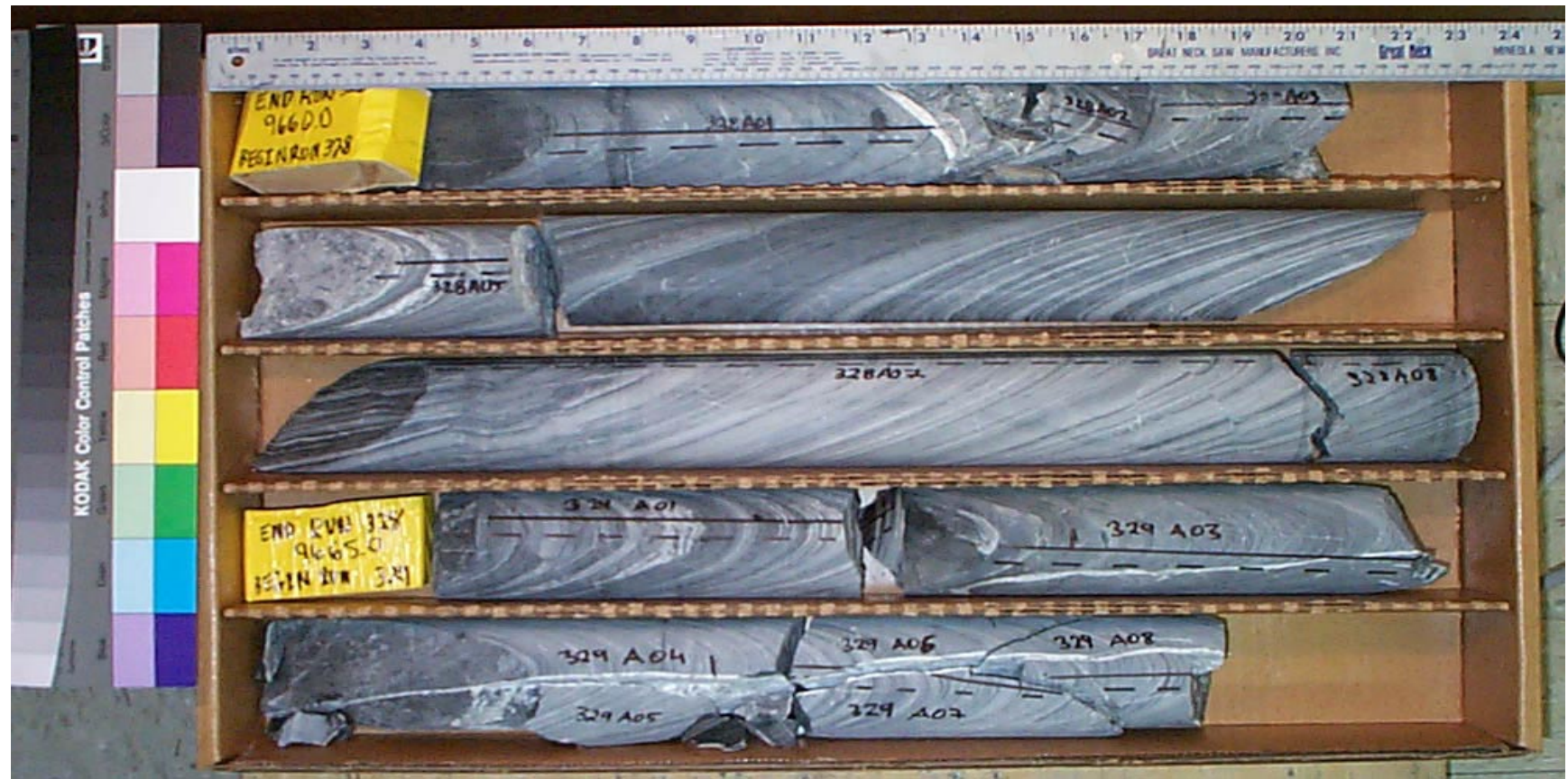

Core Scans included in this box (listed by piece going downhole):

$$
\begin{aligned}
& 328 A 0100 \\
& 328 A 0500 \\
& 328 A 0600 \\
& 328 A 0700 \\
& 328 A 0800 \\
& \text { 329A0100 }
\end{aligned}
$$

See the "reading instructions" section of the introduction for help interpreting core box photos and core piece nomenclature 


\section{LVEW Core Box 464}

Depth Interval 9667.8'-9675.0'

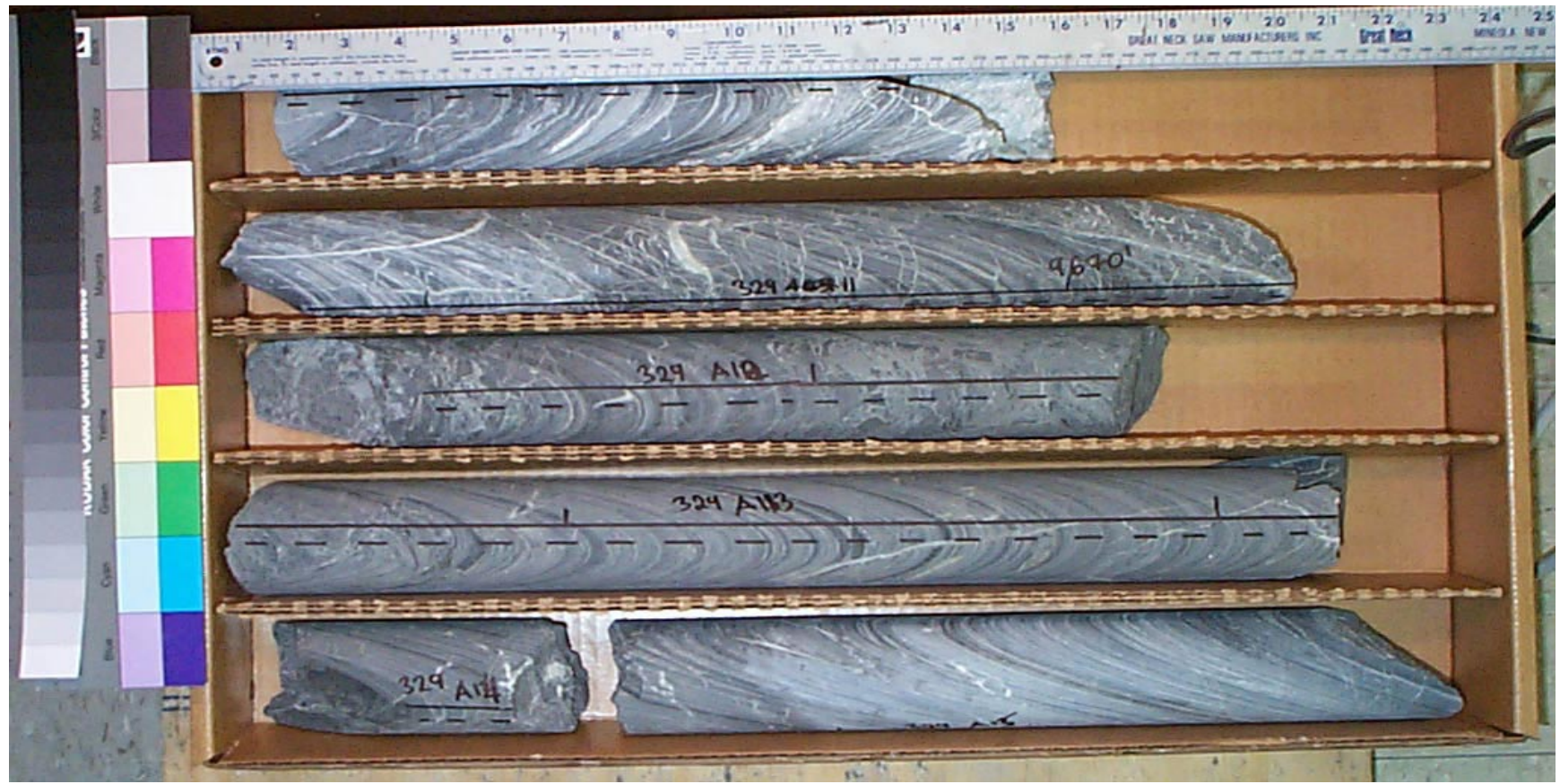

Core Scans included in this box (listed by piece going downhole):

$$
\begin{aligned}
& 329 A 0900 \\
& 329 A 1100 \\
& 329 A 1200 \\
& 329 A 1300 \\
& 329 A 1400 \\
& \text { 329A1500 }
\end{aligned}
$$

See the "reading instructions" section of the introduction for help interpreting core box photos and core piece nomenclature 


\section{LVEW Core Box 465}

Depth Interval 9675.0'-9682.5'

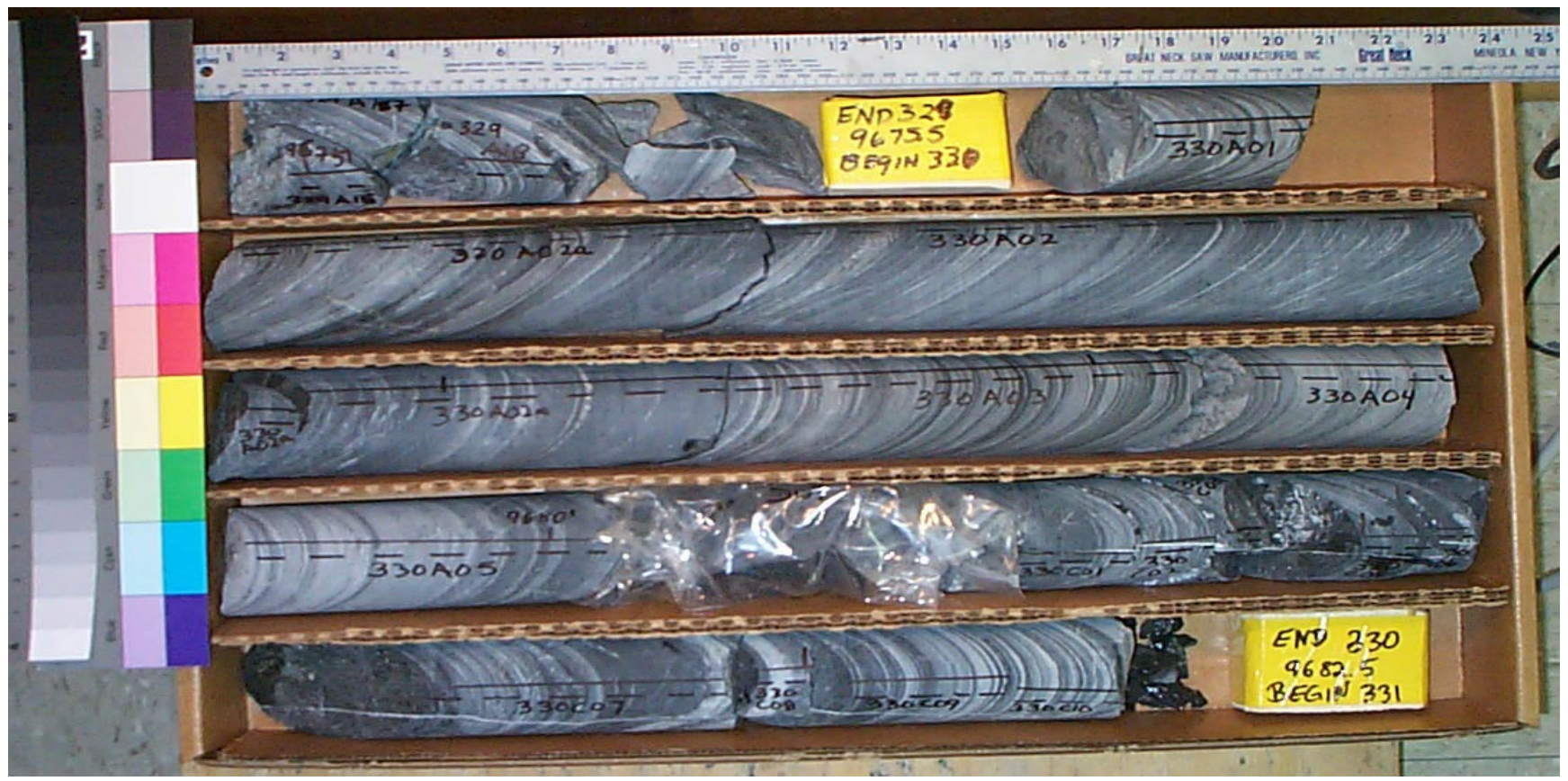

Core Scans included in this box (listed by piece going downhole):

$$
\begin{aligned}
& \text { 330A0100 } \\
& 330 A 0200 \\
& \text { 330A0300 } \\
& \text { 330A0400 } \\
& \text { 330A0500 } \\
& \text { 330C0700 } \\
& \text { 330C0900 }
\end{aligned}
$$

See the "reading instructions" section of the introduction for help interpreting core box photos and core piece nomenclature 


\section{LVEW Core Box 466}

Depth Interval 9682.5'-9689.8'

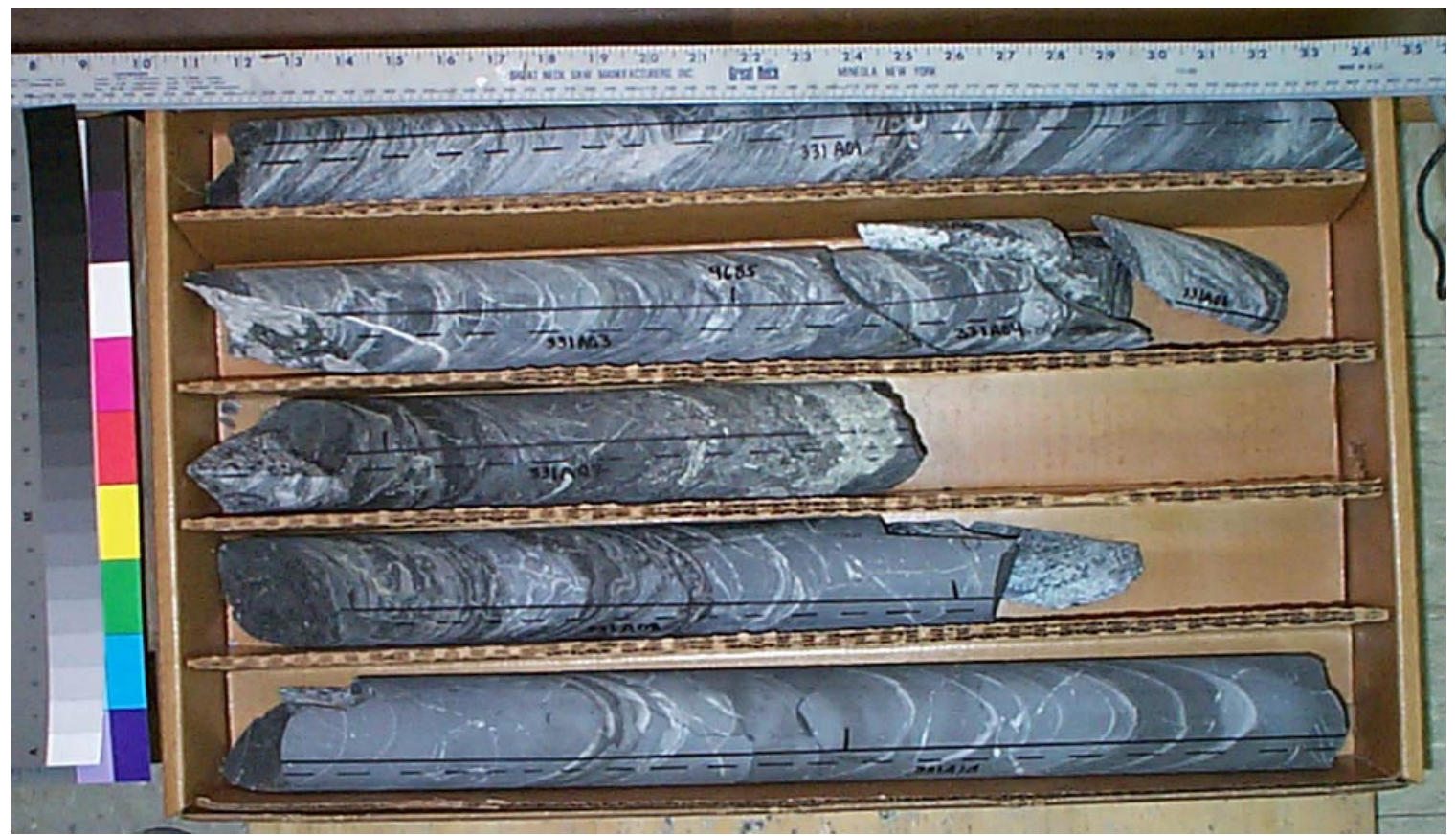

Core Scans included in this box (listed by piece going downhole):

$331 A 0100$
$331 A 0300$
$331 A 0700$
$331 A 0800$
$331 A 100 A$

See the "reading instructions" section of the introduction for help interpreting core box photos and core piece nomenclature 


\section{LVEW Core Box 467}

Depth Interval 9689.8'-9696.2'

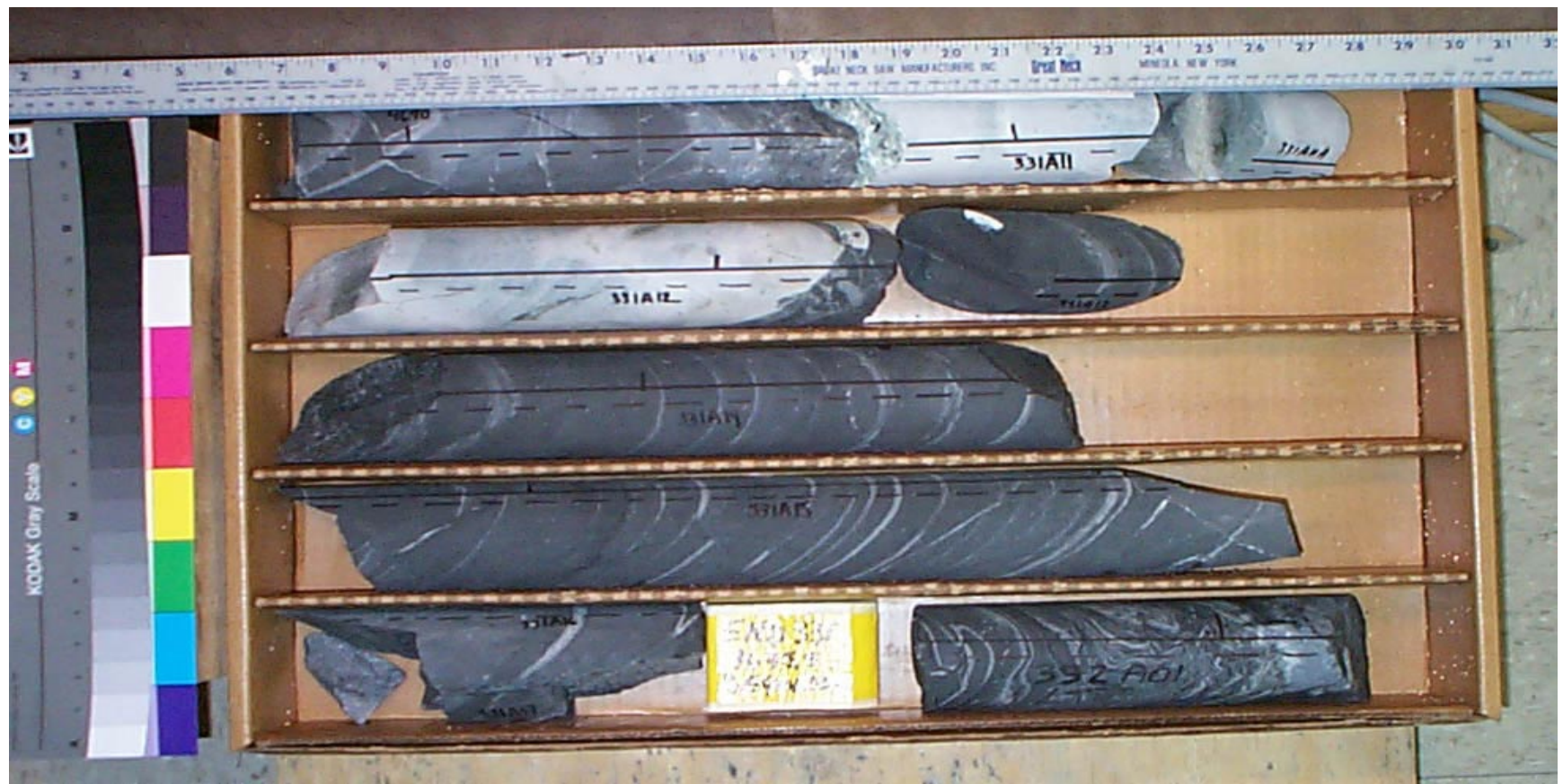

Core Scans included in this box (listed by piece going downhole):

$$
\begin{aligned}
& \text { 331A100A } \\
& 331 A 1100 \\
& 331 A 1200 \\
& 331 A 1400 \\
& 331 A 1500 \\
& 332 A 0100
\end{aligned}
$$

See the "reading instructions" section of the introduction for help interpreting core box photos and core piece nomenclature 


\section{LVEW Core Box 468}

Depth Interval 9696.2'-9703.7'

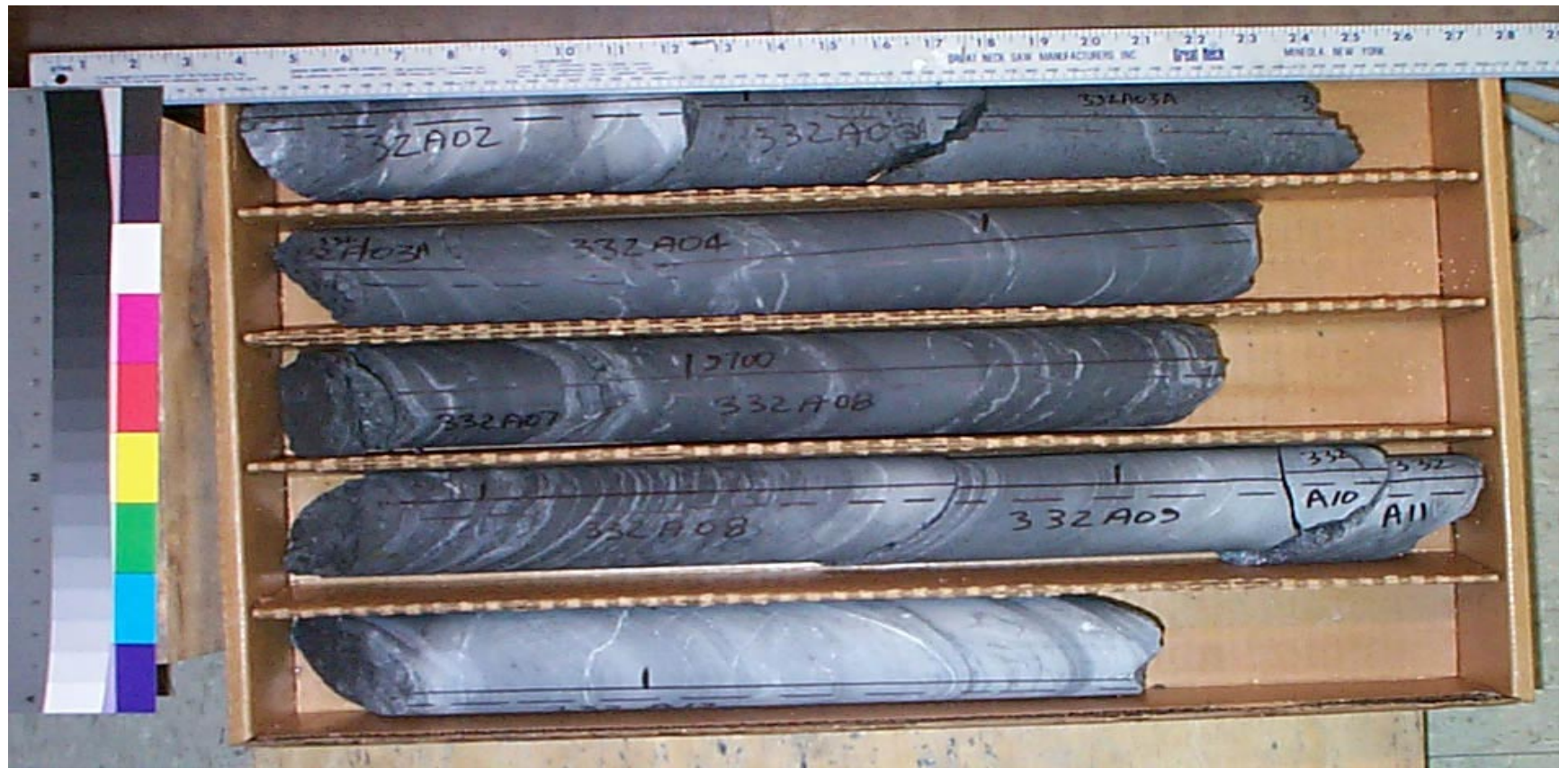

Core Scans included in this box

(listed by piece going downhole):

332A0200
332A030A
332A0400
332A0700
332A080A
332A0900
332A1100
332A1200

See the "reading instructions" section of the introduction for help interpreting core box photos and core piece nomenclature 


\section{LVEW Core Box 469}

Depth Interval 9703.7'-9711.7

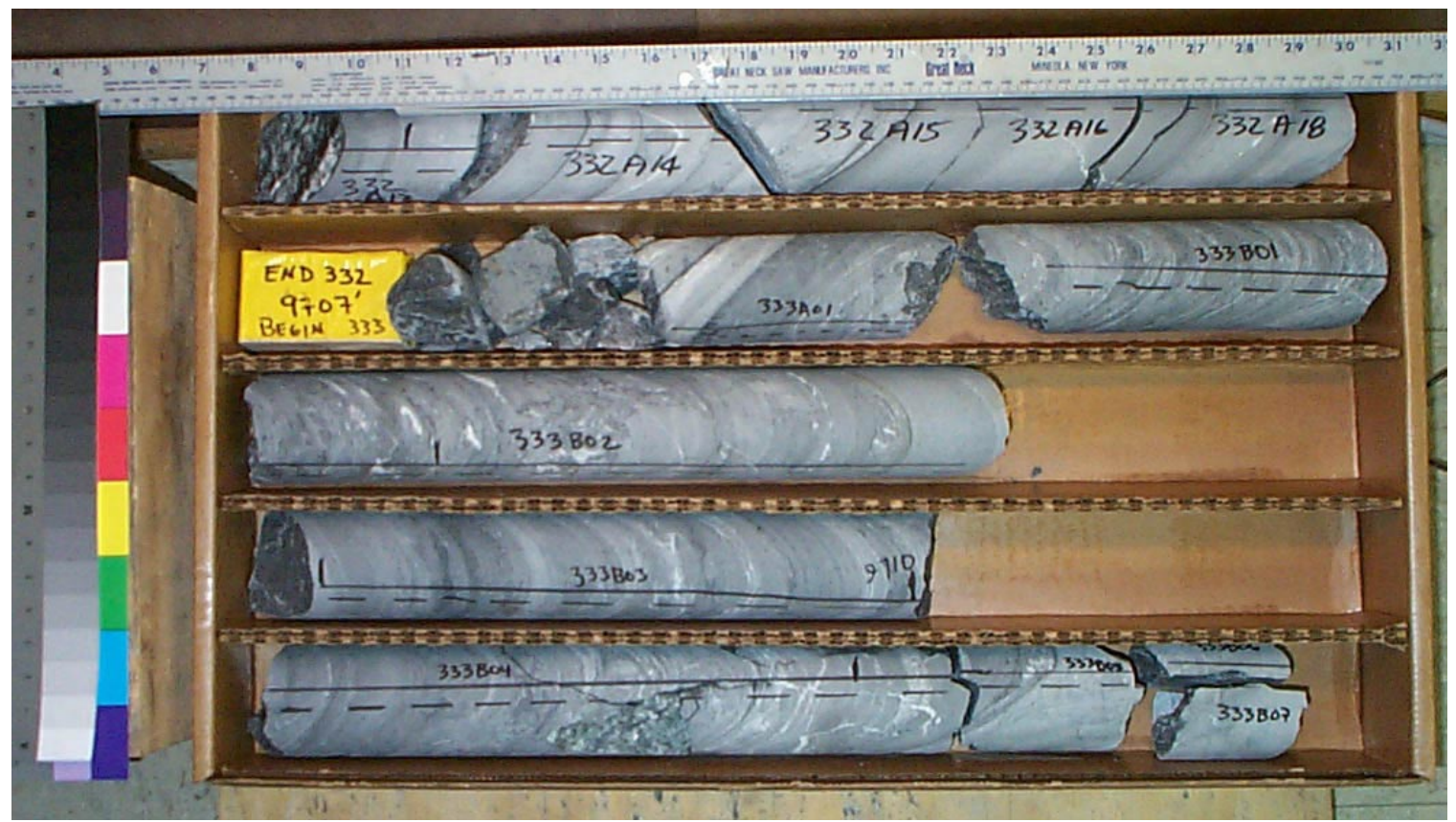

Core Scans included in this box (listed by piece going downhole):
$332 \mathrm{~A} 1300$
$332 \mathrm{~A} 1400$
$332 \mathrm{~A} 1500$
$332 \mathrm{~A} 1600$
$332 \mathrm{~A} 1800$
333A010E
333B0100
333B0200
333B0300
333B0400
333B0500

See the "reading instructions" section of the introduction for help interpreting core box photos and core piece nomenclature 


\section{LVEW Core Box 470}

Depth Interval 9711.7'-9719.2'

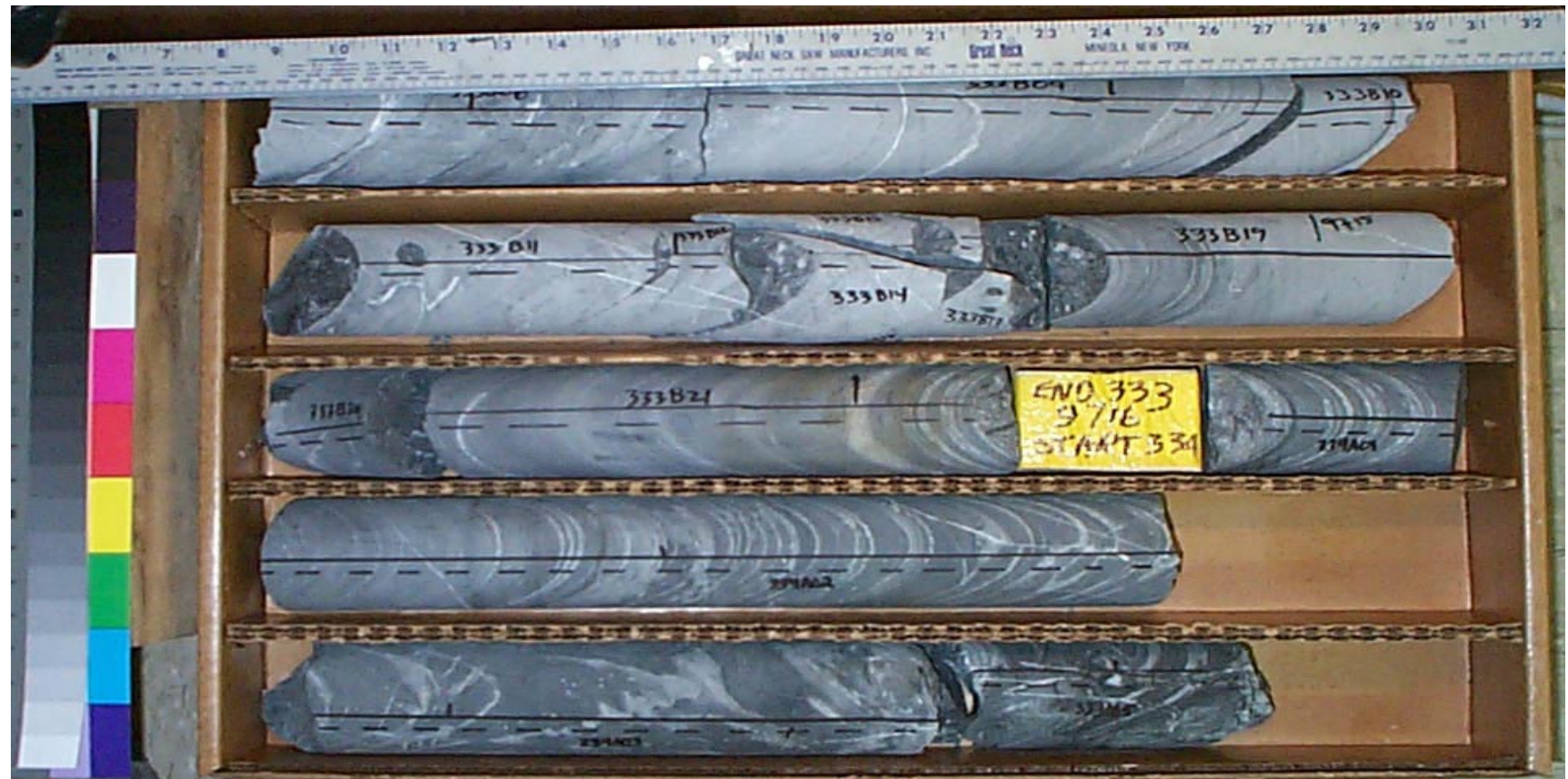

Core Scans included in this box (listed by piece going downhole):
333В0800
333В0900
333B1100
333B1200
333B1900
334A0100
334A0200
$334 \mathrm{~A} 0300$

See the "reading instructions" section of the introduction for help interpreting core box photos and core piece nomenclature 


\section{LVEW Core Box 471}

\section{Depth Interval 9719.2'-9725.8'}

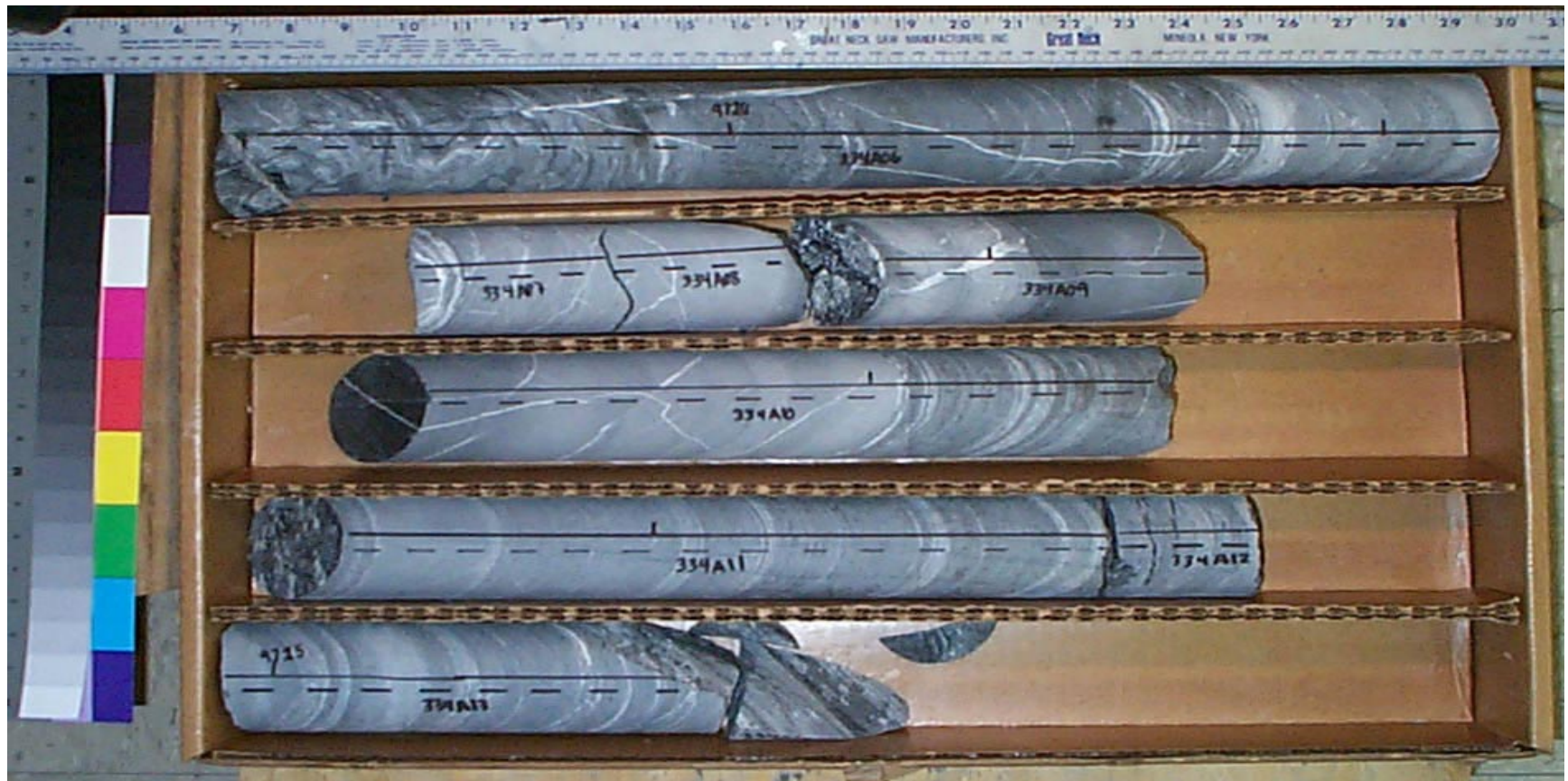

Core Scans included in this box (listed by piece going downhole):

$$
\begin{aligned}
& 334 A 0500 \\
& 334 A 0600 \\
& 334 A 0700 \\
& 334 A 0800 \\
& 334 A 0900 \\
& 334 A 1000 \\
& 334 A 1100 \\
& 334 A 1200 \\
& 334 A 1300
\end{aligned}
$$

See the "reading instructions" section of the introduction for help interpreting core box photos and core piece nomenclature 


\section{LVEW Core Box 472}

Depth Interval 9725.8'-9733.7'

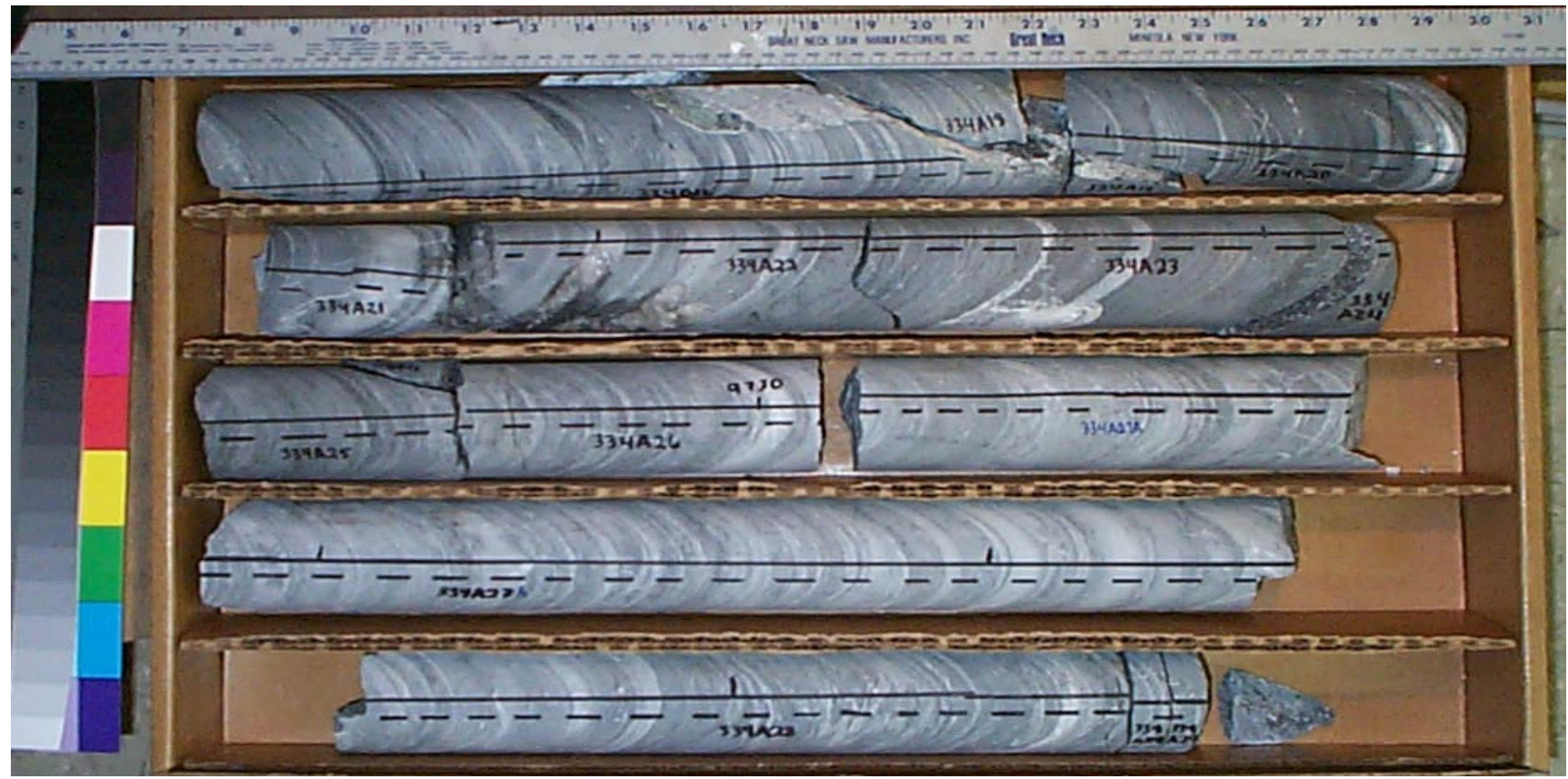

Core Scans included in this box (listed by piece going downhole):
$334 \mathrm{~A} 1600$
$334 \mathrm{~A} 2000$
$334 \mathrm{~A} 2100$
$334 \mathrm{~A} 2200$
$334 \mathrm{~A} 2300$
$334 \mathrm{~A} 2500$
$334 \mathrm{~A} 2600$
$334 \mathrm{~A} 270 \mathrm{~A}$
$334 \mathrm{~A} 2800$

See the "reading instructions" section of the introduction for help interpreting core box photos and core piece nomenclature 


\section{LVEW Core Box 473}

Depth Interval 9733.7'-9741.2'

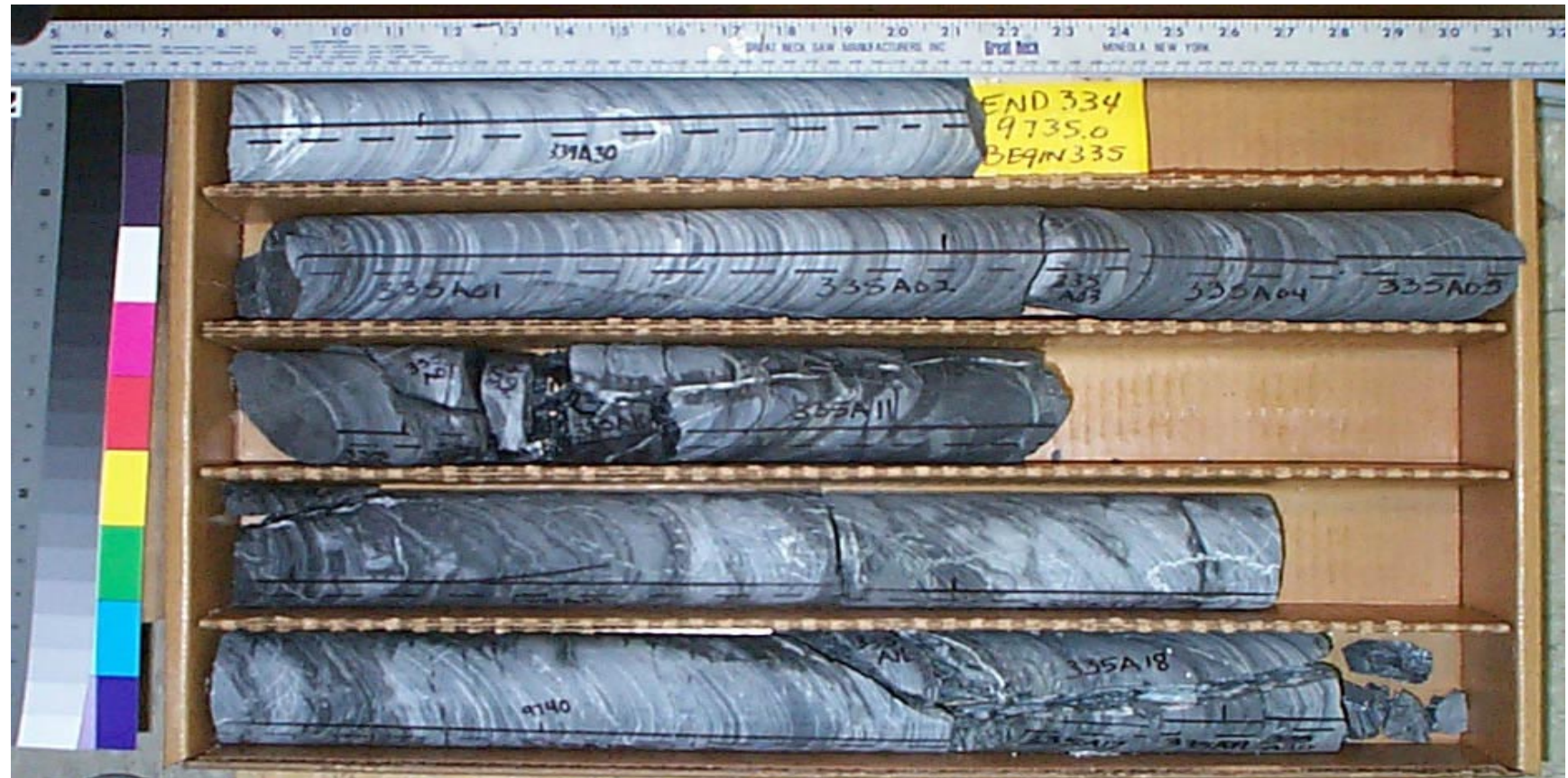

Core Scans included in this box (listed by piece going downhole):

$$
\begin{aligned}
& 334 \mathrm{~A} 3000 \\
& 335 \mathrm{~A} 0100 \\
& 335 \mathrm{~A} 0200 \\
& 335 \mathrm{~A} 040 \mathrm{~A} \\
& 335 \mathrm{~A} 0500 \\
& 335 \mathrm{~A} 1100 \\
& 335 \mathrm{~A} 1200 \\
& \text { 335A1400 } \\
& \text { 335A1500 }
\end{aligned}
$$

See the "reading instructions" section of the introduction for help interpreting core box photos and core piece nomenclature 


\section{LVEW Core Box 474}

Depth Interval 9741.2'-9748.5'

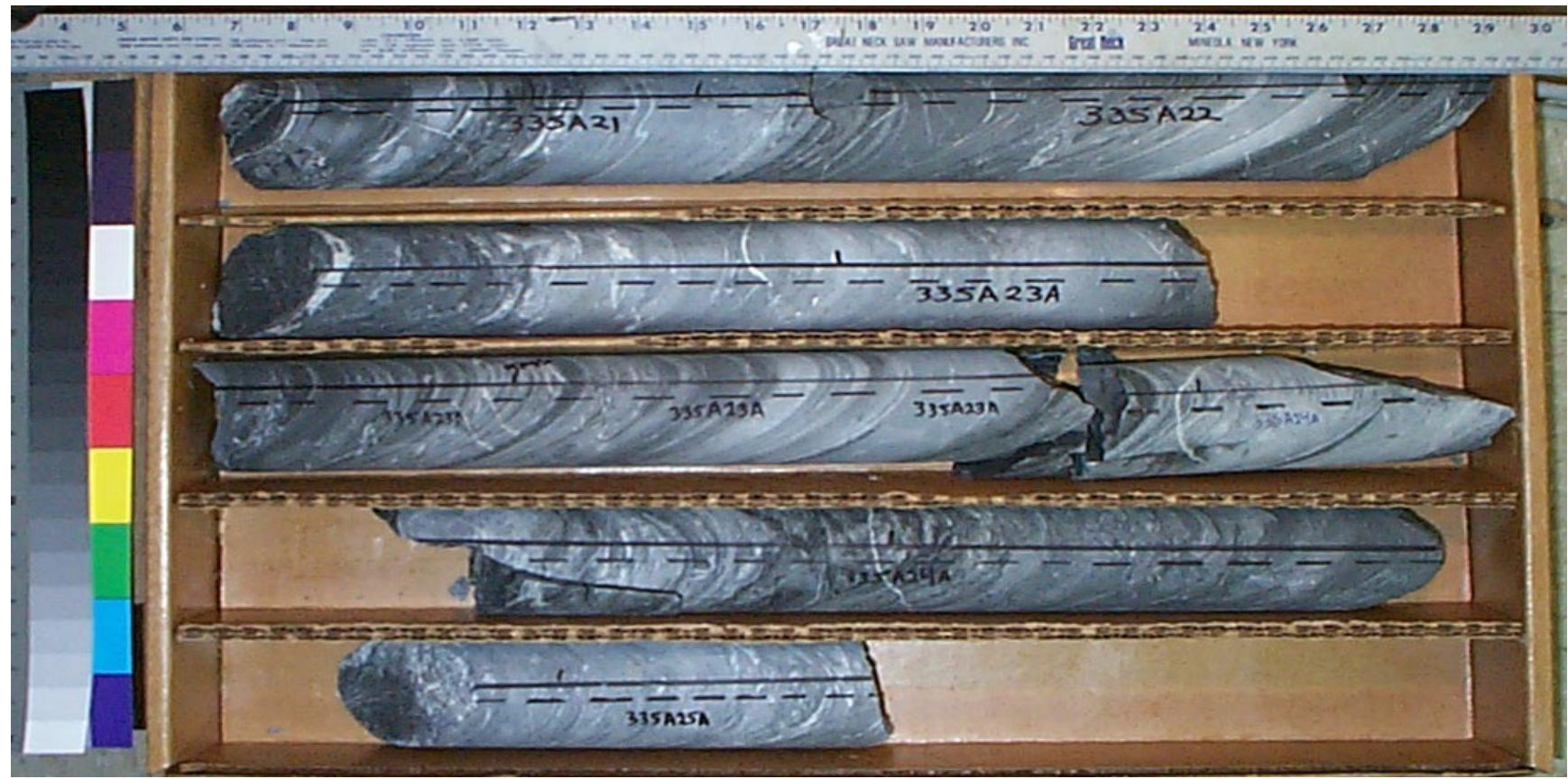

Core Scans included in this box (listed by piece going downhole):

$$
\begin{aligned}
& \text { 335A2100 } \\
& \text { 335A2200 } \\
& \text { 335A230A } \\
& \text { 335A241A } \\
& \text { 335A242A } \\
& \text { 335A250A }
\end{aligned}
$$

See the "reading instructions" section of the introduction for help interpreting core box photos and core piece nomenclature 


\section{LVEW Core Box 475}

Depth Interval 9748.5'-9756.4'

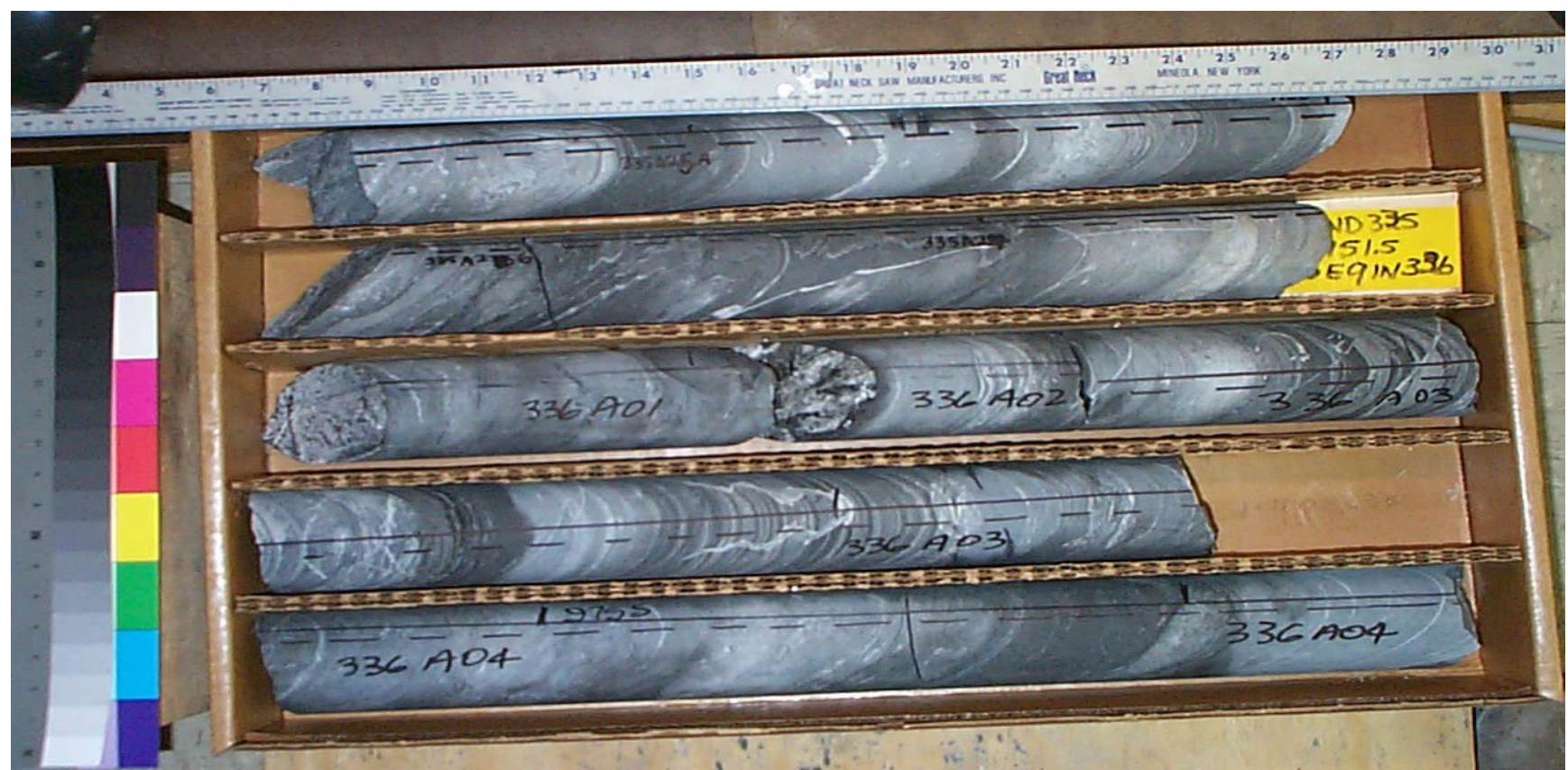

Core Scans included in this box (listed by piece going downhole):

335A2600
335A2700
336A0100
336A0200
336A030A
336A041A

See the "reading instructions" section of the introduction for help interpreting core box photos and core piece nomenclature 


\section{LVEW Core Box 476}

Depth Interval 9756.4'-9764.5'

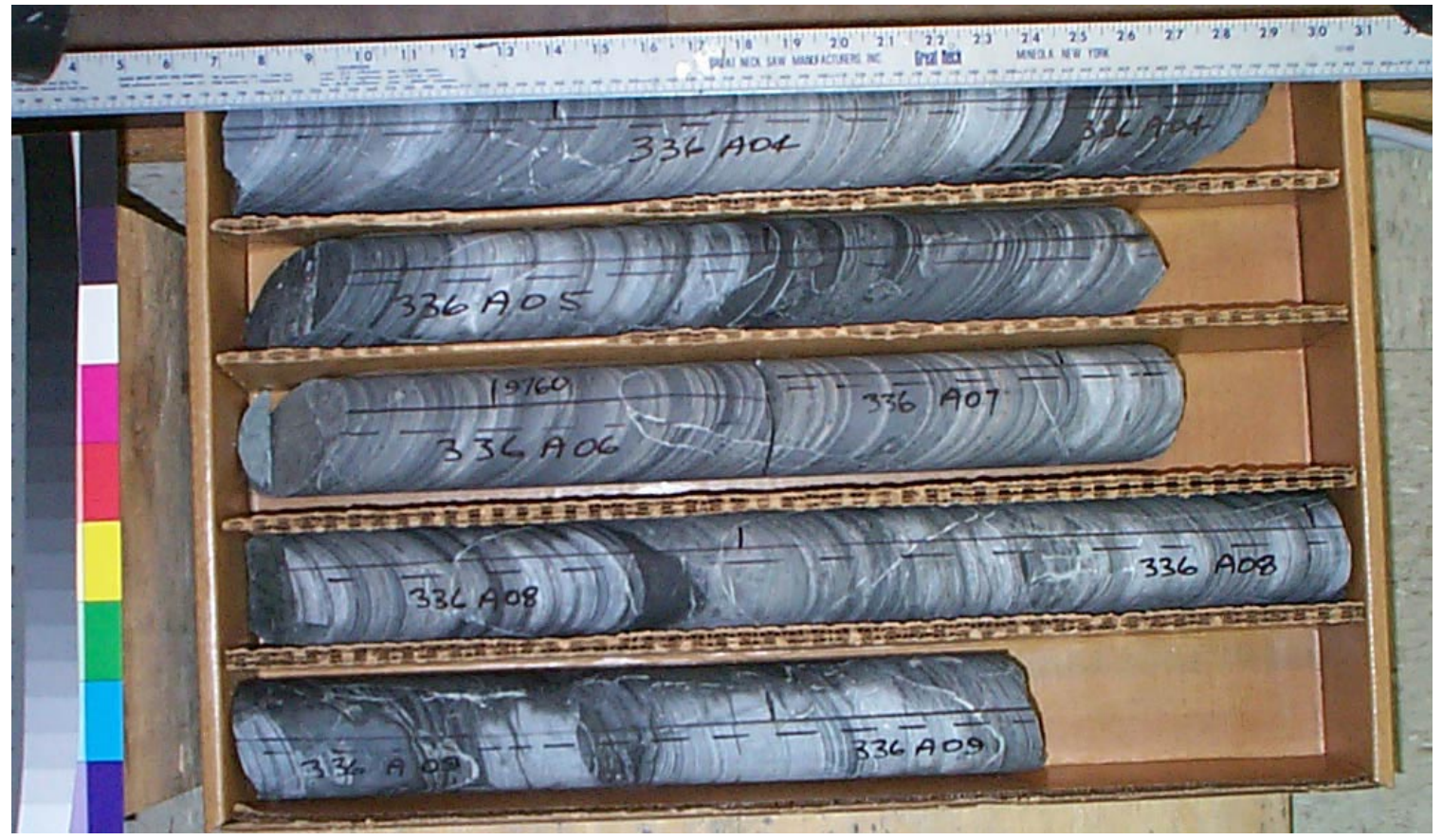

Core Scans included in this box (listed by piece going downhole):
336A042A
$336 \mathrm{~A} 0500$
336A0600
$336 \mathrm{~A} 0700$
$336 \mathrm{~A} 0800$
336A0900

See the "reading instructions" section of the introduction for help interpreting core box photos and core piece nomenclature 


\section{LVEW Core Box 477}

Depth Interval 9764.5'-9772.8'

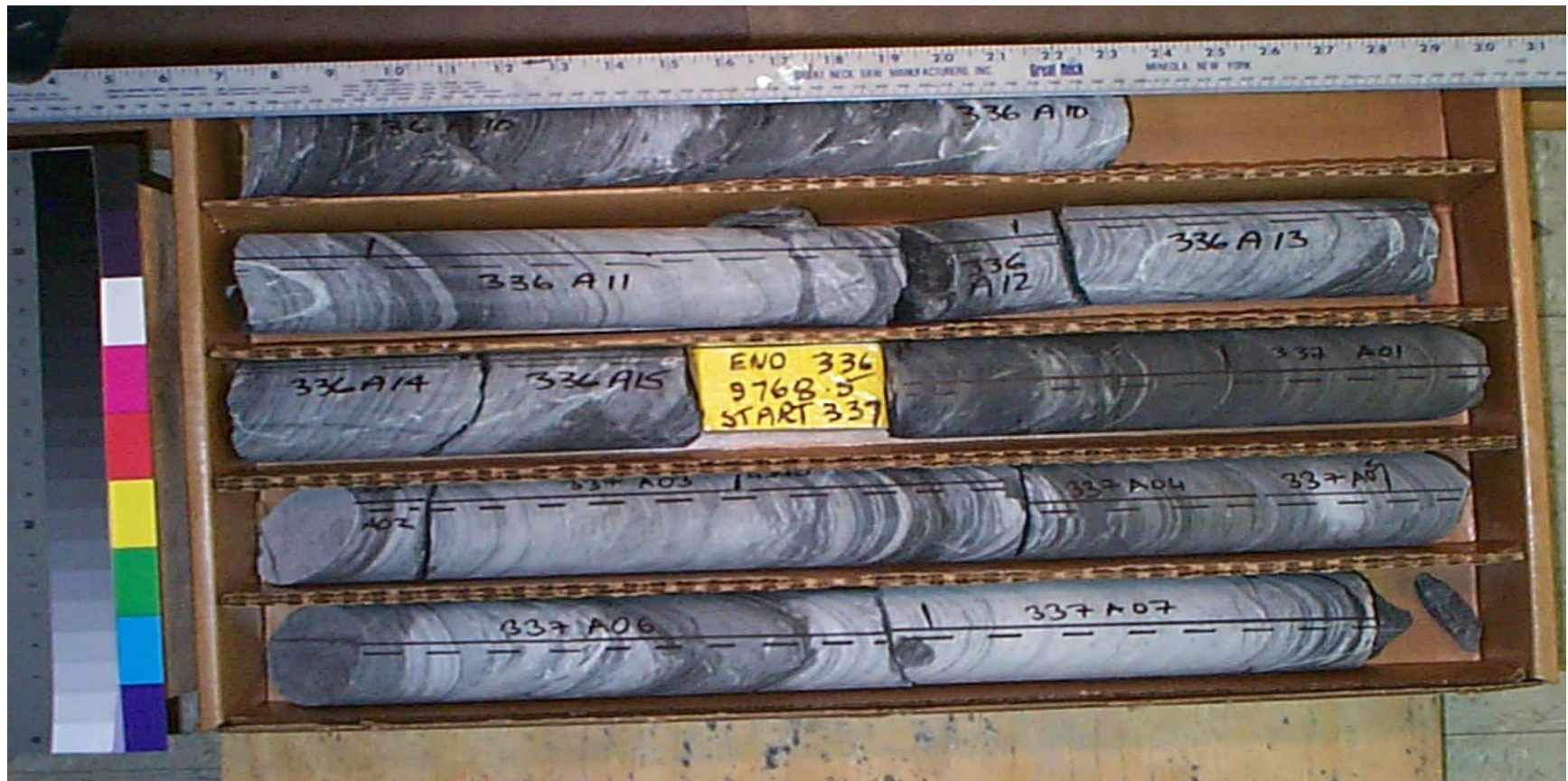

Core Scans included in this box (listed by piece going downhole):

336A1000
$336 A 1100$
$336 A 1200$
$336 A 1300$
$336 A 1400$
$336 A 1500$
337A0100

$337 \mathrm{~A} 0200$ $337 \mathrm{~A} 0300$ $337 \mathrm{~A} 0400$ $337 \mathrm{~A} 0500$ $337 \mathrm{~A} 0600$ $337 \mathrm{~A} 0700$

See the "reading instructions" section of the introduction for help interpreting core box photos and core piece nomenclature 


\section{LVEW Core Box 478}

Depth Interval 9772.8'-9780.2'

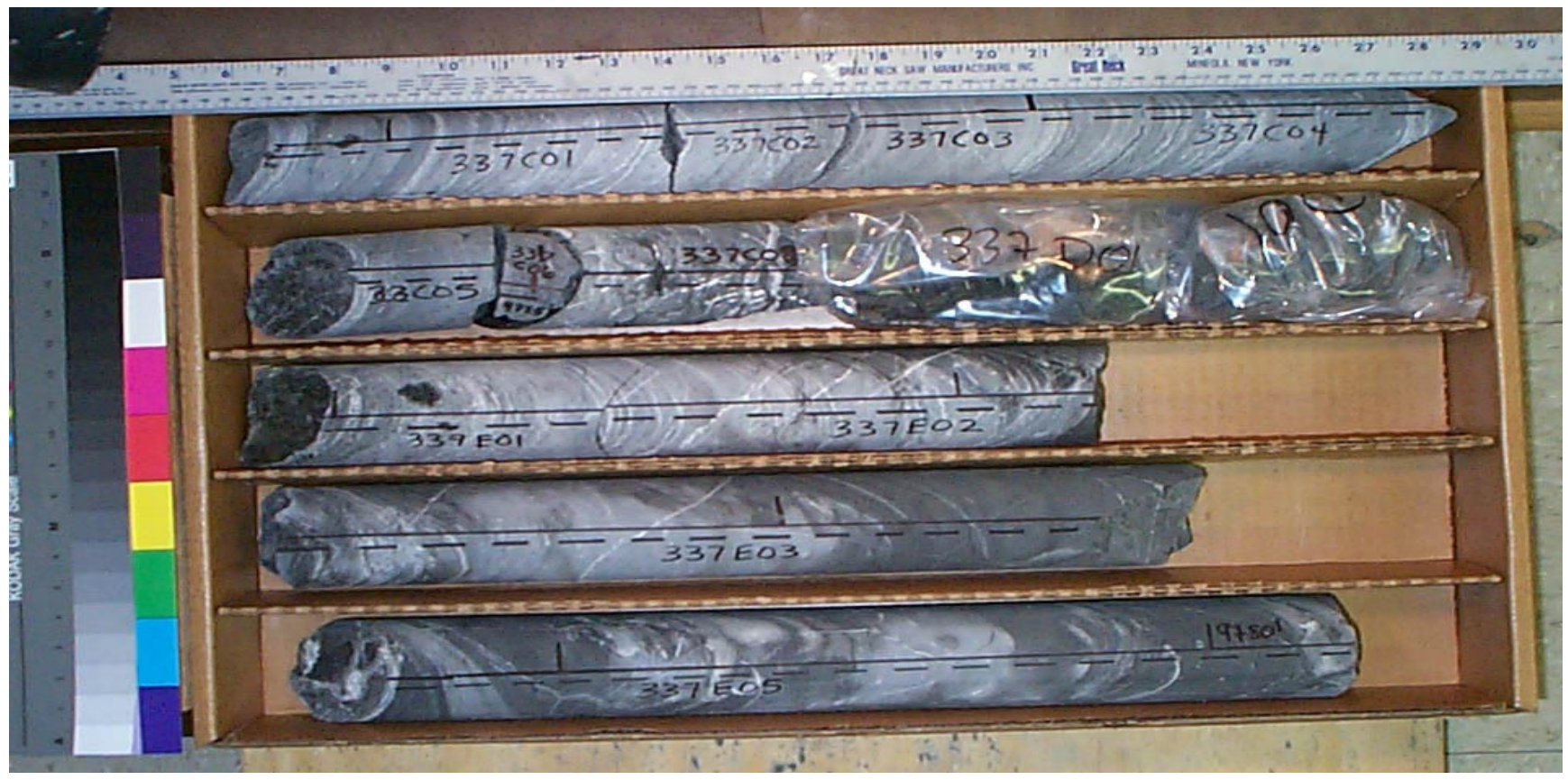

Core Scans included in this box (listed by piece going downhole):
$337 \mathrm{C} 0100$
$337 \mathrm{C} 0200$
$337 \mathrm{C} 0400$
$337 \mathrm{C} 0500$
$337 \mathrm{C} 0800$
$337 \mathrm{E} 0100$
$337 \mathrm{E} 0200$
$337 \mathrm{E} 0300$
337E0500

See the "reading instructions" section of the introduction for help interpreting core box photos and core piece nomenclature 


\section{LVEW Core Box 479}

Depth Interval 9780.2'-9787.8'

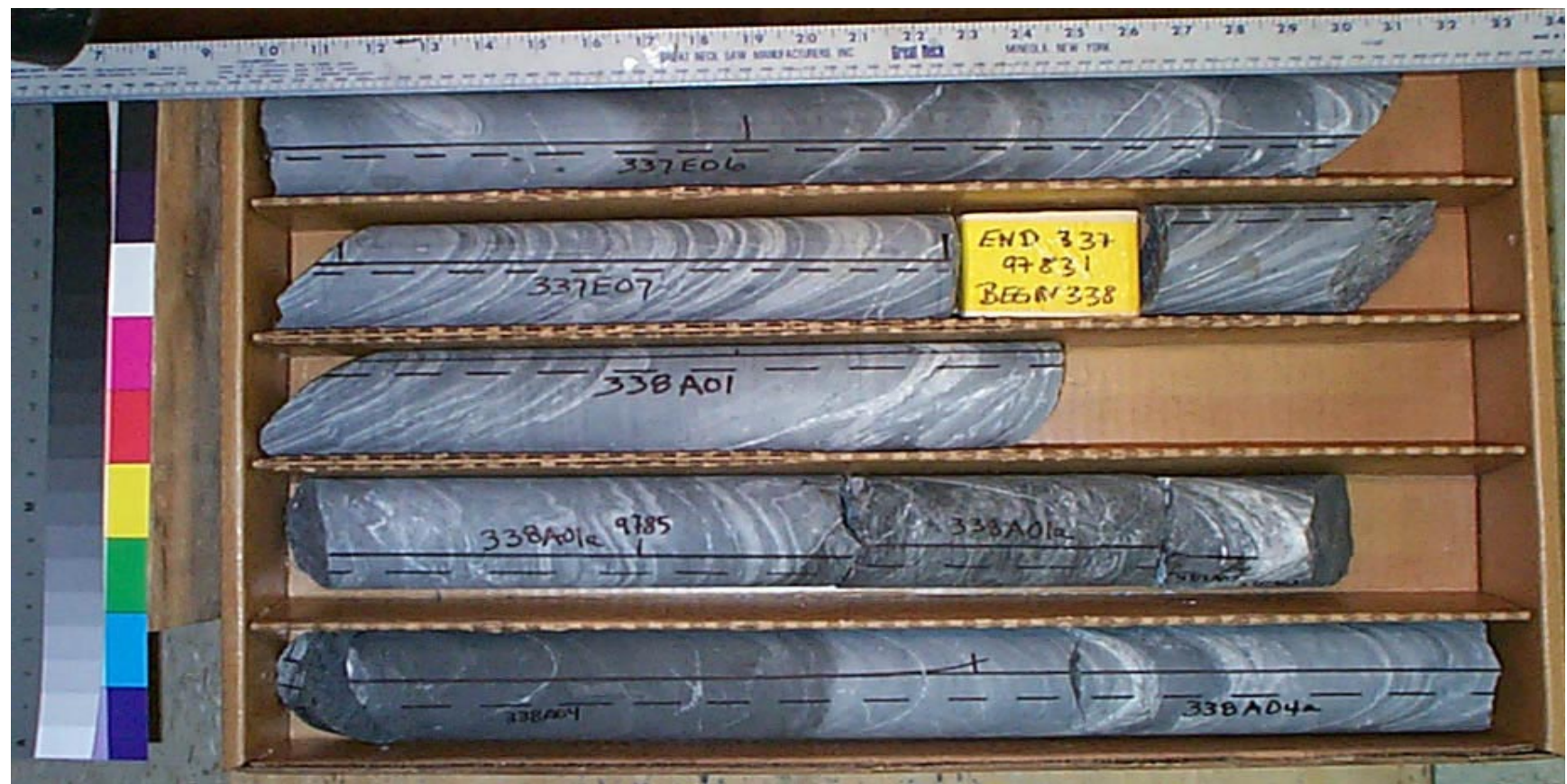

Core Scans included in this box (listed by piece going downhole):

337E0600
337E0700
338A010A
338A040A

See the "reading instructions" section of the introduction for help interpreting core box photos and core piece nomenclature 


\section{LVEW Core Box 480}

Depth Interval 9787.8'-9795.0'

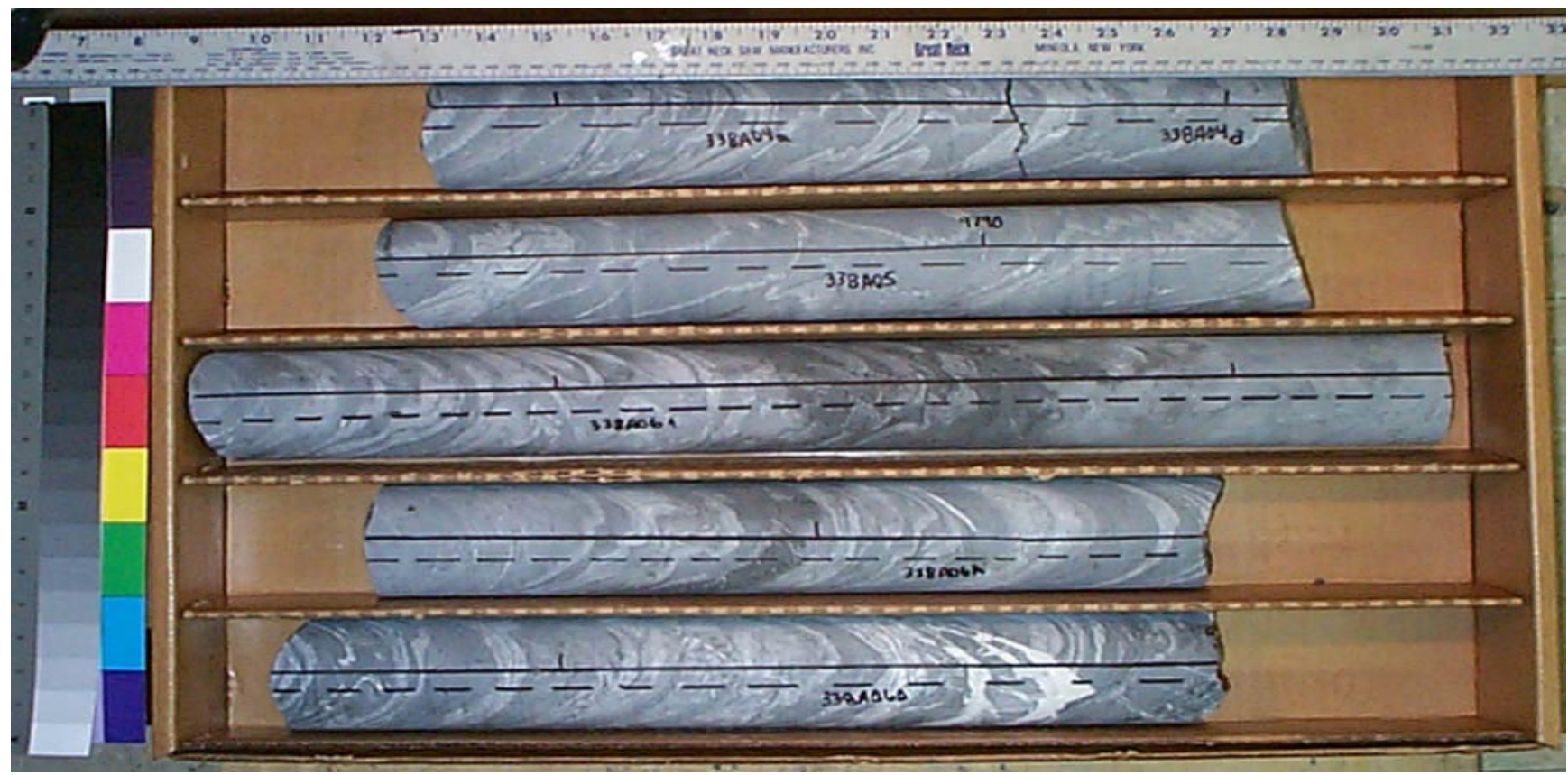

Core Scans included in this box (listed by piece going downhole):
338A040A
338A0500
338A061A
338A062A

See the "reading instructions" section of the introduction for help interpreting core box photos and core piece nomenclature 


\section{LVEW Core Box 481}

Depth Interval 9795.0'-9802.2'

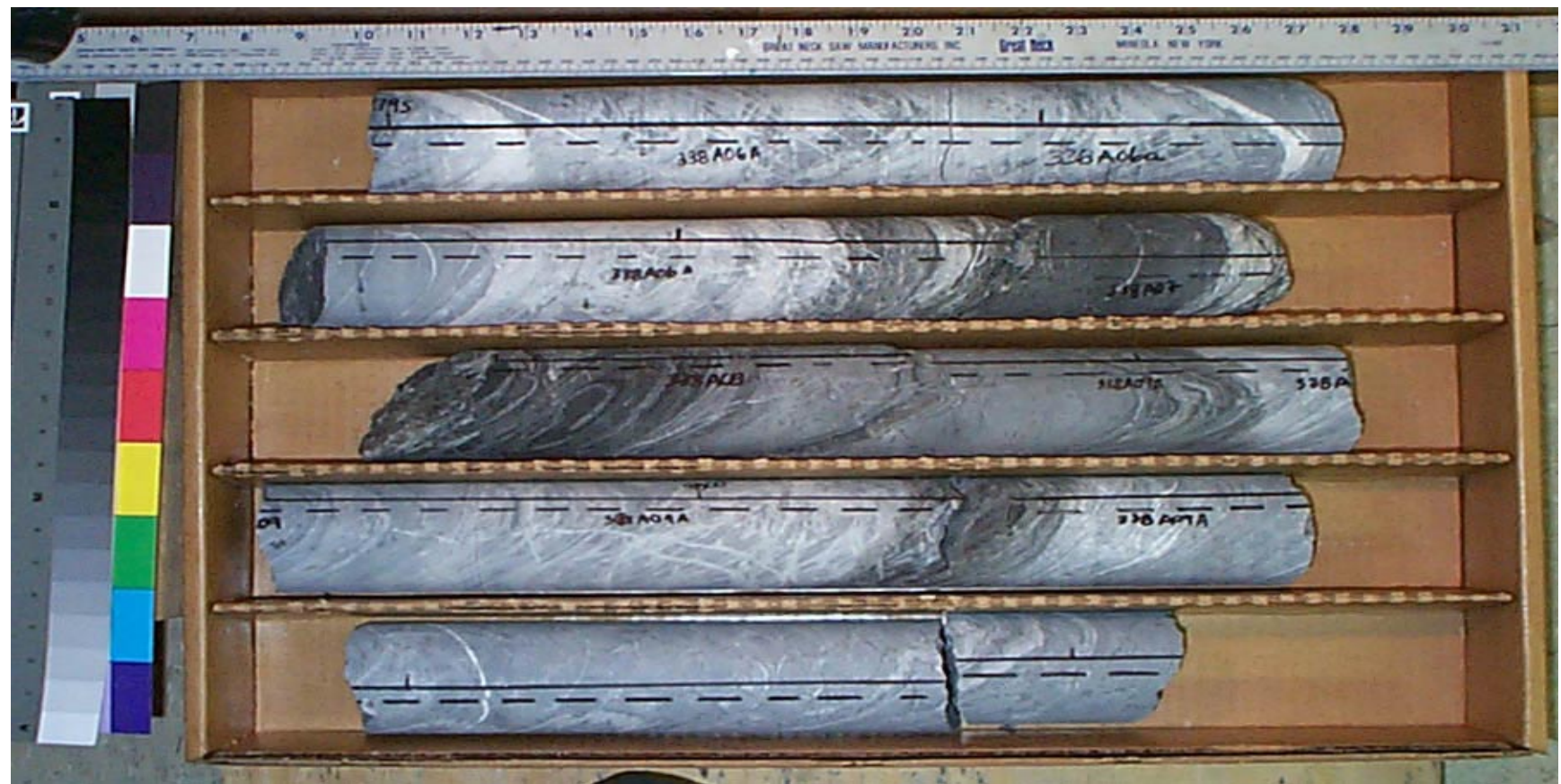

Core Scans included in this box (listed by piece going downhole):
338A062A
338A063A
338A0700
338A0800
338A091A
338A092A

See the "reading instructions" section of the introduction for help interpreting core box photos and core piece nomenclature 


\section{LVEW Core Box 482}

\section{Depth Interval 9802.2'-9809.4'}

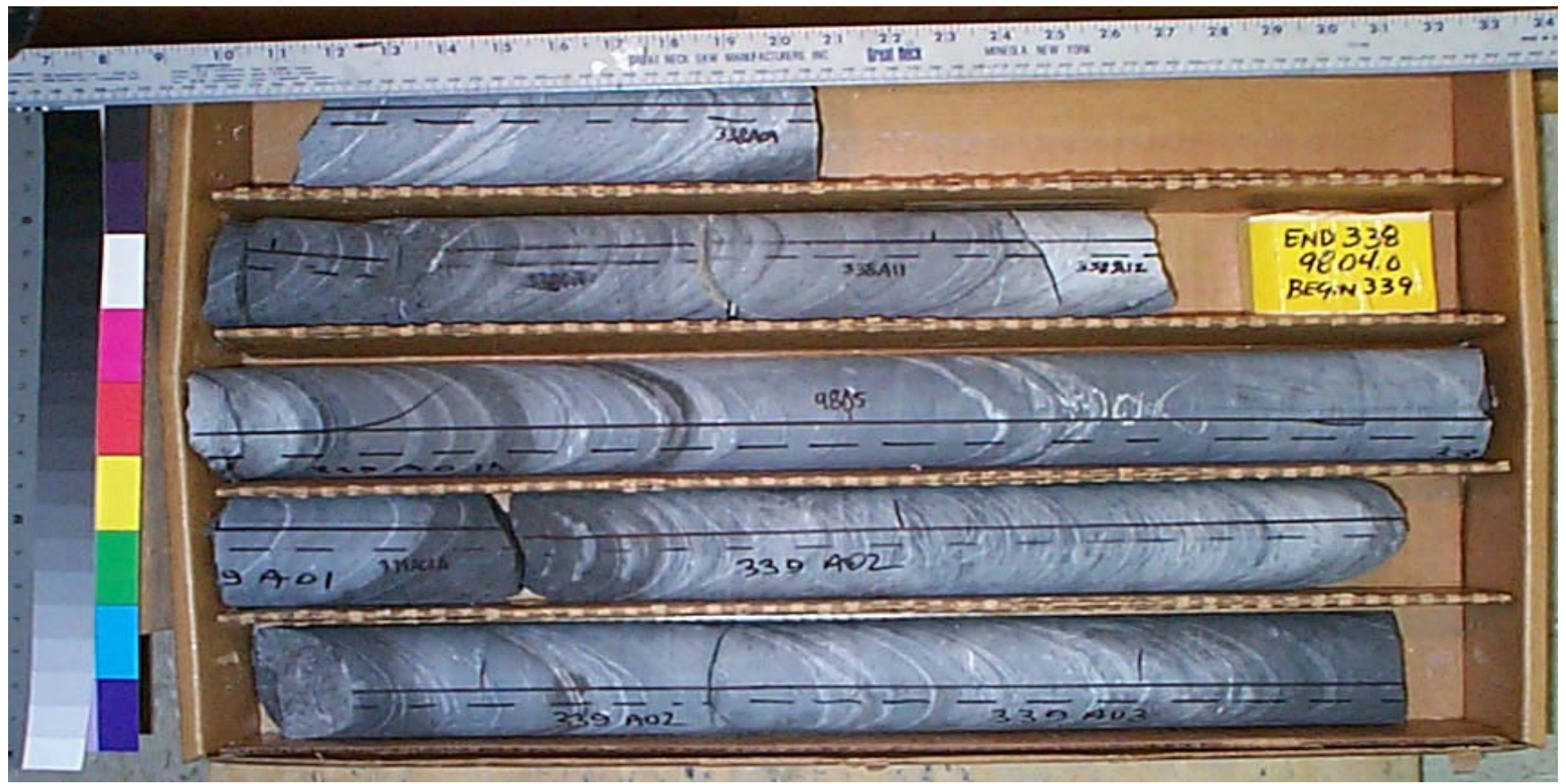

Core Scans included in this box (listed by piece going downhole):

$$
\begin{aligned}
& \text { 338A092A } \\
& 338 A 1000 \\
& 338 A 1100 \\
& 338 A 1200 \\
& \text { 339A010A } \\
& \text { 339A020A } \\
& \text { 339A0300 }
\end{aligned}
$$

See the "reading instructions" section of the introduction for help interpreting core box photos and core piece nomenclature 


\section{LVEW Core Box 483}

Depth Interval 9809.4'-9817.7'

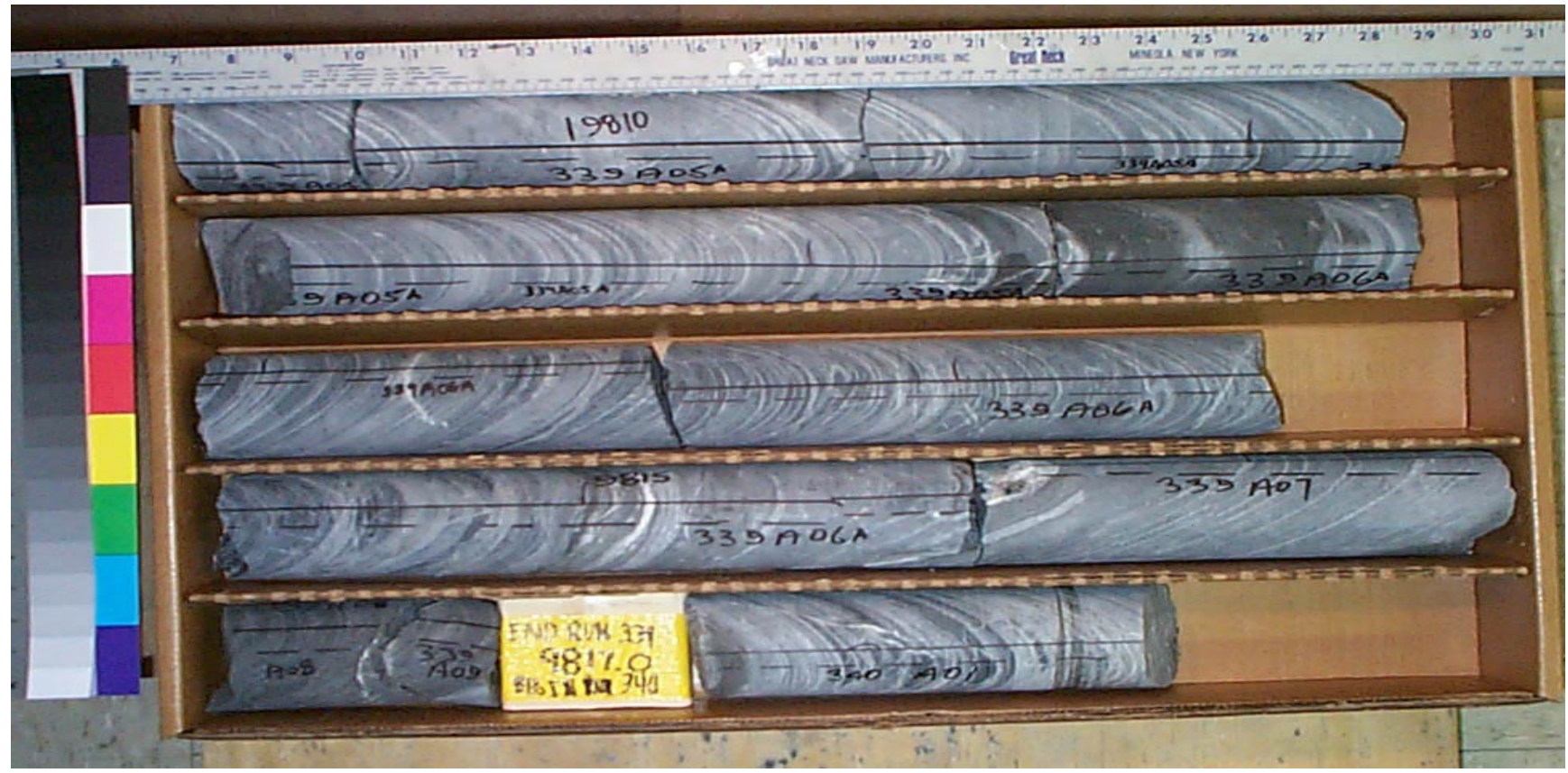

Core Scans included in this box (listed by piece going downhole):

339A0400
$339 A 050 A$
$339 A 060 A$
339A0700
339A0800
340A010A

See the "reading instructions" section of the introduction for help interpreting core box photos and core piece nomenclature 


\section{LVEW Core Box 484}

Depth Interval 9817.7'-9825.8'

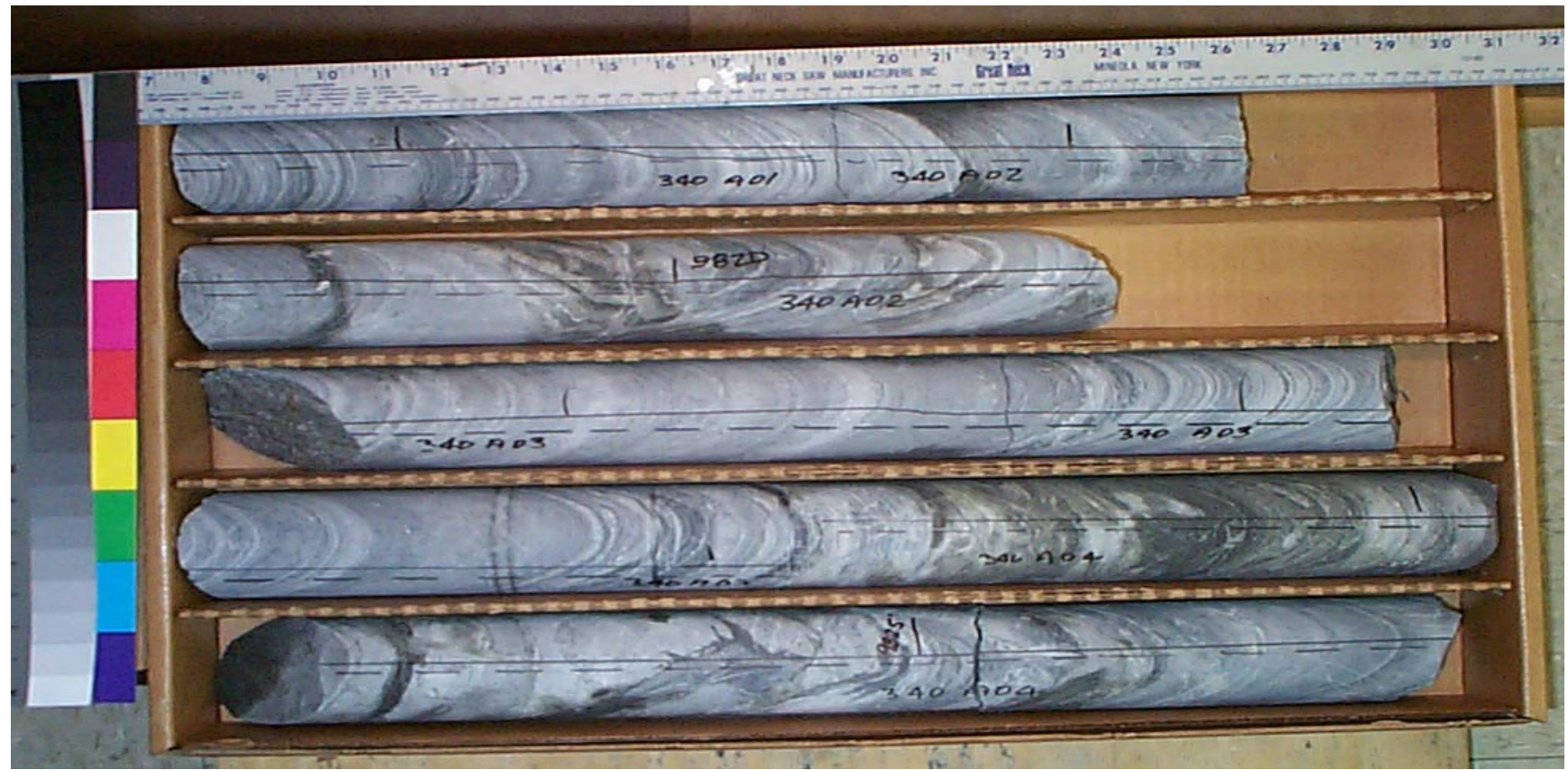

Core Scans included in this box (listed by piece going downhole):

$$
\begin{aligned}
& \text { 340A010A } \\
& \text { 340A020A } \\
& \text { 340A030A } \\
& \text { 340A041A } \\
& \text { 340A042A }
\end{aligned}
$$

See the "reading instructions" section of the introduction for help interpreting core box photos and core piece nomenclature 


\section{LVEW Core Box 485}

Depth Interval 9825.8'-9831.0'

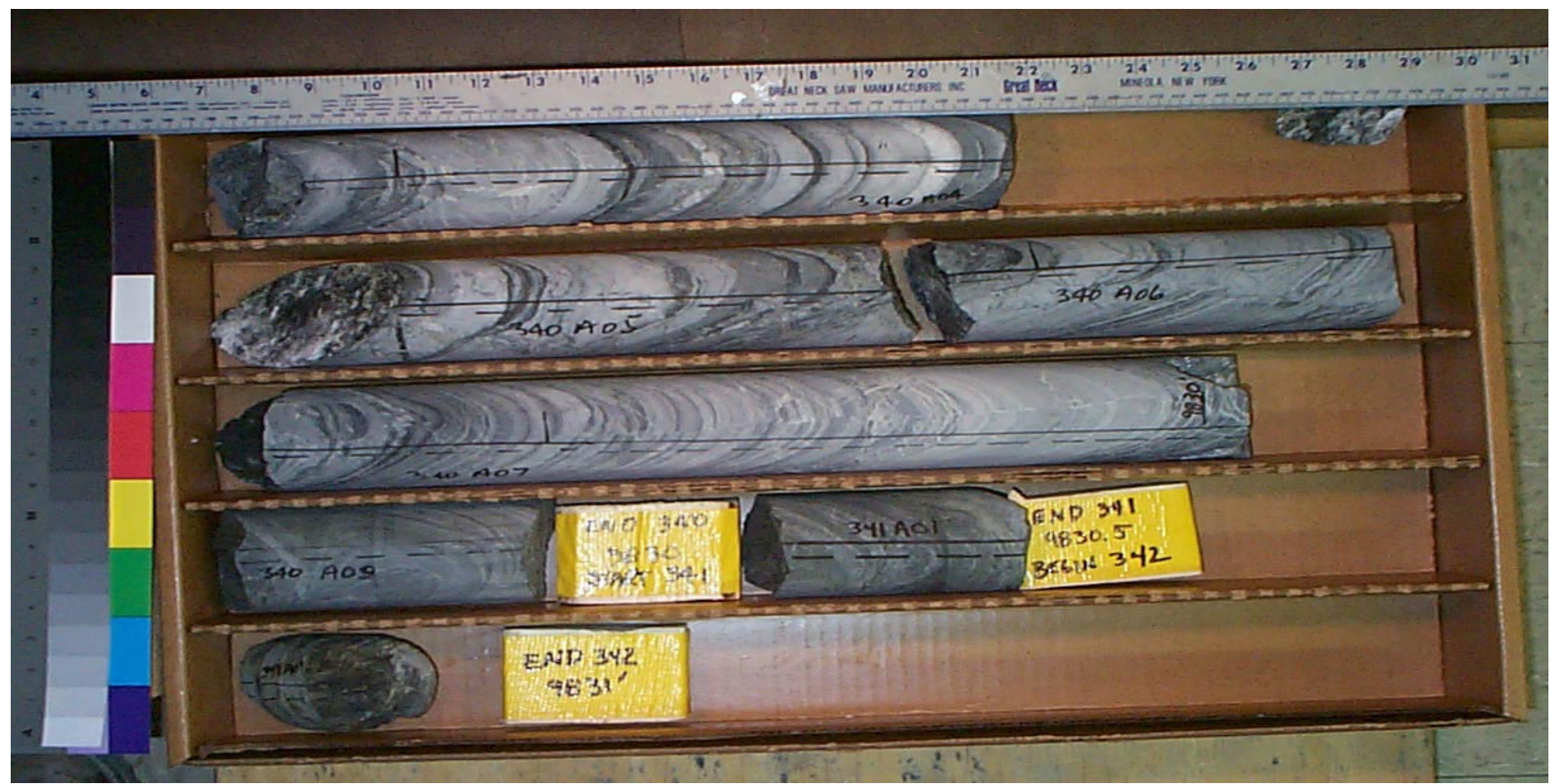

Core Scans included in this box (listed by piece going downhole):

$$
\begin{aligned}
& \text { 340A042A } \\
& \text { 340A0500 } \\
& \text { 340A0600 } \\
& \text { 340A0700 } \\
& \text { 340A0900 } \\
& \text { 341A0100 }
\end{aligned}
$$

See the "reading instructions" section of the introduction for help interpreting core box photos and core piece nomenclature 